


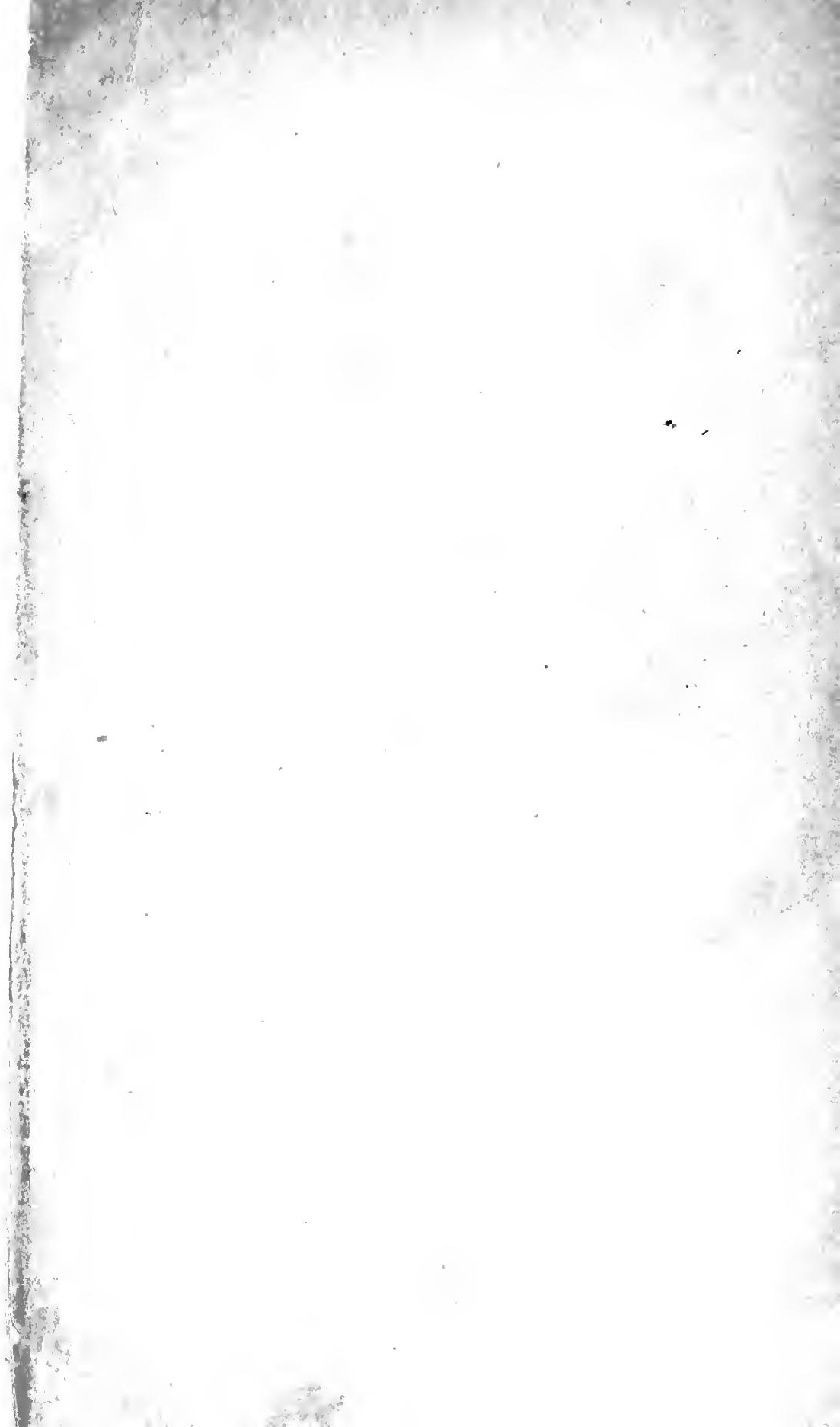



CONSTITUTIONAL LAW OF ENGLAND

THIRD EDITION 


\section{Digitized by the Internet Archive in 2008 with funding from Microsoft Corporation}




\title{
CONSTITUTIONAL LAW \\ OF \\ ENGLAND
}

\author{
BY \\ EDWARI) WAVELL RIDGES. \\ OF LINCOLN'S INN. BARRISTER-AT-LAW.
}

\section{THIRD EDITION}

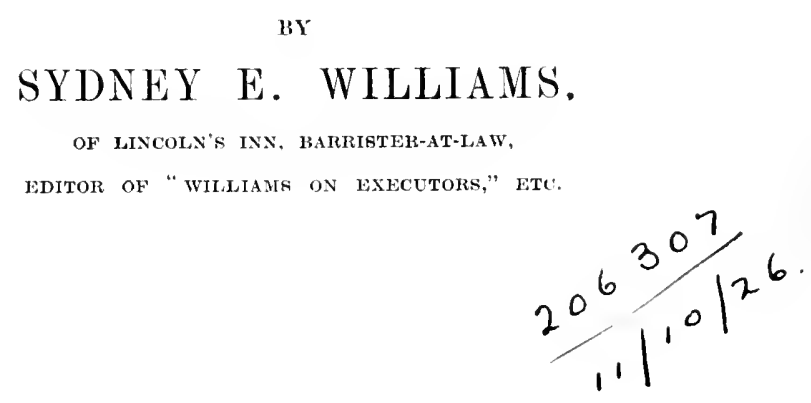

LONDON :

STEVENS \& SONS, LIMITED,

$119 \& 120$ CHANCERY LANE,

Law publisbers.

1922. 
PRINTED AT READING, HAgLANl, $\mathrm{BY}$

THE EASTERA PRESS, LIMTEN. 


\section{PREFACE TO THE THIRD EITTION.}

IT is difficult, as the late Professor Dicey has pointed out, for anyone dealing with English constitutional law to ascertain the extent and limits of his subject, the field of his labours and the mode of working it, " the whole province of so-called constitutional law is a sort of maze in which the wanderer is perplexed by unreality, by antiquarianism and by conventionalism." This difficulty has been immensely increased by the events of the past few years. In the seven years which have elapsed since the publication of the second edition, changes of the greatest importance have taken place, causing something like an upheaval in time-honoured institutions, the most important being those relating to Ireland, the franchise, the status of women, and abroad, those affecting India, Egypt and the new colonies. There is, moreover, every prospect of further important changes in the near future, one of them being the reform of the House of Lords. The constitution therefore is in some respects in a state of transition, and any work on the subject must pro tanto be lacking in finality. But it is hoped that the present volume will be found a useful introduction to the study of constitutional law as it now stands.

S. E. W.

LinCoLn's INN,

June, 1922. 
- 


\section{TABLE OF CONTENTS.}

\section{Part I.-The Nature and Sources of English Constitutional Law.}

\section{Chapter I.}

\section{THE SOURCES OF ENGLISH CONSTITUTIONAL LAW."}

\section{Laws Proper and Conventions}

Statutes

Quasi-Statutes

The Common Law

Treaties

Judicial decisions

Opinions of the Law Officers

\section{Conventions}

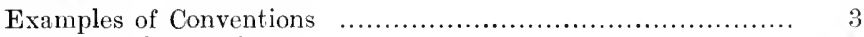

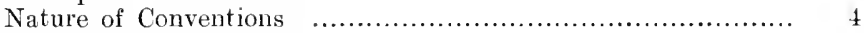

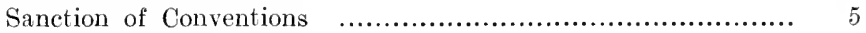

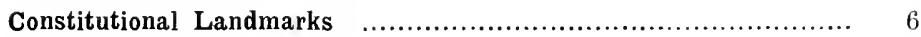

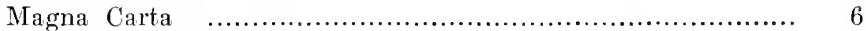

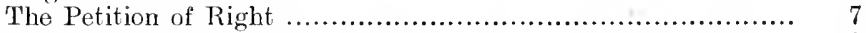

The Bill of Rights ............................................ 8

The Act of Settlement ........................................ 10

Chapter II.

CHARACTERISTICS OF ENGLISH CONSTITUTIONAL LAW.

\section{Leading Characteristics}

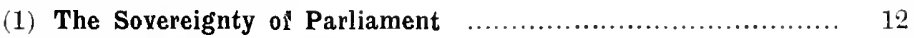

. Meaning of ................................................... 12

Stockdale $v$. Hansard ......................................... 13

External and internal limits of ............................. 13

Non-sovereign law-making bodies ............................. It

Federal States .................................................. 
The American Commonwealth …................................ 15

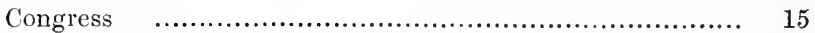

The Senate .................................................... 15

The House of Representatives .................................... 16

The Judiciary ................................................... 16

Amendments of the Constitution ................................ 16

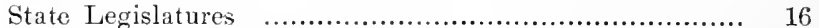

The Executive ........................................... 16

Features of the Constitution ............................... 17

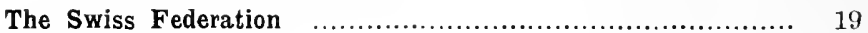

The Executive ............................................... 19

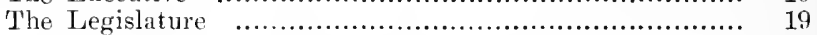

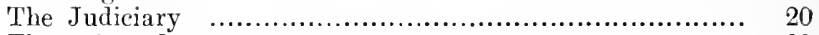

The referendum ............................................. 20

American and Swiss Constitutions compared ................ 20

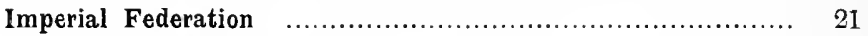

Requirements for Successful Federation ................... 21

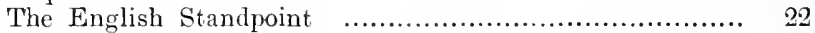

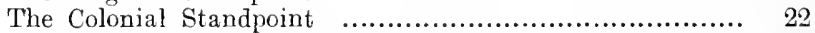

Topies for Federation .................................... 23

Proposed Federal Constitutions .................................. 24

General Conclusions as to Imperial Federation .............. 25

\section{Chapter III.}

\section{CHARACTERISTICS OF ENGLISH CONSTITUTIONAL LAW (continued).}

(2) The Right to Personal Freedom .............................. 27

Safeguards for Personal Freedom …....................... 27

The Writ of Habeas Corpus .................................. 28

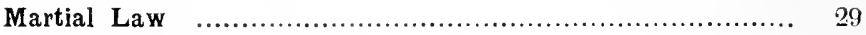

Meaning of Term ........................................... 29

Rights at Common Law .................................... 30

Martial law by virtue of the Prerogative ................. 32

Ex parte Marais ........................................ 33

Conclusions as to Martial Law .............................. 36

\section{Chapter IV.}

CHARACTERISTICS OF ENGLISH CONSTITUTIONAL LAW (continued).

(3) The Equality of all Persons before the Law .................. 37

Exceptions to the rule ...................................... 37

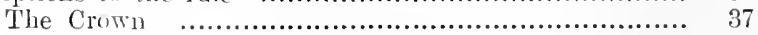

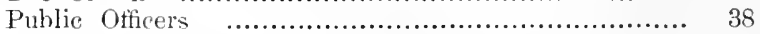

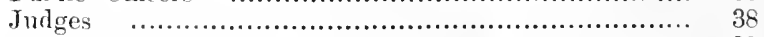

Justices of the Peace .................................... 39

Droit Administratif ......................................... 40 
(4) The Induction of General Principles from Decisions in Particular Case ............................................ 41

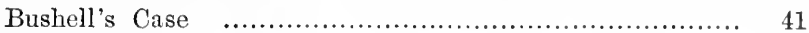

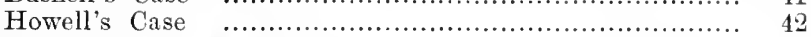

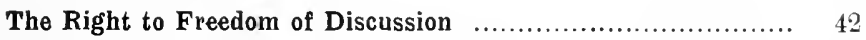

Press Restrictions ............................................. 44

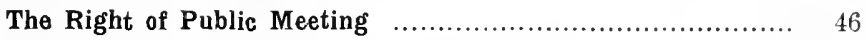

(5) The Adoption and Observance of Conventions ................... 49

(6) The Non-Taxation of British-born Subjects without adequate Representation

\title{
Part II.-The Legislature and the Public Revenue.
}

\author{
Citapter I. \\ THE MEETING AND TERMINATION OF PARLIAMENT.
}

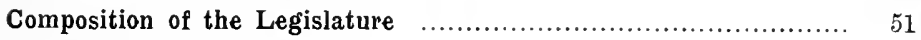

The Meeting of Parliament ..................................... 52

The Summons ................................................. 52

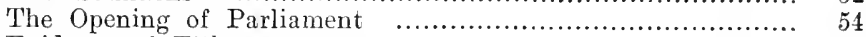

Evidence of Title ................................................ 54

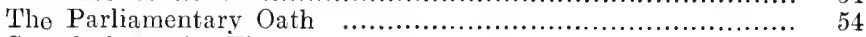

Speech from the Throne .......................................... 56

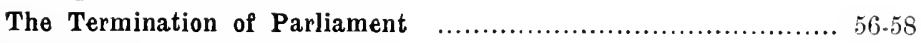

Dissolution $\quad$..................................................... 56

Effluxion of Time ................................................... 57

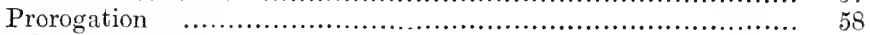

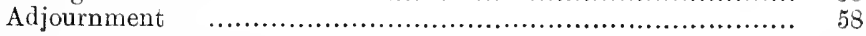

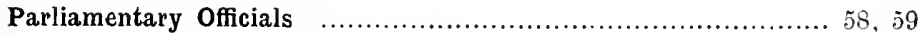

The Speaker of the House of Lords ......................... 58

The Speaker of the House of Commons ........................... 58

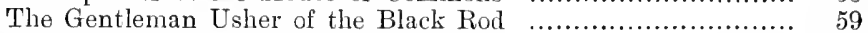

The Clerk of Parliaments ..................................... 59

The Clerk of the House of Commons .............................. 59

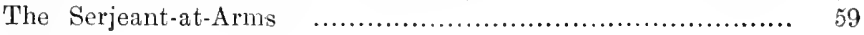

Cinapter II.

THE HOUSE OF COMMONS.

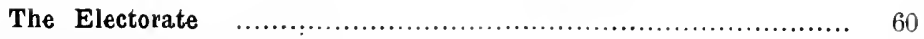

,The Present Franchise ............................................ 60

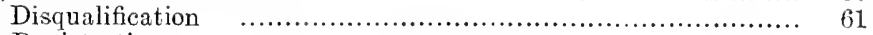

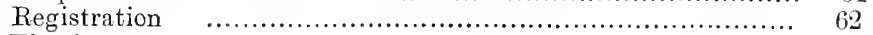

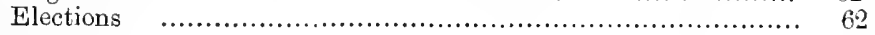


Paivileges of the House of Commons

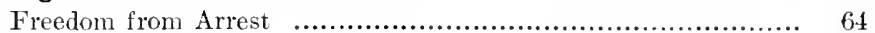

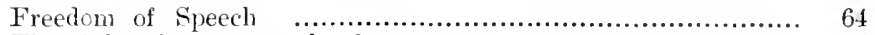

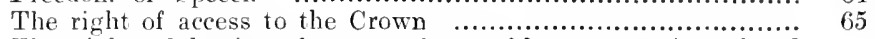

The right of having the most favourable construction placed

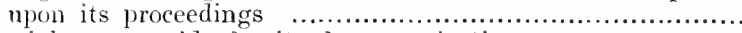

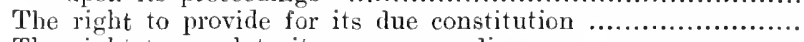

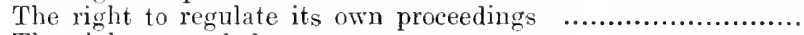

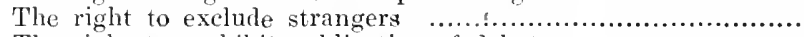

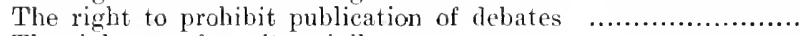

The right to enforce its privileges .................................. 69

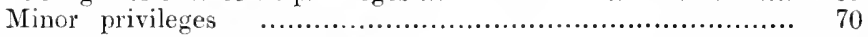

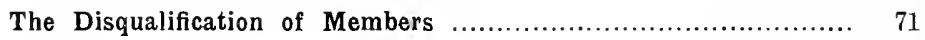

Chapter III.

THE HOUSE OF LORDS.

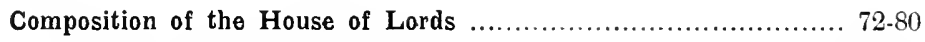

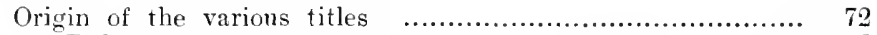

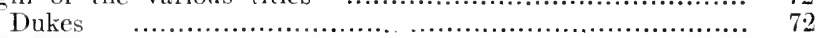

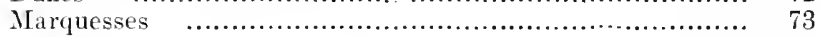

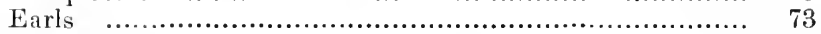

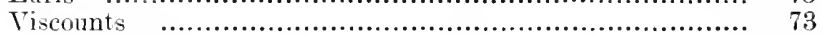

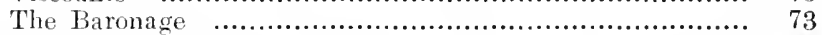

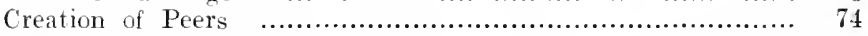

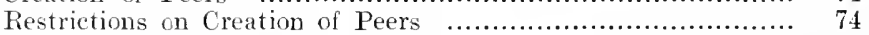

The Irish Representative Peers ................................ 75

The Scotch Representative Peers ................................ 76

The Spiritual Peers .................................................. 77

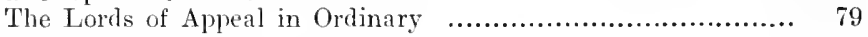

Prixileges of the House of Lords ........................................ $\quad 79$

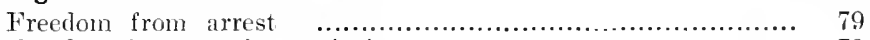

Freedon from service on juries .................................... $\quad 79$

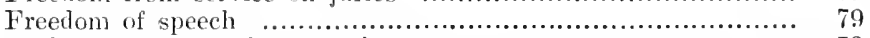

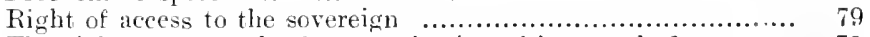

The right to see to the due constitution of its omn body ........ 79

The right to commit for contempt .............................. 80

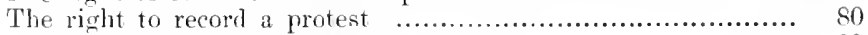

The right of exereising judicial functions $\ldots \ldots \ldots \ldots \ldots \ldots \ldots \ldots . . . . \ldots$

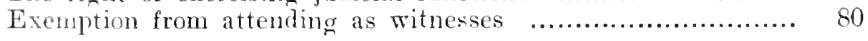

Cilapter IV.

PIBLIC, PIIYATE, AND MONEY BILLA.

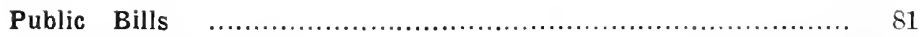

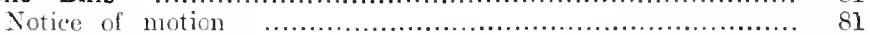

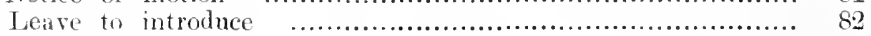

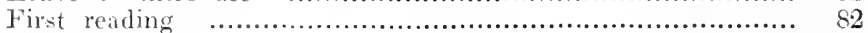

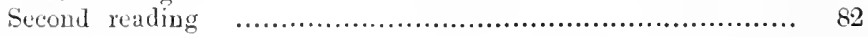


PAGE

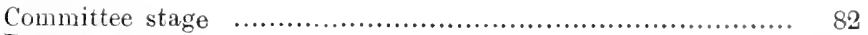

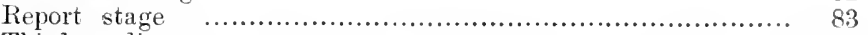

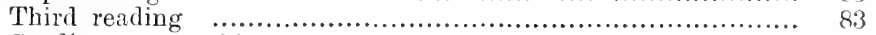

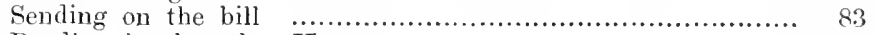

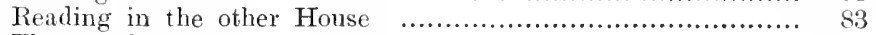

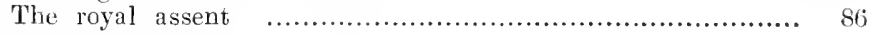

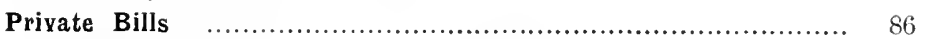

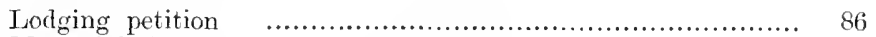

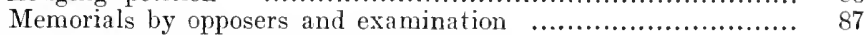

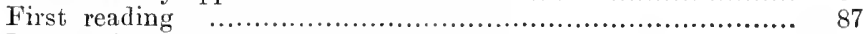

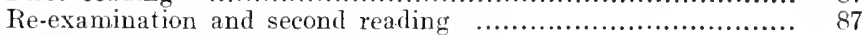

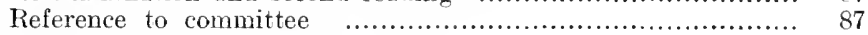

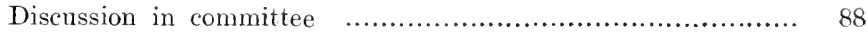

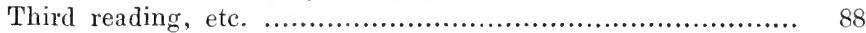

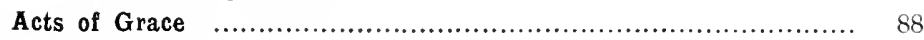

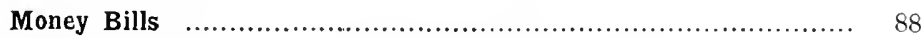

Constitutional position with regard to money bills ........... 88

Procedure $\quad$.................................................... 90

Chapter V.

THE PUBLIC RETENUE.

The Public Revenue ............................................. 93

Generally ….................................................... 93

The Consolidated Fund ……................................................ 93

Authority for payment out …............................................... 94

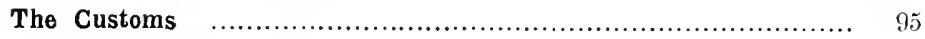

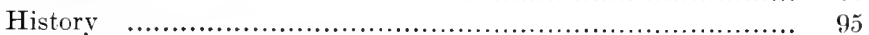

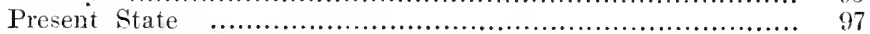

Collection and Management .............................................. 97

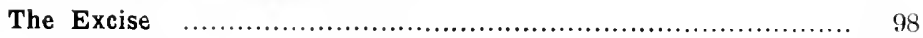

History and Present State .......................................... 98

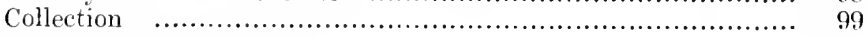

Property and Income Tax f........................................ 99

Taxes on Personalty .................................................. 89

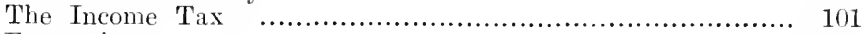

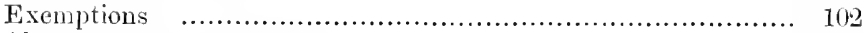

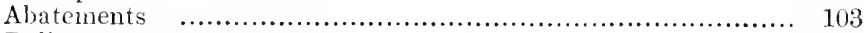

Relief from Income Tax ................................................... 104

Super Tax …....................................................... 104

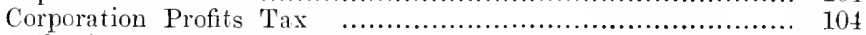

Collection and Management ...................................... 105

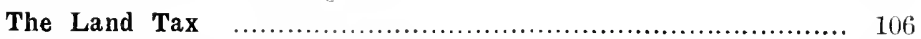

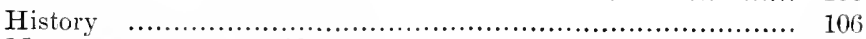

Management and Incidence ............................................. 108

The Inhabited House Duty ......................................... 109

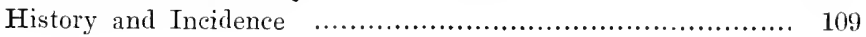


Crown Lands and Hereditary Revenues ......................... 110

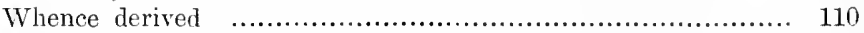

Revenue from handed over to the nation ......................... 111

Control and management ....................................... 112

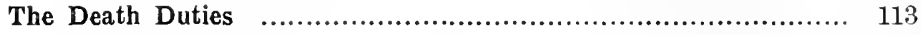

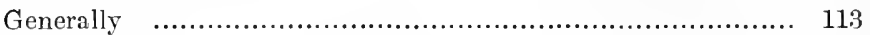

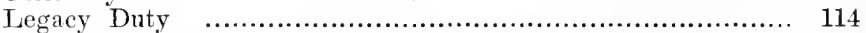

Succession Duty .............................................. 117

Estate Duty under the Finance Act, 1894 ......................... 119

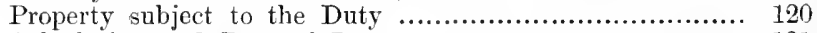

Calculation and Rate of Duty ............................ 121

Reduction of Duty in Case of Small Excess .............. 123

Relief from Duty on Quick Successions ....................... 123

Payment of Duty ....................................... 124

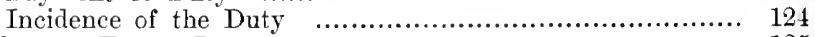

Settlement Estate Duty ...................................... 125

(1) Since the Finance Act, 1914 ........................ 125

(2) Prior to the 12 th May, 1914 ........................ 125

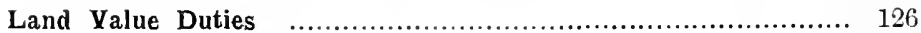

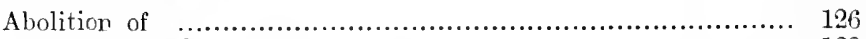

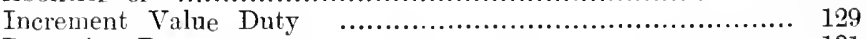

Reversion Duty ................................................... 131

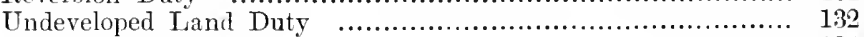

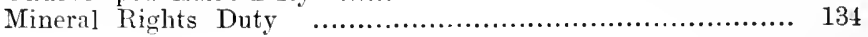

Part III.-The Executive.

Chapter I.

THE CROIIN.

The Members of the Executive ......................................... 137

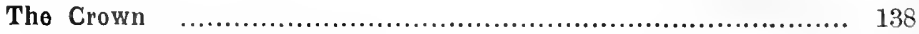

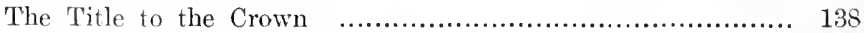

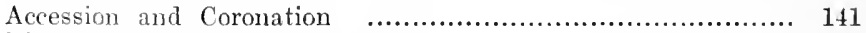

The Cromn's Duty to the Subject ................................ 141

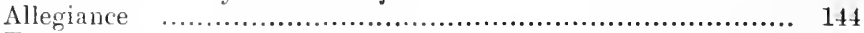

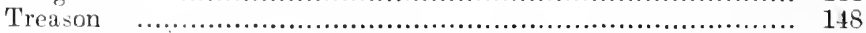

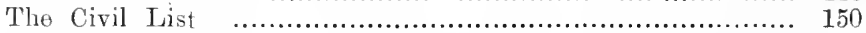

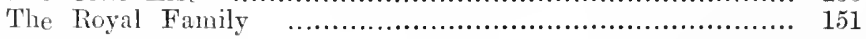

The Royal Prerogative ….............................................. 154

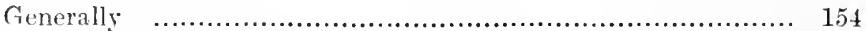

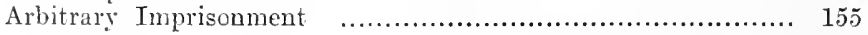




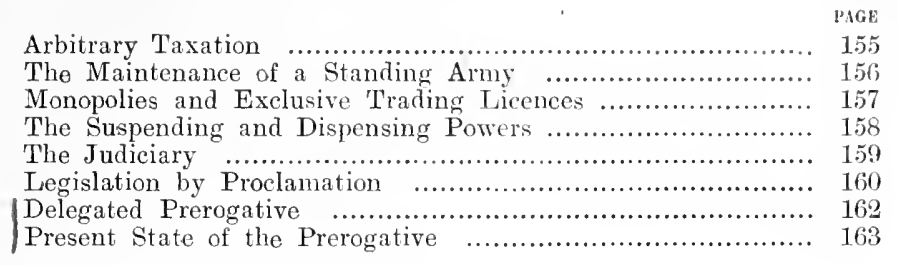

Chapter II.

THE PRIVI AND CABINET COUNCILS AND THE MINISTRY.

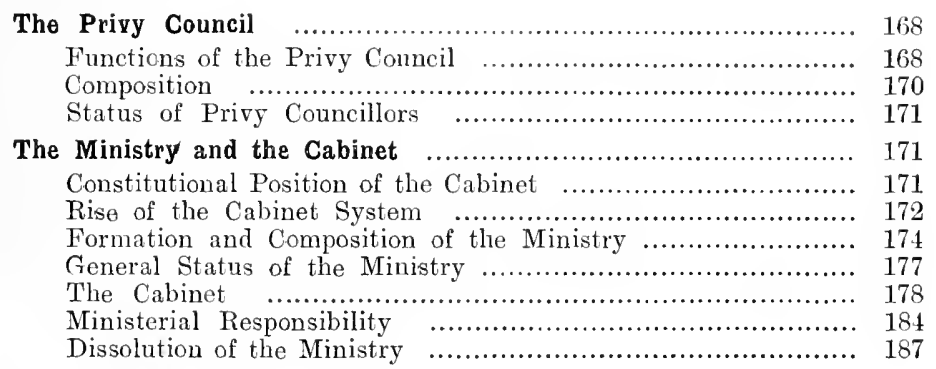

Chapter III.

THE MEMBERS OF THE EXECTTIVE.

The Lord Chancellor ...................................................... 192

The Lord Prixy Seal ..................................................... 193

The Law Officers of the Crown ...................................... 193

The Chancellor the Duchy of Lancaster .............................. 195

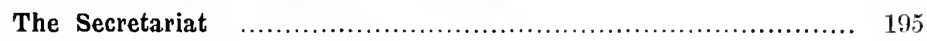

The Goxernment Departments _..................................... 196

Political and Non-Political ........................................ 196

The Permanent Civil Service …................................. 197

Advantages of the English System …........................ 198

Political Departments f........................................... 200

The Home Office .................................................... 200

The Foreign Office ....................................................... 201

The Colonial Office …........................................................... 202

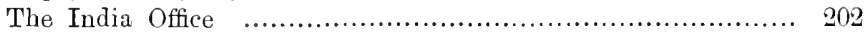




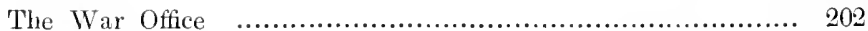

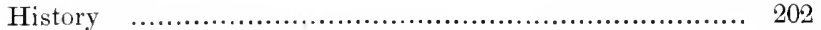

Constitution of the Army Council ............................ 205

Fumetions of the Army Council ............................... 206

The Air Ministry .............................................. 207

The Imperial Defence Committee of the Cabinet ................. 207

The Admiralty .................................................. 208

The Board of Trade ......................................... 208

The Treasury Board and the Exchequer ........................... 210

The Post Office ................................................. 212

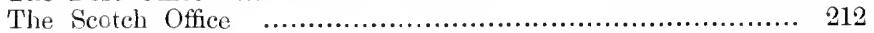

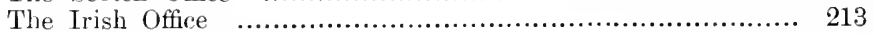

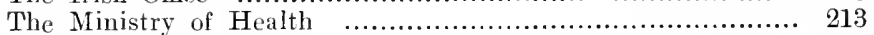

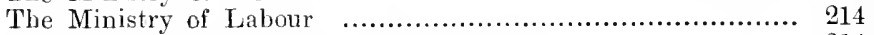

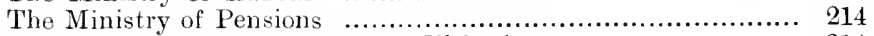

The Ministry of Agriculture and Fisheries ........................ 214

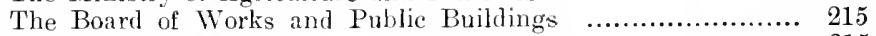

The Board of Education .................................... 215

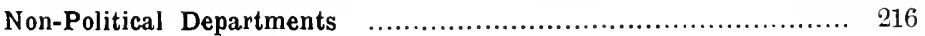

\title{
Part IY.-The Judiciary.
}

\author{
Cinapter I.
}

JUDICIAL INSTITUTIONS TO THE TIME OF EDWARD I.

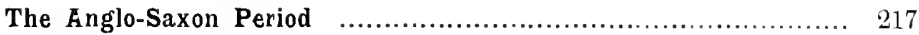

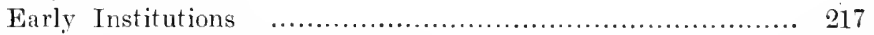

The Anglo-Saxon Courts .......................................... 218

The Anglo-Saxon Common Law ............................... 219

Anglo-Saxon Procedure ............................................ 219

The Norman Period ............................................... 220

The Feudal System .......................................... 220

The Norman Courts ............................................ 221

Features of the Norman Period .............................. 225

Separation of the Secular and Ecclesiastical Courts ............. 225

The Rise of Roral Justice ...................................... 225

The Royal Writs .................................................. 226

The Inquest or Assize ........................................... 227

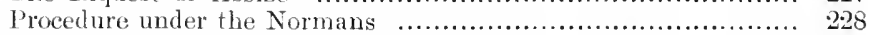

Judicial Institutions in the Reign of Edward I. ................... 229

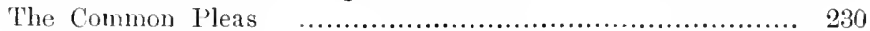

The King's Bench ........................................... 230

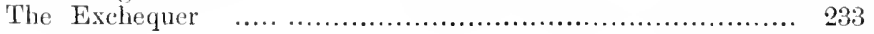


PAGE

The High Court of Parliament ............................... 233

The King's Council ............................................... 233

The Chancery ................................................... 233

The Local Courts ................................................. 234

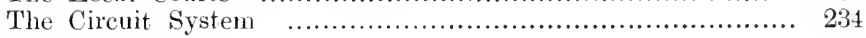

\section{Chapter II.}

JUDICIAL INSTITUTIONS FROM EDWARD I. TO THE JUDICATURE ACTS, 1873-1910.

The High Court of Parliament as a Court of First Instance ....... $2: 36$

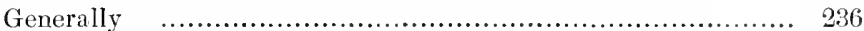

The Commons' Right of Impeachment ......................... 237

Procedure on Impeachment ................................... 238

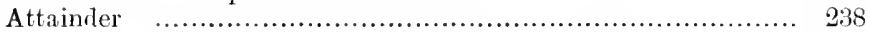

The Peers' Right of Trial by the House of Lords ............. 238

The Court of the Lord High Steward ........................... 239

Parliament as a Court of First Instance in Civil Actions ......... 239

The Appellate Jurisdiction of Parliament ......................... 240

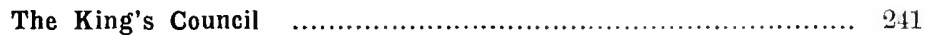

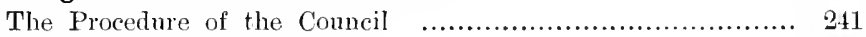

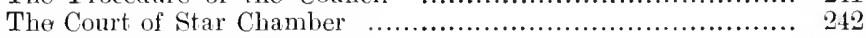

The Court of Requests ............................................ 244

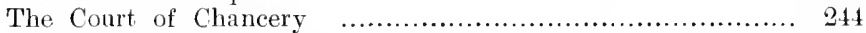

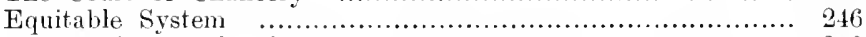

Composition of the Court ....................................... 246

The Appellate Jurisdiction of the Council ........................ 247

The Court of Admiralty .......................................... 247

Origin of the Court ............................................ 247

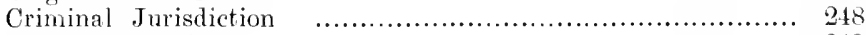

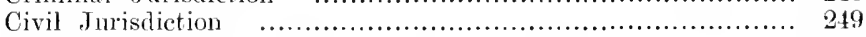

Admiralty Appeals .............................................. 250

Colonial Admiralty Courts ....................................... 250

The Ecclesiastical Courts .......................................... 250)

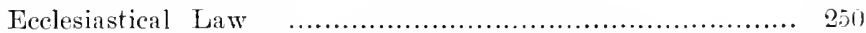

Separation of the Secular and Ecclesiastical Courts .............. 251

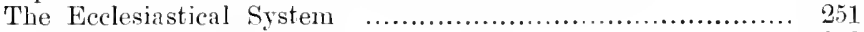

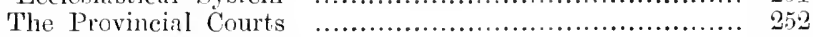

The Prerogative Conrts ..................................... 252

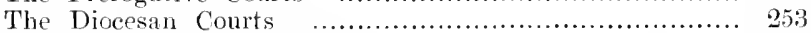

Peculiar Courts .............................................. 254

The Archdeacon's Court ...................................... 254

The Court of the Rural Dean ................................ 55

The Court of High Commission ............................. 254

The Court of Delegates .................................... 255

Jurisdiction of the Ecclesiastical Courts ........................ 255

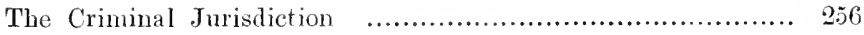




\section{Chapter III.}

JUDICIAL INSTITUTIONS FROM EDWARD I. TO THE JUDICATURE ACTS (eontinued).

\section{The Assizes}

Generally

The Commissions of Assize ....................................... 260

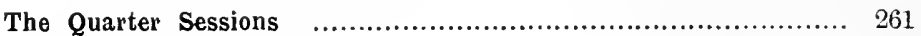

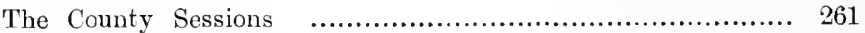

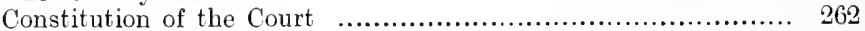

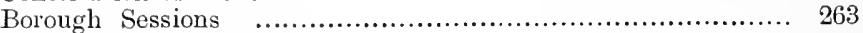

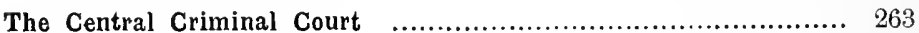

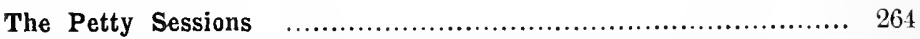

Justices of the Peace ........................................ 264

Qualification of Justices of the Peace ........................... 264

Constitution of the Petty Sessions ........................... 265

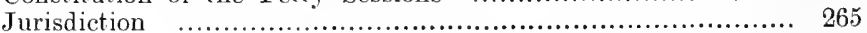

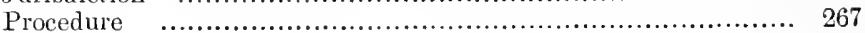

Appeal from Petty Sessions ................................... 267

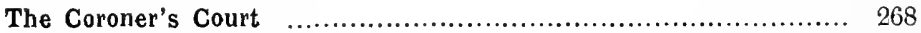

The Metropolitan Police Courts ................................. 270

The County Courts .............................................. 270

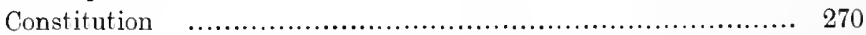

Procedure $\quad$....................................................... 271

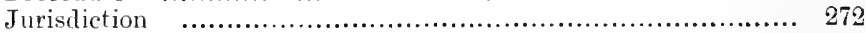

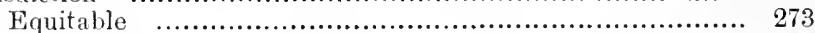

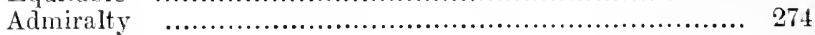

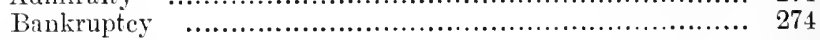

The Mayor's Court ............................................. 27.4

The Court of the Stannaries ........................................ 275

The Courts of the Counties Palatine ................................ 276

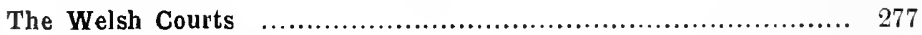

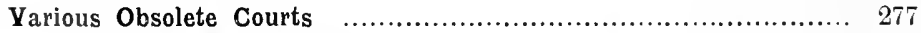

The Law Merchant .............................................. 277

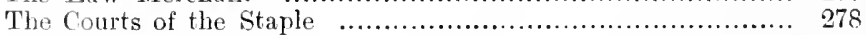

The Court of Pied Poudre ....................................... 279

The Court of Policies of Assurance ................................ 279

The Court of Marshalsea .................................... 279

The Palace Court ............................................ 279

The Court of the Constable and Earl Marshal .................... 280

Procedure in Civil Actions ......................................... 281

Forms of Action ................................................ 281

The Action of Ejectment ......................................... 283

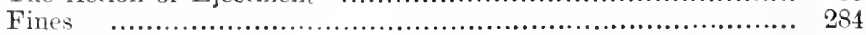

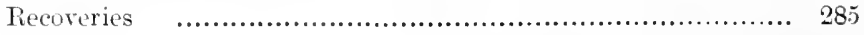


PAGB

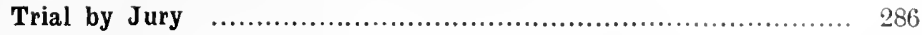

The Civil Jury .................................................. 286

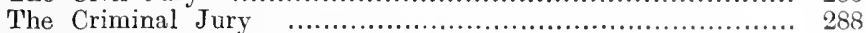

Procedure before and after the Revolution ......................... 289

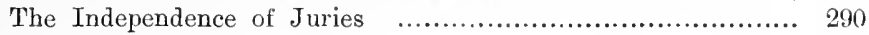

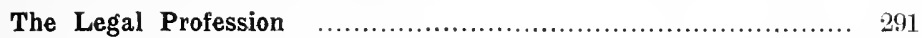

Origin $\quad$............................................................ 291

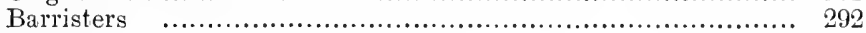

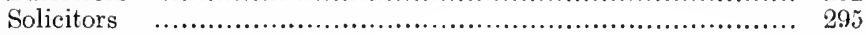

Chapter IV.

CHANGES UNDER THE JUDICATURE ACTS, 1873-1910.

Superior Courts before the Judicature Acts ......................... 298

The Supreme Court of Judicature ................................... 299

His Majesty's High Court of Justice ............................... 299

Constitution $\quad$...................................................... 299

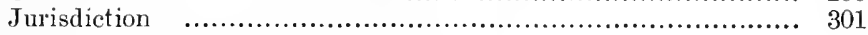

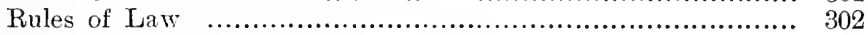

Courts of Appeal before the Judicature Acts ............................ 303

Courts of Appeal since the Judicature Acts ........................... 304

The High Court of Justice as a Court of Appeal .................. 305

The Court of Crown Cases Reserved ............................... 305

The Court of Criminal Appeal .................................... 306

The Court of Appeal . ............................................ 310

The House of Lords ........................................ 313

The Judicial Committee of the Privy Council ................... 314

Part Y.-The Church, the Naxy, and the Army.

\author{
ChAPTER I. \\ THE CHURCH.
}

The Established Church of England ............................ 316

Position before the Reformation ............................... 316

Changes brought about by the Reformation .................. 317

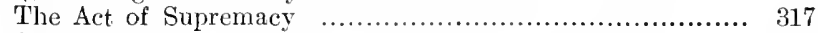

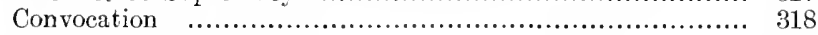

The Thirty-Nine Articles .................................... 320

The Book of Common Prayer ................................. 321

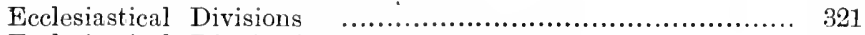

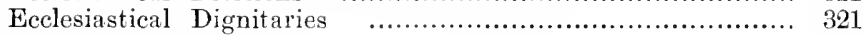

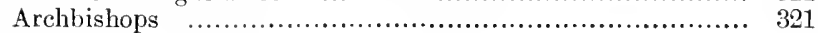

Bishops ................................................... 322 
Arehdeacons

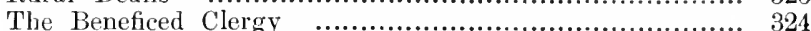

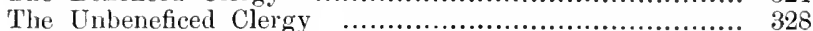

Holy Orders .................................................... 331

Privileges and Disabilities of the Clergy ....................... 332

The Church Assembly ........................................... 333

The Parochial Church Conncil ................................... 334

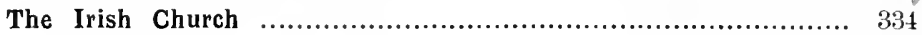

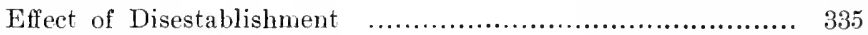

Present Position .................................................. 335

The Church in Scotland ................................................. 336

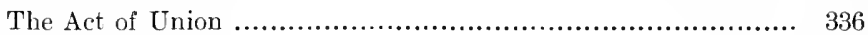

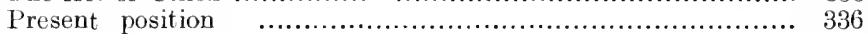

The Church in Wales ........................................... 337

Disestablishment of the Church in Wales and Monmouthshire ... 337

Effect of Disestablishment ................................. 337

Effect of the Welsh Church Act on Ecclesiastical Law ............ 338

Enforcement of Ecclesiastical Law as to property ............... 340

Provisions as to Church Property ................................. 340

The Welsh Commissioners .......................................... 341

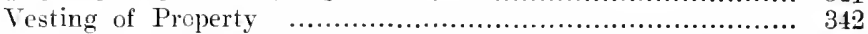

Abolition in Wales of Powers of Ecclesiastical Commissioners and Queen Anne's Bounty .................................... 343

Distribution of Property by the Welsh Commissioners ........... 344

Provisions as to Border Parishes ............................... 346

Application of Property by Welsh Commissioners ............... 347

Preservation of Existing Interests, Compensation, etc. ......... 348

Transfer of Powers of Vestries and Churchwardens .............. 349

Supplemental Provisions ..................................... 349

The Church in the Colonies ..................................... 351

Present position ................................................. 351

Decisions as to Status of Colonial Church ........................ 352

Chapter II.

THE NATY.

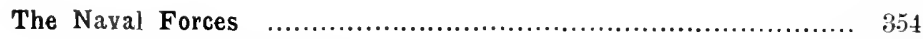

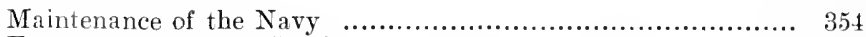

Entry and Term of Service ........................................ 35

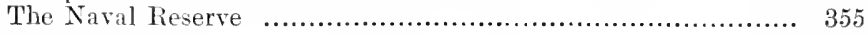

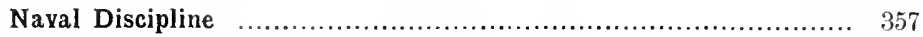

Persons Subject to Naval Discipline Acts ....................... 357

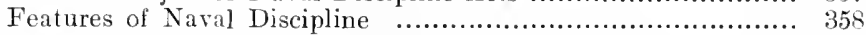

Superior Officers and their Subordinates ............................. 359

Liability of Subordinate for Illegal Acts done under Orders ..... 359

Liability of Superior to Subordinate for Acts done in the Exercise of his Authority 


\section{Chapter III.}

\section{THE REGULAR AND AUXILTARY FORCES.}

The Regular Forces

PAGE

Definition

362

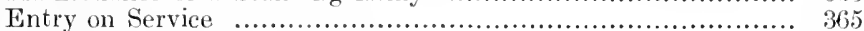

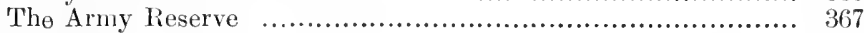

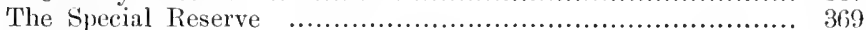

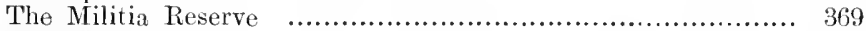

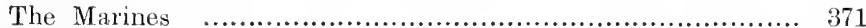

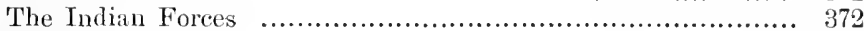

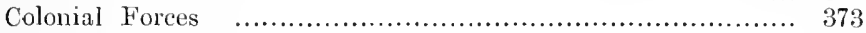

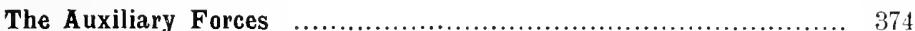

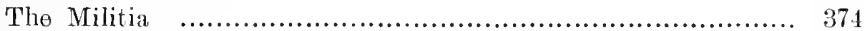

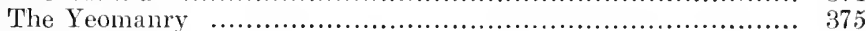

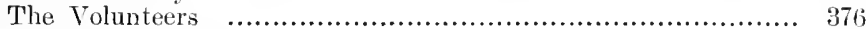

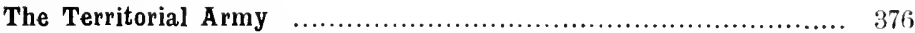

General Nature of Military Law ................................ 382

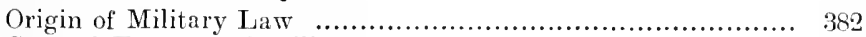

General Features of Military Law ............................. 383

The Judge Adyocate General ...................................... 386

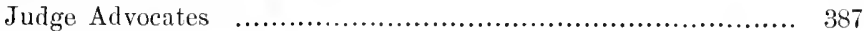

Chapter IV.

THE ROYAL AIR FORCE.

\section{Part VI.-Countries Subject to the Laws of England.}

\section{Chapter I.}

THE UNITED KINGDOM, THE CHANNEL ISLANDS, AND THE ISLE OF MAN.

General Scheme of Local Government in England and Wales ..... 390

The Parish Meeting ................................................. 391

The Parish Council ................................................. 392

Vestries $\quad$........................................................ 399

Rural and Urban District Councils ................................... 395

Borough Councils .................................................... 396

The County Councils ......................................... 397 
County Officials

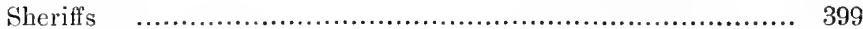

The Lord Lieutenant .............................................. 401

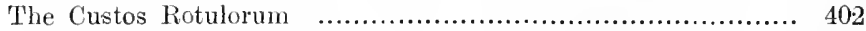

The Clerk of the Peace .......................................... 403

The Chief Constable .............................................. 404

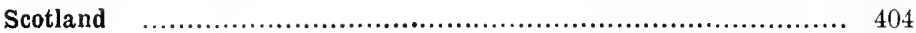

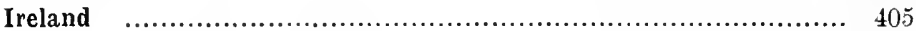

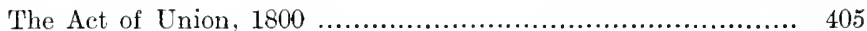

The Government of Ireland Acts, 1914 and 1920 ............. 407

The Irish Free State (Agreement) Act, 1922 ................ 408

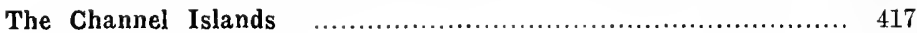

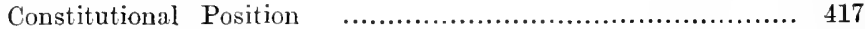

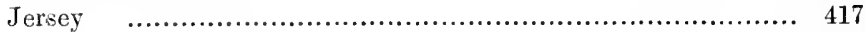

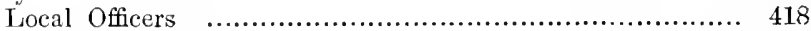

Courts and Laws ........................................... 419

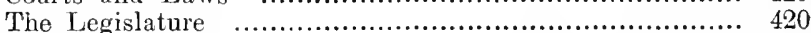

Guernsey $\quad$......................................................... 420

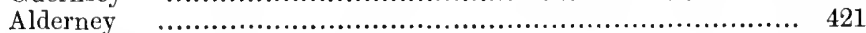

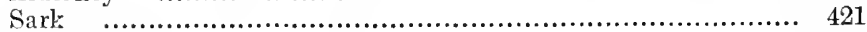

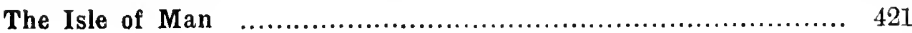

Chapter II.

THE COLONIES.

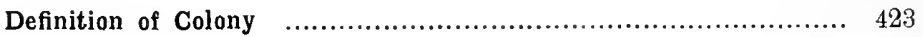

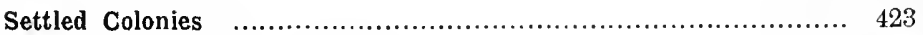

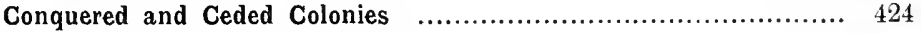

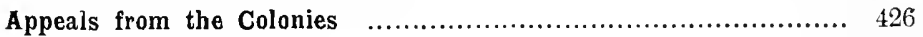

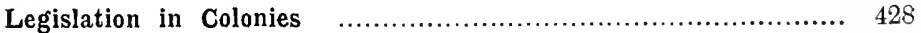

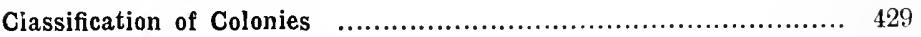

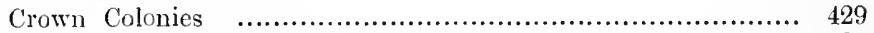

Group I. ............................................ 429

Group II. .............................................. 429

Colonies with Representative Governments ..................... 431

Group III. ........................................... 431

Colonies with Representative and Responsible Crovernments ... 432 Group IV. .............................................. 432

Privileges of Colonial Parliaments ........................... 434

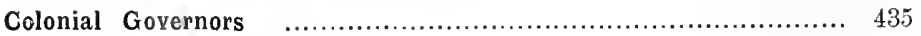

Constitutional Position ....................................... 435

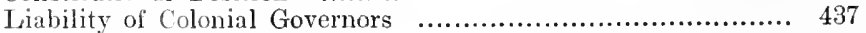

Powers and Duties ............................................. 439

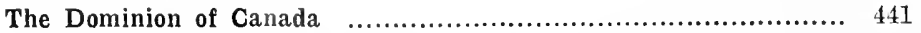

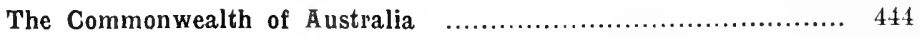

The Former Transyaal and Orange River Colonies .............. 447

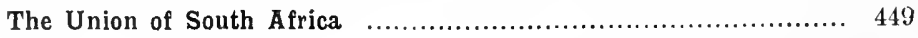


Chap'TER IIT.

THE INDIAN EMPJRE.

History of British Sovereignty in India ............................ 452

Present Constitution ............................................... 458

The Secretary of State for India .............................. 154

The Council of India .......................................... 454

The Governor-General in Council .............................. 455

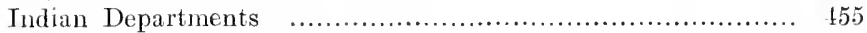

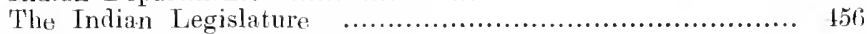

Local Governments in India ................................... 457

'The Judiciary and Indian Isims .............................. 458

The Indian Civil Service ........................................ 459

Dependent Native States ....................................... 160

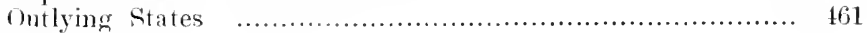

\section{Citap'TER IV.}

PROTECTORATES AND MIRCELLANEOUS POSSESSIONS.

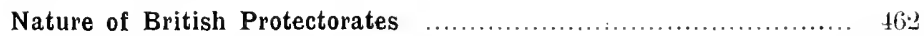

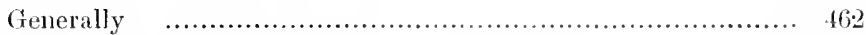

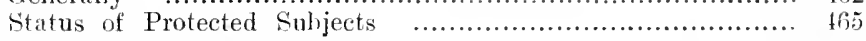

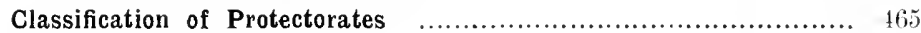

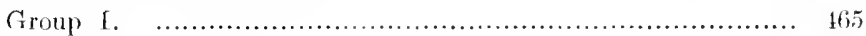

Group II. .................................................... 467

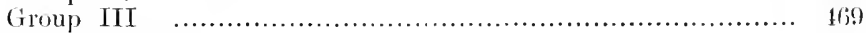

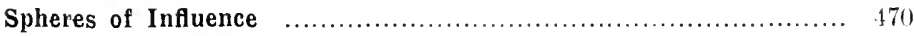

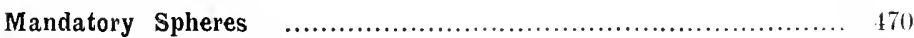

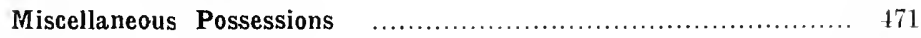

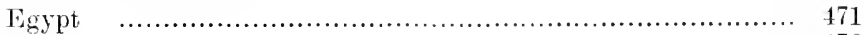

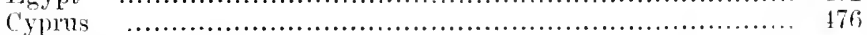

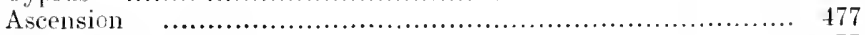

'Jristan Da Cunha ............................................ 177

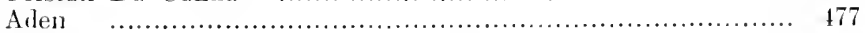

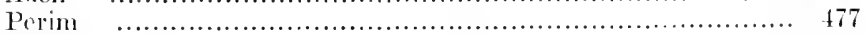

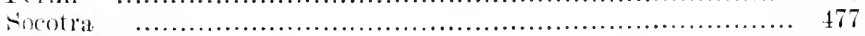

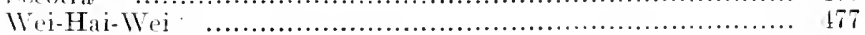

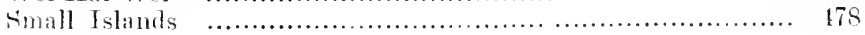

\section{IPPIETIS I.}


xxii TABLE OF CONTENTS.

APPENDIX B.

THE CROWN IN FOREIGN RELATIONS

APPENDIX C.

STATUTORY PROVISIONS FOR THE PREVENTION OF

SEDITION, ETC.

\section{APPENDIS D.}

THE LEAGUE OF NATIONS 517

INDEX

521 


\section{CONSTITUTIONAL LAW OF ENGLAND}

\section{Part I.-The Nature and Sources of English Constitutional Law.}

\section{Chapter I.}

\section{THE SOURCES OF ENGLISH CONSTITUTIONAI LAW.}

Laws Prcper and Conventions.-Unlike that of many foreign nations, for example, Switzerland or the United States, the laws of the English Constitution are not to be found in any written document, nor were they drawn up by any particular set of men and imposed upon the nation at any particular date. Rather they are the result of continuous growth, and many of the principles which lie at the root of the Constitution have not been accepted without fierce national strife, whilst others are still imperfectly defined.

The English Constitution as we find it to-day is, in fact, the product of a gradual develepment, and it would not be reasonable to suppose that the final stage of that development has been reached, but rather that it will go on growing and expanding with the ever-widening circles of national and imperial life.

It is this flexibility, and, in some sense, this ragueness of our Constitution, which has excited the wonder of foreign nations, whose constitutions, being contained in written documents, are for the most part fixed and rigid; and it is this flexibility and vagueness which form perhaps its chief excellence, for a constitution which, possibly without violent national unheaval, is capable of adapting itself to new national exigencies, or the changes brought about by the general progress of civilization, must possess many advan-

$$
\text { C.L.E. }
$$


tages over a constitution whose rules and laws are fixed, or only changeable by means of lengthy processes, or violent upheavals. Constitutional law includes " all rules which directly or indirectly affect the distribution or the exercise of the sovereign power in the State" $(a)$, and these rules are of two sorts:-

a. Laws which are observed and enforced by the courts (Constitutional Law proper).

b. Conventions or understandings which are not enforced by the courts, but which, through continual usage, have obtained nearly the force of law.

1. Laws Proper.-The first of these heads includes-

(1) Statutes. These affect a variety of subjects, such as the qualification of electors and of members of Parliament, the distribution of seats and the manner in which elections are to be held. Many of the executive functions of the Crown are exercised by virtue of statutory authority, e.g. the administration of the Coinage, the Foreign Jurisdiction, or the Extradition Acts. The succession to the Crown itself is now governed by statute $(b)$; in fact, there is no branch of constitutional law which is not affected by statute.

(2) Quasi-Statutes. These are not so much legislative enactments as solemn compacts made between the Crown and Parliament defining constitutional principles, and as such they approach more nearly to the general declarations of popular liberties which are usually found in the written constitutions of foreign nations, and they mark the result of the great national and constitutional crises in English history. The principal of these great constitutional landmarks are Magna Carta, $1215(\mathrm{c})$; the Petition of Right, 1628 (d); the Bill of Rights, $1688(e)$; and the Act of Settlement, $1700(f)$.

(a) Dicey, p. 22.

(b) Viz. The Aet of Settlement, 1700 (12 \& 13 Will. III. c. 2).

(c) See Stubbs' Select Charters, 288.

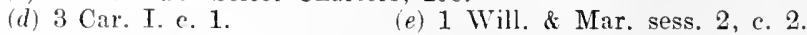

(f) 12 \& 13 Will. III. c. 2. For a short account of these important documents see post, p. 6 . 
TIIE SOLRCES OF ENGLISII CONSTITCTIONAL I.AW.

(3) The Common Law, viz. precedents and customs established by immemorial usage. The Crown's prerogative is by virtue of the common law.

(4) Treaties or Quasi-Treaties; $e . g$. the Acts of Union with Scotland and Ireland.

(5) Judicial decisions, e.g. Howell's Case (g), 1678, establishing the immunity of judges; Bushell's Case (h), 1670 , establishing the independence of juries.

(6) Opinions of the Law Officers of the Crown (the Attorney and Solicitor-General) on questions put to them by Ministers or Govermment Departments (i).

2. Conventions.-Under the second head of Conventions or Understandings are to be found many of the rules which govern the relations existing between the component parts of the sovereign power itself, and their nature and importance may best be illustrated by a few examples of some of the principal conventions generally recognised and acted upon by politicians (k).

Examples of Conventions.-As examples of conventions we may cite the following:-

(1) Parliament must be convolied at least once a year.

(2) A Ministry who have lost the confidence of the House of Commons must retire from office.

(3) The House of Lords must ultimately give way to the House of Commons in matters of legislation.

(4) The Crown must assent to any bill passed by the two Houses of Parliament. The House of Lords does not originate money bills.

(5) A Ministry which is outvoted in the House of Commons on a vital question is bound to retire from office or appeal to the electorate.

(6) If an appeal to the electorate goes against the Ministry, they will be bound eventually to retire, though in some instances they have awaited an adverse rote in the new House of Commons.

(g) Hammond v. Howell, 2 Mod. 219.

(h) (1670) 6 St. 'Tri. 999; Vaugh. 135.

(i) See Forsyth, Cases and Opinions on Constitutional Law.

(k) The whole Cabinet system rests upon Convention, but this will be fully discussed later (see post, Part III., Chap. II.). 
(7) The Cabinet are collectively responsible to Parlianent for the conduct of the executive, and for appointments made by the Crown on the advice of the Cabinet.

(8) The party who command the majority in the House of Commons are entitled to have their leaders placed in office.

(9) The most influential of these leaders ought to be the Premier, and he has the right of nominating his colleagues.

(10) The foreign policy of the country ought to be conducter according to the wishes of Parliament.

(11) Declaration of war or peace against the will of the House of Commons is unconstitutional. In cases of sudden emergency ( $\ell . g$. insurrection or invasion), if the Ministry require additional authority, they should convene Parliament.

Nature of Conventions.-Looking at these conventions we find that they are mostly rules for determining the manner in which what is known as the "discretionary prerogative of the Crown" (viz. the authority which the Crown can exercise without immediate Parliamentary sanction) is to be exercised. They are, in fact, for the most part rules formulated by politicians since the Revolution of 1688 , as the only practical means of securing the harmonious co-operation of the three parties to the government of the country-the Crown, the Lords, and the Commons-and this is done by ensuring that the discretionary authority of the Crown shall be exercised in a manner conformable to the wishes of the House of Commons, as the predominant power in the State, and therefore in a manner conformable ultimately to the wishes of the electorate.

This ultimate power of the electorate is not recognized by the courts, which acknowledge the sovereignty of Parliament alone, and the electorate must express its wishes through Parliament in the shape of legislation before the courts will take notice of them. But none the less is it a power which underlies and, we may almost say, dominates the Constitution, to such an extent must its influence be felt and submitted to by all politicians who would act constitutionally. 
That conformability to the wishes of the electorate is ultimately the true ratio decidendi as to whether a certain course is constitutional or the reverse, comes out rery clearly from a consideration of the cases in which the Crown las acted in opposition to the wishes of the House of Commons in dismissing a Ministry which possessed the confidence of the House. In 1784 and 1807 George III. dismissed Ministers who still possessed the confilence of the House, and in both cases the electorate confirmed this course by returning a majority pledged to support the Crown's nominee. In 1834, on the other hand, when William IV. called Peel to office against the wishes of the Honse, upon a dissolution the electorate refused to confirm the Crown's action. In such cases it has become recognized that the test of constitutionality in adopting such a course lies in whether or not there are good grounds for the Crorn to believe that the wishes of the electorate are opposed to the wishes of the House. If there are good grounds for such a belief, then the Crown would be acting constitutionally in opposing the wishes of the House, though it would not be acting constitutionally by attempting merely to assert its own arbitrary authority in opposition to the authority of the House. This ultimate predominance of the wishes of the electorate is expressed by saying that whilst Parliament alone is the legal sovereign, the electorate is the political sovereign.

Sanction of Conventions. - What, then, it may be asked, is the sanction of conventions, or the power which enforces their observance? The fear of impeachment is dormant, or perhaps partially obsolete, whilst the force of public opinion is a partial but not a sufficient answer. The problem is solved by a consideration of what might occur if they were not observed. If the Ministers of the Crown persisted to act in direct opposition to the will of the House of Commons, the House could, by refusing to pass the annual Army or Appropriation Acts, drive them, if they continued in office, into a course of illegal action which must eventually bring them into opposition with the courts. The courts are no longer subservient to the Crown, since the judges, though appointed by the Crown, are, by the terms of the Act of 
Settlement (l), dismissible only on an address from the two Houses of Parliament. It is easy to foresee that the courts would not support the Ministry in any illegal measures; the Ministry would thus be forced to resign, or the gorernment of the country would come to a standstill.

The force of the law, then, is the sanction upon which the observance of conventions ultimately depends, and this is what is meant when it is said that conventions are ultimately dependent upon the law of the land.

\section{Comstitutional Landmartis.}

The four great statutory landmarks of the English Constitution are Magna Carta (1215), the Petition of Right (1628), the Bill of Rights (1688), and the Act of Settlement (1700).

Magna Carta.-On June 15, 1215, the barons, who had renounced their allegiance and taken up arms in order to enforce a settlement of their grievances, met King John at Rumnymede, and presented articles containing an ontline of the concessions required. The King accepted the terms contained in the articles, and executed the Great Charter in which those terms were embodied upon the same day $(m)$.

The principal provisions of the Charter were as follows :-

(1) Heirs were to enter upon their possessions upon payment of the customary relief, and infants upon coming of age were not to pay either relief or fines.

(2) Land was not to be taken in execution. for debt if sufficient chattels were to be found.

(3) No scutage or aid was to be imposed without the consent of the Commune Concilimm (Parliament), except the three customary feudal aids.

(4) The City of London was to enjoy its ancient customs and liberties.

(5) To the Commune Concilium, to be held for the purpose of assessing aids and seutages, were to be smmmoned the following persons: (1) Archbishops, bishops, abbots, earls, and greater barons by individual writ;

(l) $12 \& 13$ Will. III. c. 2. s. 3 ; and see $38 \& 39$ Tict. c. 77, s. 5 .

(m) For the Articles of the Charter itself see Statutes of the Realm, pp. 6-13. Stubbs' Sel. Chart., pp. 281-298. 
(2) all tenants in capite by general writ addressed to the sheriff.

(6) The Common Pleas were not to follow the King's Court, but were to be held in a fixed spot (in aliquo certo loco) $(n)$.

(7) Fines were to be regulated according to the magnitude of the offence, and earls and barons were not to be fined except by their peers.

(8) No sheriff, constable, or coroner, or other officer of the Crown, was to hold pleas of the Crown.

(9) No freeman was to be arrested, imprisoned, put out of his freehold, outlawed, exiled, punished, or put upon in any way except by the lawful judgment of his peers or the law of the land.

(10) Justice was not to be sold or denied to any one, or to be delayed.

(11) Merchants were to be free to enter and leave the kingtom, and to remain there for purposes of buying and selling subject only to the customary tolls.

(12) Justices, constables, sheriffs, and other officer's of the Crown were only to be appointed from upright persons possessing knowledge of the law.

(13) All lands afforested in the reign of King John to be forthwith disafforested.

(14) The forest laws were to be reformed.

(15) On the restitution of peace, all foreign troops to be sent out of the country.

(16) All persons within the realun, whether clergy or laymen, to observe the laws and customs of the land.

(17) Twenty-five barons were to be chosen as representatives of the nation, to see that the terms of the Charter were enforced and observed.

The Petition of Right, 1628 (o).-After reciting the various statutes by which the liberties of the subject had been assured $(p)$, and the various infringements of those statutes

(n) It appears that the places for holding the Common Pleas were fixed from time to time, and that they were not fixed at Westminster immediately after the signing of the Charter. (See Pulling, Order of the Coif, p. 91).

(o) 3 Car. I. c. 1.

(p) The statutes particularly mentioned are the Statutum de Tallagio 
which formed the present subject of grievance, the Petition of light (3) Car. I. (c. 1) humbly prayed His Majesty as follows :-

- (1) That no man should be compelled to make or yield any gift, loan, benevolence, or tax without common consent by Act of Parliament.

(2) That no freeman should be forejudged of life or limb, or imprisoned or detained against the form of the Great Charter and the law of the land.

(3) That soldier's and marines should not henceforward be billeted upon private persons.

(4) That eommissions should not be issued to try persons according to the law martial, as is used by armies in time of war.

To this petition the answer was appended by the King, "Soit droit fait come est desire."

The Bill of Rights, 1688. - The Bill of Rights (1 Will. \& Mar. sess. 2, c. 2), after reciting the rarious ways in which James II. had infringed upon the liberties of the subject, and that, the throne being vacant by the abdication of James II. the Prince of Orange had caused letters to be written summoning such representatives as would ordinarily be elected for Parliament to meet and sit at Westminster, declared as follows:-

(1) That the pretended power of suspending of laws or the execution of laws ly regal authority without consent of Parliament is illegal.

(2) That the pretended power of dispensing with laws or the exceution of laws as it hath been assumed and exercised of late is illegal.

(3) That the commission for erecting the Court of Commissioners for Ecclesiastical Causes and all other commissions and courts of like. nature are illegal and pernicious.

(4) That levring money for or to the use of the Crown by pretence of prerogative without grant of Parliament for longer time or in other manner than the same is or shall be granted is illegal.

non concedendo ( 34 Ed. I. st. 4. c. 1), a statute of 25 Ed. III. against forced loans, Magna Carta, and the $28 \mathrm{Ed}$. III. c. 3. 
(5) That it is the right of the subject to petition the King, and all commitments and prosecutions for such petitioning are illegal.

(6) That the raising or keeping a standing army within the kingdom in time of peace, mless it be with consent of Parliament, is against law.

(7) That the election of members of Parliament ought to be free.

(8) That freedom of speech and debates, or proceedings in Parliament, ought not to be impeached or questioned in any court or place out of Parliament.

(9) Excessive bail ought not to be required, nor excessive fines imposed, nor eruel and unusual punishments inflicted.

(10) That jurors ought to be duly impanelled and returned.

(11) That all grants and promises of fines and forfeitures of particular persons before conviction are illegal and void.

(12) That for redress of all grievances and for the amending, strengthening, and preserving of laws, Parliaments ought to be hald frequently.

The Act further vested the Crown in William and Mary of Orange during their lives and the survivor of them, providing that the regal powers should be only in and exercised by the Prince of Orange during their joint lives. The further limitations were: (1) To the heirs of the body of Mary; (2) to the Princess Anne of Demmark and the heirs of her body; (3) to the heirs of the hody of William (Prince of Orange).

These limitations were made subject to the following provisions :-

(1) That any papist or person marrying a papist should be excluded from inheriting, possessing, or enjoying the Crown.

(2) That every King and Queen should make, subscribe, and repeat the declaration against transubstantiation and certain doctrines of the Roman Chureh contained in the Statute 30 Car. II. st. 2, c. 1.

(3) That no dispensation by non obstante to any statute 
or part thereof should in future be allowed, except in so, far as permitted by Statute $(q)$.

The Act of Settlement, 1700.-In the year 1700, Mary being then dead and William III. in a dying condition, whilst the Princess Anne of Denmark seemed past the age of childbearing, and all her children having predeceased her, it became necessary to extend the limitations of the Crown contained in the Bill of Rights, so as to provide for the devolution of the Crown in the event of their failure, which actually happened on the death of William III. and Anne of Denmark $(r)$.

The Act of Settlement therefore deelared that the Princess Sophia, Electress and Duchess Dowager of Hanover, daughter of the Princess Elizabeth, late Queen of Bohemia, daughter of James I., was to be the next in succession in the Protestant line, to the imperial Crown and dignity of the realms of England, France, and Ireland, with the dominions and territories thereunto belonging, in default of the issue of the Princess Anne of Denmark and of H.M. William III. The further limitation was to the heirs of the body of the Princess Sophia. These limitations were marle subject to the following provisions:-

(1) That any person inheriting the Crown under the Act who should profess the Roman Catholic religion or marry a papist should be subject to the incapacities provided by the Bill of Rights (1 Mill. \& Mar. sess. 2, c. 2).

(2) That persons inheriting the Crown should take the coronation oath provided by the Act for Establishing the Coronation Oath, 1688, 1 Will. i Mar. sess. 1, c. 6 , and subscribe and repeat the declaration against transubstantiation prescribed by the Bill of Rights.

(3) That any person eoming into possession of the Crown under the let should join in communion with the Church of England.

(1) In the following year (1689) an Act of Recornition (2 Will. \& Mar. c. 1) was passed acknowledging the king and queen and legalizing the Acts of the last Parliament.

ir 12 \& 13 Will. III. c. 2 . The Duke of Gloucester, the only surviror of Anne's children, laring died in July, 1700. 
(4) That in case the Crown should come to any person not being a native of England, this nation should not be obliged to engage in any war for the defence of any dominions or territories which do not belong to the Crown of England, without the consent of Parliament.

(5) That no person born outside the United Kingdom (although he be naturalized or made a denizen, except such as are born of English parents) shall be capable to become a Privy Councillor $(s)$ or a nember of either House of Parliament, or to enjoy any office or place of trust either civil or military. or to have any grant of lands from the Crown to himself or to any others in trust for him.

(Now, however, by the Naturalization Act, $1870(t)$, a person naturalized under the Act enjoys all political and other rights, powers and privileges of a natural-born British subject, except when within the limits of his own country, unless he has ceased to be a subject of such country by the laws of the same. The grant of letters of denization by the Crown is not affected by the Act $(u)$. But denizens may now, it seems, take grants of land from the Crown under the Act $(x))$.

(6) That no pardon under the Great Seal should be pleadable to an impeachment by the Commons in Parliament.

(7) Judges' commissions were to be made "quamdiu se bene gesserint"'; but, upon the address of both Houses of Parliament, it should be lawful to remove them.

(s) A naturalized alien, however, can now be a privy councillor: Rex v. Speyer [1916] 2 K. B. 858. The Act of Settlement no longer applies to naturalized persons but continues to apply to persons made denizens by the prerogative of the Crown. $I b$.

(t) 33 \& 34 Vict. $r .14$, s. 7 . This Act is now repealed by 4 \& 5 Geo. V. c. 17, which codifies the pre-existing law, see post, p. 145.

(u) Ib., s. 13 .

(x) $I b .$, s. 2. 
Chapter II.

CIIARCTERISTCS OF EXGLISH CONSTITUTOXAL LAW.

The leading characteristics of the English Constitution arte-

(1) The sovereignty or omnipotence of Parliament.

(2) The right to personal freedom.

(3) 'The equality before the law of all persons of whatever rank or station.

(4) The induction of general principles, which govern the rights of the subject, from judicial decisions in particular cases.

(5) The adoption and observance of conventions in addition to laws proper.

(6) The non-taxation of British-born subjects without adequate representation in Parliament.

\section{(1) The Sorereignty of Parliament.}

The sovereignty or omnipotence of Parliament means that Parliament is the supreme power in the State, and can matie or ummake any law; nor is there any other power in the State capable of overriding, curtailing, or prescribing its authority. Even Parliament itself cannot curtail the powers of subsequent Parliaments, it being a maxim of the common law that "Acts derogatory to the power of subsequent Parliaments bind not" (a), and therefore we see upon our Statute-books the Irish Church Act of 1869 (b) disestablishing the Irish Church, though by the Act of Union, 1800 (c), the maintenance of the Irish Established Church was made a fundamental condition of the Union of the two countries. As instances of the supreme legislative authority of l'arliament, we may cite the Bill of Rights,

(a) Sice Steph. Comm., i. p. 80.

(b) 32 \& 33 Vict. c. 42 .

(c) 39 \& 40 Geo. III. c. 67 . 
$1688(d)$, by which, on the flight of James II., the throne was declared vacant, the Crown conferred upon Williau and Mary, and the succession settled; The Septemnial Aet, $1716(e)$, by which Parliament prolonged its own existence from three to seven years, and the Parliament Act, 191!, by which it curtailed its existence from seven to five years.

It follows, also, from the " omnipotence or sovereignty" of Parliament, that there is no power capable of disregarding or setting aside its enactments. The Crown has no legislative power apart from Parliament if we except that power which it exercises by virtue of the prerogative in legislating by Order in Council for colonies which have no representative institutions of their own, and even this is regulated by statute with regard to settled colonies $(f)$.

The case of Stochdale v. Hansard $(g)$ is instructive as showing that neither House can by its own resolution negative the effect of an Act of Parliament, or make any new law. In that case the House of Commons had authorized Hansard to publish a report which contained a libel upon Stockdale; Stockdale sued Hansard for libel, and the authority of the House of Commons was pleaded in justification. Held that the House of Commons cannot by its own resolution render defamatory matter non-libellous. In consequence of this decision, and in order to render the publishers of Parliamentary reports immune from the consequences of libel, it was necessary to pass an Act in $1840(h)$, providing that a certificate in such cases, signed by the necessary officials, stating that the publication was by order of the House, should operate as a stay of proceedings.

Though Parliament is thus omnipotent, there must be what are termed the external and intermal limits to its power. Externally the power of Parliament is limited by the possibility of resistance to its enactments, either passively, as by the non-payment of rates or taxes by way of protest against any particular measure, of which there have been some

(d) 1 Will. \& Mar. sess. 2, c 2.

(e) 1 Geo. I. st. 2, c. 38 .

(f) See the British Settlements Act, 1889 (50 \& 51 Vict. c. 54).

(g) (1839) 9 A. \& E. 1.

(h) $3 \& 4$ Tict. c. 9 . 
examples, or by active force. But in this connection it must be remembered that under the Treason Act, 1351, the use of force, if it amounts to lerying war against the King in his realn, or to an insurrection accompanied by violence for an object of a public or general nature, constitutes the offence of treason; and that lerying war against the Sovereign within the United Kingdom in order by force or constraint to compel him to change his measures or counsels, or in order to put any force or constraint upon, or in order to intimidate or overawe both Houses or either House of Parliament (which would probably be held to extend to an insurrection for any of the like purposes) constitutes treason felony under the Treason Felony Act, 1848 (i).

The internal limit arises from the inherent character of Parliament itself, as reflecting the moral and intellectual stage of development of the community at large, and the impossibility of its passing measures radically opposed to its own sense of fitness, and therefore ultimately to the sense of fitness of the electorate whom it represents. The power of the British Parliament is also called constituent, that is to say, it has the power of making laws to effect changes in the constitution, and the constitution flexible, which means that as regards the procedure relating to enactment at least, though not, perhaps, as regards public opinion, such laws can be made with the same ease and by exactly the same process as ordinary laws. A non-sovereign law-making body, on the other hand, such as an English railway company, is prescribed in its legislative powers by the terms of the Act by which it is constituted, and though such a company can make or change its bye-laws at pleasure, it can only do so within certain limits, and the courts have the power of deciding as to whether those laws are ultra vires the company or not.

The principal examples of non-sovereign law-making hodies of the present day are the various federal governments such as those of Switzerland, the United States, Canada, or Australia.

Such ferteritions are composed of a group of states who have united together to form a central government, whilst 
the state governments retain certain local powers of legislation and administration. The terms of the constitution are in such cases drawn up in a code assented to by the various states forming the union, and can only be changed by exceptional and usually lengthy processes. In most of them, e.g. Switzerland, the United States, Germany, and Australia, the central legislatures have strictly defined, and the local legislatures undefined, powers. In Canada the reverse is the case, the central legislature having undefined, and the local legislatures defined, powers. In all cases there is some authority which has the power of deciding as to the validity or otherwise of enactments passed by the central or local legislatures, and in most cases this power is given to the federal courts. The characteristics of such forms of constitution compared with our own are, it has been said, rigidity and eonservatism as opposed to flexibility, and ueakness as opposed to strength; though it may be doubted whether a constitutional change cannot be effected under the former with less fear of a national upheaval than under our own; and such weakness, at any rate, is only comparative, for it is safe to say that the central government is stronger to effect the purposes for which it was created than the govermment of any individual state would have been. Another feature of federalism is legalism, or the necessary predominance given to the judiciary in making it the arbiter of the validity of laws enacted by the central or local legislatures. The principles of federation form so important a topic to Englishmen of the present day, that a short account of the constitutions of the principal federal states now existing may not be found out of place. Of Canada, Australia, and the Union of South Africa more will be said presently $(k)$, and it will be sufficient here to refer to the United States and Switzerland.

\section{The American Commommealth.}

The Constitution of the United States is contained in a document containing seren Articles, which was drawn up by a convention of the various states, at that time thirteen

(k) See post, Part TI., Chap. II. 
in number, in 1787. By its terms it was to come into operation when ratified by nine states, and that ratification took place on 21st June, 1788. The remaining four of the original thirteen states gave their assent at various times between 26th July, 1788, and 29th May, 1790, since which latter date thirty-two other states have been admitted to the Union, the last being Utah on 4th January, 1896. Between 1789 and 1870 fifteen Articles of Amendment were proposed by Congress and ratified by the various states. The Constitution of the Commonwealth as set forth in these Articles is briefly as follows.

Congress.-The central legislative power is vested in the President and Congress, which consists of two Houses, the Senate and the House of Representatives.

The Senate.-The senate is composed of two representatives from each state, chosen by their respective state legislatures for six years. The Vice-President of the United states is the President of the Senate, or in his absence a person chosen by the Senate itself. The Senate may propose bills (except money bills), its advice and consent is necessary to the President in the appointment of public officers and the conduct of foreign affairs, and it has the sole power to try impeachments of the President and other public officers, judgment entailing loss of office and disqualification from holding further office under the Government. The Senate is thus an executive comncil as well as a legislative body.

The House of Representatives.-The House of Represcutatives is composed of members elected for two years by the various states in proportion to the size of their populations, but not exceeding one for every 30,000 . It has the sole power of initiating money bills and instituting impeachments before the Senate, and equally with the Senate may initiate bills on other matters.

The assent of both Honses and of the President is required for the passing of a measure, and if the President dissents, the measure is returned to the House which initiated it, and if it is again passed by a majority of twothirds in both Honses, it becomes law.

The Judiciary.--The judicial porrer of the United States, 
or federal judiciary, is rested in the Supreme Court, the judges of which are appointed by the l'resident and hold office during good behaviour. This court has power to try all cases arising under the Constitution, and has original jurisdiction in cases where ambassadors or public officers are concemed, or where any state is a party.

The judiciary of the Commonwealth is thus constituted the sole arbiter of the Constitution, each individual state having a Supreme Court of its own with exclusive jurisdiction in matters not involving the interpretation of United States statutes or falling within the jurisdiction of the Supreme Court of the United States.

Amendments of the Constitution.-Amendments of the Constitution may only be proposed by Congress with the approval of two-thirds of both Houses, or by a convention summoned on the application of two-thirds of the state legislatures. The proposed amendments must subsequently be ratified by at least three-fourths of the state legislatures.

State Legislatures.-The powers of the state legislatures are defined by Article 10 of the Amendments of the Constitution, which enacts that the "powers not delegated to the United States by the constitution, nor prohibited by it to the states, are reserved to the states respectively, or to the people."

The Executive.-The central executive is vested in a President, who is elected together with the Vice-President for four years in the following manner. A number of electors, equal to the whole number of senators and representatives that each state is entitled to send to Congress, are appointed in each state by popular ballot. These electors meet in their several states and give their votes separately for a President and Vice-President. Lists of these votes are then made out and sent to the President of the Senate, who declares the result of the election according to the majority of votes. In case of an equality, the President is chosen by the House of Representatives by ballot, votes being taken by states, the representation of each state having one vote. In case of equality, the VicePresident is chosen by the Senate.

C.L.E. 
The powers of the President are carefully defined. $\mathrm{He}$ is the commander-in-chief of the naval and military forces, has power to grant reprieves and pardons (except in cases of impeachment), and has power with the advice and consent of the Senate to make treaties and appoint the judges, naval and military and certain other public officers. He is further empowered to conrene and, in certain cases, adjourn Congress, and generally see that the laws are faithfully maintained and executed.

The President, subject to the adrice and consent of the Senate, appoints the State ministers, who are the heads of the seven State Departments created br let of Congress, and are known as the Cabinet. He is empowered to require their opinion in writing on matters relating to their various departments, but no responsibility to Congress attaches to the ministers themselves; they are solely responsible to the President, who lias the porrer of dismissal, and who alone is responsible to Cougress for their Acts.

These points may be noted with regard to the American Constitution :- -

(1) The fundamental characteristic amed at by the frimers of the Constitution was the separation of the legislitive, executive, and judicial departments $(l)$. But whilst this is true of the judicature, it is only partially true of the executive and the legislative. It was hoped that the President would be outside of and above the sphere of party politics, but he is in fact the creature of the dominant party, and must necessarily be willing to carry out their policy. Ameriea has, in fact, in the words of Mr. Bryce, " reproduced the English system of executive govermment by a party majority, reproduced it in a more extreme form, because in England the titular head of the State, in whose name administrative acts are done, stands in isolated dignity outside party politics" ( $m$ ).

(2) Objection has been taken to the method of electing the President. Since the electors chosen by any

(b) Sece Bryce, American Commonwealth, i. 25i.

(m) Bryce, i. 25i. 
state are all pledged to vote for the same candidate, the election is practically one of states. It is therefore possible for a I'resident to be elected who might not command a majority in a popular rote over the whole Union. A further objection is the turmoil into which the country is thrown by a Presidential election every four years.

(3) Through the multitule of appointments which are in the hands of the President, he has little time to attend to other matters, and tends to beconce a wire-puller engaged in questions of patronage rather than a great executive officer ( 11 ).

\section{The Suiss C'onfederation.}

The Constitution of Switzerland is somewhat similar to that of the United States. Side by side with a federal government, whose legislative power's are strictly defined, there exists the local legislatures of the various eantons with undefined legislative powers.

The Federal Government consists of (1) a Federal Executive Council composed of seven nembers, elected by both Houses of the Federal Legislative Assembly sitting together in congress, for three years; (2) a Federal Legislative Assembly, consisting of two Houses, viz. the Council of States, composed of two members from each of the twentytwo cantons chosen by the people for varying terms (except in six cantons where they are chosen by the legislature of the canton), and the National Council, composed of members elected for three years by the people in each canton in proportion to their populations, viz. one representative for each 20,000 inhabitants.

The nembers of the Federal Executive Council must not be members of either House of the Federal Legislative Assembly; and though they may speak or introduce measures in either House, they may not rote. The President and Vice-President are nominated annually by the two Houses of the Ferleral Assembly, the President always retaining the control of foreign affairs, the other executive 
offices being distributed annually amongst the members of the Federal Council. The Federal Comeil has, in addition to its executive duties, eertain judicial functions in deciding questions of administrative and constitutional law. Though elected by the Federal Assembly, the members of the Federal Council are not dismissable by that body. In effect, the position of the Federal Couneil may be compared to that of a board of directors in a joint-stock company, which, though nominally under the control of the shareholders, in practice is never interfered with, exeept in cases of gross mismanagement. The federal legislative power is vested in the two Houses of the Federal Assembly, of which the National Couneil is the predominant member, though nominally both Houses are on an equal footing as to originating legislative measures. An appeal on certain questions of administrative law lies from the Federal Council to the Assembly.

The legislative power of the Federal Assembly is limited to eertain defined subjects, and under these powers codes of civil and criminal law have been made. The federul judiciary is composed of nineteen members chosen by the two Houses of the Federal Assembly for six years, and is empowered to determine the validity of laws made by the various cantous, but not by the federal legislature itself. It has no power to try cases of administrative law, for these are reserved for the Federal Couneil with an ultimate appeal to the Federal Assembly. No alteration of the Constitution ean be effected without resorting to the referendum; that is to say, the vote of the citizens as a whole must be taken, and the measure cannot be passed unless both a majority of the citizens and a majority of the eantons are in its farour. Any law passed by the federal legislature may also be submitted to the test of the referendum, and a certain number of citizens may initiate a law, though opposed by the legislature, and submit it to the popular vote.

\section{Differences between the American and Swiss Constitu-} tions.- It will be seen that the main points of difference between the American and Swiss Constitutions are:-

(1) The executive is rested in a President in the United States and a Federal Couneil in Switzerland. 
CHARACTERISTICS OF ENGIASH CONSTITETIONAI, I.AW. 21

(2) In the United States the President is chosen by the Electoral College, composed of elected representatives from each state, whilst in Switzerland the members of the Federal Council are elected by the Federal Assembly.

(3) The Upper House or Council of State in Switzerland has not the same weight in the Constitution as the Senate in the United States, since the consent of the latter is necessary before the President can make treaties or appoint public officers.

(4) Party government, and consequent wire-pulling, exists in an exaggerated form in the United States, whilst in Switzerland it is almost entirely absent. This result, it would seem, follows from the manner in which the executives are appointed in the tro countries, as well as from the fact that in the one case the executive is rested in a President, who appoints the various public officers, and in the other case in a council.

\section{Imperial Federation.}

Requirements for Successful Federation.--The topic of imperial federation occupies so prominent a place in English politics of the present day, that a short consideration of the various schemes which have been proposed to bring about a closer union of the colonies with the mother country may not be out of place in the present volume.

In approaching such a topic it is necessary in the first place to consider the requirements necessary to bring about a successful union of the kind in contemplation. The first requisite is obviously that stated by $\mathrm{Mr}_{\mathrm{r}}$. Dicey, riz. a group of states ready and desirous of forming a union; and this desire and readiness on the part of the rarious states can only be based upon the recognition of mutual advantage, and the firm conviction that a mion is desirable and advantageous for all parties concerned, not necessarily for all purposes and under all circumstances, but at all events, for a certain class of purposes, however narrow the limits of that class. 
The English Standpoint.-In contemplating the idea of a closer union between England and her colonies it is necessary, then, first to discover to what class of subjects it is that the combined control and management implied in any scheme of federation may be applied for the mutual benefit of the whole Empire and of each separate state.

On the part of England, the reason for seeking federation is not far to discover. A country limited in area, and in the extent of its natural resources, must necessarily, at some period of its history, arrive at a stage of development when the limit of expansion and progress within must appear to be within measurable distance of being reached. It may even be that such a country feels the strain of holding her relative position with other countries whom she has hitherto outstripped in power and wealth through more rapid development and keener enterprise, but who are now drawing level with her, and may eventually surpass her, not through any special merit, but through the more tardy but none the less ineritable development of natural resources greater in extent than her own.

To some minds England may seem to be in such a position to-day. With a population far in excess of that which can be supported by her native natural resources, and dependent in great measure upon the successful sale in foreign markets of commodities manufactured from the raw products imported from abroad, she finds herself hedged round with hostile tariffs and possibly losing her ground in the great markets of the world, whilst the growing power and wealth of other mations threaten to overshadow her position in the foremost rank. The need for the encouragement of mutual commerce with the colonies, and for combination in fighting the hostile tariffs of other countries, is one of the objects which draws England towards federation, whilst equally important and equally necessary at the present eonjuncture is the need for combination for purposes of inutual defenee and protection, to enable the Empire to maintain its position in foreign polities.

The Colonial Standpoint. - With the colonies, on the other hand, the neerl for closer union has possibly not presented itself as yet in any very forcible colours, owing to the fact that their natural resources have not been fully exploited, 
and therefore the need for seeking fresh grounds for expansion and the consequent necessity of taking a part in foreign politics has not been felt to any appreciable extent. At the same time the colonies have felt, and will increasingly feel, the harmful results of hostile tariffs upon the prices realized for their raw produce, which at present constitutes the main bulk of their export trade. Further, witl the increase of wealth and prosperity, and the rapid progress of internal development, the colonies are, no doubt, beginning to feel the necessity of taking their place in foreign politics, and to realize the importance in that connection of taking their slare in maintaining adequate naval and military forces for defensive purposes.

Here, then, are two subjects upon which the interests of the colonies and the mother country would obviously be. furthered by working in union; for it is manifest that much saving and economy both to England and the colonies must. result from the joint maintenance and control of one imperial military and naval force for the whole Empire, whilst the actual and moral weight of the whole Empire working in unison in the sphere of foreign politics, and incidently in combating the hostile tariffs of foreign nations, must, of course, vastly exceed that of any individual state, and therefore in the long rum effect more for each individual state than such state could effect for itself by relying on its own resources.

Topics for Federation.-There seems to be some consensus of opinion as to the class of subjects which could properly be entrusted to the joint control of some federal form of government. A list of such subjects would include the following :-

(1) Foreign affairs. *

(2) Naval and military forces and defence.

(3) Intercolonial, home, and foreign trade and commerce.

(4) Imperial finance.

(5) Postal and telegraph services.

(6) Immigration and emigration.

(7) Aliens and naturalization.

(8) Census.

(9) Currency, coinage, and weights and measures. 
(10) Merehant shipping and navigation.

(11) Lighthouses, beacons, buoys, etc.

(12) Sea-fisheries.

(13) Marriage and dirorce.

(14) Patents and eopyrights.

(15) Extractition.

(16) Courts of Appeal.

Prcposed Federal Constitutions.-It being conceded that subjects of such a nature are suitable to be entrusted to the eontrol and regulation of some federal form of government, it remains to consider shortly the various forms of federal constitution which have been proposed at various times $(o)$.

The first and most obvious method is the ereation of an Imperial Parliament and an Imperial Exeeutive composed of representatives of all the various colonies in proportion to their populations and of the mother eountry. Such a federal or imperial Govermment would be analogous to the dominion Govermment in Canada, or the federal Government of the U'nited States.

It would be superior to the Parliament at Westminster, which would take the position of a state legislature, administrative and legislative functions with regard to some or all of the subjeets in the above list being assigned to the Imperial Parliament to the exclusion of the colonial and home legislatures, whilst on other subjects it might have a coneurrent right of legislation or administration with the home and colonial govormment. In any case, laws made by the federal Parliament would be superior to and override laws made by any single eolony or by the home legislature.

A discussion of the arguments for and against such a seheme will not he attempted here, but the general consensus of opinion would seem to be that the time is not ret ripe for any such sweeping alteration of the Constitution, and that federation, if it is to come at all, must proceed by gradual

(o) 'The various forms of federal constitution will be fomd well treated of in a series of five essavs written for the prize competition held under the auspices of the London Chamber of Commerce in 1887 ("England and her Colonies." Swan, Sonnenschein, Lowrey \& Co.). 
stages of development, without any such sudden and drastic changes as the creation of a federal Parliament would entail at the present moment.

An alternative scheme for the creation of a federal Parliament is the inclusion of colonial representatives in both Houses of the present Imperial Parliament at Westminster, that body at the same time being relieved of its duties with regard to matters of purely local interest, such as licensing, edueation, private bill legislation and the like, which are to be handed over to local bodies or a new hone Government. Such a scheme would appear less feasible than the former; for if a federal Parliament is to be created at all, it would obviously be better to create a new bocly with new and certain functions than to attempt to sandwich new representatives and new functions in with the old body and the old functions. Such a scheme, in whatever light it be viewed, must appear of a patch-work nature, and bound to result in a medley of conflicting powers, interests, and duties. Another seheme is that a colonial council of advice should be formed to assist the English Cabinet with regard to matters in which the colonies are interested. Such a council might be formed as a committee of the present Privy Council, colonials of distinction being made members of that body. The weak points of such a scheme would appear to be that a coumeil having, no legislative or executive functions would possess little real weight or authority, whilst it would be almost impossible for the colonial representatives to truly gauge the precise shade of opinion prevailing in their own colonies at any particular moment, so that their advice would necessarily be wanting in weight and authority.

Other schemes have been proposed, such as the creation of a single federal chamber possessing both legislative and executive powers, or executive but no legislative powers; but all such sehemes would seem to be open to the objection that they go beyond the degree of federation which the present state of public opinion both at home and in the colonies would be prepared to admit.

General Conclusions as to Federation.-The conclusions, then, which may be drawn with regard to federation of the 
Empire at the present day with any degree of certainty would seem to be as follows-

(1) Federation to be successful must be built upon a solid recognition by all parties of the mutual advantages to be gained by closer union for certain definite purposes.

(2) No drastic changes in the Constitution such as would be necessitated by the creation of a Federal Parliament would at present be admitted by the state if public feeling at home and in the colonies.

(3) It is becoming recognized that in return for a roice in the foreign poliey of the Empire the colonies should contribute to the cost of Imperial defence.

(4) It is becoming recognized that combination and union in matters of trade, commerce, and tariffs will materially advance the commercial prosperity of the whole Empire collectively and individually, and assist in combating the hostile tariffs of foreign countries.

(5) A voice in foreign polities for the colonies, contribution by the colonies to Imperial defence, and possibly mutual understandings and concessions with regard to trade, commerce, and tariffs, must form the basis of any present scheme of federation.

(6) That the germ of federation is to be found at the prescnt day in the recent conferences with colonial premiers, and the recently constituted Imperial Conference.

(7) That it might be possible for the colonies to appoint accredited agents, similar to the present agentsgeneral, to act as their representatives in matters of foreign policy, Imperial defence, and trade.

(8) That it is contrary to the principles of English liberty that there should be any taxation of the colonies for Imperial or other purposes without adequate representation on the part of the colonies. 
Chapter III.

CHARACTERISTICS OF ENGLISH CONSTITUTIONAL LAW (contimued).

\section{* (2) The Right to Personal Freedom.}

The right to personal freedom means that no man may be punished, imprisoned, or coerced, except for a breach of the law proved in a legal manner before an ordinary tribunal, and this right flows directly from the provisions of Magna Carta, the Petition of Right, and the Bill of Rights $(a)$. The latter enactment, by declaring the Court of High Commission, which James II. had endeavoured to re-establish under the name of the Commissioners for Ecclesiastical Causes, to be illegal, put an end for ever to the attempts of the Crown to set up courts where men might be tried in an uncertain and arbitrary manner, and which had proved such a fertile source of tyranny in the case of the Star Chamber. It is true that at the present day a soldier may be tried and punished by court martial for certain offences, but the jurisdiction of the military courts is strictly limited by statute, and is controlled by the civil courts by means of the writs of prohibition and certiorari. Moreover, the officers who sit upon a court martial, if they exceed their jurisdiction, are liable to indictment at the suit of the party injured for assault, false imprisonment, manslaughter, or murder, and may be sued civilly for damages $(b)$.

Safeguards for Personal Freedom.-The chief safeguard, however, for the liberty of the subject lies in the legal remedies which have been provided in case of its infringement. Of these the remedies by criminal information,

(a) See ante, p. 6.

(b) A discussion as to how far martial law is admitted by the law of England will be found post, p. 29. 
indictment, or a civil action for damages are a means of obtaining redress for an injury already committed; but the principal remedy for false imprisonment or illegal detention of the subject's person is the writ of Habeas Corpus, which, in a proper case, puts an end to the imprisonment or detention itself.

The Writ of Habeas Corpus.-This is an order issuing from the King's Bench upon affidavit, either of the prisoner himself or of some other person, showing probable grounds for supposing that a case of false imprisomment exists. There are various forms of the writ, but the writ of habeas corpus al subjiciendum is the great constitutional remedy for testing the legality of a commitment or of any other form of forcible detention of the person. The writ is addressed to the person in charge of the prisoner, directing him to produce his body before the King's Bench in order that the court may inquire into the reason for his detention. If the cause of his detention is insufficient, the prisoner is entitled to be set at liberty, or released on bail in eases of misdemeanour. In cases of treason or felony, if not admitted to bail, which is at the discretion of the court, the prisoner is kept in custody; but he is entitled to be put on trial at the next sessions unless the delay is occasioned by the inability of witnesses for the prosecution to attend.

The right to the writ existed before 1679 , the date $r \cdot f$ the Habeas Corpus Act $(c)$, by which the procedure is regulated in the case of persons accused of crime. In 1816 the procedure of the Act was extended to persons confined otherwise than on a criminal charge $(d)$. In cases of emergeney, such as serious riot or rebellion, the Habeas Corpus Acts are sometimes suspended by Act of Parliament, as has been done on several occasions (c); but it is usual for Parliment to pass an Act of indemnity for acts done during the suspension $(f)$. Where a writ has been sued out the modern practice is either to move the Divisional Court, or

(c) 31 ('ar. II. c. 2.

(d) 5 ti G(o. III. c. 100.

(e) See 34 Geo. III. c. $54 ; 57$ Geo. III. c. 3; 11 \& 12 Vict. c. 35; 29 a 30 Vict.e. $1 ; 41$ is 45 Tict. c. 4.

(f) For an example of such an Act see 41 Geo. III. c. 66, and see Indemnity Act, 1920 . 
to apply by summons to a King's Bench Division judge sitting in chambers $(g)$.

\section{Martial Law.}

Meaning of Term.-As the state of things prevailing under what is known as martial law forms an exception to the general rule that no man may be punished or imprisoned, except for a breach of the law proved in a legal manner before an ordinary tribunal, it becomes necessary to consider what martial law is, and how far it is admitted by the laws of England.

Prior to the first Mutiny Act $(h)$ the Crown could, by prerogative, exercise martial law in time of war, but not in time of peace (i); and the term " martial law " seems to have been applied alike to what is now known as military law, viz., that code of laws to which the soldier, as distinct from the civilian, is subject for the maintenance of discipline, and which now derires its authority from the Army Annual Acts; and also to the sense in which the term " martial law" is now understood, viz. that authority which is exercised by the military by virtue of the royal prerogative in time of war, insurection, riot, or rebellion, to restore peace or preserve the public safety.

After the passing of the first Mutiny Act, however, and the establishment of a standing army in time of peace on a legal footing, the two terms martial law and military law became distinct, the former being always understood to apply to those exceptional methods which are adopted for the preservation of discipline and order during war or insurrection, and the latter to the code of laws by which discipline is maintained in the Army at all times.

The term martial law itself, as opposed to military law, has been applied to two quite different things: (1) To the common law right of the Crown and its servants, together

(g) Crown Office Rules, 1906, r. 216.

(h) 1 Will. \& Mar. sess. 2, c. 4.

(i) Finlason's Comm. p. iii. n. "But the Mutiny Acts are only necessary to apply in time of peace, those regulations which the Crown may by prerogative apply in time of war, or rebellion which amounts to war.' 
with all citizens, not only to repel force by force, but to dir all such acts as fall within their common law duty in order to restore peace or suppress insurrection, riot, or rebellion. (2) To that state of things which exists when, by virtue r:f the prerogative, the military authorities, in time of war, insurrection, riot, or rebellion, claim the cognizance of certain offences by means of military tribunals to the exclusion of the civil courts; such a state of affairs, namely, as is akin to the French état de siège, which is fully recognized by the Articles of the French Constitution ( $k$, and on the declaration of which, civil jurisdiction is handed over to military tribumals.

Rights at Common Law.-Martial law, in the first of these senses, is fully recognized by English law. All public officers and citizens are entitled to use so much force as is necessary for self-protection or for the suppression of insurrection, riot, or rebellion, even to the extent of taking, human life; but this right is strictly limited by necessity. Further, not only are public officer's and citizens entitled in such cases to use force, but it is their duty to use all the powers which the law allows in order to maintain the king's peace, and for a breach of this duty they will be criminally liable. This is clearly shown in the case of Rex v. Pinney (l), (1832), in which Mr. Pinney, the Mayor of Bristol, was prosecuted for not having done all in his power to suppress the riots which occurred in that city in October, 1831. A person will be criminally liable if, as was said by Littledale, J., in that case, " he has not done all that could reasonably be expected from a man of ordinary prudence, firmness, and activity, under the circumstances in which he was placed" $(m)$. In such circumstances the measure of a man's right to use force is correlative to his duty; he will be criminally liable for acts done in excess of his duty, and, on the other hand, he will be liable for omissions of duty amounting to criminal negligence.

The commands of a superior are no justification for unnecessary or excessive violence, unless the command is not

(b) Rogrer et Sorel, Codes et Lois, p. 436.

(l) (1832) 3 B. \& Ad. 947.

(m) And see the comments of Blackburn, J., thereon in Reg. v. Eyre (Finlatson's Rep., p. 57). 
necessarily or manifestly illegal, though in time of actual war the command of a superior officer night be held an absolute justification for all acts done, whether manifestly illegal or not $(n)$.

The nature of martial law used in this sense is well expressed in an opinion of Edward James, Q.C., and Fitzjames Stephen, Q.C., with reference to the Jamaica insurrection of 1866. Their views are thus summed up $(o)$ :

(1) Martial law is the assumption by the officers of the Crown of absolute power exercised by military force for the suppression of an insurrection and the restoration of order and lawful authority.

(2) The officers of the Crown (scil. all citizens also) are justified in any exertion of physical force, extending to the destruction of life and property to any extent, and in any manner that may be required for this purpose. They are not justified in the use of excessive or cruel means, but are liable civilly and criminally for such excess. They are not justified in inflicting punishment after resistance is suppressed and after the ordinary courts of justice can be reopened $(p)$. Though martial law is in full force, they will be liable (even though an Act of Indemnity has been passed) if they use their power wantonly or without due regard to humanity $(q)$.

(3) The courts martial by which martial law is administered are not, properly speaking, courts martial or courts at all. . . . They are justified with any forms and in any manner, to do whatever is necessary to suppress insurrection, and to restore peace and the authority of the law. They are personally liable for any acts which they may commit in excess of that power, even if they act in strict accordance with the Mutiny Act and Articles of War. We may add that martial law in this sense is fully recognized by

(n) Per Willes, J., in Keighley v. Bell (1866) 4 F. \& F., at p. 790; and see Forsyth, p. 216.

(o) Forsyth, p. 551 .

( $p$ ) See Wolfe Tone's case, where a Habeas Corpus was granted, Wolfe Tone having been sentenced to death by court-martial after the Irish rebellion was over. (1798) 27 St. Tri. 613.

(q) See Wright v. Fitzgerald (1799) 27 St. Tri., p. 765. 
English law, both in Englind and elsewhere; but whether under it prisoners could be sentenced to long terms of imprisonment, unless such sentences are contirmed by Act of Parliament, seems doubtiul $(r)$.

Martial Law by Yirtue of the Prerogative.-With regard to the second sense in which martial law is nsed. namely, that state of things which corresponds to the French $i$ tat de sien. where the military anthorities arrogate to themselves, by rirture of the prerogative, jurisdietion in the case of civilians amd soldiers aljke over certain oftences to the exclusion of the eivil courts. it has been laid down by many anthorities that such al state of things is utterly unlmown to English liw (s).

It must indered be almitted that martial law in this sense has neit heen put in foree in England by virtue of the preroustive, at least since the time of Charles $I$. $(t)$. It has, however. been proclamed in Ireland by statutory authority in 1799 (u). and without statutory authority in 1796, in Jamaiea hy statutory anthority in 1865, in Ceylon by statutory anthority in 18t? and recently during the South Ifrican 11 in in Cipe Colony without statutory anthority.

In those cases where martial law has been proclaimed by statutory autherity. little or no difficulty presents iself; but in those cases where martial law has been proclaimed br the otticess of the Crown without statutory authority, and the military tribunals ateting under the authority of such prexkmations have exereised juristiction orer certain oftences. in some anses, even where the civil courts were still sitting, and have sutenced civilians to death, fines, or teruns of imprisonment, it becomes necessary to consider how far the prerogative of the Crown (it it exists at all) to issute sueh proclamations extends.

\footnotetext{
$r$ See upming of IIr. Serjeant Spankie quoted by Forseth at p. 211. "Comre-natial which contemn to imprisonment and hard labour belie the netesst? under which alone the jurishetion of courts-martial can

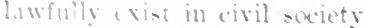

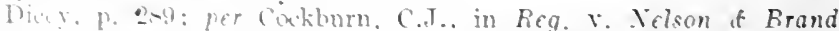

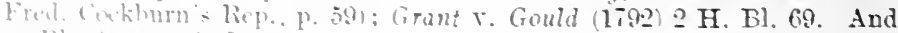

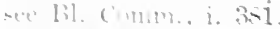

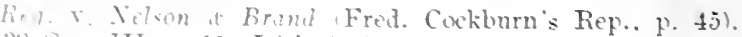

4 3it (ien. III. C. 11 (Irish A.t).
} 
The Patition of kighte (x) dirl not in terns andemm matial law in time of watr, but only in time of peace; lont that, as was sitid by lilatekburn, J., in lieg. v. ligne (y), is a very different thing from sinctioning it. Mr. linlason, however, satys in his emmonentaries (\%), "liut the Mutiny Acts are only necessitry to atuthori\%e the Crown to apply in time of peace those regulations which the Crown may by preregative apply in time of wat or of rebellion, which arrounts to war" ; and in ateecnt case before: the privy Council (a), the Hall of Halsbury, I.C., said, "The framers of the leetition of light knew well what they meant when they mate a condition of poace the glound of the illegality of uneomstitutional procedure."

In the Act of the Jrish Parliament authorizing martial law there is a proviso to the effoct that nothing in that Act contained "shall be construed to take away, abridge, or diminish the acknowlerlged prerogative of His Majesty for the public saffety to resert to the exereise of martial latw against open conemies on traitors" (b) ; and the same proviso is to be found in another statute (c). But although, as was said l.y Cockburn, C.J., in Rerg. v. Nelson \& Brand (d), " so emplatic an opinion of Parliament is certaninly entitled to great and respectlul consideration," still " it camnot prevail against fact and truth if a thorough investigation of the subject should lear to an opposito conclusion... against it maty be set the fact that Parlianent has passed Acts to indemily persons who assisted in carrying martial law into execution."

Ex parte D. H. Marais. The case of ex parte Marais (e) (1902) throws some further light on the subject. Ditvid Francesois Marais was a british subject residing in Cape Colony; on August 15, 1901, he was arresterl and kept in eustody by the chiel constable of the rlistriet under a warrant from the military atubrities, martial law having been pre-
(x) 3 Car. I. c. 1.
(y) Jinlason's Rep., p. 73.
(z) Tinlason's Comm., p. iii. $n$.
(a) F.x parte J. I. Marais. P. C. [1902] A. C. 109.
(b) 39 Gico. III. c. $11,8,6$ (Irish).
(c) 43 Gico. IIf. c. 117.
(d) Fred. Cockburn's Rep., p. 74.
(c) P. C. [1902] A. C. 109.

C.L.E. 
viously proclaimed in the district where he resided in the following terms:- "Notice is hereby given that from and after April 22, 1901, all subjects of his Majesty and all persons residing in Cape Colony, who shall in districts thereof in which martial law prevails (1) be actively in arms against his Majesty, or (2) directly incite others to take up ar'ms, or (3) actively aid or assist the enemy, or (4) commit any overt act by which the safety of his Majesty's forces or subjects is endangered, shall immediately on arrest be tried by a military court convened by authority of the Commander-in-Chief, and sliall on conviction be liable to the severest penalties, including death, penal servitude, imprisonment, and fine; any person reasonably suspected of such offences is liable to be arrested without warrant or sent out of the district to be hereafter dealt with by a military court."

Mr. Marais presented a petition to the Supreme Court of Cape Colony, alleging that his arrest and imprisonment were illegal, and asking to be liberated. Buchanan, J., having refused the application on the grounds that martial law had been proclaimed in the district, that the court ought not to go into the necessity for that proclamation, and that the court could not exercise jurisdiction as long as martial law lasted, Mr. Marais petitioned the Privy Council for special leave to appeal from the order of the Supreme Court, on the grounds, (1) that he had committed no crime; (2) that if he had he should have been arrested and tried according to law; (3) that the civil courts were open for his trial; and (4) that his arrest, deportation, and confinement were illegal. The Privy Council refused leave to appeal. In delivering the reasons on which their Lordships' judgment was founded, the Earl of Halsbury, L.C., said: "The only ground susceptible of argument urged by the learned counsel was, that whereas some of the courts were open it was impossible to apply the ordinary rule that where actual war is raging the civil courts have no jurisdiction to deal with military action, but where acts of war are in question, the military tribumals alone are competent to deal with such questions. . . That question came before the Privy Council as long ago as the year 1830, in Elphin- 
stone v. Bedreechund $(f)$. . Lord Tenterden in giving judgment said, "We think the proper character of the transaction was that of hostile seizure made, if not flagrante, yet nondum cessante bello, regard being had both to the time, the place, and the person, and consequently that the municipal court had no jurisdiction to adjudge upon the subject.'. . Doubtless cases of difficulty arise when the fact of a state of rebellion $\mathrm{Or}^{\circ}$ insurrection is not clearly established. It may often be a question whether a mere riot or disturbance, neither so serious nor so extensive as really to amount to a war at all, has not been treated with an excessive severity, and whether the intervention of the military force was necessary; but once let the fact of actual war be established, and there is an universal consensus of opinion that the civil courts have no jurisdiction to call in question the propriety of the action of military authorities. The framers of the Petition of Right knew well what they meant when they made a condition of peace the ground of the illegality of unconstitutional procedure."

It will be noticed, in the first place, that the regulation by which martial law was proclaimed gave authority to the military tribunals, not only pumish by death or fine, but also by imprisonment.

It must also be noted that Acts were passed by the Cape Parliament $(g)$ to indemnify the Governor and Military Authorities, and all persons acting under them, for "all acts done for the suppression of hostilities, or the establishment and maintenance of good order and government, or for the public safety of the colony." These Acts also confirmed all sentences passed by the military tribunals during the war, and made void all legal proceedings com. menced against the governor or the military authorities.

Further, a commission was appointed $(h)$ under the Royal Sign Manual and Signet to examine into sentences of fine and imprisonment passed by the military courts, with power, where expedient, to remit or reduce such sentences. The powers conferred by the Crown on this commission were subsequently confirmed by the Cape Parliament (i), and the

(f) (1830) 1 Knapp, 316.

(g) No. 6 of 1900, and No. 4 of 1902 (Cape of Good Hope Acts).

(h) Aug. 2, 1902. (i) No. 4 of 1902 , s. 5 (1) (Cape of Good Hope Act). 
commission accordingly sat, and in many cases reduced or remitted sentences.

Conclusions as to Martial Law by Prerogative.-From a consideration, then, of the authorities on martial law in connection with the prerogative $(k)$, the following deductions may be made:-

(1) The Crown's prerogative to declare martial law does not exist in time of peace; its extent in time of war, if it exists at all, has never been judicially determined, but the only excuse for its exercise is the necessity occasioned by an actual state of war, or rebellion or insurrection amounting to war $(l)$.

(2) Its exercise is strictly limited by, and must cease with, the necessity which gave rise to it, and the civil courts will grant a habeas corpus in the case of persons detained in military custody for acts done after the war, insurrection, or rebellion is over (Wolfe Tone's Case) (m).

(3) The extent of the Crown's prerogative being uncertain, the Government would either obtain Parliamentary sanction for its exercise, or Acts of indemnity would be passed.

(4) There seems no reason why, supposing the same necessity to exist, martial law should not be proclaimed in England, as well as in the colonies or Ireland; but in this case the Government would probably be particularly careful to obtain the sanction of Parliament.

(5) Where a state of war actually exists and is recognized by the courts, the latter, even though they may be still sitting for some purposes, have no jurisdiction over the actions of the military authorities (ex parte. Marais). But it seems doubtful whether sentences of fine or imprisonment would be valid without confirmation by Parliament.

(k) And in particular Reg. v. Eyre (Finlason's Rep.); Reg. v. Nelson i Brand (Fred. Cockburn's Rep.); Ex parte D. F. Marais [1902] A. C. 109 .

(l) Per Blackhurn, J., in Reg. v. Eyre, p. 74: "I think this much is settled, that it is by no means that wild nubounded prerogative which some persons lave been saying that it is." (m) (1798) 27 St. Tri. 613. 
Chapter IV.

CHARACTERISTICS OF ENGLISII CONSTITUTIONAL LAW (continued).

(3) The Equatity of all Persons before the Law.

THe equality of all persons before the law means that all persons are subject to the same law, and are subject to the jurisdiction of the same tribunals.

Exceptions to the Rule.-There are a few exceptions to this general rule:-

(1) The Crown is a partial exception, for, under the maxim that the Crown can do no urong, it is exempt from criminal prosecutions, and even for a civil action arising in tort $(a)$. Civil actions also against the Crown or its servants for the recovery of real or personal property (except in particular instances where a different remedy is provided by statute, as under the Crown Private Estates Acts, or the Crown Lands Acts) can only be brought by the particular process of Petition of Pight $(b)$, which is available to the subject in cases of debt, or for damages for breach of contract $(c)$; but this remedy is available as of grace and not as of right $(d)$, and it is not available in actions arising out of tort $(e)$. This prerogative of the Crown, however, forms part of the ordinary common law of the land, and, as such, the extent of the prerogative itself is cognizable by the courts.

(a) Tobin v. Reg. (1864) 16 C. B. (N. S.) 310.

(b) The procedure by Petition of Right is regulated by the Petitions of Right Act, 1860 (23 \& 24 Vict. c. 34).

(c) The damages may be either liquidated or unliquidated, Thomas v. Reg. (1874) L. R. 10 Q. B. 31 ; Att.Gen. v. De Keyser's Hotel [1920] A. C. 508.

(d) $23 \& 24$ Vict. c. 34 , s. 2.

(e) Tobin v. Reg., supra. 
(2) Public Officers.-In Macbeath v. Haldimand (f) it was held that public officers cannot be sued, either personally or in their official capacity, upon contracts made by them in their official capacity; and in such a case the only remedy apparently would be by Petition of Right $(g)$; unless the circumstances of the case make it apparent that they intended to make themselves personally liable $(h)$. This principle applies equally to a Secretary of State as to any other public officer (i). The Lords Commissioners of the Admiralty are, however, in certain cases empowered by statute to sue and to be sued $(k)$, and other government departments may, it seems, sometimes be sued in their corporate capacity (l), and government departments or public officers may be made directly liable in their official capacity by express statutory provisions. In actions of tort, public officers generally are liable to be sued in their personal or individual capacity, and no malice or want of probable cause need be shown $(m)$; though they are not liable apparently in their official capacity, at any rate in cases of trespass $(n)$.

(3) Judgos are exempt for all acts done in their official capacity, whether maliciously or not $(0)$, and this exemption extends to acts done outside their jurisdiction unless they had the knowledge or means of knowledge that the act complained of was outside their jurisdiction $(p)$.

(f) (1786) 1 Term Rep. 172; and see O'Grady v. Cardwell (1872)

20 W. R. 312: Dunn v. Macdonald, C. A. [1897] 1 Q. B. 555.

(g) See Palmer v. Hutchinson (1881) 6 App. Cas. 619.

(h) Samuel Bros., Ltd. v. Whetherly [1907] 1 K. B. 709, 715; [1908]

1 K. B. 184, C. A.

(i) Sce O'Grady v. Carduell, supra.

(7) Sce IVilliams v. Lords Commissioners of the Admiralty (1851) 12 C. B. 420.

(7) See Graham v. Commissioners of Public Works [1901] 2 K. B. 781, per Phillimore, J., 790, 791.

(m) Se Brasyer v. Maclean (1875) L. R. 6 P. C. 398 ; Cobbett v. Grey

(1850) 4 Ex. 729); and see Entick v. Carrington, post, p. 39.

(n) Raleigh v. Goschen [1898] $1 \mathrm{Ch} .73$.

(o) Hamond v. Howell (29 Car. II.), 2 Mod. 219; Anderson v. Gorrie

[1895] 1 Q. B. 670. (p) C'alder v. Halket (1839) 3 Moo. P. C. 28. 
(4) Justices of the Peace are not protected to the same extent as judges, and by Jervis' Act $(q)$ an action lies against them for wrongful acts done maliciously or without reasonable and probable cause within their jurisdiction $(r)$, or for acts done outside their jurisdiction without any such limitation (s). In all! cases, however, for acts done in their official! capacity, justices of the peace, and in certain cases. mayors, constables, and certain other officials $(t)$, are subject to certain special procedure by the same: Act, which provides that the action must be commenced within six months of the offence $(u)$; and it is provided more generally by the Public Authorities Protection Act, 1893, that actions against public officers in respect of acts done, or neglects or defaults, in the execution of Acts of Parliament, or of any public duty or authority, must be commenced within six months of the act or default, or, in the case of continuing injury or damage, within six months after the ceasing thereof $(x)$.

Apart from these exceptions, however, the law is, in general, the same for all. A minister of the Crown cannot plead the orders of the Crown as an exemption from liability for an illegal act $(y)$, and since the Bill of Rights (1688) the Crown can no longer dispense with the provisions of Acts of Parliament in favour of individuals. Moreover, since the Act of Settlement (1700) a pardon by the Crown is no longer a bar to an impeachment in the Commons $(z)$.

The English standpoint is clearly seen in the case of Entick r. Carrington (a), which was an action against the King's messenger for seizing the plaintiff's paper's under the warrant of a Secretary of State, the plitintiff being suspected of being the author of a seditious libel. It was held that the warrant was illegal, and Lord Canden, C.J., said in the course of his judgment, " With respect to the argument of State necessity, or a distinction that has been aimed at between State offences and others, the common law does not

(q) $11 \& 12$ Vict. c. 44.

(s) $I b .$, s. 2 .

(r) Ib.. s. 1 .

(x) 56 \& 57 Vict. c. 61, s. 1.

(u) S. 8.

(z) 12 \& 13 Will. HI. c. 2, s. 3.

(y) Danby's Case, 1679.

(a) 1765) 19 St. Tri. 1067. 
understand that lind of reasoning, nor do our books take any notice of such distinction." Again, a soldier or a policeman cannot plead the orders of his superior officer; they are liable equally with ordinary citizens to be sued for illegal acts, and triable by the same tribunals $(b)$. A soldier, indeed, is in a less favourable position than the ordinary ritizen, for whilst he remains subject civilly to all the liabilities of the ordinary subject, he is subject to further liabilities under military law, and he must run the risk - either of rendering himself civilly liable by obeying the orders of his superior officer's if such orders are clearly and manifestly illegal, or, on the other hand, of committing a military offence and rendering himself liable to be punished by court martial for disobedience to the commands of his superior.

Droit Administratif.-Such a state of things is expressed by saying that there exists in England no such thing as droit administratif, which obtains in certain countries, and more especially in France.

Under that system officials are not liable to be tried by the ordinary civil courts for acts done in their official capacity, but in special conrts created for that purpose, and generally composed of a large proportion of officials. The result of such a system is to create a distinction between offences committed by officials and those committed by ordinary persons, and that distinction is not likely to err on the side of harshess towards the official, whilst the power and dignity of the eivil courts obviously suffer through the withdrawal of such causes from their cognizance. Another result of this system is the necessity for the creation of a tribumal to settle questions of conflicting jurisdiction which must inevitably arise. In France this function is performed by the Tribunal des Conflits, composed of an equal number of ofticials and of the ordinary civil judiciary.

In our own country the doctrine put forward under the Tutors and Stuarts of excluding the prerogative from the cognizance of the courts and the writ de non procedendo

(b) Though he may be sued in all eases for illegal acts, the subordinate wilt not be held liable muless the commands of his superiors were clearly and manifestly illegal. In other cases the superior and not the subordinate is liable. Sre Keighly r. Bell (1866) 1 F. \& F., p. 790. 
Rego inconsulto forms the nearest approach to such a system which history affords. At the present day the only instances at all analogous are the few cases in which government servants are subject to the special methods of procedure referred to above $(c)$. There is no general principle that an official breach of trust is a crime, and although the Official Secrets Acts, 1911 and 1920, provide that certain acts of officials shall be misdemeanours, it is possible, as Mr. Dicey points out, that derelictions of duty by public servants which in other countries would be severely punished, may still in England expose the wrongdoer to no legal punishment.

\section{(4) The Induction of General Principles from Decisions in Particular Cases.}

In the written constitutions of most foreign countries there are usually to be found general declarations of popular liberties relating to such matters as the freedom of the Press, the right of public meeting, and kindred subjects. The law of the English constitution does not, however, contain in distinct tems any recognition of the rights of the subject with regard to such matters, and the general principles governing such questions must be sought for in the judicial decisions pronounced from time to time in individual cases. The importance of such a body of what has been termed judge-made law to our Constitution may well be gathered from the consideration that such vastly important principles as the independence of juries, and the immunity of judges for acts done in their official capacity, were only established by judicial decisions in particular instances. Until 1670 juries might be, and, in fact, frequently were, severely pumished for verticts proved wrong on appeal, or even for a rerdict contrary to the direction of the court.

Bushell's Casc.-In Bushell's Casc, $1670(d)$, a jury had been fined and committed in default by the Recorder of London for having acquitted Penn and Mead, who were charged at the Old Bailey with preaching in a London

(e) See ante, p. 37, et seq. (d) (1670) St. Tri. 999; Vaugh. 135. 
street. A writ of habeas corpus having been applied for, the return was made that the prisoners had been committed for having returned a verdict " against the plain and manifest weight of evidence, and against the direction of the court on a point of law." It was held by Vaughan, C.J., that a jury could not be punished in a criminal case for not finding in accordance with the weight of evidence and the judge's direction.

The immunity of jurors with regard to suits brought against them by persons injured through a wrongful verdict had previously been established in the case of Floyd v. Barker (1607) (e), and it speaks well for the respect paid by Englishmen to the weight and force of judicial precedent, that so important a principle should have become established berond the possibility of question by two isolated decisions.

Howcll's Case.-The decision in Houcll's Case (1678) (f), establishing the immunity of judges, was not less important; this was a suit arising out of Bushell's Case, and was an action for false imprisonment brought against the Recorder by one of the jurors in that case. It was held unanimously by the whole Court of Common Pleas that no action would lie against a judge for wrongful acts done in his judicial capacity.

But it is principally with regard to such questions as freedom of discussion and the right of public meeting that judicial decisions are important at the present day as determining where the rights of the general public begin and where they end: and these questions are of such general importance that a closer consideration of them may not be out of place.

The Right to Freedom of Discussion.-In English law there is no distinct recognition either by the statute or common law of freedom of speech, or of the liberty of the uress and what is meant when it is said that erery Fuglishman las the right to freedom of discussion is simply thisthat erery person is by law permitted to say, write, or publish what he pleases, so long as he does not bring himself 
within the law relating to slander or defamatory libel, or blasphemous, obscene, or seditious words written or spoken.

False defamatory words, if spoken, constitute a slander; if written and published, a libel; and words are defamatory when they are "calculated to convey an imputation on the plaintiff injurious to him in his trade, or holding him up to hatred, contempt, or ridicule" $(g)$. For both slander $(h)$ and libel a person is liable to be mulcted in damages at the suit of the party injured, whilst a libel calculated to create. a breach of the peace is a misdemeanour at common law, punishable by fine and imprisonment on information or indictment. In proceeding by criminal information, the leave of a judge of the King's Bench Division is necessary (i), and in proceeding by indictment against a newspaper, the leave of a judge in chambers $(k)$.

A person may also be proceeded against criminally for libel if the offence falls within certain statutes. By Lord Campbell's Act, 1843 (l), it is a misdemeanour punishable by fine or imprisomment to publish, or to threaten to publish, or to offer to prevent the publication of a libel in order to extort money $(\mathrm{m})$; or to maliciously publish a defamatory libel knowing the same to be false $(n)$, or without knowing the same to be false $(o)$. By the Larceny Act, $1861(p)$, it is a felony to send a letter demanding, money without probable cause $(q)$; or to accuse, or threaten to accuse, another of certain crimes with intent to extort money $(r)$.

(g) Per Lord Blackburn in Capital and Counties Bank v. Henty, H. L. (E.) (1882) 7 App. Cas., p. 771.

(h) In cases of slander it is necessary to prove special damages except in three cases : (1) for words imputing unchastity to a girl or moman. Slander of Women Act, 1891 (54 \& 55 Vict. c. 51); (2) for words imputing crime or contagious or infections disease; (3) for rords disparaging another in the way of his office, profession, or trade.

(i) 4 Will, and Mar. c. 18 , s. 1.

(k) Law of Libel Amendment Act, 1888 (51 \& 52 Vict. c. 64, s. 8).

(l) $6 \& 7$ Vict. e. 96.

(m) $I b$., s. 3 .

(n) S. 4.

(o) S. 5 .

(p) 24 \& 25 Vict. c. 96.

(q) S. 44.

(r) Ss. 46, 47. And see the Corrupt and Illegal Practices Prevention Act, 1895, with regard to publishing false statements of fact in relation to a person's character at an election. 
Besides being defamatory, words may also be blasphemous, seditious, or obscene; and such words, if written and published, or if spoken in the hearing of others, are a misdemeanour at conmon law, punishable by fine or imprisonment on indictment or criminal information.

Blasphemy is the speaking, or writing and publishing of profane words vilifying or ridiculing God, Jesus Christ, the Holy Ghost, the Old and New Testament, or Christianity in general, with intent to shock and insult believers, or to pervert or mislead the ignorant and unwary $(s)$. But it is no longer blasphemy nor contrary to the policy of the law soberly and reverently to examine and question the truth of Christian doctrines $(t)$.

Obscene words are such as are calculated to deprave and corrupt those whose minds are open to such immoral influences, and into whose hands such matter is likely to fall $(u)$.

Seditious words are such as tend to bring into hatred or contempt, or to excite disaffection against the person of his Majesty, his heirs or successors, or the Government and Constitution of the United Kingdom, as by law established, or either House of Parliament. Or to excite his Majesty's suljects to attempt the alteration of any matters in Church or State as by law established otherwise than by lawful means $(x)$; or to raise discontent or disaffection amongst his Majesty's subjects, or to promote feelings of ill-will and hostility between different classes of such subjects $(y)$.

Words, if written and published, may also amount to treason, or treason felony, if they fall within certain statutes $(z)$. Whether defamatory words in any case do cr do not constitute a libel was always a question for the jury to decide, and this rule was extended to criminal cases by

(s) See Odgers' Libel and Slander, p. 463.

(t) Shore v. Wilson $(1842)$ Cl. \& F. 355, at p. 539; and see the judgment of Coleridge, C.J., in Reg. v. Ramsay of Footc (1883) 48 L. T. 733, at p. 739: Bowman v. Secular Society [1917] A. C. 406.

(u) Per Cockburn, C.J., in Reg. v. Hicklin (1868) T. R. 3 Q. B., at 1). 371 .

(.x) 60 Geo. III. \& 1 Geo. IV. c. 8, s. 1 ; R. v. Burns (1886) 16 Cox, 355.

(y) Steph. Dig. of Crim. Law, Art. 93.

(z) 25 Ed. III. c. $2 ; 36$ Geo. III. c. $7 ; 11$ \& 12 Vict. c. 12 , s. 3. 
Fox's I ibel Aet (a). But where the judge is satisfied that the publication eannot be a libel, he is justified in withdrawing it from the cognizanee of the jury $(b)$.

What is meant by the right to freedom of diseussion, then, in England, is that a man may say or publish what he pleases with impunity, so long as he does not fall within the law under the above general outhines $(c)$.

Press Restrictions.- This was not always the case, for during the sixteenth century the Crown elaimed the monopoly of all presses by virtue of the prerogative, and no one could print except by special licence. In 1557 the exelusive right of printing and publishing was thus held by ninetyseven stationers, who formed themselves into the Stationer's' Company, with power to seize all publications by persons not belonging to their guild $(d)$.

In addition to this restriction, the Star Chamber claimed the regulation of all press matters, and press offences were tried by that court without a jury and heavy penalties inflicted. In 1586 a regular system of press censorship was established by the Star Chamber, and no book could be published unless previously read over and licensed by various authorities.

The restriction on the number of printing presses eventually broke down, but the rules as to the licensing of books before publication were made more stringent in 1637, and put upon a statutory basis by the Licensing Aet, $1662(\mathrm{c})$, and this continued until the Act expired in 1693. An attempt was made to renew it in 1695, which was, however, unsuccessful.

A previous licence is therefore no longer required for any publication, but by the Theatres Regulation Act, $1843(f)$, the Lord Chamberlain may forbid the acting or representing of any play or part of a play, for the preservation of good manners, decorm, and of the public peace $(g)$; and by

(a) 32 Geo. III. c. 60 .

(b) Cox v. Lee (1869) L. R. 4 Ex. 284.

(c) As to sedition by aliens, see Aliens Restriction Act, 1919, s. 3 .

(d) See Odgers' Libel and Slander, p. 11 et seq.

(e) 13 \& 14 Car. II. c. 33.

(f) 6 \& 7 Vict. c. 68 , s. 14.

(g) The same Act requires all theatres to be licensed either by the Lord Chamberlain or justices; the powers of the latter whth regard io 
Lord Campbell's Act $(h)$ the magistrates are empor ered to seize all the stock at the publisher's and bookseller's and prevent the further issue of any copies of books proved to be obscene.

Further, the Court of Chancery and the House of Lords oceasionally exercise by injunction the right of restraining the publication of libels amounting to contempt of court, and under special circumstances the courts will grant an injunction restraining the further publication of defamatory libels (i).

The provisions of the $32 \& 33$ Viet. e. $24(k)$ may also be noted, by which every paper or book intended to be published or dispersed must bear upon it the name and address of the printer; and of the Newspaper Libel and Registration Act, $1881(l)$, by which all newspaper proprietors must register their names at Somerset House, with the object of enabling persons libelled to ascertain who is responsible.

The position of the press in England, therefore, at the present day is that any person may publish what he pleases (subject to the regulations noted above) without obtaining any previous licence. He may, however, be proceeded against for libel, and in both eivil and criminal cases he will only be liable where a jury of twelve persons have, by their verdict, declared him guilty of libel.

The Right of Public Meeting.-The right of public meeting, like that of freedom of discussion, is not recognized in terms either by the statute or common law of England. What is meant by the right of public meeting simply amounts to this: that people may meet together when and where they please so long as they do not by so doing commit a trespass or a nuisance, or so long as the meeting does not constitute an unlawful assembly. With regard to trespass, little need be said. It is obvious that even if there be no other place available for the purpose of public meeting,

the licensing of playhouses have now, however, been transferred to the County Councils.

(h) 20 \& 21 Vict. c. 83.

(i) Sce Odgers' Libel and Slander, p. 383.

(k) Re-enacting a similar provision contained in the 2 \& 3 Vict. c. 12, s. 2 .

(I) $41 \& 45$ Vict. e. 60 , s. 9 . 
that fact would not justify the infringement of another's private rights, and all persons who commit a trespass for the purpose of holding a meeting are liable to be mulcted in damages.

With regard to nuisance it may be noted that the law does not recognize any specific locality, such as Trafalgar Square, as being a public forum where people may meet and discuss public questions $(m)$; it is true that the streets are open to the public, but they are to be used by the public for purposes of traffic only, and any one who, by holding a meeting or otherwise, interferes with the right of every individual to use the streets for purposes of traffic, commits a nuisance, which constitutes a misdemeanour for which he may be fined $(n)$.

Any person taking part in an unlawful assembly is guilty rof a misdemeanour for which he may be punished on indictment or criminal information, and an unlawful assembly is one which (1) assembles to commit, or when assembled Ldoes commit, a breach of the peace; (2) assembles to commit a crime; (3) assembles for any purpose, lawful or unlawful, but (through the conduct of those engaged in it, such as carrying arms or the like) in such a manner as to cause reasonable persons to fear that a breach of the peace will be committed $(0)$. All persons may, and must when called upon to do so, assist in dispersing an unlawful assembly; and when a meeting becomes riotous, any amount of force may be used according to the necessity of the case, and it is not necessary that the Riot Act $(p)$ should first be read. The only effect of the reading of the proclamation is that any twelve persons not dispersing within an hour? $0 . k$. of the reading of the proclamation are guilty of a felony.

Magistrates not only may disperse an unlawful assembly, but they are guilty of criminal negligence if they do not malse use of every means in their power to do so $(q)$. That

(m) R. v. Graham (1888) $16 \mathrm{Cox}, 420$.

(n) Ex parte Lewis (1888) 21 Q. B. D. 191.

(o) Reg. v. Neale (1839) 9 Car. \& P. 431.

(p) 1 Geo. I. c. 5 .

(q) As to the duty of a magistrate in suppressing riot see Rex. v. Pinney (1832) 5 Car. \& P. 254; and as to dispersing unlawful assemblies see the judgment of Littledale, J., in Reg. v. Neale (1839) 9 Car. \& P. 431. 
persons, however, who meet to carry out a lawful purpose in a lawful manner do not constitute an unlawful assembly because they may by so doing provoke others to commit a breach of the peace, is shown by the case of Beatty v. Gillbanks $(r)$. In that case the Salvation Army had been in the habit of parading the streets of Weston-super-Mare carrying banners and singing hymns. Their proceedings caused much annoyance to the residents, and a body calling themselves the Skeleton Army had declared their intention of opposing them and breaking up their meetings, and this was well known to the Salvationists, who, however, persisted in holding meetings and processions, with the result that serious tumult and disturbance took place. A public notice signed by two Justices of the Peace was accordingly posted up and served upon Beatty, the leader of the Salvationists, calling upon all persons to abstain from assembling to disturb the public peace. In spite of this notice, however, the Salvationists continued to parade the streets, with the result that Beatty and tro of his companions were arrested and convicted at petty sessions of having taken part in an unlawful assembly. On a case being stated, however, by the magistrates, the Court of King's Bench held that the conviction was wrong on the ground that a man cannot be convicted for doing-a lawful act even though he knows that his doing it may cause another to commit an unlawful act. The recent case of Wise v. Dunning (s) must now be read in comnection with this, which shows that if persons meet to carry out an otherwise lawful purpose in an unlawful manner, such as holding meetings and using language slanderous of Roman Catholies in Liverpool, being a district largely inhabited by persons of that religion, they would be guilty of an unlawful assembly, or at least a magistrate would be justified in binding them orer to keep the peace if there is evidence to warrant the apprehension that a breach of the peace would be committed $(t)$. In

(r) (1882) 9 Q. B. D. 308; and see Reg. V. Justices of Londonderry [18:1] 28 L. R. Ir. 440 , at p. 461.

(s) $[1902] 1$ K. B. 167.

(t) A local Act in force in Liverpool prohibits the use of threatening, abusive, and insulting words or behaviour in the street; but this fact does not appear to have influenced the decision (see the judgment of Dirling, J., at p. 177). 
an older case $(u)$ a constable was held to be justified in taking an orange lily from a lady who was wearing it under such circumstances as to cause tumult and excitement, and to lead to the fear of a breach of the peace being committed. But, as was said by O'Brien, J., in that case, such an extreme case of interference with the private rights of individuals can only be justified by the strongest necessity.

A proclamation by a Secretary of State or by a magistrate cannot make an otherwise lawful assembly unlawful; the only effect of such a proclamation can be to make people thoroughly cognizant of what is likely to oceur, and therefore to militate against their chance of escapiug liability on the ground of non-participation in the event of an unlawful assembly actually taling place and their being charged with the offence $(x)$.

Where, however, a breach of the peace has actually occurred through the attacks of wrongdoers, a meeting perfectly lawful in its inception and in the mamner of its carrying out, may be called upon by magistrates and constables to disperse. But this is only justifiable by necessity, and the constables ought first to arrest the wrongdoers $(y)$.

How far persons who are taking part in a lawful assembly are justified in resisting the efforts of the police or other persons to disperse them seems open to doubt. But, as was pointed out by Wilde, C.J., in Reg. v. Ernest Jones (z), it is obvious that in all cases they are not justified in using extreme measures and must only act in self-defence; their duty is evidently to retreat where possible rather than by standing their ground to cause a breach of the peace, and their proper remedy is an action for damages for assault or false imprisonment.

By the Public Meeting Act, 1908, disorderly conduct at any lawful public meeting is punishable by fine or imprisonment, and in the case of a political meeting is an illegal practice within the Corrupt Practices Act, 1883.

(u) Humpliries v. Connor (1864) Ir. C. L. R. 1.

(x) Rex v. Fursey (1833) 6 Car. \& P. 81.

- (y) See O'Kelley v. Harvey (1882) 14 L. R. Ir. 105.

(z) (1848) 6 St. Tri. (N. S.) 783 ; and see Rex v. Fursey cited above. C.L.E. 


\section{(5) The Adoption and Observance of Conventions in Addition to Laus Proper.}

This is one of the most important of the characteristics of the English Constitution, but as this topia has already been discussed (a), nothing further need be said here.

\section{(6) The Non-taxation of British-born Subjects without Adequate Representation in Parliament.}

This feature of the English Constitution is founded upoin the provision of Magna Carta, by which King. John promised not to levy any aids or scutages, except the three recognized feudal aids, without the consent of Parliament. It forms the great keynote of English liberty, the grand foundationstone of the Constitution, the struggle to establish which has in bygone days occasioned so much bitter strife between the Crown and Parliament; and to the violation of this principle is due the one great blot upon the history of our colonial empire-the loss of the American colonies. The thorougl recognition of this principle by English statesmen of the present day forms the secret of England's success in governing her colonies. For it may be said to be a constitutional maxim, that representative institutions are granted to every colony and dependency as soon as they have reached the necessary stage of advancement. In India and in Crown colonies and protectorates, where the population is mostly native, the principle cannot be said to be non-existent, but rather in abeyance; and when the native mind and character have become, through contact and intercourse with Englishmen, so thoroughly imbued with English sentiment and ideas as to be capable of selfgovernment, it is safe to say that representative institutions will not be withheld.

(a) See ante, p. 3. 


\title{
Part II.--The Legislature and the Public Revenue.
}

\author{
Chapter I.
}

\section{THE MEETING AND TERMination OF PARLIAMENT.}

The Sovereign Power or Government of England eonsists of the legislature, the executive, and the judiciary, and these will now be considered in their order.

Composition of the Legislature.-The legislature consists of the King in Council in Parliament: the three parties necessary to legislation being, (1) the Crown, (2) the Lords Spiritual and Temporal, and (3) the Commons. So the enacting clause at the commencement of each Act of Parliament runs: "Be it enacted by the King's most excellent Majesty, by and with the advice of the Lords Spiritual and Temporal and Commons in this present Parlianent assembled, and by the authority of the same as follows." The composition of Parliament was first marked out by King John in Magna Carta (1215), when he promised not to levy scutages or aids other than the three recognized feudal aids, except with the consent of the Commune Concitium, which was to consist of archbishops, bishops, abbots, earls, and greater barons, who were to be summoned individually by writ, and the tenants in chief, who were to be summoned by general writs addressed to the sheriffs.

Shire representation occurred first in 1254 (a), when four knights were summoned from each shire, and in Simon de Montfor't's Parliament of 1265 we find the first example of distinct representation for shires, cities, and boroughs. This 
method of representation was established by Edward I. in 1295, when the sheriffs were directed to cause to be elected two knights of each shire, two citizens of each eity, and two burgesses of each borough $(b)$. To this Parliament seven earls and forty-one barons were summoned by special writ, whilst the writ to the archbishops and bishops contained the primunientes clause, directing the attendance of the representatives of the chapters and of the parochial clergy. Thus we have the three estates of the realm, the clergy, the baronage, and the commons.

The pramunientes clause is still inserted in the writs addressed to the arehbishops and bishops, but the elergy ceased to attend since the end of the fourteenth century, preferring to meet in their own convocations, where they taxed themselves. In 1664 by a tacit understanding the clergy gave up the right to tax themselves and were included in the general scheme of taxation; in return for this they assumed the right to vote for the return of knights of the shire as freeholders of their glebes, and this right they have continued to exercise ever since, though without any direct statutory authority $(c)$.

\section{The Meeting of Parliament.}

The Summons.-Upon the dissolution of an existing Parliament, which can take place 'either by direct exercisè of the Crown's prerogative, or by effluxion of time, the Crown by virtue of the prerogative summons a new Parliament by proclamation. With regard to statutory authorities ensuring the regular summons and session of Parliament, an old statute of the reign of Edward III. (d) enacts that " a Parliament shall be holden every year once, and more if need be" ; this enactment, however, was more often disregarded than observed, and many years frequently elapsed between the meetings of Parliament. More recent enactments are the 16 Car. II. c. 1, which provides that " the sitting and holding of Parliament shall not be intermitted or discontinued above three jears at the most," and the Triennial

(b) Stubls' Const. Hist., p. 223.

(c) The right of the clergy to vote has, howerer, been assumed by statute to exist; see 10 Anme, c. $23 ; 18$ Geo. II. c. 18 ; and see Phil. Eccl. Law. p. 1538.

(d) 4 Ed. III. c. 14 . 
Act, 1694 (6 Will. \& M. c. 2), which directs that the writs for the summons of a new Parliament shall be issued within three year's of the dissolution of the preceding l'arliament. The principal security, however, at the present day for the regular summons of Parliament does not rest so much upon statutory authority as upon the necessity for passing the Army and other annual Acts, without which the government of the country could not legally be carried on.

The dissolution of one Parliament and the calling of another in its place are now usually announced by proclamation under the Great Seal issued by the Crown on the advice of the Priry Council. The proclamation announces at the same time an Order in Council directing the Lord Chancellors of Great Britain and Ireland respectively to cause the necessary writs to be issued. Writs are accordingly issued by the Crown Otfice to the following persons:-

(a) The spiritual peers.

(b) The temporal peers.

(c) The twenty-eight representative Irish peers.

(d) The judges, the attorney and solicitor-general, and the king's ancient serjeant (when that office is filled).

(e) The returning officers for the election of members of the House of Commons.

The spiritual peers are summoned "on their faith and love," the temporal peers " on their faith and allegiance."

The judges, the attorney and solicitor-general, and the king's ancient serjeant (when that office is filled) are summoned in a subordinate capacity " to attend with us and the rest of our comneil to treat and give your advice" ; but these writs are not issued to the Lords Justices of Appeal, or to those of the judges who are entitled to be summoned as temporal peers. No writs are issued to the Scotch representative peers, who are elected afresh for each Parliament at a meeting of the Scotch peers directed to assemble for that purpose by proclamation (e). The writs to the returning officers are in the form provided by the Ballot Act, $1872(f)$, and are returnable in thirty-five days $(g)$.

(e) 6 Anne, c. $23 ; 14$ \& 15 Vict. c. 100. (f) 35 \& 36 Vict. c. 23. (g) The writs were returnable formerly in forty and then in fifty days, altered to thirty-five days by 15 Vict. c. 23. 
Opening of Parliament.- Upon the day appointed in the proclamation the Sovereign opens Parliament either in person or through five Lords Commissioners appointed under the Great Seal. The Commons, who have been previously summoned to the House of Lords, are directed by the Lord Chaneellor to choose a Speaker; the Commons then retire, elect their Speaker, and adjourn until the following day, when the Speatier is summoned to the House of Lords and submits himself for the approval of the Crown, which is signified by the Lord Chancellor. The Speaker then demands " the ancient and undoubted rights and privileges of the Commons" $(h)$, which are granted, and the Speaker returns to the lower House.

In the case of a new Parliament, before the members of either House are entitled to sit and rote, they must now give evidenee of their title, and take the oath of allegiance.

Evidence of Title.-In the Lords those who have received writs of summons present them at the table of the House.

The Clerk of the Crown delivers a certificate of a return made to him by the lord elerk register of Scotland of the names of the Scoteh representative peers. New peers present their patents to the Lord Chancellor, and these with their wits of summons are read by the Clerk of the House.

In the Commons the Clerk of the Crown in Chaneery delivers to the Clerk of the House a book eontaining the names of members appearing in the returus to the writs issued.

The Parliamentary Oath.-Formerly there were three parts to the Parliamentary oath: (1) the oath of supremacy, repudiating the spiritual or ecclesiastical authority of any foreign prince, person, or prelate. This was imposed upon the Commons in the fifth year of Elizabeth (i). (2) The onth of allegiance, which was imposed upon the Commons in the reign of James $I .(k)$, and in the reign of Charles II. both Lords and Commons were required to take the oaths of supremaey and allegiance at the tables of their respeetive Houses, a declaration against transubstantiation being added at the same time (l). (3) The oath of abjuration, relouncing
(h) As to the'se, see post, p. 63.
(i) 5 Eliz. c. 1, s. 16 .
(k) 7 Jac. I. c. 6.
(l) 30 Car. II. st. 2. 
all adherence to the person (viz. the son of James II.) who since the death of James II., had set up a title to the Crown under the style of James III, was added in the reign of William III. $(\mathrm{m})$.

The penalty imposed for sitting and roting without having. taken these oaths was $£ 500$ for each offence, and disability to hold any oftice or to sit in either House $(n)$. The declaration against transubstantiation and the oath of supremacy prevented Roman Catholies from sitting, whilst the oath of abjuration, terminating with the words "on the faith of a Christian," debarred the Jews. To remedy these evils the Roman Catholic Relief Act, 1829 (o), provided a form of oath to be used by Roman Catholies, and abolished altogether the declaration against transubstantiation. In 1858 a single form of oath for Protestants was substituted for the three oaths of supremacy, allegiance, and abjuration, and the House was emporrered to dispense with the words " on the faith of a Christian" in individual cases $(p)$. By the Parliamentary Oaths Act, $1866(q)$, a single form of oath was provided for persons of all denominations, the words obnoxious to Jews being omitted altogether, and Quakers, Moravians, and other people to whom the taking of an oath of any sort was objectionable were permitted to make an affirmation in the form prescribed. In Bradlaugh's Case (r) it was held by the Court of Appeal that the provisions of the Parliamentary Oaths Act, 1866, with regard to those who had a conscientious ohjection to taking an oath, did not apply to the case of those who had no religious belief at all, and therefore on whom an oath would not be binding. This was remedied by the Oaths ict, $1888(s)$, which provided that "in all places and for all purposes where an oath is required by law, any person stating that he has no religious helief, or that the taking of an oath is contrary to his religions belief, shall he permitted to make a solemn aftirmation."

(m) 13 Will. III. c. 16 .

(n) 1 Geo. I. st. 2 , c. 13 , ss. 7,8 .

(o) 10 Geo. IV. c. 7.

(p) 21 \& 22 Vict. c. 48.

(q) 29 \& 30 Vict. c. 19.

(r) Att.-Gen. v. Bradlaugh, C. A. (1885) 14 Q. B. D. 667.

(s) $51 \& 52$ Vict. c. 46. 
The ordinary Parliamentary oath is now in the forn provided by the 31 \& 32 Vict. c. 72 , and is as follows:-

"I, , do swear that I will be faithful and hear true allegiance to His Majesty King George V., his heirs and successors according to law. So help me God.'

Speech from the Throne.-These preliminaries having been disposed of $(t)$, the business of each session is invariably opened by a speech from the Throne, dealing with the general political situation, and indicating in outline the purposes for which the Parliament has been summoned. The speech is read either by the Sovereign in person, or, if Parliament is opened by commission, by the Lord Chancellor, the Commons having been in the one case commanded, or, in the other case desired, to attend at the bar of the House of Lords. The speech deals in outline with the general political outlook, the legislative measures to be introduced during the session, and calls attention to the requirements of the Crown for supplies to carry on the government of the country. The speech having been read, the Commons retire, and in each Houser a bill is read for the first time in order to mark the right of the two Houses to initiate legislation independently of the King's speech. The speech is then read a sceond time in both Houses, and an address, having been settled and approved, is presented to the Sorereign by either House.

\section{The Termination of Parliament.}

The sitting of Parliament may be terminated either by dissolution, prorogation, or adjourmment.

Dissolution. - This brings the life of an existing Parliament to an end, and may be effected in two ways: (1) By an exercise of the Crown's prevogative. If Parliament is sitting, this may be done either in person or by Royal Commission, but the more usual method is first to prorogue Pirliament, which may then be dissolved by proclamation.

(t) At the commencement of a session of an already existing Parliament these preliminaries are not necessary. and the session is opened directly by the speech from the Throne. 
The constitutional moment for the exercise of this prerogative arrives when the Sovereign las reason to suppose that the Parliament, and thus in effect the party which possesses a majority in the House of Commons, no longer enjoys the confidence of the electorate (u).

(2) Effuxion of Time.-The second way in which Parliament may be dissolved is by the natual eftuxion of time. The Triemnial Act, $1694(x)$, limited the life of Parliament to three years, but on the accession of (ieorge $\mathrm{I}$, the country being in an unsettled state, and the prospect of a dissolution appearing likely to promote rebellion, Parliament passed the Septemial Act, $1715(y)$, prolonging its own and the life of future Parliaments to a term of seven years. Now under the provisions of the Parliament Act, 1911 (z), the duration of Parliament is limited to five years. But by the same Act it is provided that measures for extending the duration of Parliament are excluded from the operation of the Act.

It may be that the payment to all umofficial members of Parliament of a salary of $\$ 400$ a year may have the effect of making catch Parliament endure for its full legal duration, or nearly the whole of the five years.

Formerly Parliament was dissolred by the demise of the Crown, but by the Representation of the People Act, 1867 (a), the duration of the existing Parliament is no longer affected by a demise of the Crown. If a demise of the Crown occurs during a dissolution, the preceding Parliament is revived for six months (b).

(u) For instances in which the Crown has called a ministry to office contrary to the wishes of the House of Commons, or dismissed a ministry which still retained the confidence of the House, see ante, p. 5 .

(x) 6 \& 7 Will. \& Mar.c. 2. Previonsly to this the first Triennial Act, 16 Car. I. c. 1, limited the duration of Parliament to three years; but this was repealed in 1664 (16 Car. II. c. 1) as being contrury to the prerogative, the same Act providing that Parliament should be held three years at the furthest from the previous Parliament. The Triemnial Act, 169.4, continued this provision, at the same time limiting the duration to three years.

(y) 1 Geo. I. st. 2, c. 38. This Act received the Royal Assent on the 7th May, 1716, the title stated in the text is that given by the Short Titles Áct, 1896.

(z) 1 \& 2 Geo. T. c. 13, s. 7.

(a) 30 \& 31 Tict. c. 102 , s. 51 (b) 37 Geo. III. c. 127. 
Prorogation.-This terminates a session of Parliament, and is effected by an exercise of the Crown's prerogative, either by the Sovereign in person or by commissioners appointed for that purpose under the Great Seal. A bill which has passed some but not all of its stages at the time of prorogation must begin at its earliest stage in the next session. If it is desired to postpone the date of the meeting of Parliament for not less than fourteen days from the date fixed at the time of prorogation, this is done by proclamation $(c)$.

Adjournment.-This does not put an end to the existence or to a session of Parliament, but postpones the further transaction of business for a specified time, and is effected in either House by resolution.

The Crown has no power to compel either House to adjourn, but where both Houses stand adjourned for more than fourteen days, it can compel their meeting at an earlier date by proclamation $(d)$.

\section{Parliamentary Officials.}

The Speaker of the House of Lords. - The prolocutor or Speaker of the House of Lords is the Lord Chancellor, when that office is filled $(c)$, but in case a vacancy occurs the Lords may choose their own Speaker. In order to officiate as Speaker the Lord Chancellor need not necessarily be a peer, though he almost invariably is so; an instance to the contrary, however, occurring in 1830, in the case of $\mathrm{Mr}$. Broughan $(f)$. The Lord Chancellor as Speaker sits upon the Woolsack, and in his absence his duties are performed by a deputy Speaker.

The duties of the Speaker of the House of Lords are not so extensive as those of the Speaker of the House of Commons; he has no power to rule on points of order, and generally his powers are the same as those of an ordinary member, his duties being confined to merely formal acts, such as signifying the approval of the Crown to the election of the Speaker of the House of Commons, reading the royal speech and messages from the Crown, desiring the attend-

(c) $30 \& 31$ Tict. c. 81 .

(d) 39 \& 40 Geo. III. c. 14, amended by 33 \& 34 Vict. c. 81.

(e) Standing Order No. 9. (f) See May's Parl. Pract., p. 185. 
ance of peers as witnesses, appointing tellers, and putting questions and the like. In addressing the House the Lord Chancellor has precedence by courtesy.

The Speaker of the House of Commons.-This official is appointed at the commencement of a new Parliament, in the manner described above $(g)$, and his office lasts for the whole Parliament. His principal duties are to act as the representative and monthpice of the House collectively upon all occasions, to preserve order in the House and in debates, and to rule upon points of order. He decides whether a bill is or is not a money bill, he admonishes or reprimands members, issues warrants of commitment, and desires the attendance of witnesses. The Speaker puts the questions, and declares the result of a division, and in case of an equality of votes, he has a casting rote, though otherwise he never votes. On entering and leaving the House, and on State occasions, the mace is borne before him by the Serjeant-at-arms as the symbol of his authority.

Other Parliamentary officials are-The Gentleman Usher of the black rod in the House of Lords, who is appointed by the Crown by letters patent. He desires the attendance of the Commons at the opening and proroguing of Parliament, and when the royal assent is given to bills, and executes order of commitment. The clerk of Parliaments in the House of Lords and the clerk of the House of Commons are appointed by letters patent from the Crown; their duties are principally to make entries and lieep the records of either House.

The Serjeants-at-arms in either House are appointed by the Crown by letters patent, they attend the Speakers of either House with the mace, and the Serjeant-at-arms of the House of Commons (whose duties are more extensive than those of the Serjeant-at-arms in the Lords) executes warrants of commitments, brings prisoners to the bar, attends to the service of messages and orders, sees to the withdrawal of strangers, and maintains order in lobbies and passages, together with various other duties $(h)$.

(g) Ante, p. 54.

(h) For the duties of the various officials see May's Parl. Pract., p. 193 et seq. 
Chapter II.

\section{THE HOUSE OF COMMONS.}

The Electorate.

The Present Franchise.-Under the Representation of the People Act, 1918, a man is entitled to be registered as an elector if he is a British subject and of full age and under no legal incapacity. Further, he must have the requisite residence qualification or business premises qualification, that is, he must during the last day of that period be residing or occupying business premises in the constituency and must during the whole of that period have resided or occupied business premises in or near the constituency. The qualifying period is six months, ending January 15 and July 15. "Business premises" means land or other premises of the yearly value of $£ 10$ at least occupied for the purpose of business, profession or trade.

A woman can be registered as an elector if she is thirty years of age, if she is not subject to any legal incapacity, and if she is entitled to be registered as a local gorernment elector as in section 4 mentioned.

A man is entitled to be registered as an elector for a university if he is of full age and not subject to any legal incapacity and has received a degree other than an honorary degree at such university, or, in the ease of Scottish universities, is qualified under section 27 of the Representation of the People (Scotland) Act, 1868. A woman is also entitled to be registered as an elector for a university if she is thirty years of age and would be entitled to be so registered if she were a man (s. 4).

Persons serving on war service are entitled to be registered as clectors for any constituency for which they might have been registered but for such war service, but they camnot be registered in respect of a residence qualification. 
except on making a claim and declaration as in the Act mentioned (s. 5).

Every person on the register is entitled to vote, but no person, whether man or woman, may have more than two rotes, one of which must be a residence vote (s. 8).

A person is not disqualified from voting by reason that he has received poor relief or other alms, nor by reason that he is employed for payment by a candidate at the election so long as the employment is legal (s. 9).

Disqualification.-Certain persons are disqualified from exercising the franchise. These are-

(1) Infants ( 7 \& 8 Will. III. c. 25, s. 7).

(2) All peers, both of the realm and of Parliament, but the incapacity of a peer to vote at an election does not extend to peeresses in their own right $(a)$.

(3) Persons convicted of treason or felony, unless the conviction has been quashed, or unless they have served their sentence or received a pardon (b).

(4) Persons convicted of corrupt practice (other than personation, or aiding, etc., personation) may not vote at an election in the United Kingdom for seven years $(c)$.

(5) Persons convicted of an illegal practice, and candidates or agents who are convicted of illegal payments, employment, or hiring, may not rote at an election in the place where the offence was committed within five years $(d)$.

(6) Aliens, unless naturalized, or unless they have been made denizens by letters patent $(e)$.

(7) Idiots and lunatics, unless the returning officer is satisfied that at the time of voting they are sufficiently compos mentis to discriminate between the candidates and take the oath intelligently $(f)$.
(a) $7 \& 8$ Geo. V. c. 64, s. 9 (5).
(b) 33 \& 34 Vict. c. 23 , s. 2.
(c) 46 \& 47 Vict. c. 51 .
(d) $46 \& 47$ Vict. c. 51 , ss. $10,21$.
(e) 33 \& 34 Vict. c. 14 , s. $2 ; 7$ \& 8 Geo. V. c. 64 , s. 9 (3).
(f) See Heywood on County Elections, 2nd Ed., 260. 
(8) Returning officers, except in the case of an equality of rotes, when they may give a casting vote $(g)$.

Registration.-The registration of parliamentary voters is regulated by the Representation of the People Act, 1918, ss. 11-19. Two registers of electors are prepared in each rear, one in spring and one in autumn (s. 11). Each parliamentary borough and county is a registration area, the registration officer in the former being the town clerk, and in the latter the clerk of the county council (s. 12), and it is their duty to compile the registers (s. 13). An appeal lies to the county court from any decision of the registration officer on any claim or objection, and an appeal on a point of law will lie from the county court to the Court of Appeal (s. 14).

Persons entitled to register as electors may claim to be placed on the absent voter's' list, and the registration officer, if satisfied that the claimant may by reason of his employment be debarred from voting, shall place his name on such list, and the officer is bound to place on such list persons in the Army, Navy, or Air Service. Persons whose names are entered on the list may vote by proxy in certain cases (s. 23 and 10 \& 11 Geo. 5. c. 35).

Even though upon the register, a person's vote is liable to be rejected by the returning officer or disallowed upon an election petition if subject to "some inherent or for the time irremovable quality (e.g. infants and peers) in limself by which he is prohibited by statute or common law from holding the status of a Parliamentary elector" $(h)$. This is not the case if the disqualification is such that objection ought to havo been taken before the revising barrister, $\epsilon . g$. disqualifications on the ground of property, occupation, or the receipt of parochial relief (i).

Elections. - At a general election all polls must be held on one day (s. 21). By the Parliament Qualification of

(g) 35 \& 36 Vict. c. 32 , s. 2.

(h) The construction pliced upon section 7 of the Ballot Act, 1872, in Stoue v. Joliffe (1874) L. R. 9 C. P., at p. 750. Section 7 enacts that every person whose name is upon the register shall be entitled to vate unless "prohibited by any statute, or by the common law of Parliament."

(i) Stowe V. Joliffe, supra. 
Women Act, 1918, a woman ean be eleeted and rote as at member of the House of Commons. A returning officer, if his duties are discharged by the acting returning offieer, ean be a candidate (s. 30). Every candidate for Parliament must deposit $£ 150$ (s. 26). If the candidate is not elected and the number of votes polled by him does not exceed oneeighth of the total votes polled, or one-eighth divided by the number of member's to be elected, the deposit will he forfeited to the Crown, but in any other case the amount will be returned to the candidate, though he cannot in any case recover more than one deposit (s. 27).

The principle of proportional representation is to be applied at contested elections for university constituencies where there are two or more members to be elected, each elector having, one transferable rote. The same prineiple may also be applied to other constituencies at a general election if, and when, a scheme is prepared and approved by Parliament (s. 20); but no such scheme has been yet approved.

\section{Privileges of the House of Commons.}

These may be grouped under two heads. (1) Those demanded of the Crown by the Speaker of the House of Commons at the commeneement of each Parlianent and granted as a matter of course $(k)$. These are-

(a) Freedom from arrest.

(b) Freedom of speech.

(c) The right of aceess to the Crown.

(d) The right of having the most favourable construction placed upon its proceedings.

(2) The second group comprises those not demanded by the Speaker. These are-

(a) The right to provide for the due composition of its own body.

(b) The right to regulate its own proceedings.

(c) The right to exchude stranger's.

(d) The right to prohibit publication of its debates.

(e) The right to enforce observance of its privileges by fine, imprisomment, or expulsion.

(k) The custom of demanding the ancient privileges of the Commons dates from 6 Hen. TIII. See May's Parl. Pract., 10th Ed., p. 57. 
Freedom from Arrest.-This privilege exists during, and for forty days before and after, a session of Parliament $(l)$. Formerly it extended to the servants of nembers also, and in addition no action could be commeneed against a member or his servant during the same period. This proved the souree of great hardship and delay to suitors, and it was finally enacted by the 10 Geo. III. e. 50, s. 4, that any action could be commeneed at any time against members or their servants, that no process was to be stayed by reason of privilege, but the persons of members were to be privileged from arrest and imprisonment. The privilege in favour of members' servants is thus impliedly revolied.

The privilege does not exist in the ease of treason, felony, or breach of the peace; and, in spite of a decision of the Common Pleas in Wilkes' Case (1763) (m), it was resolved by both Houses that the privilege should not extend to seditious libel. In Mr. Long Wellesley's Gase (1831) (n), the committee of privileges decided that it should not extend to cases of eriminal contempt of court.

Freedom of Speech.-This was always elaimed by the House as their aneient light, but was frequently violated under the Tudors and Stuarts by an undue extension of the prerogative. The last instance of direct proceedings against nembers for words spoken in Parliament was Eliot's Case (1629) (o), where judgment in the King's Bench was obtained against Sir John Eliot, Denzil Hollis, and Benjamin Valentine for seditious speeches in Parliament. This judgment was, however, declared to.be illegal and against the privileges of Parliament by a resolution of both Houses, and was subsequently reversed on writ of error by the House of Lords $(p)$. It was finally enaeted by the Bill of Rights $(q)$ " that the freedom of speech and debates or proreedings in Parliament ought not to be impeached or questioned in any place out of Parliament." Since that

(1) Coudy v. Duncombe (1847) 1 Ex. 430: and see Anglo-French Co-operative Society, In re (1840) 14 Ch. D. 533.

(iil) (1763) 19 St. Tri. 982.

(n) Journ. H. of Com., lxxxvi. 701

(o) (16:29) 3 St. Tri. 294.

(p) Journ. H. of Com., ix. 19-25; Journ. H. of Lords, xii. 166, 223.

(i) 1 Will. \& Mar. sess. 2, c. 2. 
enactment the Crown has oceasionally endeavoured to control Parliament by depriving members of some post or office for acting in opposition to its wishes, the last ease occurring in 1764, when General Conway was dismissed from his post as colonel of a regiment in consequence of having opposed Grenville's ministry $(r)$. Since that date the question of outside influence has not arisen, the House itself, however, retaining the right to control undue licenee of speech on the part of its members.

The Right of Access to the Crown. - This right may be exereise by the House collectively through the medium of the Speaker. There is no right of individual aceess as in the case of the House of Lords.

The Right of having the most Fayourable Construction placed upon its Proceedings. - This exists as a matter of courtesy, and is essential, as would be the case between ordinary business partners, to the harmonious co-operation of the Crown in its relations with the other nembers of the legislature.

The Right to provide for its Due Compcsition.-This eonlprises: (a) The right of the Speaker to issue a new writ on a vaeaney occurring during the existence of a Parliament. If in session, the writ is issued in aceordance with the order of the House. If not in session, the procedure is regulated by certain statutes $(s)$.

(b) The right to determine questions as to the legal qualifications of its own members, as in Mitchel's Case (1875), and Michael Davitt's Case (1882), both these persons being disqualified as undergoing sentence in consequence of conviction for felony.

In Mitchel's Case the House declared the seat vacant, but on his being elected a second time they allowed the courts to determine the question, and it was held that the rotes given to Mitchel were thrown away and his opponent at

(r) Anson. i. 149.

(s) See 24 Geo, III. c. $26 ; 21$ \& 22 Tict. c. 110; 26 Vict. c. 20; $46 \& 47$ Vict. c. 52 , s. 83.

C.L.E. 
the election duly elected in consequence $(t)$. In Michael Davitt's Case the House resolved that the election was roid, and a new writ was accordingly issued $(u)$.

(c) 'The right to expel a member although subject to no legal disqualification. In Willes' Case (1769), Wilkes haring been expelled and re-elected, the House passed a resolution declaring his election void, and the member next on the poll duly returned $(x)$. In 1782 the House declared this resolution void, as being subrersive of the rights of the electors, and the proceedings in connection with the election were expunged from the journals $(y)$. The proper course in such a case would therefore be for the House to expel the member a second time, if so disposed.

Formerly the House clained and exercised the right to determine questions of disputed elections, and these were referred first to a committee of privileges and elections, then to a committee of the whole House, and in 1770 to a select committee. In 1868 the trial of disputed elections was handed ovel to the law courts by statute (z), and the election petition having been tried by two judges of the High Court, the result is intimated to the Speaker, who either confirms the election or issues a new writ.

\section{The Right to regulate its own Proceedings.-Within} certain limits either House has the exclusive right to discuss and adjudge matters arising in that House, and, except in the case of a criminal offence, the courts will not interfere.

In the case of Bradliugh v. Gossett (a), the plaintiff complained that, haring been duly elected member for Northampton, the House, by passing a resolution excluding him from the House, had prevented his taking the oath required by the Parliamentary Oaths Act, 1866 (b). $\mathrm{He}_{8}$ asked the court to declare the order of the House to be

(t) Sce Journ. H, of Com., cxxx. 235.

(ii) Ib. cxxxii. 140.

(x) 16 . xxxii. $228-9,385-6,387$.

(y) Ib. xxxviii. 977 .

(z) 31 \& 32 Tict. c. 125 ; and sec 46 \& 47 Vict. c. 51.

(a) (1884) 12 Q. B. D. 271 .

(b) 29 \& 30 Vict. c. 19. 
void, and to restrain the serjeant-at-arms from carrying it into effect. The court held that " the House of Commons has the exclusive power of interpreting the statute so far as the regulation of its own proceedings within its own walls is concemed; and even if that interpietation should be erroneous, the court has no power to interfere with it, directly or indirectly", (c).

Reference may here be made to the closure, the guillotine and suspension. The closure is a device for extinguishing a debate or speech at once. When a member moves that the question be now put and the Speaker or Chairman accepts the motion and it is carried, not less than 100 member's roting in its support, further debate on the subject must cease, but the Speaker may stop the motion if it operates as an abuse of the rules of the House (Ilbert, 113, 271).

The guillotine is a device for curtailing the length of a debate, a definite period being set apart for stages of a bill and for speeches thereon.

Where a member disobeys the Speaker or chairman or deputy chairman in committee or is guilty of obstruction or behaves objectionably, the Speaker or Chairman may be asked to name him. The question of suspension is then put, and if carried the member can be expelled for as long as the rest of the session.

Another device, popularly known as the Kangaroo, enables the Chairman during the debate on a bill in a committee of the whole House to choose the amendments for discussion, and the same power is rested in the Speaker or Chairman at the report stage.

The Right to exclude Strangers. - This right exists for two reasons. (1) That no stranger may be present and counted in a division, as actually occurred on one occasion. (2) In order to prevent outside influence through the speeches and actions of members being reported to the outside world.

Any member who is dissatisfied with the presence of strangers, and taking notice of the same, the Speaker or

(c) Judgment of Stephen, J., at P. 280. 
the Chaiman (if the House is in committee) is bound by a resolution of the House passed in $1875(d)$ to forthwith put the question "that stranger's be ordered to withdraw" ; or the Spealier or Chairman may order their withdrawal at itny time on his own initiative.

Upon a division the question "that strangers withdraw" is put by the Speaker, and carried as a matter of course; the order for withdrawal, however (unless the Speaker or the Chairman otherwise directs), only applying to those. strangers present who oceupy seats below the bar, and not to those present in the galleries $(c)$.

\section{The Right to prohibit Publication of Debates.-Both} Houses have frequently declared by resolution that the. publication of debates constitutes a breach of privilege. This privilege was enforced by the Commons down to 1771, and in such accounts of debates as did appear members were represented under fictitious names. In 1771 the House sent a mossenger to arrest one Miller, a printer of Parliamentary debates; the printer, howerer, gave the messenger into custody for assault, and the Lord Mayor and two aldermen (Wilkes and Oliver) committed him for trial, allowing him bail. Upon this the House caused the entry to be erased from the book of recognizances, and committed the Lord Mayor and two aldermen to the Tower $(f)$. Owing to the fecling aroused, the House has, since that date, waived the right to restrain publication of its debates, which are, however, still permitted upon sufferance only, and in case of wilful misrepresentation the House would still exercise the right to pumish the offender.

In Wrson r. Ifalter (1868) $(g)$, it was held that faithful and fair reports of Parlianentary proccedings, although containing matter disparaging to individuals, is privileged;

(d) The practice is now resulated by Standing Orders, Nos. 88, 89, 90. See standing Orders of the $\mathrm{H}$, of $\mathrm{C}$. 1913. Pub. Business.

(e) Standing Order. No. 89, and see May's Parl. Pract., p. 837. Standing ()rder No. 8 applies to strangers below the bar and in the front Eallery, Lut the provision as to the latter is not usually enforeed.

(f) Sie Miy's Const. Hist., rol. i. 421-427.

(g) (187is) L. R. 4 Q. B. 73. 
though the publication of a particular speech malu fide, with the object of damaging an individual, would not be privileged. Since that decision it has been more generally enacted (44\& 45 Vict. c. 60) that fair and accurate newspaper reports of the proceedings of public meetings, published without malice and for the public benefit, are privileged.

The Right to enforce its Privileges. - This the House may do by admonition, reprimand, commitment to the custody of the serjeant-at-arms or to prison, fine, or expulsion.

The House of Commons (unlike the House of Lords) cannot commit for a fixed term, but only until prorogation or dissolution, when the prisoner would be entitled to his discharge upon writ of habeas corpus.

It was beld in the case of the Sheriff of Middlesex (h) that it is sufficient if the warrant expresses the commitment to be for contempt, and the court will not go behind that to inquire what the contempt actually was. But if the warrant does not profess to be for contempt, but for some other matter, the court would inquire into the legality or otherwise of the commitment (i).

Ashby v. White (k) was an action brought by an elector against a returning officer who had refused to allow his vote, to which he was, in fact, legally entitled. The House of Commons resolved that Ashby was guilty of breach of privilege in having applied to the court for relief rather than to the House of Commons. The Queen's Bench upheld this view, and decided that Ashby had no cause of action; this decision was, however, reversed on writ of error by the House of Lords. A dispute ensued between the two Houses, and in the meantime five other Aylesbury men, having brought similar actions, were committed by

(h) (1840) 11 A. \& E. 273. The Sheriff had been committed by the House for contempt in having levied execution upon Hansard consequent upon the judgment in Stockilale v. Hansard (1839) 9 A. \& E. 1. See also Burdett v. Abbot (1812) 14 East, 1; Reg. v. Paty, 2 Ld. Raym., 1105.

(i) Per Lord Ellenborough, C.J., in Burdett v. Abbot (1812) 14 East, at p. 150 .

(k) 2 Ld. Raym., 938. 
the House of Commons for contempt, and on suing out a writ of habeas corpus, it was held by three judges to one that, the Spealier's warrant having been expressed to commit for contempt, the court could not go behind that and inquire what the contempt was (l). The matter was, however, disposed of by the prorogation of Parliament.

In Stockdule v. Hansard $(m)$ privilege was claimed for libellons matter published by order of the House. It was held that the House could not, by its resolution, alter the law of the land so as to legalize an otherwise illegal act; and further, that a resolution of the House declaring its privilege would not prevent the court from inquiring into the ralidity or otherwise of such privilege $(n)$.

So that, though the House in the past has clamed the right to determine its own privileges, it now seems clearly settled that in a proper case the courts have the power to pronounce on the validity or otherwise of alleged Parliamentary privileges.

Minor Privileges.-The House of Commons also claims certain other minor privileges, such as exemption from attending as witnesses, which is, however, ustually waived (o), and exemption from service as sheriff.

The question of the latter privilege was discussed in 1904 on the nomination of Major Coates, M.P. for Lewisham, as Sheriff for Surrey. It appeared that a resolution of the House of 7 th January, 1689, declared that a writ nominating a member a sheriff was a breach of the privileges of the House, and doubt was expressed by Lord Alverstone, C.J., whether a privilege of the House could be waived. In the result Major Coates' name was placed third on the list on the understanding that the matter would be brought forward in the House at an early date $(l)$.

17) Pey. V. Paty, known as the case of the Men of Aylesbury 12 Ld. Raym. 1115).

(im) (1839) 9 A. त E. 1.

(n) See jurlgment of Lord Denman, C.J., in Stoclidale v. Hansard (1839) 9 A. \& E., pp. 108-148.

(o) Anson, i. 218.

(1) Sice the Times. Nov. 14, 1904, p. 13. 


\section{The Disqualification of Members.}

Among the numerous persons incapable of being elected to or voting in the Commons are aliens $(q)$, bankrupts $(r)$, peers, clergymen, felons, infants, lunatics $(s)$, judges, holders of certain offices, and persons guilty of corrupt. practices $(t)$. The acceptance of an office of profit in some cases not only vacates the seat but also disqualifies the holder from re-election. But by the Re-election of Ministers Act, 1919 (9 Geo. V. c. 2), a member is not to lose his seat by reason of acceptance of an office of profit under the Crown if that office is an office the holder of which is capable of being elected to or voting in the House and if such acceptance has taken place within nine months after the issue of a proclamation summoning a new Parliament. The same Act also provides that where a privy councillor is appointed to be a Minister of the Crown at a salary without any other office being assigned to him he shall not be incapable of being elected to or voting in the Commons, provided that not more than three such Ministers shall sit as members of the House at the same time.

(q) Ante, p. 11.

(r) Bankruptcy Act, 1883, s. 32; Bankruptcy Act, 1914, s. 106.

(s) Lunacy (Vacation of Seats) Act, 1886.

(t) $46 \& 47$ Vict. c. 51. 
Chapter III.

THE HOUSE OF LORDS.

Composition of the House of Lords.

The Honse of Lords is composed of the lords spiritual and temporal, at present (1921) about 725 in number, and these may be dirided into three groups.

(1) Hereditary peers of England or the United Kingdom, who are also hereditary lords of Parliament. These are (a)-

(a) 29 dukes.

(b) 40 marquesses.

(c) 166 earls.

(d) 76 viscounts.

(e) 344 barons.

(2) Hereditary peers who are not hereditary lords of Parliament. These are-

(a) The sixteen representative peers of Scotland.

(b) The twenty-eight representative peer's of Ireland.

(3) Peers and lords of Parliament during life only. These are-

(a) The twenty-six spiritual peers (two arehbishops and twenty-four bishops).

(b) The six lords of appeal in ordinary.

Thus it will be seen that all peers are not necessarily hereditary lorts of Parliament, nor are all lords of Parliament necessarily hereditary peers.

Origin of the Various Titles.-The style of Duke was used by the Anglo-Saxons as a title of dignity, but does not seem to have been employed by the early Norman lings, who, being dukes of Normandy themselves, probably

(a) These numbers are subject to variation owing to the ereation or extinction of peerages. 
thought it derogatory to their orn dignity to confer i! similar title upon a subject. The first duliedom was conferred upon Edward the Black Prince (b), who was created Duke of Cornwall by Edrard III. in 1337, the title being hereditary and devolving upon the eldest son of the reigning sovereign.

Marquess was a term which applied originally to the Lords Marchers (c); it was first used as a title of dignity by Richard II., who created Robert de Vere Marquess of Dublin in 1386 (d).

Earl was the equivalent of the Anglo-Saxon Ealdorman. It was the highest lereditary dignity until the creation of the dukedom in 1337.

Visconnt was a title borrowed originally from the French, and was first conferred as a title of honour by Henry VI. (e), who had been erowned King of France, upon Lord Beaumont, created Viscount Beaumont.

The Baronagc.-The early history of the baronage is involved in some obscurity; originally it seems that the term "baron," as equivalent to lord of a manor, applied to all who held as tenants in capite under the Crown $(f)$; it was, however, only the greater harons who had both a civil and criminal jurisdiction in the court baron, the lesser barons having eivil jurisdictions only.

The distinction between the greater and lesser tenants in capite is olserved in Magna Carta, the ling promising to summon the majores barones by individual writ (sigillatim), whilst the other tenants in capite were to be summoned through the sheriffs $(g)$.

Baronies were thus an incident of tenure originally, and continued such for at least two centuries after the Conquest. They could be alienated with the land, and in 1433 possession of the castle of Arundel wis held to eonfer an earldom $(h)$.

(b) Selden, Tit. Hon., 751.

(c) As to the Lords Marchers, see post, Part IV., Chap. III.

(d) Selden, Tit. Hon., 759.

(e) Pike, Const. Hist. of the House of Lords, 113. The title was originally the same as Vicecomes or Sheriff (Selden, Tit. Hon., 762).

(f) See Pike, p. 87 et seq.

(g) See Stubbs' Sel. Chart., p. 290.

(h) Pike, p. 80 . 
Tenure per Baroniam, however, never of itself conferred an absolute right to be summoned to Parliament, nor was it a condition precedent to a writ of summons, it always remaining open to the king within certain limits of summoning whom he pleased (i). The idea that the issue of a writ to an individual conferred upon his heirs an heleditary right to be summoned seems, however, to have become generally recognized by the time of Richard II. (k).

The question of baronies by tenure was finally settled by the House of Lords in 1861, in the Berkeley Peerage C'rse $(l)$, where it was held that the tenure of certain lands could not of itself confer a barony.

In the Clifton Case (1673) ( $m$ ), it was definitely decided that a writ of summons, followed by taking a seat in the House, confer's an hereditary peerage, and in the Frescheville Case (1677) ( $n$ ), that a writ of summons alone, not followed by taking a seat, does not confer a peerage.

A peeress in her own right cannot sit in the Lords.

Creation of Peers.-Earldoms and other ranks were always conferred by charter or letters patent, but lichard II. was the first monarch to create a barony in that way $(0)$. A new hereditary peer is now invariably created by letters patent, followed by a writ of summons to take lirs seat in the House.

Restrictions on Creation of Peers. - The Crown has the exclusive privilege of creating peers, and can create as many as it pleases, subject to the following restrictions:-

(1) No new Scotcl peer may be created, since there is no provision to that effect in the Act of Union.

(2) By the Act of Union with Ireland $(p)$ the Crown may create one new peer of Ireland for every three that

(i) Pike, Const. Hist. H. of Lords, p. 92.

(k) $1 b$. pp. 99, 100.

(l) (1861) 8 H. L. Cas. 21.

( $m$ ) Collin's Baronies by Writ, p. 291; and see the Hastings Peerage case $(1840) 8 \mathrm{Cl}$. \& F. 144.

(n) Lds. Rep., iii. 29.

(o) The first Baron so created was Lord de Beauchamp. Baron of Kidderminster, in the year 1387. (Pike, p. 109; Selden, Tit. Hon., 1. 747 ).

(p) $39 \& 40$ Geo. III. c. 67, s. 4. 
become extinct after the date of the union, but in order to keep the number of Irish peers who are not hereditary lords of Parliament up to the number of one hundred, one new peer may be created for every vacancy occurring below that number.

(3) It is doubtful whether the Crown can create peerages with limitations wihch would be void in ordinary law. Thus in the Devon Pecrage Case $(q)$ an earldom granted to a man and his heirs male was held to be good, whilst in the Writtes' Case (r) a similar grant was held to be bad. The fact, however, that a peerage by writ of summons descends to the heirs lineal, and not to the heirs general, which is a form of descent not otherwise known at law, might form an argument in favour of the Crown's power to make such a grant. In the Wonsleydalc Peerage Case (1856) (s), it was held that the Crown had no power to create life peerages with a right to sit in the House of Lords. Such grants are therefore void so far as the right to a writ of summons is concerned.

Subject to these restrictions the Crown may create an unlimited number of peerages, and might thus ensure the passing of any measure by the House of Lords. This was successfully accomplished by Anne in 1712 in the case of the Treaty of Utrecht $(t)$. In 1719 a Peerage bill restraining the creation of peers was brought in by Lord Sunderland. This measure was carried by the House of Lords, but thrown out by the Commons $(u)$, and no statutory restraint has since been attempted.

The Irish Representative Peers.-By the let of Union, (1800) $(x)$, the number of Irish representative peers is fixed at twenty-eight, and they are elected for life.

On a vacancy occurring through the death or attainder of a representative peer, the mode of election of a new

(q) (1831) Dow \& Cl. 200.

(r) (1869) L. R. 4 H. L. 126.

(s) (1856) 5 H. L. Cas. 958; and see May's Const. Hist., i. 291-299.

(t) Pike, p. 363.

(u) $I b$.

(x) 39 \& 40 Geo. III. c. 67 , s. 4. 
representative peer is regulated by an Act passed by the Irish Parliament and incorporated into the Act of Union $(y)$. Briefly it is as follows: A certificate of the death or attainder is sent by two temporal peers to the Lord Chancellor, who canses a writ to be issued to the Chancellor of Ireland, directing him to eause writs to be issued by the clerk of the Crown in Ireland to the Irish temporal peers, with a form of return attached in duplieate, upon which the name of the peer roted for is to be filled in. Before filling up the retum, those peers who are not already representative peers must take the oath of allegiance in the manner prescribed by the Act. The writs and returns are then sent back, within fifty-two days from the date of issue, to the clerk of the Crown, who sends one copy of the writs and retums to the clerk of Parliament, and the peer who las obtained the majority of votes is then entitled to a writ of summons at that and succeeding Parliaments.

In case of an equality of rotes, the names of the peers who have obtained equal votes are written on slips of paper and placed in a glass at the table of the House of Lords. The peer whose name is first drawn out by the clerk of Parliament is deemed elected.

No vacancy in the number of representative peers occurs through one of their number being promoted to the peerage of England or the C'nited Kingdom, and thus becoming an hereditary lord of Parliament $(z)$.

The Scotch Representative Peers.-By the Act of Union, (1706i) (a), the number of Scotch representative peers is fixed at sixteen, and they are elected for each Parliament. The mode of election prescribed by statute $(b)$ is as follows:

Whenever a new Parliament is summoned a proelamation $i_{\text {is }}$ issued under the Great Seal commanding all the Scotch peers to assemble at Edinburgh or the place named in the proclanation and proceed to the election of the sixteen representative peers. The eleetion talies place at Holyrood, atm each pecr, having taken the oath of allegiance pre-

(y) $39 \& 40$ (Feo. III. c. 67 , s. 8.

(z) Anson, i. 211.

(a) 5 Anne, c. 8 .

(b) 6 Anne, c. 23 . Amended by $14 \& 15$ Vict. c. 100. 
scribed by the Act, rotes for the sixteen peers whom he desires to be elected. A certificate of the peers elected is then made out by the lord clerk register and sent to tho clerk of the Crown in Chancery; this certificate is evidence of their title, and no writs of summons are issued. By the $10 \& 11$ Vict. e. 52, peerages in respect of which no vote had been given since the year 1800 were to be struck off the roll at future elections, and no vote is to be registered in respeet of them unless the House of Lords otherwise directs. Cases of disputed elaims to vote are to be settled by the House of Lords. As by the Act of Union the right to sit in the House of Lords otherwise than as representative peers was specially excepted from the privileges to be enjoyed by Seotch peers (c), it was held by the House of Lords in the Duke of Hamilton's Case (1711) that a peerage of the United Kingdom (in this ease that of Brandon) did not carry with it a right to a writ of summons as an hereditary lord of Parliament (d). This deeision was, however, reversed in 1782, the House of Lords having obtained the unanimous opinion of the judges (c), and the Duke of Hamilton's elaim to sit allowed. In 1787, the Duke of Queensberry and the Earl of Abereorn having been created peers of the United Kingdom, the House of Lords resolved that they ceased to sit as representative peers $(f)$. So that now it seems the elevation of a Scoteh peer to a peerage of the United Kingdom ereates a vacancy amongst the Scoteh representative peers.

The Spiritual Peers.-The Crown's right of summoning bishops is limited to twenty-six, of whom five must eonsist of the arehbishops of Canterbury and Iork and the bishops of London, Durham, and Winchester (y). The mode of appointment of bishops is regulated by a statute of Henry VIII. (h). On a vaeancy oceurring in an arehbishopric or bishoprie, the lean and chapter notify the fact

(c) 5 Anne. c. 8, s. 23 .

(d) Journ. H. of Lords, xix. 346.

(e) $I b . x \times x v i .517$.

(f) $I b$. xxxvi. 594 .

(g) See $10 \& 11$ Vict. c. 108.

(h) 25 Hen. VIII. c. 20 ; repealed 1 Ph. \& Mary, c. 8, ss. 9-11; but re-enacted 1 Eliz. c. 1, ss. 7, 10. 
to the clerk of the Crown in Chancery, and the Crown then grants them a congé d'élire or licence to proceed to an election, accompanied by letters missive nominating the person to be appointed. If the dean and chapter do not elect the person nominated within twelve days, the Crown, by letters patent under the Great Seal, nominates and presents a person to the archbishop of the province in the case of a bishopric, and to one archbishop and two bishops or to four bishops in the case of an archbishopric for investment and consecration (i), and the archbishop must invest and consecrate the person so presented within twenty days, or incur the penalties of a præmunire $(k)$.

If the dean and chapter elect the person named in the letters missive within twelve days, the Crown, by letters patent under the Great Seal, notifies the fact to the arch-. bishop of the province, or, in the case of an archbishopric, to one archbishop and two bishops or to four bishops, commanding him or them to confirm, invest, and consecrate the bishop-elect, and this he or they are bound to do within twenty days, or incur the penalties of a præmunire. Confirmation takes place before the vicar-general, and part of the ceremony consists of a citation, calling upon persons desirous of opposing the confirmation to appear; but should opposers appear, the vicar-general is not obliged to hear their objections.

In Dr. Hampden's Case (1848) (l), upon application to the Court of Queen's Bench for a mandamus to compel the vicar-general to hear objections, the court was evenly divided as to whether it should issue or not. But in the case of Canon Gore, the bishop-elect of Worcester, 1902 ( $\mathrm{m}$ ), the Court of King's Bench unanimously held that a mandamus should not issue to compel the vicargeneral to hear objections on the ground of doctrine, so that the citation of objectors (at any rate with reference to matters of doctrine) is now, from a legal point of view, simply an empty formula.

(i) $25 \mathrm{Hen}$. VTII. e. 20 , s. 4 . It will be noticed that in this case no confirmation is necessary.

(i) $I b, s, 7$.

(1) Reg. V. Areh. of Canterbury, Hampden, in re (1848) 11 Q. B. 483.

(m) Rex V. Arch. of Canterbury \& Another [1902] 2 K. B. 503. 
Having been confirmed, the spiritualities of the see are committed to the bishop, but he is not entitled to the temporalities until after consecration, homage, and the taking of an oath of fealty.

The Lords of Appeal in Ordinary.-There are now six Lords of Appeal in Ordinary appointed by the Crown under the provisions of the Appellate Jurisdiction Acts, 1876, and $1913(n)$. In order to be eligible for appointment, they must have held high judicial office for two years, or have practised at the English, Scotch, or Irish bar for fifteen years. They are entitled to a salary of $£ 6,000$ per anmum, and are removable only on an address to the Crown by both Houses.

They are entitled to the dignity of Baron, and to a writ of summons to sit and vote in the House of Lords for life $(o)$.

\section{Privileges of the House of Lords.}

These are-

(1) Freedom from arrest, except in cases of treason, felony, or refusal to give security for the peace. This privilege the Lords claim for themselves by Standing Orders, $64 \& 67$, " within the usual times of privileges of Parliaments," viz. within forty days before and after each session, and for their servants within twenty days.

(2) Freedom from service on juries, and this privilege has been confirmed by statute $(p)$.

(3) Freedom of speech.

(4) Individual freedom of access to the sovereign.

(5) The right to see to the due constitution of its own body, and therefore to decide on the validity of new creations. Peerage claims are heard by the Com-

(n) $39 \& 40$ Vict. c. 59, ss. 6, 14: $3 \& 4$ Geo. T. c. 21, s. 1. Four are appointed under the former and two under the latter Act.

(o) Prior to $\mathbf{1 8 8 7}$ they were only entitled to sit and vote in the House of Lords whilst remaining in the fulfilment of their office. By 50 \& 51 Vict. c. 70 , s. 2 , they arc entitled to sit and vote for life.

(p) 6 Geo. c. 50, s. 2 ; 33 \& 34 Vict. c. 77, s. 79. 
mittee of Privileges; the Lords cannot, howerer, decide on claims to old peerages, except on reference by the Crown.

(6) The right to commit for contempt, and this they may do for a definite term, imprisonment not being terminated by prorogation, as in the case of the Commons, unless the commitment was for an indefinite term.

(7) The right individually or collectively of recording a protest on the journals of the House.

(8) The right of exercising judicial functions as a Court of Appeal, and as a court of first instance, presently to be noticed $(q)$.

(9) The privilege of exemption from attending as witnesses is usually waired, as in the case of the Commons $(r)$.

(q) See post, pp. 238, 241, 312. Formerly the Lords claimed and exercised the right to rote by proxy, but this has been discontinued by Standing Order passed in 1868.

(r) Anson, i. 218. 


\section{Chapter IV.}

\section{PUBLIC, PRIVATE, AND MONEY BILLS.}

Is early times bills were enacted in the form of petitions to the Crown, which, with the Royal assent, were entered upon the Rolls of Parliament, and subsequently drawn up in the form of statutes by the judges, and placed upon the statute roll. This system seems to have giren rise to some abuse, provisions often being inserted in the statute itself which were not to be found in the original petition (a), and the practice of introducing bills in the form of complete statutes, as at present, beeame established about the reign of Henry VI.

\section{Public Bills.}

At the present day the procedure for public bills, which, with a few slight variations, is the same in either House, is as follows:-

Bills may originate in either House, except money or appropriation bills, and bills dealing with the representation of the people, which originate in the Commons, and bills for the restitution of honour's, and bills of attainder and pains and penalties, which generally originate in the Lords. It is usual, also, for bills affecting the privileges or proceedings of either House to commence in that House. The regulations for the proceedings with regard to publie and private bills are to be found in the Standing Orders of either House. Every public bill must pass through several stages.

1. Notice of Motion.- In the Commons, prior to the year 1902, notice of motion for leave to introduce a bill had to be entered by the member who wished to bring in the bill. Since 1902 (in pursuance of Standing Order (Public Business) No. $31(2)$ ), a nember may either give notice of his 
intention to adopt the old procedure, or may, after notice, present a bill at the Table without an order of the House. In the Lords, no notice of motion or leave is necessary, and any member may present a bill, and have it laid upon the table.

2. Motion for Leave to Introduce.-Under the old procedure the motion for leave to introduce the bill is made in due conse, and this is either carried or negatived without debate.

3. First Reading.--The bill is then presented, either at the same or a subsequent sitting, in aceordanee with the order granting leave to introduce the bill; or is presented under the new procedure without any sueh order. The question is then put, "That the bill be now read a first time, and that the bill be printed," and this is usually. carried as a matter of course, no amendment or debate being allowed at this stage $(b)$. At the same time a date is fixed for the second reading, and in the meantime the bill is printed and distributed amongst members.

4. Second Reading.--At the seeond reading the prineiple of the bill is diseussed, but not the details, and the question put, "That the bill be now read a second time," and this is either carried-in which case the prineiple of the bill is affirmed-or an amendment is moved, "That the bill be read six months hence," or at some date beyond the probable duration of the session. If the amendment is carried, the effect is to prevent the bill being passed into law during that session. An alternative mode of opposing a bill is by moving a resolution as an amendment to the original question " that the bill be read a second time," stating reasons why the House should not proceed further with the con. sideration of the bill. If this amendment is carried, it negatives further proceedings with regard to the measure on that particular occasion, though the bill may again be brought up for second reading at some future date.

5. Committee Stage.-Having passed the second reading, the bill (if it is a money bill) is now referred to a committee 
of the whole House, presided over by the chairman of committees: All other bills stand committed to one of the six standing conmittees, unless the House, on motion decided without annendment or debate, otherwise orders, when it may be referred to a committee of the whole House, or to a select committee, or a joint committee of the two Houses (Standing Order No. 46). The bill is now said to be in committee, and is considered clause by clause and amendments made.

6. Report Stage.-Having passed through committee, the fact is reported to the House by the chairman, and this is temed the Report Stage. On a day named the bill is considered in its amended form, and further amendments maly be marte or clauses added (c), or it may be again referred to committee.

7. Third Reading.--The bill is then read a third time, and though the question, "That the bill be now read a third time," may be negatived, this is not necessarily fatal to the passing of the measure, which may be brought up for third reading at some future date. In the Commons only verbal amendments may be made at this stage $(d)$; in the Lords, new clauses may be added or amendments made.

8. Sending on the Bill.- The bill is then sent to the other House. If the bill is sent to the Lords from the Commons, it is endorsed, "Soit baillé aux seigneurs "; if sent from the Lords to the Commons the indorsement is, "Soit baillé aux communes."

9. Reading in the other House.-The bill is read three times in the other House, and may be agreed to either with o: without amendments, or rejected.

Prior to the passing of the Parliament Act, 1911, which relates only to bills sent up by the Commons to the Lords, the position with regard to bills sent from either of the two Houses to the other House was as follows:-

(c) But at the Report Stage no amendment which could have been proposed in Committee may be made without an instruction from the House (Standing Order, No. 41).

(d) Standing Order, No. 42. 
If the bill were returned by one House to the other with amendments, the House which originally passed the bill might determine to abandon it, in which case it was lost; or a compromise might be effected in one of two wayseither by a formal conference with the other House, or by communicating a statement of reasons for disagreeing tc the amendments.

If the Lords rejected a bill sent up from the Commons, or if no compromise conld be arrived at with regard to amendments, the only solution of the difficulty if the Commons refused to abandon the measure, was an appeal to the electorate by a dissolution, when, if a majority were returned pledged to support the measure, the Lords would either give way, or, in the event of their not doing so, the Crown could create sufficient new peers to ensure the passing of the measure, as was done in 1712 on the occasion of the passing of the Treaty of Utrecht, and as was threatened to be done, should the Lords refuse to give way, in the case of the Parliament Act, 1911. On the occasion of the passing of the Reform Bill of 1832 , the bill was rejected on its second reading in the Lpper House; but having been reintroduced in the Commons and sent back, the Lords rielded to the combined pressure of the Crown and the Commons, and passed the measure.

The above is still the position in so far as it relates to bills sent by the Lords to the Commous. As to bills sent by the Commons to the Lords, it will be seen that in the case of a House of Lords having a large majority opposed to the policy of the party in power in the House of Commons, it was possible for the former to obstruct the measures of the latter by rejecting them altogether, or inscrting unaceptable amendments; the only effective remedy for the ministry being to advise the Crown to create large numbers of new peers, so as to enable them to obtain the marjority requisite to pass their measures in the House of Lords, such a course being for many reasons wholly to be deprecated. It was such a course of events which led to the passing of the Parliament Act, 1911.

Under this Act, which eame into force on the 18th 
August, 1911, if any public bill (other than a money bill (e), or a bill providing for the maximum duration of Parliament beyond fire years) is passed by the House of Commons in three successive sessions (whether of the same Parliament or not), and has been sent up to the House of Lords at least one month before the end of each session, is rojected $(f)$ by the House of Lords in each of those sessions, unless the House of Commons directs to the contrary, the bill is to be presented to the Crown, bearing an indorsement signed by the Speaker of the House of Commons, that the provisions of the Act have been complied with, and becomes an Act of Parliament on the royal assent being signified in the usual manner $(g)$. This provision, howerer, does not take effect mless two years have elapsed between the date of the second reading in the House of Commons in the first session, and the date on which it passes the House of Commons in the third session $(h)$.

On the passage of the bill in the second and third session the House of Commons may suggest amendments to be considered by the House of Lords, which if agreed to by the latter may be inserted in the bill. Otherwise on any successive passing and sending up to the House of Lords the bill may contain only such alterations as have been rendered necessary by the lapse of time since the last passing, or which represent amendments made by the Lords in the preceding session, or in the third session, and agreed to by the Commons (i). Not having been passed by the House of Lords, a change in the usual form of wording of the enacting clause is required for bills passed under the Act; and this is provided for by the Act (ki).

(e) For the provisions of the Act relating to money bills, see p. 92 , post.

(f) A bill is deemed to be rejected by the House of Lords if not passed either without amendments, or with such amendments as may be agreed to by both Houses. Parlianent Act, 1911 ( 1 \& 2 Geo. V. c. 13 , s. 2 (3)).

(g) Parliament Act, 1911, 1 \& 2 Geo. V. c. 13, s. 2 (1).

(h) $I b$. s. $2(2)$.

(i) $I$ b. s. 2 (4).

$(k)$ The enacting clause of bills passed under the Act is to run :"Be it enacted by the King's most Excellent Majesty, by and with consent of the Commons in this present Parliament assembled, in accordance with the provisions of the Parliament Act, 1911, and by authority of the same, as follows." 
10. Royal Assent.-Having passed both Houses, or having complied with the provisions of the Parliament Act, 1911. stated above, the bill is ready for the royal assent, which may be affixed either in person or by commission miler the sign manual and Great Seal (l). The form of assent for ordinary bills is le roy le veult, for money bills le roy remercie ses bons sujets, accepte leur benevolence, et ainsi le veult. Assent is refused by the words le roy sacisera. Assent was refused frequently hy William III., but has been uniformly granter since 1707, when Anne refused assent to the Scoteh Militia Bill.

If the Crown is opposed to a measure at the present day, it would either attempt to dissuade the Ministry from introducing it, or dismiss the Ministry and appoint a new one. Failing this, the only alternative is an appeal to the nation by dissolution, and if the nation shows itself in favour of the measure the Crown must yield, or it would probably be forced to abdicate or fight.

A view of the constitutional position of the Crown with regard to the exercise of the prerogatives of dissolution of Parliament, and dismissal of the Ministry, will be found stated later $(m)$.

\section{Private Bills.}

These are either Icts concerning private persons in connection with such matters as marriage settlements, marriage, or divoree, or local Acts comnected with such matter's as railways, canals, drainage, or the like, passed generally on behalt of public companies or municipal corporations. The procedure, which with slight variations is the same for bills originating in either House, is in outline as follows:-

1. Lcdging Petition.-A petition with a copy of the bill annexed must be lodged at the Private Bill Office, on or before the 17th of December, and a printed copy of the bill

(1) 33 Hen. VIII. c. 21.

(m) ivee as to dissolution, and as to dismissal, post, Part III.. Chap. II. 
at the Treasury, and at the General Post Office on or before the 18th December $(n)$.

2. Memorials by Opposers.-Memorials by opposers of the bill that the Standing Orders have not been complied with may now be lodged at the same office, and on the 18th of January following the bill goes before two examiners, when supporters and opposers are heard with the object of ascertaining whether the Standing Orders have been complied with $(0)$.

3. First Reading.- The petition is then sent back to the Private Bill Office with an indorsement that the Standing Orders have been complied with or the reverse, and within one day of such indorsement must be presented to the House by being laid upon the table of the House. The bill is laid upon the table of the House by the clerk of the Private Bill Office, and is either read a first time or referred to the Standing Order's Committee if the Standing Orders have not been complied witl $(p)$.

4. Re-examination and Second Reading.-The bill is then sent back to the Private Bill Office and again examined as to whether it is in accordance with the Standing Orders, and if this is so it comes on for second reading in not less than three days or more than seven days from the first reading $(q)$ : If it passes the second reading the principle or expediency of the bill is affimed, conditionally however, and subject to proof of the allegations of fact contained in the petition before committee.

5. Reference to Committee.-The bill is then referred to the Committee of Selection, mless it is a railway, canal, or divorce bill, in which case it is referred either to the General Committee on Railway and Canal Bills, or to the Select Committee on Dirorce Bills $(r)$.

(n) Standing Orders, No: 32, 33. See also the provisions of the latter Order as to copies to be deposited at various offices.

(o) $I b$. Nos. 69, 74 .

(p) Standing Orders, Nos. 195, 196, 197, 199.

(q) Standing Order, No, 204. (r) Standing Order. No. 208. 
6. Discussion in Committee.-Before the committee counsel for the promoters or opposers of the bill are heard and elauses added or amendments made.

7. Third Reading, etc.-The bill as amended in committee is reported to the House and comes up for third reading. If it passes the third reading (at which no amendments, not being merely rerbal, may be made) it is sent up to the House of Lords, and eventually reeeives the royal assent in the same way as other bills.

It may be noticed that the provisions of the Parliament Aet, 1911, do not apply to private bills, but only to publie, and money bills.

\section{Acts of Grace.}

Aets for granting a general pardon are usually designated "Aets of Grace." They are generally introduced in the House of Lords at the instance of the Crown by a Minister of the Crown, and after being read a first time, a motion is made that the bill be accepted and passed, which is carried without opposition. The bill is then sent to the House of Commons, where it goes through a similar process, and is then presented for the royal assent in the usual manner.

\section{Money Bills.}

\section{The Constitutional Position with regard to Money Bills.} - With the Bill of Rights the attempts of the Crom to impose taxation without the eonsent of Parliament eame to an end; the Crown, however, remains the heal of the executive, and retains through its constitutional ministers the control and management of the public revenue, nor can any sum of money, even though granted by the Commons, be applied by the Treasury in defraying the expenses of the pulblic services without the authority of an order under the sign manual.

It is also a constitutional prineiple that no bill ereating a charge upon the publie revenues, or altering the incidence of or imposing new taxation upon the people, shall be introduced in the Commons exeept upon the recommendation of 
the Crown, expressed through a member of the Ministry $(s)$. Such is the present constitutional position of the Crown with regard to the initiation of taxation and the control of the public revenue. The position of the Lords with regard to money bills passed by the Commons, either granting supplies, or imposing new taxation, is at the present day limited to assent. In 1671 the Commons passed a resolution to the effect that the rate of taxation imposed by the Commons should not be altered by the Lords: and again in 1678, that all aids and supplies are the sole gift of the Commons, and ought to begin with the Commons, and such grants should not be changed or altered by the Lords in any way $(t)$. Thus the Commons assumed the right to initiate and regulate taxation. The Lords, however, might still reject altogether money bills passed by the Commons, and this they did in 1860, refusing to pass the bill for the repeal of the paper duties. In consequence the Commons passed a resolution to the effect that the House regarded the power of the Lords to reject money bills with very great jealousy, and that to guard against the undue exercise of that power in the future, the Commons had it in their own power to impose and remit taxation (u). In the next session the Lords gare way and passed an Act corering the whole financial scheme for the year, and incluting the repeal of the paper duties. Since that time it has been customary for the Budget imposing new taxation for the year to be comprised in single Acts, known since 1894 as Finance Acts, which, until the year 1909 , were generally passed by the Lords as a matter of course without amendment. In the ycár 1909, howerer, the refusal of the House of Lords to accept the scheme of taxation (involving the Land Talue duties) initiated by a Liberal Government, led to the rejection of the Finance Act of that year. Upon the subsequent dissolution and appeal to the electorate, the Liberal Government was again returned in a majority, anch the Lords gave way rather than submit to the wholesale creation of peers, which would otherwise have been rendered necessary. The

(s) See Standing Order, No. 66 .

(t) Journ. H. of Cont, ix. 235, 509

(u) Ib. exv. 360 . 
Budget proposals of 1909 was therefore enacted in 1910 in the form of the Finance (1909-1910) Act, 1910. The inconvenience caused to the country and the Ministry by the delay of the financial neasures necessary for the gorernment of the country, was one of the principal reasons which led to the passing of the Parliament Act, 1911, which enables money bills to receive the royal assent and become Acts of Parliament, eren though rejected by the House of Lords. The provisions of the Act relating to money bills will be fouml stated later $(x)$.

The present position with regard to money bills, therefore, is that they are originated in the Commons only on the recommendation of the Crown through its responsible ministers, and are either assented to by the Lords and presented to the Crown for the royal assent as a matter of course; or in the event of their being rejected by the Lords, are presented to the Crown for the royal assent under the Parliament Act, 1911.

Procedure with Regard to Money Bills.-The demand by the Crown for supplies to meet the services for the year is made in the speech from the throne, which also intimates that estimates will be submitted of the amounts required. The estimates for the financial year, which commences on the 1st of April, are accordingly made out and submitted to the Treasury by the heads of the various departments. The discussion of financial arrangements for the ensuing year is opened by the Chancellor of the Exchequer in his Budget Speech, in which the requirements, as based upon the estimates, are detailed; and if the proceeds of permanent or existing annual taxation are insufficient to meet the demand made by the estimates, a new scheme of taxation is proposed. All questions with regard to money matters are then considered by the House of Commons, either in Committee of Supply or in Committee of Trays and Means, which are both committees of the whole House $(y)$.

(r) See p. 92, post.

(y) The chairmen of these committees are appointed at the commencement of each session, immediately after the address to the sorercign has been agreed to. (Standing Order, No. 14.) 
In Committee of Supply the estimates for the expentiture of the ensuing financial year are considered and discussed, and supplies roted to mect the requirements of the year as based upon the estimates (z).

In Committee of Ways and Means any new modes of taxation, which may be necessary, are discussed and considered, and resolutions passed accordingly, which are subsequently reported to the House and emborlied in bills known as Customs and Inland Revenue Acts and the annual Finance Acts. The taxes which are thus considered and dealt with in Committee of Ways and Means are, however, only such as are required to meet the immediate exigencies of the public revenue. More weighty matters involving changes in the fiscal system or the alteration of pemanent duties are dealt with in a separate committee of the whole House $(a)$.

In Committee of Ways and Means resolutions are also passed, and subsequently embodied by the House in Consolidated Fund Acts, authorizing the payment out of the Consolidated Fund of lump sums to meet the current expenditure of the year as based upon the supply grants already voted in committee of supply $(b)$. The authority for the issue of the sums so granted is, properly spealing, not complete without an order from the Sovereign uniler the sign manual, and to meet this a provision is usually inserted in the Consolidated Fund Acts, authorizing the Bank of England to advance the sums named in the Acts on the security of Treasury bills.

Finally, at the end of the financial year an Appropriation det is passed, which embodies the rarious Consolidated Fund Acts passed during the year, authorizes the payment out of the Consolidated Fund of any balance required to make up the total of the supply grants, and specifically appropriates the sums so granted to the specific heads of expenditure embodied in the estimates. The authority for the payment out of the various sums by the Treasury is then made complete by a royal order under the sign manual $(c)$.

(z) May's Parl. Pract., 555.

(a) May's Parl. Pract., 557.

(b) See May's Parl. Pract., 555. (c) See May's Parl. Pract., 558. 
Such money bills, whether Finance Acts, or Consolidated Fund Acts, are subject to the same procedure as to first, second, and third reading, and sending up to the House of Lords, as other public bills, which have already been treated of (d). But by the Parliament Act, 1911, if a money bill (viz. a public bill which, in the opinion of the Speaker of the House of Commons, deals only with certain matters specified by the Act relating to money) is sent up to the Lords at least one month before the end of the session, and is not passed by the latter within one month, then, unless the House of Commons otherwise directs, such bill is to be presented to the Crown and becomes an Act of Parliament on the royal assent being signified $(c)$. Any such bill when sent up to the Lords and when presented for the royal assent must be endorsed with a certificate signed by the Speaker of the House of Commons that it is a money bill; and before giving his certificate the Speaker is to consult, if practicable, two members appointed from the chairmen's panel at the beginning of each session by the Committee of Selection $(f)$.

(d) See p. 81, ante.

(e) Parliament Act, 1911, 1 \& 2 Geo. V. c. 13, s. 1 (1), (2).

(f) $I b$. s. 1 (2). (3). 


\section{Chapter V. \\ THE PUBLIC REVENUE.}

The Revenue generally.-The estimated revenue for the year ending March 31, 1922, amounted to the sum of $£ 1,216,650,000$, made up as follows :-

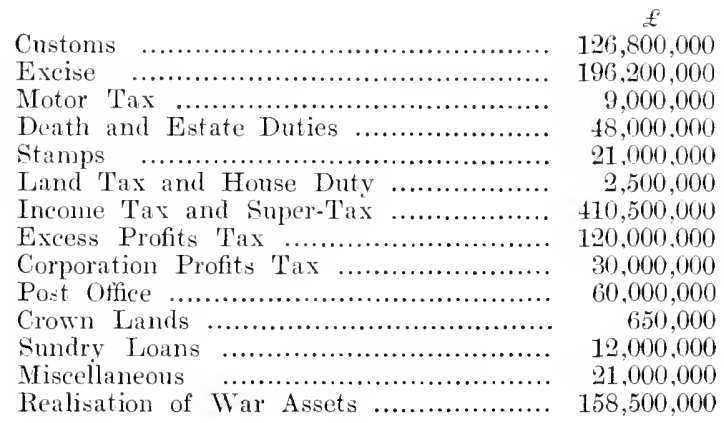

The whole of this revenue is paid into the Consolidated Fund account at the Bank of England, created in 1787 (a), and payments out are made only by the authority of an Act of Parliament, and come under two heads: (1) Consolidated Fund services, or payments made under the alithority of a permanent Act. These include the interest on the national debt, the civil list, annuities to the royal family and pensions, salaries of the judges and other officers and certain miscellaneous items. (2) Supply services, or payments made on the authority of annual Acts, termed Consolidated Fund Acts, which embody resolutions passed by the House of Commons in Committee of Ways and Means, and authorizes the payment out of rarious lump sums to meet the current expenditure of the vear. These sums, though authorized by Act of Parliament, cannot pro- 
perly be issued by the Treasury without the authority of an order from the sovereign under the royal sign manual (b). This difficulty is obviated by a provision inserted in the various Consolidated Fund Acts empowering the Bank of England to advance the amounts covered by the Acts on the security of Treasury bills. The amount so adranced forms part of the Consolidated Fund, and is placed to the credit of the Exchequer account, which is available for current cxpenditure by the Treasury. At the end of each financial year an Appropriation Act is passed which authorizes the payment out of the Consolidated Fund of any balance (c) required to make up the total amount of the supply grants roted in Committee of Supply, and appropriates the sums already granted by the various Consolidated Fund Acts $(d)$ to meet the expenditure upon the public services in accordance with the estimate already considered and sanctioned by the House in Committee of Supply. Finally, an order from the sovereign under the royal sign manual completes the authority for the issue by the Treasury of the sums so granted.

The enormous growth of the national revenue in the last two hundred and fifty years becomes apparent when we compare the sum at present paid unto the Exchequer with the revenue raised under the Commonwealth. The principal sources of revenue at that time were the fixed assessments (generally made monthly) on realty and personalty (e), the excise, and the customs. On the arerage the sum produced by these did not much exceed $£ 2,000,000(f)$, though the actual purchasing power of money was then, of course, considerably greater than it is now. The whole levenue of Charles I. does not appear to have exceeded what to us would seem the modest sum of $£ 900,000(g)$; it is hardly to be wondered at that that monarch should have found a difficulty in carrying on the business of the country.

(b) See May's Parl. Pract., 558.

(c) This balance is ascertained by deducting the total sums granted by Consolidated Fund Acts from the total of the supply grants.

(d) For an example of a Consolidated Fund Act, see 3 Ed. VII. c. 3.

(e) Those assessments developed later into the present Land Tax. See post, p. 106.

(f) See Hume's Hist. of England, vii. 337 et seq.

(g) Ib. 338, n. 
The old practice seems to have been to furm out the revenues. In 1650 commissioners were appointed to collect customs and excise, but in 1657 Cromwell returned to the old system, and seems to liave obtained a larger sm than the commissioners. At the present day the collection and management of the taxes is under the control of various bodies of commissioners, and regulated by statute $(h)$.

\section{The Customs.}

Histcry.-The origin of the customs is to be found in the early Norman period, when it became customary for merchants to pay tolls to the ling on all merchandise imported or exported as a sort of passport or safe conduct for themselves and their goods, which were chiefly wine by way of import, and wool, woolfells, and leather by way of export. The toll on wine, which was the principal import, was termed prisage, or butlerage, and later on tunmege, and consisted in the right to take one tun from every cargo of ten tuns, and two tuns for every cargo of twenty tuns (i).

The amount of these tolls became fixed in course of time, and were termed consuetudines, or customs, and Magna Carta expressly forbade the exaction of unjust tolls, or any except the ancient and just consuctudines. In 1275, at the instance of the merchants, Parliament granted to Edward I. certain duties on wool, woolfells, and leather exported from England and Wales, and these duties became known subsequently as the ancient customs (antiquu custuma) ( $k$ ). In 1302 Edward I. came to an agreement. with the foreign merchants by which they agreed to pay two shillings for every tun of wine instead of the old prisage, and certain additional duties on wool, woolfells, leather, and cloth, and a poundage of threepente on all other goods imported or exported. These duties became known as the nova sive parva custuma, as opposed to the antiqua sive magna custuma. Additional duties under the name of subsidies of tumnage and poundage were granted to Richard II. in 1397 for life, and these life grants became more or less customary in subsequent reigns.

(h) See the Taxes Management Act, 1880 (43 \& 44 Vict. c. 19).

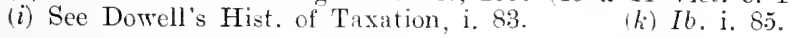


All the Tudor monarchs received life grants of tunnage and poundage, and under Mary (circa 1558) the "Book of Rates" was adopted, which specified values at which goods were to be rated in lieu of the old system of accepting the merchants' valuation. Under Elizabeth a new book of rates was introduced, and was continued in use when the customs duties, or subsidies of tunnage and poundage as they were called, were granted to James I. for life $(l)$.

On the accession of Charles I. Parliament did not follow the practice of granting the eustoms for the life of the sovereign, and proposed to limit the grant to one year. Charles, however, proceeded to levy the tax under Order of the Council by Royal Warrant, and continued to levy it during the period $1629-1640$, in which he reigned without a Parliament. On reassembling in 1641, the Long Parliament granted the customs for two months (m), and this grant was subsequently continued $(n)$.

After the Restoration in 1660, an Act called the Great Statute (o) granted the customs to Charles II. for life, and established a new book of rates. James II., on his accession, imprudently levied the customs by proclanation before they had been granted by Parliament. The legular Parliamentary grant for life was, however, made shortly after $(p)$.

After the Revolution of 1688, Parliament showed their intention of keeping the revemue in their own hands by granting the eustoms duties for four years only $(q)$; but a few years later a new subsidy of customs was granted to the king for life $(r)$.

The subsequent history of the customs is one of increasing taxations to meet the inereased expenditure of 130 years of war. In 1815, at the termination of the war with France, every conceivable article was subject to taxation, and the condition of the Englishman was thus described by Sidney Smith in 1820, in an article in the Edinburgh Rerieu": "The schoolboy whips his taxed top; the beardless youth nuanages his taxed horse, with a taxed bridle, on a taxed roal; and the dying Englishman, pouring his

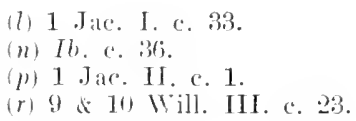

(r) 9 a 1i) Will. III. c. 23.

(m) 16 Car. I. c. 8.

(o) 12 Car. II. c. 4.

(q) 2 Will. \& M. c. 1. 
medicine, which has paid 7 per cent., into a spoon which has paid 15 per cent., flings himself back upon lis chintz bed, which has paid 22 per cent., and expires in the arms of an apothecary who has paid a licence of a hundred pounds for the privilege of putting him to death. His. whole property is then immediately taxed from two to ten. per cent. His virtues are handed down to posterity on: taxed marble, and he will then be gathered to his fathers: to be taxed no inore."

In 1842 Peel effected the first great revision of the tariff, which then comprised some 1200 dutiable articles. His reforms affected some 750 articles. In 1845 he made a second revision, when some 450 articles were entirely removed, and again in 1846. As a result of Mr. Gladstone's revision in 1853, some 48 dutiable articles only were left $(s)$.

Present State of the Customs.-The principle of further reductions continued, the duties on corn of all descriptions being repealed in $1869(t)$. The present tariff, which depends on the Customs Duties Consolidation Act, $1876(u)$, with the modifications made by various Customs and Inland Revenue Acts and Finance Acts passed since that date, comprises only some twenty dutiable articles, the chief revenue-bearing items, of which are beer, wines, spirits, tobacco, sugar, tea, coffee, cocoa, currants, and phums.

The principle of the present tariff is revenue and not protection $(x)$, and there are no export duties. Generally spealing, duties are not imposed on raw materials, but only on goods not produced at home, e.g. wine, tea, coffee, tobacco. In cases where dutiable goods are produced or manufactured at home, e.g. spirits, beer, cards, an equivalent or countervailing excise duty is levied.

The customs revenue for the year ending 31st March, 1921 , was $£ 150,000,000$.

Collection of the Customs. - The collection of the customs was in early days farmed out to individuals, a system

(s) See the Tariff Act, $1860(23 \& 24$ Tict. c. 110).

(t) $32 \& 33$ Vict. c. 14.

(u) 39 \& 40 Vict. c. 35 .

(x) But see Safeguarding of Industries Act, 1921 (11 \& 12 Geo. V. c. 47$)$. 
productive of many evils. At the end of the seventeenth century a board of commissioners was appointed to manage and control the customs, and the present Board of Commissioners is appointed by the Crown under the Act of $1876(y)$. The Commissioners of Customs and Excise appoint officers for the management and collection of the customs, and are subject to the supervision of the Treasury Commissioners (z).

The punishment for customs offences is the infliction of a penalty, according to the nature of the offence, followed by imprisomment in default of payment. Formerly penalties could only be enforced by an action in the Court of Exchequer and subject to special procedure.

In 1853 and 1876 statutory provisions were made for the punishment of smaller offences by justices in petty sessions, according to prescribed formalities and procedure, and by the Summary Jurisdiction Act, 1879 (Scotland, 1881), the ordinary law of summary procedure was extended to customs offences. The limit of imprisonment is three months, and in certain cases, where the penalty exceeds $£ 50$, six months. In all cases where more than one month's imprisonment is inflicted, the case is referred for consideration to the Treasury, who may remit a portion of the sentence.

In important cases, the old Exchequer procedure still exists, the action being brought in the King's Bench Division of the High Court. The procedure is by arrest under a writ of capias granted by a judge in chambers, evidence being given on affidavit. The prisoner must give sufficient bail, or is committed to prison until trial. If the offence is proved, judgment is given for the penalty, or imprisonment until payment or during the Crown's pleasure.

\section{The Excise.}

History and Present State.-Excise duties were first im- posed by an ordinance of the Long Parliament in 1643 (a) on beer, ale, cider, perry, wine, and tobacco. From time to time various other articles were charged with excise

(y) $39 \& 40$ Tict. c. 36 , s. 1 .

(z) $I b$. s. 2.

(a) Scobell's Collection of Acts and Ordinances, p. 49. 
duties, and after the Restoration they were granted to Charles II. for life $(b)$. Nearly all the old excise duties have been remitted at various times, and the prineipal existing duties are those on beer, spirits, and ehicory.

The exeise also includes the revenue derived from licences. These exeise licences were originated in 1784 , when they were eharged upon the makers of and dealers in various exeiseable artieles (c), and they have sinee been extended to various trades, sueh as beer or spirit dealers, distillers, house agents, pawnbroliers, tobaceonists, and many others, and on such various subjects as dogs, armorial bearings, guns, game, patent medieines, men-servants, and carriages.

A third branch of the exeise revenue is that derived from the railway passenger duties imposed by $10 \& 11$ Viet. c. 42.

Collection.-The eollection and management of the exeise was formerly under the control of the Commissioners of Inland Revenue, four in number, subjeet to supervision by the Treasury. They were appointed by letters patent under the Great Seal, and hold office during pleasure. The management is now under the control of the Commissioners if Customs and Exeise.

\section{Property and Income Tax.}

Taxes on Personalty.-Taxation of personalty was originated by Henry II. in 1188, when he exaeted the Saladin Tithe. In 1193 a tax of one-fourth of the ralue of their personalty was exacted from every person in order to raise the sum required to ransom Richard I.

During the thirteenth, fourteenth, and fifteenth eenturies a tax on movables, eonsisting of a tenth and fifteenth part for the towns and shires respeetively, was frequently granted by Parliament, and it took the place in part of the old seutage, hidage, or tallage. Eventually the grant of a tenth and fifteenth eame to be understood as the grant of a fixed sum, amounting to some $£ 30,000$ (d), which was

(b) 12 Car. II. c. 23.

(d) Dowell's Hist. of Taxation, i. 193.

(c) 24 Geo. III. c. 41. 
termed a subsidy; but during the sixteenth century both tenths and fifteenths and subsidies were granted side by side. In the seventeenth century the grant of tenths and fifteenths became rare, though an example oceurs as late as 1623 , when three entire subsidies, and three tenths and fifteenths were granted by Parliament to James I. (e). The tax on personalty, in the form of subsidies or aids, continued to be levied with the tax on realty until 1798, when the taxes on realty and personalty were directed to be levied separately $(f)$. In the following year (1799) the first Income 'Tax was imposed by $\mathbf{M r}$. Pitt $(g)$, and the old tax on personalty was finally abolished in $1833(h)$.

The consideration of taxes on personalty would not be complete without some reference to the system which at one time existed of raising revenue by means of foreed loans or benevolences. These were first levied by Richard II. (i). They were declared illegal by Parliament in $1351(k)$ and $1483(l)$, but reintroduced by Henry VII., when they became known as Morton's Fork, through the directions given by the Chancellor Morton to the commissioners appointed to raise the loans, to answer persons who objected on the ground of poverty, "that they ought by reason of their parsimony to have the more laid by" ; whilst those who were lavish in their expenditure were to be told they must needs have money " by reason of their port and manner of living" $(m)$. Persons who objected to pay the loan were summoned before the Privy Council, and often subjected to fine and imprisonment by the Star Chamber. In $1615 \mathrm{Mr}$. Oliver St. John, having objected that the exaction of the loan was contrary to Magna Carta, was sent to the Tower, and sentenced by the Star Chamber to pay a fine of $£ 5,000$, which, however, was afterwards remitted $(n)$.

The exaction of a general loan by Charles I. in 1626

(e) 21 Jac. I. c. 34 .

(g) 39 Geo. III. c. 13.

(h) $3 \& 4$ Will. IV. c. 12.

(f) 38 Geo. III. c. 60 .

(li) 25 Ed. III. st. 1, c. 6 ; recited in the Petition of Right (3 Car. I. c. 1).

(l) 1 Ric. III. c. 2 .

(m) See Taswell Langmead's Const. Hist., 5th Ed., p. 312.

(n) Gardiner's Hist. Eng., ii. 172. 
caused great discontent, and many persons were committed to prison for refusing to pay. Sir Thomas Darnel and five others, who had been so committed under a rarrant from the Privy Council, sued out their habcas corpus in the King's Bench; but it was held by Chief Justice Hyde that the King's Bench could not inquire into the grounds of the commitment, the warrant having been made "by special command of the king" (o). Forced loans and benevolences were finally declared illegal by the Petition of Right ( 3 Car. I. c. 1).

The Income Tax.-In 1799 the first Income Tax was established by Mr. Pitt $(p)$. The tax was modified by Addington's Act in 1803 ( $q$ ), and again in 1806 ( $r)$, but dropped altogether in 1816, after the battle of Waterloo. It was, however, reintroduced by Sir Robert Peel in $1842(s)$, and this Act, which was modelled on the Act of 1806 , was the basis of the present tax.

The Act of 1842 was temporary in its nature, and was renewed from time to time. Since 1853, when Mr. Gladstone extended it to Ireland $(t)$, the tax embraces the whole of the United Kingdom. The general scheme and mode of assessments are fixed by the Act of 1918, whilst the rate at which it is levied and variations in detail depend upon annual Acts. The present rate is $6 \mathrm{~s}$. in the $\&$, the first $£ 225$ being chargeable at half that rate.

Generally speaking, the tax falls on (1) all income derived from any source in the United Kingdom, irrespectively of whether the persons who receive the income are residents, absentees, subjects, or aliens; (2) all income from outside the United Kingdom received by subjects or aliens therein $(u)$.

Residence under the Acts means established place of abode, and not domicil $(x)$; and revenue paid to persons abroad through trustees, guardians, or agents in the United Kingdom is subject to the $\operatorname{tax}(y)$.

(o) Darnel's Case (1628) 3 St. Tri. 1.
(p) 39 Geo. III. c. 13.
(r) 46 Geo. III. c. 65 .
(t) $16 \& 17$ Vict. c. 34 .
(q) 43 Geo. III. c. 122.
(x) Rogers v. Inland $R$
(s) 5 \& 6 Vict. c. 35 .
(u) Act of 1918.
(y) Act of 1918. 
In the case of realty the tax is collected from the occupier, who must deduct the amount from the current rent; the owner cannot shift the liability on to the tenant.

Income is classified under five schedules:-

Schedule A deals with the ownership of landed property, which is charged according to the annual value at a rack rent (viz. the full annual value where the landlord and tenant pay their respective legal charges, and the landlord undertakes repairs), subject to certain deductions. The tax is adjusted so as to fall on the persons who actually enjoy the income.

Schedule B deals with the benefit derived from the occupation of land in the way of trade, business, or profession, whether the occupation be that of a tenant or of the actual owner, and the tax is assessed on twice the rent or annual. value.

The valuations are to be made annually, but stand generally for five years, the annual Finance Acts continuing the previous year's valuation. The valuation once adopted, cannot afterwards be questioned $(z)$. In the Metropolis the valuation is that made every five years under the Valuation of the Metropolis Act, 1669 (a), and is the same as that adopted for rating purposes.

Schedule C deals with public funds.

Schedule $\mathrm{D}$ deals with incomes derived from trades, professions, or other occupations, or any income not embraced by the other schedules. The assessment is made on a three years' a verage of the net profits.

Schedule $\mathrm{E}$ deals with salaries of public serrants.

Exemptions.-Under the Acts certain incomes are alto gether exempted from the payment of income tax, the most important of these exceptions are-

(1) The Crown is exempt from income tax under the general rule which excludes the Crown from the operation of any Act unless it is expressly named $(b)$. This exemption extends to lands and buildings

(z) Turner v. Carlton [1909] 1 K. B. 932 .

(a) $32 \& 33$ Tict. c. 67.

(b) See Mersey Docks and Marbour Board v. Cameron (1865) 11 H. L. Cas. 443. 
occupied by public servants, or servants of the Crown, for government purposes, e.g. county and police courts. Where, however, the oceupation is actually a tenancy at a rent there is no exemption. Or where the oceupation is simply for the benefit of the public apart from government purposes; sueh as property vested in trustees to improve docks and harbours (c). And by the Crown Private Estates Act, $1862(d)$, the private estates of the Crown are subject to ineome tax, which is payable out of the privy purse.

(2) Ineomes not exeeeding $£ 130$ are totally exempt $(e)$.

(3) The income of property held in trust for purposes of charity $(f)$.

(4) Hospitals, public schools, and almshouses.

(5) The incomes in eertain cases of sueh bodies as friendly and industrial societies, savings banks, trade unions.

(6) Public buildings belonging to universities, or literary or seientific institutions, and the lands and the stock held by the trustees of the British Museum.

Abatements.-The limit of ineome for which abatements have been allowed has varied from time to time, but is now fixed $(g)$ at $£ 700$, and between this amount and $£ 130$ (which is totally exempt) the rates of abatement are-(h)

Income not

exceeding

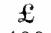

400

600

700
Abatement equal to the income tax on

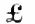
120

100 70

This applies to the incomes of individuals only, which excludes corporations; and where the joint income of husband and wife does not exeed $£ 500$, the separate ineomes of husband and wife may, in certain cases, be treated separately for purposes of abatement (i).

(c) Mersey Dochs and Harbour Board v. Cameron, supra.

(d) $25 \& 26$ Vict. c. 37, s. 8 .

(e) The amount for which total exemption is allowed has varied from time to time, but is now fixed at $£ 130$ (8\& 9 Geo. V. c. 40, s. 10), and see deductions, infra.

(f) Act of 1918 , s. 37.

(g) S. 11.

(h) Ib.

(i) S. 8 . 
Relief and Deductions. - The total income of a taxpayer is in the first place reduced by deducting one-tenth of the earned income. The deduction is allowed irrespective of the amount of the total income, but it must not exceed $£ 200$.

From the assessable income thus arrived at the following deductions may be claimed:-

A personal allowance of $£ 225$ in the case of a taxpayer whose wife lives with him, and $£ 135$ in any other case. If the wife has earned income of her own a further allowance requal to nine-tenths of her earned income may be granted, but this may not exceed $£ 45$.

An allowance for children of $£ 36$ for one and $£ 27$ each for others provided they are under 16 or receiving full-time instruction at an educational establishment. Adopted and step-children are within the allowance, but not a child having an income of $\$ 40$ a year.

An allowance for dependent relatives of $£ 45$ may also be claimed in certain cases.

The taxable income remaining after such deductions have been made is charged at $3 \mathrm{~s}$. in the $\mathfrak{E}$ on the first $£ 225$, and 6s. in the $f$ on the remainder.

Super Tax.-In addition to income tax an additional duty called super tax was imposed by the Finance Act, 1910, and under the Finance Acts of 1920 and 1921 it is now payable on incomes exceeding $£ 2,000$ at the following rates:-

In respect of the first $\$ 2000$

In respect of the excess over $\$ 2000$

for every $\&$ of the first $£ 500$ of the excess

, , ,

, , , ,

, , ,

, , ,

, , ,

, , ,

, , , , ,

next $\$ 500$

next $21000=$

next $\$ 1000$

next $\$ 1000$, ,

next $\$ 1000 \quad$,

next $\$ 1000$,

next $\$ 12000$,

next $£ 10000$

remainder of the excess

nil

, "

Corporation Profits Tax.-This tax was imposed by the Finance Act, 1920 , s. 52, and, subject to the provisions of 
the Act, it provided that a duty of an amount equal to five per cent. should be charged (1) on profits of a British company carrying on any trade or business or any undertaking of a similar character, and (2) on profits of a foreign company carrying on in the United Kingdom any trade or business or any undertaking of a similar character so far as those profits arise in the United Kingdom.

Collection and Management.-The management and collection of the tax is under the general supervision of the Commissioners of Inland Revenue $(k)$, and under the Board various officers assist in its assessment and collection. The Surveyors of Taxes are appointed by the Treasury. They examine and amend returns and assessments, and act as assessors in the Metropolis or any parish where there are no assessors. There are also additional commissioners appointed by the General Commissioners for any districts; special commissioners, consisting of the Commissioners of Inland Revenue, and others appointed by the Treasury; and commissioners under Schedule E. The assessors are appointed by the General Commissioners and supervised by the Surveyors of Taxes.

The various bodies of eommissioners act as quasi judicial tribunals in settling contested assessments, and appeals on points of law raised before the General or Special Commissioners on special ease, which must be stated by them on the demand of the appellant, or the Surveyor of Taxes, go to the King's Bench Dirision, and thence to the Court of Appeal and House of Lords $(l)$. The taxpayer has also a remedy in appropriate cases by mandamus and by Petition of Right under the Petitions of Right Act, 1860. The collection of the tax is enforced by penalties and distraint (which takes precedence of landlord's claim for rent) and sale. If there is no suffieient distress, the defaulter can be committed to prison by the General Commissioners until he gives bail or security to pay the tax and costs.

Quære, whether before the Act imposing the tax has

(k) 8 \& 9 Geo. V. c. 40 , s. $57 ; 10$ \& 11 Gco. V. c. 18 , s. 61 .

(l) $1 b$. s. 149 . 
been passed the revenue authority can assess and demand payment of it $(\mathrm{m})$.

\section{The Land Tax.}

History.-The origin of the Land Tax is only to be found by going back to early feudal times. Tenures by military service were commuted into money payments in the reign of Henry II., and these money payments became known as scutage, carucage, hidage, or tallage. The place of these was eventually taken by tenths and fifteenths, which were augmented by subsidies under Richard II. These subsidies were levied on real and personal property, generally at the rate of $4 s$. in the $£$ for realty, and $2 s$. $8 \pi$. for personalty. The amount which a subsidy so levied brought in came to be recognized as a fixed sum of $£ 70,000$, and that sum was understood when Parliament granted to the Crown a certain number of subsidies at one time. Subsidies were continued under the Tudors and Stuarts, and were granted sometimes by fixed sums and sometimes by a general rate of $4 s$, and $2 s .8 d$. in the $\&$. The Commonwealth continued to levy fixed sums by quotas from each county or borough, and these quotas were raised by a rate on an assessment of the annual values of the real and personal property in each parish or district, made by commissioners $(n)$ appointed for that purpose. After the Restoration in 1660, feudal tenures, the Court of Wards and Liveries, and the right of purveyance with the corresponding revenues were finally abolished by the 12 Car. II. c. 24 , and it appears that Parliament contemplated a perpetual grant of $£ 100,000$ per annum by a tax levied on land in lieu of these revenues (o). This resolution was not carried into effect, and the Act abolishing the feudal tenures granted the Crown certain taxes on ale, beer, and other liquors to make up for the loss of the feudal revenue.

The system, however, adopted by the Commonwealth

(m) Boules v. Att.-Gen. [1912] 1 Ch. 123.

(n) See Scobell's Collection of Acts and Ordinances, 1640-1656, p. 400 et seq.

(o) See resolution of the House of Commons to that effect, Journ. H. of Com., 1660, p. 45. 
continued to be practised, and fixed sums under the name of an aid (and occasionally of a subsidy $(p)$ ) levied on real and personal property by fixed quotas from each county or borough, or by a rate of varying amount on the annual value $(q)$, were generally granted in every year $(r)$ during the reign of Charles II. and subsequent reigns. The valuations of the annual values of real and personal property were made by commissioners for each district appointed by the Act which granted the tax, and the necessary quotas were raised by a rate on the annual values so determined. In the reign of Amne $(s)$ we find a grant of an aid by divers subsidies and a land tax; and in the same year a grant of a land tax to meet the expenses of the war against France and Spain $(t)$. But though called a land tax, a tax on personalty was included in the Acts, which were annual until 1798. The tax did not, and does not now, extend to Ireland, but it was extended to Scotland by the Act of Union in $1707(u)$, the quotas for the two countries being fixed in the proportion of $£ 48,000$ for Scotland and $£ 1,997,763$ for England. The present quotas raised from each county and borough are those fixed by the Land Tax Perpetuation Act, $1798(x)$, which made perpetual, subject to redemption, the provisions of the Land Tax, 1797, as to the quotas to be raised from the various counties and boroughs, and as to the amounts to be contributed by England and Scotland, which were fixed at $£ 1,989,673$ and $£ 47,954$, respectively $(y)$. The tax on personalty was, by the Act of 1797 , directed to be levied at the rate of $4 s$. in the $f(z)$, but the Act of 1798 provided

(p) See 15 Car. II c. 9.

(q) See 1 Will. \& M. sess. 2, c. 1 , where the rate was 2 s. in the $\mathscr{L}$ on the annual value of real and personal property.

(r) See amongst others 12 Car. II. ce. 2,27 ; 29 Car. II. c. 1.

(s) 1 Anne, c. 12.

(t) 1 Anne, st. 2, c. 1.

(u) 5 Anne, c. 8 , s. 9 .

(x) 38 Geo. III. c. 60 ; re-cnacted by 42 Geo. III. c. 16 . And see Reg. v. Tower Land Tax Commissioners (1853) 22 L. J. Q. B. 386 . The quotas fixed upon the various parishes by the Commissioners in 1798, under the Land Tax Act, 1797 (38 Geo. III. c. 5), cannot now be varied so as to cqualize the incidence of the tax. ( $I b$.

(y) 38 Geo. III. c. 5, ss. 2, 128.

(z) 38 Geo. III. c. 5, s. 3. 
that the rates on personalty were to be levied separately and according to the provision of future Acts $(a)$. In 1799 Pitt introduced the Income Tax (b), but the old tax on personalty still continued to be levied under the authority of annual Acts until it was finally abolished in 1833 (c).

Management and Incidence.-The collection and management of the tax is now under the control of the Inland Revenue Commissioners, subject to the supervision of the Treasury. The tax falls on owners, and must not exceed $1 s$, or be less than $1 d$. in the $\mathfrak{f}$, on the same valuation as that made by the General Commissioners of Income Tax for the purposes of Schedule A of the Income Tax Act, 1812 , viz. on the yearly value at a rack rent subject to certain deductions $(d)$.

On questions of assessment appeal lies to the district commissioners, whose decision is final, and there is no appeal by case stated to the High Court, as in the case of . Income or House Tax.

Unless otherwise provided for in the lease, a tenant pays the tax and deducts it from the current rent, and unless he does so he cannot recover it later. Crown property in the occupation of the Crown is exempt, but not if it is in private occupation (e); and owners, the ralue of whose lands in the aggregate does not amount to the yearly value of $20 s$, are also exempt. The tax may be redeemed by any person having an interest in the land except tenants at a rack rent, and tenants under the Cromn $(f)$, and the amount payable for redemption is now fixed at thirty years' purchase by the Finance Act, $1896(g)$. Redemption is controlled by the Commissioners of Inland Rerenue, and the tax has now lost much of its former importance, since the greater portion of it has now been redeemed.

(a) 38 Geo. III. c. 60 , s. 2.

(b) 39 Geo. III. cc. 13, 22 .

(c) $3 \& 4$ Will. IV. c. 12.

(d) Finance Act, 1896, ss. 31-35.

(e) See 42 Geo. III. c. 116 , s. 141.

(f) $I b$. s. $10 ; 16$ \& 17 Vict. c. 117 , s. 1 .

(g) S. 40. 


\section{The Inhabited House Duty.}

Histcry and Incidence.-This tax was first imposed in 1778; it was, however, abandoned in 1834, but re-imposed in $1851(h)$ on the abolition of the Window Tax, which was first imposed in 1696.

The tax applies to Great Britain only, and not to Ireland, and falls upon occupiers (not lodgers or servants). It is charged upon all inhabited houses of the annual value of $£ 20$ and upwards. To bring a house within the Act as inhabited some one must sleep upon the premises (i); but this does not include premises used purely for trade, business or professional purposes, in which a caretaker resides solely for purposes of protection $(k)$.

Houses belonging to the King, public offices, and such buildings as hospitals, charity schools, or houses for the relief of the poor, are exempt from the tax, as also are premises occupied for purposes of trade or for professional purposes only, houses of less than $£ 20$ yearly value, houses subdivided into dwellings of less than that amount, dwellinghouses unoceupied or unfurnished and in the occupation of a caretaker only. The assessment in country districts is made by local assessors under the local Income Tax Commissioners $(l)$ on the annual value at a rack rent, or the rent at which the property is worth to be let by the year. Appeal lies to the local Income Tax Commissioners, whose decision is final, unless they choose to state a case for the High Court. The assessment must not in any case be less than the poor rate valuation. In the County of London the valuation is that made by the surveyors of taxes under the Metropolis Valuation Act, $1869(\mathrm{~m})$. By the Act of 1851 and subsequent Acts two scales of duty are fixed. For ordinary dwelling-houses the rates are-

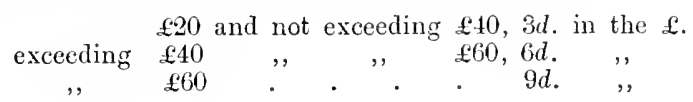

(h) 14 \& 15 Vict. c. 36.

(i) Riley v. Read (1879) 4 Ex. D. 100.

(k) 41 \& 42 Vict. c. 15 , s. 13 (2); 44 Vict. c. 12 , s. 31 . As to houses let in tenements or flats, see 3 Ed. VII. c. 46, s. 11.

(l) Taxes Management Act, 1880 (43 \& 44 Vict. c. 19).

(m) 32 \& 33 Vict. c. 67. 
In the second class are shops, hotels, inns, coffee, lodging, and farm houses, and the corresponding rates for these are $2 d ., 4 d .$, and $6 d$.

The collection and management of the tax is under the control of the Commissioners of Inland Revenue.

\section{Crown Land, and the Hereditary Revenues of the Crown.}

The ancient hereditary revenues of the Crown are derived principally from such lands, or interests in land, as have, or may become, vested in the Sovereign in his body politic in right of the Crown $(n)$. In addition to these are the revenues derived from prerogative rights relating to property; such are the right to bona vacantia (including waifs, wrecks, estrays, and treasure trove), and to certain fisheries, royal fish, and swans; the revenues derived from droits of Admiralty, and the Courts of Justice, and from fines, recognizances, legal fees and forfeitures. Besides these there were formerly certain revenues derived from prerogative rights relating to the Church, such as the temporalities of bishoprics during vacancy, corodies, firstfruits, and tenths, which have been diverted to other uses, or, in the case of corodies, fallen into disuse (o); together with

(n) These comprise the ancient demesne lands which the Crown acquired on the original distribution of property, and lands coming to it afterwards by virtue of the prerogative, such as the foreshore, lands formed by alluvion, or diluvion, or the right to royal mines, or lands acquired by escheat or forfeiture. (See 1 Bl. Com., 14th Ed. 286.)

(o) The temporalities of bishoprics on aroidances are now paid to the Ecclesiastical Commissioners and the bishop receives a fixed income in lien of the former revenues. (See the Ecclesiastical Commissioners Act, $1860,23 \& 24$ Vict. c. 124 , s. 1.) A corody was the right to send a chaplain to be maintained by the bishop, or to have a pension allowed him until the bishop promoted him to a benefice; this has apparently fallen into disuse. (See 1 Bl. Com., 14th Ed. 283). Firstfruits consist of the first year's whole profits of a benefice, and tenths, of the tenth part of the annual revenues and profits. They were first introduced into England, it seems, by Pandulph, the Pope's legate, in the reign of John and Henry III. (See 1 Bl. Com., 14th Ed. 283; 26 Hen. YIII. c. 3, s. 29; Rochester (Bishop) v. Le Fanu [1906] 2 Ch. 513, 518). They were made payable to the Crown out of all livings, and enforceable by writ of extent. (See stats. $26 \mathrm{Hen}$. VIII. c. $3 ; 33$ Hen. VIII. c. 39, s. 55). They were resigned by Anne to trustees to form the fund called Queen Anne's Bounty. (See $2 \& 3$ Ann. c. 11, Ruff. s. 1). They are now rated under statute at $£ 1$ and 17is. 6d. for every $£ 100$ of the annual value, and paid to the Governors 
certain revenues derived from taxation which were settled upon the Crown by statute, and have now been surrendered to the nation along with the other hereditary revenues in the manner presently mentioned, and are either paid into the Consolidated Fund, or have ceased to be chargeable. These were the revenues derived from the post office, which are now paid into the Consolidated Fund; the hereditary excise on beer, ale, and cider, now no longer chargeable $(p)$, and certain duties derived from wine licences, and the West India duties now repealed.

After the Revolution in 1688, and the accession of William III., the hereditary revenues continued to be settled upon the Crown by statute, until the accession of George III., the principle of contribution to the national revenue being preserved in the preamble to the Acts $(q)$.

Since the accession of George III., in $1760(r)$, it has been customary for succeeding sovereigns to surrender the hereditary revenues to the nation, to be paid into the Consolidated Fund, in return for a fixed income known as the Civil List $(s)$, the statutes by which this is effected, termed Civil Lists Acts, containing a clause preserving the rights of the Crown to the hereditary revenues, and being made to take effect for the life of the reigning Sovereign and six months after.

As a result of the various surrenders which are cumulative in effect $(t)$, the whole of the hereditary revenues in

of Queen Anne's Bonnty, to form a fund for the augmentation of poor livings. (See the Ecclesiastical Commissioners Act, 1836,6 \& 7 Will. IV. c. 77; O. in C. 27th Nov., 1852; Rochester (Bishop) v. Le Fanu, supra, at p. 520).

$(p)$ The hereditary excise and a duty on wine licences were settled upon the Crown by statute for ever in 1660 in place of the revenues arising from military tennres, which were abolished by the Act (12 Car. II. c. 24, ss. 15-27). They are now no longer chargeable. (Civil List Act, 1901, 1 Ed. VII. c. 4, s. 9 (3)). For the listory of the Wine Licences, abolished in 1757, sce the Laws of England, Vol. VII., p. 109, note $(g)$.

(q) See the preambles to the Crown Lands Act, 1702, 1 Ann. st. 1, c. 7, Ruff; and the statutes 1 Geo. I. st. 1, c. 1; 1 Geo. Il. st. 2, c. 1 .

(r) See 1 Geo. III. c. 1.

(s) So called because the salaries of eertain public officers, and the Civil Service were originally charged upon it. See 1 Geo. III. c. 1, s. 6.

( $t$ ) George III. surrendered the whole of the hereditary revenues except those of Scotland, and Ireland, and the Duchies of Lancaster and Cornwall, in return for an annuity of $\& 800,000$ upon which certain 
England, Scotland, and Ireland (including the revenues of the Osborne Estate $(u)$, but excepting those of the Duchies of Lancaster and Cornwall, and the Principality of Scotland, which are retained by the Crown for its private use (or, in the case of the Duchy of Cornwall, for the use of the Heirs Apparent), together with the surplus revenues of Gibraltar, or any other possession of the Crown out of the United Kingdom, and all casual revenues at home and abroad, are to be paid into the Consolidated Fund during the present reign and six months after $(x)$. In return for this surrender, provision is made for the King and certain other members of the Royal Family in the manner mentioned later $(y)$.

The control and management of the Crown lands is regulated by the $10 \mathrm{Geo}$. IV. c. 50, and various amending Acts. Under these Acts the Commissioners of Woods; Forests and Land Revenues, appointed by the Crown, and holding office during pleasure, with the Minister of Agriculture and Fisheries, who since 1906 is an ex officio Commissioner (z), exercise the powers of leasing and selling or exchanging the Crown lands conferred upon them by the Acts. The commissioners are bound to exercise due regard both to the interests of the nation and to those of the Crown to which the capital reverts six months after the death of the reigning Sovereign.

The nation is in effect in the position of tenant for the life of the reigning Sovereign, and the commissioners must

salaries were charged, by statute 1 Geo. III. c. 1 . The Irish revenues were surrendered by an Irish Act later in the same reign, 32 Geo. III. e. 1, Irish. A similar arrangement was made by George IV. (see 1 Geo. IV. c. 1 ; and 2 Geo. IV. e. 31 ) and by William IV., who surrendered in addition the revenues of Scotland (except the Principality, and the West India duties, since repealed. Queen Victoria made the same surrender, receiving an income of $£ 385,000$, but this was cleared of all charges for salaries of public servants or other national purposes (sce the Civil List Act, $1837,1 \& 2$ Viet. c. 2). The succeeding Act.s are the 1 Ed. VII. c. 4, and the present Civil List Act, 1910, $10 \mathrm{Ed}$. VII. and 1 Geo. V. c. 28 , the former of these providing that the hereditary excise duties should cease to be chargeable.

(u) This was presented to the nation by his late Majesty King Edward VII., as a memorial to the late Queen. See 2 Ed. VII. c. 37.

(c) Civil List Act. 1910, 10 Ed. TII. and 1 Geo. T. c. 28.

(y) See p. 150 , post.

(z) 14 \& 15 Vict. c. 42, s. $1 ; 6$ Ed. VII. c. 28 , s. 1. 
obtain as large an income as is compatible with the preservation of the capital. But though the hereditary revenues are legally liable to resumption by the Crown at the expiration of the term provided by the Civil List Act, such an event may now be regarded as merely a bare possibility, the surrender having become in practice virtually an established custom $(a)$.

\section{The Death Duties.}

The principle of raising revenue by means of a toll levied upon the property of a deceased person is no new thing in English history, the present-day system being simply a recrudescence in another form of the old feudal reliefs and primer seisins, payable by the heir on the death of a tenant either to the superior lord or to the ling $(b)$. These methods of raising revenue fell with the abolition of the feudal tenures in 1661 (c), though a survival of the old system is still to be found in the reliefs, fines, and heriots, payable on the descent of copyhold estates in various manors.

The new system was inaugurated by the probate duties created in 1694, which have since been continued by various enactments. The present death duties may be classed under two heads-(1) A tax upon the general estate of the deceased, real or personal, independently of the particular interest taken by any beneficiary and comprising the old probate, account, and temporary estate duties, the place of all of which has been taken by the present estate duties created by the Finance Act, 1894. (2) A tax upon the property passing to beneficiaries under a will or upon an intestacy, comprising the legacy and succession duties, and payable upon the interest of beneficiaries in addition to and independently of the old probate account, and temporary

(a) See the authorities cited in the Laws of England, Vol. VII., p. 111, note $(e)$.

(b) Relief was a tribute paid to any superior lord for taking up an estate which had lapsed or fallen in by the death of the last tenant; primer seisin, which consisted of a whole year's profits (or half a year's if the estate was in reversion), was only payable to the King by tenants in capite. (See Steph. Comms., i. pp. 177, 198).

(c) 12 Car. II. c. 24.

C.L.E. 
estate duties, and the present estate and settlement estate duties. Of these duties the old probate, account, and temporary estate duties are nearly obsolete so far as the payment of duty at the present day is concemed, since owing to the provisions of the Finance Act, 1894, they are now only payable in respect of deaths occurring prior to the 2nd August, 1894, haring been superseded by the estate duties as to deaths occurring on or after that date.

Legacy Duty.-Legacy duty was first imposed in $1780(d)$, and is now leviable under the provisions of the Legacy Duty Act, 1796 (e), the rates, which vary according to the date of the death in respect of which it is due, being regulated by the Stamp Act, 1815, as to deaths occurring before the 30th April, 1909, and, as to deaths occurring on or after that date, by the Finance (1909-1910) Act, $1910(f)$. It is payable independently of and in addition to probate, account, or estate duty, except the one per cent. duty in the case of lineal ancestors or descendants, which before the Finance Act, 1910, came into operation was not leviable on property on which account or estate duty is chargeable $(g)$, but is now payable under that Act, on deaths occurring on or after the 30th April, 1909.

Generally speaking, the property subject to the tax includes ail personal property (except leaseholds) (h) passing to legatees or devolving upon tlie next of lin upon an intestacy, and the duty falls upon the interest taken by the beneficiary, and not upon the general estate of the testator or intestate, unless otherwise provided by the testator (i). The duty is due as from the date of the death, but need not be paid until the expiration of one year, when any accretions are also taxable. The receipt for payment if the legacy must contain the particulars required by the Legacy Duty Act (a form for which is provided by the

(d) 20 Geo. III. c. 28 .

(e) 36 Geo. III. c. 52 .

(f) See 55 Geo. III. c. 181 , s. 2, Sched. Pt. III.; 10 Ed. VII. c. 8, s. 58 .

(g) 44 Tict. c. 12 , s. $11 ; 57$ \& 58 Vict. c. 30 , s. 1 , sch. I. (5).

(h) Which since 1853 are subject to succession duty $(16 \& 17$ Vict. (.. $5 \overline{\mathrm{T}}$, s. 1,19$)$.

(i) 36 Geo. III. c. 52. s. 21. 
Inland Revenue authorities), and be stamper with the duty payable before or within twenty-one days of the receipt of the legacy; an acknowledgment of the payment of the duty is indorsed upon the receipt $(k)$. The amount of the duty is regulated by a graduated scale, varying with the different degrees of relationship, the rates on deaths occurring before the 30th April, 1909, being fixed by the Stamp Act, 1815, and on deaths occurring on or after that date, by the Finance Act, 1910, as follows:-

Scale I.-Deaths occurring before 30th April, 1909:-

\section{Rate \\ per cent.}

1

$\begin{array}{llll} & \cdots & \ldots & \ldots\end{array}$

$5 \quad \cdots \quad \cdots \quad \cdots$

$\begin{array}{llll}6 & \cdots & \cdots & \ldots\end{array}$

$10 \quad \ldots \quad \ldots \quad \ldots$ 1909.

Scale II.-Deaths occurring on or after the 30th April, Rate

per cent.

1

5

10
Degree of relationship.

Lineal ancestor's or descendants (not pajable where account or estate duty is paid).

Brothers or sisters or their descendants

Uncles or aunts or their descendants.

Great-uncles or great-aunts or their descendants.

More remote relations or strangers.

Degree of relationship.

Lineal ancestors or descendants (payable also by husbands and wives, and where account or estate duty is paid except in the cases mentioned below).

Brothers or sister's or their descendants.

$\ldots\left\{\begin{array}{l}\text { Uncles or aunts or their descendants. } \\ \text { Great-uncles or great-aunts or their descendants. }\end{array}\right.$ More remote relations or strangers.

Excmptions.-Certain property is exempt from legacy duty, e.g. legacies to a spouse, on deaths occurring before the 30th April, 1909 ( $l$ ), but the 1 per cent. duty is payable on deaths after that date under the Finance Act, 1910; specific (but not pecuniary) legacies under $£ 20(\mathrm{~m})$; estates of which the net value (exclusive of property settled otherwise than by the will of the deceased) does not exceed $£ 1,000$ (which forms an estate by itself for purposes of estate duty) where the fixed duty or estate duty is paid upon the principal value of the estate $(n)$; sums payable

(k) 36 Geo. III. ss. 27, 29 .

(l) 55 Geo. III. c. 181, s. 2, sch.

(m) $I b$, sch.; $44 \& 45$ Vict. c. 12 , s. 42.

(n) Finance Act, 1894 , s. 16 (3). No settlement cstate duty or succession duty is payable on such estates. (Ib.) 
to lineal ancestors or descendants where account or estate duty is leviable, on deatlis prior to 30th April, 1909 (o).

Under the Finance Act, $1910(p)$, the 1 per cent. duty is not payable in the three following cases:-(1) Where the principal value of the property passing on death (other than property in which the deceased never had an interest, and property of which the deceased was never competent to dispose, and which on his death passes to persons other than the husband or wife or lineal ancestors or descendants) does not exceed $£ 1,500$ whatever the value of the legacy or succession. (2) Where the amount of the legacy or succession, together with any other legacy or succession derived by the same person from the testator, intestate, or predecessor, does not exceed $£ 1,000$, whatever the principal value of the estate may be: (3) In the last exemption, where the person taking the legacy or succession is the widow, or child under twenty-one years of age of the testator, intestate, or predecessor, the legacy or succession is exempt if it does not exceed $£ 2,000$ under similar eonditions.

Peduction of Duty.-In the case of estates slightly exceeding $£ 1,000$, a reduction of duty is in certain eases allowed under the Finance Act, 1914, as presently to be noticed $(q)$.

Incidenee.-Unlike probate duty, which only falls upon personalty situate within the jurisdiction of the High Court of Justice, legacy duty is payable upon personal property wherever situate, provided the deceased was domiciled in the United Kingdom, the law of the domicile and not the lex loci rei sitae governing the succession in such cases $(r)$. Therefore personalty situate in Scotland was held not to be liable to the duty on the death of the owner domiciled in Demarara $(s)$. And where the domicile is foreign, foreign personalty is not generally subject to legacy duty.

(o) 44 Vict. c. 12 , s. $41 ; 57$ \& 58 Vict. c. 30 , s. 1, sch. I. (5).

(p) S. 58, 2 (a), (b), (c).

(q) See p. 119 , post.

(r) For the purposes of collection and administration, however, personalty is governed by the lex loci, and not by the law of the domicile. See Blackwood v. Reg. (1882) 8 App. Cas. 82; Preston v. Viscount Melcille (1811) H. T. (Sc.) 8 Cl. \& F. 1).

(s) Thomson v. Advocate-General (1845) CI. \& F. 1. 
Succession Duty.-Sucecssion duty was imposed by the Succession Duty Act, 1853 (16 \& 17 Vict, e. 51), for the purpose of embracing those classes of property which the legacy duty failed to hit. Like the legacy duty, it is payable independently of and in addition to probate, account, ar estate duty (subject to the exception as to the one per cent. duty mentioned below), and falls upon the property (termed a succession) passing on the death of any person (termed the predecessor) to another" (termed the successor), and not upon the general estate of the testator or intestate, unless otherwise provided by the will. It was originally levied at the same rate and according to the same scale of relationship as the legacy duty, the 1 per cent. duty, however, in the case of lineal ancestor's or descendants not being payable (prior to April 30, 1909) where account or estate duty is paid $(t)$. Since June 30, 1888, the 1 per cent. duty payable in the case of lineal ancestors and descendants was increased to $1 \frac{1}{2}$ per cent., the other rates of duty being increased by $1 \frac{1}{2}$ per cent., except in the case of leaseholds, or property on which account duty has been paid $(u)$. When estate duty under the Finance Act, 1894, is chargeable, these additional duties do not apply $(x)$.

Rates under the Finance Act, 1910.-The above still applies to deaths occurring before the 30th April, 1909, but on deaths occurring on or after that date the rates are regulated by the Finance Act, 1910, being the same as in the case of the legacy duty, as previously set out in Scale (2): 'The 1 per cent. duty is made payable in the case of lineal ancestors and descendants, and also in the case of husbands or wives, even where account or estate duty is paid; but it is subject to the exemptions mentioned in the case of the legacy rluty.

Incidence and Payment.-The Act embraces property devolving to the heir or next-of-kin, or passing by a disposition made otherwise than for money or money's worth (including marriage and voluntary settlements), and of the following classes:-

(t) $57 \& 58$ Vict. c. 30 , s. 1 , sch. I. (5); $44 \& 45$ Vict. c. 12, s. 41.

(u) $51 \& 52$ Vict. c. 8 , s. 21.

(x) $57 \& 58$ Vict. c. 30 , s. 1, sch. I. (3). 
(1) All realty situate in the United Kingdom, whatever the domicile of the predecessor, but not where it is situate abroad, such property being subject to the lex loci rei sitae.

(2) All chattels real and all personalty (including leaseholds) wherever situate, not subject to legacy duty, where the predecessor was domiciled in the United Kingdom at the time the succession was created; but, generally speaking, foreign personalty is not subject to the duty if the predecessor was domiciled abroad, except in the case of property which is subject to a British trust, or vested in trustees in such a manner that the forum to which the beneficiaries would have to resort in order to recover the property would be an English, Scotch, or Irish court $(y)$.

(3) Legacies charged upon or payable out of real estate of persons dying on or after the 1st of July, 1888; or out of or upon any moneys to arise from the sale, mortgage, or other disposition of such real estate $(z)$.

Succession duty is payable by the successor himself, or by the trustees in whom the legal estate is rested, and also by persons taking the property subject to the duty under a derivative title. It was originally levied, in the case of real property, on the capitalized value, reckoned as an annuity equal to the annual value of the property for the life of the successor, according to actuarial tables, whether the interest was absolute or not, and made parable by eight equal half-yearly instalments, the first payment becoming due at the end of one year after entering into possession (a).

If the successor died before all the instalments had become due, such instalments as had not become due ceased to be payable, except in the case of a successor competent by will to dispose of a continuing interest in the property, when they remained a continuing charge on such

(y) See Att.-Gen. v. Campbell (1872) L. R. 5 H. L. 521; Re Cigala's Settlement (1878) 7 Ch. D. 351 ; Att.-Gen. v. Felce (1894) 10 T. I. R. 337: Att.-Gen. v. Jewish Association [1901] 1 K. B. 123.

(z) 51 Vict. c. 8 , s. 21 (2).

(a) 16 \& 17 Vict. c. 51 , s. 21 . 
interest. An optional method is provided for parment of the duty on realty on deaths occurring after the 1st of July, 1888, by two equal moieties, payable by instalments extending orer four or eight years $(b)$. By the Finance Act, 1894 , in the case of a sucession to real property, where the successor is competent to dispose of it, the ralue is no longer to be the capitalized value reckoned as an annuity, but the principal value (after deducting estate duty and the expenses incidental to paying the same) calculated in the same manner, and payable by the same instalments as in the case of estate duty (c).

Reduction of Duty.-Where the net value of the property real and personal on which estate duty is payable on the death of the deceased (exclusive of property settled otherwise than by the will of the deceased) exceeds $£ 1,000$, the amount of legacy and sucession duty payahle is not to exceed the amount by which the net value of the property estimated for purposes of estate duty, exceeds $£ 1,000(d)$.

\section{Estate Duty under the Finance Act, 1894, and Subse-} quent Acts. - The present estate duty was first imposed by the Finance Act, 1894 (57 \& 58 Vict. e. 30), which still remains the principal Act, to take the place of the old probate, account, and temporary estate duties, which, together with the additional $\frac{1}{2}$ per cent. and $1 \frac{1}{2}$ per cent. succession duties imposed in 1888, are no longer to be payable where estate duty is chargeable $(e)$ : And where the net value of the estate, exclusive of property settled otherwise than by the will of the deceased, does not exceed $\& 1,000$, and where the fixed duty or estate duty has been paid on the principal value of that estate, settlement estate duty, and legacy and succession duty are not to be paid under the will or intestacy $(f)$. The 1 per cent. legacy and suceession dutics payable in the case of lineal ancestors and descendants was remitted by the Act of 1894 , where estate duty is payable, but reimposed by the Finance Act, $1910(g)$,

(b) 51 Vict. c. 8 , s. 22 .

(d) Finance Act, 1914, s. 13 (2).

(c) $57 \& 58$ Vict. c. 30, s. 18 .

(e) $57 \& 58$ Vict. c. 30 , s. 1 , sch. I.

(f) Finance Act, 1894, s. 16 (3).

(g) Finance Act, 1910, 10 Ed VंTI. c. 8, s. 58 (2). 
the incidence at the same time being extended to include the husband or wife of the testator, intestate, or predecessor. The Act affects the estates of persons dying after the 1st of August, 1894, and the legacy and succession duties are still payable as heretofore, subject to the exceptions just noted.

Property subject to Estate Duty.-The class of property affected by the Act is much wider than that which was formerly subject to probate or account duty, and comprises all real and personal property passing on the death, or at a period only ascertainable by reference to the death, of the deceased, either immediately or after any interval, either certainly or contingently, and either originally or by way of substitutive limitation (h). It includes property which would be subject to account duty under the Acts of 1881 and 1889, and whether settled or unsettled. Limited interests which had been surrendered in farour of the reversioner or remainderman were formerly held not subject to the duty (i), but since the 31st of March, 1900, such property is liable to duty unless the surrender, assurance, divesting, or disposition, whether for value or not, was bonâ fide made twelve months before the death, and unless bont fide possession and enjoyment and possession of the property was assumed to the entire exclusion of the person who had the estate or limited interest $\left(l_{i}\right)$.

Every conceivable species of property, real and personal, may then be said to be embraced by the Act which is capable of passing or of changing hands on the death, subject to the special savings and exemptions mentioned in the Act of 1894 or amending Acts; and in cases where an actual passing or change of hands cannot well be understood, as in the case of the cessor of a limited interest in possession, reversion, or remainder, a kind of notional passing or change of hands is provided by the Act (l).

(li) Ss. 1, 22 (1), (1).

(i) Earl Couley v. Commissioners of Inland Revenue [1899] A. C. 198; Att.-Gen. v. Beech [1899] A. C. 53; Att.-Gen. v. De Préville [1900] 1 Q. B. 223.

(k) Finance Act, 1900, s. 11 (1).

(l) Finance Act, 1894, s. 2 (b); and see Att.-Gen. v. Wood [1897] 2 Q. B. 102 , as to the effect of $\mathrm{s} .7$ (7) on the valuation of such an interest not in possession. 
There is no provision in the Act with regard to property situated in the United Kingdom owned by persons domiciled abroad, but it would seem that all such property is embraced by the Act in analogy with the property subject to probate duty. In the case of property situate abroad, estate duty is payable in cases where legacy or succession duty is payable, or would be payable but for exemption on the ground of relationship (m); that is to say, in the case of personalty, where the deceased was domiciled in the United Kingdom, and in the cases noted above, where the property forms the subject of an English trust (n), whilst realty situate abroad is in all cases exempt.

Calculation and Rate of Duty.-The rate of duty payable depends upon the principal value of the estate, all classes of property passing on the death and subject to the duty being aggregated together so as to form one estate for the purpose of ascertaining that value $(0)$, except (1) property in which the deceased never had an interest $(p)$ (which is to be treated by itself); (2) where the net value of the estate, exclusive of property settled otherwise than by the will of the deceased, does not exceed $£ 1,000$, such property is to be treated as an estate by itself $(q)$; (3) pictures, books, etc., which appear to the Treasury to be given or bequeathed for national purposes, or to certain public institutions, and on which they have remitted the duty $(r)$; (4) where property, such as pictures, books, etc. (whether settled or not), appears to the Treasury to be of national or artistic, etc., interest, such property is to form an estate by itself, and duty is chargeable only when the property is sold, and then only on the last death (s). (4) Settled property passing on death under a disposition made by a person dying before the 2nd August, 1894, and which would,

(m) S. 2 (2).

(n) Ante, P. 118.

(o) Ss. 4, 7 (10); but no property is to be aggregated more than once. $I b$.

(p) $\mathrm{Ib}$; F Finance Act, 1900 , ss. 12 (1), 18.

(q) Finance Act, 1894 , s. 16 (3); and when the fixed duty, or estate duty, has been paid upon the principal value of that estate, settlement estate duty, and legacy and succession duty shall not be paid under the will or intestacr.

(r) Finance Ät, 1894, s. 15 (1).

(s) Finance Act, 1896, s. 20 (1); Finance Act, 1910, s. 63. 
if the disposer had died on or after that date, have been liable to estate duty, is treated as an estate by itself $(t)$.

In determining the value of the estate allowances are made for reasonable funeral expenses, debts, and incumbrances; and where property is situate outside the United Kingdom the commissioners may make an allowance for the additional expense incurred in administering or realizing such property, and must make an allowance for any duty payable abroad in respect of the property $(u)$. The value is to be estimated at the price which the property would (in the opinion of the commissioners) fetch if sold in the open market at the time of the death; and where the commissioner's require a valuation to be made by a person named by them, they are to bear the expense of such valuation. Property is not to be aggregated nor estate duty. paid, more than once on the same death $(x)$.

The duty is payable by means of a stamp, and a certificate of payment of the duty must be furnished by the commissioners on the application of the person accounting for the duty $(y)$. Appeal from the decision of the commissioners on questions of raluation or the rate at which duty is assessed lies to the High Court, and thence to the Court of Appeal, with the leave of the High Court or of the Court of Appeal (z). The conditions and time of appeal are subject to rules made by the court, and the costs of the appeal are in the discretion of the court. Where the value of the estate does not exceed $£ 10,000$ there is an alternative right of appeal to the County Court, and thence to the Court of Appeal (a).

Upon the principal value of the estate so found, the rates of duty are determined by four scales according to the date at which the deceased died, fixed respectively by the Finance Acts of 1894, 1907, 1910, 1914, and 1919.

(t) Finance Act, 1900, s. 12 (2); Finance Act, 1907. s. 16. But where the deceased died before 19th April, 1907, but after 8th April, 1900 , special provision is made as to aggregation. See Finance Act, 1900 , s. 12 (2).
(u) S. 7 (1)-(4).
(x) S. 7 (5), (8), (9), (10).

(y) Sis. 8 (2). 11 (1). The form of certificate is provided by Rules 101, 106.

(z) S. 10 (1), (2).

(a) S. 10 (5): Finance Act, 1896, s. 22. 
In the case of persons dying after 31st July, 1919, where the property $(b)$

\begin{tabular}{|c|c|c|c|c|c|}
\hline $\begin{array}{c}\text { Exceeds: } \\
£\end{array}$ & & $\begin{array}{c}\text { Per cent. } \\
\stackrel{\vdots}{ \pm}\end{array}$ & $\begin{array}{l}\text { Exceeds: } \\
\qquad £\end{array}$ & & $\begin{array}{l}\text { Per ent. } \\
£\end{array}$ \\
\hline 100 & $\ldots$ & $\begin{array}{ll}\ldots & 1\end{array}$ & 150,000 & $\ldots$ & $\ldots \quad 17$ \\
\hline 500 & $\ldots$ & $\ldots$ & 175,000 & $\ldots$ & 18 \\
\hline 1,000 & $\ldots$ & $\ldots$ & 200,000 & $\ldots$ & $\ldots$ \\
\hline 5,000 & $\ldots$ & $\ldots$ & 225,000 & $\ldots$ & 20 \\
\hline 10,000 & $\ldots$ & $\ldots$ & 250,000 & $\ldots$ & 21 \\
\hline 15,000 & $\ldots$ & $\ldots$ & 300,000 & $\ldots$ & 22 \\
\hline 20,000 & $\ldots$ & $\ldots$ & 350,000 & $\ldots$ & 23 \\
\hline 25,000 & $\cdots$ & $\begin{array}{l}\cdots \\
\ldots\end{array}$ & 400,000 & $\begin{array}{l}\cdots \\
\ldots \\
\end{array}$ & 24 \\
\hline 30,000 & $\ldots$ & $\cdots$ & 450,000 & $\ldots$ & $\ldots$ \\
\hline 40,000 & $\ldots$ & 10 & 500,000 & $\ldots$ & $\ldots$ \\
\hline 50,000 & $\ldots$ & 11 & 600,000 & $\ldots$ & $\ldots$ \\
\hline 60,000 & $\ldots$ & 12 & 800,000 & $\ldots$ & 28 \\
\hline 70,000 & $\ldots$ & 13 & $1,000,000$ & $\ldots$ & $\ldots \quad 30$ \\
\hline 90,000 & $\ldots$ & 14 & $1,250,000$ & $\ldots$ & $\ldots \quad 32$ \\
\hline 110.000 & $\ldots$ & 15 & 1.500000 & $\ldots$ & $\ldots$ \\
\hline 130,000 & $\ldots$ & 16 & $2,000,000$ & $\ldots$ & $\ldots$ \\
\hline
\end{tabular}

Reduction of Duty in Case of Small Excess.-Where necessary the amount of duty payable under the above rates, is to be reduced so as not to exceed the highest amount of duty which would be payable at the next lower rate, with the addition of the amount by which the value of the estate exceeds the value on which the highest amount of duty would be payable at the lower rate $(c)$.

Relief from Duty on. Quick Successions.-Where estate duty is payable on property consisting of land, or a business not carried on by a company, or any interest in land or such a business, passing upon death, and subsequently within five years estate duty again becomes payable on the property or any part of it passing on the death of the person to whom the property passed on the first death, the amount of the duty payable on the second death (if that occurs after the 31st July, 1914) is to be reduced as follows $(d)$ :

Where the second death occurs within-

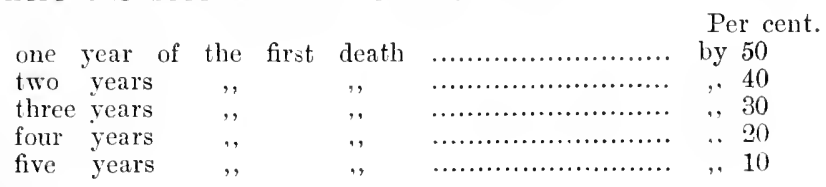

(b) Finance Act, 1919 (9 \& 10 Geo. V. c. 32), s. 29.

(c) Finance Act, 1914 , s. 13 (1).

(d) Ib. s. 15 . 
But where the value of the property on the second death exceeds the value of the same property on the first death, the latter value is to be taken for the purpose of calculating the amount of duty on which the reduction is to be allowed.

Payment of Duty.-An affidarit containing particulars of the estate must be delivered by the executors or administrators within six months of the death, and the duty is calculated as at the time of death, and becomes due on the delivery of the affidavit or at the expiration of the six months, whichever first happens, interest at 4 per cent. on the duty being payable from the date of the death $(e)$.

In cases of hardship the commissioners may postpone payment, or remit it altogether after the expiration of twenty years $(f)$, and in the case of real property the duty may be paid by eight yearly or sixteen half-yearly instalments, the first becoming due at the end of twelve months from the death, and interest at 3 per cent. due on the umpaid instalments being paid with each instalment. The whole duty and interest may be paid off at any time, and in the case of a sale it must be paid off, otherwise it becomes duty in arrear $(g)$. The duty on interests in expectancy may be paid either with the rest of the estate duty or when the interest falls into possession $(h)$. The provisions of ss. 12, 14 of the Customs and Inland Revenue Act, 1889, apply as to the limitations of claims for estate duty (i).

Incidence of the Duty.-The executor or administrator of the deceased is accountable for the estate duty in respect of all property, wherever situate, of which the deceased was competent to dispose, but is not liable for any duty in excess of the assets which he has received as executor, or might, but for his own neglect or default, have received $(k)$. The duty upon the property passing to the executor as such

(e) S. 6 (7); Finance Act, 1919, s. 30.

(f) S. 8 (9), (11).

(g) S. $6(8)$.

(h) S. 7 (6).

(i) S. 8 (2).

(k) S. 8 (3). 
(which includes personalty and leaseholds) (l) is borne, like probate duty, by the general personal estate, to the exclusion of specific legacies; but the rateable proportion of the duty on other species of property which do not pass to the executor as such (including realty which passes to the executor or administrator under the provisions of the Land Transfer Act, $1897(\mathrm{~m})$, is a first charge upon such property, except as against a bona fide purchaser without notice $(n)$, and if paid by the executor or any other person authorized or required to pay the duty, may be recovered by him from the trustee or owner $(o)$.

Settlement Estate Duty. (1) Since the Finance Act, 1914.-In addition to the estate duty payable under the Finance Act, 1894, a further duty at the rate of 1 per cent., raised to 2 per cent. in 1909, termed "Settlement Estate Duty," was imposed by the Act on settled property passing on deaths occurring after the 1st August, 1894, the property being at the same time relieved from further payment of estate duty or settlement estate duty during the continuance of the settlement. On deaths occurring after the 11th May, 1914, it is provided by the Finance Act, 1914, that settlement estate duty is no longer to be paid, the relief from further payments of estate duty on subsequent devolutions of the property occurring on deaths during the continuance of the settlement being at the same time removed in the case of persons dying after the 15th August, 1914, subject, however, to the reduction in the rates of duty chargeable in the case of quick successions previously mentioned $(p)$, and subject also to an exception in the case of the death of one of the parties to a marriage settlement, and to the deduction from the estate duty payable of the amount of settlement estate duty already paid, as provided by the $\operatorname{Act}(q)$.

(l) Property disposed of by will under a general power of appointment does not pass to the executor as such: Re Power, Aeworth v. Stone [1901] 2 Ch. 659; Re Moore, Moore v. Moore; O'Grady v. Wilmot [1916] 2 A. C. 231.

(m) See Land Transfer Act, 1897, s. 5.

(n) Finance Act, 1894, s. 9 (1).

(o) Ib. ss. 9 (7), 14 (1).

(q) Finance Act, 1914 (4 \& 5 Gco. V. c. 10), s. 14.

(p) See p. 123, ante. 


\section{Land Talue Duties under the Finance (1909-1910) Act, 1910.}

In the year 1909 the policy of raising a tax upon what has been termed the " unearned increment ralue" of land, or the amount by which the ralue of land increases owing to increased demand due to the progress and development of the community as a whole, independently of the exertions of the owner, was initiated by the Finance Act of that year, which, howerer, owing to the opposition to its passage through the House of Lords, did not come into operation until the 29th April, 1910.

Under this Act the duties are grouped under four heads, so as to embrace every kind of interest in land; viz. (1) increment value duty, which applies to grants of fee simple or other interests in land, grants of leases exceeding fourteen years, and interests in land passing on death, and is a charge of $£ 1$ in every $£ 5$ of the increase in the site value of the land on those occasions; (2) reversion duty, which applies to the benefit accruing to the lessor on the expiration of a lease, the original term of which exceeded twentyone years, and is a charge of $£ 1$ in every $£ 10$ of the benefit to the lessor arising through the determination of the lease; (3) undeveloped land duty, which is an annual charge of $\frac{1}{2} d$. in the $\&$ on the site ralue of undeveloped land where that value exceeds $£ 50$ an acre; (4) mineral. rights duty, which is an annual charge of $1 s$. in the $\&$ on the rental ralue of minerals, and mineral wayleaves.

Of these land value duties the first three are abolished by the Finance Act, 1920, s. 57 , and excess mineral rights duty by the Finance Act, 1921, s. 40.

Where increment duty has been paid, a special reduction is allowed in assessing the amount on which undereloped land duty is payable $(r)$. The site value of undeveloped land, for purposes of assessing undereloped land duty, does not include the value of minerals $(s)$. Except with regard

(r) Finance Act, 1914, s. 16 (3); and see p. 133, post.

(s) Finance (1909-1910) Act, 1910, 10 Ed. TII. c. 8, s. 16 (1), (2). 
to certain of the more conmon minerals $(t)$, reversion duty and (in general) increment value duty are not chargeable on mineral rights: Where increment value duty is chargeable it is an annual sum, and the mineral rights duty is to be reduced by the amount paid as increment value duty $(u)$.

General Exemptions.-The following interests are exempt from the incidence of some or all of the duties: (1) No duty under the Act is payable on land or any interest in land held by or on behalf of a rating authority $(x)$; (2) Increment value, reversion, and undeveloped land duties are not pay. able in respect of land held by a statutory company (viz. railway, dock, canal, or water companies, or any other company authorized by special Act to carry on public undertakings) for the purposes of its undertaking, and which cannot be appropriated except for those purposes. But increment value duty is chargeable where the land is sold or ceases to be so held (y); (3) Reversion duty, and undeveloped land duty are not payable in respect of land held by or on behalf of a governing body constituted for charitable purposes, and occupied and used by that body for the purposes of the body; and no increment value duty is payable by such a body on land held for the purposes of that body, whether it is used and occupied by the body or $\operatorname{not}(z)$.

This exemption includes a corporation sole, pioperty appropriated for the purposes of any naval or military forces of the Crown, all universities, colleges, schools, and other institutions for promoting literature, science, or art; and is expressly extended to certain registered friendly societies, and to any company within the meaning of the Companies

( $t$ ) These are enumerated, p. 135, post. They are, it seems, subject to both reversion and morement value duty as other interests in land (see note $(h), i b$. ).

(u) See p. 135 , post.

(x) Finance (1909-1910) Act, 1910, 10 Ed. VII. c. 8, s. 35 (1).

(y) $I b$. s. 38 (1), (2). The company has not to make returns as to valuation in respect of such land, other than as to actual cost; and that cost for the purposes of the Act is to be substituted for the original site value $(I b$.$) . The exemption extends to lands held by the company,$ and ultimately to be appropriated for works, but temporarily used for other purposes. (Ib.)

(z) Ib. s. 37. 
(Consolidation) Act, 1908, or body of persons incorporated by special Act, if precluded from sharing profits amongst members $(a)$.

Appeals._Except in eertain specified cases with regard to which special provision is made $(b)$, an appeal lies to a referee appointed under the Act, on any matter which the Commissioners are to determine or may determine under the Act: From the decision of the referee appeal lies to the High Court (in the manner and on the conditions directed by rules of court made under the Act) (c); From the decision of the High Court there is no appeal without the leave of the High Court or of the Court of Appeal (d).

\section{Application of Act in particular Cases.-(1) The Act} applies to copyhold interests; and in the case of copyholds of inheritance, and for life or lives or for years, where the tenant has the right of renewal, and customary freeholds, the total and site values are to be determined as if the land were freehold, subject to a deduction equal to the amount which it would cost to enfranchise. In the case of copyholds for life or lives, or for years where the tenant has no right of renewal, the land is treated as if it were freehold, and the copyhold interest were a leasehold interest $(e)$. (2) On sales under the Lands Clauses Aets, the amount of inerement value duty payable by the transferor is not to be treated as part of the costs or expenses of the conveyance of the land, and is not to be taken into aceount in assessing the compensation to the lessor $(f)$. (3) In the case of settled land, the tenant for life or trustee who pays increment value or reversion duty, may by deed charge the amount which he has paid, or may at any time be liable to pay, together with reasonable expenses in connection with the payment, upon the land. The benefit of such a

(a) Finance (1909-1910) Act, 1910, 10 Ed. VII. c. 8, s. 37.

(b) These provisions will be found in ss. 17 (3), 33 (1) (a), (b).

(c) $I b$. s. 37 (2), (3), (4). The provisions of the Finance Act, 1894, s. $10(2),(3),(4)$ are to apply to such appeals.

(d) $I b$. s. 37 (4) ; Finance Act, 1894, s. 10 (2).

(e) $I b$. ss. 40 (1) (a), (2).

(f) $I$ b. s. 38 (3). 
charge may be transferred as a mortgage. Notice of the deed must be given to the trustees of the settlement for the purposes of the Settled Land Act, $1882(\mathrm{~g})$. (4) A mortgagee may add to his security the amount of the increment value, or reversion duty to which he is liable, and expenses, properly incurred, in comnection with payment $(h)$.

Increment Yalue Duty.-Incidence.-This duty is calculated at the rate of $£ 1$ in every $£ 5$ on the increment value of land (viz. the amount by which the site value on the occasion of payment, as ascertained under" the provisions of the Act, exceeds the original site value on the 30th April, 1909 , as ascertained by a valuation made under the Act) accruing after the 30th April, 1909. The amount on which the duty is payable as so found is, however, to be reduced by an amount equal to 10 per cent. of the original site value if it is the first occasion of payment, or, on a subsequent occasion, by an amount equal to 10 per cent. of the site value at the time of the last preceding payment (i).

When payable.-The duty is made payable upon the following occasions $(k)$ : (1) On the occasion of the transier on sale of the fee simple, or other interest in land, or on the grant of a lease exceeding fourteen years, in pursuance of a contract made after the 29 th April, 1910 . (2) On deaths occurring after the 29th April, 1910, where the fee simple or any interest in land is comprised in property passing on the death within the meaning of ss. 1, and 2 (1) (a) (b) (c), (3) of the Finance Act, 1894, as amended by any subsequent Act; (3) Where the fee simple, or other interest in land, is held by a body corporate, or a body unincorporate as defined by s. 12 of the Customs and Inland Revenue Act, 1885 , in such a manner that it is not liable to death duties, the duty is payable on the 5th April, 1914, and every subsequent fifteenth year.

(g) Finance (1909-1910) Act, 1910, 10 Ed. VII. c. 8, s. 39 (1), (2).

(h) $I b$. s. 39 (4).

(i) $I b$. ss. $1,2,3$ (5). But there is to be no remission of duty which will make the amount of increment value on which duty has been remitted during the preceding period of five years exeed 25 per cent. of the site value on the last occasion of payment prior to that period, or of the original site value. $I b$.

(k) Ib. s. 1, 6 (1).

C.L.E. 
How paid.-The tax is a stamp duty payable by the transferor or lessor on the instrument or agreement for the transfer or lease $(l)$; and contracts for shifting the burden of payment on to the transferee or lessee are roid (m). As to payment on deaths the provisions relating to payment and collection of Estate Duty are applicable; and where the land passes to the personal representative as such, the duty is payable by him out of that interest, in exoneration of the rest of the estate $(n)$.

Excmptions.-The following interests in land are exempt from the tax: (1) Agrieultural land while that land has no higher value than its market value at the time of assessment for agricultural purposes $(o)$. (2) The site of a dwelling-house which has been oceupied by the owner as a residence for the twelve months immediately previous to the collection of duty, where the value for purposes of Schedule $A$ of the income tax does not exceed, (a) $\$ 40$ in the administrative County of London, (b) $£ 26$ in boroughs or urban distriets with a population of 50,000 or upwards, (c) $\$ 16$ elsewhere. (3) Agricultural land oceupied and cultirated by the owner for twelve months previous to the collection of duty, which together with any other land belonging to the same owner does not exceed fifty aeres, and where the average total value does not exeed $£ 75$ per aere. This exemption does not, however, apply to land occupied with a dwelling-house, which for purposes of Schedule A of the income tax, exceeds $£ 30$ in value $(p)$. (4) Land held by a body corporate or unineorporate without a view to the payment of profits or dividends and used bona fide for games or recreations, where the land is held under an agreement not determinable for five years, or

(l) Ss. 3 (6), 4 (1), (2). The instrument or agreement is not duly stamped unless it is stamped with (1) a stamp denoting payment of the duty, or (2) denoting that particulars for assessment have been given and security for payment where so desired, or (3) denoting that no duty is payable. (Ib. s. 4 (3)).

(m) Revenue Act, 1911, 1 Geo. T. c. 2, s. 1.

(n) Finance Act, 1910, s. 5 .

(o) $I b$. s. 7. The value for sporting purposes or other purposes dependent upon agriculture is treated as value for agricultural purposes, except where the value for such purposes exceeds the agricultural value. Ib.

(p) $I b$. s. 8 (2). 
where it is probable that it will continue to be so used $(q)$. (5) Land held by or in trust for His Majesty, or any department of Government $(r)$.

Reversion Duty.-This duty is payable by the lessor on the determination of a lease of land, the original term of which exceeds twenty-one years, at the rate of $£ 1$ in every $£ 10$ on the value of the benefit accruing to him by reason of the determination of the lease. The "benefit" accruing is the amount by which the total value of the land at the determination of the lease (less moneys expended by the lessor and attributable to works, or expenditure of a capital nature, or compensation to the lessee for the same) exceeds the total value at the time when the original lease was granted, these values being ascertained in accordance with the provisions of the Act. (s).

The duty is recoverable from the lessor as a debt due to the Crown; but ranks pari passu with all other debts due from the lessor. The lessor must deliver an account to the commissioners of Inland Revenue within three months of the determination of the lease, subject to a penalty on failure to do so $(t)$.

In the case of merger, provision is made for reduction of the duty, and mode of calculation in the event of the vesting of the lessor's and lessee's interests in the same person before the expiration of the lease $(u)$.

Exemptions.-.The duty is not payable in the following cases: (1) On a reversion to a lease purchased before the 30th April, 1909, where the lease determines within forty years of the purchase, if the lease determines under the original lease, and not by agreement. (2) Where the land is, at the determination of the lease, agricultural land. (3) Where the original term did not exceed twenty-one years. (4) Where the interest of the lessor at the termmation of the lease is a leasehold interest not exceeding twenty-one years $(x)$. (5) Where the lessec acquires the

(q) Finance Act, 1910, s. 9.

(r) $I b$. s. 10 .

( $s$ ) Finance Act, 1910, s. 13.

(t) $I b$. s. 15.

(u) Revenue Act, 1911, s. 3 (1).

(x) Finance Act, 1910, s. 14. 
lessor's interest by agreement, no duty is payable if, at the determination of the lease under the agreement, the lease has fifty years of the original term to run, and if the total value of the land does not exceed $£ 500(y)$. (6) Where a lease which is held in trust for a body of persons is surrendered and new leases are severally granted to the individuals composing that body, the plots so leased aggregating to the amount of the whole land, and the several rents aggregating to the amount of the whole original rent, but not exceeding it, no duty is payable. But in this case the lessor must deliver an account as if reversion duty were payable $(z)$.

Allowance for Increment Value Duty.--Increment value duty and reversion duty are not both payable in respect of the same benefit; and when one has been paid, it is to be credited as a payment in respect of the other in assessing the amount chargeable when that becones due $(a)$.

Undeveloped Land Duty.- This duty is payable annually by the orner, as a deht due to the Crown, and notwithstanding any contract to the contrary, at the rate of $\frac{1}{2} d$.

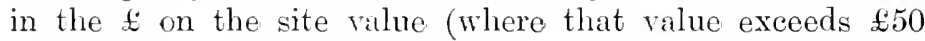
per acre) of mdeveloped land excluding minerals. Undeveloped land is defined as being land not developed by the erection of dwelling-houses, or buildings for the purposes of any business, trade, or industry other than agriculture (but including glasshouses or greenhouses), or not otherwise used bonâ fide for any business, trade, or industry, other than agriculture $(b)$.

A periodical valuation is to be made by the Commissioners of the site value of undeveloped land as on the 30th April in the year 1914, and in every subsequent fifth rear; and the site value for the purpose of assessing undeveloped land duty is either the original site value as ascertained under the Act, or the site ralue obtained under any subsequent periodical valuation $(c)$.

(y) Revenue Act, 1911, s. 3 (3).

(z) $I b$. s. 3 (4).

(a) Finance Act, 1910, s. 14 (4).

(b) $I b$. ss. 16 (1), (2), (4), 17 (1), 19.

(c) $I b$. ss. 28, 16 (3). 
The duty is assessed and payable at any time after the 1st January in each year. If not assessed within the year it is payable at any time within two months of assessment, provided not more than three years have elapsed from the expiration of the year for which it is charged (d).

Allowances.-(1) Where inerement duty has been paid, the site value for purposes of undeveloped land duty is to be reduced by a sum equal to five times the amount paid as increment value duty $(e)$. (2) An allowance of one acre is to be made for every $£ 100$ expended by the owner or his predecessors in title on roads or sewer's with a view to development, provided the expenditure has oceurred within twenty years of the occasion of payment ( $f$ ). (3) On agricultural land, where the site value exceeds $£ 50$ per acre, the duty is payable only on the amount by which the site value exceeds the agricultural value $(g)$.

Exemptions.-(1) Subject to the provisions of the Act, woodlands, parks, gardens, and open spaces, and lands used for games and recreations, or kept free from buildings in pursuance of a development scheme, are exempt from the duty (h). (2) Duty is not chargeable where the site value does not exceed $£ 50$ per acre (i). (3) Agricultural land cultivated by the owner, where the value of the land together with any other land belonging to him does not exceed $\$ 500(k)$. (4) The site value of land not exceeding one acre occupied with a dwelling-house; or the site value of gardens or pleasure grounds (not exceeding five acres) where the site value of the gardens and pleasure grounds together with the site value of the house does not exceed twenty times the annual value as adopted for Schedule A of the ineome tax (l). (5) Agricultural land held under at tenancy created before the 30th April, 1909, whilst the tenancy continues during the term granted. But where

(d) Finance Act, 1910, s. 19 .

(e) $\mathrm{Ib}$. s. 16 (3).

(f) $I b$. s. 16 (2) (b) ; Revenue Act, 1911, s. 4.

(g) Finance Act, 1910, s. 17 (2).

(h) $I b$. s. 17 .

(i) $I b$. s. 17 (1).

(k) Ib. s. 18. Owner, here, includes lessec where the original tern granted was fifty years or more.

(l) Ib. s. 17 (4). 
the landlord has power to determine the tenancy of the whole or any part of the land, the tenancy of the whole or such part is not to be deemed to continue after the earliest date at which he could so determine it $(m)$.

Mineral Rights Duty.-This duty is an annual charge if $1 s$. in the $£$ on the rental value of all rights to work minerals, and mineral wayleaves $(n)$, the rental value being either: (1) the rental paid by the working lessee in the previous year less the amount (if any) which represents cxtra rent or return to the lessor for expenditure by him which would ordinarily have been incurred by the lessee; or (2) where the minerals are worked by the proprietor, the amount which would have been received by him as rent, if the mineral rights had been let upon the customary. conditions; or (3) in the ease of mineral wayleaves, the amount paid as rent in the last working year (o).

Payment.-On notice being given by the commissioners the proprietor, or person receiving the rent, must give particulars within thirty days subject to a penalty not exceeding $£ 50$.

The duty is then assessed by the Commissioners of Inland Revenue, and becomes payable at any time after the 1 st January in any year.

It is recoverable as a debt due to the Crown from the proprietor, when he works the minerals, and in any other case from the immediate lessor of the working lessee, who must bear the duty notwithstanding any contract to the contrary made before or after the passing of the let (riz. 29th April, 1910) (p).

Where the duty falls upon an intermediate lessee he is entitled to deduct the amount of the duty from the rent payable to his lessor; and any person from whom a deduetion is so made, may, if himself a lessee, make a similar deduction from the rent payable by him in respect of the mineral right or wayleare. Contracts for the payment of

(m) Finance Act, 1910, s. 5

(n) Ib. s. 20 .

(o) $I b$. s. 20 (1), (2).

(p) $I b$. s. $20(3),(4)$. 
rent without allowing this deduction are void; and any person refusing to allow the deduction is liable to a penalty not exceeding $£ 50(q)$.

Provisions as to Increment Value and Reversion Duty.No reversion duty is payable on the determination of a mining lease $(r)$. Increment value duty is not payable on the grant of a mining lease; or in respect of minerals which are comprised in a mining lease or are being worked, except as an annual duty payable as provided by the Act $(s)$. Increment value duty is not to be cluarged on minerals. which on the 30th April, 1909, were comprised in a mining lease; or were being worked by the proprietor, so long as they continue to be so comprised, or worked. This exemption continues though they cease to be so comprised or worked during a period not exceeding two years $(t)$. Where increment value duty is chargeable upon mineral rights, it is an amnual sum calculated according to the provisions of the Act, and collected as Mineral Rights Duty, subject to the same right of deduction; the rental value upon which it is charged is subject to a reduction of that part of the rental which represents a return for money expended by the lessor within fifteen years, in boring or otherwise $(u)$.

Where increment value duty is paid on mineral rights in any year the proprietor or lessor is entitled to be reliever in that year from payment of mineral rights duty up to the amount paid in respect of increment value duty $(x)$.

Exemptions.-Mineral rights duty is not to be charged in respect of common clay, common brick clay, common brick earth, or sand, chall, limestone, or gravel $(y)$.

Valuation of Unuorked Minerals.-Where minerals cease to be comprised in a mining lease, or to be worked, their capital value (viz. their total value less the amount allowed

(q) Finance Act, 1910, s. 21 (1), (2).

(r) $I b$. s. 22 (1).

(s) $I b$.

(t) $I b$. s. $22(2)$.

(u) Ib. s. $22(2),(3),(4),(5)$.

(x) $I b$. s. 22 (6).

(y) $I b$. s. 20 (5). These ninerals are specially excepted from the operation of $\mathrm{s}$. 22 relating to reversion and increment value duties as stated in the text above. It would therefore seem that they are subject to these duties. 
by the commissioners as capital. expenditure to bring the mines into working) is to be ascertained in the manner provided by the Act, and the capital value so found is to be treated as the original capital value of the minerals (z).

For the purposes of this valuation the minerals are to be treated as a separate parcel of land $(a)$.

(z) Finance Act, 1910, s. 22 (7).

(a) $I b$. s. 23 (2). Since the expression "land" in the Act (except where the context otherwise requires it) is to be construed, so far as respects minerals, as a reference to the capital value so found (see s. 23 (4)), it would seem that the value of such unworked minerals would have to be taken into account for purposes of increment value or reversion duty. 


\title{
Part III.--The Executive.
}

\author{
Chapter I.
}

THE CROWN.

Members of the Executive.-Though nominally the supreme executive power is rested in the Sovereign, and all executive acts are done in his name, in practice the Crown acts upon the advice of its ministers, and the executive business of the country is carried on by the various Government departments, in accordance with the general policy determined upon by that special group of ministers known as the Cabinet. The heads of the more important departments form the Ministry, who are persons nominated by the Prime Minister from amongst the leading members of his party; the principal of these, with the Prime Minister at their head, constitute the Cabinet.

Omitting the House of Lords, who, though constitutionally entitled to advise the Sovereign on affairs of State, can hardly be said to take an active part in the conduct of the executive, the principal members of the executive may be enumerated as follows:-

(1) The Crown.

(2) The Privy Council.

(3) The Ministry and the Cabinet.

(4) The Lord Chancellor.

(5) The Lord Priry Seal.

(6) The Secretariat, or the five principal Secretaries of State, viz. the Home Secretary, the Foreign Secretary, the Colonial Secretary, the Secretary of State for India, and the Secretary of State for War.

These are the political heads of the corresponding departments of State. 
(7) The Law Officers of the Crown, viz. the Attorney and Solicitor General for England, the Attorney and Solicitor General for Ireland, and the Lord Advocate and Solicitor General for Scotland.

(8) The Chancellor of the Duchy of Lancaster.

(9) The political departments of State. These are-
(a) The Home Office.
(b) The Foreign Office.
(c) The Colonial Office.
(d) The India Office.
(e) The War Office.

The political heads of these form the Secretariat.

(f) The Admiralty Board.

(g) The Treasury Board and the Exchequer.

(h) The Post Office.

(i) The Scotch Office.

(j) The Irish Office.

(k) The Board of Trade.

(l) The Ministry of Health.

(m) The Ministry of Agriculture and Fisheries.

(n) The Board of Works and Public Buildings.

(o) The Board of Education.

(p) The Tmperial Defence Comnittee of the Cabinet. (10) The non-political departments $(a)$.

\section{The Croun.}

The Title to the Crown.- The Anglo-Saxon lings were elected by the Witenagemot, but it became customary to choose a member of the late King's family, though not necessarily his hereditary successor by right of primogeniture. Similarly the Conqueror submitted to an election by the Witan to fortify his title by right of conquest. Gradually the importance of election and coronation diminisher, whilst the doctrine of hereditary right became more firmly established, and in 1272 Edward I. commenced to reign before his coronation, which did not take place until the 19th of August, 1274. His son Edward II. com-

(a) The principal of these will be found enumerated post, p. 216 . 
menced to reign from the day after his father's death. From this point until the Act of Settlement, 1700, the title to the Crown fluctuates between Parliamentary grant and hereditary right. Richard II. was forced to resign in 1399 , and the Crown entailed by Parliament on Henry IV. and his heirs male. Edward IV., 1461, claimed the Crown by hereditary, right as the nearest male representative of Edward III., and enforced his right by force of arms. Henry VII., 1485, claimed the Crown partly by hereditary light and partly by right of conquest, but permitted his title to be fortified by statute. James I., 1603, claimed by descent from Margaret, and, in spite of the exclusion of the Scoteh line by the will of Henry VIII., Parliament acknowledged his title by passing an Act of Recognition (b).

On the flight of James II., Parliament, by the Bill of Rights, 1688 (c), declared the throne vacant by abdication, and settled the Crown upon William and Mary of Orange during their lives and the life of the survivor of them, the further limitations being (1) the heirs of the body of Mary, (2) the Princess Anne of Denmark and the heirs of her body, (3) the heirs of the body of William. In the year 1700 Mary, having left no descendants, and William being in a dying condition, and Anne's children all dead, further limitations became necessary in order to provide for the event of Anne's dying without leaving issue, which seemed probable, and the Act of Settlement $(d)$ was passed, under which the Crown is now held.

Under this Act the Crown was settled upon the heirs of the body of Sophia, widow of the Elector of Hanover, and daughter of Elizabeth, Queen of Bohemia, who was the daughter of James I. This settlement was made subject to the provisions, (1) that no papist should succeed, (2) that the declaration against transubstantiation in the form provided by Statute in 1677 (30 Car. II. stat. 2, c. 1), should be made on the first day of the meeting of the first Parliament, or at the coronation, (3) that the coronation oath, in the form provided by the Act for Establishing the Coronation Oath, 1688 (1 Will. \& Mar. sess. 1, c. 1), s. 3,

(b) 2 (Vulgo. 1) Jac. I. c. 1.

(c) 1 Will. \& M. s. 2, c. 2.

(d) $12 \& 13$ Will. III. c. 2. 
should be taken at the coronation, (4) that the person who succeeds should join in communion with the Church of England.

On the death of Queen Anne in the year 1714, leaving no issue, these limitations took effect, and, Sophia being dead, the Crown devolved upon her son, George I. From George I. the Crown descended lineally to George II., George III., and George IV., and from the latter to his brother William IV., in the year 1830, from whom it descended to Queen Victoria, niece of William IV., in 1837, and from the latter in 1901 to her eldest son, Edward VII., from whom it descended in 1910 to His present Majesty King George V., the eldest surviving son of Edward VII.

The present legal aspect, then, of the descent of the. Crown may thus be stated:- In the absence of statutory limitations the mode of devolution is governed at common law by the feudal rules of hereditary descent formerly applicable to land, subject to the distinctions, (1) that in the case of daughters the eldest alone inherits and her issue, the Crown not descending to all the daughters equally as coparceners, (2) that the old rules relating to the exclusion of the half-blood do not apply $(e)$. At common law, therefore, the Crown descends lineally to the issue of the reigning Sovereign, males taking before females, and subject to the right of primogeniture, children representing their deceased ancestors, per stirpes in infinitum. Upon failure of lineal descendants, the Crown passes to the nearest collateral relation of the blood royal $(f)$. The right of inheritance is, however, subject to be defeated by parliamentary enactment $(g)$, in which case the Crown descends according to the statutory provisions, but, subject to these, retaining its hereditary qualities as at common law. It may in fact be said that the old elective and hereditary principles, which appear in the early form of coronation service, still apply to the descent of the Crown.

(e) See 1 Bl. Comm. 14th Ed. 192, 193; 25 Ed. III., stat. 2, Ruff; Willion v. Berliley (1561), Plowd. 223, 245.

(f) See ib.

(g) Succession to the Crown Act, 1707 (6 Anne, c. 7, Ruff), ss. 1-3. 
Accession and Coronation.-In consequence of the legal maxim that the king never dies (Calvin's Case, 1608) (h), on the demise of the Crown the person who succeeds is entitled to exercise all prerogative rights before coronation. The accession of the new Sovereign is, however, customarily announced to the public as soon as conveniently may be after the former Sovereign's death by means of a proclamation issued, by the lords spiritual and temporal, members of the late Sovereign's Privy Council, and the principal gentlemen of quality, with the Lord Mayor, aldermen, and citizens of London (i). The following ceremonies complete the title to the Crown:-

(1) A declaration against transubstantiation required by the Act of Settlement $(k)$.

(2) A subscription to the oath for the security of the Established Church in England and the Presbyterian Church in Scotland, required by the Act of Union with Scotland $(l)$.

(3) A coronation by the Primate, when the four following essential ceremonies are observed:-

(a) A presentation by the Primate and recognition by the people in the presence of the hereditary officers of State.

(b) The administering of the coronation oath as required by the Act of Settlement $(m)$.

(c) An anointing by the Primate.

(d) Coronation by the Primate, and enthronization.

The following ceremonies are also usually observed:-

(e) An oblation by the Sovereign of an altar cloth, and a wedge of gold.

(f) The celebration of the Litany and Communion, and the delivery of a sermon.

(h) 7 Co. Rep. $10 \mathrm{~b}, 11$.

(i) For the form of proclamation used on the accession of King Edward VII., see the Supplement to the London Gazette Extraordinary, 22nd Jan., 1901.

(k) $12 \& 13$ Will. III. c. 2, s. 2. The form of declaration is provided by 3 Car. II. st. 2, c. 1 .

(l) Union with Scotland Act, 1706, 5 \& 6 Anne, c. 8, Ruff. Art, xxv., ss. 4,8 .

( $m$ ) The form of coronation oath is that prescribed by 1 Will. \& Mary, c. 6. This form, with some slight modifications, was used on the coronation of King Edward VII. (Sec Times, 11th Aug., 1902). 
(g) A presentation to the Sovereign of the Sword and Spurs, and oblation of the Sword by the Sovereign.

(b) An investiture with the Armilla and Imperial Mantle, and presentation to the Sorereign of the Orb with the Cross.

(i) An investiture with the ring and the two sceptres.

(j) A presentation of the Bible to the Sovereign.

(k) The Benediction and Te Deum.

(l) Homage by archbishops, bishops, and peers $(n)$.

Reference may here be made to certain offices of an hereditary nature connected with honorary services to be performed at the coronation ceremony, or the coronation banquet in Westminster Hall, if that is held. These offices are descendible either in gross (that is to say, they belong to particular persons independently of any other office or of the tonure of land), or as an incident of some other office or title, or of the tenure of land by grand serjeanty. Many of these services may be, and usually are, dispensed with by the Sovereign, though the persons from whom they are due are bound to perform them if ealled upon to do so. The validity of claims to perform the services is determined by the Court of Claims, which is eustomarily held prior to the coronation. This court was originally held by the Lord High Steward, but that office having merged in the Crown (o), the court is now composed of a royal commis. sion appointed by proclamation under the great seal, and termed the "Committee of Clains." This proclamation also usually signifies what portions of the ceremony are to be observed, and summons persons to attend upon a day named to submit their claims $(p)$.

The following are examples of the services usually claimed and allowed:-(1) the offices of the Lord Great Chamberlain, the Usher of the White Rod or principal Usher for Scotland, the hereditary Standard Bearer of Scotland, the hereditary Lord High Constable of Scotland, and the Lord

(n) See Wickham Legg. Eng. Coron. Rec.; Bodley's Coron. of Ed. VII.

(o) See 'Taylor's Glory of Regality, p. 110; Wollaston, Coronation Claims, p. 9 .

(p) For an example of such a proclamation, see the Coronation Proclamation, 26th June, 1901, published in the London Gazette. 
High Steward of Ireland. These offices are hereditary in gross. (2) Various services claimed as belonging to the holders of certain offices; such as the claim of the dean and chapter of Westminster to assist in the coronation; of the barons of the Cinque Ports to carry a canopy over the King; or of the lord mayor of the City of London to walk in the procession. (3) Various services incidental to the tenure of land by grand serjeanty; such as the claim of the lord of the manor of Worksop to find a glove for the King's right hand; or that of the lord of the manor of Scrivelsby to perform the office of King's Champion $(q)$. Where the service is incident to grand serjeanty it must, it is said, be performed in person, though a proper deputy may be appointed by the King's licence $(r)$.

Formerly on the demise of the Crown a proclamation was issued by the new Sovereign retaining old servants of the Crown in office, but this is now unnecessary, the Demise of the Crown Act, $1901(\mathrm{~s})$, providing that the holding of any office under the Crown shall not be affected by the demise of the Crown.

By the Royal Titles Act, $1901(t)$, the King was empowered by proclamation to make such addition as might seem fit, with a view to the recognition of the colonial dominions beyond the sea. This was accordingly done by proclamation of the 4th of November, $1901(u)$, the words "and of the British dominions beyond the seas" being added after the word "Ireland." The royal title is now, therefore, "George V. by the Grace, of God of the UnitectKingdom of Great Britain Ireland and of the British Dominions beyond the seas King, Defender of the Faith, Emperor of India." The King also inherits the titles of Earl of Dublin (conferred by letters patent in 1849) and Duke of Lancaster. The title of Duke of Cornwall and the Duchy vest in him in the absence of an heir apparent.

(q) For a full account of the claims claimed or adjudicated upon in 1901, see Wollaston's Coronation Claims. The various offices will be found enumerated in the Laws of England, Vol. VI., p. 330.

(r) 1 Co. Just., 106 b, $107 a, b$; Taylor, Glory of Regality, p. 111.

(s) 1 Ed. VII. c. 5.

(t) $I b$. c. 15 .

(u) See the London Gazette, 4th November, 1901. 
The Crown's Duty towards the Subject.-The duty of the Crown towards the subject, which rested originally upon the feudal bond which required service and obedience from the subject as " liege subjects," in return for protection from the King as " liege lord," is now to be found expressed in the terms of the oaths which he is required to take before or at the coronation. The duties imposed by the coronation oath (the necessity for taking which is imposed by the Act of Settlement) are: (1) To govern according to the laws and customs of the kingdom. (2) To cause law and justice in mercy to be administered. (3) To maintain the laws of God, the true profession of the Gospel, and the Protestant reformed religion as by law established. (4) To maintain and preserve inviolably the settlement of the Church of England, and the doctrine, worship, discipline, and government thereof as by law established in England. (5) To preserve to the bishops and clergy of England, and to the Church committed to their charge, all rights and privileges which by law appertain to them. The form of the oath as now administered differs slightly from the form prescribed by the Act for establishing the Coronation Oath, 1688, owing to the disestablishment of the Irish Church $(x)$. The Sovereign is also bound by the Union with Scotland Act, 1706 (5 \& 6 Ann. c. 8, Ruff), to preserve the Presbyterian Church in Scotland.

Allegiance.-The duty of allegiance is the direct outcome of the old feudal bond between the King and his people (Calvin's Case (1608) (y)); it is due to the actual or de facto King in possession, independently of his right by inheritance, and his subjects are by the Treason Act, 1495 (11 Hen. VII. c. 1), bound to serve him in war and assist him against rebellion, and are protected in so doing from the consequences of treason and all other penalties. It is due to the King both in his natural as rell as in his lingly or regal capacity (Desponcer's Case (1320)) (z).

(x) For the form of the oath administered in 1902, see Bodley's Coronation of Edward VII., p. 438.

(y) 7 Co. Rep. 1, 5 a.

(z) 1 St. Tr. 23. 
The duty of allegiance may be distinguished as natural, local, or acquired: (1) Natural allegiance is due from all natural-born British subjects. (2) Local allegiance is due from all aliens resident, or whose families are resident, within the realm, whether their country at amity with this country or not, but not from alien enemies invading the realm (Calvin's Case (1608)) (a). (3) Acquired allegiance is due from persons naturalized under the Naturalization Act, 1870, or the British Nationality and Status of Aliens Act, $1914(b)$, or by Act of Parliament, or made denizens by letters patent under the Great Seal, or by Act of Parliament, denization conferring some of the privileges of a British subject according to the terms of the grant. Unless born of English parents, however, a denizen is prevented by the Act of Settlement, 1700, from becoming a Privy Councillor, or a member of either House of Parliament, or from enjoying any office or place of trust, civil or military $(c)$.

At common law and by statute (Calvin's Case (1608); British Nationality and Status of Aliens Acts, 1914 and 1918), natural-born British subjects include all persons born within the King's dominion and allegiance (including persons born on board a British ship whether in foreign territorial waters or not) whatever their parentage (d). The following persons are also British subjects by statute:-

(1) By the British Nationality and Status of Aliens Act, 1914, a person born out of His Majesty's dominions

(a) 7 Co. Rep. 1, 6 a.

(b) The Naturalization Act, 1870, is repealed as from the 7th August, 1914, by the British Nationality and Status of Aliens Act, 1914, and naturalization must as from that date be effected under the latter Act.

(c) 12 \& 13 Will. III. c. 2, s. 3. This provision also applied to persons naturalized, but was impliedly repealed to that extent by the Naturalization Act, 1870, and is now expressly so repealed by s. 3 (2) of the British Nationality and Statns of Aliens Act, 1914, 4 \& 5 Geo. V. c. 17, ante, p. 11.

(d) British Nationality and Status of Aliens Act, 1914 (4 \& 5 Geo. T. c. 17 , s. 1 (1) (a) (c). Persons born on foreign ships within British territorial waters are not to be deemed British subjects by reason only of the ship being in such waters at the time of their birth (ib. s. 1 (2)); and except as otherwise provided (see note (e), infra) nothing in s. 1 is to affect the status of persons born before the 7 th August, 1914 (ib. s. 1 (3)), which will therefore remain as at common law (Calvin's Case, 1608), or as previously affected by the British Nationality Acts, 1730 and 1772, and the Naturalization Act, 1870.

C.L.E. 
is a British subject, whose father was a British subject at the time of his birth, and was either born within His Majesty's allegiance, or was a person to whom a certificate of British naturalization lad been granted (e), or had become a British subject by reason of any annexation of territory or was at the time of that person's birth in the service of the Crown $(f)$.

(2) Aliens who have become naturalized British subjects after five years' residence in England, or after five years' service under the Crown, under the provisions of the Naturalization Act, 1870, or (as from the 7th August, 1914) the British Nationality and Status of Aliens Act, 1914, and who enjoy the status and privileges of natural-born British subjects $(g)$.

A certificate of naturalization under the latter Act may, if the Secretary of State thinks fit on the application of the alien, include the names of children of the alien born before the date of the certificate, and being minors and not already British subjects. Within one year of obtaining their majority such children may make a declaration of alienage $(h)$.

A person naturalized under either Act may make a subsequent declaration of alienage if a subject of a state with

(e) British Nationality and Status of Aliens Act, 1914, s. 1 (1) (b). Whether born before or after the 7th August, 1914, the child of a British subject is to be deemed to be born within the King's allegiance if born in a place where by treaty, grant, usage, sufferance, or other lawful means $H$ is Majesty exercises jurisdiction over British subjects ( $i b$. s. 1 (1) (c)).

(f) $8 \& 9$ Geo. V. c. 38 , s. 2 (1).

(g) 33 \& 34 Vict. c. 14, s. $7 ; 4$ \& 5 Geo. V. c. 17, ss. 2, 3 (1). The former Act is repealed by the latter as from the 7th August, 1914, after which date naturalization must therefore be effected under the latter Act. By s. 5 (2) of the latter, the Secretary of State may grant certificates to minors.

(h) 4 is 5 Geo. V. c. 17 , s. 5 (1). Under the Naturalization Act, 1870 , s. $10(2)$, (4), the child of parents whose father or widowed mother was readmitted to British nationality or became a naturalized British subject (provided the child was an infant at the time of naturalization, and afterwards became resident with its parents in the United Kingdom) became a British subject. This provision (semble) still applies to a child of persons naturalized before the 7th August, 1914. 
which a convention lias been made to that effect, when he ceases to be a British subject (i).

(3) The wife of a British subject is herself a British subject, and the wife of an alien an alien. But where the husband ceases to be a British subject, the wife may make a declaration retaining her British nationality $(k)$, and the wife of an alien enemy who was at birth a British subject may resume her British nationality $(l)$.

(4) Any persons naturalized by Act of Parliament.

A person born within the King's dominions or allegiance, or on a British ship, if at the time of his birth or during minority he became also a subject of a foreign state, and not being under any disability, may divest himself of his British nationality by a declaration made under the provisions of the British Nationality and Status of Aliens Act, 1914. And under the same Act, persons who, though born out of the King's dominions, are British subjects may (if not under disability) make a similar declaration without any such condition as to foreign nationality $(\mathrm{m})$.

Under the same Act a British subject who becomes a naturalized subject of a foreign state, thereby divests himself of his British nationality $(n)$.

He cannot, however, by becoming a naturalized subject of an enemy's country, in time of war, divest himself of the duty of allegiance, so as to be able to commit acts of treason with impunity (R. v. Lynch [1903]) (o).

It was held in Calvin's Case $(p)$ that Scotchmen, born

(i) $33 \& 34$ Vict. c. 14 , ss. 3,$7 ; 4 \& 5$ Geo. V. c. 17, s. 15 .

(k) 4 \& 5 Geo. V. c. 17 , s. 10.

(l) 8 \& 9 Geo. 5 , c. 38 , s. 2 (5).

(m) 4 \& 5 Geo. V. c. 17 , s. 14 (1), (2). Previously to this enactment similar declarations by persons born in the British dominions could be made under s. 4 of the Naturalization Act, 1870 .

(n) 4 \& 5 Geo. V. c. 17, s. 13 . Where a person ceases to be a British subject, his children also being minors cease to be British subjects, unless they do not become by the law of another country naturalized in that country (ib. s. 12 (1)) (8 \& 9 Geo. V. c. 38, s. 7A). And where a British subject ceases to be a British subject he is not thereby discharged from any obligation, duty, or liability in respect of acts done before he ceased to be a British subject (ib. s. 16). As to change of name by aliens, see 9 \& 10 Geo. V. e. 92 , s. 7.

(o) R. v. Lynch [1903] 1 K.'B. 444.

(p) (1608) 2 St. Tri. 559. 
after the accession of James I. to the English throne, were citizens of both England and Scotland, and that Englishmen born after the same date were citizens of Scotland as well as of England.

By the British Nationality and Status of Aliens Act, 1918, the Secretary of State may revoke a certificate of naturalization where its continuance is not conducive to the public good.

Treason.-The offence of treason arose originally out of the old feudal bond, and if committed by a person in allegiance in any part of the world $(q)$ is punishable by the courts as soon as the offender comes within the jurisdiction. By the Treason Act, 1695, in the case of acts of treason or misprision of treason, other than a design or attempt to assassinate the King, committed in England or Wales, an indictment must be found by a grand jury within three vears after the commission of the offence $(r)$. But this provision does not, it seems, extend to treason committed outside the realn, or in Scotland, or Treland.

The offences constituting treason were first statutorily defined by the Treason Act, 1351 (25 Ed. IJI., st. 5, c. 2), which still remains the basis of the law of treason. By this Act, as extended by subsequent Acts (s), the following offences now constitute treason:--

(1) Compassing or imagining the death of the king or queen, or of the king's wife during the king's life, or of the king's eldest son and heir: also, it is said by Lord Coke, of the heir apparent, unless he be a collateral.

This was subsequently extended by the Treason Act, 1795 , to compassing or devising, etc., any bodily harm tending to death or destruction, maiming or wounding, imprisonment or restraint of the person of the ling, his heirs and successors $(t)$.

(q) For a case of treason committed outside the realm, see $R$. v. Lynch, supra; and sec R. v. Casement [1916] 2 K. P. 858.

( $r$ ) Treason Act, 1695 ( 7 \& 8 Will. III. c. 3), ss. 5, 6.

(s) The principal of these are the Treason Act, 1795, 36 Geo. III. c. 7 ; and the 57 Geo. III. c. 6 , repealed, but re-enacted in parts by the Treason Felony Act, 1848, 11 \& 12 Tict. c. 12.

(t) 36 Geo. III. c. 7 , s. 1 . 
(2) Levying war against the king in his realm; extenderl to cases of riot in Dammaree's Casc (1710); but there must be, it seems, an insurrection accompanied by force, and for an object of a public or general nature (u). (R. v. Frost (1839).)

(3) To adhere to the king's enemies, giving them aid and comfort in the realm or elsewhere $(x)$.

(4) 'To violate the king's wife during his life, or the wife of his eldest son during coverture, or the king's eldest daughter, being ummarried.

(5) By the Treason Act, 1702, and the Succession to the Crown Act, $1707(y)$, it is treason to endeavour to deprive or hinder the person next in sucession under the Acts regulating the succession to the Crown, from succeeding to the Crown; or maliciously and advisedly to affirm in writing or printing that any other person has any right to the Crown otherwise than according: to the Bill of Rights, 1688, the Act of Settlement, 1700, and the Union with Scotland Act, 1706.

Three other offences were also declared to be treason by the Act of Ed. III., but these may now be treated as felony or murder simply $(z)$. These were: (1) To counterfeit the Great Seal, Privy Seal, or coin of the realm; $(2)$ to issue false money; (3) to lill the Chancellor', 'Treasurer, or any of the king's justices in the execution of their office.

The penalty of drawing and quartering, together with forfeiture (except on outlawry), having been abolished by the Forfeiture Act, 1870, the punishment for treason is hanging; but the Sovereign may direct decapitation in place of hanging, by order under the sign manual countersigned by a Secretary of State $(a)$. There are no accessories in treason before or after the fact, all such persons being

(u) Dammaree's Case (1710) 15 St. Tri. 521; R. V. Frost (1839) 9 C. \& P. $129 ; 3$ Co. Inst. 9, 10.

(x) R. v. Ahlers [1915] 1 K. B. 616.

(y) 1 Ann., stat. 2, c. 17, Ruff.; 6 Ann. c. 7, Ruff.

(z) 24 \& 25 Vict. cc. 98, 99, 100.

(a) See the Treason Acts, 1790 and 1814 (30 Geo. III. c. 48, s. 1; 54 Geo. III. c. 146 , s. 1); the Forfeiture Act, 1870 (33 \& 34 Vict. c. 23, s. 31) ; and as to decapitation, the Treason Act, 1814, s. 2. 
principals $(b)$. The oath of two witnesses is required before proceedings can be commenced.

By the Treason Felony Act, 1848, the following offences constitute treason felony $(c)$ :-

(1) Compassing or devising, etc., to depose the Sovereign, his heirs and successors.

(2) Lerying war against the Sovereign in the United Kingdom or without, in order to make him change his counsels, or to intimidate or overawe either House of Parliament.

(3) Inciting foreigners to invade the realm or any of the King's dominions.

Misprision of treason is the bare concealment or keeping secret of any high treason $(d)$, and in order to constitute the offence there must be a knowledge both of the persons as well as of the treason itself. To avoid the guilt of misprision of treason, disclosure of the treason must be made to some magistrate or person in authority $(e)$. Conviction, for which the oath of two witnesses is required, entails imprisonment for life or outlawry.

The offences which constituted petty treason under the Treason Act, 1351, are now by the Offences Against the Person Act, 1861, to be treated as murder simply.

The Civil List.- In return for the surrender to the nation of the hereditary revenues of the Crown in the manner previously stated $(f)$, provision is made for the King's civil list by the Civil List Act, 1910 (g), as follows: There is to be paid for the King's civil list during the present reign and six months after the yearly sum of $£ 470,000$, and in the event of Queen Mary surviving the King, an amnuity of $£ 70,000$ is to be paid to her during her life. Provision is also made for the future Princess of Wales in the event of

(b) 3 Co. Inst. 138 .

(c) 11 \& 12 Vict. c. 12. The penalty is penal servitude for life, or any period not less than three rears, or imprisonment with or without hard labour for a term not exceeding two years (ib. s. 3; 54 \& 55 Vict. c. 69 , s. 1).

(d) 1 \& 2 Phil. \& Mar. c. 10. s. 8.

(e) See 1 East, P. C. 139, 140.

(f) See ante, p. 112.

(g) 10 Ed. VII. and 1 Geo. V. c. 28. 
the marriage of the Prince of Wales, and a trust fund is ereated for the benefit of the King's other children $(h)$.

The application of the sum paid for the eivil list is provided for as follows:-

1. Their Majesties' Privy Purse

2. Salaries of His Majesty's household and retired allowances

3. Expenses of His Majesty's household

4. Works

125,800

193,000

5. Royal bounty, alms, and special services

20,000

6. Unappropriated

13,200

8,000

470,000

The Royal Family.-For the purposes of the Royal Marriage Act, 1772 (12 Geo. III., e. 11), the roval family is now composed of His Majesty King George V. and his descendants, together with the descendants of the followinir persons: (1) The late King Edward VII.; (2) Queen Vietoria; (3) the first Duke of Cambridge, seventh son of George III., and uncle of Queen Vietoria; (4) the first Duke of Cumberland, fifth son of George III., and King of Hanover.

The Sorereign is bound by the ordinary law as regards marriage and diroree.

Under the Crown Private Estates Aets, 1800 and 1862, he may freely dispose of, and devise or bequeath his private property how he pleases (i), and his representatives are free from the obligation of taling out probate of his will $(k)$. The Crown's private estates are subject to parliamentary and parochial rates and taxes as the property of the subject, and these are to be paid out of the priry purse $(l)$. The position of a queenregnant is the same in

(h) The Princess of Wales is to receive an annuity of $\$ 10,000$ during the continuation of her marriage, and in the event of her surviving the Prince of Wales, an annuity of $\$ 30,000$ during life. In respect of each son of the King who attains twenty-one years, there is to be paid to trustees provided by the Act the aniual sum of $\mathfrak{E} 10.000$, and in respect of each son who marries, $\$ 15,000$. In respect of each of the King's daughters who attains twenty-one years or marries, there is to be paid to the trustees the annual sum of $\$ 6,000$. But these sums are to cease to be payable on death ( $10 \mathrm{Fd}$. VII. and 1 Geo. V. ss. 4, 5).

(i) 39 \& 40 Geo. III. c. $88 ; 25$ \& 26 Vict. c. 37.

(k) $25 \& 26$ Vict. c. 37.

(l) Crown Private Estates Act, 1862, ss. 8, 9. 
all respects as that of a ling $(m)$. The eldest son of the king inherits the title of Duke of Cornwall, the duchy having originally been conferred upon the Black Prince and his heirs, being the eldest son of the King of England, by Edward III. in 1337. The title of Prince of Wales was originated by Edward I., who, upon the conquest of Wales in 1284, conferred it upon his second son Edward $(n)$, subsequently Edward II. Since then it has been customary to confer the title of Prince of Wales and Earl of Chester upon the eldest son of the reigning sovereign, that is to say upon the heir apparent, but not the heir presumptive. This is affected by letters patent.

By the Treason Act, 1351, it is treason to compass the death of the Prince of Wales, or to violate the chastity of his wife, or of the eldest daughter, being unmarried, of the king or queen.

The children of sons of the Sovereign are entitled to the style of " Royal Highness" (conferred by letters patent in 1864); and by a statute of Henry VIII. the king's children are entitled only to such precedence as Parliament and the Council allows $(o)$.

By the Royal Marriages Act, 1772 (12 Geo. III. c. 11), no descendant of George II. (except the issue of princesses married into foreign families) may contract a valid marriage without the consent of the king or queen given under the Great Seal. But at the age of twenty-five they may marry without such consent after twelve months' notice to the Privy Council, if in the meantime the two Houses of Parliament have not disapproved of such marriage $(p)$.

The queen consort is, in general, a subject of the king and amenable to the ordinary law, except (1) that she is free from the disabilities of married women with regard to

(m) See 1 Mary, st. 3, c. 1. By the Interpretation Act, 1889 (52 \& 53 Vict. c. 63), s. 30 , the mention of the king in statutes includes the queen regnant.

(n) See Hume's Hist. of Eng., ii. 243.

(o) 31 Hen. TIII. c. 10. By this Act none but the King's children are to presume to sit at the side of the cloth of estate in the Parliament chamber, and certain preedence above all others is conferred upon such dukes as are the King's sons, brothers, uncles, nephews, or brothers' or sisters' sons.

(p) 12 Geo. III. c. 11 . 
property and procedure, and may sue and be sued as a fome sole; (2) her life and chastity are protected by the law of treason during her marriage with the king. She is represented in the courts by her own attorney and solicitorgeneral. The queen dowager ceases to be protected by the law of treason.

The position of a king consort has varied at different times. When Queen Mary married Philip of Spain, it was statutorily provided that the Queen was to enjoy all the prerogatives and exereise all the powers of the Crown as sole Queen. Official documents were, however, to be executed in their joint names $(q)$.

William III. declined to be king consort, and it was provided by statute that the regal power was to be vested solely in and be exercised solely by his Majesty in the joint names of both their Majesties $(r)$. The Crown was limited to the King and Queen to hold during their joint lives and the life of the survivor of them $(s)$.

The consort of Queen Anne became a naturalized British subject by statute in $1702(t)$, and was also introduced to the Privy Council. In other respects he was an ordinary subject of the Queen.

When Albert of Saxe-Coburg and Gotha married Queen Victoria, he was naturalized by statute $(u)$, and introduced to the Privy Council $(x)$. He was invested by the Queen in the exereise of her prerogative with precedence next to that of the Queen, and was created Prince Consort by letters patent in 1857. In other respects he was an ordinary subject of her Majesty.

(q) 1 \& 2 Ph. \& M. c. 10.

(r) 2 Will. \& M. st. 1 , c. 6.

(s) 1 Will. \& M. sess. 2 , c. 2.

(t) 1 Anne, c. 2.

(u) $3 \& 4$ Vict. cc. 1,2 .

$(x)$ He did not, however, become a privy councillor, it being provided by the Act of Settlement that "no person born ontside the United Kingdom (although he be naturalized or made a denizen, except such as are born of English parents) shall be capable to become a privy councillor or a member of either House of Parliament." As to persons naturalized under the Naturalization Act, 1870, see, however, p. 11, ante. 


\section{The Royal Prerogative.}

The Crown's prerogative may be defined in Blackstone's words with a slight modification as being " that which the ling hath over and above all other persons, by virtue of the common law, but out of its ordinary course, in right of his roval dignity" $(y)$. The prerogative as thus defined springs from three sources: (1) the old system of tribal chieftaincy, which gave rise to the executive powers of the Crown; (2) the old system of feudal chieftaincy, which gave rise to such rights as escheats, treasure trove, the custody of infants and idiots, and from which the doctrines of allegiance and treason sprang; (3) the various legal maxims evolved by lawyers, e.g. " the king can do no wrong," or " nullum tempus occurrit regi."

The present state of the prerogative can scarcely be understood without some reference to its past history and the struggle between the Crown and Parliament to fix its limits, which occupies so large a space in the history of England, from the time of Magna Carta, 1215, to the Act of Settlement, 1700 . The results of this struggle are embodied in the four great statutory landmarks, viz. Magna Carta, 1215; the Petition of Right, 1628; the Bill of Rights, 1688; and the Act of Settlement, 1700. With the last of these the struggle was practically ended, and the limits of the prerogative, which had been stretched by the Stuarts to an umbridled extent under the theory of divine right, were fixed in accordance with the popular will.

These constitutional documents, however, must not be considered so much as encroachments upon existing prerogative rights, as agreements come to, reluctantly perhaps, on the part of the Crown as to what the limits of that prerogative, which had never hitherto been fixed, actually were.

The principal topics which were the source of strife between the Crown and Parliament weresarbitrary imprison-

(y) The rorls "hy virtue of the common law" are added to Blackstone's definition, because it is clear that the prerogative forms part of the common linw, and the conts have frequently adjudicated upon its extent. 
ment, arbitrary taxation, the maintenance of a standing army and the issuing of commissions of martial law in time of peace, the granting of monopolies and exclusive trading licences, the suspension of and dispensing with Acts of Parliament, the control of the judiciary, and the right of independent legislation.

Arbitrary Imprisonment.-This, or indeed arbitrary punishment of any kind, was a direct infringement of the terms of Magna Carta, and the Petition of Right, 1628, again affirmed that no freeman should be imprisoned or detained contrary to the law of the land. The jurisdiction of the King in Council, exercised by the Star Chamber and the Court of High Commission, and commissions of martial law still remained as standing grievances, and were justly held in odium through the arbitrary nature of their proceedings. The Star Chamber and the Court of High Commission fell in $1640(z)$, and by the Bill of Rights, 1688, the issuing of commissions of martial law in time of peace was forbidden. The greatest safeguard, however, for the liberty of the subject at the present day is to be found in the Habeas Corpus Acts (a).

Arbitrary Taxation.-Arbitrary taxation by means of proclamation, letters patent, or writs under the Great Seal was frequently resorted to by the Tudors and Stuarts in order to meet the inroads made upon the Exchequer by expensive wars, and often by their own extravagance. The Commons no doubt granted money reluctantly, and, in many eases, too sparingly to meet the national requirements, as was perhaps only natural at a time when they had little or no voice in its expenditure. The government of the country, however, and the public services had to be carried on, and it seems hardly to be wondered at that the Crown was often foreed into methods of taxation opposed to the spirit of Magna Carta. The juticiary openly sided with the Crown in its illegal impositions, and both Bates' Case (1606), and Hampden's Case (1637), were given in its

(z) 16 Car. I. cc. 10, 11. The Court of Commissioners for Ecclesiastical Causes, established by James II., was abolished by the Bill of Rights.

(a) 31 Car. II. c. 2 ; 56 Geo. III. c. 100, as to which see ante, p. 28. 
favour; but it must be remembered that the judges at that time held office at the pleasure of the Crown, and the more likely perhaps to be subservient in their decisions. In the former case, an information having been laid against John Bates for refusing to pay a customs duty of five shillings per cwt. on currants, this tax having been imposed by letters patent, it was pleaded on behalf of the defendant that the duty was illegal. The four Barons of the Exchequer decided unanimously in favour of the Crown $(b)$. This decision led to the Petition of Grievances, 1610, which resulted in a remission of the taxes on alehouses and sea coal, but not in the concession of the principle involved. The Petition of Right followed in 1628, by which Charles I. pledged the Crown not to resort to taxation otherwise than by Act of Parliament; this pledge, however, he studiously disregarded, and in 1637 Hampden's Case (known as the Case of Ship Money) was given in favour of the Crown by seven judges out of twelve $(c)$. In consequence of this decision the Long Parliament passed an Act declaring all the proceedings in Hampden's Case " contrary to the laws and statutes of the realm, the rights of property, the liberty of the subject, and the Petition of Right," and vacated and cancelled the judgment $(d)$.

The attempts of the Crown to impose taxation without the consent of Parliament came to an end with the Revolution of 1688, and the Bill of Rights, 1688, which gave the Crown to William and Mary, at the same time declared that the levying of money for the use of the Crown without grant of Parliament is illegal.

The Maintenance of a Standing Army.-The maintenance of a standing army, or rather the continuous embodiment of the militia, which at that time took the place of a standing army, and the issue of commissions of martial law in time of peace, formed one of the great grievances against Charles I. It was obvious to Parliament that a standing army under the sole control of the King was a perpetual menace to the liberties of the subject, and though the Peti-

(b) (1606-1610) 2 St. Tri. 371.

(c) (1637) $3 \mathrm{St}$. Tri. 825 .

(d) 16 Car. I. c. 14 
tion of Right (1628) did not expressly forbid it, it did what amounted to the sane thing by prohibiting in time of peace the billeting of soldiers or sailor's on private houses, and the issue of commissions of martial law, by which alone the army could be properly disciplined.

After the Restoration an Act was passed which declared the militia and all other forces by sea and land to be under the sole government and command of the King (e), and both Charles II. and James II., with the consent of Parliament, kept up a permanent body of guards, which the latter monarch increased to 30,000 on his own authority $(f)$. The Bill of Rights declared the maintenance of a standing army and the issue of commissions of martial law in time of peace illegal, and since that date the regular standing army has been maintained on a legal footing by means of annual Acts known as Mutiny Acts down to 1881, and since then as the Annual Army Acts.

\section{Monopolies and Exclusive Trading Licences. - The} Tudors and Stuarts claimed and frequently exercised the prerogative of granting monopolies for the exclusive right of manufacturing, selling, buying, or using commodities, whether they were the invention of the grantee or not. This right of granting monopolies indiscriminately was not admitted at the common law, though the grant of the sole use to a person for a reasonable time of any new art in: vented by him was held to be within the Crown's preroga: tive. The great authority for this common law right of the Crown is the case of Darcy v. Allein (g) (44 Eliz. 1602), commonly called "the Case of Monopolies"; there the grant of a patent for the exclusive making and importing of playing-cards was held to be a monopoly, and therefore roid as contrary to the common and statute law and to public policy; the right of the Crown to grant a patent for new inventions was, however, admitted by the judges. This view was maintained by the Statute of Monopolies (21 Jac. I. c. 3), which, while prohibiting the grant of mono-

(e) 13 Car. II. c. 6 .

(f) Steph. Comm., ii. 598.

(g) 11 Co. Rep. 84 (d). 
polies generally, expressly excepted the grant for the term of twenty-one years of a patent for " the sole working or making of any new manner of manufacture within this realm to the first and true inventor or inventors of such manufacture" (h), and this language has been impliedly incorporated into the Patents and Designs Act, 1907 (i), by which the grant of letters patent is now regulated, the duration of the patent being, however, limited to the term of fourteen years, subject to extension in certain cases.

The Statute of Monopolies expressly excepted the rights of corporations, and of any companies or societies, from the operation of the Act $(k)$, and in 1683 it was held in the case of East India Company v. Sandys (l), known as "the Great Case of Monopolies," that a grant to the Company of the sole right of trading to the East Indies was good. In 1694 a new charter was granted to the Company, and in consequence the House of Commons passed a resolution to the effect that " all subjects have equal rights of trading to the East Indies unless restrained by Act of Parliament" $(m)$. Since that date the creation of such exclusive rights of trading have been clearly recognized as illegal.

The Suspending and Dispensing Power.-The claim put forward by the Crown under the Tudors and Stuarts of the power to suspend Acts of Parliament altogether, or to dispense with them in favour of particular persons, was contested judicially on various occasions. The decisions were in at least two instances favourable to the Crown within certain limits, but the fact must be taken into consideration that the judges were then dismissible at the pleasure of the Crown, and for that reason perhaps the more likely to be subservient in their decisions.

In Thomas v. Sorrell (n) the plaintiff, as common informer, claimed a large sum of money from the defendnt as the penalty for selling wine without a licence. The

(h) 21 Jac. I. c. 3 , s. 5 .

(i) 7 Ed. VII. c. 29 , ss. 17,18 .

(k) 21 Jac. I. c. 3 , s. 9.

(l) (1683-1685) 10 St. Tri. 371.

(m) 5 Parl. Hist. 828.

(n) (1674) Vaugh. 330. 
king's dispensation having been pleaded by the defendant, it was held that the ling cannot dispense with any general penal law made for the common good or that of a third party, but that he could dispense with a penal law the breach of which would only affect the king himself.

In Godden v. Hales (o) (1686, 2 Jac. II.), which was a similar action to recover a penalty from Sir Edward Hales for not having taken the oaths of supremacy and allegiance imposed by the Test Act, for which he had bcen indicted and convicted, it was held that the plea of dispensation was good, it being the king's "inseparable prerogative to dispense with penal laws in particular cases and upon particular necessary reasons of which the king himself is sole judge."

In the Seven Bishops' Case (1688) (p) the bishops were charged with seditious libel for having petitioned the king against a declaration of indulgence "founded on such a dispensing power as has often been declared illegal in Parliament." Two judges were in favour of conviction and two against it, but the jury, after twelve hours' discussion, acquitted.

Thus it will be seen that the Crown was not without some measure of judicial support in exercising the suspending and dispensing power, but the question was finally set at rest by the Bill of Rights $(q)$, which declared "the suspending or dispensing with laws or the execution of laws by the Crown illegal.'

The Judiciary.-The judges were and still are appointed by the Crown, but until the Act of Settlement, 1700, they were liable to dismissal at the royal pleasure. Whilst such a state of things existed, it can easily, be surmised that justice was not likely to be biased in favour of the subject.

The Act of Settlement declared that judges' commissions should be made "quamdiu se bene gesserint, but upon the address of both Houses of Parliament it may be lawful to remove thein."

(o) (1686) 11 St. Tri. 1166.

(p) (1688) 12 St. Tri. 183.

(q) 1 Will. \& M. sess. 2, c. 2. 
The tenure of office by the judges is now regulated by the Judicature Act, 1875, which provides that they are to " hold office during good behaviour, subject to a power of removal by his Majesty on an address presented to his Majesty by both Houses of Parliament" $(r)$. From the wording of this provision it seems a little open to doubt whether the Crown could or could not dismiss a judge for want of good behaviour without an address from the two Houses. Whether this be so or not the position of the judiciary is now, for all practical purposes, independent of outside influence, a position essential to the distribution of umpolluted justice.

Legislation by Proclamation.-Formerly the Crown claimed the right of what amounted to independent legislation by means of proclamation. A statute of Henry VIII. (s) enacted that proclamations issued by the king with the advice of his comeil should have the force of Acts of Parliament; this statute was, however, repealed in the reign of Edward VI. $(t)$.

In the Case of Proclamations (1610, 8 Jac. I.) (u), Coke, C.J., having been asked by the Privy Council to state his opinion whether the king might by proclamation prohibit new buildings in and about London and the making of starch of wheat, of which latter the Commons complained, it was subsequently resolved by the two Chief Justices, the Chief Baron of the Exchequer, and Baron Altham, after conference with the Privy Council, that " the king cannot create any offence which was not an offence before, for then he may alter the law of the land in his proclamation in some high point;. . . also the law of England is divided into three parts, the common law, statute law, and custom, but the ling's proclamation is none of these; . . . the king has no prerogative but that which the law of the land allows him."

In spite of this fecision, proclamations continued to be issued, and were enforced by the Star Chamber until that court was abolished in 1640 .

(r) 38 \& 39 Vict. c. 77 , s. 5 .

(t) 1 Ed. VT. c. 12 , s. 4. (s) 31 Hen. VrII. c. 8 .

(a) (1610) 2 St. Tri. 723. 
Since the Revolution of 1688 , the only instance of legislation by means of proclamation occurred in 1766 , when, in a case of emergency, and Parliament not being assembled at the time, the King was advised by his ministers to lay an embargo on all ships laden with wheat and flour. This was done with the object of preventing the scarcity arising from exportation, and the ministers were eventually indemnified by Parliament, though not without some difficulty.

It is now well-settled law that the Crown cannot by proclamation make or unmake any latw $(x)$ unless the proclamation is issued by the authority of some Act of Parliament. Royal proclamations have in no sense the force of law; they serve to call attention to the law, but they cannot of themselves impose any legal obligation or duty not imposed by common law or statute $(y)$. The Crown may, however, legislate by Order in Council, or', it seems, by proclamation $(z)$ in conquered and ceded colonies ( $a$ ), to which representative governments have not been granted; and in some instances the Crown is authorized to bring into operation the provisions of some statute which would otherwise remain dormant, for example, the Prevention of Crimes (Ireland) Act. Proclamations are also used to call the attention of the public to some act of the executive, e.g. the declaration of war or peace, or the provisions of some already existing statute.

What may be described as an important innovation in our constitutional law is the Emergency Powers Act, 1920 (b), which confers on his Majesty the power to issue a proclamation of emergency whenever it appears that (1) "Action has been taken or is immediately threatened" by any "person or body of persons" which is calculated "to deprive the community, or any substantial portion of the community, of the essentials of life"; (2) the action in question must be of " such a nature and on so extensive 662.

(x) See Ex parte Chavasse, in re Grazebrook (1865) 4 De G. J. \& S.

(y) Grieve v. Edinburgh, \&c. [1918] S. C. 700.

(z) Jephson v. Riera (1835) 3 Knapp, at p. 152.

(a) As to setrled colonies, see post, Part VI., Chap. II.

(b) $10 \& 11$ Geo. V. c. 55 .

C.L.E. 
a scale " as to have the effect just described; (3) the action must attempt to achieve that effect "by interfering with the supply and distribution of food, water, fuel, or light, or with the means of locomotion."

The Proclamation of Emergency, when made by the Crown, is to be in force for only one month, but may be succeeded by another at or before the end of that period (s. 1 (1)). It is to be communicated "forthwith" to Parliament. If Parliament is not sitting, but will in the ordinary course of events resume its sitting within five days, no further step to call together Parliament is necessary. But if Parliament is not due to resume within five days, then it must be recalled by Proclamation within five days (s. 1 (2)). This is an important safeguard on sound constitutional lines. It is evidently intended to preserve the "Supremacy of Parliament," so far as is feasible in circumstances which call for rapid action.

Section 2 of the statute goes on to give the Crown power, by Order in Council, to issue Proclamations for carrying out its main purposes (s. 2 (1)). But a proviso forbids " any form of compulsory military service or industrial conscription." Another proviso renders invalid any regulation purporting to create the act of striking into an offence. Offences against the regulation are to be tried by Summary Jurisdiction Courts (s. 2 (3)). And Parliament ean by a resolution of either Honse disallow a regulation at the end of seven days (s. $2(2))$.

Delegated Prerogative.-There was a time not so very long ago when the law of the land was to be found almost exclusively in the statutes of the realm and the decisions of the law courts. But things have changed, and there is now in addition a vast mass of statutory rules and orders made by the King in Council, of regulations by Government departments and of bye-laws by local authorities and statutory companies. Wuch of this consists of matters within the powers of the royal prerogative, and it is computed that nearly one-half of modern delegated legislation consists in reality of the exercise by subordinate bodies, under the authority of Parliament, of powers residing in the Prerogative. But the Crown seldom or never 
ventures to exercise prerogative rights adversely to, or, even in addition to, powers conferred by an Act of Parliament. Indeed, there is in such a case really no prerogative to exercise, since the prerogative, as we shall presently see, is merged in or abridged by the statute. The existence of so much delegated legislation may be a victory for Parliament over the Prerogative, but it is also a victory of the Bureaucracy over Parliament. What the ministers of despotic sovereigns dared not do under undoubted prerogative because of public opinion, the bureaucrat can now do without a moment's anxiety under the agis of parliamentary authority (c).

The Present State of the Prerogatixe.-Limitations of the Prerogative.-The result of the Petition of Right, 1628, the Bill of Rights, 1688, and the Act of Settlement, 1700, was thus a vast curtailment of the unbridled prerogative claimed by the Stuarts under the theory of divine right. The king could no longer impose taxes or legislate independently of Parliament, and he was prevented from using force in carrying out unconstitutional measures, since the existence of a standing army depended upon Parliament. He could no longer erect courts, such as the Star Chamber or Court of High Commission, which would enforce his proclamations; nor could he ereate a subservient judiciary who would enable him to disregard statutes with impunity. In addition to these curtailments the Act of Settlement provided that a pardon under the Great Seal should not be pleadable in defence to an impeachment by the Commons; the Crown was thus debarred from shielding its ministers from the consequences of illegal acts. Noreover, in cases where no actual illegality has been committed, and therefore no remedy by action lies, but where a subject deems himself unduly oppressed by the conduct of an official, or the sentence of a judge, the right of petitioning the king free from commitment or prosecution for so doing, as declared by the Bill of Pights, 1688, affords a partial remedy.

Such limitations of the prerogative made it impossible

(c) See Solicitor's' Journal, Tol. 66, p. 265. 
for the Crown to earry on the govermment of the country without the good will of Parliament, and thus eventuater? the eonstitutional eonvention of the necessity of the choice of ministers from amongst the leaders of the party who possess a majority in the House of Commons. It is now a well-established constitutional doctrine that the Crown is earrying on the executive acts through the various departments of State on the advice of the ministers who are at the liead of those departments, or on the advice of that group of ministers known as the Cabinet, and this system has become recognized as the only practical means of reconciling the exercise of the Crown's prerogative with the popular will as expressed in Parliament. The prerogative is no longer the personal prerogative of the King, but the privilege of the executive.

Constitutional Restraints upon Improper Exercise.From what has been already said it will be seen that the principal constitutional safeguards against an undue exercise of the prerogative are: (1) The fact that the ministers of the Crown, or public officials, must have recourse to the ordinary legal tribunals to enforce obedience to their commands, and that in so doing the plea of the king's commands (Danby's Case (1683) (d)), or State neeessity (Entick v. Carrington (1765) (e)), will not justify illegal acts, whilst the existence of any alleged prerogative may be judicially inquired into and detemined. (2) Under the doetrine of ministerial responsibility, ministers may be punished by Parliament for improper advice given to the Crown, by loss of office, eensure, or impeachment. (3) The liability of all servants of the Crown in their individual eapacity, either civilly or eriminally, for all tortious or criminal aets. (4) The right of petitioning the Crown. (5) The necessity for obtaining supplies, and passing the various Aets expiring annually, obliges the Crown to summon Parliament regularly, and observe the eonventional laws of the constitution.

Merger in Statute. - When a statute is passed empowering the Crown to do a certain thing which it might hereto-

(d) Danby's (Earl) Case (1683) 11 St. Tri. 599.

(e) Entick v Carrington (1765) 19 St. 'Tri. 1030. 
fore have done by virtue of its prerogative, the prerogative is merged in or abridged by the statute, and the Crown can only do that thing in accordance with the provisions of the statute, and its prerogative to do that thing is in abeyance $(f)$.

Present State of the Prerogative.--At the present day, then, the king is nominally the supreme executive power, and all executive acts are done in his name. He summons, dissolves, and prorogues Parliament, and is also the titular head of the Church, the Army, and the law. He confers all titles, honours, and distinctions, and has the power of declaring peace or war, of making treaties with foreign nations, and regulating this country's relations with them by means of ambassadors. He exercises the right of pardoning offenders after conviction, confers peerages and other titles and honours, and appoints bishops and judges. It must be understood, however, that in the exercise of all these prerogative rights the Crown acts on the advice of its ministers, who are responsible to Parliament (and in the case of illegal acts to the law) for the proper exercise of the prerogative. There is, in fact, no executive act of the Crown for which some one of its ministers or officers is not responsible.

The Crown also enjoys many legal privileges and exemptions. From the maxim that the king can do no wrong flows the result that no action can be brought against him in criminal suits, or in civil causes arising out of tort; in civil cases arising out of contract the subject must proceed by the special method of Petition of Right, which is granted as of grace and not upon compulsion, the procedure being now principally governed by the Petitions of Right Act, $1860(\mathrm{~g})$. Also from the maxim Nullum tempus oeeumit regi flows the result that no negligence or laches can be attributed to the Crown, but in suits relating to the recovery of land (except liberties and franchises which may be prescribed for at common law) the Crown is barred under the Nullum Tempus Act, 1769, by the lapse of sixty

(f) Att.-Gen. v. De Keyser's Royal Hotel [1920] A. C. 508.

(g) 23 \& 24 Vict. c. 34 . As to actions against the Crown and its servants generally, see $\mathrm{p} .37$, ante. 
years $(h)$, in informations for usurping corporate offices or franchises by the lapse of six years (i), and an indictment for treason (except for an attempt to assassinate the king) must be brought within three years $(k)$. The Crown also enjoys the right of granting safe conducts to foreign subjects (generally umnecessary except in case of war); the right (in so far as it is not obsolete) of recalling subjects from beyond the seas by letters under the Great Seal $(l)$; but it cannot, it seems, compel a subject to leave the realm (at any rate in time of peace) for war or any other purpose (Broadfoot's Case (1743)) ( $m$ ), except on process of outlamy, no: prevent a person leaving the kingdom except under s. 6 of the Debtors Act, 1869; the riglit to the custody and care of infants, idiots, and lunatics, now entirely regulated by statute and delegated to the Chancery. Dirision of the High Court of Justice, and the Lunacy Commissioners respectively; the regulation of weights and measures (now dealt with entirely by statute); the giving of currency to coins; together with many prerogative rights in relation to property,--such as the right to escheat and forfeiture of land (which latter has been entirely abolished by the Forfeiture Act, 1870, except on outlawry); the right. to royal mines of gold and silver; the right to the foreshore (except in the Duchy of Comwall, where it belongs to the Prince of Wales, and except where it has been granted out to the lords of manors), and to lands formed by alluvion, or left bare by dilurion; the right to hold its property exempt from taxation (except when expressly named in statutes, and except as to statutory private estates); the right to bona vacantia, or goods in which no one can claim a property, such as the personal estate of persons dying

(h) 9 Geo. III. c. 16 .

(i) 32 Geo. III. c. 58 .

(k) 7 is 8 Will. III. c. 3 . As to death duties, see Finance Act, 1894, s. 8 (2).

(l) $\mathrm{Br}$ Magna Carta all persons, unless under sentence of outlawry or imprisomment, were to be free to enter or leave the realm by land or sea (see Stubbs' Sel. Chart., 8th Ed., p. 301). See, per contra, BI. Con. 14th Ed. 270, which may, however, be doubted.

(m) Broadjoot's rase (1743) Fost. 154. There is autlority for restrain. ing persons from leaving the realm in time of war by proclamation. See 3 Co. Inst. 179. 
intestate and without next of kin, or personal estate rested in trustees for beneficiaries all of whom are dead, wreck not claimed within a year, treasure trove, waifs (viz. stolen goods thrown away by a thief in flight), estrays (viz. wandering animals where the owner cannot be found); and the right to royal fish (viz. whales and sturgeons caught within territorial water's), and royal swans (viz. swans swimming in open and common rivers, and unmarked). 
Chapter II.

\section{THE PRIVY AND CABINET COUNCILS AND THE MINISTRY.}

\section{The Privy Council.}

Functions of the Privy Council.-The consultative and advisory functions which were formerly exercised by the Priry Council have now devolved upon the Cabinet or the heads of the various departments $(a)$, and the duties of the Privy Council (except where it acts through committees such as the Judicial Committee of the Privy Council, the standing committees to advise on questions relating to the universities of Oxford and Cambridge and Scottish Universities, and on constitutional matter's relating to the Channel Islands, and charter's for municipal corporations $(b)$ ) are now for the most part confined to formal executive acts. In the first stages of its development the Cabinet system was viewed unfavourably by Parliament, as it was thought that the practice of seeking advice from a group of ministers who occupied no definitely recognized place in the Constitution, and whose names were often unknown, would tend to bring the conduct of the executive more immediately under the personal influence of the Sovereign, whilst the responsibility to Parliament for the advice given to the Crown would be lessened from the uncertainty upon whom to fix it. A provision was accordingly inserted in the Act of Settlement $(c)$ to the effect that "matters

(a) The Board of Trade, the Local Government Board, the Board of Edncation, and the Board of Agriculture were all originally Committees of the Council.

(b) As to the standing committees on the universities, see the Universities of Oxford and Cambridge Act, 1877 (40 \& 41 Vict. c. 48), ss. 3-6; the Universities (Scotland) Act, 1889 (52 \& 53 Vict. c. 55); as to charters, the Municipal Corporations Act, 1882 (45 \& 46 Vict. c. 50), ss. $210,211$.

(c) $12 \& 13$ Will. III. c. 2, s. 3 (4). 
which had formerly been transacted by the Privy Council should continue to be transacted there." This provision was, however, repealed in the reign of Amne, before it could come into foree $(d)$, and the Cabinet system left to develop unhindered.

In purely executive matters, also, the Privy Council has lost mucl of its former inportance, the duties of some of the former committees of the Council having been handed over to various departments (suel as the Board of Trade, the Ministry of Health, the Ministry of Agriculture and Fisheries, and the Board of Education), whilst in such formal exeeutive matters as it does transaet, it aets for the most part upon the responsibility of a department.

Apart from the business transacted by the various committees mentioned above, the Privy Couneil now aets generally merely as the formal medium for giving expression to the measures determined on by the Crown on the adviee of its ministers in the exercise of those exeeutive functions which it possesses either by virtue of the prerogative or of statutory authority, $e \cdot g$. matters relating to the government of Crown eolonies and protectorates, the deelaration of peace or war, treaties, etc., and the vast importance of the business which is thus transacted without Parliamentary sanction or discussion is noterrorthy. The Council expresses the wishes of the Crown in such matters either by order in Couneil or by proclamation. Orders in Comneil are used when new rules and regulations are approved and passed by the King in Couneil. Proclamations are used where it is required to give publicity to such matter's as the summons, dissolution, or prorogation of Parliament, or the deelaration of peace or war. Three members of the Council form a quorum, and the orders of the Comneil are authenticated by the signature of the clerk to the Council.

Other matters transacted by the Privy Council inelude the administration of official oaths, the appointment to and resignation of offices under the Crown, homage by bishops, and the selection of sheriffs.

Meetings of the Privy Council are summoned by the elerk to the Council in ordinary, and, except at meetings of the

(d) 4 Anne, c. 8, ss. 24, 25. 
various committees when it is unconstitutional for him to be present $(c)$, the King presides.

The ordinary civil and criminal jurisdictions which the Council formerly exercised were handed over for the most part to such courts as the Star Chamber, the Court of High Commission, and the Court of Requests, and have now become merged in that of the ordinary civil courts. The appellate jurisdiction is, now exercised by the Judicial Committee of the Priy Coumcil, established in 1833.

Composition of the Prixy Council.-The Privy Council at present (1922) consists of the lord president, appointed by declaration of the King in Council, and some three hundred members, and these are chosen by the Crown from amungst noblemen of high rank, persons who have held or hoil high political, judicial, or ecclesiastical uffice, distinguisher persons in colonial politics, and occasionally eminent persons in science or letters. Such dignitaries as the Prime Minister and other members of the Cabinet, the Lord Chancellor, Lord Chief Justice, Lords of Appeal in Ordinary and Lords Justices of Appeal, the two Archbishops, and the Bishop of London, together with near relatives of the Sovereign, are invariably Privy Councillors. Privy Councillors are called to office by the invitation of the King, and may be removed by him. On becoming members of the Council they must take the oath of allegiance and the Privg Councillor's oath, and their office lasts for the life of the Sovereign and six months after $(f)$, the old members being generally reappointed by a new Sovereign.

It is provided by the Act of Settlement $(g)$ that no person born outside the British Dominions, although he be made a denizen, except he be born of British parents, is capable of becoming a Privy Councillor. But since the Naturalization Act, 1870 , a naturalized alien can become a Priry Councillor, the British Nationality and Status of Aliens Act, 1914 , s. 3 (2), not having revived the disqualification contained in s. 3 of the Act of Settlement $(h)$.

(e) See Parliamentary Debates, 3rd Ser., vol. clxxr., 251.

(f) Succession to the Crown Act, 1707 (6 Ann. c. 7 Ruff.) s. 8; and see the Demise of the Crown Act, 1901 (1 Ed. VII. c. 5), s. 1 (1).

(g) 12 \& 13 Will. III. c. 2.

(h) R. v. Speyer [1916] 2 K. B 858, ante, p. 11. 
Status of Privy Councillors.-Privy Councillor's are entitled by letters patent (granted by James I.) to the style of "Right Honourable," and to precedence, with Knights of the Garter and of St. Patrick, next after the eldest sons of barons. The office entails no special emoluments, but their names are placed upon the commission of the peace for all counties in England. If members of the House of Commons, they do not racate their seat on appointment to the Council per se, though they would be obliged to do so on appointment to any office of profit under the Crom which usually involves elevation to the rank of Privy Councillor.

\section{The Ministry and the Cabinet.}

Constitutional Position of the Cabinet.-The consultative and advisory functions which formerly belonged to the Privy Council are now performed by that group of ministers known as the Cabinet, which advises the Crown in the exercise of its prerogative rights with regard to the conduct of the executive, and directs its general policy, besides being responsible for the general policy and character of the principal measures of legislation which are introduced during its tenure of office. Though occupving so important a position in the Constitution, the Cabinet is a body unlinown to and unrecognised by substantive larr. The rules which determine the manner in which its members are nominated and dismissed, and which govern its relations with Parliament and the Crown, are not rules which are recognised or enforced by the courts, but belong to the sphere of political conventions or understandings. Though this is so, the observance of these rules is equally necessary to the harmonious working of the political machine, as is the observance of laws proper; for they have been formulated by politicians since the Revolution of 1688 , as the outcome of actual experience, and because they have been found to be the best and the only means of obtaining the harmonious co-operation of the executive and the legislative, by ensuring that the general policy of the executive shall be conducted in a manner conformable to the wishes 
of the House of Commons, as representing the electorate and the taxpayer. That the executive must necessarily be conducted in conformity with the wishes of the House of Commons follows obviously from the consideration that the latter have the power at any moment of stopping supplies, and thus checking the whole machinery of government. The Cabinet system is, in fact, a device for ensuring that the hand which supplies the funds for carrying on the government shall direet the manner in which those funds shall be expended, and any rules which have been found by experience indispensably necessary to secure such a result, may be said to be growing out of the sphere cf convention into that of customary law. It must, however, be noted that at common law a particular eustom must be immemorial, that is to say, it must date its origin prior to. the commencement of the reign of Richard I. (1189), that being the date to which legal memory extends. Hence, unless placed upon a statutory basis, the conventional rules relating to the Cabinet can never become substantive law, at least whilst the common law rule remains in force.

Rise of the Cabinet System.-Traces of a tendency on the part of the Crown to consult with a group of the more important members of the Privy Couneil (sometimes termed the "Junto"), rather than with the larger and more cumbrous bodv itself, may be found as far back as the reign of Charles I. (i), but it was not until the reign of Charles II. that the practice was definitely adopted. The select committee, with whom Charles II. consulted, were known in 1671 as the Cabal (k), and the system, uncontrolled by the present rules and conventions, was justly unpopular, as tending to increase the personal influence of the Cromn, whilst uneertainty as to the persons from whom advice was sought rendered it impossible to fix the responsibility for misgovernment.

The system, as continued by William III., became more

(i) Hallam's Const. Hist., iii. 182.

(k) From the initials of the five Privy Councillors, Clifford, Arlington, Buckingham. Ashley, and Lauderdale. They were also known as the "Cabinet " because they met in the King's closet, all these names being terms of reproach. 
and more unpopular, with the result that two clauses were inserted in the Act of Settlement, with the object of checking its further development, but which were not to come into force until the death of Anne. The first of these provided that the okd consultative functions should be restored to the Privy Council, and (in order to fix the responsibility) that all resolutions come to there should be signed by the members present $(l)$. The second, with the object of checking corruption, provided that no person holding an office or place of profit under the Crown should serve as a member of either House $(m)$. Had this provision come into force it would have had the effect of entirely cutting off the executive from Parliament, a result directly opposite to that desired. Both sections were, however, repealed in the reign of Anne before they could come into force $(n)$, though shortly afterwards the Succession to the Crown Act, 1707 (the provisions of which will presently be noticed), was passed, preventing holders of offices or places created since the 25th of October, 1705, from sitting in the House of Commons, and this provision is still in force $(o)$. Under. the first two Georges, whose interests were largely occupied with Hanover, the personal influence of the Crown diminished, and since the reign of George I. the Crown has ceased to attend meetings of the Cabinet.

The attempts of George III. to revive the personal influence of the Sovereign gave rise to Mr. Dunning's famous motion, "That the influence of the Crown hats increased, is increasing, and ought to be diminished" $(p)$, which he successfully carried.

In the same reign it first became customary to divulge to the public the names of members composing the Cabinet,

(l) $12 \& 13$ Will. III. c. 2 , s. 3 (4).

(m) $I b$. s. 3 (6).

(n) 4 Anne, c. 8 , ss. 24,25 .

(o) 6 Anne, c. 7. This Act also contained a clause making it necessary for a member to vacate his scat on acceptance of one of the older offices, though making him re-eligible for election. Now by the $30 \& 31$ Vict. c. 102), s. 52, the removal of a minister from certain offices to another does not vacate the seat, and by the 1 Ed. VIr. c. 5 the holding of office is not affected by the demise of the Crown, and no fresh appointment is necessary. Sce also p. 178, post.

(p) Cobbett's Parl. Hist., xxi. 347 . 
and the failure of the King to extort a promise from the Grenville ministry in 1807 that they would propose no further concessions to the Roman Catholics $(q)$, gave rise to the doctrine that the Crown must not fetter its advisers by exacting pledges as to future actions. Under George I. and George II. (1721-1742) Walpole was the first Prime Minister to exercise the right of nominating his own colleagues. But this immovation was due to his personal ascendancy, and the rule was not established, George III. claiming and exercising the right of nominating a portion of his ministers. After the Reform Act of $1832(r)$, the executive became completely dependent upon the party having a majority in the House of Commons, and the free ehoice of his colleagues by the Prime Minister became a necessity, this doctrine being fully recognised with Sir Robert Peel's Administration in 1834. The reign of George IV. marked the final downfall of personal government by the Crown.

In 1841 a resolution of the House of Commons to the effect that " the Whig Ministry, not having the confidence of the House, their continuance in office under such circunstances was at variance with the spirit of the Constitution" (s) marked the adoption of the doctrine that the Cabinet is dependent for its existence upon the good will of the party which commands a majority in the House of Commons.

\section{Formation and Composition of the Ministry.-The} prescnt practice upon the formation of a new ministry, consequent upon the dissolution of the previous ministry by resignation or dismissal, and usually within a few days of such dissolution $(t)$, is for the Crown to call upon the recognised leader of the party which has been returned with a majority in the House of Commons to nominate his

(q) See May's Const. Hist., i. 90, 96, 97.

(r) Representation of the People Act, 1832 (2 \& 3 Will. IV. c. 45).

(s) Sce May's Const. Hist., i. 131

( $t$ ) As to the dissolution of the ministry, see p. 187, post. The summons to the new premier shonld be marle, according to Todd, within a reek. See Todd, Parl. Govt., i. 216. But the trme rule would appear to be that there should be no unreasonable delay, Parliament having in sone cases addressed the Crown where delay las occurred. 
colleagues who are to oceupy the most important posts at the head of the various departments of State. Upon acceptance of this task, and after kissing the King's hands, the person so called upon becomes known as the Prime Minister or Premier, though this is not a post which carries any salary, nor does it entail any legal duties or obligations upon the holder; his retention of the post is, in the first place, however, dependent in practice upon his ability to form a ministry, that is to say, upon his ability to find colleagues who have sufficient confidence in his ability to render them willing to act with him. Like the Cabinet itself, of which he is the head, the existence of the Prine Minister is unknown to and unrecognised by substantive law.

The Prime Minister, however, usually fills one or other of the most important offices, such as that of Secretary for Foreign Affairs, or, as is the case at present, First Lord of the Treasury. He may be and invariably is a Privy Councillor, and a nember either of the House of Commons or the House of Lords, and preferably of the House of Commons as being more in touch with his colleagues. Sinee the year 1905 he also enjoys place and precedence next after the Archbishop of York, this status having been conferred upon the then existing and all future Prime Ministers by Royal Warrant (u).

In addition to the Prime Minister, the other menbers of the Ministry nominated by the Prime Minister eomprise the holders of some fifty-six various offices, and they retire from office upon defeat in the House of Commons or at the polls of the party to which they belong.

Of these the present Cabinet is comprised of the holders of nineteen offices, including that of Prime Minister. These offices are-

(1) The Prime Minister (who is also First Lord of the Treasury).

(2) The Lord Chancellor of Enghanil.

(3) The Lord President of the Council.

(4) The Lord Privy Seal.

(u) See the London Gazette, 2nd December, 1905. The Prime Minister also enjoys the use of the official residence in Downing Street. 
(5) The First Lord of the Treasury.

(6) The First Lord of the Admiralty.

(7) The Home Secretary,

(8) The Foreign Secretary,

(9) The Seeretary for War,

(10) The Colonial Seeretary,

The five principal

(11) The Secretary for India,

secretaries of State.

(12) The Chief Secretary to the Lord-Lieutenant of Ireland.

(13) The Chancellor of the Exchequer.

(14) The Seeretary for Scotland.

(15) The President of the Board of Trade.

(16) The Minister of Health.

(17) The Minister of Labour.

(18) The Minister of Agriculture and Fisheries.

(19) The President of the Board of Education.

Other offices, the holders of which were sometimes included in the Cabinet, are those of the Lord Chancellor, the Lord-Lientenant of Ireland, and the PostmasterGeneral.

The other members of the Ministry who are not members of the Cabinet comprise the following:-

The three Junior Lords,

The Finanee Secretary,

The Patronage Secretary,

Treasury.

The Paymaster-General,

The four Junior Naval Lords,

The Civil Lord,

The Parliamentary Secretary

'The Finance Seeretary,

Admiralty.

The five Military Members,

The Civil Member,

Fiuance Member,

Army Couneil $(x)$.

The Attorney and Solicitor General for England,

The Attorney and Solicitor General for Ireland,

The Lord Advocate and Solicitor General for officers. Scotland,

(x) It does not appear whether the military members of the Army Council retire from office with the Ministry or not, but presumably they do in analogy with the constitution of the Admiralty. 
The Parliamentary secretaries of these departments.

\author{
(Home Office. \\ Foreign Office. \\ Colonial Office. \\ India Office. \\ Board of Trade. \\ Ministry of Health. \\ Board of Education.
}

General Status of the Ministry.-The various ministers are usually appointed at a meeting of the Privy Council, by delivery of the appropriate seals or symbols of office; and certain of their number are required to take the oath of allegiance and official oath, or the oath of allegiance and judicial oath in the manner provided by the Promissory Oaths Act, 1868, and the Judicature Act, 1875 (y). 'Their' salaries vary with the different posts, and except where statutorily charged upon the Consolidated Fund (as in the case of the Lord Chancellor) are roted in the annual estimates, and therefore subject to alteration or disallowance by Parliament. Under the established usage (though $\mathrm{Mr}$. Gladstone in 1845-1846 affords an exception) the members of the Cabinet are required to be members either of the House of Lords or House of Commons (z). The oth, $\mathrm{r}$ members of the ministry are not, howerer, necessarily members of either House, though the majority of the Parliamentary secretaries and under-secretaries invariably are so. It is, however, provided by the Government of India Act, 1858 (a), that not more than four of the Principal Secretaries of State, nor more than four of their under-secretaries, may sit in the House of Commons at the same time.

Under the provisions of the Succession to the Crown Act, $170.7(b)$, the acceptance of any office of profit under the Crown (interpreted as applying to offices created prior to

(y) 31 \& 32 Vict. c. 72, s. 5, Scheds. I., II.; 38 \& 39 Vict. c. 77, s. 5. Certain other officials are also inchuded by later statutes, e.g., the President of the Board of Agriculture and Fisheries under certain circumstances $(52$ \& 53 Vict. c. 30, s. 8 (2)); and the President of the Board of Education (62 \& 63 Vict. c. 33 , s. 8).

(z) See Parl. Debates, vol. ix. p. 287.

(a) 21 \& 22 Vict. c. 106 , s. 4 ; but see 27 \& 28 Vict. c. 34.

(b) 6 Anne, c. 7 (Ruff.), ss. 24, 25 .

C.L.E. 
the 25th October, 1705) vacates the seat, if the person appointed is a nember of the House of Commons, and a writ for a new election is to issue, though he is capable of re-election. Under the same Act, persons holding new offices (viz. offices created after the 25th October, 1705), and certain specified offices, are altogether barred from being elected to or sitting and voting in the House of Commons, unless specially exempted (as frequently is the case, e.g. the Paymaster-General) by later statute from the operation of the Act. It is, however, provided by the Representation of the People Act, 1867 (c), that the holders of certain specified offices, if members of the House of Commons, do not vacate their seats on the acceptance of any such specified offices from the Crown in lien of, and in succession to, their former office or offices; and by the Re-election of Ministers Act, 1919, the necessity for reelection is further restricted $(d)$.

Ministers hold their offices at the pleasure of the Crom, and may be dismissed at any time. They retire collectively with the Cabinet upon a change of Government.

The Cabinet.-General Status and Functions.-The smaller body of ministers by whom, under the leadership of the Prime Minister, the general policy of the executive, as of the principal legislative measures introduced in Parliament, is decided, is known as the Cabinet. But, like the Prime Minister himself, the Cabinet is not recognised as a body either by the common or statute law; so much is this the case that in the year 1711 the House of Commons refused to permit the use of the words "Cabinet Council" in an address to the Crown (e), and in 1857 a proposal to give Cabinet Ministers certain priority in passing to the House of Lords was rejected by the Commons because such persons were unknown to the Constitution and possessed no legal status $(f)$. The rules which regulate the relations of the Cabinet with the Crown, Parliament, and the Prime Minister, fall therefore within the sphere of conventional law, or usage, certain general principles being now suffi-

(c) 30 \& 31 Vict. c. 102 , s. 52 , Sched. H.; 9 Geo. V. c. 2.

(d) See ante, p. 71 .

(f) Parl. Deb., 3rd Series, exviii., 1927, 1939 et seq., 1960. 
ciently clearly defined and recognised, though always remaining subject to variation in accordance with modifications or changes in existing political and legislative institutions.

The choice of Cabinet Ministers rests with the Prime Minister, and their number, though unrestricted and subject to a tendency to grow larger, is under the present practice generally confined to the holders of some twenty offices. Subject to the recognised usage previously stated, which requires Cabinet Ministers to be members either of the House of Lords or the House of Commons, the Premier is unrestricted in his choice by any legal conditions or qualifications, but for reasons of political expediency, and as being open to grave constitutional objections, Archbishops, the Lord Chief Justice, and the Chief of the General Staff (who has replaced the Commander-in-Chief), are usually excluded under the modern practice, though they have occasionally been included during the earlier period of Cabinet history $(g)$, as also have persons not holding any office (h). Any person may, however, be summoned to attend a Cabinet meeting, who from special knowledge or for any other reason may be considered qualified to give useful assistance or advice, and this principle has beeil recognised by Parliament (i).

The tendency towards the recognition of a definite number of offices as being " cabinet offices" is best illustrated by a brief reference to Cabinet history. During the earlier period after 1688, the departments worked independently under the general supervision of the Crown. The principal ministers, however, met informally, and under Anne such meetings appear to have been held weelily, the Queen usually presiding $(k)$. The number of regular attendants

(g) See the instances as to the Archbishops of Canterbury in Walpole's Administration, the commander-in-chief in 1770 and 1772, and Lords Hardwicke, Mansfield, and Ellenborough, as Lords Chief Justices (Todd, Parl. Govt., vol. ii., 154, 157, 160). See also the resolutions of both Houses as to the expediency of keeping the functions of Ministers and common-law judges separate (which were, however, rejeeted) (Com. Journ., 3rd March, 1806; Lds. Jonrn., 3rd March, 1806).

(h) See 'Todd, Parl. Govt., ii. 154, 155.

(i) Parl. Deb., vi. 327 ; ib. 4th Series, cxlii. 864.

(k) See Campbell, Lives of the Chancellor's, 4th Ed., vol. v. 249. 
was smaller than at present, varying from six or seven in the reign of George I. to fifteen or sixteen towards the middle of Queen Victoria's reign. There was, however, a larger or outer circle of ministers who were occasionally summoned, and these, with the inner group, have been divided into three grades according to their relative importance about the year 1782 ; viz. (1) the ordinary and larger group of ministers without any distinctive authority; (2) a smaller group " with eireulation," viz. entrusted with the keys of the Cabinet boxes in which foreign despatches or other important documents were sent round for perusal; (3) a still smaller group "with circulation" and the powers (such as that of opening private letters) generally aceredited to a Secretary of State $(l)$. Eventually the outer or larger circle dropped off, whilst the inner or efficient circle grew larger, their authority becoming more nearly assimilated. The circulation of documents amongst members of the Cabinet is still kept up iy means of Cabinet despatch boxes of which each member has a master key.

Cabinet Minister's are also invariably Privy Comeillors, and thus bound by the oath of secrecy; exception has been taken in Parliament to the inclusion of the name of a person as Cabinet Minister who was not a Privy Councillor ( $m$ ). The Cabinet in fact originated as, and is still in a sense, a committee of the Privy Comncil.

Meetings of the Cabinet are usually summoned by the Prime Minister, and may be held anywhere as the state of public affairs requires, without restriction as to time or place $(n)$. No official records of the transactions at Cabinet meetings are kept, the decisions arrived at being conveyed either verbally or embodied in the form of written minutes to the Sovereign by the Prime Minister, who acts as the

(l) See Todd, Parl. Govt., ii. 118.

( $m$ ) Viz. Lord Cawdor, when nominated to the office of First Lord of the Admiralty, in 1905. His attendance was excused by Lord Lansdowne on the ground that his presence was required (see Parl. Debates, 4th Series, cxlii. 864, 865).

(n) In Tondon they are usually held at the Premier's residence in Domning Street, or at his private room at Westminster, or at the Foreign Office (see Told, Parl. Govt., ii. 189). Except in cases of special urgeney, meetings are not frequently lueld during the usual prorogation of Parliament between August and October. 
formal medium of communication between the Crown and its ministers.

Though originally the Sovereign presided at meetings of the Cabinet, and it is sair that Queen Anne generally attended weekly (o) the absence of the Sovereign from all meetings of ministers where deliberations or discussions take place, including committees of the Privy Council, has become clearly recognized as a constitutional necessity, at least since the reign of George III. This practice originated in the neglect of George I., owing to his ignorance of the English language, and his habitual preference of Hanoverian to English affairs; and since his reign it is said there are only three instances of attendance of the Sovereign for formal purposes $(p)$. The constitutional doctrine enunciated above was clearly expressed by Lord Granville in Parliament in 1864 with reference to the attendance of the Queen at a committee of the Priry Council (q).

The Prime Minister thus presides in place of the Sorereign at meetings of the Cabinet, and his opinion is of paramount weight and importance; and though members meet nominally on an equal footing, the rote of the majority in ordinary cases deciding the question $(r)$, he has the power in the last resort of requiring the resignation of a minister, or, by himself resigning, of bringing about the dissolution of the Ministry as a whole. Individual ministers have, however, it appears, the right of access to the Sorereign on matters concerning their own departments, though, out of courtesy and loyalty to their chief, any such communications should be made known to the Premier immediately beforehand or afterwards $(s)$.

Though the Sovereign is thus debarred from taking any part in the formal deliberations of his ministers, he is constitutionally entitled to criticise the conduct of the executive, and for this purpose the resolutions of the Cabinet ought, it seems, to be commmicated to him, together with the fullest information on all important matters, in time

(o) See Campbell, Lives of the Chancellors, 4th Ed., v. 249.

(p) See Todd, Parl. Govt., ii. 115; Anson, 3rd Ed., ii. 40, note (2).

(q) See Parl. Debates, 3rd Series, clxxy. 251.

(r) See Report of the Admiralty Committee, 1861, p. 168.

(s) See Todd, Parl. Govt., ii. 208. 
to enable him to come to a proper.decision. Measures sanctioned by the Sovereign should not, it appears, afterwards be arbitrarily altered or modified without reference to $\lim (t)$.

Since the Ministry is collectively responsible to Parliament for the advice given to the Crown, so that advice ought to be unanimous; and, as a necessary corollary, it is not, in general, constitutional for the Sovereign to inquire into the lines of division in the Cabinet. This doctrine is to be found enunciated in the House of Commons by Lord North in the reign of George III. $(u)$.

If the Crom refuses to accept the advice of its ministers the usual and recognized course is for the latter either to modify their decision in accordance with the wishes of the Sovereign or resign $(w)$. But except possibly in cases of grave importance, where it is necessary for the Sovereign to hear the riews of all parties, or where the Sovereign differs from his ministers and wishes to find others who would accept responsibility for his action by taking office in case of resignation of the existing Ministry, it is clearly recognized as unconstitutional for the Crown to take advice from persons other than its ministers. An illustration of the recognition of this principle is to be found in the frequent denunciations in Parliament of the "influence behind the throne" during the reign of George III. due to the party known as "King's men," or the "King's Friends," which that Sovereign attempted to form on the advice principally of Lord Bute $(x)$.

The expression of the Sovereign's political views to persons other than his ministers is also regarded as unconstitutional; though, it is said, he may listen to the views of others, or act as a mediator in the case of political quarrels $(y)$. It is also regarded as unconstitutional for the

(t) See the Memorandum addressed to the Foreign Secretary (Lord Palmerston) by Queen Victoria through the Prime Minister (Lord John Russell) in $18 \tilde{1} 1$ (Parl. Debates, 3rd Series, cxix. 90; see also Ib. clxxxviii. p. 1113. Report on Official Salaries, 1850, Evidence No. 326).

(u) See Parl. Hist. xxiii. 678; xxiv. 291.

(u) See Parl. Debates, ix. 239. See also p. 185, post.

(x) See Parl. Debates, xvi. 9; May, Const. Hist., I. 11, 12, 84.

(y) See Todd, Parl. Govt., ii. 202, 203, 205; May, Parl. Pract., Ed. $1863,314$. 
Sovereign to take any independent action either in foreign polities or by influencing ministers or executive officers $(z)$ withont reference to his responsible adviser $(a)$; and that a minister who acts without consulting his colleagues camnot escape responsibility on the ground that he acted in compliance with the Sorereign's wishes, is instanced by the case of Lord Somers in 1701, who was impeached for causing the Great Seal to be affixed to the Partition Treaties concluded by William III. without authority and without communicating with his colleagues (b). Even visits of state to the crowned heads of foreign countries are somewhat jealously regarded by Parliament, and on such occasions it is said that the political wishes or intentions of the Sovereign-should be fully disclosed to his minister's $(c)$. It also appears to be proper (and was usual with Queen Victoria) to disclose to the Prime Minister the private correspondence of the Sovereign with crowned heads or foreign minister's when it touches upon political matters $(d)$. As, with a view to preserving the independence of ministers in forming their decisions, the Sorereign is no longer present at their deliberations, so his ministers are constitutionally entitled at all times to tender him free and unfettered advice; any attempt on the part of the Sovereign to limit the nature of that advice, or to exact pledges, either as the condition of summons to office, or by threat of dismissal, is clearly recognized as unconstitutional. This principle became fully recognized in 1807, when George III. endearoured to exact a pledge from the Grenville Ministry not to make further proposals in favour of Catholies, and actually dismissed the Ministry for recording in the council

(z) See the references in notes $(a),(b)$, ic), post.

(a) Sce the instance as to the exercise of the prerogative of mercy by the Lord-Lientenant of Ireland in the reign of George IV., cited by Anson, 3rd Ed., ii. 44.

(b) Somers' (Lord) Case (1701) 14 St. Tri. 250. On two occasions Lord Hardwicke refuscd to affix the Great Seal to treaties at the instance of George II. (see Harris, Life of Hardwicke, ii. 59, 369).

(c) See the discussions in Parliament as to the visit of King Edward VII. to the Tsar of Russia, Parl. Debates, 4th Series, cexxxix. $963-966,1119,1262,1290,1570,1571$. On such occasions the King is not necessarily accompanied by the Foreign Secretary or any member of the Cabinet (Ibid.).

(d) See Anson, 3rd Ed. ii. 43. 
minutes their right at any time to submit their views upon the Catholic question. Though no direct rote was taken, the principle being clearly admitted, resolutions were formulated in both Houses to the effect that it is contrary to the first duties of the confidential serrants of the Crown to restrain themselves, by any pledge express or implied, from offering to the King any advice which circumstances may render necessary for the welfare of the lingdom $(c)$.

Ministerial Responsibility.-The ministers of the Crown may be made responsible for the conduct of the executive, or for administrative or legislative acts in three ways: (1) Firstly, they are individually and personally liable for tortious or criminal acts, and in such cases are in general amenable to the ordinary legal processes in the manner and. subject to the exceptions previously mentioned $(f)$.

(2) Secondly, they are immediately responsible to Parliament, and ultimately to the electorate, for the general conduct of the executive and the advice given to the Crown, as also for the policy of the legislative measures initiated under Govermment auspices, and this responsibility may be enforced in the case of Parliament, either by impeachment, or by direct vote of censure, or want of confidence, or defeat of a Government measure in the House of Commons, either of which latter erents are generally understood to necessarily entail the resignation of the Ministry and consequent loss of office $(g)$, unless on an appeal to the electorate at a general election consequent upon a dissolution, they are again returned to power with a majority sufficient to enable them to carry the measure in question. $I_{i}$ is in this sense that they are said to be ultimately responsible to the electorate.

Of these methods of enforcing Parliamentary responsibility that by impeachment, being in its essence more in the nature of a criminal prosecution than a remedy in case of mistalien or distasteful policy $(h)$, has tended to become

(e) Parl. Debates, ix. 285, 328-9, 335. 362, 380; May. Const. Hist., i. 96,97 .

(f) See p. 38, ante.

(g) As to resignation generally, see p. 185, post.

(ii) See the Laws of England, vii. p. 47, note $(a)$. 
obsolete at the present day, loss of office consequent upon defeat of a Goremment moasure, or rote of want of confidence, or of censure, being the usual mode of enforcing obedience to the wishes of the House of Commons (i).

(3) Thirdly, though the responsibility of ministers has in the main shifted from the Crown to Parliament since the Reform Act of 1832, the Ministry still is in theory constitutionally responsible to the Crown for the conduct of the Govermment, and in exceptional or grave cases this responsibility might, it is apprehended, be enforced by the exercise of the prerogatives of reto, dissolution, or dismissal $(k)$.

Though in the earlier periods of Cabinet history ministers did not necessarily retire from office together, and instances have occurred where ministers have remained in office through successive administrations (l), it is now generally recognized that upon vital questions the Ministry are collectively responsible to Parliament, the Crown, and the electorate, this implying as a necessary corollary that on such questions their advice must be, or appear to be, unanimous, and that they must stand or fall together (m). Cases, however, not of vital importance may quite conceirably arise where the Ministry might not hold themselves, or be held responsible for the act of an indiridual minister $(n)$.

It is now a generally recognized constitutional doctrine that there is no executive or legislative act of the Crom for which some minister or the Ministry as a whole is not immediately responsible, or for which some person or group of persons not at the time in office may be held constructively responsible, the latter part of the proposition meaning to imply that in the event of the Sorereign's acting in opposition to the advice of his ministers on some vital question (such as the exercise of the prerogatives of reto

(i) See as to resignation, post, p. 185 .

(k) As to veto, see p. 86, ante; as to dissolution, p. 56, ante; as to dismissal, p. 190, post. And generally as to the exercise of these prerogatives, p. 187, post.

(l) E.g. Lord Thurlow, L.C.; Lord Palmerston. 1809-1828, 1830-1834.

(m) See Parl. Debates, 3rd Series, cxxvi. 883.

(n) See the instance as to the Solicitor-General for Ireland (Todd, Parl. Govt., ii. 332). 
or dissolution) which would entail the resignation or dismissal of the existing Ministry, there must be some group of persons who would be willing to endorse the Sovereign's action by accepting office, at least until the sense of the electorate could be taken upon a dissolution (o). The evolution of this doctrine to its present comprehensive form has been gradual, and is to be discerned in the Grand Remonstrance of 1641 . After the Revolution of 1688 it is to be found frequently asserted in Parliament $(p)$, but whilst the Crown continued to take an active and independent part in politics, as in the case of William III. and the Partition Treaties in 1698 and 1699, or in the case of the attempts made by George III. to revive the royal influence, which led to the lament by Fox in 1778 that the king was " his own unadvised minister" $(q)$, and to the forced retirement of Pitt in 1761, because he claimed "responsibility only to Parliament $(r)$, it cannot be said to have received complete recognition, at any rate on the part of the Sovereign.

The doctrine in its entirety is to be found expressed in Parliament in 1807 by Lord Sellirk on the occasion of the dismissal of the Grenville Ministry for refusing to pledge themselves upon the Roman Catholic question at the instance of George III. $(s)$, but the seal of actual necessity was set upon it by the Representation of the People Act, 1832 (known as the Reform Act), which by rendering the executive Govemment completely dependent upon the party majority in the House of Commons, in effect shifted the responsibility of ministers to the Crown (which still, how-

(o) The doctrine of the responsibility, of the incoming Ministry for the events which led to the resignation or dismissal of their predecessors was clearly recognized in the debates in Parliament in 1807 on the occasion of the dismissal of the Grenville Ministry by George III., for refusing to pledge themselves upon the Roman Catholic relief question (see Parl. Debates, ix. 335, 381). It was also freely admitted by Sir Robert Peel in 1834 (see Parl. Debates, 3rd Series, xxvi. 216, 223).

(p) E.g. in 1711 (see Parl. Hist., vi. 972, 1083); 1739, by the Duke of Argyle (Parl. Hist., x. 1138); 1741, by Sir John Barnard (Parl. Hist., xi. 1268); 1807, by Lord Selkirk (Parl. Debates, ix. 335, 381).

(q) See Todd, Parl. Govt., i. 175.

(r) See Mahon, Hist. of Eng., iv. 240.

(s) See Parl. Debates, ix. 335, 381. 
ever, remains in a modified form) to the House of Commons.

The acceptance of the doctrine in its entirety is thus a negation of the porer of completely isolated or independent action by the Crown. Isolated action on the part of the Crown with regard to the exercise of the powers of veto, dissolution, or dismissal, without the endorsement and support of the leaders of some one or other of the political parties in the House of Commons might lead to an untenable position in which the Sovereign would find himself unable to find persons who would accept office, and would thus be a crushing blow to the regal authority. But in grave cases of doubt as to the views of the electorate upon some question of vital importance, and where such action is endorsed by some group of party leaders in the House of Commons, it cannot be doubted that the Sovereign is constitutionally entitled to the exercise of one or other of the prerogatives of veto, dismissal, or dissolution; such an exercise being in effect the only constitutional means of bringing about what is the nearest equivalent which our Constitution affords to a " referendum." It may, however, be pointed out that by its position of independence from party politics, the Crown being recognized by the Constitution as the ultimate and final arbiter with regard to the necessity for the exercise of such a prerogative, its decision should be accepted loyally, and that any attempt on the part either of its ministers or those who are dissatisfied with the political views of its ministers, to prevent in the one case, or to bring about in the other, the exercise of such a prerogative, by show of force, or by constraint or intimidation, must necessarily fall within the scope of unconstitutional and treasonable action $(t)$. Such measures on the part either of ministers or others must in effect tend to defeat their own ends, since the Crown, which might otherwise have considered it necessary to excrcise such a prerogative, might be unwilling to do so under stress of intimidation.

Dissolution of the Ministry.-The dissolution of the Ministry takes place in one of two ways, either by resigna-

( $t$ ) See the offences which constitute treason and treason felony, p. 148 , ante. 
tion, or by dismissal by the Sovereign, in the exercise of bis prerogative right. But the demise of the Crom does not affect the existence of the Ministry, since by the Demise of the Crown Act, 1901, the holding of any office under the Crown is not affected by the demise of the Crown (u); nor does the dissolution of Parliament itself necessarily terminate the existence of the Ministry, unless effected by an exercise of the Royal prerogative in opposition to the advice of the existing Ministry (which would entail the resignation of the Ministry), or unless, upon the consequent general election, the former Ministry is returned in a minority, which would also entail resignation. The death, dismissal, or resignation of the Premier does not of itself dissolve the Ministry, or entail the shifting of the Government from one political party to another; but in. effect it is equivalent to a dissolution of the Ministry, since in such cases the various offices are invariably placed at the disposal of the new Premier $(x)$.

The exercise of the right of dismissal being now rarely required, the resignation of the Ministry usually follows upon the defeat of a Govermment measure, or the passing of a vote of censure or want of confidence in the House of Commons, or upon a defeat at the polls in the case of a general election; and since 1841 the dissolution of the Ministry has invariably been due to one or other of these causes, except in the cases of the reorganization of the Ministry in 1865 and 1908 , consequent upon the deaths of the premiers, Lord Palmerston and Sir Henry CampbellBannerman respectively. Resignation of a Ministry consequent upon finding itself in a minority in the House of Commons needs little or no comment, the instances in later Cabinet history being numerous. The principle was

(u) See p. 143, ante.

(x) The death of Pitt in 1806 was followed by an attempt to patch up the Ministry, which failed, and Grenville's Ministry succeeded. The deaths of Lord Palmerston in 1865, and Sir Henry Campbell-Bannerman in 1908, afford examples of reconstructed ministries. Disagreement in 1761 of the elder Pitt with his colleagues caused the immediate resignation of the latter (though not their downfall) and the retirement of the former. In 1868 and 1894, when Lord Derby and Mr. Gladstone respectively retired from ill-health, the administration mas taken over in the one case by Mr. Disraeli, and in the other by Lord Rosebery, without a general dissolution. 
first illustrated by the resignation of Walpole in 1742, though he was not accompanied by all his colleagues $(y)$. In 1782 the whole Ministry, except Lord Thurlow (Lord Chancellor), retired with Lord North, consequent upon the narrow defeat by nine votes, of a vote of confidence $(z)$. Since that date, except in a few instances where individual ministers (as Lord Thurlow and Lord Palmerston) have retained their offices in successive administrations, the resignation of the premier has entailed the retirement of the Ministry collectively.

A resolution of the House of Commons in $18+1$ to the effect that " the Whig Ministry not having the confidence of the House, their continuance in office was at variance with the spirit of the Constitution " (a), marked the complete and final adoption of the doctrine rendered necessary by the Reform Act of 1832, that the existence of the Min. istry is dependent in the first place upon the good will of the House of Commons. An adverse rote on a vital question is now invariably followed either by resignation $\mathrm{cr}^{\circ}$ appeal to the electorate by dissolution.

The principle of resignation without meeting Parliament after an adverse verdict at a general election was illustrated in 1868 by the retirement of the third Derby and first Disraeli administration. Since that date the practice after a general election has varied, three ministries (viz. the first Gladstone Ministry in 1874, the second Disraeli Ministry in 1880, and the third Gladstone Ministry in $1886(b))$ having resigned immediately without meeting Parliament, whilst two (viz. the first and second Salisbury Ministries in 1886 and 1892), awaited a vote of want of confidence in the new House of Commons $(c)$.

The refusal of the Ministry to modify their riews in compliance with the wishes of the Crown has led to the dis-

(y) See Mahon, Hist. of Eng., iii. 101, 112.

(z) See Knight, Hist. of Eng., vi. 453.

(a) See May, Const. Hist., i. 131.

(b) See Political History of England, xii. 259, 300, 387.

(c) See Political History of England, xii. 375, 416. In 1905 the Balfour Ministry, though obviously in a precarious position as the result of adverse by-elections, deferred resignation until defeated by direct vote in the House of Commons. (See The Times, 21st July, 5th December, 1905). 
missal or resignation of the former on various occasions. In 1801, Pitt's resignation was due to his inability to fall in with the views of George III. on the Roman Catholic question, and the administration was successfully entrusted to Addington (then Speaker of the House of Commons), who carried on the Government (though with decreasing majorities) until 1804. In 1832, when Lord Grey resigned in consequence of the reluctance of William IV. to create the large number of peers (about one hundred) necessary to carry the Reform Bill through the House of Lords, the King summoned the Duke of Wellington and Lord Lyndliurst to office; but on their failure to form an administration the matter ended in the recall of Lord Grey and the passage of the bill through the House of Lords by the abstention of the Duke of Wellington with one hundred. other peers from voting.

The prerogative of dismissal was exercised successfully by George III. in 1783-4, and 1807, and unsuccessfully by William IV. in 1834, each of these cases being followed either immediately or shortly afterwards by an appeal to the electorate by dissolution. In 1783-4 the occasion of dismissal was the failure of North and Fox to carry the Government of India Bill through the House of Lords. On their dismissal in December, 1783, though having a large majority in the House of Commons, the younger Pitt was summoned to office, but shortly afterwards defeated on his India Bill in the House of Commons. Upon a dissolution and general election in April, 1784, he was returned with a large majority.

In 1807 , the occasion was the well-known instance of refusal on the part of the Grenville Ministry to pledge themselves not to introduce further measures for the relief of Roman Catholics. The Duke of Portland was summoned to office, and shortly afterwards upon a dissolution returned by the electorate with a large majority.

In November, 1834, two years after the passing of the Reform Act, the occasion of the dismissal of Lord Melhourne's Whig Administration was the evident reaction in favour of the Conservatives. Sir Robert Peel was summoned and held office for a few months. But being returned in a 
minority upon a dissolution, he was obliged to retire, and the Melbourne Ministry resumed office in April, 1835. The view has been expressed that the Crown would be justified in exercising the prerogative of dismissal in a case where it is unable to repose confidence, or for want of ability or unfitness, or where the existence of the Ministry in office through dissensions or otherwise is ruinous to the country $(d)$. But at the present day, unless under some very exceptional circumstances, there can be little doubt that the prorogative of dissolution (which if exercised contrary to the advice of the Ministry would no doubt entail resignation on their part) would be more generally resorted to than dismissal, as being a milder form of exercise of the prerogative.

(d) See Parl. Hist., xxxv. 1121; Parl. Debates, ix. 377; Mirror of Parliament, 1835, 28, 29. 


\section{Chapter III.}

\section{THE MEMBERS OF THE EXECUTITE.}

\section{The Lord Chancellor.}

The Lord Chancellor is appointed by the Crown on the advice of the Prime Minister by delivery of the Great Seal, of which he is the keeper, and his office is not determined by the aemise of the Crown. He is chosen from amongst the adherents of the party in power, is invariably a member of the Cabinet, and resigns with the Ministry on a change of Government. The appointment of a Roman Catholic or a Jew would certainly be deened unconstitutional, and is probably ilegal under the provisions of the Roman Catholic Relief Act, 1829, and the Religious Disabilities Act, 1846. Otherwise no definite legal qualifications are required; the post is, however, invariably offered to some distinguished member of the Bar.

$\mathrm{He}$ is the principal logal dignitary and president of the High Court of Justice (a); he is not, however, a permanent judge of that court (b). $\mathrm{He}$ is also President of the Court of Appeal, and of the Chancery Dirision of the High Court of Justice $(c)$. In precedence (if, as is usually the case, of the degree of baron of Parliament or above) he ranks next after the Archbishop of Canterbury $(d)$.

The Lord Chancellor is $c x$ officio Speaker of the House of Lords, and presides at judicial proceedings on appeal. He is also an ex officio member of the Court of Appeal, and exlord chancellors are also ex officio judges of that court, but

(a) Judicature Act, 1873, s. 5 .

(b) Ib. 1875, s. 3 .

(c) Ib. 1873 , s. 31 (1); Ib. 1875 , s. 6 .

(d) Stat. (1539) 31 Hen. VIII. c. 10, s. 4. See ib. s. 8, if below the degree of baron. 
they are not obliged to sit and act, except with their consent, upon the request of the Lord Chancellor (c).

He enjoys a salary of $£ 10,000$ per annum, and a retiring pension of $£ 5,000$. He is conservator and justice of the peace throughout England, and all judges of the High Court are selected by him, the Lord Chief Justice, however, being nominated by the Prime Minister. He appoints county court judges (except within the Duchy of Lancaster, where they are appointed by the chancellor of the duchy), and may remove them for inability or misbehaviour $(f)$. $\mathrm{He}$ is also the patron of all Crown livings under $£ 20$ per annum according to the valuation taken in the reign of Henry VIII., and, on the recommendation of the lords lieutenant, advises the Crown as to the appointment of justices of the peace.

\section{The Lord Privy Seal.}

The duties of this office were abolished by statute in 1884. The office itself, however, still remains (though practically involving no duties), and is filled by a member of the Cabinet, who usually occupies in addition some other important post. Formerly it was necessary for many instruments, and specially letters patent, to pass under the Privy Seal before they could pass under the Great Seal. Now, by the Great Seal Act, 1884, a warrant under the sign manual, countersigned by the Lord Chancellor, or a Secretary of State, or the Lord High Treasurer, or two Treasury commissioners, is sufficient authority for passing any instrument under the Great Seal, and for the future no instrument need be passed under the Privy Seal $(g)$.

\section{The Law Officers of the Crown.}

These are the attorneys and solicitors general for England and Ireland respectively, and the lord advocate and solicitor-general for Scotland. They are appointed by

(e) Judicature Act, 1891, s. 1.

(f) County Courts Act, 1888, ss. 8, 15.

(g) $47 \& 48$ Vict. c. 30 , s. 3.

C.L.E. 
letters patent, and hold office durante bene placito. They are members of the Ministry, but (except the AttorneyGeneral, in the last two administrations) not of the Cabinet, and vacate their office with the party to which they belong.

The attorneys-general in England and Ireland and the lord advocate in Scotland are the heads of the bar in their respective countries, and their duties are to represent the Crown in legal proceedings, to conduct Crown prosecutions, and to act as the legal advisers of the various departments. They may stay proceedings in any criminal prosecution (or, it seems, in ciril proceedings $(h)$ ) by nolle prosequi at their own discretion, without calling upon the prosecutor to show cause (i), and they have the right to reply in all criminal cases, whether evidence had been called for the defence or not. They may also demand a trial at bar as of right where the Crown is interested $(k)$. They are usually members of the House of Commons, and share, in a sense, in the general responsibility to Parliament of the administration as a whole for advice given to the Crown.

By a Treasury minute of the 5th of July, 1895, the salaries of the attorney and solicitor-general were increased to $£ 7,000$ and $£ 6,000$ per annum respectively, and they are no longer permitted to engage in private practice.

The duties of the solicitor-general are similar but in subordination to those of the attorney-general. When the office of attorney-general is racant, the full duties of his office devolve upon the solicitor-general (l).

In certain legal proceedings, e.g. petition for revocation of a patent, the fiat of the attorney-general is necessary.

There is also an attorney-general of the Duchy of Lancaster, who represents the Crown in the Duchy Court, and an attorney-general and solicitor-general of the County Palatine of Durham, who exercise like functions in the Chancery Court of Durham.

(h) See $R$. v. Evans (1819) 6 Price, 480.

(i) See Reg. v. Allen (1862) 1 B. \& S. 850.

(k) See Crown Office Rules, 1906, r. 151; Bellamont's Case (1700), 2 Salk. 625.

(l) Rex v. Wilkes (1770) 4 Burr. 2527, 2554, 2570. 


\section{The Chancellor of the Duchy of Lancaster.}

This officer is a member of the Ministry and appointed by letters patent. He controls the courts of the duchy, which, since the Judicature Act, 1873, consists only of the Chancery Court, and appoints and dismisses county court judges within the duchy. $\mathrm{He}$ is also responsible for the management of the Crown lands within the duchy. His duties, however, in all these matters are discharged by subordinates, and the office is practically a sinecure.

\section{The Secretariat.}

The office of king's secretary dates from the thirteenth century, and it became customary to appoint two secretaries, who were at first minor officers of the household, acting as the means of communication between the Crown in its relations with the Privy Council and its various committees, and with foreign representatives and subjects.

Down to 1782 there were two secretaries for foreign affairs, one for the northern states of Europe and one for the southern. In 1782 the northern department took over the entire management of foreign affairs, whilst the latter looked after home, Irish, and colonial affairs. In 1794 a Secretary of State for War was added, and the management of the colonies was transferred to him in 1801. In 1854 a Secretary of State for War was appointed, in whom were combined the offices of the former secretary at war and of the Secretary of State for War, whilst colonial affairs were entrusted to a separate Secretary of State for the Colonies. In 1858 a fifth Secretary for India was appointed.

The five Secretaries of State are now invariably members of the Cabinet; they advise the Crown in the conduct of their departments, and exercise certain statutory powers. In the absence of any statutory provision to the contrary, any principal Secretary of State may perform the duties of any other principal secretary. It was decided in Entick v. Carrington $(m)$ that a Secretary of State cannot issue a

(m) (1765) 19 St. Tri. 1030. 
general warrant for the arrest of any person. He may, however, issuc a warrant for treason (n). Secretaries of State are appointed by the Crown by delivery of the seals, consisting of the signet, lesser secretarial seal, and the cachet. The office of the signet was abolished in 1851 and each department now uses its own seals.

\section{The Government Departments.}

Political and Non-Political Departments.-The executive business of the country may be classed broadly under two heads: Firstly, matters the administration of which is in the main left to the Crown exercising its discretionary prerogative with the advice of its constitutional ministers, though such matters may be, and in fact frequently are, regulated in part by statute. Such are the administration of the Army and Navy, the conduct of foreign and colonial affairs, and the like.

Secondly, matters relating to the administration of statutes, or the exercise of powers conferred by statute, in which little or no discretion is left to the administrative heads. Such are the collection and management of customs and excise, and other taxes and duties, the management of public museums and galleries, the granting and registration of patents, the registration of births, marriages, and deaths, the auditing of public accounts, and the like.

$\checkmark$ It is obvious that the administration of such important matters of either class can only be adequately attended to by means of permanent offices, with an adequate staff of officials, and these public offices or State departments have consequently been created from time to time as occasion demanded, their constitution and the functions of their principal officers being regulated by the Crown by Order in Council or by statute.

In addition to the distinction arising from the manner of their creation (viz. either by the Crown in the exercise of its prerogative, or by statutory authority) there is this further distinction between the various departments, viz.

(n) Reg. v. Oxford (1840) 4 St. Tri. (N. S.) 497. 
they are either political or non-political. The most important departments of either class are political, that is to say, their heads are members of the Ministry and retire from office with that body on a change of Government; as members of the Ministry they are almost invariably members either of the House of Commons or of the House of Lords (generally the former), and of the Cabinet. In addition to the Parliamentary head, the political departments have in some cases a Parliamentary and a permanent secretary. At the present time some fifteen departments are political, that is to say, their heads are members of the Ministry. Of these the heads of all, except the Board of Works, are included in the present Cabinet, whilst the heads of the Foreign Office, the Home Office, the Colonial Office, the War Office, and the India Office are the five principal secretaries of state who form the secretariat.

The less important departments of either class are nonpolitical, that is to say, the head of the department is an ordinary member of the permanent Civil Service, having no voice or status in politics beyond that of the general electorate, of which he forms a unit. If deemed of sufficient importance a non-political department may at any time become a political department by the appointment of a Parliamentary head; or the reverse may be the case, and a political may be turned into a non-political department, if convenience seems to require that course, by the nonappointment of a Parliamentary head. Variations have also occurred from time to time as to the number of ministers or heads of departments included in the Cabinet.

The Permanent Civil Service.-All Government departments, whether political or non-political, have a permanent staff composed of members of the Civil Service.

The system of open competition by public examination was extended to situations in various branches of the Civil Service in the year 1855, Civil Service commissioners being appointed by Order in Council to organize and hold examinations (o). The members of most branches of the Civil

(o) Order in Council, 21st May, 1855. 
Service are now recruited in that manner $(p)$, and there are two divisions or classes $(q)$, with a corresponding higher or lower standard of examination.

If successful in the competitive examination, members of the Civil Service pass through a six months' period of probation. When finally appointed, they hold office durante bene placito; but in practice they are permanent officials, and are never removed except for misconduct or inefficiency. They are entitled to a pension on retirement, or superannuation $(r)$.

Members of the Civil Service are expected to act loyally to their political heads, to whatever party those heads belong; they are therefore not expected to take any prominent part in politics, and though there is no restriction as to their exercise of the Parliamentary franchise, they are compelled by Order in Council to resign their post on becoming a candidate for a seat in Parliament $(s)$.

No contractual relation exists between the head of the department and the members of the permanent staff-they are all alike servants of the Crown; and therefore the Secretary at War was held not liable in an action for the recovery of pay by a clerk in the War Office $(t)$. In such a case the proper remedy would be by Petition of Right.

Advantages of the English System.-The advantages of the system which thus prevails in the principal Government departments in England of combining a changing Parliamentary head with a non-changing permanent staff, may be clearly seen by a comparison with the systems adopted in foreign countries.

In America the principle of changing the Government officials with every change of government is not confined to the heads of departments alone, but extends to minor situations in the Government service.

(p) As to the situations open to competition by examination, see Order in Council, 4th June, 1780, sch.

(q) Orders in Council, 12th February, 1876; 21st March, 1890; 15th August, 1890.

(r) See 22 Vict. c. 26:34\& 35 Vict. c. 36.

(s) Order in Council, 29th November, 1884.

(t) Gidley v. Lord Palmerston (1822), $3 \mathrm{Br}$ \& \& B. 275. 
The insecurity of tenure existing amongst Government servants under such a system must manifestly lead to many evils. That Government offices should be filled up every few years with possibly an untried and inexperienced set of men, with but small inducements to learn and thoroughly understand their business, owing to the uncertainty of retaining office, would appear to us almost inconceivable, and certain to result in chaos. Further, such insceurity of tenure must inevitably lead to the organization of the Civil Service vote at elections, in order to secure the return of members who may be relied upon to retain the old servants in office, with all the consequent wire-pulling and corruption of politics. At the same time, the policy of an administration subject to such frequent changes cannot but be desultory, fluctuating, and incalculable, owing to the want of a permanent staff, which would, from the very fixity of office routine and the acquired force of tradition, act as a restraining check upon the tendency to too sudden innovations on the part of a temporary political head.

On the other hand, the conduct of the business of Government departments by a set of permanent officials, secure in their office, and exempt from the constant personal control and supervision of members of the Govermment by whom they are employed, which would be free from many of these evils, would lead in greater or less measure to highhanded officialdom and inertness. The want of the personal incentive of ambition, too, amongst the heads of such departments, who, having reached the limits of advancement, must come in time to view the fulfilment of their office in the light of a task to be performed in return for a fixed stipend, must produce as a result the subordination of all higher aims to mere office routine and red tape.

The English system may be said to minimize the evils of both such systcms, and at the same time to combine their advantages. The presence of a permanent staff ensures the efficiency and experience necessary to the proper conduct of the ordinary everyday business of the Government offices, whilst practical security of tenure and the system of open competitions for situations in the Civil Service eradicates the evils of corruption and wire-pulling. 
At the same time the Parliamentary head brings to his work that energy due to the personal incentive of ambition, and infuses into the policy of the departments the stimulus of those higher aims, by the success of which he hopes to make his name distinguished in the annals of political history. The mere drudgery of routine work is left to the staff, whilst his mind is left free to shape means to ends. In the words of Mr. Bagehot, "His function is to bring a representative of outside sense and outside animation in contact with the inside (official) world, though no man is a perfect representative of outside sense: . . . that manysided sense finds no microcosm in any individual " $(u)$.

The Parliamentary head also acts as an official representative of his department in Parliament, shields it from the attacks of the Opposition, and lends the moral support of the weight of opinion in the House of Commons to its actions. The Parliamentary head is not likely to become slack or inert in the conduct of his business, because the desire to retain office, and therefore to stand well with the country, must act as an incentive to exertion, whilst the keen criticism of an active Opposition is sure to expose blunders and ensure the exercise of care and attention to his duties. In addition to these advantages, the Parliamentary head may be said to act as a check upon the tendency to high-handedness in dealing with the public on the part of the permanent staff, whilst the latter act as a check upon any tendency on the part of the head towards sudden or desultory changes of policy.

\section{Political Departments.}

The Home Office.-In the year 1782 the old southern department became the Home Office, transacting also Irish and colonial affairs. Subsequently colonial and Irish affairs were transferred to other departments, and the Home Secretary, assisted by parliamentary and permanent secretaries, at the head of his department, now attends only to home affairs.

(u) Bagehot's Eng. Const., p. 201. 
These comprise a variety of matters, such as the supervision and control of prisons, criminal lunatic asylums, reformatories, and industrial schools.

The Home Secretary advises the Crown in the exercise of its prerogative of mercy, which is effected by royal warrant countersigned by the Home Secretary, and may be by way of reprieve, commutation, or pardon. He administers the Extradition Acts, 1870 and 1873, advises the Crown as to the appointment of recorders of boroughs, the assistant judge of the London sessions, stipendiary and metropolitan police magistrates, and the public prosecutor and his staff.

The Home Secretary is also the means of communication between Crown and subject, and receives petitions addressed to the Crown. In proceeding by Petition of Right, the petition must be left with the Home Secretary, who, upon the advice of the attorney-general that the case is a proper one, obtains the royal fiat-Let right be done.

The Home Secretary is also the principal officer for maintaining the ling's peace. He administers the Foreign Enlistment Act, makes provisions for the enrolment of special constables, and, when necessary, calls in the aid of the regular naval or military forces. He exercises a general control over the local, borough, and City of London police, and the metropolitan police are directly under his supervision. He may also detain and open letters and telegrams in the Post Office, and restrain persons from leaving the lingdom by obtaining the issue of a writ of ne exeat regno, which is now generally confined to the case of absconding debtors under the Debtors Act, $1869(x)$.

The Home Secretary also administers the various Acts relating to such matters as building societies, coal-mines, burials, markets and fairs, sewers, drains, nuisances, and open spaces within the metropolis, employers' liability, factories and workshops, and explosives.

The Foreign Office.-Down to 1782 duties in connection with foreign affairs were divided between the old northern and southern departments. In that year the northern departments took over the sole management of foreign 
affairs, with the Secretary of State for Foreign Affairs at its head.

The department, which consists of a Parliamentary and a permanent secretary, three assistant secretaries, a librarian, and a head of the treaty department, with a permanent clerical staff, attends to communications from diplomatic and consular agents, and determines the foreign policy of this country. Several African protectorates are also under the control of the Foreign Office.

The Colonial Office.-Colonial affairs were attended to by the Home Secretary down to 1801, when they were handed over to the Secretary for War. At the time of the Crimean War, in 1854, the two offices were separated, and colonial affairs have since been attended to by the Colonial Secre-. tary, assisted by a permanent and a Parliamentary secretary and the clerical staff of the department.

The India Office.-Down to 1858 the government of India was carried on by the East India Company, supervised by a government Board of Control in England. By the Government of India Act, 1858, the government of India was transferred to the Crown, acting on the advice of the Secretary of State for India in Council $(y)$. The council, of which the Secretary of State is president, is under the, Government of India Act, 1919, composed of members appointed by the Crown, not less than eight or more than twelve in number, as the Secretary of State may determine (z). The department, with the Secretary of State, a Parliamentary and a permanent secretary at its head, is for convenience divided into various sub-departments, viz. the correspondence, accountant-general's, funds, store, registry and record, and the miscellaneous departments.

The War Office. History (a).-The office of Secretary at War dates from the reign of Charles II., and in addition a

(y) $21 \& 22$ Vict. c. 106.

(z) 8 \& 9 Geo. V. c. 101 , s. 31.

(a) For the account here given of the history of the War Office, see Clode. Military Forces of the Crown; and the Report of the War Office (Reconstitution) Committee, 1904 (Parl. Paper, 1904, Cd. 1932, vol. viii.). 
Secretary of State for War was appointed in 1794, the latter also discharging the duties of colonial secretary. The two oftices of Secretary at War and Secretary of State for War existed side by side until 1854, when, owing to the pressure of business entailed by the Crimean War, it was found necessary to separate the duties of the Colonial Secretary and of the Secretary of State for War, and the two offices of Secretary at War and Secretary of State for War were combined in the same person. The office of Secretary at War was abolished by the Secretary at War Abolition Act, 1863, his duties being amalgamated with those of the Secretary of State for War.

In 1793 the King gave up the personal control of the army, and the office of commander-in-chief was created. Prior to 1855 the administration and control of military matters was divided between a variety of departments, and during the Crimean War such a system was found to lead to endless confusion and inefficiency. The conduct of military matters was therefore centralized in the War Office under the dual control of the Secretary of State for War and the commander-in-chief. Since then various changes have taken place in the organization of the War Office with the object of securing efficiency in military administration, all these changes, however, having until the year 1904 proved unsatisfactory, for various reasons. Between 1855 and 1870 the control of military matters was shared by the commander-in-chief and the Secretary of State, the latter remaining responsible to Parliament and to the Crown for the conduct of the whole. Under this arrangement the duties of the Secretary of State were found to be too heavy, and in 1870, by statute and Order in Council, the War Office was definitely divided into three departments, military, ordnance, and finance.

In 1888 a further reorganization took place, the War Office being divided into a military and a civil side, the commander-in-chief as the head of the military side advising the Secretary of State on all military matters, whilst the latter remainer responsible for the conduct of the whole. The duties of the commander-in-chief under this system were found to be too onerous, and in 1894 four 
officials were appointed to assist him. These were the adjutant-general, the quartermaster-general, the inspectorgeneral of ordnance, and the inspector-general of fortifications. Upon these four officers was thrown the duty of advising the Secretary of State upon matters connected with their several departments, subject to the supervision of the commander-in-chief, who still remained the principal adviser.

This arrangement was, however, found to work unsatisfactorily during the South African War, and in 1901 a further distribution of duties was made by Order in Council (b) amongst the commander-in-chief and eight officials at the head of their corresponding departments, these being-

(1) The Adjutant-General.

(2) The Director-General of Mobilization and Mili- tary Intelligence.

(3) The Military Secretary.

(4) The QuartermasterGeneral.

(5) The Inspector-General of Fortifications.

Under the direct control of the

Commander-in-Chief.

Under the general supervision of the Commander-in-Chief, the heads of these departments acting as the immediate advisers of the Secretary of State on matters connected with their departments.

(8) The Financial Secretary.

The Director-General of Ordnance.

(7) The Director-General of the Army Merical Department.

Report of Lord Esher's Committee.-The reform of military administration did not end here, and as the result of the report made by the War Office Reconstitution Committee of inquiry under the presidency of Lord Esher in the year 1904, still wider and more sweeping changes were made in the organization of the War Office $(c)$. The report of this committee attributed the previous inefficiency in the

(b) Order in Council. 4th November, 1901.

(c) This committee was composed of three members, Lord Esher. Admiral Sir John Fisher, and Colonel Sir G. Clarke. For the text of the report see The Times of 1st February, 1904. 
administration of military matters to five principal causes, and made recommendations to meet the defects.

Constitution of the Army Council.-Parts II. and III. of this report, dealing with the creation of the Army Council, and the appointment of inspectors-general, have been adopted by the Government and put in force, the office of commander-in-chief having been abolished, and the members of the Army Council subsequently appointed by letters patent of the 6th of February, 1904.

By these letters patent the Army Council is constituted of the following officials :-

(1) The Secretary of State for War, President of the Council.

(2) The Chief of the General Staff,

(3) The Adjutant-General,

(4) The Quartermaster-General,

(5) The Master-General of Ordnance, Military members.

(6) The Deputy Chief of General Staff.

(7) The Under Secretary of State for War.

(8) The Financial Secretary to War Office.

(9) The Director-General of Movements and Railways.

(10) The Surveyor-General of Supply.

In addition to these there is a permanent secretary of the Army Council appointed by the council, but who is not a member of the council, and a director of army finance to assist the financial member. The duties of the council as set forth by the letters patent are " to administer matters pertaining to the military forces and the defence of his Majesty's dominions with such power and authority as has hitherto been exercised under the royal prerogative by the secretary of state, the commander-in-chief, and other officer's acting under the secretary of state." The council is also endowed with "full power and authority to appoint such officers for the conduct of the business of the civil departments of the military service as they shall think fit, and to make contracts and do all other things which may seem necessary in their discretion "' $(d)$. The signature of the council is to be affixed by any two of its members, or any one with the Secretary appointed by the council.

(d) See the London Gazette, 12th February, 1904. 
Functions of the Army Council.--The duties and functions of the various members of the council have been defined by Order in Council $(e)$ as follows:-

(1) The Secretary of State is to be responsible to his Majesty and Parliament for all the business of the Army Council.

All business, other than business which the Secretary of State specially reserves to himself, is to be transacted in the following principal divisions:-

(a) The first military member of the Army Council (the Chief of the General Staff), the second military member of the Army Council (the AdjutantGeneral), the third military member of the Army Council (the Quartermaster-General), and the fourth military member of the Army Council (the Master-General of Ordnance), and the fifth member (the Deputy Chief of the General Staff), to be responsible to the Secretary of State for the administration of so much of the business relating to the organization, disposition, personnel, armament, and maintenance of the Army as shall be assigned to them or each of them from time to time by the Secretary of State.

(b) The finance member of the Army Council to be responsible to the Secretary of State for the finance of the Army, and for so much of the other business of the Army Council as may be assigned to him from time to time by the Secretary of State.

(c) The civil member of the Army Council to be responsible to the Secretary of State for the noneffective votes, and for so much of the other business of the Army Council as may be assigned to him from time to time by the Secretary of State.

(2) The secretary of the War Office acts as secretary of the Army Council, and is charged with the interior

(e) Order in Council, 10th August, 1904. See the London Gazette of the 16th August, 1904. The statutory duties and powers formerly exercised by the commander-in-chief are transferred to the council by statute : see 9 Ed. VП. c. 3. 
economy of the War Office, and the preparation of all official communications of the council, and with such other duties as the Secretary of State may from time to time assign to him.

The office of Inspector-General was abolished in 1915, the duties being taken over by the Chief of the Staff.

The Air Ministry.-By the Air Force Constitution Act, 1917 ( 7 \& 8 Geo. V. c. 51), an Air Council was established which took over the powers, duties, etc., of the Air Board constituted by the New Ministries and Secretaries Act, 1916. The Air Council consists of the Secretary of State for Air, Under Secretary, Chief of the Staff, ControllerGeneral of Civil Aviation, Director-General of Supply and Research, and three others. The Air Ministry was established in 1918 to take over the control of the Air Force, and in addition the Air Navigation Act, 1919, enacts that the purposes of the Air Council shall include all matters connected with air navigation.

The Imperial Defence Committee of the Cabinet.-The Defence Committee of the Cabinet was originally formed in 1895 to consider wide questions connected with the defence of the Empire, where the joint operation of the naval and military forces was concerned. It was originally composed of the Prime Minister, the heads of the Admiralty and War Office, the First Lord of the Treasury, and the Colonial Secretary. Its constitution was, however, remodelled in 1902, and then consisted of the Prime Minister and such other members as, having regard to the nature of the subject to be discussed, he might from time to time summon to assist him. Though subject to change or modification the committee now appears to include the Prime Minister, the Secretaries of State for War, Foreign Affairs, Colonies and India, the Chancellor of the Exchequer, the First Lord of the Admiralty, the Chief of the General Staff, the First Sea Lord, the Directors of Naval and Military Intelligence, together with any persons who may be deemed specially qualified to assist with advice.

Until 1904 there was no permanent staff or secretariat to keep permanent records of the work of the committee, 
or assist the committee in its duties. But, as a result of the recommendation of the War Office Reconstitution Committee $(f)$ of that year, a permanent staff was appointed, consisting of a secretary and two assistant secretaries, one of whom is nominated by the First Lord of the Admiralty, the other by the Secretary of State for War. The duties of the secretariat are: (1) To preserve a record of the deliberations and decisions of the committee; (2) to collect information and statisties connected with questions of Imperial defence, and prepare memoranda thereon for the use of the committee; (3) to make possible a continuity of method in the treatment of the questions which come before the committee.

The committee may, therefore, now be ranked under the head of a permanent Gorernment department. Its functions, however, being purely consultative or advisory, the secretariat has no administrative or executive power, and any decisions arrived at by the committee are carried out by the heads of the various departments concerned $(g)$.

The Admiralty.-The duties of the Lord High Admiral are now performed by "commissioners for executing the duties of the Lord High Admiral of the United Kingdom," appointed by letters patent. The commissioners, who are five in number, comprise a first lord, who is always a Cabinet Minister, a senior second, third, and junior naval lords, and a civil lord; these are assisted by a Parliamentary and financial secretary, and a permanent secretary appointed by the board. The First Lord is responsible to the Crown and Parliament for the conduct of naval affairs, which is distributed amongst the other lords as he thinks fit, the naval and civil lords being responsible to the First Lord for the conduct of the various matters entrusted to them.

The Board of Trade.-The origin of this body is to be found in the committee of the council created by Cromwell

(f) See ante, p. 204.

(g) For this account of the early constitution of the Defence Committee see Treasury Minute of the 4th of May, published in The Times of the 3rd of August, 1904. 
in 1660 to advise on matters connected with "Trade and Plantations." This committee, under the name of the "Board of Trade and Plantations," existed down to 1782 , when it was abolished by statute, it being provided that the business of the board should be transacted by such committee or committees as his Majesty should be pleased to appoint $(h)$.

Since that date the board has continued nominally to exist, its duties being discharged by the president, assisted by a Parliamentary and a permanent secretary (i) at the head of the permanent clerical staff of the department. The board has ceased to take any part in colonial affairs since 1854, when a separate Secretary of State was created for the colonies.

The constitution and duties of the board with those of the Local Govermment Board came under the consideration of Lord Jersey"s committee in 1904, which recommended that. as the responsibility for the business of the board rests with the president, and as the board itself never meets, its constitution is obsolete, and should not be continued. The committee also recommended that the president should be placed upon the same footing as a Secretary of State, with certain increases in his salary and those of the political and permanent secretaries, whilst it might be desirable to alter the title of the president to that of Minister of Commerce and Industry $(k)$.

The department register's ships and seamen, collects home and foreign trade statistics, and generally looks after the interests of British commerce, controls and supervises grants of letters patent, trade marks, and designs; keeps the standard of weights and measures; supervises bankiuptey proceedings in their non-legal aspect and the registration of joint-stock companies, and administers a rariety of statutes relating to such matters as railways, tramways, water, gas, and electric lighting companies, the maintenance of harbours and lighthouses, and merchant shipping.

(h) 22 Geo. III. c. 82, s. 15 .

(i) A parliamentary secretary was appointed by the $30 \& 31$ Vict. c. 72 to take the place of the old vice-president.

(k) See The Times, 10th of June, 1904.

C.I.E. 
The Orerseas Trade Department (Secretary) Act, 1918, provides for the joint appointment by the Board of Trade and the Foreign Secretary of a Secretary of the Orerseas Department.

The Treasury Board and the Exchequer.-Originally the collection of the revenue was attended to by the old Court of Exchequer, and this duty has now devolved upon four departments - the Customs, the Inland Revenue, the Post Office, and the Commissioners of Woods and Forests-and by these the public revenue is now collected and paid to the credit of the Exchequer account at the Bank of England, which is termed the Consolidated Fund.

The duties of the Treasury Board are not connected with the actual collection of the revenue, but consist in considering how money is to be raised to meet the national expenditure and in supervising the estimates for that expenditure submitted by the rarious departments.

The Scotch Treasury was combined with the English Treasury at the time of the Act of Union, and the Irish Treasury in 1816. The office of Lord High Treasurer and Treasurer of the Exchequer dates from 1216, and the Treasury Board, which now represents that functionary, is composed of the First Lord of the Treasury, who is usually the Prime Minister and leader of the House of Commons, the Chancellor of the Exchequer, and three junior lords, who are generally appointed one for each kingdom, together, usually, with a fourth junior unpaid lord. These are appointed by letters patent, and are assisted in their duties by a political financial secretary and the patronage secretary, who is also the Chief Goremment Whip. The routine business of the department is attended to by permanent, financial, and administrative secretaries, and a staff of clerks and other officials.

Originally the Treasury Board met regularly to transact business, the King being present. When George III., however, gave up the Crown revenue in return for a fixed civil list, he ceased to attend, and the other members in turn dropped off. The duties of the board are now discharged by the department under the supervision of the Chancellor of the Exchequer, as representing the old Under Treasurer, 
whilst the duties of the other members of the board are chiefly political.

The chancellor at the head of the department consults with heads of the various spending departments and ascertains what the requirements of the financial year are likely to be. After the estimates for the expenses of the various departments have been supervised and considered by the Treasury, whose duty it is to check excessive expenditure in any branch of the public service, a scheme of taxation to meet the requirements of the year is arranged by the Chancellor and submitted to Parliament by him in the form of "The Budget," together with the various estimates; supplies are then granted by Parliament in the manner described in a previous chapter $(l)$.

In addition to his duties at the Treasury, the Chancellor also has duties, which are chiefly nominal, in connection with the boards of various departments (viz. the Ministry of Health, the Ministry of Agriculture and Fisheries, and the Board of Education $(m)$ ) of which he is an ex officio member. He is also Master of the Royal Mint ( $n)$, and presides in Court at the annual appointment of sheriffs $(o)$.

Closely connected with the Treasury is the department of the Comptroller and Auditor-General, an office created by the Exchequer and Audit Act, 1866 $(p)$, to take the place of the Comptroller-General of the Exchequer. The Comptroller and Auditor-General and the Assistant Comptroller and Auditor are appointed by letters patent, and are dismissible only by the Crown on an address from both Houses of Parliament. Their salary is charged upon the Consolidated Fund; they are thus beyond the reach of party or personal influence.

No money can be obtained by the Treasury except through the medium of the Comptroller-General, who, upon the Sovereign's order, countersigned by two lords of the Treasury, being presented to him, gives the lords of the Treasury a credit upon the Exchequer account at the Bank

(l) See ante, p. 88.

(m) See pp. 213-215, post.

(n) See the Coinage Act, 1870 (33 Vict. c. 10, s. 14).

(o) See post, Part VI., Chap. I.

(p) $29 \& 30$ Vict. c. 39. 
of England. The amount is accordingly transferred by the bank to the credit of the Paymaster-General, and becomes available for expenditure amongst the various public services.

The Comptroller and Auditor-General also sees that the sums for which he has given the Treasury credit are spent in accordance with the Parliamentary grants. He accordingly examines and audits the accounts of the various departments, and his report is presented to the Public Accounts Committee of the House of Commons. After due consideration of this report, the House passes the Appropriation Act for the session, and the final sanction of Parliament for the expenditure for the year is obtained.

The Post Office.-The Post Office is one of the four great revenue-receiving departments, the other three being the Customs, the Inland Revenue, and the Commissioners of Woods and Forests. The estimated revenue of the Post Oitice for the year 1921-1922 amounted to about sixty millions. At what date the Government first took over the conduct of postal matters does not seem to be accurately linown. A master of the posts was, however, created as early as 1516 .

The Penny Post was established in 1841, and the Post Otfice Sarings Bank in 1861. The head of the department is the Postmaster-General, whose office dates from 1710. He is sometimes a member of the Cabinct, and is assisted in his duties by a permanent secretary. Cnder various statutes passed in 18:37, the Post Office enjoys the monopoly of the carriage of letters, newspapers, and telegrams, and also of telephonic communications (q). Questions likcly to affect the revenue, such as the alteration of postal lates, mast have the sanction of the Treasury.

The Scotch Office.-The Scotch Office dates from 1885, when is Secretary for Scotland was created by statute $(r)$ to talie over the duties with regard to Scotland, formerly discharged hy the Home Secretary, assisted by the Lord

(q) Att.-Gen. V. Edison (1880) 6 Q. B. D. 244.

(r) 48 \& 49 Vict. c. 61. The secretary for scotland may appoint ( $\pi$ ith the sanction of the Treasury) such officers, clerks, etc., as he may determine (ib.). 
Advocate for Seotland, eertain duties of the Privy Council, the Treasury, and the Local Government Bourd with relation to Scotland being handed over to him at the same time. 'The Secretary for Scothand, who is appointed by warrant under the sign manual, administers the Scotch Education Acts, is Vice-President of the Committee of Council on Education in Scotland, and keeper of the Great Seal of Scotland. He also exercises, as regards Scotland, some of the duties of a principal Secretary of State $(s)$.

The Irish Office.-A Secretary for Treland was first appointed by George II., and until the Union he acted as leader of the Irish House of Commons. The Chief Secretary for Ireland (or sometimes in his place the LordLieutenant) was always a member of the Cabinet, and responsible for the conduct of Irish affairs, which were administered by the Irish Office, the Lord-Lientenant acting for the most part merely as the instrument for putting into force in Ireland measures which had been decided on by the Chief Secretary for Ireland, the Home Office acting as the formal means of communication, but merely as a. matter of routine.

Ministry of Health.-This department was created by the Ministry of Health Act, 1919 ( $t$ ), to exercise powers with respect to health and local government and to do the work which was formerly done by the Local (iovernment Board, which has been abolished. Its head is the Minister of Health, who has a seat in the Cabinet and is assisted by a parliamentary secretary and other secretaries and officials. The powers and duties of this department include the powers and duties of the Local Govermment Board and of the Insurance Commissioners, the porrers and duties of the Board of Education with respect to the health of mothers and children, the powers of the Privy Council under the Midwives Acts, the powers of I'art I. of the Children Act, and other powers and duties relating to the health of the people. By Order in Council the Crom may transfer to

(s) See the Secretary for Scotland Act, 1887 (50 \& 51 Vict. c. 52); 8 Ed. VII. c. 49 , s. 2 (1).

(t) $9 \& 10$ Geo. V. c. 21. 
the Minister any other powers and duties relating to the health of the people.

Ministry of Labour.-This department was created by the New Ministries and Secretaries Act, $1916(u)$. Its head is the Minister of Labour, who has a seat in the Cabinet. There is also an Under-Secretary with a seat in Parliament and a Permanent Secretary with a large clerical staff. The department took over certain work from the Board of Trade and from the Treasury and is responsible for industrial arbitration, labour exchange, insurance, labour statistics and the like. Power is also reserved to the Crown to assign to it other duties by Order in Council. The Minister is also responsible for the Industrial Court $(x)$.

Ministry of Pensions.-This department was created by the Ministry of Pensions Act, $1916(y)$. Its head is the Ministry of Pensions assisted by a parliamentary undersecretary. It took over the functions formerly discharged in relation to pensions by the Army Council, the Admiralty, and the Commissioners of Chelsea Hospital.

The Ministry of Agriculture and Fisheries.-The Board of Agriculture, consisting of the Lord President of the Comncil, the five principal secretaries, the First Lord of the Treasury, the Chancellor of the Exchequer, the Chancellor of the Duchy of Lancaster, and the Secretary for Scotland, was created by the Board of Agriculture Act, 1889 (z). To this board were handed over the duties formerly discharged by a committee of the Privy Council in connection wit? diseases of animals, and the duties of the former land conn. missioners in connection with tithe commutation, copyholds, inclosures and allotments, and the drainage and improvement of land. By the Board of Agriculture and Fisheries Act, 1903, the superintendence of fisheries was transferred from the Board of Trade to the Board of Agriculture, and the name of the latter changed to that of the Board of Agriculture and Fisheries. In addition to these duties the

(u) $6 \& 7$ Geo. Y. c. 68.

(y) 6 \& 7 Geo. V. c. 65. (x) $9 \& 10$ Geo. V. c. 69.

(z) $52 \& 53$ Vict. c. 30. 
board, whose duties are discharged by the departmental staff under a president and secretary, supervises the Ordnance Survey, collects agricultural statistics and intelligence, and generally looks after the welfare of agriculture. In 1919 the Ministry of Agriculture and Fisheries was substituted for the board $(a)$.

The Board of Works and Public Buildings.-The department of the Commissioners of Works and Public Buildings was created by statute in 1851 (b) to take over the duties of the former Commissioners of Woods, Forests, and Land Revenues, with regard to parks and public buildings. The board is composed of a First Commissioner, who is a member of the Ministry, and sometimes of the Cabinet, and retires from office with the Government, the five principal Secretaries of State, and the President of the Board of Trade. The board itself never meets, and its duties are discharged by the First Commissioner, assisted by a permanent secretary at the head of the permanent staff of the department, which is for convenience split up into several divisions $(c)$.

The Board of Education.-A committee of the Council was appointed in 1839 to attend to matters connected with education. By the Board of Education Act, 1899 (d), the committee of Council was abolished, and the present Board of Education established with a permanent departmental staff. The board consists of a president, the Lord President of the Council (unless he is appointed president), the five principal secretaries, the First Lord of the Treasury, and the Chancellor of the Exchequer $(e)$. The duties of the department, which consist in supervising the administration of the various Education Acts, are discharged by the president and vice-president, with permanent and political secretaries and a permanent staff.

(a) $9 \& 10$ Geo. V.c. 91 .

(b) 14 \& 15 Vict. c. 42 .

(c) These are secretarial, finance, architect's and surveyor's, engineering and stores.

(d) 62 \& 63 Vict. c. 33.

(e) To these was added a consultative committee, as to which see Education Act, 1921, s. 2. 


\section{Non-Political Departments.}

The principal of these, which it will be sufficient here to enumerate, are-

The Customs Establishment.

The Inland Revenue Department.

The Charity Commissioners.

The Ecclesiastical Commissioners.

The General Registry of births, marriages, and deaths.

The Friendly Societies Registry.

The Public Record Office.

The Public Trustee.

Trinity House.

The Public Works and Loan Department.

The National J)ebt Office.

The Patent Office.

The Commissioners of Queen Anne's Bounty.

The Civil Serrice Commissioner's.

The Exchequer and Audit Department.

The College of Arms.

"The British MIuseum.

The National Gallery.

The Port of London Authority. 


\section{Part IV.-The Judiciary.}

\section{Chapter I.}

JUDICIAL INSTITUTIONS TO THE THE (OF EDWARI) I.

$$
\text { The Anglo-Suxom Period. }
$$

Early Institutions.--In the early times of semi-barbarism justice was, no doubt, purely retributive, and vengeance for loss of life or property belonged to the fanily of the wronged. Gradually, we may suppose, this right of vengeance becane limited to the near relations of the person mronged, and we get the blood-feud.

Then there grew up the idea of compensation, the AngloSaxon bot, for the wrong done, and that, except in the case of certain bootless offences, the acceptance of compensation ought not to be denied.

In Anglo-Saxon times this compensation or weregild was regulated for injuries of all kinds according to a fixed scale. Thus in Anglia the scale was 30,000 thrysmae for the life of the King; for an archbishop or earl, 15,000; for a general or sheriff, 4,000; for a priest or thegn, 2,000; whilst the life of a commoner was valued at 266 thrysmae, and so on for every other kind of offence (a). Half of this compensation went to the King, and was called wite, whilst the other half went to the injured party or his relatives, and was called wer or were (b).

It has been suggested that the origin of the distinction between crime and tort is to be found in the fact that the King, in order to replenish his exchequer, overlooked the

(a) Reeves, H. E. L., i. 28; Stubbs' Sel. Chart., 65.

(b) Reeves, H. E. L., i. 29 ; Carter, H. E. L., I. 14. 
bootless offences on payment of a fine to himself; but it is possible that the underlying idea which differentiates crime from tort, may always have been as it is now, the damage done to society as a whole, and the need of preventing its recurrence.

As soon as this stage was reached the difficulty arose, which has arisen in all legal systems, of inducing the plaintiff and defendant to submit to the jurisdiction of the various courts instead of taking private revenge; thus there is a provision in the Dooms of Ine of Wessex, A.D. 680 (c), against taking the law into one's own hands. Soon the penalties of distraint and outlawry were used to compel consent to the jurisdiction, and the peine forte et dure, which consisted in pressing a defendant who was unwilling to submit to the jurisdiction with lieavy weights, and feeding him with bad bread and stagnant water on alternate days, was used down to Bumwater's Case (1726). In that case Burnwater refused to plead to a charge of murder at Kingston Assizes, and in consequence he was pressed with four cwt. of iron, after which he pleaded not guilty, was convicted and hanged $(d)$. The object in refusing to plead in felony seems to have been that, as there could be no conviction, no forfeiture of the accused person's lands and goods could occur.

The Anglo-Saxon Courts of Justice.-Not much is known of these, but it is certain that there were-

(1) The Sheriff's Tourn, or the two great annual meetings of the county court or shire mote at Easter and Michaelmas to hear criminal cases. The sheriff was president, and the landowners were the judges. The county court also exercised civil jurisdiction; but it does not seem certain how often it met in this capacity, though later on it appears to have sat monthly $(e)$.

(c) Wilkin's Leges Anglo-Sax., p. 16.

(d) See Steph., Hist. Crim. Law, i. 298. The peine forte et dure was finally abolished in 1772, and standing mute in felony made equivalent to conviction (12 Geo. III. c. 20 ). In 1827 it was enacted that in such a ease a plea of not guilty was to be entered ( $7 \& 8$ Geo. IV. c. 28).

(e) Sce Reeves, H. E. L., i. 15. According to another view, the Sheriff's Tourn was held in the Hundred Court. See Pol. \& Mait., i. 546 , and the authorities there cited. 
The Sheriff's Tourn held a view of frankpledge, a system of police established by the Anglo-Saxons, under which the community was divided into associations of ten families or tithings, the heads of which were responsible for the good behaviour of all the rest. On an offence being committed by one of their number, the rest were bound to produce him, or, in the erent of their being implicated in his escape, to make good the loss $(f)$.

(2) The Hundred Court, which met every four weeks and exercised mainly civil jurisdiction.

(3) The Witenagemote, or Great Council, which was, properly spealing, not a court at all, but a meeting of all the wise men to settle the affairs of the nation. Plaintiffs could only go there on a failure of justice in the local courts.

The Anglo-Saxon Common Law.-At first there was no common code of laws administered in these courts, and after the Danish invasion there were three different sets of law prevailing in different districts: (1) the Mercen Lage, or Mercian Laws, in the Midlands; (2) the West-Saxon Lage, or laws of the West Saxons, in the sonth-west; (3) the Dane Lage, or Danish laws, on the East Coast and in some of the Midlands $(g)$. Alfred made a uniform digest of all these laws in his Dom-boc, and he is generally styled the Conditor, or founder of the English common law. This code, however, seems to have fallen into disuse, for Edward the Confessor restored Alfred's code with such alterations as lapse of time had made necessary. $\mathrm{He}$ is therefore styled the Pestitutor, or restorer of the English common law. The Norman kings made frequent promises to maintain these laws as a means of winning popular favour and to induce the people to grant them the funds required for their various military undertakings.

Anglo-Saxon Procedure.-The Anglo-Saxon forms of proof were-

(1) Compurgation and oath, or wager of law, where the accused denied the accusation on oath, and brought up other freeholders, generally twelve, to swear

(f) Reeves, H. E. L., i. 25 et seq.

(g) Steph., Comm., 10th Ed., i. 47. 
that he was oath-worthy; these were termed compurgators $(h)$.

This form of proof was abolished by Henry III., but appears to have survived in some boroughs, such as London, until 1824 (i). It was finally abolished in 1833 by the $3 \& 4$ Will. IV. c. 42.

(2) Ordeal.-This was used in criminal cases where the accused could not get compurgators to swear to his eredibility, and generally in eases of deficient evidence. It does not appear to have been used in eivil eases.

There were three forms of ordeal, the holding of red-hot iron, plunging the arm into boiling water, and being thrown into water. Curiously enough, in the first two instances going through the ordeal unscathed was the test of inno-. cence, whilst in the latter the per'son who sank was deemed imocent $(k)$.

Ordeal was abolished by Innocent III. at the Lateran Council of 1215, and forbidden by Henry III. in a writ addressed to the itinerant justices in 1219 (l).

(3) Witnesses. - These gave evidence only of facts which they had seen and heard (de visu et auditu), but only of such facts as were asserted by the party producing them, and then only aceording to a set formula.

(4) Charters.-These were superior to all other forms of proof, and if old or illugible, they might be reinforced by other evidence.

Such were the Anglo-Saxon forms of proof, for battle did not malie its appearance until its introduction by the Normans.

\section{The Normun Period from the Conquest to Edward $I$.}

The Feudal System.- Some sort of feudal system was no doubt in use amongst the Anglo-Saxons before the Norman

(h) See Bl. Comm., iii. 339-343.

(i) See King v. Williams (1824) 2 B. \& C. 538.

(k) See Pol. \& Mait., ii. 596.

(l) $\mathrm{Ib}$, ii. 597 . 
invasion, and it is even probable that the manorial courts existed in those times, or at least the judicial rights granted by the Anglo-Saxon kings to great earls and men of importance, under the name of sac and soc, would seem to approach very nearly to such rights of jurisdiction as the lords of manors held under the Norman kings. However, the full Norman feudal polity was not introduced at once by the Conqueror, but was gradually established by the Norman barons in such lands as they had received by gift from the Conqueror. The immediate purpose was, no doubt, to put the nation into a thorough state of defence, for in 1085 there was fear of a Danish invasion. The king held a great council, the result of which was the compiling of Domesday Book in the following year, and at the end of the same year the ling met all his nobility and principal landholders at Sarum, where they agreend to submit to the yoke of military tenure, by what is known as the Statute of Sarum, 1086. The terms of this statute are interesting and important, because from it we see that the Conqueror claimed not only the ban-that is, the right of exacting military service from his immediate vassals-but the arriere ban also-that is, the right to exact military service from the rassals of his immediate rassals. Thus he was in a much stronger position than the feudal lings on the continent, who had not this arriere ban.

It is noteworthy, however, that though the Norman kings claimed the arrièe ben, still each lord claimed the right of trying his own vassals in his own court. This claim eventually failed, and Edward I., by his writs of quo uerranto, called upon the lords of manors to show title to their rights of jurisdiction, and where they could show none they were prevented from exercising any in future. This was a great step on the road to the establishment of the king's right of administering justice.

The Norman Courts of Justice.-After the Conquest the Norman courts of justice were as follows:-

(1) The Witenagemote or Great Council (Curia Magna or Conmune Concilium).

(2) The King's Court (Curia Regis).

(3) The Exchequer. 
(4) The County Court or Shiremate.

(5) The Burghmote.

(6) The Hundred Court.

(7) The Manorial Court.

(8) The Forest Courts.

(1) The Witenagemote had existed under the same name in Saxon times, and was, properly speaking, not a court at all, but a meeting of all the wise men to settle the affairs of the nation and, under the Normans, to assess aids and scutages. Only earls and greater barons could bring suits there, originally as being entitled by Magna Carta to judicium parium ( $m$ ). The lesser follis brought their suits in the local courts and could only petition the Great Council on a failure of justice in the local courts.

(2) The King's Court. Originally there does not seem to have been any definite distinction between the King's Court (Curia Regis) (n) and the Great Council (Witenagemote, Commune Concilium or Curia Magna). What is known, however, as the residuary royal justice (i.c. when there was a failure of justice in the local courts) seems to have been exercised by the ling acting on the advice of a body of men smaller than the Curia Magna, but composed of the greater earls and barons, who were members of the Great Council and usually attended his person. By a provision of Magna Carta the Common Pleas (that is, the King's Court exercising its civil jurisdiction) was to be fixed in some certain place (o), and the other branch of the King's Court, which by the time of Edward I. had become known as the King's Bench, contiuued to follow the king's person.

(m) See Stubbs' Sel. Chart., p. 293.

(n) Curia Regis is a term which seems to have been applied indiscriminately to the Great Council (Curia Magna), the King's Court, and the shiremote or eounty court when the sheriff presided under the King's writ, or when the itinerant justices presided. See Carter, H. E. L., I. 35 ; Pol. \& Mait., i. 132.

(o) It seems that the Common Pleas did not become fixed at Westminster for some time after the year 1215 (see Pulling's Order of the Coif, p. 91). 
(3) The Exchequer attended to Treasury business and kept accounts of the ling's revenue, the justiciar and chancellor presiding. In the reign of Henry I. it began to take cognizance of pleas between subject and subject, thus trespassing on the jurisdiction of the Common Pleas.

(4) The County Court or Shiremote was the only court of general jurisdiction. The sheriff presided, and the free men or landholders of the county were the judges. It had jurisdiction to try causes which could not be brought in the manorial or hundred courts. At first it met twice a year, later once in each month.

(5) The Burghmote was equiralent to a county court in a city.

(6) The Hundred Court was composed of landowner's having no jurisdiction of their own by custom or franchise. It was presided over by the ealdorman in Saxon times, later on by the bailiff of the hundred, the free suitors being the judges. In the reign of Henry $I$. it met twelve times a year, and from the year 1234 once every three weeks $(p)$. The hundred court had jurisdiction to try such causes as were not within the jurisdiction of the manorial court, and held a view of frankpledge twice a year. Not being a court of record, it fell eventually under the provisions of the $30 \& 31$ Vict. c. $142(q)$.

(7) The Manorial Courts, or Courts Baron, ranked with the hundred courts, and depended for their jurisdiction on royal charter or long usage. They were incident to every manor in the kingdom, the steward of the manor presiding, with the copyholders and freeholders as judges. In this court bye-laws were made and local business transacted. It also met every three weeks to try personal actions up to $40 s$. before the freeholders, and to decide questions relating to land within the manor in the action

(p) See Pol. \& Mait., i. 544.

(q) See post, p. 270. 
called the Writ of Right $(r)$. In the customary court of the manor copyholds were transferred by surrender and admittance, as they are to this day, and the customary court attended to matters connected with the villenage until villein tenures eventually became turned into copyholds.

Sometimes the lords of manors enjoyed by charter Regalia, or rights of administering justice equal to that of the king himself, and in many cases they had the right of holding a court leet to try criminal cases, and in that case suitors within the jurisdiction were exempt from attending the Sheriff's Tourn. This jurisdiction seems to have been usurped in many cases without good title, and Edward I. by his writs of quo warranto ealled upon the manorial courts to show title to their jurisdiction; where no title could be shown, they were prohibited from exereising jurisdiction in future. Through inefficieney the manorial courts, or courts baron, fell long ago into disuse, and not being eourts of record they fell eventually under the provisions of the 30 and 31 Vict. e. $142(s)$. Surrenders and admittances of copyhold estates, however, still continue to take place in the customary court, the steward alone being present, the free suitors having long since ceased to attend.

(8) The Forest Courts, which were held before the warden and foresters, presented criminals before the itinerant justices in eyre of the forest $(t)$. The jurisdiction of these courts was mostly ex delicto, but extended also to clearings and leases of forest lands. They were rery unpopular, and provisions remitting the burden of attending the forest courts, and disafforesting certain lands, were inserted in Magna Carta (u), and again in the Carta de Forestâ granted by Henry III. (1217) $(x)$. Eventually the powers

(r) See Pol. \& Mait., i. $57 t$ et seq.

(s) Sce post, p. 270.

(t) See Holdsworth, H. E. I.. 314 et seq.

(u) See Stubbs' Sel. Chart., 294.

(x) Ib. 338 . 
of the warden, chief justices, and justice in eyre of the forests became rested in his Majesty's commissioners of woods, forests, and land revenues.

Features of the Norman Period.-The main features to be noted with regard to the administration of justice during the period now under review are: (1) The separation of the civil and ecclesiastical courts; (2) the rise of royal justice through the use of the king's writ, and the corresponding increase in the jurisdiction of the King's Court at the expense of the local courts; (3) the changes brought about in procedure by the introduction of battle and inquest or assize; (4) the adoption of the circuit system.

\section{The Separation of the Civil and Ecclesiastical Courts.-} During the Anglo-Saxon period the bishops sat with the earls and barons in the hundred and county courts, and cleries and laymen alike were tried in those courts. The Conqueror, however, forbade ecclesiastical causes to be tried in the secular courts $(y)$, and henceforward ecclesiastial pleas were heard only in the ecclesiastical courts $(z)$. To this measure is due the subsequent development of the ecclesiastical judicial system.

The Rise of Royal Justice.-The adoption of a universal common law was essentially necessary to the trial of causes from any part of the country in the King's Court. Such a system of laws had been embodied by Alfred in his code, and restored by Edward the Confessor. The Norman kings made frequent promises in their charters to maintain these laws as the best means of obtaining popular favour and the funds necessary for carrying on the wars upon which they were constantly embarking, so that by the time of Edward I. they had become firmly established as the law of the land and the law administered by the King's Court, the customs of Kent, and of various boroughs, such as London, only excepted. Thus the first requisite for the

(y) See Stubbs' Sel. Chart., 81.

(z) Henry I. restored the union of the ecclesiastical and secular courts, but they were again separated by his successor Stephen.

C.L.E. 
universal atministration of justice by the King's Court was attained. The second requisite for the administration of justice by a common court for the whole land was the holding of the King's Court in a definite spot, instead of following the king from place to place, as was the custom under the early Normans. This purpose was partly attained by Magna Carta, which provided that the common pleas should no longer follow the ling, and probably from the confirmation of Magna Carta by Henry III. onwards the Common Pleas sat at Westminster. In all cases where the injury was alleged to be contra pacem domini regis the cause went to the King's Court, it being provided by Magna Carta that the sheriff, who had formerly exercised certain criminal jurisdiction in the court leet of the sheriff, or the Sheriff's Tourn (a), should no longer hold pleas of the Crown.

By the Statute of Marlborough, $1267(b)$, it was provided that no one should answer for his freehold without the king's writ; and by the Statute of Gloucester, 1278 (c), pleas above $40 \mathrm{~s}$. were to be taken in the King's Court. Thus the sheriff's jurisdiction in the county court was still further abridged.

The Royal Writs.-The various royal writs which came into use at this period were as follows:-

(1) The Writ of Right for land might be returned into either the manorial court or the King's Court; it, however, always contained a nisi feceris clause, sending it to the sheriff's court if not tried in the manorial. The lord might also give his tenant leave to try bis cause in the King's Court, in which case the writ contained the words quia dominus remisit curiam $(d)$.

(2) The writ of Pracipe Quod Reddat, which might be used for land or debt, was always returnable in the King's Court.

(3) The Justicies was a writ addressed to the sheriff,

(a) Names given to meetings of the county court, at least when the sheriff exercised criminal jurisdiction.

(b) 52 Hen. III. c. 22.

(c) 6 Ed. I. c. 8 .

(d) See Pol. \& Mait., i. 368 et seq.; Reeves, i. 193 et seq. 
directing him to try the case, where it was not desired to hear the cause at Westminster.

The following writs were used when it was desired to remove a cause from one of the inferior courts into the sheriff's or ling's courts:

(a) Tolt, by which the cause was removed by the sheriff's precept from the manorial or hundred courts to the shire court.

(b) Ponc, by which the cause was called up from the shire court to the King's Court.

(e) Error.- In the case of some error on the face of the pleadings, the cause might be ordered up by writ of error to be reviewed in the King's Court at Westminster, after judgment had been given in the lower court.

(d) Recordari Facias.-If the lower court were not a court of record, the judges were ordered to make a record by the writ of Recordari facias and send it up to Westminster.

By these writs the King's Court supervised the inferior local courts $(e)$.

The Inquest or Assize.-This was a method of procedure in the King's Court introduced in the reign of Henry II., by which the title to land was tried by an inquest of twelve vieini or neighbours, who gave their verdict from their personal knowledge of the facts. There were several methods of proceeding by inquest or assize.

(1) The Graid Assize.-If any action for property in land was brought in the feudal court, the tenant might have the action removed into the King's Court. The title was then tried by the vicini or neighbours, and the tenant was said to put himself on Grand Assize. This method was found to be tedious, therefore in 1166 the petty assize of novel disseisin was instituted.

(2) Petty Assize of Novel Disseisin, 1166.-If A were not out of possession, by this assize his remedy was by

(e) For examples of the various writs see Holdsworth, H. E. L., 424 et seq. 
royal writ, and a jury of vicini was summoned to decide the question of fact, whether the disseisin was wrongful. This possession, as opposed to property, was protected, and that by the king's writ independently of the lord's jurisdiction. This assize, however, did not help the heir of the person originally disseised or put him into possession, and it did not lie against the heir of the disseisor, therefore was instituted-

(3) The Assize of Mort d'Ancestre, which put the heir into possession.

(4) The Assize of Darrein Presentment.-By this assize the title to advorsons was decided; a jury was summoned under the king's writ to determine who presented last, and the right to the next turn depender on their decision.

(5) The Assize Utrum. - This was to decide whether land was lay or held in frankalinoigne, as the Church was entitled to hold pleas of land given in elymoscne (i.e. in alms) $(f)$.

In all these assizes the procedure was the same; the plaintiff got the ling's writ directing an inquiry and the impanelling of twelve men to form a jury, who gave their verdict from a linowledge of the facts. The method of proceeding by assize seems to have remained in use until the abolition of real actions in $1834(g)$.

Procedure under the Normans.

(1) Civil.-The AngloSaxon mode of proof were ordeal, compurgation, witnesses, and charters, but of these ordeal does not seem to have been used in civil cases, and compurgation disappeared before the system of inquest or assize introduced by Henry II. The Normans introduced battle, and in the case of a writ of right for land the defendant might either choose battle or inquest $(h)$. If lie chose battle, it was fought out by champions and not by the parties themselves, as

(f) As to these assizes see Pol. \& Mait., i. 123-129; Glanvil, ii. 6 et seq. ; Holdsworth, H. E. L. pp. 21, 150.

(g) 3 \& 4 Will. IV. c. 27 , s. 36.

(h) Reeves, H. E. I., i. 185. 
in criminal cases. It first the jury who took part in the inquest were composed of the vicini, ni twelve men of the neighbourhood, who spoke from their linowledge of the facts, and trial by evidence as we now understand it does not appear to have come into use until about the reign of Henry VI. The presence of two hundredors was required upon the inquest, but this was rendered unnecessary by a statute passed in the reign of Anne (i). The parties themselves were first rendered competent witnesses in $1851(k)$.

(2) Criminal.-The Anglo-Saxon mode of trial in criminal accusations was either by ordeal, or by oath and compurgation after presentment or accusation by the grand jury under the system of frankpledge. The Normans introduced battle, and this was incident to the form of private accusation known as appeal, which might be pursued either in Parliament or in the King's Court.

Compurgation did not last long in criminal cases after the Conquest, and ordeal was abolished by the Lateran Council in $1215(l)$. After ordeal and compurgation had gone, no means remained to test the truth of the accusation of the grand jury, and this seems to have led eventually to the introduction of the petty jury. After the abolition of ordeal it would seem, then, that accusation by a grand jury was equivalent to conviction, though in the case of a private accusation by appeal, battle could be resorted to.

\section{Judicial Institutions in the Reign of Edward I.}

Edward I. has been called "the English Justinian," because in his reign the judicial institutions of the country became settled upon a basis which remained unaltered in the main until the modern changes brought about by the Judicature Acts, 1873 to 1902. The term, however, is somewhat misleading, for Justinian merely codified the already existing law, as did Alfred the Great, whilst

(i) 4 \& 5 Anne, c. 16 .

(k) $14 \& 15$ Vict. c. 99.

(l) See Pol. \& Mait., ii. 597. 
Edward I. really altered the already existing institutions, and settled them upon a new and permanent basis. From the Curia Regis, as understood in the sense of the King's Court or King's Council, had now separated definitely the courts of the Exchequer, the Common Pleas, and the King's Bench, whilst the King's Council, which had become a body distinct from the Commune Concilium, or Parliament, continued to exercise certain original judicial functions, principally it seems at this epoch in connection with the issue of new writs, for which no precedent existed in the Chancery or Exchequer, and for which the consent of the council had to be obtained. In the residuary or supervisory jurisdiction still appertaining to the council can be traced the origin of the present judicial functions exercised by the Privy Council. A short consideration of the various courts in order as they existed in the reign of Edward $I$. will serve to show how nearly the judicial system approached to that wihch obtained before the passing of the Judicature Acts.

The Common Pleas.-This court sat at Westminster since the confirmation of Magna Carta by Henry III. It heard causes between subject and subject not amounting to a brcach of the king's peace, and its records were called de Banco rolls ( $m$ ).

The King's Bench.-This court continued to follow the king, and its records were therefore called Coram Rege rolls $(n)$. Later on it became fixed, like the Common Pleas, at Westminster. It was constituted of a chief justice and three puisne judges, and originally its jurisdiction was confined to crimes amounting to a breach of the king's peace (infractio pacis regis), and to matters of which the other courts did not take cognizance. It soon, however, began to encroach upon the jurisdiction of the Common Pleas by a

(m) Pol. \& Mait., i. 177, 393.

(n) The Sovereign in person used to sit in the Aula Regis, or King's Court. in early times; James $I$. is said to have revived the practice, but the judges informed him that he could not deliver an opinion. Steph. Comm., iii. 357, $n$. 
method of procedure known as the Bill of Middlesex (o), which alleged trespass vi et armis, and therefore breach of the king's peace, against the defendant in Middlesex, and upon this charge he was brought before the court by the sheriff; once before the court, he could be tried for debt or upon any other charge. If the defendant was not in Middlesex, the writ of Latitat $(p)$ was issued to the sheriff of the county where he was to be found.

At first the defendant was retained in the custody of the court, but later on appearance or bail was sufficient. As the true cause of complaint was not alleged on the bill, a statute of Charles II. $(q)$ enacted that the true cause must be expressed, or the person arrested could give bail in a sum not greater than $£ 40$. To meet this an ac etiam clause was added to the writ which gave the real charge, and this continued until the Uniformity of Process Act (2 Will. IV. c. 39), which reduced all processes to the same form, but confirmed the jurisdiction of the King's Bench, in civil actions $(r)$. Besides its jurisdiction in criminal and civil actions, the King's Bench exercised jurisdiction over the other courts by means of the following writs:-

(1) Mandamus.-This is a prerogative writ issuing from the King's Bench to an inferior court, person, or corporation, directing them to do some act appertaining to their duty or office, as in the case of a delay of justice in an inferior court $(s)$. An order nisi is made, and on the return to the writ the other side may show cause why it should not issue. The penalty for disobedience to the writ is attachment and committal for contempt.

(2) The writ of Prohibition.-This also is a prerogative writ issuing from the King's Bench and returnable there. It is directed to the judge or parties in an action in any inferior court, commanding them to

(o) So called because the court sat in Middlesex : see Steph. Comm., iii. $358, n$.

(p) For examples of these writs, see Holdsworth, H. E. T. 438.

(q) 13 Car. II. st. 2, c. 2.

(r) The corresponding writ used by the Common Pleas was that of Quare Clausum Fregit, which contained a nec non clause corresponding to the ac etiam clause.

(s) See Bl. Comm., iii. 103. 
desist from further proceedings on the ground that the cause does not belong to the jurisdiction of that court $(t)$. Formerly the only means of appeal was under the statutum de consultatione (u), but now since the Judicature Acts appeal lies to the Court of Appeal, and thence to the House of Lords. The penalty for disobedience is attachment and committal for contempt.

(3) The writ of Certiorari-A prerogative writ issuing from Chancery or King's Bench to judges of any inferior court, commanding them to send the proceedings into the King's Bench. The subject obtains this writ at the discretion of the court chiefly on the following grounds: (i.) That an impartial trial cannot he had elsewhere; (ii.) that important. questions of law are involved; (iii.) that a special jury is required to try the case.

(4) The writ of Error issued from the King's Bench to an inferior court, some error of law or fact being alleged on the face of the pleadings. Error lay from the Common Pleas to the King's Bench, but the Exchequer refused to send their record on writ of elror to the King's Bench in the time of Edward III. A committee of the council was therefore formed to review errors in the Exchequer $(x)$, and finally it was enacted in 1830 that error on any judgment in the King's Bench, Common Pleas, or Exchequer was to go to the Court of Exchequer Chamber to be heard by the judges of the other two courts, and thence to the House of Lords (y). After the passing of the Judicature Act, 1873, appeal lay to the Appeal Court, and the writ no longer existed except in criminal cases, where there was some error in law apparent on the face of the record (z). In such a case it issued from the Crown

(t) B1. Comm. iii. 105.

(u) (1296) 24 Ed. I. For the writ of consultation see Holdsworth, H. E. L. 430.

(x) $31 \mathrm{Fd}$. III. st. 1, c. 12.

(y) 11 Geo. IV. and 1 Will. IV. c. 70.

(z) Judicature Act, 1873, s. 47. 
Office on the fiat of the attorney-general to the judge of some court of record, directing him to send the record to the proper court to be there inspected and reviewed and examined $(a)$.

The writ of error has now been finally abolished by the Criminal Appeal Act, 1907 (b).

The Exchequer.-This court originally attended only to revenue matters, which at this epoch were heard by the treasurer, who had taken the place of the justiciar, and barons of the Exchequer (c). Soon, however, the Exchequer developed a common law side, and trespassed upon the jurisdiction of the Common Pleas in cases of debt by means of the writ of Quominus, which proceeded under the fiction that $A$ being indebted to $B$, he was by that fact the less able to pay the king's debt $(d)$.

The Exchequer also developed an equitable jurisdiction, which was, however, taken away in 1842 (e).

The High Court of Parliament.--Parliament was now distinct from the King's Council, and continued to exercise judicial functions principally in connection with petitions.

The King's Council.-As we have seen, this body, now distinct from Parliament, exercised judicial functions principally in connection with the granting of new writs $(f)$ for which no precedent existed.

The Chancery.-The lord chancellor's power was at this epoch in its initiatory stage, and his functions were mainly secretarial. He had power to issue de cursu writs, or those for which a precedent already existed, but he could not

(a) As to the issue of these writs to any part of the King's dominions except Scotland, see Rex v. Cowle (1759) 2 Burr. 855.

(b) See s. 20.

(c) See Madox, Hist. Ex., ii. 26. Originally cases in the Exchequer were heard before the justiciar and chancellor; barons of the Exchequer were appointed temp. Hen. III.

(d) BI. Comm., iif. 278. For an example of the writ, see Holdsworth, H. E. L. 439.

(e) 5 Vict. c. 5.

(f) Writs for which a precedent already existed were termed de cursu writs. 
issue new writs without the leave of the King in Council, for new remedies would give rise to new rights, and this could only be effected with the sanction of the council. The chancellor's judicial authority was thus in its origin derived from the council, which at first seems to have regarded his rising power with some disfavour, for by the Provisions of Oxford, $1258(g)$, he was forbidden to issue new writs without the council's leave. Later on, by the Statute of Westminster the second (h), the clerks in Chancery were empowered to isue writs in consimili casu, or writs analogous to those already in use. This statute, however, they neglected to take advantage of, and eventually such causes as the common law courts could not take cognizance of, by reason of want of precedence for a writ, came under the chancellor's immediate jurisdiction, petitions being referred. to him directly.

The Local Courts.-The manorial and county or shire courts continued to exist at this period, but their jurisdiction was increasingly on the wane.

By the writ of Quo warranto Edward I. ealled upon the lords of manors to show title to their juriscliction, and where no grant or charter could be shown, they were forlbidden to exercise jurisdiction in the future.

The Circuit System.-The circuit system, inaugurated by Henry I. and improved upon by Henry II., continued to flourish at this period, and it seems probable that the justices in eyre, who went through the country at intervals inquiring into the administration of justice and other matters, but who also held pleas for the Crown, existed alongside with the commissioners of assize. In the reign of Edward I., however, there are traces of the growing importance of the latter, for the Statute of Westminster the second (i) enacted that the justices or commissioners of assize were to be appointed out of the ling's sworn justices, and to act with one or two discreet knights of the shire.

(g) Sce Stubbs' Sel. Chart., 380 .

(h) 13 Ed. I. st. 1, c. 24 .

(i) 13 Ed. I. st. 1, c. 30 . 
JUDICIAL INSTITUTIONS TO TIIE TIME OF EDWARD I. 235

By the same statute the commission of nisi prius was annexed to that of assize, and to these, fourteen years later, that of gaol delivery was also added $(k)$.

The circuit judges were still, however, subordinate to the King's Bench, and the writs of mandamus and error lay to them. This continued until the Judicature Act, 1873, when the assize courts were placed upon the same footing as courts of the High Courts of Justice.

(k) 27 Ed. I. st. 1, c. 4. The commissioners of assize eventually entirely superseded the old justices in eyre. 


\section{$(236)$}

Chapter II.

\section{JUDICIAL INSTITUTIONS FROM EDWARD I. TO THE JUDICATURE ACTS, 1873 TO 1910.}

\section{The High Court of Parliament as a Court of First Instance.}

WE have seen already that the great earls and barons would bring their suits in Parliament originally instead of in the local courts as being entitled to judicium parium, a term which occurs first in Magna Carta. Private subjects also could petition Parliament, and new writs, and therefore new remedies, were sanctioned by this body or the King's Council. Further, cases of treason were often preferred in Parliament at the suit of the Crown, and it seems to have been the practice for subjects to bring criminal accusations in Parliament in the reign of Richard II., the procedure being by way of criminal appeal and battle. A statute of Henry IV. (a) (1399) put an end to criminal appeals in Parliament, but a commoner might still appeal a peer $(b)$. In 1663 the Lords resolved that a peer could not appeal another of treason $(c)$, and later impeachment, attainder, and indictment took the place of this procedure. Eventually appeal in criminal cases was entirely abolished in 1819 . The functions of Parliament as a court of first instance then come to (1) the commons' right of impeachment; (2) procedure by attainder; (3) the functions now vested in the House of Lords of trying peers accused of treason or felony; (4) the functions of Parliament as a court of first instance in civil actions.

(a) 1 Hen. IV. c. 14.

(b) In 1626 the Earl of Bristol appealed the Earl of Conway and the Duke of Buckingham on various charges (see 2 St. Tri. 1267).

(c) 6 St. Tri. 317 . 
The Commons' Right of Impeachment.-Impeachment first came into use towards the end of the reign of Edward III., the first real instance occurring in $1376(d)$. Towards the end of the reign of Richard Il. it became common, and was generally used by the Commons as a means of bringing ministers of the Crown to account for conduct opposed to the welfare of the State. From 1450 until the reign of James I. attainder seems to have taken the place of impeachment, and there is no real case of the latter during that period.

In Danby's Case (1679) the principle was established that a minister cannot plead the king's commands in justification of an unconstitutional act. In 1685 it was decided by the Lords that impeachment was put an end to by the determination of the session (e), and Danby's impeachment came to an end in consequence. In Warren Hastings' Case a special Act was passed, providing that the impeachment was not put an end to by prorogation or dissolution $(f)$, and a similar Act was passed in Melville's Case (1805 (g).

By the Act of Settlement, 1700, it was provided that no pardon under the Great Seal should be pleadable to an impeachment by the Commons in Parliament, though the Crown may still pardon offenders after conviction, and thus in effect shield its ministers from the results of impeachment should such a course be necessary, which is extremely improbable at the present day.

In Fitzharris' Case (1681) ( $h$ ), the Lords refused to try the accused on the ground that he was a commoner. The Commons thereupon passed a resolution to the effect that " it was their undoubted right to impeach any peer or commoner for treason or any other crime or misdemeanour" (i), and in $1689 \mathrm{Sir}$ Adam Blair and four other commoners were impeached. Since then the right of the Commons to impeach a commoner has not been disputed $(k)$.

(d) Pike's Const. Hist. of House of Lords, p. 206.

(e) Journ. H. of Lords, xiv. p. 11.

(f) 26 Geo. III. c. 96.

(g) 45 Geo. III. c. 125 .

(h) 8 St. Tri. 231.

(i) Journ. H. of Com., ix. 711.

(k) Pike's Const. Hist. House of Lords, 232. 
Procedure on Impeachment.-Impeachment is the prosecution of an offender by the Commons before the Lords. The Commons appear by managers, who present articles of impeachment. The Lords act as judges, and are presided over, in the case of a peer by the lord high steward, and in the case of a commoner by the lord chancellor.

The Lords pronounce the accused guilty or not guilty, but cannot pass judgment unless the Commons demand it.

Attainder.-Attainder was really invented as a means of proceeding against a person when no real charge could be substantiated, as in Strafford's Case (1640). It took the place of impeachment to a large extent between 1450 and $1621(l)$.

It is an Act of Parliament condemning a man to death; it passes through all the stages of a regular bill, and receives the royal assent. It is subject to the rule that bills affecting the rights of peers commence in the Lords $(m)$.

It originated in very early times, and was frequently made use of during the Wars of the Roses and under the Tudors. It was forbidden by the $1 \& 2$ Phil. \& Mary, c. 10 , but revived by the Stuarts.

The last case of attainder was that of Sir John Fenwick, 1696.

Formerly attainder entailed corruption of blood, so that the heir could not inherit title or lands through the attainted person; attainder or corruption of blood (except on outlawry) has now, however, been abolished in all cases by the Forfeiture Act, $1870(n)$.

\section{The Peers' Right of Trial by the House of Lords in Cases} of Treason and Felony.-The expression of right of trial by one's peers occur's first in Magna Carta, judicium parium, and since then peers have always claimed their right to be tried in cases of felony by their own equals, because it would seem that, as forfeiture resulted on conviction, they would not submit to the jurisdiction of their inferiors in

(l) Pike's Const. Hist. House of Lords, 228.

(m) $\mathrm{Ib} .335$.

(n) $33 \& 34$ Vict. c. 23 , s. 1. 
estate. The spiritual peers never claimed the right to be tried as peers, relying on their right to be tried in their own courts by elaiming Benefit of Clergy. Cranmer in 1553 put himself upon a jury and did not claim trial by the peers, and since then the right has never been put forward $(o)$. Further, spiritual peers are not entitled to give their vote (on the trial of a peer) on the final question of guilty or not guilty, not being capable of passing a blood sentence, but they may sit and vote on preliminary issues. Any peer of England, Ireland, and Wales, and any peeress by birth or marriage $(p)$, is entitled to trial by the peers, and the privilege cannot be waived.

The House is presided over by the lord high steward appointed for this purpose under the Great Seal. The peers are the jury, and the verdict of the majority decides the question. The lord high steward acts as judge. The procedure is this: The peer having been indicted in the ordinary way of treason or felony, the case is brought into the House of Lords on writ of certiorari, as in Earl Russell's Case (1901) $(q)$. When the feudal tenures went in (16 Car. II.) this right of the peers would have probably gone also, but it was preserved in all statutes dealing with treason or felony.

'The Court of the Lord High Steward.-If Parliament is not sitting, the peer is tried by the Court of the Lord High Steward, who is a peer appointed to preside under the Great Seal. This court dates from the reign of Henry IV., and originally the lord high steward could summon any twelve or more peers and thus pack the court. But by $7 \& 8$ Will. III. c. 3 , in cases of treason or misprision of treason the lord high steward must summon all peers twenty days before the trial, and they are entitled to sit and vote. The lord high steward acts as judge and settles all points of law, the peers acting as the jury.

\section{Parliament as a Court of First Instance in Civil Actions.}

-The last occasion in which an ordinary civil action was

(o) Pike's Const. Hist. House of Lords, 221.

(p) Co. Inst. ii. c. 29.

(q) [1901] A. C. 446. Earl Russell was tried for bigamy, and this is the last instance of trial of a peer by Parliament. 
brought in Parliament was the case of Skinner v. East India Company (1666-1670) ( $r$ ). Skinner petitioned the King, complaining that the Company had seized his ship and committed other injuries. The case, after having been referred to a committee who reported favourably to the petitioner, was heard by the Lords, who awarded Skinner $£ 5,000$ damages. The Company then petitioned the Commons, who declared the trial by the Lords illegal. A dispute between the two Houses ensued, and Parliament was prorogued. The matter was finally settled by the King's intervention in 1670, and the records of the case erased by both Houses. Since then no attempt has been made to bring a civil action in Parliament as a court of first instance.

\section{The Appellate Jurisdiction of Parliament.}

The House of Lords. - In the reign of Edward I., as we have seen, error lay from the Common Pleas to the King's Bench, but the Exchequer refused to send error there, and in the reign of Edward III. (s) the first Court of Exchequer Chamber (which was really a committee of the King's Council) was formed to review errors in the Exchequer.

There was still, however, an ultimate Court of Appeal superior to the Court of Exchequer Chamber, namely, the King in Council in Parliament, and when the council split off definitely from Parliament, as it did about the reign of Richard II., this appellate jurisdiction of the King in Council in Parliament became vested in the House of Lords. This body was recognized as the ultimate Court of Appeal, probably by the time of Henry IV. ( $t$ ). In 1830 it was statutorily provided that error from the King's Bench, Common Pleas, and Exchequer should lay to the Court of Exchequer Chamber, and thence to the House of Lords $(u)$.

Thus the House of Lords takes the place of the Curia Regis with regard to its appellate jurisdiction.

The jurisdiction of the House of Lords in Chancery appeals came later, the first instance being Sir John Bour-

(r) (1666) 6 St. Tri. 710.

(s) 31 Ed. III. st. 1, c. 12.

(t) See Carter, H. E. I., I. 97.

(u) 11 Geo. IV. and 1 Will. IV. c. 70. 
chier's Case in 1621. In the reign of Charles II., 1675, the Commons disputed this jurisdiction, but since then the House of Lords has exercised it without interruption $(x)$.

\section{The King's C'ouncil.}

We have now traced the functions of Parliament as a court of first instance 1 ntil they have arrived at the stage in which we now find them. The functions of the King's Council, Curia Regis, in so far as it claimed the right to supervise the judgments of the King's Bench, Common Pleas, and Exchequer, have also been traced and found to resolve themselves into the system which obtained immediately before the passing of the Judicature Acts, viz. appeal from King's Bench, Common Pleas, and Exchequer, to the Court of Exchequer Chamber (which was in its inception a committee of the council), and thence to the House of Lords. It remains to trace the developments which occurred with regard to the remaining portions of the original and appellate jurisdiction of the King in Council as exercising what remained of the old right of administering the residuary royal justice. The original jurisdiction of the council will be found to resolve itself eventually into the criminal jurisdiction exercised by the Star Chamber, the civil jurisdiction of the Court of Requests, and the jurisdiction of the Court of Chancery, of which, under the modern system, the Court of Chancery alone remains, whilst the appellate jurisdiction of the council, formerly exercised in ecclesiastical and admiralty matters by the Court of Delegates $(y)$, finally came to be vested in the judicial committee of the Privy Council with regard to ecclesiastical mattcrs, and in the Court of Appeal with regard to admiralty matters.

The Procedure of the Council.-In civil matters the jurisdiction of the council was generally brought into play

(x) Pike's Const. Hist. House of Lords, 298.

(y) Previously to the establishment of the Court of Delegates (25 Hen. VIIT. c. 19) ecclesiastical appeals were heard by the King in Council, the first statute of Præmunire (27 Ed. III. st. 1, c. 1) having forbidden appeals to the Papal Court, and directed them to be brought before the King in Council.

C.L.E. 
upon petition for redress for wrongs where the ordinary course of justice failed to supply an adequate remedy. These petitions the council answered either by summoning the offender before it by writ of subpona and administering justice as seemed fit, or by the issue of special commissioners of Oyer and Terminer.

The methods of procedure used by the council may be enumerated as follows:-

(1) Writ of Scire facias (z).

(2) Commissions of Oyer and Terminer.

(3) Writ of subpena.

(4) Præmunire Writs, or Quibusdam certis de causis (since the first Statute of Præmunire, $27 \mathrm{Ed}$. III. st. 1, c. 1).

(5) Bail (first found temp. Richard II.).

(6) Writ of $\mathrm{Ne}$ exeat regno (formerly used to restrain fraudulent debtors from absconding).

(7) Commissions of Rebellion, issued to the sheriff and justices, directing them to arrest the wrong-doer in cases of disobedience to the council's orders.

The council's methods of procedure were very unpopular, being considered, perhaps justly, uncertain and oppressive; and many instances of petitions against the various writs are to be found during the fourteenth century $(a)$, and various statutes were passed to remedy abuses $(b)$. Eventually the original jurisdiction of the council was abolished in $1640(c)$.

The Court of Star Chamber.-The term Star Chamber (Camera Stellata or Chambre des Estoycrs) occurs first about 1348, and refers to the decoration of a room at Westminster Palace in which meetings of the council were frequently held to exercise the criminal jurisdiction of the King in Council. These sittings of the council to exercise criminal jurisdiction became known as the Court of Star Chamber, and in the third year of Henry VII. the Star

(z) Sce Carter, H. E. L. I. 116.

(a) See the instances cited by Holdsworth. H. E. L. $268 \mathrm{et} \mathrm{seq}$.

(b) See 2 Ed. III. c. 8; 5 Ed. III. c. 9 ; 25 Ed. III. st. 5, c. 4.

(c) 16 Car. I. c. 10 . 
Chamber Act (d) was passed, which did not ereate, but remodelled the constitution of the court. As constituted by this Act, the court consisted of the chancellor, treasurer. lieeper of the privy seal, one bishop, one temporal lord, and the two chief justices, or two other justices in their stead. 'The lord president of the council was added in the reign of Henry VIII. (e).

The court sat in the Star Chamber, and took over most of the criminal duties of the council with regard to such matters as "murders, robberies, perjuries, and unsureties of all men living" $(f)$. The chief offences tried by the court were perjury, forgery, maintenance, riot, fraud, libel, and conspiracy, and generally such offences as the common law did not take cognizance of. But when the Star Chamber was abolished in the reign of Charles I., the Act $(g)$ recited that as the offences triable therein were then all known to the common law, there was no necessity for the court. The Star Chamber also endeavoured to excreise supervision over juries, as in Sir Nicholas Throckmorton's Case (1554). Sir Nicholas Throckmorton was tried in the Court of Queen's Bench for high treason, but was acquitted by the jury. The jury were then committed to prison, and eight of them were eventually brought before the Star Chamber and heavily fined $(h)$. The independence of juries was, however, finally established in Bushell's Case (1670) (i).

The court was especially severe against libellers, and in 1623 William Prynn, on account of his book, Histrio Mastix, was sentenced by the Star Chamber to be disbarred and deprived of his university degrees, to stand in the pillory and have his ears cut off, to be fined $£ 5,000$, and to be perpetually imprisoned without books, ink, or paper $(j)$.

Thus on account of the severity of its sentences, the arbitrary nature of its proceedings, and the fact that it kept no records, the court was justly held in national odium.

(d) 3 Hen. VII. c. 1.

(e) 21 Hen. VIII. c. 20.

(f) 3 Hen. VII. c. 1 .

(g) 16 Car. I. c. 10.

(h) Steph., Hist. Crim. Law, i. 326 et seq.

(i) (1670) 6 St. Tri. 999.

(j) (1623) 3 St. Tri. 562. 
It was finally abolished, together with certain other courts and all jurisdiction of the King in Council, in the year $1640(k)$.

The Court of Requests.-This court was another branch of the King's Council, and took orer some portion of its civil jurisdiction, hearing complaints of poor men and of persons of the king's household. Its jurisdiction was largely equitable, and the court was extremely popular as affording a cheap and easy remedy for small suits not sufficiently important to be brought in the Court of Chancery itself. In Elizabeth's reign it came into collision with the courts of common law, who considered its jurisdiction illegal, and endeavoured to restrain its exercise by the writs of prohibition and habcas corpus.

In 1640 the original jurisdiction of the council was abolished $(l)$; the Court of Requests, however, remained until the outbreak of the civil war in 1642, when it died a natural death. After the Restoration Charles II. did not attempt to restore it.

The Court of Chancery. Rise of Chancery.-Is we have seen, the Chancellor derived his authority originally from the lords of the council, and at first he could only act judicially with the council's authority, his judicial duties being mainly secretarial $(m)$, and connected with the issue of writs. In early times he was generally an ecclesiastic $(n)$, and it has been said of him that he "kept the King's seal and the King's soul." By the provisions of Oxford, 1258, he was prevented from issuing new writs without the council's leave (o), but by the Statute of Westminster the Second ( $m$ ) the clerks in Chancery were empowered to issue writs in consimili casu. This it appears they neglected to do, so that eventually such causes as the courts of common

(k) 16 Car. I. c. 10 .

(l) 16 Car. I. c. 10.

(m) See Reeves, H. E. I. i. 96.

(n) Nicholas Bacon, in the reign of Elizabeth (1558-1579), was the first professional lawyer to be appointed.

(o) See Stubbs' Sel. Chart., 393, 395.

(b) 13 Ed. I. c. 24. 
law would not recognizc came under the Chancellor's jurisdiction.

Jurisdiction.-The jurisdiction thus acquired by the Chancellor extended to such matters as " uses," which he enforced as being binding on the eonscience, and which the other courts would not recognize $(q)$-fraud, force, unfair or inequitable transactions, covenants, agreenents, and declarations of trust. To the Court of Chancery is also due the doctrine of specific performance of contracts.

Procedure.-The Chancellor made use of the following writs: (1) The writ of subpana, by which a person was ordered to attend before the Chancellor. In case of disobedience the commission of rebellion was issued $(r) ;(2)$ the Premunive writ, which commenced with the words, quibusdam certis de causis; (3) writ of Scirc facias, to repeal letters patent, or upon recognizances, directed to the sheriff bidding him cause the defendant to appear $(s) ;(4)$ writ of Corpins cum cansa, used in cases of a complaint of unlawful imprisonment. The chancellor could not, like the common law courts, issue writs of execution, but acted in all cases in personam; that is to say, in cases of disobedience to a decree, the delinquent was punished by attachment and committal as for a contempt, until he submitted to the decree. The commission of sequcstration, by which a person's lands were sequestrated, was sometimes used, and was the nearest approach to the common law writ of execution.

The system of administering intcroyatories, or making the defendant answer questions on oath, was also due to Chancery, whilst at common law the parties themselves were not even competent witnesses until $1851(t)$. The use of the injunction was also due to Chancery, and this seems to have first been introduced about the reign of Henry VI. It was principally in connection with the use of injunctions that the courts of common liw came into collision with the

(q) Uses of land were introduced about the end of the reign of Ed. III. See Steph., Comm., iii. 350.

(r) The writ of subpona is said to have been introdnced by John Waltham, chancellor to Richard II. See Steph., Comnı., iii. 35.

(s) See Holdsworth, H. E. L. 227, 427.

(t) 14 \& 15 Vict. c. 99. 
Chancery, and it was specially used to prevent persons taking advantage of their strict common law rights in matters connected with mortgages and trusts, in which the Court of Chancery eventually acquired a monopoly. The method adopted by Chancery was to issue an injunction restraining a person from bringing a suit at common law, or to prevent his executing a judgment given in the common law courts $(u)$, and in 1616 occurred the famous battle between Lord Chancellor Ellesmere and Lord Chief Justice Coke. Lord Ellesmere issued an injunction to prevent a judgment obtained before Lord Coke by gross fraud from being executed. The parties, solicitors, counsel, and even a master in Chancery were then indicted by Lord Coke for having questioned his judgment. The king was called in to settle the dispute, and, having taken the advice of the principal law officers, supported the chancellor on the ground, however, of prerogative $(v)$. Since then the right of Chancery to issue an injunction has not been questioned.

Equitable System.-Equitable rules and doctrines were at first ill defined and without system; they varied, according to Selden, " with the length of the chancellor's foot." Gradually rules and precedents grew up and an equitable system was evolved, such men as Lord Bacon (who succeeded Lord Fllesmere) and Sir Heneage Finch, 1673 (afterwards Lord Nottingham), doing much to further that end, and in more modern times Lord Hardwicke (1737-1757) and Lord Eldon (1801-1820), until at the present day the rules and principles of equity are almost as well ascertained as those of the common law itself.

Composition of the Court.-Originally the lord chancellor sat sometimes with the lords of the council, sometimes alone, and later on he was assisted by the master of the rolls, whose judgments, however, were at one time subject to be discharged or altered by the lord chancellor $(w)$. A vice-chancellor was subsequently appointed $(x)$, and later on, in 1841, two additional vice-chancellors $(y)$, on the

(u) See Courtney v. Glanvil (1615) Cro. Jac. 343.

(v) See Steph., Comm., iii. 353.

(w) See 3 Geo. II. c. 30 , and $3 \& 4$ Will. IV. c. 94. s. 24.

(x) 53 Geo. III. c. 24.

(y) 5 Vict. c. 5, s. 19. 
equity business of the Exchequer being transferred to the Court of Chancery. In 1851 (z) two lords justices of appeal in Chaneery were created, who, with the lord chancellor, formed a Court of Appeal in Chancery, from which appeal lay to the House of Lords, and this system prevailed until the passing of the Judicature Aets.

The Appellate Jurisdiction of the Council.-After the establishment of the Court of Exehequer Chamber to review error's in the courts of common law, and the recognition of the House of Lords as the ultimate court of appeal from the Exchequer Chamber, there still remained to the council appellate jurisdiction in ecelesiastical, admiralty and lunacy matters, and in appeals from English courts abroad.

This jurisdiction, as to eeclesiastieal and admiralty eauses, went to the Court of Delegates on the formation of that court by Henry VIII. in 1534 (a). The Court of Delegates was abolished in 1832 , and its jurisdiction restored to the King in Couneil (b), and in the following year to the judieial eommittee of the Privy Council (c). Finally, by the Judicature Act of 1873 , so much of the jurisdiction of the Privy Council as related to admiralty and lunaey matters was handed over to the Court of Appeal $(d)$.

The judieial committee of the Privy Council therefore only retains so much of the former appellate jurisdiction of the King in Couneil as relates to ecclesiastical matters and appeals from English eourts abroad.

\section{The Court of Admirulty.}

Origin of the Court.-The origin of the Court of Admiralty is obseure, but the term admiral seens first to have been used in the year 1300, when one Gervase Alard was made admiral of the fleet and of the Cinque Ports, and in 1360) John Pavely was made captain of the fleet with power to hold pleas $(e)$.

(z) 14 \& 15 Vict. c. 83.

(a) 25 Hen. VIII. c. 19.

(b) 2 \& 3 Will. IV. c. 92.

(c) $3 \& 4$ Will. IV. c. 41.

(d) Julicature Act, 1873, s. 16 .

(e) See Carter, H. E. I. I. 167, 169. 
At first one or more admirals were appointed, later on a single lord high admiral $(f)$, his duties with regard to particular districts being delegated to deputies or viceadmirals $(g)$. In addition to the admiral's jurisdiction there were also several seaport towns which had courts of the scaport with maritime jurisdiction.

The history of the Admiralty Court is closely connected with its jurisdiction in civil and criminal matters, so that these may be considered separately.

Criminal Jurisdiction. - A statute of Richard II. (h) gave the admiral jurisdiction in cases of death and mayhem occurring in "great ships" being in the mouths of "great rivers." On the other hand, certain seaport towns were given jurisdiction to the exclusion of the admiral. The admiral's court proceeded without a jury and according to the methods of the civil law. It was therefore enacted by a statute of Henry VIII. (28 Hen. VIII. c. 15) that all felonies, murders, robberies, etc., committed on the sea, $O{ }^{2}$ in any haven, river, or creek (i), should be tried under the king's commission by the admirals and " three or four other substantial persons", (who were generally two common law judges), "according to the ordinary course of the common law," that is to say, by a petty jury after indictment by a grand jury. Various statutes regulating the lord high admiral's jurisdiction continued to be passed (i), and eventually in 1833 the Central Criminal Court was empowered to try all offences falling within the admiralty jurisdiction $\left(k_{i}\right)$, and in 1844 commissioners of oyer and termincr and of gaol delivcry were invested with all the powers of the commissioners under the Act of Henry VIII.

Thus the criminal jurisdiction of the admiral has passed to the ordinary courts. The provisions of the Territorial

(f) There seems to be some doubt whether the first lord high admiral was the Earl of Arundel and Surrey, temp. Richard II., 1386, or Sir Thomas Beaufort, 1408.

(g) Steph., Hist. Crin. Law, ii. 17.

(h) 15 Ric. II. c. 3.

(i) This Act is still the main authority for the extent of the aduiraity jurisdiction : and see Rex v. Bruce (1812) 2 Leach, C. C. 1093.

(j) See 11 \& 12 Will. III. c. 3 ; 39 Geo. III. c. $37 ; 46$ Geo. III. c. 54; 7 Geo. IV. c. 38.

(k) 3 \& 4 Will. IV. c. 36. 
Waters Jurisdiction Act, 1878 (40\& 41 Viet. e. 7:3), passed in consequence of the decision in Reg. v. Keyn (l), may be noted, under which an offence committed by a foreigner either on a British or foreign ship within one marine league (three miles) of the eanst, falls within the admiral's jurisdiction, provided a Secretary of State grants a cortificate to that effect.

It may also be noted that the part of the coast between high and low water marks falls within the jurisdietion of the common law courts when the tide is out, and of the admiralty when the tide is in $(m)$.

The Civil Jurisdiction.-A statute of Henry VIII. gave the admiralty eourts jurisdiction in contracts made abroarl, charterparties, insurance, general average, freights, etc., but the courts of common law came into conflict with the courts of admiralty and eneroached mon their jurisdiction. Further, the Arlmiralty Court was not a court of reeord, and unless the transaction actually took place at sea, prohibition lay to it from the common law courts. For this reason the Admiralty Court fell into disfavour with merclunts; therefore the Admiralty Court lets of 1840, 1854, and 1861 (n) were passed, giving the High Court of Admiralty full jurisdiction over all maritime matters, and its proceedings could be either in rem or in personam. The High Court of Admiralty, as constituted by these Aets, was precided over by a judge, who acted as the deputy of the lord ligh admiral, and who was the same person as the judge of the Court of Probate (o).

By the County Courts Acts, 1868 and 1919 (p), jurisdiction in smaller cases was conferred on certain of the county courts.

Finally, by the Judicature Act of 1873 , the jurisiliction of the Admiralty Court was merged in that of the High Court of Justice and has been extended by a reeent Act $(q)$.

(l) (1876) L. R. 2 Ex. D. 63.

(m) Steph., Hist. Crim. Lam, ii. 26.

(n) $2 \& 3$ Vict. ce. 65,$66 ; 17 \& 18$ Vict. cc. $78,104: 24$ \& 25 Vict. c. 10 .

(o) Established by $20 \& 21$ Vict. c 85.

(p) 31 \& 32 Vict. c. $71 ; 9$ \& 10 Geo. V. c. 73, s. 13.

(q) Administration of Justice Act, 1920, s. 5 . 
Admiralty Appeals.-In the fifteenth century admiralty appeals went to delegates or commissioners appointed by the Crown, and in $1534(r)$ the Court of Delegates was formed to hear admiralty and ecclesiastical appeals.

The same Act which destroyed the jurisdiction of the Court of Delegates in ecclesiastical causes destroyed it also in admiralty causes, namely, the $2 \& 3$ Will. IV. c. 92, by which its jurisdiction was transferred to the King in Council; and finally, by 3 \& 4 Will. IV. c. 41, jurisdiction both in ecclesiastical and admiralty appeals was transferred to the judicial committee of the Privy Council. By the Judicature Act of 1873 the Court of Admiralty was merged in the Probate, Divorce, and Admiralty Division of the High Court of Justice. Appeal lies to the Court of Appeal and thence to the House of Lords.

The Colonial Admiralty Courts.-These were established, under the name of Vice-Admiralty Courts, to hear causes arising in the colonies, and in 1832 , by the 2 \& 3 Will. IV. c. 51, their jurisdiction was defined as being such matters as fell under the cognizance of the Admiralty Court, viz. collision, salvage, pilotage, bottomry, etc. Appeal lay to the Privy Council. By the Vice-Admiralty Court Act, 1863 (26 Vict. c. 24), governor's of colonies were made ex-officio vice-admirals, and colonial chief justices were made $e x$ officio judges of the court. The Colonial Courts of Admiralty Act, 1890 (53\&54 Vict. c. 27), provided that all courts of law in British possessions having unlimited civil jurisdiction, should be courts of admiralty, with jurisdiction equal to that of the High Court of Justice in England. Appeal lies to the Appeal Court of the colony and thence to the Privy Council.

\section{The Ecclesiastical C'ourts.}

Ecclesiastical Law.- The ecclesiastical law in use after the Conquest, and which became known as the corpus juris canonici, was a body of Roman ecclesiastical law, appertaining to such matters as the Church had jurisdiction over. 
This corpus juris canonici was made up of certain collections made by rarious popes and known as Gratian's Decree. Gregory's Decretals, the Sixth Decretal (by Boniface), the Clementine Constitutions, and the Extravagants of John and his successors.

In addition to this corpus juris canonici, there also came into use a kind of national canon law composer of (a) Legatine Constitutions, enacted in national synods under the cardinals Otho and Othobon in the reign of Henry III.; (b) Provincial Constitutions, enacted by various archbishops in provincial synods $(s)$.

At the time of the Reformation it was enacted that a review was to be made of the canon law, and that until then all canons then in use, and not repugnant to the law of the land, should remain in force $(t)$. No such review was in fact ever made, so that the only canon law now binding on clergy and laity, apart from that which has since been expressly sanctioned by statute, would seem only to be such as falls under the above heading, viz. such canons as were in use before the passing of the $25 \mathrm{Hen}$. VIII. c. 9, and are not repugnant to the law of the land.

Separation of the Civil and Ecclesiastical Courts.-As we have seen, the Conqueror separated the civil and ecclesiastical courts. Henry I. restored the union; but this was unpopular with the popish clergy, who imposed an oath on his successor Stephen that ceclesiastical persons and causes should only be subject to ecclesiastical jurisdiction. Since then the separation has been maintained undisturbed, the ecclesiastical courts conforming to the Roman or civil law, the temporal courts to the English law. To this separation is due the subsequent derelopment of the ecclesiastical judicial system.

The Ecclesiastical System.--The ecclesiastical system was this: The kingdom was divided into two provinces, Canterbury and York, the provinces into dioceses, dioceses into archdeaconries, and the latter into rural deaneries:

(s) Steph., Comm., i. 43, 44.

(t) 25 Hen. VIII. c. 9. 
besides these, there were peculiars, consisting of such parishes in the two provinces as did not come within the jurisdiction of any bishop (or ordinary).

The ecclesiastical courts (u) correspond to these divisions, and were as follows:-

(1) The Provincial Courts of Canterbury and York.These are the Court of Arches in Canterbury, and the Court of Chancery in Sork, presided over formerly by the officials principal of the archbishops in both provinces. By the Public Worship Regulation Act, 1874, the archbishops may appoint (subject to the Crown's approval) a barrister of ten years' standing, or a judge of a superior court, to be a judge of the provincial courts of Canterbury and York. This judge is ex-officio judge of the Court of Arches and of the Chancery Court in York. The jurisdiction of the provincial courts is chiefly on appeal from the lower courts. But where the lower courts have waived their rights, by what are known as letters of request, original suits may be brought there in matters concerning the fabric, ormaments, or furniture of any church, or in respect of the burial ground, or concerning ritual $(x)$. Appeal lies to the King in Council, that is, since 1833, to the judicial committee of the Privy Council $(y)$.

(2) The Prerogative Courts of Canterbury and York.When the ecclesiastics obtained jurisdiction over wills and administrations in the twelfth and thirteenth centuries, this jurisdiction was exercised by the ordinary (or bishop) of the diocese. But if the deceased had bona notabilia, that is goods to the value of $100 \mathrm{~s}$. in two provinces, to save the expense of separate probates the will was proved before the archbishop in the prerogative court of the province.

In 1857 the jurisdiction in wills and administration was taken from the ecclesiastical courts and handed over to the Court of Probate $(z)$, and by the Judicature Act, 1873 , to the Probate Divorce and Admiralty Dirision of the High Court of Justice.

(u) The ecclesiastical courts were abolished with the Court of High Commission in 1640 (16 Car. I. c. 11), but revived again after the Restoration (13 Car. II. st. 1, c. 12).

(x) Public Worship Regulation Act, 1874.

(y) $3 \& 4$ Will. IV. c. 41.

(z) $20 \& 21$ Vict. c. 77. 
In addition to the Court of Arches in Canterbury and the Court of Chancery in York, there are in Canterbury the court of the Commissary, which is the ordinary consistory court for the archbishop's diocese; the Court of the VicarGeneral, before which the confirmation of bishops takes place (a); and the Court of the Master of the Faculties, which attends to matters connected with public notaries, who are still appointed by the Archbishop of Canterbury by faculty $(b)$.

In York there is also the ordinary consistory or diocesan court of the archbishop. In both provinces there were formerly Courts of Audience, where the archbishop himself presided, but these have fallen into disuse (c).

(3) The Diocesan or Consistory Conrt of the Bishop.This court was presided over by the bishop's chancellor, who must be, since 1603 , a bachelor of laws or a master of arts. Originally the court thus constituted had cognizance of all ecclesiastical causes arising within the diucese. Jurisdiction over offending clerks was taken from the chancellor ii 1840, and handed orer to the lishop sitting with five assessors. It was, however, restored to the chancellor by the Church Discipline Act, 1892 (d) (with regard to offences falling within the Act), which provided that complaints on the ground of immorality against the clergy should be held in the consistory court before the chancellor, and five assessors if either party desire. Appeal may be, at the option of the appellant, to the provincial court or to the King in Council, but either is final. Questions of ritual and doctrine do not come within the Act.

By the Public Worship Regulation Act, 1874 (e), questions concerning the fabric, ornaments, or furniture of any church, or in respect of the burial ground or concerning ritual may be represented to the bishop by an archdeacon, a churchwarden, or any three parishioners; the bishop may either refuse to institute proceedings, or, with the consent

(a) See ante, p. 78 .

(b) Phill., Eccl. Law, 945.

(c) As to these varions courts sce Phill., Eccl. Law, 922 et seq.

(d) 55 \& 56 Vict. e. 32.

(e) $37 \& 38$ Vict. c. 85. 
of both parties, deal finally with the case; if the parties do not so consent, the case goes to the provincial court.

(4) Peculiar Courts.-Besides the consistory courts, there were in various dioceses peculiar courts with jurisdiction over such causes as arose within the peculiar parishes mentioned above. The Dean of the Court of Arches, which took its name from the form of the arches in the steeple of Bow Church in London, where the court was held, formerly exercised the peculiar jurisdiction of the Archbishop of Canterbury over the parish of Bow and twelve other parishes, which were exempt from the Bishop of London's jurisdiction $(f)$. This appellation of Dean of the Arches became synonymous with the archbishop's official principal, who presided over the Court of Appeal of the province of Canterbury, known as the Court of Arches ( $g$ ).

This peculiar jurisdiction has been abolished, and no Dean of the Arches is in fact now appointed.

The jurisdiction of the peculiars has now for most purposes been abolished and handed over to the archbishop or bishop of the diocese. Certain peculiars may, however, grant marriage licences concurrently with the bishop $(h)$.

(5) The Archdcacon's Court.-The functions of this court were originally to hold inquiries into matters relating principally to church fabrics and furniture. It, however, extended its jurisdiction at the expense of the consistory court. It has now become obsolete.

(6) The Court of the Rural Dean.-This court was held preparatory to the visitation of the archdeacon's court. This also has now become obsolete.

(7) The Court of High Commission.-This court was brought into existence by the 1 Eliz. c. 1, which gave the Crown power to issue commissions to try all manner of errors, schisms, heresies, abuses, offences, contempts, and enormities.

A permanent court was constituted in 1583 of forty-four persons, twelve being bishops and three forming a quorum. Under these very wide powers the court proceeded in that

(f) Phill., Eccl. Law, 214.

(g) Ib. 924.

(h) Ib. 214. 
and the two following reigns to exercise almost despotic powers of fining and imprisoning, but it had no power of inflicting death or torture. Its sentences were arbitrary and severe, and it tried offences both of elergy and laity. The court was abolished with the other ecclesiastical courts in 1640 (i). James II. endeavoured to revive it as the court of commissioners for ecclesiastical causes with Judge Jeffreys as its president. His subsequent flight put an end to the attempt, which was declared illegal by the Bill of Rights.

(8) The Court of Delegates. - This court was established by the 25 Henry VIII. c. 19 (1534), which authorized the Crown to issue a commission out of Chancery to hear appeals in ecclesiastical causes. Appeals to this court took the place of appeals to Rome, and its decisions were final. Appeals lay to it from all the inferior ecclesiastical courts until 1832, when a royal commission, which had been formed for the purpose, having reported unfavourably of it, it was abolished by the $2 \& 3$ Will. IV. c. 92, and its powers transferred to the King in Council, and eventually, by the $3 \& 4$ Will. IV. c. 41, to the judicial committee of the Privy Council. The Judicature Act, $1873(k)$, threatened to destroy the appellate jurisdiction of the Privy Council with that of the House of Lords, but it was restored by the Appellate Jurisdiction Act, 1876, which provided for the appointment of certain of the archbishops and bishops to sit as assessors of the judicial committee to hear ecclesiastical causes $(l)$.

Jurisdiction of the Ecclesiastical Courts. - The ecclesiastical courts enjoyed, and still enjoy, jurisdiction over such purely ecclesiastical matters as ordination, consecration, ecclesiastical status, church fabric and repairs, and the like, but in addition they obtained jurisdiction over such purely temporal matters as wills and administrations, and matrimonial causes and divorce. They also enjoyed certain criminal jurisdiction, and prior to the Restoration this extended over clerics and laymen alike. Their jurisdiction in

(i) 16 Car. I. c. 11. The ordinary ecclesiastical courts were revived after the Restoration in 1661 (13 Car. II. st. 1, c. 12).

(li) S. 20.

(l) App. Jur. Act, 1876, s. 14. 
wills and administrations was abolished in 1857, and lianded over to the Court of Probate $(m)$, and in the same year jurisdiction in matrimonial causes was handed over to the Court of Divorce $(n)$. Both these jurisdictions have, since the Judicature Act of 1873 , become vested in the Probate, Divoree, and Admiralty Division of the High Court of Justice, appeal lying in ecclesiastical matters to the judicial committee of the Privy Council, and in matrimonial matters and divorce to the Court of Appeal.

The Criminal Jurisdiction.-The ecclesiastical courts, however, retained their criminal jurisdiction-(1) In cases where a clerk was accused of felony. This right of trying their own clerks was termed Benefit of Clergy, and consisted in the right of the clerk in orders, when before the temporal court on a charge of felony, of being handed over to the ecclesiastical courts, where he could clear himself by compensation. This privilege was eventually extended to all persons who could read, and by a statute of Anne (o) even this qualification was rendered unnecessary, and all cleries and laymen could claim Benefit of Clergy alike. But a layman claiming the benefit couk be branded in the hand, and he could claim it once only $(p)$. Subsequently in the greater offences, when guilt was certain, the clerk was handed over absque purgationc facienda, which meant that he had to undergo imprisonment for life. Subject, however, to this, clerks who had committed "clergyable offences got off with the forfeiture of their goods as often as they offended, and the same was the case with the peers and peeresses as regards the first offence. In the rise of commoners the right became restricted to the first offence, and released them from capital pumishment only.

In the case of the more heinons felonies Benefit of Clergy was abolished by various statutes, and it was finally abolished altogether in 1827 ( $7 \& 8$ Geo. IV. c. 28) in the case of commoners, and by $4 \& 5$ Vict. c. 22 in the case of peers.

(2) In matters of a purely spiritual nature. These were principally proceedings pro salute animx of the offender,

(m) $20 \& 21$ Vict. c. 77

(o) 6 Anne, c. 9 . (n) Ib. c. 85 .

(p) 4 Hen. V'II. c. 13. 
and this jurisdiction the Church claimed over laymen as well as clerics. Such matters as adultery, perjury, defamation, swearing, profanity, drunkenness, faith, morality, and heresies came under this head, and the Court of High Commission tried errors, schisms, abuses, offences, contempts, and enormities. The penalties inflicted by the ordinary courts were mostly by way of penance and could be commuted by payment; the Court of High Commission could sentence to fine or imprisonment, but could not inflict death or torture. The proceedings were either by way of inquisition, accusation, or denunciation $(q)$, and it was on account of the abhorrence in which they were held that Parliament abolished the ecclesiastical courts in 1640; but, with the exeption of the Court of High Commission, they were reestablished in $1661(r)$.

At the present day many of the offences formerly tried by the ecclesiastical courts have been made by statute punishable at the common law, e.y. unnatural offences, witcheraft, bigamy, perjury, slander, brawling in churches, and the like, though there is no legal reason why other offences should not still be tried in the ecclesiastical courts. As a matter of strict law, it appears that a layman guilty of such offences as atheism, blasphemy, heresy, schism, or the like, might still have public penance inflicted upon him by an ecclesiastical court; on refusal to do penance be might be excommunicated, and on that the temporal court might direct imprisonment for not more than six months $(s)$.

Ecclesiastical jurisdiction over laymen has, however, fallen into disuse, though the ecclesiastical courts still enforce propriety of conduct on members of the profession $(t)$.

The history of heresy is worth consideration. The first writ de haretico comburendo was issued by the Crown with the consent of the Lords in 1400 for buruing one William Sawtre, who had been convicted by the council of being a relapsed heretic $(u)$. In the same year a statute was.

(q) Steph., Hist. Crim. Law, ii. 401.

(r) 13 Car. II. st. 1, c. 12.

(s) See 53 Geo. III. c. 127.

(t) See Steph., Hist. Crim. Jaw, ii. 437.

(u) Ib. ii. 445.

C.L.E. 
passed $(x)$ providing that all relapsed heretics should be burnt. In 1414 a sererer Act was passed and people burnt frequently. In 1539 the Act of the six articles (31 Hen. VIII. c. 14) punished heresy with burning, imprisonment, or execution. Edward VI. repealed these statutes, but preserved the old writ de hxretico comburendo. Mary again revived the heresy laws, which were again repealed by Elizabeth, except with regard to Anabaptists, who were burnt down to 1612 under the old writ. The ecclesiastical courts were abolished in 1640 , but on their revival in 1661 the old law of heresy had fallen into oblivion. The writ de haretico comburendo was finally abolished by a statute of Charles II. $(y)$.

We may note a provision of the Clergy Discipline Act, $1892(z)$, which enacts that, with regard to the offences mentioned in the Act, within twenty-one days of a conclusive verdict in a civil court the bishop shall declare the preferment empty. If the bishop will not act, the duty derolves on the archbishop.

By the Benefices Act, 1898 (a), the bishop may refuse to admit to a benefice on the grounds prescribed by the Act. Appeal lies to the archbishop, who sits with a judge nominated by the lord chancellor for the purposes of the Act.

(x) 2 Hen. IV. c. 15.

(y) 29 Car. II. c. 9.

(z) 55 \& 56 Vict. c. 32 , s. 1.

(a) 61 \& 62 Vict. c. 48 . 
Chapter III.

\section{JUDICIAL INSTITUTIONS FROM EDWARD I. TO THE JUDICATURE ACTS (continued).}

The Assizes.

As we have already seen, the circuit system was instituted by Henry I., and improved upon by Henry II. in 1166 . It appear's that the circuit judges, or judges of assize, eventually superseded the old justices in eyre, who, in the time of Henry II., went through the country once in seven years, inquiring into the system of legal administration. It seems probable, however, that the two systems existed side by side originally.

By a statute of Edward I. (a) the justices or commissioners of assize were to be appointed out of the king's sworn justices, and to act with one or two discreet linights of each shire. Eventually by the Judicature Acts, 1873 and 1875 , the Crown was empowered to issue commissions of assize, oyer and terminer, and gaol delivery to any judges of the High Court of Justice, or to serjeants-at-law or king's counsel (b); and by the Judicature Act, 1884, county court judges may be included in the commission (c).

At the present day the various circuits are regulated principally by various Orders in Council, made under the authority of the Judicature Acts, 1873, and 1875 (d). To summarize the existing system, which is regulated principally by Order in Council of the 28th of July, $1893(e)$, and

(a) 13 Ed. I. st. 1, c. 30 .

(b) Judicature Act, 1873, s. 37 ; Judicature Act, 1875, s. 8; and see Appellate Jurisdiction Act, 1876 , s. 15.

(c) S. 7 .

(d) $36 \& 37$ Vict. c. 66 , s. $75 ; 38 \& 39$ Vict. c. 77, s. 23 ; and see the Winter Assizes Act, 1876 and 1877 (39\& 40 Vict. c. $57 ; 40 \& 41$ Vict. c. 46), and the Spring Assizes Act, 1879 (42 \& 43 Vict. c. 1).

(e) Stat. R. \& O. 1893, p. 165. 
various amending orders, there are at the present day eight different circuits, viz. the Northern, the South-Eastern, the North-Eastern, the Midland, the Oxford, the North and South Wales, the South Wales, and the Western. To some of the circuit towns two judges are sent down, to others one only, according to the amount of business to be transacted. On all the eireuits summer, autumn, and winter assizes are held $(f)$, and in Manchester, Liverpool, and Leeds, Easter assizes may also be held. The eireuits themselves, or any of them, may be altered or discontinued by Order in Council, as also the towns at which the assizes are held $(g)$.

The Commissions of Assize.-The rarious commissions of assize were as follows:-

(1) Criminal, riz. of the peace, of oyer and terminer, and of general gaol delivery.

(2) Civil, viz. assize and nisi prius.

Previously to the invention of the misi prins writ civil eauses, triable by the High Court, had to come up to Westminster. The writ of nisi prius provided that it should still do so, unless before (nisi prius) the day appointed for trial the judges of assize should risit the county. By the Common Law Procedure Act, 1852 (h), the trial may be held before the judges of assize without any proviso of nisi prins.

The judges now sit under three commissions: (1) gcneral gaol delivery, under which the gaols are cleared of all persons awaiting trial; (2) oyer and termincr, under which eases in which the grand jury have returned a true bill are tried; (3) assize, under which eivil cases are taken, and to this the commission of nisi prius was annexed by the Statute of Westminster the second (i). By a statute of Edward I. justices of assize were also to be commissioners of oyer and

(f) Some of the circuit towns are, however, only risited at the summer and winter assizes.

(g) Judicature Act, 1875 , s. 23. A table printed by Messrs. Waterlow \& Sons, Ltd., may be obtained, showing the arraigements made for the assizes.

(h) $15 \& 16$ Vict. c. 76.

(i) 13 Ed. I. st. 1, c. 30 . 
terminer (li); the commission of assize by itself therefore now includes the other commissions.

By the Judicature Act, 1873, a judge sitting on assize is now to be deemed to constitute a court of the High Court of Justice $(l)$, and therefore mandamus no longer lies to him as it did formerly, though a writ of certiorari will issue in criminal cases to remove the cause into the King's Bench Division on the ground that a fair and impartial trial cannot be held elsewhere, or that some difficult question of law or fact is likely to arise. This writ may also issue to remove a cause from the Central Criminal Court into the King's Bench Division.

By the Administration of Justice Act, 1920 (10 \& 11 Geo. V. c. 81) porver is given to try matrimonial causes of any prescribed class at the assizes.

We may conclude is remarking that the utility of the present system has of recent years been much questioned owing to the want of business in many of the assize towns, the waste of time spent by the various judges in travelling from place to place, and the subsequent congestion and delay of important business in the London courts during their absence. It is possible, therefore, that some alteration or modification of the system as it at present exists may be looked for in the near future $(m)$.

\section{The Quarter S'essions.}

These are either the general county quarter sessions or the borough sessions.

The County Quarter Sessions.-The times for holding the general county quarter sessions are fixed by statute ( $(n)$, and are as follows:-

In the first week after the 11th of October, 28th of December, 31st of March, and 24th of Jume. These times

(k) 2 Ed. III. c. 2. The commission of general yaol delivery had been previously added (27 Ed. I. st. 1, e. 4).

(l) Judicature Act, 1873, s. 29.

$(m)$ And see the County Courts Act, 1903, cxtending the jurisdiction of the county courts from $£ 50$ to $£ 100$ in contract and tort.

(n) 11 Geo. IV. and 1 Will. IV. c. 70. 
may, however, be varied within certain limits by the justices at the previous quarter sessions, so as not to clash with the assizes $(o)$.

Constitution of the Court.-All the justices holding a commission of the peace in the county may be members of the court, but there must be at least two present to form a quorum. The county sessions are convened by a precept of two justices of the peace of the county, or of the custos rotulorum (or lieeper of the records) and one justice, addressed to the sheriff, requiring him to summon the sessions on the day named, and to give notice to coroners, gaolers, stewards, etc., in his bailiwick, and to return $a$ grand and petty jury. The court of quarter sessions may try appeals from petty sessions, and it has an extensive jurisdiction in all criminal matters except those excluded by statute, of which the principal are treason, murder or any capital felony, perjury, forgery, bigamy, abduction, rape, or any felony for which a person not previously convicted is subject to penal servitude for life $(p)$.

An order on motion, made in a summary way, may be removed into the King's Bench Division on writ of certiorari, and there either quashed or confirmed. But an indictment found at quarter sessions may only be removed into the King's Bench Division on writ of certiorari on the ground that a fair and impartial trial camnot be had in the court below, or that some difficult question of law or fact is likely to arise, or that a special jury or view of premises may be required. By the Judicature Act, $1894(q)$, all appeals from petty or quarter sessions are to go before a divisional court of the High Court of Justice.

Where the justices are made judges of fact as well as of law, their decision was formerly final; but they could state a special case for the opinion of the King's Bench Division on some difficult question of law, in the meantime quashing the order, and the High Court would then confirm or quash the action. In other criminal cases the judgment of quarter

(o) $57 \& 58$ Vict. c. 6 .

(p) $5 \& 6$ Vict. c. 38 .

(q) $57 \& 58$ Vict. c. 16 . s. 1 (5). 
sessions could only be inquired into on writ of error. Appeal now lies to the Court of Criminal Appeal under the Criminal Appeal Act, 1907, on convictions on indictments, criminal informations, and cases dealt with by quarter sessions under the Vagrancy Act, 1824, as presently stated.

Borough Sessions.-Most boroughs have their own quarter sessions $(r)$ independently of the general quarter sessions held once in each quarter. The recorder of the borough (who must be a barrister of five years' standing) is the sole judge, but he may have an assistant, and in case of absence may appoint a deputy. Their jurisdiction is practically the same as that of the county sessions.

\section{The Central C'riminal Court.}

This conrt was constituted in $1834(s)$, and its jurisdiction was to extend to indictable offences in the counties of London and Middlesex, and in certain parts of Essex, Kent. and Surrey. The Central Criminal Court acts as the assize: court for these districts $(t)$, and before it all indictments not triable at quarter sessions within the above districts are laid; the court also sits as the court of quarter sessions for the City of London. Amongst others the following persons are judges: The lord mayor of London, the lord chancellor, all the judges of the High Court of Justice, the aldermen, the recorder, and the common serjeant of the City of London, with certain others, and also such persons as the Crown from time to time appoints. To any of these persons the Crown delivers from time to time commissions of oyer and terminer and of gaol delivery to try all treasons, murders, felonies, and misdemeanours committed within the district of the Central Criminal Court. Certiorari lies to the Central Crininal Court from the courts of quarter sessions within the district, and by the same writ an indict-

(r) Separate quarter sessions are now granted on the petition of the borough council under the Municipal Corporations Act, 1882, s. 162.

(s) 4 \& 5 Will. IV. c. 36 ; and see 38 \& 39 Vict. c. $79 ; 51$ \& 52 Vict. c. 41 .

( $t$ ) As to the times of sitting see $4 \& 5$ Will. IV. c. 36, s. $15 ; 44 \& 45$ Vict. c. 58 , s. 18 . 
ment found at the Central Criminal Court may be remored into the King's Bench Division of the High Court.

Courts of quarter sessions within the above distriets may also transmit cases to be heard by the Central Criminal Court.

\section{The Courts of Petty Sessions.}

Justices of the Peace.-A statute of Edward IV. (u) took away from the old criminal court of the sheriff's tourn the power of hearing and determining eriminal eharges, and conferred it on the justices of the peace, who had been appointed as early as the reign of Edward I. Of justices of the peace some were so by virtue of special offices from very early times, and still remain so. Of these the prineipal is the king by virtue of his royal dignity, and others are the lord chancellor, the lord treasmer, the lord high steward, the lord high constable, the judges of the High Court, and the master of the rolls (the latter by preseription). The coroner and the sheriff are conservators of the peace within their own comnty, and the lord mayor and aldermen of the eity of London are also justices of the peace. All these may commit persons breaking the king's peace, or bind them in recognizances to keep it. Justices of the peace not holding virtute officii were originally chosen by the freeholders by virtue of the king's writ directing their election in full county court before the sheriff. The 34 Edward III. c. 1 gave them the power of trying felonies, and since then they have been appointed by the Crown on the adrice of the lord chancellor, and no longer by the freeholders. The justices of the peace for each county are recommended to the lord chancellor for appointment by the lord lieutenant, and they hold office by virtue of a speeial commission under the Great Seal, the form of which was settled as early as 1590 .

Qualification of Justices of the Peace.-Justices of the peace act gratuitously, and by two statutes of George II. they were required to have an estate in possession of at

(u) 1 Ed. IY. c. 2. 
least $£ 100$, or a reversion or remainder expectant on such lease as therein mentioned with reserved rents of the elear yearly value of $2300(x)$. Further, any person who for the space of tro years previously had been assessed to the inhabited house duty at a value of not less than $\$ 100$, and who had been rated to all rates and taxes in respect to such premises, was eligible to become a justice of the peace, provided not otherwise disqualified $(y)$.

The qualification by estate in the case of justices of the peace for any court has now been abolished by the Justices of the Peace Act, 1906 (z); and it is also provided by the same Act, that a person may be appointed justice of the peace though he does not reside in the county for which he is appointed, provided he resides within seven miles of it.

Constitution of the Petty Sessions.-Any court of summary jurisdiction consisting of two or more justices sitting in a petty sessional court house (inchuling the lord mayor of London and any alderman), or any police or stipendiary magistrate sitting in a court house at which he is authorized to do any act anthorized to be done by two or more justices, forms a court of petty sessious (a), special provision being made under the Children Act, 1908, for the hearing of charges, etc., as to children and roung persons under the age of sixteen in special "Juvenile Courts " established by the Act in the metropolis and elsewhere (b). No indictable offence may be dealt with summarily except at petty sessions, and no fine exceeding trenty shillings or imprisonment of more than fourteen dass may be inflicted ly any court of summary jurisdiction other than a petty sessional court $(c)$.

\section{Jurisdiction of the Petty Sessional Court.- Jurisdiction} has been conferred upon magistrates hy various statutes (the principal of which are the Criminal Law Consolidation

(x) 5 Geo. II. c. $18 ; 18$ Geo. II. c. 20.

(y) $28 \& 29$ Vict. c. 54 ; and see 45 \& 46 rict. c. 50.

(z) 6 Ed. VII. c. 16, ss.1, 2.

(a) Interpretation Act, $1889(52 \& 53$ Vict. c. 63, s. 13 (12)). A petty sessional court house is defined, $I b$. s. 13 (13).

(b) 8 Ed. VII. c. 67 , s. 111 .

(c) Summary Jurisdiction Act, 1879 (42 \& 43 Tict. c. 49, s. 13 (7) (8)). 
Act of 1861, and the Summary Jurisdiction Act, 1879) (d) to try offences in a summary way without committing to the quarter sessions or assizes. In some cases one justice alone is empowered to act; but the court cannot properly be termed a court of petty sessions except in cases where two or more justices must act $(e)$.

Three classes of persons $(f)$ come within the scope of the Summary Jurisdiction Acts:-

(1) Children under twelve rears of age, who, except in cases of homicide, may be dealt with summarily with the consent of the parent or guardian. Not more than one month's imprisonment may be inflicted, nor a fine of more than forty shillings $(g)$.

(2) Young persons between the ages of twelve and sixteen may be dealt with summarily for larceny and other. minor indictable offences if they consent to that course. Imprisonment with or without hard labour, for not more than three months, or a fine of not more than $£ 10$ may be inflicted $(h)$. In addition, children may be sentenced to six strokes of the birch, and adults to twelve strokes. Provision is also made by the Children Act, 1908 (8 Edw. VII. c. 67), for the punishment and correction of children and young persons under sixteen, by confinement in special places of detention provided by the Act, and otherwise: and by the Criminal Justice Administration Act, 1914, for the committal to Borstal institutions of young persons between the ages of 16 and 21 (i).

(3) Adults, if they consent, may be dealt with summarily for a limited class of indictable offences, and sentenced to not more than three months' hard labour. An adult may, if he pleads guilty to a certain class of more serious indictable offences, be

(d) And see as to theft, $18 \& 19$ Vict. c. 126 .

(e) Sce definition of petty sessional court. supra.

(f) See the Summary Jurisdiction Act, 1879 (42 \& 43 Vict. c. 49).

(g) $I b$. s. 10 .

(h) $I b$. s. 11 .

(i) 4 is 5 Geo. V. c. 58, ss. 7. 9, 10. See also the Probation of Offenders Act, 1907, and the Prevention of Crimes Act, 1908, ss. 1 (1), 2. 
sentenced to not more than six months' imprisonment with or without hard labour $(k)$. The magistrate's jurisdiction extends only to cases in his own county, borough, or district.

The principal offences in which summary jurisdiction has been given to magistrates are: (1) Small larcenies and embezzlements, and also in cases where the property exceeds forty shillings, if the accused pleads guilty and the magistrates elect to deal with him summarily; (2) common assaults and batteries; (3) the taking of personal property, trees, animals, etc., being non-indictable larcenies; (4) small wilful injuries to property; (5) certain offences relating to game.

Procedure.-The procedure is by way of information laid before the magistrate (not necessarily on oath unless a warrant for arrest is required) and summons.

On the day named in the summons the case comes on for hearing in open court. The magistrates hear the case viva voce, the prosecutor and his witness and the defendant and his witnesses giving their evidence on oath or affirmation. Either party may be represented by counsel or attormey.

The magistrates consider the case and proceed to convict, or dismiss the summons. Judgment is then passed and punishment awarded; the judgment may be enforced by distress, or in some cases by imprisomment.

Appeal from Petty Sessions.-Appeal lies from petty sessions-(1) to quarter sessions. This is not as of common right, but must be by special statute, the principal of which is the Summary Jurisdiction Act, $1879(l)$. But under this Act no appeal is allowed where the defendant has pleaded guilty or admitted the truth of the information or complaint, or where imprisomment is inflicted for failing to comply with an order for payment of money, entering into recognizances, etc., or where a person elects to be dealt with summarily on an indietable offence $(m)$. In the metro-

(k) 4 \& 5 Geo. V. c. 58, ss. 12, 13.

(l) $42 \& 43$ Vict. c. 49.

(in) $I b$. s. 19 . 
polis there is an appeal in every case (except in revenue eases) where a fine of more than $\& 3$ is inflicted.

(2) To the King's Bench Division of the High Court of Justice. There is a right of appeal to the High Court of Justice on the ground that the order made is croneous in point of law, or is in cxcess of jurisdiction. (n). The person injured applies to the court to state a special case, and if this is refused he may apply to the High Court of Justice for an order requiring the case to be so stated. If this right be resorted to, the right to appeal to quarter sessions is lost $(o)$; and by the Judicature Act, 1894, the appeal is to be heard by a divisional court, and without the leave of that court or of the Court of Appeal the decision is final $(p)$.

We may note that in many of the offences which have by statute been made triable by magistrates in a summary. way, one magistrate alone is empowered to act, but this cannot properly be called a petty sessions. If there is no direction in the Act as to the number of justices, one alone may act, and he must sit in open court either in a petty sessional court house or an occasional court house. What has already been said above as to the appeal from petty sessions applies also to appeals from orders made by a single magistrate. Further, we may note that in all eases where a prisoner is committed (with bail or otherwise) for trial for an indictable offence, the accused must first be brought up before a magistrate or magistrates and the charge investigated in the usual way.

The writ of certiorari lies to remove proceedings from hefore the magistrate or magistrates into the King's Bench Dirision, where, if necessary, they may be quashed.

\section{The Coroner's Court.}

It seems clear that coroners existed at any rate as early as the reign of Richard $\mathrm{I}$, and their duties were defined by the 4 Edward I. st. 2. Until 1888 the coroner was elected by the freeholders in the county court, but by the Loeal

(ii) 42 \& 43 iict. c. 49, s. 33 .

(o) $20 \& 21$ Vict. c. 43 , s. 14 .

(p) $57 \& 58$ Vict. c. 16 , s. 1 (5). 
Government Act, $1888(q)$, the county council are made the electors, except in boroughs having a separate court of quarter sessions and whose population exceeds 10,000, where they are appointed by the borough council $(r)$.

The coroner's principal duties are: (1) To hold inquests in cases of suspicious deaths. In such a case the coroner (on notice of the death) issues his warrant for the summoning of a jury, who must not be more than twenty-three or less than twelve $(s)$. The inquest is then held super visum corporis, and the witnesses are examined on oath, and on the jury (twelve at least must concur) finding a verdict of murder or manshaughter against the accused, the coroner must commit lim if present, if not, issue a warrant for his arrest. This finding is equivalent to the finding of a grand jury, and the accused may be prosecuted as on an indictment. But it is a common practice (though not necessary) to take the accused before a magistrate, who then commits the prisoner, the trial taling place on indictment in the usual way.

In addition to his duty of holding inquests in cases of suspicious deaths, the coroner has jurisdiction to hold inquests in cases of treasure trove, who were the finders, where it is, and whether any person is suspected of having concealed it $(t)$. Formerly, also, the coroner had jurisdiction in cases of shipwreclis; but by the Merchant Shipping Acts, 1854, 1862, and 1894, the general superintendence of matters relating to wrecks las been luanded over to the Board of Trade.

The coroner also held inquests on royal fish (viz. whales or sturgeon caught on or near the coast), but this jurisdiction was taken from him by the Coroners Act, 1887, together with his jurisdiction relating to wrecks (u).

Further, we may note that a coroner becomes a magistrate virtute officii; also, lie is the sheriff's substitute in executing process when exception has been taken to the sheriff on the ground of partiality or for some other cause.

(q) S. 5 .

(r) $45 \& 46$ Vict. c. 50, s. $171 ; 51$ \& 52 Vict. c. 41 , s. 38 (2).

(s) The Coroners Act. 1887 (50 \& 51 Vict. c. 71, s. 3),

(t) 50 \& 51 Vict. c. 71 , s. 36.

(u) Ib. s. 44. 
All matters relating to the coroner's office are now principaly regulated by the Coroners Act, 1887.

\section{The Metropolitan Police Courts.}

Of these there are now thirteen in and about the metropolis, presided over by metropolitan police magistrates, who form a court of petty sessions sitting alone. The powers and duties of these magistrates and the various officers connected with the courts are regulated by a number of statutes passed in the reign of Victoria, which it will not be convenient here to enlarge upon.

In addition to the metropolitan magistrates, stipendiary magistrates (of whom there are now eighteen) have been appointed $(x)$ for various towns in different parts of the. kingdom, and their duties correspond to those of the metropolitan police magistrates.

\section{The County Courts.}

Constitution.-The old shire-mote or county court of the sheriff fell into disuse, owing to the dilatory nature of its proceedings, and to the fact that it was not a court of record. The remedy afforded by the superior courts in debts and demands of small amount was almost equally objectionable; therefore Courts of Request or of Conscience were formed by special statutes in different parts of the kingdom, to take cognizance of small causes. These were, however, found inadequate for the purpose, and in 1846 the first County Courts Act was passed, which abolished the Courts of Request or Conscience and substituted the new county courts $(y)$.

There was also a provision in the Act enabling the lord of any hundred, honour, manor, or liberty, being entitled to hold a court in right thereof, to surrender to the Crown the right of holding such court, and this provision was further extended in favour of the county courts by the County Courts Act, 1867 (z), which provided that any action which

(x) See $5 \& 6$ Will. IV. c. $76 ; 46 \& 47$ Vict. c. 18.

(y) $9 \& 10$ Vict. c. 95 .

(z) 30 \& 31 Vict. c. 142. 
could be brought in a county court should not be commenced in any inferior court not being a court of record.

Several Acts amending and extending the Act of 1846 were subsequently passed, and in 1888 a great consolidating Act $(51 \& 52$ Vict. c. 43) was passed, by which as amended the county courts are now principally regulated.

The general system instituted by these Acts is as follows: A certain number of county court districts are appointed in each county, the court in each district being held once a month generally, and being a court of record. These districts are divided into a number of circuits, to each of which a judge is appointed by the lord chancellor, who must be a barrister of seven years' standing. Besides the judge there is a registrar, clerks, and subordinate officers for each district, with a bailiff and assistant bailiff. It is not proposed here to enter into full details of the practice and procedure of the county court, which will be found in the Act of 1888 , and the rules made thereunder. In outline the practice and procedure is as follows:-

Procedure in the County Court.-The first step is the entry of a plaint by the plaintiff in a book kept by the registrar of the district. This is followed by a summons served on the defendant, and on the day named both parties must appear, or judgment goes in default. The plaintiff may also issue a default summons (on obtaining leave, which he may do in some cases on swearing to the truth of his claim), and in that case he may sign judgment at the end of eight days from service of the summons, unless the defendant gives notice of defence. The case being called on, the judge tries it in a summary way, evidence being taken viva voce and on oath. The judge determines all questions of law and of fact, unless a jury is summoned, which may be done on the requisition of either party, where the amount of the claim exceeds $£ 5$, and if under $£ 5$ at the discretion of the judge on the application of either party. Tluis jury consists of eight (a) persons being qualified to serve on a jury in the High Court of Justice, and their verdict must be unanimous. But the Court has power to order a trial

(a) County Courts Act, 1919, s. 22. 
without a jury if satisfied that the case cannot be conveniently tried with a jury (b). An order for parment having been made and not complied with, execution issues against the goods of the debtor. If the judgment debtor has no goods, the judge may order a writ of certiorari to remove the judgment into the High Court, when a writ of elcgit can issue against the debtor's lands.

On any point of law or equity, or on the admission or rejection of evidence, either party may appeal to a divisional court of the High Court of Justice, unless both parties have previously agreed in writing that the decision shall be final. Generally speaking, in actions of contract or tort, the right of appeal does not exist (except by leave of the judge, and in cases respecting the title to real property) where the amount claimed is not above $£ 20$.

The Jurisdiction of the County Courts.-This is prineipally for debts, demands, and damages of small amount, and includes all personal actions in contract or tort, where the claim does not exceed $£ 100(c)$. But if the claim exceeds $\$ 20$ in contract, or $\$ 10$ in tort, the defendant may object to the case being tried by the county court, and on giving the proper security, and obtaining a certificate from the judge that some difficult question of law or fact is likely to arise, he may have the cause removed into the High Court of Justice. The county court alone takes cognizance of cases under the Employer's' Liability and Workmen's Compensation Acts. Some personal actions are, however, expressly excepted from the jurisdiction of the county court; such are breach of promise of marriage, libel, slander, seduction, or actions in which the title to any toll, fair, market, or franchise is in question. A patent is a " franchise," therefore the validity of a patent cannot be tried in the county court. The court also has jurisdiction to try any cause assigned to the King's Bench Division where the parties (or their solicitors) sign a memorandum in writing, agreeing to have the cause so tried. With regard to realty, actions of ejectment may be brought where

(b) Administration of Justice Act, 1920, s. 3 .

(c) 3 Ed. VII. c. 42 . 
the value or the rent of the tenement does not exceed $\$ 50$ yearly value. Also actions where the title to any corporeal or incorporeal hereditament comes into question may be tried in the county court, where the ralue or rent does not exceed £50 yearly value; and by agreement between the parties, where the value exceeds $£ 50$, an action involving the title to any corporeal or incorporeal hereditament, or to any toll, fair, market, or franchise may be tried, but the decision as to the title is not to be evidence of title in any other action.

The county court has no jurisdiction to try an action brought on a judgment in the High Court, nor the High Court to try an action brought on a judgment in the county court.

Further, a judge of the High Court of Justice may in certain cases, on the application of either party, remit the cause to the county court. Certain penalties with regard to costs are imposed by the Act in the case of a plaintiff bringing an action in the High Court which might have been tried in the county court $(d)$.

The above must, however, be read subject to the provisions of the County Courts Act, 1903 (e), which enacts that in certain cases where the words "fifty pounds" occur in the Act of 1888 , the words " one hundred pounds" are to be substituted therefor. His Majesty is empowered by Order in Council to designate certain county courts in which actions involving a sum of more than $£ 50$ are to be tried; and county court juries are to be composed of eight instead of five as previously $(f)$.

The Equitable Jurisdiction.-By the Act of 1888 the county courts may try (a) Administration actions where the value of the estate does not exceed $£ 500$; (b) suits for the execution of trusts in estates up to $\$ 500$; (c) foreclosure and redemption actions, or for enforeing any mortgage, charge, or lien, where the amount of the charge does not exceed $£ 500$; (d) specific performance and rectification

(d) $9 \& 10$ Geo. V. c. 73 , ss. 11,12 .

(e) $3 \mathrm{Ed}$. VII. c. 42 . The sections of the County Courts Act, 1888, to which the Act applies are ss. 56, 57, 58, 59. 60, 81, 96, 116, 138, 139.

(f) $9 \& 10$ Geo. T. c. 73 , s. 22 . 
of agreements, where the property sold or leased does not exceed $\$ 500$ in value; (e) proceedings under the Trustee Relief Acts, where the property does not exceed $£ 500$; (f) maintenance, or advancement of infants up to $£ 500$; (g) dissolution, or winding-up of partnerships, the assets not exceeding $£ 500$; (h) suits for relief against fraud or mistake, where the damages, or the estate or fund, does not exceed $£ 500$; and (i) winding-up of companies where the capital is under $£ 10,000$.

Admiralty Jurisdiction.-In 1868 certain county courts in the neighbourhood of the sea were given a limited jurisdiction in admiralty as to salvage, towage, necessaries or wages, damage to cargo or by collision, agreements for the use or hire of ships, claims with respect to the care of goods carried in ships, or any claim in tort with respect to such goods $(g)$.

Bankruptcy Jurisdiction.-In 1869 certain county courts were given jurisdiction in banliruptey, and this was confirmed by the Banliruptcy Act, 1914, s. 96, and by section 103 the county court may exercise, with regard to all causes of action within its jurisdiction, all the powers of the High Court.

\section{The Mayor's Court.}

The Court of the Portrecve in London existed in very early times, and it seems that this split up about the reign of Henry III. into the Court of Hustings and the Lord Mayor's Court $(h)$. The lord mayor and all the aldermen are the judges, the recorder sitting by custom as sole judge, and in his absence the common serjeant (i). An assistant judge is now appointed under the Local Courts of Record Aet, 1872 , s. 7 .

The court also possesses a serjeant-at-mace, whose duties are similar to those of the sheriff of the High Court.

(g) 31 \& 32 Vict. c. 71 ; but see now 9 \& 10 Geo. V. c. 73 , s. 13.

(h) Glyn is Jackson, p. 1.

(i) They or either of them may in certain cases appoint a deputy (Mayor"s Court Procedure Act, 1857. s. 43). 
The court enjoys an extensive legal and equitable jurisdiction, but apart from statute this jurisdiction only embraces causes arising wholly within the limits of the city. This jurisdiction is concurrent with that of the High Court.

Appeal lies to a divisional court of the High Court of Justice in claims over $£ 20$, or application may be made to the Mayor's Court for a new trial $(k)$.

The court enjoys special forms of procedure, which are principally regulated by the Mayor's Court Procedure Act, $1857(l)$. The Mayor's Court and the City of London are now amalgamated and form one Court which has all the powers and jurisdiction of both courts $(m)$.

\section{The Court of the Stumnaries.}

From the earliest times the Crown enjoyed certain royal rights over the mines in Devonshire and Cornwall, and the mines in those districts were subject to the jurisdiction of the courts of the Stannaries, separate courts existing for the district of the Stannaries in Cornwall and the districts of the Stannaries in Devon. This jurisdiction was recognized by various charters in early times $(n)$, and the officials of the court consisted of the lord warden, the vice-warden, and stewards.

A court was held by the stewards and a jury of six every three weeks (o), and appeal lay to the vice-warden and thence to the lord warden, with a final appeal to the Prince in Council $(p)$. Error did not lie to the courts of common law. The Devonshire Stannary courts seem to lave gradually fallen into disuse, whilst in Cornwall the court of the vice-warden alone seems to have attracted any suitors. Eventually the vice-warden's court in Cornwall was recon-

(k) See Glyn \& Jackson, p. 138 et seq.

(l) $20 \& 21$ Vict. c. 157.

(m) 10 \& 11 Geo. V. c. cxxxiv.

(n) See Smirke's Rep. of Vice v. Thomas, App., p. 95.

(o) $\mathrm{Ib}$

(p) The Duchy of Cornwall and the Stannary jurisdiction were granted by Edward III. to the eldest son of the reigning Sovereign. 
stituted in $1856(q)$ with jurisdiction over the Stannaries in Devonshire.

By the Judicature Act, 1873, the appellate jurisdiction of the lord warden's court was merged in that of the Court of Appeal; whilst in 1896 the court of the vice-warden was abolished, and its powers transferred to such of the new county courts as the lord chancellor should direct $(r)$.

\section{The Courts of the Counties Palatine of Chester, Durham, and Lancaster.}

These were, properly speaking, not inferior courts, as full jura regalia or rights of administering royal justice were granted to them originally, to the exclusion of the king's writ $(s)$.

The county palatine of Durham was granted by the Conqueror to the then Bishop of Durham.

The county palatine of Chester was granted by the same ling to Hugh Lupus, his nephew.

The county palatine of Lancaster was granted by Edward III. in 1376 to John of Gaunt.

The king's writ did not run into the counties palatine, all writs and indictments of treason and felony ruming in the name of him who had the county palatine, and the latter appointed all justices of eyre, of assize, and of the peace within the jurisdiction of the court of the county palatine.

Subsequently these palatine jurisdictions were transferred to the Crown; that of Lancaster in 1461, that of Durham in $1830(t)$, and that of Chester in $1830(u)$. Still, the ordinary royal writs did not run into these counties, the writs being issued from Westminster to the chancellor of the county palatine, who issued his mandate to the sheriff; the assizes also sat there by virtue of a special commission from the Crown as owner of the franchise, under the seal

(q) $18 \& 19$ Vict. c. 32.

(r) $59 \& 60$ Vict. c. 45 .

(s) These counties palatine were separate kingdoms or principalities in themselves, and seem to have been created as a means of defence against the neighboming Welsh and Scotch.

(t) 6 \& 7 Will. IV. c. 19 .

(u) 11 Geo. IV. and 1 Will. IV. c. 70. 
of the chancellor of the particular county palatine. In the year 1830 the 11 Geo. IV. and I Will. IV. c. 70, enacted that assizes should be held in Chester and Wales as in other places, and by the Judicature Act, 1873, the jurisdiction of the courts of Common Pleas of Lancaster and Durham was vested in the High Court of Justice, and by the same Act the counties palatine of Durham and Lancaster were to cease to be counties palatine as regards the issue of commissions of assize or other like cormmissions, but no further. The Chancery jurisdiction of Durham and Lancaster therefore still remains, and appeal lies to the Court of Appeal from Lancaster. By the $52 \& 53$ Vict. c. 47 appeal lies to the Court of Appeal from the county palatine of Durham, appeals from that court having previously been taken to the House of Lords.

\section{The Welsh Courts.}

In the time of Edward I. six counties in Wales had courts of justice on the English pattern. The rest of Wales was subject to the despotic authority of lords marchers, and into their lordships the king's writ did not run. By two statutes of Hen. VIII. (1535 and 1543) (x), the lordships marchers were abolished and Wales was divided into counties with courts of its own.

In 1830 (11 Geo. IV. \& 1 Will. IV. e. 70) the separate jurisdiction of the county palatine of Chester and the principality of Wales was abolished, and Wales was included in the English judicial system.

\section{Various Obsolete Courts.}

The Law Merchant.-In early times the law relating to merchant's transactions, and in particular to foreign merchants, did not form part of the general common law, but was administered in particular courts, such as the Courts of the Staple attached to certain staple towns, the Courts of Pied Poudre attached to fairs and markets, the Court of Policies of Assurance in London, besides the various courts having admiralty jurisdiction. 
Staple towns dated from the reign of Edward I. (y), and were the only towns permitted by charter to deal with foreign merchants in the staple articles of commerce, such as wool, woolfells, leather, etc. The Statute Merchant $(13 \mathrm{Ed}$. I. st. 3) provided a form of recognizance termed a statute merchant, to be entered into by a debtor before the mayor or chief warden of a city, town, or borough, and in default of payment a speedy remedy.

The Statute Staple was a similar form of recognizance provided by the $27 \mathrm{Ed}$. III. st. 2, c. 9, to be entered into before the mayor or constables of the staple towns (z). In adddition to the staple towns which enjoyed the exclusive privileges of trade mentioned above, in all towns the merchants in early times formed themselves into guilds merchant, and no person who was not a member of the guild was allowed to trade within the town. These guild merchants split up eventually into particular craft guilds, mysteries, and trading companies, the members of which also enjoyed exclusive privileges of trading in their several arts or industries. These exclusive privileges were finally abolished by the Municipal Corporations Act, 1835 (a), which provided that any person, whether lie enjoyed the freedom of the borough or of certain guilds, mysteries, and trading companies or not, should in future be free to use any trade, wholesale or retail, or to keep a shop in any city or town. The courts administering the law merchant gradually fell into desuetude, and by the time of Lord Mansfield, who is said to be the founder of the commercial common law of England (b), it had become incorporated with the ordinary common law of the land.

The Courts of the Staple.-These courts were established in staple towns in the reign of Edward III. (c) to hear cases between merchants of the staple before the mayor and two constables of the staple. The staple court administered the

(y) Co. Inst. iv. 237.

(z) Both these statutes, having long fallen into disuse, were repealed by the Statute Law Revision Act, 1863.

(a) $5 \& 6$ Will. IV. c. 76, s. 14.

(b) See Lichbarrow v. Mason (1793) 1 S. L. C., p. 704.

(c) 27 Ed. III. st. 2, c. 21 . 
law merchant, and its jurisdiction excluded that of the courts of common law. They have long since fallen into disuse.

The Court of Pied Poudre.-This was a court of record attached by the common law to every fair or market in the county to try causes arising in that particular fair or market. The steward of the market was the judge, and it derived its name from the dusty feet of the suitors.

It has long since fallen into disuse, though the Bristol Tolzey and Pied Poudre Court still survives.

The Court of Policies of Assurance.-This court was. established in the reign of Elizabeth $(d)$ for determining all causes connected with policies of assurance in London. It was abolished by statute in $1863(e)$.

The Court of Marshalsea.-This court tried cases of trespass where one of the parties was a member of the royal household, and cases of contract where both parties were members. It was abolished by the 12 \& 13 Vict. c. 101.

The Palace Court.-This court sat at Westminster and heard causes arising within twelve miles of Whitehall Palace. It also was abolished by the $12 \& 13$ Vict. c. $101(f)$.

(d) 43 Eliz. c. 12 .

(e) $26 \& 27$ Vict. c. 125 .

(f) In addition to these there are still in existence certain inferior courts which have power to exercise justice under ancient charter. Some of these are regulated by statute, viz.-

The Liverpool Court of Passage.

The Salford Hundred Court of Record.

The Oxford Tniversity Chancellor's Court.

Others have no special Acts governing their procedure; these are-

The Derby Court of Record.

The Exeter Provost Court.

The Kingston-upon-Hull Court.

The Newark Court of Record.

The Northampton Borough Court.

The Norwich Guildhall Court.

Peterborough Court of Common Pleas.

Preston Court of Pleas.

Romsey Court of Pleas.

The Southwark Court of Record.

As to the Salford Hundred Court see 31 \& 32 Vict. c. 130; and as to the Oxford University Chancellor's Court see 25 \& 26 Vict. c. 26. 
The Court of the Constable and Earl Marshal.-It was customary in early times for the ling, with the advice of the constable and earl marshal, to issue rules to be observed for the due ordinance and discipline of soldiers in time of war, and these rules and orders were enforced by the Court of the Constable and Earl Marshal $(g)$.

The offices of constable and earl marshal were distinct, both being hereditary in different families. The office of the constable became extinguished by the attainder of the Duke of Buckingham in the thirteenth year of Henry VIII., and his jurisdiction aceordingly reverted to the Crown. The office of earl marshal continued and still exists by hereditary right in the Duke of Norfolk's family, but it seems that the earl marshal had no power to hold his court in the absence of the constable. The court of chivalry, however, was never wholly abolished $(h)$.

The juristliction thus acquired by the Crown was unduly extended under the Tudors and Stuarts, and it formed one of the grievances recited in the Petition of Right (i), that commissions of martial law were issued in time of peace and to try civilians as well as soldiers.

These commissions of martial law were finally declared illegal by the Bill of Rights, and courts martial to try military offences, which have taken the place of the old Court of the Constable and Earl Marshal, are now held under the authority of the Annual Army Acts. The Court of the Constable and Earl Marshal, in addition to military offences, took cognizance of contracts relating to military matters, prisoners of war, prize, and the like. It also sat as a court of honour to settle disputes between military men.

The constable ceased to be appointed in the reign of

(g) Hale's Hist. Com. Law, 42. The jurisdiction of the court was regulated by statute; the 13 Ric. II. c. 2, enacted as follows: "To the constable it pertaineth to have cognizance of contracts touching deeds of arms and of war out of the realm, and also of things that touch war within the realm and which cannot be determined nor discussed by the common law, with other usages and customs to the same matters pertaining."

(h) See Adye on Courts Martial, p. 2 et seq.

(i) 3 Car. I. c. 1 
Henry VIII. ( $k$ ), and the last case to he tried in the court was that of Sir H. Blount in 1736 (l).

\section{Procedure in Civil Actions.}

Forms of Action.-As in the early times of Roman law set forms of actions were invented, and it became a rule that each injury could only be redressed by its own particular remedy, any flaw in that particular form vitiating the whole proceedings, so in English law from the earliest times there were fixed forms of complaint, each form appropriate to the particular injury to be redressed. We have seen how difficult it was for a suitor to obtain redress for some injury for which there was no precedent for a writ: how eventually the clerks in Chancery were in such cases authorized to issue writs in consimili casu, and how eventvally the chancellor took cognizance of those grievances which could not be fitted exactly into the hard and definite forms of the common law writs. According to the ancient dirision, actions were either (a) Personal, (b) Real, or (c) Mixed.

(a) Personul actions were considered as being founded on contracts or torts. Torts denoted all wrongs independent of contract, and were of three kinds: (1) Nonfeasances, or the omission of an act which a man was legally bound to perform. (2) Misfeasances, which meant the improper performance of a lawful act. (3) Malfeasances, or the commission of unlawful acts.

The forms of personal actions founded on contract ( $e x$ contractu) were: (1) Deht, where a certain sum of money alleged to be due from the defendant to the plaintiff was sought to be recovered. (2) Covenant, where damages for breach of an agreement by deed were sought. (3) Assumpsit, for damages for breach of an agreement not made by deed. Those founded on tort (ex. delicto): (1) Detinue, to recover a personal chattel unlawfully detained. (2) Trespass, where damages for an injury accompanied with actual force (vi ct armis) were claimed, such as a wrongful entry upon 
another's lands, or a wrongful taking of another's personal goods. (3) Trover, where damages were claimed for the wrongful keeping or conversion of another's goods.

Trespass on the case, being a form of action which came into use in the reign of Edward IV., and invented under the authority of the statute in consimili casu $(m)$ on the analogy of the older writ of trespass. It lay where damages were claimed for an injury to property or person not coming within the other forms, as where there was a culpable omission of some act, or where the act was injurious only by consequence or collaterally. Also, where the idea of force was not applicable, the subject-matter being incorporeal and intangible. (5) Replevin, which lay for the recovery of goods alleged to have been wrongfully distrained. By the Common Law Procedure Act, 1852 (15 \& 16 Vict. c. 76), these forms in personal actions were abolished, and the ordinary writ with the endorsement suitable to the particular case was substituted. Now the procedure in civil actions is gorerned by the Judicature Acts and the rules and orders made thereunder.

(b) Real actions and (c) Mixed actions. These may be considered together. All actions involving the right to real property were formerly conducted (as in the case of personal actions) in certain set forms, such as the Writ of Right Close, Writ of Pight quia dominus remisit curiam, Writ of Assize of Novel Disscisin, Trit of Pight Juris Utrum, and many others, some of which have been noticed above. But these remedies were found tedious, and through the great nicety required in their management, the fact that judgment was conchusive, and that they could be brought in the Common Pleas, they fell into disuse. The action in ejectment therefore took their place. These real and mixed actions were formally abolished in 1833 (3\& 4 Will. IV. c. 27 , s. 36), the writ of Doucr, the writ of Qune Impedit and of Ejectment being, however, specially exempted from the operation of this statute. Prior to the Common Law Procedure Act, 185.2, the action of ejectment was often considered as a mixed action, although in its form it was a species of the persoual action for trespass. This arose

(m) Statute Westminster the second (13 Ed. I. st. 1, c. 24). 
through the fact that personal actions were not subject to the disadvantages stated above, and the application of this form of personal action to the recovery of real property seems to have been invented as early as the reign of Henry VIII. This personal action of trespass was called de ejectione firmae, and afterwards simply an ejectment.

The Action of Ejectment.-Prior to the Common Law Procedure Act, 1852, the procedure in the action of ejectment was as follows (and it may here be noted that, in addition to damages, it had been decided that the plaintiff, if he succeeded, was entitled to the recovery of the land itself; so that any person who had been ousted of land in any way whatever brought his action in this form, the title to the land being decided by it, and not only the question of damages).

The action commenced with a declaration by a fictitious plaintiff (John Doe) against a fictitious defendant (John Roe) complaining that the real claimant, A, having granted a lease for a term of year's to Doe, and Doe having entered, the defendant Roe ousted him, for which Doe claimed damages; a notice to the real tenant in possession (i.e. the defendant, B) was subjoined, to the effect that Roe was sued as casual ejector only, and would make no defence. Therefore, if $B$ wished to defend his title he had to appear in court the following term, otherwise judgment would be given against Roe, and $B$ would be turned out of possession. In the following term $A$, the real plaintiff (called the lessor of the plaintiff), moved the court in the name of Doe for a rule for judgment against the casual ejector (Roe). The court then granted a rule nisi, that is to say, the rule would be made absolute unless in the time named the defendant $B$ appeared to plead. If $B$ now wished to defend, he had to sign a consent rule, which confessed possession on his part, the lease made by the lessor of the plaintiff, the entry of the plaintiff, and the ouster by himself as alleged. He was then allowed to enter an appearance and plead not guilty. The issue was then sent for trial as an action at the suit of Doe on the demise of $A$ (the lessor of the plaintiff) against $B$, the defendant in possession, and 
the real question turned on the point whether $A$ had a good title to demise to Doe on the day stated. A (lessor of the plaintiff) was bound to make out a clear title, otherwise he lost the action; but if he did so, then he obtained judgment and a writ of ejectment (n). Now by the effect of the Common Law Procedure Act, 1852, and of the Judicature Acts, an action for the recovery of land is commenced with the ordinary writ of summons indorsed with a claim for the recovery of the land in question, and no other claim may be joined with it (except by leave of the court) except for mesne profits, arrears of rent, or damages for breach of corenant (Order XVIII. 22); the usual pleadings, statement of claim, defence, and reply follow as in the ordinary course of an action.

We may here also notice fines and recoveries. These were a species of fictitious or collusive action, which had the effect of conveyances by matter of record; originally they were actions commenced in the Court of Common Pleas at Westminster for the recovery of land, but erentually they were adopted as a means of conveying estates where the ordinary conveyances could not be brought into play, and more particularly in the case of entailed estates. In such cases they were merely collusive actions.

Fines.-These were of very ancient origin, dating back to a period prior to the Norman Conquest.

The statute $18 \mathrm{Ed}$. I. (called Modus Levandi Fines) regulated the procedure. They were so called because they put an end to all other suits concerning the same land. The party leying the fine (who was always in collusion with the defendant) was called the cogmizor, and the person to whom it was levied (or the defendant in the action) the cognizee. The point of the action consisted in an acknowledgment made in the Court of Common Pleas by the defendant that the land in question was the plaintiff's.

The concluding stages of the action were (1) the note of the fine, which was an abstract of the writ, and the acknowledgment or concord, and which was enrolled in the proper office; (2) the foot of the fine, which recited the whole pro-

(n) See Steph. Comm., iii. 424 et seq.; Bl. Comm., iii. 177 et seq. 
ceedings at length. Of this indentures were made amd delivered to the cognizor and cognizee (or plaintiff and defendant).

By 4 Hen. VII. c. 24 it was enacted that a fine after leing engrossed should be openly proclaimed in court sixteen times, and these proclamations were endorsed on the record.

Fines were of four kinds: (1) The fine Sur cognizance de droit come ceo que il ad de son don, which operated to pass an estate in fee-simple or for life, an acknowledgment of a former feoffment being made in court; (2) Sur cognizance de droit tantum, which passed a reversionary interest after the particular estate determined; (3) Sur concessit, when a new estate for life or years was granted, reserving a rent; (4) Sur don grant et render, which was used to create particular limitations. Fines then became one of the common methods of conveying estates, and by $32 \mathrm{Hen}$. VIII. c. 36 it was enacted that a fine levied with proclamations should bar all those claiming under an entail, but not those in reversion or remainder $(o)$.

Recoveries.--These were also collusive actions in which the plaintiff (the recoveror) recorered the land in question from the defendant (the recoveree) in an action carried through all its stages.

A fictitious person (called the common ronchee), generally the crier of the court, was brought into the action, who was supposed to have warranted the title to the defendant. But he making default, by understood arrangement, in showing his title, judgment went for the plaintiff, the defendant being left to get land of an equal value from the common vouchee under the warranty, which, of course, he never did, the whole action resulting as an absolute converance from the defendant to the plaintiff $(p)$.

The principal use of recoveries was to convey entailed estates, for it was decided in Taltarum's Case $(q)$ that a common recovery suffered by tenant in tail should convert

(o) Bl. Comm., ii. 302 et seq.; Steph. Comm., i. 540 et seq.

(p) See Steph. Comm., i. 547 et seq.

(q) (1472) Year Book, 12 Ed. IV. 14, 19. 
the estate into a fee-simple absolute, barring not only those claiming under the entail, but those in reversion and remainder also. These methods of conveyancing being found intricate and costly, an Act was passed in $1834(r)$ for the abolition of fines and recoveries and the substitution of more simple modes of assurance.

With regard to estates tail, a simple deed enrolled in Chancery within six months of execution is substituter, subject to the provisions in the Act as to the consent of the protector (if any) of the settlement.

Fines and recoveries were also used to pass the estates of married women, but by the same Act a married woman is empowered to convey her estate as if she were a feme sole, provided that at the time of the execution of the deed an acknowledgment be made by her before the proper authorities appointed for that purpose, the woman being examined apart from her husband. By the Converancing Act, 1882. s. 7, a memorandum of such acknowledgment in the cases in which it is required is simply made at the foot or in the margin of the deed, the acknowledgment being taken before one commissioner instead of two; and by the Married Women's Property Act, 1882, a married woman may now in all cases convey her separate estate as a feme sole without acknowledgment, provided she was married, or the property accrued to her, after the date of the Act.

\section{Trial by Jury.}

The Civil Jury.- Some sort of trial by jury no doubt existed in civil cases in Anglo-Saxon times, but the jurors were the suitors of the court and swore to the facts of their own knowledge. The modern jury, however, had its origin in the system of inquest introduced by the Normans, and which Henry II. used in the grand and petty assizes referred to above. The grand assize was composed of twelve knights of the neighbourhood, who were themselves chosen by four linights appointed for the purpose in the presence of the justices. The petty assize was composed of twelve freemen chosen by the sheriff. 
In an action for the recovery of land the defendant might choose battle, which was fought ont by champions, and not as in crimimal cases by the parties themselves (s), or he might put himself upon the country, that is to say, he might have the matter tried by the new assizes. The jurors combined the functions of the modern jury and of witnesses, and spolie from their own knowledge of the facts (de proprio visu et auditu). In a small society this was perhaps possible; but as the community grew it would become difficult to find twelve men who knew the facts, and it became the jurors' duty to make inquiries from those who did know. Gradually documents, charters, etc., could be used as evidence, and the jurors could listen to persons produced in court by litigants. Still the juror's were bound to be of the vicinage, and up to the reign of Elizabeth it was a cause of challenge to a juror that he was not a hundredor. Some hundredor's were required to be present up to the reign of Anne, when it was enacted $(t)$ that the absence of hundredors should not be a cause of challenge to the jury. The jury were now summoned independently of any knowledge of the case they might be supposed to possess, and the practice of summoning witnesses who had that linowledge and could expound it to the jury became firmly established through actual necessity. Thus the jury, who had originally acted both as witnesses and judges, eventually acted in the latter capacity alone. In the year $1851(14 \& 15$ Vict. c. 99$)$ the parties to a civil action became competent witnesses.

By the Aliens Restriction (Amendment) Act, 1919 (9\& 10 Geo. V. c. 92), s. 8, no alien shall sit upon a jury in any judicial or other proceedings if challenged by any party to such proceedings.

Women are now liable to serve on juries, whether civil or criminal, and a jury may be composed of women only, but they may be exempted from service by reason of the nature of the evidence or of the issue to be tried $(u)$.

By the Administration of Justice Act, 1920, the court or a judge has power, subject to the prorisions of the Act,

(s) See BI. Comm, iii. 338 et seq.

(t) 4 \& 5 Anne, c. 16.

(u) 9 \& 10 Geo. V. с. 71. 
to order any action or matter in the High Court to be tried without a jury $(x)$.

The Criminal Jury.-Trial by battle, as we have seen, was introduced by the Normans, and this was incidental to the mode of criminal accusation known as appeal $(y)$. Usually, however, the accusation was brought in the first instance by indictment or the presentment of twelve knights of the shire, and appeal and battle were only resorted to in case the relatives were greatly dissatisfied with the verdict. Criminal appeals were not abolished until 1819, consequent upon the case of Ashford v. Thornton (z). Ashford appealed Thornton in the King's Bench on a charge of murder, and Thornton wagered battle. In consequence the 59 Geo. III. c. 46 was passed abolishing criminal appeals.

In Anglo-Saxon times it was the practice for twelve thegns of each wapentake to present criminals, and this appears from a law of Ethelred. No doubt this practice continued after the Conquest, but the criminal jury is first mentioned in the Assize of Clarendon, 1166. Br the Assize of Northampton, 1176, all criminals aceused before the justices on the oath of twelve linights of the shire, or on the oath of twelve lawful freemen and of four men from each town, were to go to the ordeal of water. If he failed at the ordeal he was to lose a foot and a right hand, and exile himself within forty days. But in cases of nurder or baser felony he must abjure the kingdom in forty dars, whether acquitted by the ordeal or not. When ordeal was abolished by the Lateran Council in 1215 no method remained of testing the truth of the accusation brought by the presenting jury; thus the practice arose of allowing a second or petty jury to try the truth of the accusation. The accused was not compelled to plead, but if he stood mute he had to undergo the peine forte et dure, which consisted in pressing the defendant with heavy weights and feeding him on bread and water on alternate days. The peine forte et dure existed down to

(x) 10 \& 11 Geo. V. c. 81, s. 2.

(y) For examples of procedure by battle see Lowe v. Paramour (1571) Dyer, 301 ; Claxton v. Lilburn (1638) Lea, 244.

(z) (1818) 1 B. \& Ald. 457 . 
1726 (a), but has long since fallen into disuse, and by the 12 Geo. III. c. 20 it was enacted that in cases of felony standing mute should be equivalent to a conviction, and by the $7 \& 8$ Geo. IV. c. 28 , in case of a person standing mute in treason, felony, piracy, or misdemeanour, the court may order the proper officer to enter a plea of not guilty on his behalf, and such plea is to have the same effect as if the prisoner himself had pleaded not guilty.

At first the petty jury, like the grand jury, spoke from their knowledge of the facts, and not from evidence given in court; later on, witnesses and documents were allowed to supplement the knowledge of the jurors, and under Henry IV. the practice of hearing evidence in open court became established. In the reign of Mary the jury were not summoned on account of their special knowledge of the facts, rather they were supposed to be in ignorance, and it has remained so up to the present day.

Procedure before and after the Revolution.-(1) Before the Revolution of 1688 the prisoner was kept in more or less secret confinement, and could not prepare lis defence.

(2) No notice was given him of the evidence to be produced against him.

(3) There were no rules of evidence, nor was he confronted with the witnesses.

(4) He had no counsel before or at trial.

(5) $\mathrm{He}$ was not allowed to call witnesses on his own behalf, and if he did they were not examined on oath.

After the Revolution of 1688 . (1) In $1695 \quad$ (7 \& 8 Will. III. c. 3) persons indicted for high treason or misprision of treason were to have a copy of the indictment five days before trial; they could summon witnesses on oath, and counsel were allowed to defend.

(2) In 1708 (by the 7 Anne, c. 29) the prisoner could have a list of the witnesses and jury ten days before trial.

(3) In 1702 (by the 1 Anne, st. 2, c. 29) in treason and felony the prisoner's witnesses were to be sworn.

(4) By 6 \& 7 Will. IV. c. 114 all prisoners accused of

(a) Burnwater's Case. See ante, p. 218; Steph. Hist. Crim. Law, i. 298 .

C.L.E. 
felony may be fully defended by counsel; and a person committed for trial or held to bail may have a copy of the depositions of the witnesses taken against him.

(5) Now, by the Criminal Evidence Act, 1898 (b), every person charged with an offence, or the wife or husband of the person charged, is rendered a competent witness in all cases, but only upon the application of the person charged and subject to the provisions of the Act.

The Independence of Juries.- Juries were not at first independent, and were liable to be fined and imprisoned for a wrong verdict. There was possibly some reason for this when the jury gave a rerdict from their own knowledge, for in the case of a wrong verdict they would then be committing perjury, and where this was suspected, the first jury were put upon their trial before a second or grand jury of twenty-four by writ of attaint. If the verdict went against them, they were imprisoned for a year, forfeited all their goods, and were rendered infamous for ever (c). Attaint seems to have fallen into disuse, but was not finally abolished until $1825(d)$. Juries were, however, frequently fined by the Star Chamber for giving a rerdict manifestly against the weight of evidence, or contrary to the direction of the judge $(e)$. Thus in 1534, Sir Nicholas Throckmorton having been accused of treason, and acquitted by the jury, the latter were brought before the Star Chamber and imprisoned; four of their number were released on acknowledging their offence, but the remainder were fined, some $£ 2,000$, others 1,000 marks; but it appears these penalties were subsequently reduced $(f)$.

After the reign of Elizabeth there were not many cases of this kind, but after the Restoration two successive chief justices (Hyde and Keeling) revived the practice, which was declared illegal by a Resolution of the House of Commons in $1667(g)$. Eventually, in 1670, the independence of juries was finally established by Bushell's Case (h).

(b) 61 \& 62 Vict. c. 36.

(d) 6 Geo. IT. c. 50 , s. 60 .

(c) Bl. Comm., iii. 389 et seq.

(c) See 23 Hen. VIII. c. 3; 13 Eliz. c. $25 ; 11$ Hen. VII. c. 24.

(f) (1554) 1 St. Tri. 869.

(g) Journ. H. of Com., the 16th of Oct. 1667.

(h) (1670) St. Tri. 999. 
In this case the recorder of London, on the acquittal of Penn and Mead on a charge of unlawful assembly for having preached in the streets of London, fined the jury 40 marks each. One of the jurors, Bushell, was committed for nonpayment of the fine. Thereupon he sued out a writ of habeas corpus, and on the return to the writ in the Common Pleas, Mr. Justice Vaughan held that the grounds of the commitment were insufficient. Since then the independence of juries has not been questioned.

We may note that if the grand jury consider there is sufficient evidence they find a true bill; if not, they ignore the bill. The most notable case of this was Shaftesbury's Case in 1681, when, the accused being brought before a grand jury on a charge of high treason, the latter returned au ignoramus, although he was manifestly guilty.

The power of a judge to dismiss a jury who, after a reasonable time has elapsed, cannot agree on a verdict, was not settled until the case of Winsor v. The Queen in 1866 (i).

\section{The Legal Profession.}

Origin.-In early times there was no trained class of lawyers, and in the reign of Henry III. laymen and clerics seem to have been appointed judges of the King's Court indiscriminately, no particular knowledge or study of the law being essential to the holding of such a post.

In very early days a litigant appears to have been allowed (except in cases of felony) to bring with him into court friends with whom he might confer before pleading, and a practice seems to have sprung up as early as the reign of Henry III. of allowing a friend (amicus curix) to address the court on his behalf $(k)$. In these unprofessional friends, who took no remuneration for their services, we can trace the origin of the present solicitors and counsel.

By the Statute of Merton, 1236, the right was conceded to every freeman of being represented by attorney at the county, trything, hundred, wapentake, and manorial courts $(l)$. At this period there seems to have been per-

(i) (1866) L. R. 1 Q. B 289.

(b) Pol, \& Mait., i. 190.

(l) $20 \mathrm{Hen}$. III. c. 10 
mitted also a countor or advoeate, who eould address the court (corresponding to the old amicus curic), whilst the attorney, who was at first merely a lay friend, simply represented the litigant in court, and whether the latter was allowed to address the court seems open to doubt.

In the reign of Edward I. a definite class of professional lawyers first appears. The King had a number of trained pleaders styled serjeants-at-law (servientes ad legem), and there were also about the courts a number of young men, the apprentices of the serjeants (apprenticii ad legem), engaged in the study of the law $(m)$.

About this period (towards the close of the thirteenth century) it seems that the two professions of attorney and countor (or serjeant-at-law) became definitely separated, the mayor and aldermen of London having passed an ordinance that no countor was to practise as an attorncy $(n)$. From this point, then, we may consider the two professions separately.

Barristers.-The old informal class of advocates, then, represented by the amicus curice and later on the countor, seem to have formed themselves into a definite professional body about the reign of Edward I. The English law had now become systematized by the writings of such men as Glanvill and Bracton, and from 1292 onwards we get the Year Books giving the reports of cases and legal decisions, so that it became more and more necessary to have trained adrocates as the weight of precedent and the consequent. necessity for the knowledge of case law grew. Another factor which tended to promote the growth of a professional class of advocates was the fixing of the Court of Common Pleas at Westminster, which took place in the reign of Henry III., it having previously been made a provision of Jolm's Great Charter that the Common Pleas should no longer follow the king. Later on the King's Bench followed the example of the Common Pleas and sat only at. Westminster.

Thenceforth the professors of English municipal law formed themselves into an aggregate body, and as the

(m) Pol. \& Mait., i. 194.

(ii) Ib., i. 195 . 
universities confined their teaching to the civil or Roman law, and as in that alone degrees were conferred by them, it became necessary to establish colleges of their own in which the English common law might be taught and degrees conferred.

Accordingly they purchased various houses known as the Inns of Court and of Chancery situated between Westminster and the City of London, in which the sons of gentry, noblemen, and others resided to pursue the study of the common law, and in which degrees were conferred; and these societies were further fostered by an order issued by Henry III. in the nineteenth year of his reign to the mayor and sheriffs of London, which prevented any law schools within the city from teaching laws; so that the Inns of Court and Chancery thus obtained a monopoly of legal tuition $(o)$.

The younger students were generally placed in the Inns of Chancery, but as by the 25 Hen. VIII. c. 21 it was declared that the people of England were "free from any man's laws, and subject only to such as have been devised, made, and ordained within this realm," or to such others as by the sufferance of the Crown " the people of this realm have taken at their free liberty by their own consent to be used among them," and consequently the validity of the civil and canon law depended on its adoption by statute or long usage into our own common law, the universities gave up the teaching of the civil and canon law, and took to the English common law.

It became, therefore, the custom for those younger students to seek their education in the common law at the universities rather than at the Inns of Chancery, which latter gradually fell into disuse.

The Inns of Court however remained, and still have the exchusive privilege of conferring the degree of " Barristerat-law."

There are now four Inns of Court, viz. Lincoln's Inn, Gray's Inn, and the Inner and Middle Temples. In order to take his call to the bar, which he must do to enable him to practise as an advocate, a student must now enter his

(o) See Steph. Comm., i. 16. 
name at one of these four Inns, and in general must have kept commons for twelve terms (there being four terms in each vear). In addition, he must have passed the examinations in the various subjects prescribed by the consolidated regulations.

In early times the serjeants (servientes ad legem) were the highest rank of barristers; they were appointed from the apprentices (apprenticii ad legem) of sixteen years' standing by writ of summons under the Great Seal issued by the King in Council $(p)$, and the call to the coif $(q)$ was marked by various impressive ceremonies. Until the Judicature Act of 1873 came into force, judges were always appointed from amongst the serjeants, who ranked socially but not professionally before the ling's counsel, and even the attorney-and solicitor-general. The Judicature Act, 187:, provided that any barrister of ten years' standing may be appointed a judge of the High Court of Justice, and any person who before the Act was qualified to be a judge of appeal in Cliancery, or any judge of the High Court of not less than one year's standing, may be appointed an ordinary judge of the Court of Appeal; the degree of serjeant-at-law is no longer a necessary qualification in either case $(r)$. Since this provision came into force the degree of serjeant and the order of the coif has fallen into disuse, and the serjeants sold their inn in Chancery Lane (known as Serjeants' Inn) in 1877 , their numbers being then very small. The origin of the attorney-and solicitor-general is to be found in the attornati regis, appointed as early as $1279(\mathrm{~s})$, and up to the seventeenth century there were no other ling's counsel recognized than the king's serjeants $(t)$ and the attorney- and solicitor-general $(u)$.

(p) See Pulling's Order of the Coif, p. 31.

(q) The Coif was the name given to the peculiar headdress worn by the serjeants, consisting of a white covering of lawn or silk surmounted by a black skull cap of silk or velvet. The modern representation of this headdress is the small black patch surrounded by a white border upon the top of the wig. (See $I b$. pp. 13 et seq.)

(r) 36 \& 37 Tict. c. 66, s. 8. By 14 \& 15 Vict. c. 83, s. 1, any barrister of fifteen years' standing might be appointed a lord justice of appeal in Chancery.

(s) Pulling's Order of the Coif, p. 181.

(t) The king's serjeants were of higher degree than the ordinary serjeants.

(u) Pulling's Order of the Coif, p. 185. 
In $1604 \mathrm{Sir}$ Francis Bacon was appointed king's counsel extraordinary, but merely it seems honoris causî; and this example was followed in 1668 by Francis North (afterwards Lord Guildford), who obtained a patent as king's counsel without having taken the degree of serjeant $(x)$. During the reigns of William, Mary, and Anne no king's counsel were appointed, but from the end of the eighteenth century $(y)$ onwards they became recognized as a distinct class or order, and have continued to grow to their present numbers and importance.

Originally, as we have seen in criminal cases, the prisoner was not allowed the benefit of counsel to defend him, but gradually in cases of felony it became the custom to allow counsel to conduct the prisoner's case, but not apparently to address the jury for him. In 1836 prisoners accused of felony were statutorily permitted to be fully defended by counsel $(z)$.

The admission of women to the Bar of England has now been legalised by the Sex Disqualification Removal Act, 1919.

Solicitors.-As we have seen by the Statute of Merton, 1236, every free man might be represented at the county, trything, hundred, and manorial courts by attorney. In the reign of Edward I. attorneys had ceased to be lay friends casually assisting in suits, and had become a professional class accepting payment for representing their clients (a.), and various statutes were passed in that and succeeding reigns permitting attorneys to act instead of the parties themselves in a variety of causes and matters $(b)$. Soon their numbers increased very greatly, and it being found that many of them were ignorant and incompetent men, the

(x) Pulling's Order of the Coif, p. 189.

(y) In 1775 there were fourteen king's connsel ( $I b .193$ ).

(z) $6 \& 7$ Will. IV.c. 114. Previously to this, by the $7 \& 8$ Will. III. c. 3, prisoners accused of treason, or misprision of treason, might be defended by counsel.

(a) Pol. \& Mait., i. 192.

(b) As to attorneys acting in wits of assize see statute Westminster I. (1275); as to pleas touching wounds and maims, 6 Ed. I. c. 1; as to attorneys generally, $13 \mathrm{Ed}$. I. st. 1, c. 10: as to persons unable to travel, 27 Ed. I. st. 2 ; in novel disseisin, 13 Ed. II. c. 1 ; persons leaving the realm, 7 Ric. II. c. 14 ; pauper litigants, 11 Hen. VII. c. 12. 
4 Hen. IV. c. 18 enacted that all attorneys should be examined by the justices, and at their discretion their names put on the roll, which is perhaps the origin of the roll of attomeys. In the reign of Henry VI. and later on in the reign of Janes $I$. it hecame necessary to limit the numbers of attorners, and an Act was passed in 1605 (c) " to reform the multitudes and misdemeanours of attorneys and solicitors at law, and to avoid mnecessary suits and charges in law.'

Here we notice the occurrence of the term solicitor. $\mathrm{He}$ appears to have transacted business in the Equity Court, while the attomeys were confined to the common law courts $(d)$. But, unlike the attorners, solicitors were at first subject to no rules as to qualification. In 1729 the 2 Geo. II. c. 23 was passed " for the better regulations of attorneys and solicitors.'

By this Act none were allowed to practise unless they had been enrolled and taken the oath to act "truly and honestly" ; further, he must have been examined by the judges, and have served as a clerk for five years.

Acts continued to be passed regulating the practice and charges of solicitors and attorneys, and especially with regard $\left.t_{1}\right)$ their education and examination, and in 1836 the first examination of clerks desiring to be admitted was held.

The old distinction between attorneys and solicitors had gradually disappeared and they are now lnown generally as solicitors, and their practice, the rules for their education, admission, and enrolment are embodied in a rariety of Acts the principal of these being the Solicitors Act, 1843, the Solicitors' Remuneration Act, 1881, the Solicitors Act, 1888, and the rules and orlers made thereunder.

It will be sufficient to state here that in order to become qualified to practise a person must in general have served a term of five years (in some cases four) as an articled clerk to a solicitor, and must in addition have passed a preliminary, an intermediate, and a final examination. These examinations are held undel the management of the Law Society, a hody which originated in 182.5 to look after the interests of the profession. Haring serred the necessary term under

(c) 3 Jas. I. c. 7 .

(d) See Christian, Hist. Solicitors, 70 et seq. 
articles and passed the prescribed examination, the intending solicitor may then, on parment of the necessury fees, be admitted and enrolled, after which he becomes qualified to practise.

A woman is now entitled to be admitted and enrolled as a solicitor after serving under articles $(e)$.

By the Solicitors Act, 1919, the porrer to strike a solicitor off the Rolls is given to the Committee of the Law Society $(f)$.

(e) $9 \& 10$ Geo. V.c. 71 , s. 2.

(f) $I b .$, c. 56, s. 5 . 
Chapter IV.

CHANGES UNDER THE JUDICATURE ACTS, 1873 TO 1910 , ETC.

Superior Courts before the Judicature Acts.

WE have seen what the judicial institutions of the kingdom were up to the year 1873, the date of the first Judicature Act $(a)$, which came into force on the 1st of November, 1875, by virtue of the Supreme Court of Judicature (Commencement) Act $(b)$ of that year. It remains to see the changes brought about by that and the succeeding Acts.

Briefly, before the Judicature Acts the superior courts of first instance were as follows:-

(1) The King's Bench, presided over by the lord chief justice and puisne judges.

(2) The Common Pleas, presided over by the lord chief justice of the Common Pleas and puisne judges.

(3) The Court of Exchequer, presided over by the lord chief baron and barons of the Exchequer. From these three courts appeal lay to the Exchequer Chamber, and thence to the House of Lords.

(4) The Court of Chancery, presided over by the lord chancellor, with the master of the rolls and three vice-chancellors.

(5) The High Court of Admiralty, presided over by a judge who sat as the lord high admiral's deputy. Appeal lay at first to the Court of Delegates, and later, by $3 \& 4$ Will. IV. c. 41 , to the judicial committee of the Privy Council.

(6) The Court of Bankruptcy, established in 1831 (c),

(a) $36 \& 37$ Vict. c. 66.

(b) $37 \& 38$ Vict. c. 83 , s. 2 ; and see $38 \& 39$ Vict. c. 77, s. 2, and the App. Jur. Act, 1876, s. 24.

(c) 1 \& 2 Will. IV. c. 56. 
and presided over by a chief judge and other judges.

Appeal lay to the lord chancellor.

(7) The Court of Probate, presided over by the judge of the Probate Court. Appeal lay to the full Court of Divorce.

(8) The Court for Divorce and Matrimonial Causes, presided over by the judge ordinary, who was the same person as the judge of the Probate Court.

(9) The Chancery Court of Lancaster.

(10) The Court of Common Pleas at Lancaster, and the Court of Pleas at Durham.

(11) The Court of the Stannaries in the Duchy of Cornwall $(d)$.

\section{The Supreme Court of Judicature.}

By the Judicature Act, 1873, which came into force on the 1st of November, 1875, the former courts of King's Bench, Common Pleas, Exchequer, Chancery, Probate, and of Divorce and Matrimonial Causes were united into the Supreme Court of Judicature. The Supreme Court of Judicature was subdivided into two divisions, namely, his Majesty's High Court of Justice and his Majesty's Court of Appeal. The Court of Bankruptcy remained as a separate court until the Bankruptcy Act of $1883(e)$, when it became part of the Supreme Court, its jurisdiction being merged in that of the High Court. The Chancery Court of Lancaster was left untouched by the Judicature Acts, but the jurisdictions of the Court of Common Pleas at Lancaster and of the Court of Pleas at Durham were merged in that of the High Court.

\section{His Majesty's High Court of Justice.}

The High Court of Justice, under the Act of 1873, comprised the following divisions:-

(1) The Chancery Division, consisting of the lord chancellor as president, the other judges being the master

(d) The jurisdiction of the Stannary courts was, however, handed over to the county courts in 1896 (59 \& 60 Vict. c. 45).

(e) 46 \& 47 Vict. c. 52 , s. 92 et seq. 
of the rolls and the three vice-chancellors. The master of the rolls became a permanent judge of the Court of Appeal by the Jndicature Act, $1881(f)$, and has therefore ceased to act as a judge of the Court of Chancery; whilst the vice-chancellors have been replaced by those judges of the High Court who are attached to the Chancery Division, and who are now six in number.

(2) The King's Bench Division, consisting of the lord chief justice of England and some of the former justices of the King's Bench.

(3) The Common Pleas Division, consisting of the lord chief justice of the Common Pleas as president, with some of the former justices of the Common Pleas. To this division was assigned the jurisdiction exercised by the former Court of Common Pleas, of the Court of Common Pleas at Lancaster, and of the Court of Pleas at Durham.

(4) The Exchequer, consisting of the lord chief baron of the Exchequer, and some of the former barons of the Exchequer.

(5) The Probate, Divorce, and Admiralty Division, consisting of the former joint judge of the Court of Probate and of the Court of Divorce and Matrimonial Causes as president, with the judge of the former Court of Admiralty or his successor. To this division is assigned the jurisdiction of the former Courts of Probate, of Divorce and Matrimonial Causes, and of the Court of Admiralty.

By Order in Council of the 16th of December, 1880, the King's Bench, Exchequer, and Common Pleas Divisions were amalgamated into the King's Bench Division of the High Court of Justice. The lord chief justice of England is the president, and the powers of the former chief justice of the Common Pleas and of the chief baron of the Exchequer (these two offices being abolished by the Order) are rested in lim. The other judges of the King's Bench are now under the Judicature Act, $1910(g)$, sixteen in number.

(f) S. 2.

(g) 10 Ed. VII. \& 1 Geo. V.c. 12 , s. 1. 
The High Court of Justice, therefore, now comprises three divisions-

(1) The King's Bench Division, consisting of the lord chief justice of England as president, and fifteen other judges $(h)$.

(2) The Chancery Division, consisting of the lord chancellor as president and six other judges.

(3) The Probate, Divorce, and Admiralty Division, consisting of the president and one other judge.

The Chancery Court of Lancaster still remains untouched.

Jurisdiction.-To the King's Bench has been assigned the former jurisdiction of the Courts of Common Pleas, King's Bench, and Exchequer, together with the jurisdiction formerly exercised by the Court of Common Pleas at Lancaster and the Court of Pleas at Durham (i).

To the Chancery Division the Judicature Act of $1873(k)$ especially assigned jurisdiction in the following causes and matters, in addition to the exclusive jurisdiction which it already possessed by statute:-

(a) Administration of the estates of deceased persons.

(b) Dissolution of partnerships, or the taking of purtnerships or other accounts.

(c) Redemption and foreclosure of mortgages.

(d) Raising of portions or other charges on land.

(e) Sale and distribution of property subject to any lien or charge.

(f) Execution of trusts, charitable or private.

(g) Rectification or cancellation of deeds or other written instruments.

(h) Specific performance of contracts with regard to realty, including leases.

(i) Partition or sale of real estates.

(h) The two additional judges recently appointed are not necessarily a permanent increase.

(i) By the joint effect of the Judicature Act, 1873, s. 34, and Order in Council of the 16th of December, 1880.

(k) S. 34 . 
(j) Wardship of infants, and the care of infants' estates $(l)$.

Rules of Law.-By the Judicature Act of $1873(\mathrm{~m})$ the following rules of law, amongst others, are to be observed in future :-

(1) No claims of a cestui que trust for any property held upon an express trust, or in respect of any breach of such trust, is to be barred by any Statute of Limitations. This provision, however, must now be taken in conjunction with section 8 of the Trustee Act, 1888, which enacts that trustees are to enjoy the privileges of any Statute of Limitations in the same way as other persons, except (a) where the claim is founded upon any fraud or fraudulent breach of trust to which the trustee was party $\mathrm{ol}^{\circ}$ privy; or (b) to recover trust property still retained by the trustee or previously received and converted to his own use $(n)$.

(2) An estate for life without impeachment of waste is not to confer upon the tenant the right to commit equitable waste, unless such an intention expressly appears by the instrument creating the trusts.

(3) There is not to be any merger by operation of law only where the beneficial interest would not be deemed to have merged in equity.

(4) A mortgagor entitled to possession or the receipt of the rents and profits may sue for such possession or the recovery of the rents and profits in his own name without joining the mortgagee.

(5) An absolute assignment in writing of any debt or legal chose in action, of which notice in writing shall have been given to the debtor or other person from whom the assignor would hare been entitled to claim, shall pass and transfer the legal rights to

(l) Amongst other matters now assigned to the Chancery Division are those arising under the Conveyancing and Sottled Land Acts and Bankruptey business.

(m) S. 25 .

(n) 51 \& 52 Vict. c. 59 , s. 8 . 
such debt or chose in action, and enable the assignee to give a good discharge for the same.

(6) Stipulations in contracts as to time or otherwise which would not, before the passing of the Act, have been considered in equity as of the essence of the contract, are to have the same construction and effect in all courts as they would have received in equity.

(7) By the Judicature Act, 1875, on the death of an insolvent debtor, or in the winding-up of the affairs of an insolvent company, the same rules are to be observed in the administration of the estate as are in force with regard to persons adjudged bankrupt (o). Generally it was enacted by the Judicature Act, 1873, that law and equity are to be concurrently administered in every court, and that where the rules of law and equity clash, the latter are to prevail.

Remedies and defences which had hitherto been appropriate only in the Court of Chancery, may now be given effect to in either division $(p)$ (e.g. injunctions, specific performance).

Any barrister of ten years' standing may be appointed a judge of the High Court $(q)$. Judges are appointed by the Crown on the advice of the lord chancellor. They hold office during good behaviour, subject to removal by his Majesty on an address from both Houses of Parliament $(r)$. A judge on circuit sitting under his Majesty's commission is to be deemed to be a court of the High Court of Justice (s).

\section{Courts of Appeal before the Judicature Acts.}

These were-

(1) The Court of Exchequer Chamber, to which appeals lay from the King's Bench, Common Pleas, and Exchequer, and from the Courts of Common Pleas of Lancaster and the Court of Pleas of Durham.

(o) Judicature Act, 1875, s, 10.

( $p$ ) A general statement of the effect of s. 21 of the Judicature Act, 1873.

(q) Judicature Act, 1873, s. 8.

(r) Ib. 1875, s. 5.

(s) $I b .1873$, s. 29. 
(2) The Court of Appeal in Chancery, to which appeals lay from the Court of Chancery and the Chancery Court of Durham.

(3) The Lord Chancellor, to whom appeal lay from the Court of Bankruptcy.

(4) The full Court of Divorce, which heard appeals from the Court of Probate and the Court of Divorce and Matrimonial Causes.

(5) The Court of Appeal in Chancery of the County Palatine of Lancaster, which heard appeals from the Chancery Court of Lancaster.

(6) The Court of the Lord Warden of the Stannaries, sitting with assessors, which heard appeals from the Stannary Courts of Devon and Cornwall $(t)$.

(7) The judicial committee of the Privy Council, to which. appeals lay from the Admiralty Court, from the Channel Islands and all English courts abroad, and appeals in lunacy and ecclesiastical causes.

(8) The House of Lords, which was the ultimate court of appeal from all the above courts, except the Privy Council, from which there was no appeal.

Courts of Appeal since the Judicature Acts.

The Supreme Court of Judicature was divided by the Judicature Act, 1873, into his Majesty's High Court of Justice and his Majesty's Court of Appeal. Both these divisions enjoy certain appellate jurisdiction under the Acts, and these, with the Court of Criminal Appeal established in 1907, the House of Lords and the Privy Council, will now be considered under the following sub-headings. The special modes, or quasi-modes, of appeal in criminal cases as they existed prior to the passing of the Criminal Appeal Act, 1907, and the effect of the latter Act in abolishing writs of error and motions for new trials, will be found fully treated of in the Appendix $(u)$.

(t) The jurisdiction of the Stannary Courts was handed over to the county courts by $59 \& 60$ Vict. c. 45.

(u) See post, App. A. 
The High Court of Justice as a Court of Appeal. The Divisional Court.-By the combined effect of the Judicature Acts of 1873 and 1894, in all cases where there is a right of appeal from any inferior court (viz. county courts, petty and quarter sessions, and the mayor's court in London) or person to the High Court of Justice, the appeal is to be brought in a divisional court of the High Court of Justice The decision of the divisional court is final unless leave t; appeal is given by that court or the Court of Appeal $(x)$. In cases where the decision of the High Court or its predecessor, the superior court, is by statute declared to be final, the right to appeal from the divisional court is absolutely barred $(y)$. This provision embraces all criminal matter's in which appeal lies to the High Court, whose decision is by the Judicature Act, 1873, declared to be final, except in cases of error of law apparent upon the record $(z)$.

A divisional court is constituted of two judges of the High Court (a), or more if the president and two other judges of the division consider it necessary $(b)$. Any judge of the High Court sitting in the exercise of its jurisdiction elsewhere than in a divisional court may reserve any case, or any point in a case, for the consideration of a divisional court, or may direct any case or point in a case to be argued before a divisional court (c).

The Court of Crown Cases Reserved.-This court (the jurisdiction of which has now been handed over to the Court of Criminal Appeal established in 1907, and dealt with under the next sub-heading) was originally created by the Crown Cases Act, 1848, $11 \& 12$ Vict. c. 78 , to settle difficult points of law arising in criminal trials and specially reserved for the decision of that court. The questions of law which might be so reserved are those mentioned in the Crown Cases Act, $1848(d)$, and the decision of the court was final

(x) Judicature Act, 1873, s. 45; Judicature Act, 1894, s. 1 (5).

(y) App. Jur. Act, 1876 , s. 20.

(z) Judicature Act, 1873 , s. 47.

(a) App. Jur. Act, 1876 , s. 17.

(b) Judicature Act, 1884 , s. 4.

(c) $I b .1873$, s. 46 .

(d) Ib. s. 100 ; and see post, App. A.

C.L.E. 
except in case of error of law apparent upon the record, and as to which no question had been reserved (e).

The court was composed of five or more judges of the High Court, of whom the lord chief justice was obliged to be one, unless he certified by writing under his hand, or that of his medical attendant, that he was unable to be present $(f)$.

The jurisdiction of the court in relation to cases stated on a point of law arising in criminal trials under the Crown Cases Act, 1848, and the Judicature Act, 1873, has now been transferred to the Court of Criminal Appeal by the Criminal Appeal Act, 1907 (g), by which the latter court was established.

Prior to the passing of the last-mentioned Act, the stating of a case on a point of law under the Crown Cases Act, 1848, was entirely at the discretion of the judge, commissioner, or justices, who tried the case. Now, under the Act of 1907 , where a person appeals against a conviction on a point of law alone, the Court of Criminal Appeal may require a case to be stated as under the Crown Cases Act, $1848(h)$, and such a case will be heard (semble) by the Court of Criminal Appeal.

The Court of Criminal Appeal. Composition.-This court was established by the Criminal Appeal Act, 1907 (i), in consequence of the growing consensus of opinion as to the necessity for such a court, and as an indirect result of the committee of inquiry into the ease of Mr. Adolf Beck, who was twice wrongfully convicted (viz. in 1896 and 1904) upon a criminal charge $(k)$. The court is composed of the Lord Chief Justice and all the judges of the King's Bench Dirision of the High Court of Justice, any three, or an uneven number, of whom form a quorum (l). The sittings of the

(e) Judicature Act, 1873, s. 47 .

(f) $\mathrm{Ib}, 1881$, s. 15 .

(g) 7 Ed. VII. c. 23 , s. 20 (4).

(h) Criminal Appeal Act, 1907 (7 Ed. VII. c. 23), s. 20 (4).

(i) 7 Ed. VII. c. 23.

(k) See as to this case the first edition of this book (1905). Appendix A., p. 417. The report of the committce did not advocate the creation of a Court of Criminal Appeal.

(l) Act of 1907 . s. 1, as amended by the Criminal Appeal (Amendment) Act, 1908 (8 Ed. VII. c. 46), s. 1. 
court are as provided by rules of court under the Act, and the determination of the appeal is according to the majority of the judges sitting, and, except on questions of law where the court directs to the contrary, judgment is delivered by the president (viz. the Lord Chief Justice, or senior judge), and no separate judgments are delivered. The judgment of the court is final, except where the director of public prosecutions, or the prosecutor, or defendant, obtains the certificate of the Attorney-General that the decision involves a point of law of exceptional public importance, when appeal may be brought to the House of Lords $(m)$.

Jurisdiction.-The provisions of the Criminal Appeal Act, 1907, apply to convictions on indictments, criminal informations, coroner's' inquisitions, and cases dealt with by Quarter Sessions under the Vagrancy Act, 1824, and also to detention in a Borstal institution (n), the operation of the Act being similar in all cases as provided by the Act on indictments. But the Act does not apply to convictions on indictment or inquisition charging a peer or peeress, or person claiming the privilege of peerage, with any offence not lawfully triable by a Court of Assize; nor to convictions on indictment at common law in relation to the non-repair or obstruction of any highway, public bridge, or navigable river $(o)$.

A person convicted on indictment (or in any of the above ways) may appeal either against conviction, or against the sentence passed. The right to appeal is, however, subject to leave of the court, or the judge who tried the case, in certain cases.

(1) He may appeal against conviction without leave on any ground of appeal involving a question of law alone. But in cases where the notice of appeal does not show a substantial ground of appeal the registrar may refer the application to the Court of Criminal Appeal for summary determination, and if the court (which in this case may not be a single

(m) Act of 1907 , s. 1.

(n) 4 \& 5 Geo. V. c. 58, s. 10 (5).

(o) Act of 1907 , s. 20 (2), (3). In the latter class of cases appeal lies as from a verdict at assizes in civil actions, and not under the Criminal Appeal Act. 
judge) considers the appeal frivolous or vexatious, it may (without adjourning the matter for full hearing) dismiss the appeal summarily without calling on any persons to attend or to appear for the Crown $(p)$.

(2) He may appeal against conviction with the leave of the Court of Criminal Appeal (which may be granted by one judge, who may refer to the Court of Criminal Appeal, or, if he refuses leave, the appellant may apply to the court for leave) or upon the certificate of the judge who tried him that it is a fit case for appeal, on any ground involving a question of fact, or law and fact, or any other sufficient ground $(q)$.

(3) He may appeal against sentence with the leave of the Court of Criminal Appeal unless the sentence is one fixed by law, e.g. death in murder cases $(r)$.

Procedure.-Notice of appeal (in cases where leave is not required), or notice of application for leave to appeal must be given within ten days of the date of the conviction in the manner provided by the rules of court made under the Act; and, except in cases involving sentence of death, the time may be extended at any time by the Court of Criminal Appeal or a single judge of that court $(s)$.

The appellant may, if he so desires, present his case and argument in writing instead of by oral argument $(t)$.

No costs are allowed on either side on appeals under the Act $(u)$.

Powers of the Court.-(1) If the Court of Criminal Appeal allows an appeal against conviction, they must quash the conviction and direct a judgment and verdict of acquittal. The court must allow the appeal in the following cases: (a) if it thinks the verdict of the jury was unreasonable, or cannot be supported by the evidence; (b) or that the judgment should be set aside on the ground of wrongful decision of any

(p) Act of 1907, ss. 3, 15 (2).

(q) $I b$. s. $3(2)$.

(r) $I b$. s. 3 (3).

(s) $I b$. s. 7 (1).

(t) $\mathrm{Ib}$.

(u) $I b$. s. 13 (1). 
point of law; (c) or that on any ground there was a miscarriage of justice.

But though the court thinks the case might be settled in farour of the appellant, they may dismiss the appeal if they consider that no miscarriage of justice actually occurred.

If the court does not allow the appeal, it must dismiss it $(x)$.

(2) On an appeal against sentence, the court may quash the sentence and pass such other sentence in substitution as may be warranted in law by the verdict, whether more or less severe $(y)$. But on a plea of guilty they have no power, it seems, to substitute another sentence ( $R$. v. Ettridge) (z).

(3) If it appears to the court that the appellant has not been properly convicted on some count or part of the indictment, but has been properly convicted on some other count or part, they may either affirm the sentence, or pass such sentence in substitution as they think proper and as may be warranted in law by the verdict on the count or part of the indictment on which they think he has been properly convicted $(a)$.

(4) Where on conviction the jury could have found the appellant guilty of some other offence, and on the finding it appears to the Court of Criminal Appeal that the jury must hare been satisfied of facts which proved him guilty of that other offence, they may substitute for the vardict of the jury a verdict of guilty of that other offence, and may pass such sentence, not being greater in severity, as may be warranted in law for that other offence $(b)$.

(5) In the case of a special verdict, where the Court of Criminal Appeal thinks that a wrong conclusion has been arrived at on the effect of the verdict, they may (instead of allowing the appeal) order the right

(x) Act of 1907, s. 4 (1).

(y) Ib. s. 4 (2).

(z) $[1909] 2$ K. B. 24.

(a) Act of 1907 , s. 5 (1).

(b) $I b$. s. 5 (2). 
conclusion to be recorded as appears to be in law required by the verdict, and pass such sentence in substitution as may be warranted in law $(c)$.

(6) If it appears that the appellant, though guilty of some act or omission, was insane, the court may quash the sentence and order the appellant to be kept in custody as a criminal lunatic under the Trial of Lunatics Act, $1883(d)$, in the same manner as if a special verdict had been found by the jury under that Act $(e)$.

Transfer of Jurisdiction, etc.-As previously stated (f), the jurisdiction of the Court of Crown Cases Reserved as to cases stated on a point of law, is transferred to the Court of Criminal Appeal, and power has been given to the latter to require a case to be stated under the Crown Cases Act, 1848 , where the appeal is against conviction on a point of law alone $(g)$.

Writs of error, and the powers and practice existing in the High Court at the time of the passing of the Act in respect of motions for new trials $(h)$, or the granting thereof in criminal cases, are abolished by the Act (i).

On the consideration of a petition for pardon in reference to conviction on indictment, information, etc., or to the sentence (other than sentence of death) passed on a person convicted after the 18th April, 1908, the Home Secretary (or a secretary of state) is empowered to refer the whole case to the Court of Criminal Appeal, which must hear and determine the case as on an appeal by a convicted person; or he may refer any point arising in the case to the court for their opinion. This provision, however, does not extend to Scotland or Ireland, nor is the prerogative of mercy affected by it $(k)$.

His Majesty's Court of Appeal.-Composition.-This court, as established by the Judicature Acts, 1873, 1875,

(c) Act of 1907 , s. 5 (3).

(d) $46 \& 47$ Vict. c. 38.

(e) Act of 1907, s. 5 (4).

(f) See ante, p. 305 .

(g) Act of 1907, s. 20 (4).

(h) See as to the former practice post, App. A.

(i) Act of 1907, s. 20 (1).

(k) $I b$. ss. 19,23 . 
and 1876, was composed of fire ex-officio judges, viz. the lord chancellor, the lord chief justice of England, the lord chief justice of the Common Pleas, the lord chief baron of the Exchequer, and the master of the rolls (l), together with not more than five $(m)$ ordinary permanent judges, styled "lords justices of appeal" (n).

By the Judicature Act, 1881, the master of the rolls was made a permanent judge of the Court of Appeal, and the president of the Probate, Divorce, and Admiralty Division was made an ex-officio judge (o); whilst by Order in Council of the 16th of December, 1880, the offices of lord chief justice of the Common Pleas and lord chief baron of the Exchequer were abolished, and their duties handed over to the lord chief justice of England. By the Appellate Jurisdiction Act, $1913(p)$, the Lords of Appeal in Ordinary were made ex-officio judges of the Court of Appeal, if at the time of their appointment they were judges of the Court of Appeal, or qualified to be such. But they are not required to sit and act as such unless they consent to do so upon the request of the Lord Chancellor. The Court of Appeal, therefore, is now composed of the following ex-officio judges, viz. the lord chancellor, the lord chief justice of England, the president of the Probate, Divorce, and Admiralty Division, and the six Lords of Appeal in Ordinary, together with six permanent judges, viz. the master of the rolls and five lords justices of appeal.

In addition to these the lord chancellor is empowered by the Appellate Jurisdiction Act, 1908, to request the attendance at any time of any judge or ex-judge of the High Court to sit as an additional judge of the Court of Appeal $(q)$.

Ex-lord chancellors are also ex-officio judges of the Court of Appeal, but they are not required to sit and act except

(7) Judicature Act, 1875 , s. 4.

(m) Three under the Judicature Act, 1875, increased to five by the joint effect of the Judicature Act, 1876, s. 15, and the Judicature Act, 1881, s. 3.

(n) This style was conferred by the Judicature Act, 1877, s. 4. Under the Act of 1875 they were styled "justices of appeal."

(o) Judicature Act, 1881, ss. 2, 4. As to precedence, see 10 \& 11 Geo, V. c. 81 , s. 7.

(p) 3 \& 4 Geo. V. c. 21 , s. 2 .

(q) 8 Ed. VII. c. 51 , s. 6 (1); 10 \& 11 Geo. V. c. 81 , s. 8. 
with their consent, upon the request of the lord chancellor $(r)$.

Jurisdiction.-To the Court of Appeal thus constituted was handed over the appellate jurisdiction of the Court of Appeal in Chancery, together with the appeliate jurisdiction of the lord chancellor in bankiruptcy, of the Court of Exchequer Chamber, of the Court of Appeal in Clancery of Lancaster, of the court of the lord warden of the Stannaries sitting with assessors, of the full Court of Divorce, and so much of the jurisdiction of the Privy Council as related to admiralty and lunacy matters $(s)$.

Appeal lies to the Court of Appeal from any judgment or order of the High Court of Justice (ineluding courts of assize), but the following statutory restrictions should be noticed :-

(a) The judgment of a divisional court on an appeal from an. inferior court is final, unless leave to appeal be given by the divisional court or by the Court of Appeal $(t)$.

(b) The judgment of the Court of Crown Cases Reserved (now the Court of Criminal Appeal) was final; and no appeal lay from that court to the Court of Appeal in criminal matters, except for some error of law apparent upon the record (u). The judgment of the Court of Crininal Ippeal is final, except in the cases previously mentioned, when appeal lies to the House of Lords.

(c) No appeal lies, except by leave, from an order made by consent, or as to costs only, which by law are left to the discretion of the judge $(x)$.

(d) An appeal does not lie direct to the Court of Appeal from an order made in chambers $(y)$, unless by

(r) Judicature Act, 1891, s. 1.

(s) $I b .1873$, s. 18 . The appellate jurisdiction of the full Court of Divorce was transferred to the Court of Appeal by the Judicature Act. 1881 , s. 9.

( $t$ ) Judicature Act, 1873, s. 45: Judicature Act, 1894, s, 1 (5).

(u) $I b$, s. 47.

(x) Ib. s. 49 .

(y) $I b$. s. 50. Appeal from a judge in chambers in K. B. D., except in matters of practice and procedure, is to a divisional court (R. S. C., (). 54, 1.23). 
special leave of the judge by whom the order was made or of the Court of Appeal.

(e) No appeal lies where by statute the decision of a court or judge is to be final (z).

(f) Without special leave the decision of the High Court on questions of law in parliamentary and municipal election cases is final (a).

(g) No appeal lies from any interlocutory order or judgment without the leave of the judge or of the Court of Appeal (b).

(h) A decree nisi is appealable without leave (c). But no appeal lies from an order absolute for dissolution or nullity of marriage in favour of any party who, having had time and opportunity, has failed to apply from the decree nisi $(d)$.

An appeal to the Court of Appeal from any decree, final order, or judgment, or to set aside a verdict, finding, or judgment in any trial with a jury in the High Court, is to be heard by three judges of appeal $(c)$. But appeals from an interlocutory order, decree, or judgment are heard by two judges $(f)$. And where all the parties to an appeal or motion before the hearing file a consent, the appeal or motion may in general be heard and determined by tro judges $(g)$.

The Judicature Act, $1875(h)$, empowered the Court of Appeal to sit in two divisions at the same time; by the Judicature Act, 1902 (i); it may now sit in three divisions at the same time.

The House of Lords. - The appellate jurisdiction of this body was threatened by the Judicature Act, 1873 (k), but

(z) App. Jur. Act, 1876, s. 20.

(a) Judicature Aet, 1881, s. 14.

(b) $I b .1894$, s. 1 (1) (b); but see the exeeptions there mentioned.

(c) $\mathrm{Ib} .1894$, s. 1 (1) (b) iv.

(d) $I b .1881$, s. 10 .

(e) $I b .1875$, s. 12 ; Judicature Aet. 1890 , s. 1.

(f) $I b .1875$, s. 12 .

(g) $I b .1899$, s. 1 ; but see the exeeption there mentioned with regard to infants and lunaties.

(h) S. 12 .

(i) 2 Ed. VII. e. 31 , s. 1.

(k) S. 20 , the operation of which was suspended by the Judicature Act, 1875 , s. 2 . 
subsequently confirmed by the Judicature Act, $1876(l)$, and to it now lie appeals from the Court of Appeal in England, and from those courts in Scotland and Ireland from which error or appeal lay to the House of Lords.

Composition.-On the hearing of an appeal there rist he present at least three lords of appeal from amongst the following persons:-

(1) The Lord Chancellor.

(2) The Lords of Appeal in Ordinary (now six in number).

(3) Such Peers as hold or have held high judicial offices.

There are now six lords of appeal in ordinary appointed under the provisions of the Appellate Jurisdiction Acts, 1876 and $1913(\mathrm{~m})$.

A lord of appeal in ordinary ranks as a baron, and may sit and vote in the House of Lords during his life $(n)$. He is also (if a privy councillor) a member of the judicial committee of the Privy Council, and must sit as such, without prejudice to his duties in the House of Lords. The House of Lords may sit as a Court of Appeal during prorogation if the House of Lords during the preceding session so appoints (o). It may also sit during dissolution if authorized by his Majesty under the sign manual $(p)$.

The Judicial Committee of the Privy Council.--Appeals to this court from the ecclesiastical courts, the Channel Islands, and from English courts abroad were left untouched by the Judicature Acts.

Composition.-As originally constituted in 1833 (3 \& 4 Will. IV. c. 41), the members of the judicial committee comprised the lord president, the lord chancellor, such of the members of the Privy Council as hold or hare held

(l) S. 3 .

(m) Two having been appointed under s. 6, and two more under s. 14 of the Act of 1876 respectively. The Act of 1913 raises the number to six.

(n) App. Jur. Act, 1876, s. 6; App. Jur. Act, 1887. s. 2. Until the passing of the latter the lords of appeal in ordinary could only sit and vote during tenure of office.

(o) App. Jur. Act, 1876 , s. 8.

(p) App. Jur. Act, 1876 , s. 9. 
certain offices, inchuding, in ecclesiastical cases, every archbishop or bishop being a privy councillor $(q)$. By the Judicial Committee Act, $1871(r)$, four paid nembers were added.

The six lords of appeal in ordinary have now taken the place of the four paid members of the judicial committee $(s)$, whilst the posts which constitute "high judicial office" are defined by the Appellate Jurisdiction Act, $1887(t)$. Former chief justices or judges of the superior courts in various colonies, being members of the Privy Council, are also to bs members of the judicial committee, their number not exceeding seven, under the Judicial Committee Amendment Act, 1895, and the Appellate Jurisdiction Act, 1913; and by the Appellate Jurisdiction Act, 1908, former chief justices or judges of any high court in British India, being members of the Privy Council, may be members of the judicial committee (but not exceeding two in number) if his Majesty so directs $(u)$. Such archbishops and bishops as are privy councillors no longer sit as members of the committee, but may be called in as assessors $(x)$.

Under the original Act four members formed a quorum $(y)$, but this number was reduced to three by the $6 \& 7$ Vict. c. 38 .

Industrial Courts.-Reference may here be made to the Industrial Courts Act, 1919 (9\& 10 Geo. V. c. 69) by which an Industrial Court and Courts of Inquiry in connection with trade disputes were established. The Industrial Court consists of persons appointed by the Minister of Labour some of whom are to be independent, some representing employers, some representing workmen, and one or more women. The Minister may refer any trade dispute to a Court of Inquiry appointed by him, which shall consist of a chairman and other persons or of one person.

(q) $3 \& 4$ Will. IV. c. 41 , ss. $1,6,16,30$.

(r) $34 \& 35$ Vict, c. 91.

(s) App. Jur. Act, 1876, ss. 6, 14, 24: App. Jur. Act, 1913, s. 1.

(t) S. 5 ; and see App. Jur. Act, 1876, s. 25 ; and the Judicial Committee Act, 1881, s. 1 .

(u) 58 \& 59 Vict. c. $44 ; 8$ Ed. VII. c. 51 , ss. 2 (1) (2), 3.

(x) App. Jur. Act, 1876, ss. 12, 24.

(y) $3 \& 4$ Will. IV. c. 41 , s. 5 . 


\section{Part V.- The Church, the Navy, the Army, and Air Force.}

Chapter I.

THE CIIURCH.

\section{The Established Church of England.}

Ix legal phraseology the English Church is spoken of as being " by law established," and this means that the Church is built into and forms part of the fabric of the Constitution, mainly by the legislative enactments of the reigns of Henry VIII., Edward VI., and Elizabeth. The changes brought about by these enactments were both doctrinal and constitutional. The doctrine of the Church was fixed by thirty-nine Articles, which declared the authority of every national church to ordain, change, or abolish ceremonies or rites ordained only by man's authority. Constitutionally, the changes brought about by the Reformation were: (1) The abolition of the papal authority, and the restoration of the judicial authority of the Crown orer ecclesiastical causes; (2) the subordination of the legislative powers of the clergy to the Crown and Parliament; (3) the sanction given by Parliament to the Thirty-nine Articles and the Book of Common Prayer.

Position of the Church before the Reformation.-Previously to the Reformation the position of the Church was briefly as follows. William the Conqueror had separated the civil and ecclesiastical courts, and the result of this separation (discontinued by Henry I., but restored by Stephen) was the growth of an entirely separate ecclesias- 
tical jurisdiction, to which the clergy were subject free from any secular supervision and extending to matrimonial and testamentary causes which concerned laity as well as clergy. The clergy also claimed immunity from the jurisdiction of the secular courts, and appeals from the ecclesiastical courts were often carried to Rome, in spite of the rules made by the Conqueror and the Constitutions of Clarendon.

With regard to legislation, the clergy refused to attend Parliament, and legislated for, and even taxed, themselves in their own Convocations.

Changes brought about by the Reformation.-(1) The Act of Supremacy (26 Hen. VIII. c. 1) declared the King to be "the only supreme head of the English Church on earth." This Act was repealed by Mary, but Elizabeth's Act of Supremacy (a) declared the Queen to be sovereign over all persons and causes, to the exclusion of every foreign power, and required all holders of office, lay and clerical, to acknowledge the same by taking the oath prescribed by the Act.

(2) Appeals to Pome.-These were forbidden in 1533 (b) under penalty of incurring a premunire, and by the Act for the Submission of the Clergy (25 Hen. VIII. c. 19) appeals from the archbishop were to lie to the king in Chancery, and this jurisdiction was exercised by the Court of Delegates. Erentually, in $1832(c)$, jurisdiction in ecclesiastical appeals was handed over to the Privy Council, and in 1833 to the judicial committee of the Privy Council on the formation of that body $(d)$.

Elizabeth's Act of Supremacy (e) went further than this, and vested in the Crown the ecclesiastical jurisdiction by visitation, and this was exercised by the Court of High Commission until the abolition of that body in the reign of Charles I. $(f)$. James II. endeavoured to revire it under the name of the Commissioners for Ecclesiastical Causes, but the Bill of Rights finally dechared such a court illegal.

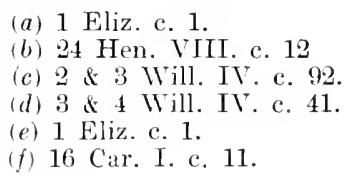


(3) Convocation.-By the Act for the Submission of the Clergy, $1533(g)$, Convocation can only be summoned by the king's writ, and canons can only be enacted with the royal licence and assent. By the same Act $(h)$ such canons as were in use, and were not repugnant to the common or statute law, or to the royal prerogative, were to remain in use until a commission sat to inquire into and affirm them. This commission never did sit, and therefore the only canons passed before 1533 which have any legal effect are such as are repugnant neither to the common or statute law nor to the royal prerogative.

Before the passing of the statute the clergy taxed themselves by granting subsidies in the provincial synods or Conrocations summoned by the archbishop. These subsidies were passed in Convocation, and generally, though. not always, confirmed by Parliament (i). In 1633 four subsidies were granted in this way for the last time, and since that date the clergy have been taxed with the laity by tacit consent; at the same time they have assumed (though without direct statutory authority) the privilege of roting for the return of members of Parliament, and this right, having been assumed by statute $(k)$ to exist, is not likely to be questioned. Convocation is now summoned and dismissed in the following manner:-

An Order in Council is issued to the lord chancellor, directing him to issue the necessary writs to the archbishops. This is accordingly done, and in Canterbury the archbishop issues a mandate to the dean of the province (the Bishop of London), directing him to summon the bishops of the province. The bishops in their turn cite the deans and archdeacons, and procure the election of one proctor for each chapter, and two proctors for the clergy in each diocese.

In York the archbishop cites the bishops, and the latter cite the deans in their dioceses, and procure the election of one proctor for each chapter, and two proctors for each

(g) 25 Hen. VIII. c. 19.

(h) $\mathrm{Ib}$. s. 7 .

(i) Phill., Eccl. Law, p. 1537.

(k) 10 Anne, c. :3 and 18 Geo. II. c. 18, and see Phill., Eccl. Law, p. 1538 . 
archdeaconry. The ordinary clergy are thus more largely represented in York than in Canterbury. The bishops form the Upper House; the deans, archdeacons, and proctors, with a prolocutor at their head, form the Lower House.

The Crown's licence and consent is necessary before Convocation can enact canons.

When a canon is to be enacted the following procedure is observed: Letters of business are first sent by the Crown to Convocation, suggesting topies for discussion, for Convocation cannot even confer to constitute a canon without the King's licence $(l)$.

When a canon is to be enacted the letters of business are accompanied by a licence, in the form of letters patent, to make or alter a canon. The canon must then be confirmed by further letters patent, which grants leave to promulge the canon, and promulgation takes place in the presence of both Houses.

A canon so enacted and promulgated binds the elergy, but it does not bind the laity without the authority of an Act of Parliament $(m)$. And even with regard to the clergy it cannot be executed after the royal assent, if it is contrary ti the common or statute law, or the king's prerogative, or to the custom of the realm $(n)$. Canons which bind the laity may be enforced by excommunication and refusal to administer the sacrament; and by 53 Geo. III. c. 127 , an excommunicated person who refuses to obey the orders of the ecclesiastical court may be sentenced to six months' imprisonment; further, if he dies in contumacy, the clergy may refuse to read the burial service over him.

Though canons cannot be enacted or even discussed, apparently, by Convocation without the King's licence, it may, and frequently does, discuss various matters without any royal mandate. When any such matter has been duly considered, the prolocutor and clergy are sent for to the Upper House, and any agreement they may come to thereon is passed in the form of a synodical Act $(o)$.

(l) The Case of Convocations (8 Jac. I.) 12 Co. Rep.. p. 72.

(m) Cox's Case (1700) 1 P. Wms., p. 32; Middleton v. Croft (1736), 2 Atk. 650 .

(i) The Case of Convocations (8 Jac. I.) 12 Co. Rep., p. 72.

(o) Phill., Eccl. Law, p. 1551. 
In the year 1717 Convocation was prorogued and did not meet again for the transaction of business, except on one or two occasions, until early in the reign of Victoria $(p)$. From 1840 onwards Convocations have been summoned regularly and discussions on important topics take place. Much valuable work has also been done in the shape of the reports drawn up by committees appointed to consider important questions affecting the Church. The absence of lay representation in the Houses of Convocation led to the formation of a House of Larmen, composed of elected members, about the rear 1886, for the province of Canterbury $(q)$. Subsequently a House of Laymen was formed for the province of York.

Meetings of these Houses of Larmen have been invited by the archbishops at the times when Convocation meets, but they are purely voluntary, and have no legal status or connection with Convocation, which, howerer, is largely influenced in its acts by the views of the Houses of Laymen.

The practice of holding joint sessions of both Convocations to consider important questions, the attendance of the Houses of Larmen being invited at the same time, seems to have originated in 1896 with relation to the Bill for Elementary Education ( $r)$. The practice has since been continued from time to time, the joint session taling place for purposes of discussion only, all formal business, such as the enactment of canons or the passing of resolutions, being transacted by the Conrocations of both provinces as formerly. Convocation now usually meets three times in each year.

(4) The Thirty-nine Articles of Religion were drawn up by Convocation of all the clergy in 1562 . The clergy were required to subscribe to them by the 13 Eliz. c. 12 , and the penalty of deprivation was provided for maintaining doctrine contrary or repugnant to the Articles.

The subscription of the clergy now depends upon the Clerical Subscription Act, $1865(s)$; the only laymen who

(p) See Phill.. Eccl. Law, p. 1540.

(q) See The Times. the 9 th of February, 1887, p. 10, where the House of Laymen for Canterbury is stated to have entered upon its third session.

(r) See The Times, the 8th of July, 1896.

(s) 28 \& 29 Tict. c. 122 . 
are now required to subscribe are ecclesiastical jurlges and the governors or heads of the colleges of Westminster, Winehester, and Eton.

(5) The Book of Common Prayer.-The use of the Book of Common l'rayer was enjoined on all ministers by the Acts of Unifomity of Edward VI. and Elizabeth. Certain alterations were made by Convocation and the rubric thus altered received parliamentary sanction by the Act of Uniformity (14 Car. II. c. 4). In 1872 a shortened form of morning and evening service for use in cathedrals and churches was settled by Convocation and sanctioned by Parliament by the Act of Uniformity Amendment Act, $1872(t)$.

Ecclesiastical Divisions.-For ecclesiastical purposes Great Britain is divided into two provinces (Canterbury and York), and each province is further divided into dioceses, of which there are twenty-five in Canterbury and ten in York (including the archbishops' dioceses). Each diocese is presided over by a bishop, and contains a cathedral and a dean and chapter. Dioceses are divided into archdeaconries, archdeaconries into rural deaneries, and rural deaneries into parishes. Outside these there are certain divisions known as peculiars with separate ecclesiastical jurisdictions, which are, however, for the most part obsolete $(u)$. They are analogous to the ancient liberties in secular jurisdiction. Over these divisions are the corresponding ecclesiastical dignitaries.

Ecclesiastical Dignitaries.-(1) Archbishops are appointed in the same manner as bishops $(x)$, and are, like bishops, nominated by the Crown on the advice of the Prime Minister. The Archbishop of Canterbury is primate and metropolitan of all England, and he enjoys the right of crowning the king or queen regnant, whilst the Archbishop of Iork claims the right of crowning the queen consort.

Archbishops are styled " grace," and " most reverend Father in God," and write themselves "by divine provi-

(t) $35 \& 36$ Vict. c. 35 .

(u) See 10 \& 11 Vict. c. $98 ; 3 \& 4$ Vict. c. 86.

(x) See ante, p. 77.

C.L.E. 
dence," and not, as hishops, "by divine permission." The Archbishop of Canterbury is the first peer of the realm, ranking next after princes of the blood royal; the Archbishop of York ranks next after the Arehbishop of Canterbury and the Lord Chancellor.

Archbishops have jurisdiction as ordinary bishops within their own dioceses, and also a visitorial jurisdiction over all bishops in their province for ecclesiastical offences.

(2) Bishops are appointed in the manner described above $(y)$, and they are said to be installed in their cathedrals. At present twenty-four bishops and the two archbishops sit as spiritual peers in Parliament, but they are not entitled, like other peers, to be tried by the House of Lords $(z)$.

A bishop exercises the following powers: he confers. order's, confirms, consecrates churches and burial grounds, and takes part in the institution of a clerk in holy order's to a rectory or vicarage. He also exercises ecclesiastical jurisdiction in his diocese, enforcing his orders in the consistory court, and governs the revenues of the see. Bishops are in law corporations sole, and they rank next after the roungest sons of marquises. During a racancy the temporalities of the see are in the hands of the Crown; they become vested in a new bishop only after consecration and installa. tion and homage done to the sovereign.

In addition to diocesan bishops there are also suffragan and coadjutor bishops. Suffragan bishops are appointed to fulfil the functions of the diocesan bishops when absent in such matters as ordinations and confirmations (a) on application to the Crown by the diocesan bishop.

Coadjutor bishops are appointed under the provisions of the Bishops Resignation let, 1849, to assist aged and infirm bishops in their duties.

Every cathedral has also a dean and chapter, whose function is to assist the bishop and act as his council in administering the affairs of the diocese (spiritual and tenporal), and to join with him in making leases and grants $(b)$.

(y) Sue arte, p. 77 .

(z) See ante, p. 239.

(a) They are appointed under the provisions of the 26 Hen. IIII. c. 14 and 51 \& 52 Tict. c. 56 .

(b) See Phill., Eccl. Lam, p. 137 et seq. 
The constitution, appointment, and functions of deans and chapters now depend principally upon certain Victorian statutes $(c)$. Since these statutes deans are appointed by letters patent from the Crown. Chapters consist of the dean and canons, whose numbers vary in each cathedral, and the canons are appointed in some cases by the bishop or archbishop, and in some cases by the Crown. In addition to the dean and canons who constitute the chapter under the Acts, there are certain non-residentiary prebendaries who are also members of the chapter and have the right of voting at elections of proctors $(d)$, and in connection with the cathedral there are also certain honorary and minor canons who, however, do not form part of the chapter proper.

To be eligible for appointment both deans and canons must have completed six years in orders $(e)$.

(3) Archdeacons are appointed generally by the bishops, but the office may be in the gift of a lavman who presents his nominee to the bishop. The functions of the archdeacon are to assist the bishop in the ministration of the Church and in matters relating to the inferior clergy, and he also exercises certain jurisdiction within the diocese (especially with regard to the maintenance and fabric of the churches within the diocese) apart from the bishop, the extent of his jurisdiction being founded on immemorial custom in subordination to the bishop's $(f)$. The archdeacon's court is sometimes presided over by a judge termed the official, and appeal lies from the archdeacon's to the bishop's court. The qualification of archdeacons is similar to that of deans and canons $(g)$.

(4) Rural Deans are appointed by the bishops on the recommendation of the archdeacon from clergy of the diocese, and their principal duty is to inspect and report

(c) The principal of these are the $3 \& 4$ Vict. c. 113;6\& 7 Vict. c. 77 .

(d) Phill., Eccl. Law, p. 185 .

(e) $3 \& 4$ Vict. c. 113 , s. 27.

(f) Phill., Ecel. Law, p. 200 et seq. This jurisdiction is mostly obsolete.

(g) Viz. six years in holy orders (3\& 4 Vict. c. 113, s. 27 ). 
upon the conduct and lives of the minor clergy within the rural deanery.

(5) The General Body of the Clergy.-Beneath the rural dean come the general body of the clergy, and these are either bencficed or unbeneficed.

The beneficed clergy are-

(1) Parsons or rectors.

(2) Vicars.

(3) Curates perpetual.

(4) Donees.

The unbeneficed clergy are-

(1) Curates stipendiary.

(2) Ministers of chapels of ease.

(3) Chaplains.

(4) Lecturers.

(5) Readers (who may also be laymen).

The Beneficed Clergy.--(1) The Parson or Rector is the incumbent of a parish church, and as the difference between parsons, vicars, and curates perpetual is connected with the histor'y of the parish church, it will be as well to consider it a little closely.

Originally it scems there was only one general church for each diocese, the bishop and his clergy living together in one fraternity, and enjoying such property as the Church possessed in common. As the Christian community grew, horrever, it became necessary to send members of the clergy (or presbyters) to perform services and ministrations in ontlying districts; and branch churches were established and endowed with the tithes of the parish $(h)$.

The tithes so set apart for the maintenance of the parish church were distributed in four parts, one for the use of the bishop, the second for maintaining the fabric of the church, the third for the poor of the parish, and the fourth for the incumbent (the parson or rector). Eventually, when the sees of the bishops hecame otherwise amply endowed, they were prohibited from participating in these tithes, 
which were distributed for the three remaining purposes only.

The incumbent of such parish churches was called the parson or rector, and the benefice itself the parsonage or rectory.

(2 and 3) Vicars and Perpetual Curates.-In course of time the advousons, or the right of presentation to many churches so established, came to be vested in bodies of monks, religious houses, colleges, or nunneries, being spiritual corporations aggregate, who uppropriated the emoluments of the benefice (i) to their own use, the religious services and ministrations of the Church being performed by one of their own number. Such appropriations could only take place with the licence of the Crown and of the bishop, who upon an appropriation would lose their right to present by lapse, since the corporation aggregate never died. The consent of the original patron was also in all such cases implied, because the right of presentation itself passed into the hands of the religious corporation.

A statute of Richard II. (k) enacted that upon appropriation the vicar or the person appointed by the religious house or monastery was to be sufficiently endowed by the bishop of the diocese. And by a statute of Henry IV. the vicar is to be perpetual and a secular person (l), instituted and induct by the bishop and cndowed $(m)$.

Upon the dissolution of the monasteries by Henry VIII. these rights were taken away from the various bodies of monks, and became vested in the Crown (n). The Crown in turn granted them out again either to lay persons or to corporations sole or aggregate, such as bishops, colleges, or religious houses, or retained them in its own hands.

Whether therefore the benefice, as originally created, remains in the hands of a corporation, or in the Crown, or

(i) For a definition of the term benefice see 1 \& 2 Tict. c. 106, s. 124; 2 \& 3 Vict. c. 49 , s. $21 ; 3$ \& 4 Vict. c. 86 ; the definitions lecing. however, only for the purposes of the Acts. As to union of benefices, see 9 \& 10 Geo. V. c. 98, and Union of Benefices Measure, 1921.

(k) 15 Ric. II. c. 6.

(l) Perpetual means not removable at the will of the religions house; secular person, a person other than a member of a religious house.

(m) 4 Hen. IV. c. 12.

(n) 27 Hen. VIII. c. 28: 31 Hen. VIII. c. 13. 
has been granted out to a layman (termed a lay impropriator, who is also the lay parson or rector), the vicar represents the minister appointed by the old religious house before the dissolution of the monasteries; he is endowed $(o)$ under the Acts of Richard II. and Henry IV., and he must also be a secular person, perpetual, and instituted and induct by the bishops under the Act of Henry IV. But in other cases where the benefice was granted originally to a religious house or body of monks not under the common form of appropriation, but ad mensam monachorum and pleno jure, such appropriations escaped the effect of the 4 Hen. IV. e. 12 as to institution, induction, and endowment. On the dissolution of the monasteries such appropriations passed into the hands of the Crown, and, as is generally the case, have been granted out de novo by the Crown to lay impropriators. In such cases the person appointed by the Crown or by the lay impropriator (termed also lay parson or lay rector) to carry on the services of the Church is termed a curate perpetual, and he is neither instituted nor induct by the bishop, but merely licensed. $\mathrm{He}$ is said to be perpetual because he can be removed only by the revocation of the bishop's licence $(p)$.

The person so appointed curate perpetual by the lay parson or rector must necessarily be a clerk in holy orders, otherwise he could not perform the services of the Church; and if he is entitled to perform marriages, churchings, and baptisms, and to claim the fees thereof for his own use, he is for purposes of style and designation, but for no other purposes, to be deemed and styled the vicar, and the benefice a vicarage $(q)$.

(4) Donees. - Where a preferment is in the hands of a free patron, who may present a clerk in holy orders without either admission, institution, induction, or licence, the preferment is said to be donative, and the cleric who obtains the preferment the donee.

(o) The endowment is usually by a portion of glebe or lands of the rectory, and of the titles; the remainder belong to the lay impropriator, and are termed rectorial tithes.

(p) Sce Plill., Ecel. Law, p. 240.

(q) Under the provisions of the 31 \& 32 Vict. c. 117. 
Mode of Entry upon Benefice.-Perpetual curates then, as we have seen, are put in possession of their benefices lyy the patron's nomination and licence from the bishop of the diocese; whilst donees enter upon possession of the benefice merely by the presentation of the free patron without any further ceremony.

Apart from these, however, the main body of the beneficed clergy, being parsons or rectors and vicars, must, if the benefice is in the gift of the Crown or a lay parson or corporation $(r)$, have passed through the following ceremonies before they can enter upon possession of the benefice:(1) presentation to the bishop by the patron or lay impropriator; (2) examination by the bishop; (3) admission; (4) institution: (5) induction.

Presentation is a formal request in writing made by the patron or lay impropriator to the bishop, desiring him to admit and institute the clerk and to cause him to be inducted. Presentation is merely a formal act, and differs from nomination, which is the right to select a clerk and may be granted by the patron to some third person, the patron retaining merely the right of presentation.

Examination by the bishop is (1) as to the person, whether he is of proper age, and such like; (2) as to his conversation or character, whether he has been convicted of crime or the like; (3) as to ability, viz. whether he is unlearned and so unable to discharge the services $(s)$.

Admission.-The examination being satisfactory, the clerk is then said to be admitted; but before institution or collation he must-

(1) Take the oath or declaration against simony prescribed by canon 40 of $1865(t)$.

(2) Subscribe the declaration of assent to the Thirty-nine Articles and the Book of Common Prayer (u).

(r) This may be either through impropriation, as described above, or as the owner of an advowson. Advowsons seem to have originated with the formation of parish churches, and consisted in the right of those who contributed to the building or endowment of such churches, by grants of land or money. to present a clerly to the bishop who was invested with the revenues accruing from such contribution. They may be either appendant to a manor or in gross. See Phill., Eccl. Law, 261.

(s) $I b .316$ et seq.

$\begin{array}{ll}\text { (t) } 28 \text { \& } 29 \text { Tict. c. } 122, \text { s. } 2 . & \text { (u) } / \text { b. s. } 1 .\end{array}$ 
(3) Take the oath of allegiance prescribed by the $31 \& 32$ Vict. c. $72(x)$.

Institution.- Ifter the above ceremonies the clerk must then be instituted, either by the bishop in person or by the bishop's ricar-general, chancellor, or commissary under the bishop's fiat.

The ceremony consists in the utterance of certain formal words, and entry in the public registry of the ordinary.

Induction.- This takes place by the bishop's mandate to the archdeacon or other proper person to induct.

The archdeacon either inducts the clerk himself or gives a precept to some other clergyman. The formal act of induction consists in taking the clerk's hand and laying it upon the key or ring of the church door or some other portion of the building, and repeating certain formal words. The inductor then opens the door of the church and puts the person to be inducted in. The latter usually tolls the bell to make his induction linown. A certificate of the induction is then indorsed on the archdeacon's mandate $(y)$.

Collation.-Where the benefice is in the gift of the bishop himself, which would be where the original appropriation was made pleno jure but not rested in a religious house, no presentation or examination is required. In such a case the bishop simply collates the clerk, collation being the act by which the bishop admits and institutes a clerk to a benefice of his own gift $(z)$.

B. the Act of Uniformity (13\& $\& 14$ Car. II. c. 4) no person is to be admitted to any parsonage, vicarage, benefice, or other ecclesiastical promotion or dignity unless he shall have been ordained priest $(a)$.

The Unbeneficed Clergy.--(1) Curates Stipendiary.These are elerlis in holy orders appointed at a stipend by the incmbent of a benefice to assist in the duties of the Church. In certain cases ther may be appointed, and their stipend regulated by the bishop himself. They require the

(rr) Formerly the aths of supremacy and allegiance 28 \& 29 Vict. e. 122): altered into a single oatl of allegiance hy 31 \& 32 Vict. c. 72.

(y) See Phill. Eccl. Law. p. 359 et seq.

(z) Ib. 1). 277 .

(a) S. 19. 
bishop's licence, both the ineumbent and the curate must sign the Stipendiary Curates Deelaration, and the latter must subseribe the declaration of assent to the Thirty-nine Articles and Book of Common Prarer; but no other ceremonies need be observed (b).

(2) Ministers of Chapels of Ease.-After the establishment of parishes and parish churehes it hecame eustomary to build private ehapels for the benefit of such inhabitants of outlying parts of the parish as would find it difficult on aecount of the distanee to attend the parish church. These are termed chapels of ease, and the minister or elerk in charge was endowed sometines by a private person, such as the lord of the manor, but more generally was a stipendiary curate of the parson or reetor of the parish (c).

By a statute of George I. (d) where such chapels of ease have received the angmentation of Queen Amne's Bounty, they are theneeforth to be perpetual cures and benefices, and where this is the case the eurates of ministers in charge must take all the oaths prescribed by statute for the beneficed clergy $(c)$. The consent of the patron, the incumbent, and the ordinary is necessary to the creation of chapels of ease forming part of the establishment of the Church of England $(f)$. The minister of a chapel of ease must be nominated by the patron and licensed by the bishop, and, in addition, he must have taken the oaths required by statute for beneficed clergy, or if not a perpetual curate he must have made the declaration required by eertain canons $(g)$. If a stipendiary curate he must be a deaeon at least, but unless he is ordained priest lie cannot consecrate the Lord's Supper $(h)$. If he is a perpetual eurate he must have been ordained priest (i).

(3) Chaplains.-Formerly certain privileged persons, such as arehbishops, dulies, viscounts, ete., were entitled by a

(b) 28 \& 29 Vict. c. 122. The position and legal status of Curates Stipendiary is regulated principally by the $1 \mathrm{k} 2 \mathrm{Tict}$ c. 107.

(c) See Phill., Eccl. Law, p. 246 et seq.

(d) 1 Geo. I. st. 2 , e. 10 , s. 4.

(e) $28 \& 29^{\circ}$ Tict. c. 122 .

(f) Bliss v. Il ood.s (1 $\$ 31), 3 \mathrm{Hagrer}$. Ecel., at p. 509.

(g) See Phill.. Ecrl. Law, p. 24!).

(h) 14 Car. II. c. 4, s. 10 .

(i) $\mathrm{Ib}$. 
statute of Henry VIII. ( $k$ ) , to maintain a certain number of chaplains, the numbers allowed rarying between six and one, according to the status of the privileged person. This statute has, howerer, been repealed $(l)$, and it is doubtful whether the chaplains of such pririleged persons have any legal status at the common law $(m)$.

There are, howerer, still thirty-six royal chaplains $(n)$, whose duty it is to wait in rotation one at a time throughout the months of the year. His Majesty may also nominate honorary chaplains to the number of twelve. Since the Restoration a chaplain has been appointed to the House of Commons, whose duty it is when present to read prayers and to preach before the House when desired (o).

In the army, for which no special form of service is provided as in the navy, there is a chaplain-general, whose. office has existed since 1846 , and is similar to that of an archdeacon, though with more extensive jurisdiction $(p)$. In addition, staff chaplains are appointed by the archbishops of the provinces and the Bishop of London $(q)$.

In the navy special forms of prayer to be used at sea are contained in the Prayer Book, and there are a body of naval chaplains, who must have been ordained deacon and priest, the head of whom is the chaplain of Greenwich Hospital, styled "Chaplain of the Fleet."

The office of naval chaplain is regulated by " the king's regulations and the admiralty instructions for the government of his Majesty's naval service," and by various Orders in Council.

The position and duties of chaplains to gaols, workhouses, lunatic asylums, and cemeteries are regulated by various statutes.

(4) Lecturers.-In London and in other cities lecturers are frequently appointed by the vestry to assist the rector, and one or more lecturers are appointed in most eathedrals,

(k) 21 Hen. VIII. c. 13.

(l) 57 Geo. III. c. 99, s. $10 ; 1$ \& 2 Vict. c. 106.

(m) Phill., Eccl. Law, p. 456 .

(n) Formerly forty-eight, reduced to thirty-six in 1860 .

(o) Plill., Ecel. Law, p. 457.

(p) Clode. Mil. Forces, ii. 383 et seq.

(q) The relation of these to the bishop of the diocese and the incumbent of the parish is regulated by 31 \& 32 Vict. c. 8\%. 
many lectureships being founded and endowed by private donations. The lecturer must be a clerk in holy orders, and must be licensed by the archbishop or bishop $(r)$. Where there is no fixed salary the bishop may refuse to grant a licence $(s)$. The office of lecturer is now largely regulated by statute $(t)$.

(5) Readers.-In churches or chapels where the endowment is small and no clergyman can be found to fill the post, readers are appointed, who are generally deacons. Their functions are to keep the register, read Divine service, the burial service, etc., but not to administer the sacrament, and also to read a portion of the Scriptures daily $(u)$. Certain lay readers are also appointed by the bishops in various dioceses, with the consent of the incumbent.

Holy Orders. - Whether beneficed or umbeneficed all members of the clergy must have been admitted to Holy Orders, of which there are three, viz. bishops, priests, and deacons. The office of deacon differs from that of a full priest in that he may not consecrate the sacrament or pronounce absolution $(x)$. A man cannot be ordained deacon under twenty-three or priest under twenty-four years of age, and generally (though not necessarily) if the bishop so chooses a man should be ordained deacon for one year before ordination as a priest. Both priests and deacons must be ordained according to the form set forth in the Book of Common Prayer, which received statutory authority by the $5 \& 6$ Ed. VI. c. 1 ; and previous to ordination they must have assented to the Thirty-nine Articles, the Book of Common Prayer, and the Ordination of Bishops, Priests, and Deacons, and made the declaration against simony in the form prescribed by the Clerical Subscription Act, $1865(y)$.

(r) 14 Car. II. c. 4 , s. 15.

(s) The Lecturer of St. Anne's. Westminster (1743), 2 Str. 1192.

(t) 7 \& 8 Vict. c. 59; 23 \& 24 Vict. c. 142; and see Phill., Eccl. Law, p. 414 et seq.

(u) A Readership is a benefice under the 3 \& 4 Vict. c. 86.

(x) See 14 Car. II. c. 4, s. 10. By the same statute no clerk may be admitted to a benefice unless he is ordained priest.

(y) $28 \& 29$ Vict. c. 122. 
T'hey must also have taken the oath of allegiance in the fcrm prescribed by the Promissory Oaths Act, $1868(z)$.

Under the Clerical Disabilities Act, 1870 (a), priests and deacons are now enabled to relinquish their orders so as to be rostored to their former civil status by means of a deed enrolled in Chancery, of which an office copy is presented to the bishop, who causes it to be entered in the registry of the diocese.

Privileges and Disabilities of the Clergy.--The status of the clergy involves certain privileges and disabilities. A clergrman cannot be called upon to serve in any temporal office, nor may he be an advocate in any civil cause concerning blood or in any cause except such as are allowed by law (b). He is not bound to serve in war $(c)$ or on a jury (d). He cannot be arrested during attendance on Divine serve or on a visitation, and eundo, redeundo, et morando $(e)$; but he is not protected in such cases under a criminal warrant $(f)$. He is also exempt from tolls when on parochial duty $(q)$; and probably be cannot be called upon to disclose anything communicated to him under the seal of confession $(h)$.

On the other hand, a clergyman cannot be elected a nember of Parliament (i), a councillor, alderman, or mayor $(k)$. He may, howerer, be a county, district, or parish councillor.

Without licenee from the bishop a clergyman may not (under penalty of a fine) farm on his own account more than eighty acres ( $(1)$, or engage in or carry on any other trade or dealing for gain or profit, except under certain. cir-

(z) 31 \& 32 Vict. c. 72 , s. 8 .

(a) $33 \& 34$ Vict. c. 91 .

(b) Othobon, pp. 89, 91. The King may, however, employ the clergy in any post of eivil government.

(c) Co. Inst., ii. p. 3.

(d) Beecher's rase (4 Leon, 190).

(e) Phill., Eccl. Law, 475.

(f) Cripps, p. 67.

(g) 3 Geo. IV. c. 126 , s. 32.

(h) It is stated to the contrary in Steph. Digest of the Lan of Evidence, Art. 117: but see the note thereon.

(i) 41 Geo. IJI. c. 63.

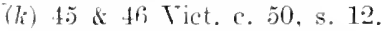

(l) 1 \& 2 Vict. c. 106 , s. 28. 
cumstances $(m)$, and if he does so he is subject to suspension or deprivation $(n)$. His contracts are, lowever, valid in a civil court, and he is sulject to the bankruptey laws (o).

The Church Assembly.-By the Chureh of England Assembly (Powers) - Act, 1919, the Chmeh Assembly means the Assembly constituter as set forth in the Appendix to the addresses to his Majesty by Convocation on May 10, 1919, and laid before both Houses of Parliannent. It consists of three Houses: the House of Bishops, House of Clergy, and House of Laity. Every measure passed by the Church Assembly shall be submitter by the Legislative Committee to the Ecclesiastical Committee, who shall consider the measure or invite the Legislative Committee to a conference to discuss it, and the Ecclesiastical Committee shall then draft a report thereon to Parliament, but shall not present it to Parliament until the Legislative Committee signify its desire that it should be so presented. The report, together with the text of the measure, must be laid before both Houses of Parliament and thereupon, on a resolution being passed by each House of Parliament directing such measure to be presented to his Majesty, such measure shall be presented to his Majesty and shall have the force and effect of an Act of Parliament on the royal assent being signified thereto in the same manner as to Acts of Parliament. The Ecclesiastical Committee consists of fifteen nembers of the House of Lords nominated by the Lord Chancellor, and fifteen members of the House of Commons nominated by the speaker, to be appointed at the commencement of each Parliament to serve during that Parliament, and any twelve members nay sit and transact business $(p)$. The Legislative Committee is appointed by the Assembly and ineludes nembers of all three houses. A "measure" is defined as a legislative measure intended to receive the roval assent and to have effect as an Act of Parliament.

The "measures" passed in pursuance of the Act and having the effect of an Act of Parliament are the Parochial

(m) 1 \& 2 Vict. c. 106 , s. 29.

(o) 46 \& 47 Vict. c. 52 , s. 52 . (ii) Ib.s. 31 .

(i) 9 \& 10 Geo. T. с. 76 . 
Church Councils (Powers) Measure, 1921, the Ecclesiastical Commissioners Measure, 1921, and the Union of Benefices Measure, 1921.

This method of legislating by " measures" instead of by bill in the usual way seems to be a novel and somewhat unconstitutional proceeding; it is inconvenient, to say the least of it, and might easily form a very dangerous precedent.

Parochial Church Councils.-A parochial church council consists of the incumbent, the senior curate, such number of lay representatives of either sex as the annual parochial church meeting shall decide and such co-opted members as the council shall decide, not exceeding one-fifth of the elected lay representatives. Qualified electors must be members of the Church of England of either sex, above the age of eighteen, resident in the parish, and who do not belong to any other religious body. The primary duty of the council is to co-operate with the incumbent in the initiation, conduct and development of Church work, both within the parish and outside. The powers, duties and liabilities of the vestry and of the churchwardens relating to the affairs of the church are, with certain exceptions, transferred to the council, and the council has power to acquire property, real or personal, for any ecclesiastical purpose affecting the parish. The council must hold not less than four quarterly meetings in each year, but other meetings may be convened if necessary. No business can be transacted at any meeting of the Council unless at least one-third of the full number of members are present. In the event of disagreement between the council and the incumbent where their joint action is required the bishop may give directions.

\section{The Irish Church.}

Disestablishment.-By Article 5 of the Act for the Union of Ireland with Great Britain $(q)$, the Irish Church was united to the Established Church of England, and the preservation of the United Church was declared to be an

(q) $39 \& 40$ Geo. III. c. 67. 
essential and fundamental part of the union of the two countries. Nevertheless, in 1869 , the Irish Church let $(r)$ was passed disestablishing the Irish Church, and dissolving the union between the English and Irish Churches.

Effect of Disestablishment.-By this Act the Church property formerly vested in the Ecclesiastical Commissioners for Ireland, and all other Cliurch property in Ireland, was vested in the Church Temporalities Commissioners, power being, however, given to the Church to appoint a representative body, which might be incorporated by the Crown with power to hold Church property.

This representative body was subsequently incorporated by royal charter $(s)$, and in this body the property of the Irish Church has now been vested by order of the 'Temporalities Commissioners. The Irish Land Commissioners now stand in the place of the Church Temporalities Commissioners $(t)$.

All ecclesiastical corporations in Ireland were dissolved by the Act, and all ecclesiastical law and jurisdiction abolished. But the law hitherto in force, and the doctrines and ordinances of the Church (subject to any changes to be made by the Irish Church as then constituted), were thenceforward made binding on the Irish clergy in the same manner as if they had agreed to abide by the same by contract. Another effect of the Act was to deprive the Irish bishops of their right to sit in the House of Lords; whilst, on the other hand, the licence of the Crown is no longer necessary on the election and appointment of an Irish bishop.

Present Position of the Irish Church.-The Church in Ireland is therefore now an independent body, free from any State intervention or control. It can make such changes in its rules and doctrines as it thinks fit. Such rules and doctrines are, however, enforceable upon members of the Irish clergy by the temporal courts whenever questions as to the right to Church property are concerned, the holding

(r) 32 \& 33 Vict. c. 42.

(s) The 15 th of October, 1870.

(t) $44 \& 45$ Vict. c. 71. 
of Church property heing by statute considered as subject to a trust to observe the rules and doctrimes in force for the time being (u). The Church is not in terms affected by the Irish Free State (Agreement) Act, $1922(w)$, but by section 16 provision is made for securing religious equality.

\section{The Church in Scotlund.}

The Act of Union.-By the Act for the union of England and Scothand, passed in $1706(x)$, the Presbyterian government of the Protestant Scotch Chureh by means of kirk sessions, presbyteries, provincial srnods, and general assemblies (being the form of government ratified and confirmed by the 1 Will, \& Mary, c. 5) was confirmed and made unalterable, and it was declared that this Presbyterian govermment was to be the only government of the Church in Seotland $(y)$.

By the same Act the preservation of the Established Church in England as settled by the 6 Anne, c. 8, and of the Protestant religion and Presbyterian Church in Scotland, are made essential conditions of the union $(z)$.

Position of the Scotch Church.-The Scoteh Chureh forms its orn national branch of the early Episcopalian Church, and is entirely at one with the English Church on matters of religion, adopting as her standard faith the Thirty-nine Apticles, and claiming the authority to change or abolish any ceremonies or rites of the Chureh ordained only by man's authority, allowed to every national Chureh by Article 34. The difference then between the Scotch and English Churches is that each has its own distinet form of internal govermment, and that while the English Church is amply endowed and closely incorporated with the State, the Scotch Church is merely tolerated by, and receives no support in spiritual matters from, the State (a).

(u) $32 \& 33$ Vict. c. 42. s. 20.

(w) 12 Geo. T. c. 4 .

(x) 6 Anne. s. 11 .

(y) Ib. s. 2.

(z) $I b$. s. 5 .

(a) Sce preface to the revision of the Seotch Canons. 1838, quoted in Phill. Eecl. Law, at p. 1763. 
The Scotch Church, however, looks to the civil power for peace and protection in the enjoyment of its rights and privileges, and acknowledges the King to be the only supreme governor within his dominions of clergy as well as laity, and she renounces the authority of any foreign prince, potentate, or prelate within the realm (b).

There are now seven sees in Scotland, and in each diocese the bishop must appoint a dean chosen from the presbyters. The synod consists of two chambers, the bishops comprising the first, and the deans and a representative elected by the clergy from each diocese, the second. In addition, a Church Council was established in 1876, composed of bishops, clergy, and lay representatives.

\section{The rhurch in Wales.}

Disestablishment of the Church in Wales and Monmouthshire.-By the Welsh Church Act, 1914, passed under the provisions of the Parliament Aet, 1911 (c), (and which was to come into force on such day as might be fixed by Order in Council after the expiration of six months, or such extended period as might be fixed by the Order, not being more than twelve months after the 18th September, $1914(d)$ ), the Church of England in Wales and Monmouthshire is to cease to be established by law, and no person is, after the 18th September, 1914, to be appointed or nominated by the Crown or any person by virtue of any existing right of patronage, to any ecclesiastical office in the Church in Wales $(e)$.

In consequence of the state of war existing with Germany the date of disestablishment of the Church in Wales was, however, postponed by the Suspensory Act, $1914(f)$, and did not take effect until March 31, 1920.

Effect of Disestablishment.-The effect of disestablishment on the Church in Wales is threefold, and relates to

(b) Phill., Eccl. Law, at p. $\mathbf{1 7 6 3 .}$

(c) As to the procedure under this Act, see ante, p. 84 .

(d) Being the date on which the Act received the royal assent.

(e) Welsh Church Act, 1914 (4\&5 Geo. T. c. 91), s. 1.

(f) 4 \& 5 Geo. V. c. 88 , s. 1 (1).

C. L.E. 
(1) the status and privileges of the clergy, (2) ecclesiastical courts and laws, and (3) the property of the Church.

The Status of the Clergy.-The Act affects the status of the Welsh clergy in the following manner. (1) On the date of disestablishment all cathedrals and ecclesiastical corporations sole or aggregate in the Church in Wales, are to be dissolved. As from the same date no Welsh bishop ats such is to be summoned to, or qualified to sit or vote in, the House of Lords $(g)$; apart from this provision bishops, deans, canons, archdeacons, and all holders of ecclesiastical offices in the Church in Wales are to continue to enjoy luring life the same title and precedence as before the passing of the Act $(h)$.

(2) As from the same date the bishops and clergy of the Church in Wales are to cease to be member's of or represented in the Houses of Convocation of the Province of Canterbury (i).

(3) On and after the date of disestablishment no person is to be disqualified or liable to any penalty for sitting or voting in the House of Commons by reason of having been ordained priest or dencon if the ecclesiastical office he holds is an office in the Church in Wales, or, if he does not hold any ecelesiastical office, if the last such office which he held was an office in the Church in Wales $(j)$.

Effect of the Act on Ecclesiastical. Lau.-The general effect of the Act is to abolish the ecclesiastical courts in Wales, and the legal force of the ecclesiastical law of the Church in Wales, and to render the latter only binding in so fir as it relates to property held on behalf of or by members of the Church, as though it were in trust to be held on behalf of persons bound by such law. Power is also afforded by the Act to the members of the Church in Wales to for'm a representative body and hold synods, with power

(g) Bishops not disqualified by the Act from sitting in the House of Lords are to receive writs of summons as if the bishops so disqualified had vacated their sees. Welsh Church Act, 1914 (4 \& 5 Geo. V. c. 91), s. $2(3)$.

(h) Ib. s, 2 (1) (2).

(i) $I b . \mathrm{s} .3(\tilde{5})$. But nothing in the Act is to affect the powers of those Houses relating to matters outside Wales and Monmouthshire.

(j) $I b$. s. $2(4)$. 
to make regulations and constitutions. The general provisions are as follows:-

(1) Abolition of Ecclesiastical Law and Courts.-As from the date of disestablishment the jurisdiction of ecclesiastical courts and persons in Wales and Mommouthshire is abolished, and the ecclesiastical law of the Church in Wales is to cease to exist as law $\left(k_{i}\right)$. This is, however, subject to the following important modifications.

(2) Power to Form Representative Body. - Notwithstanding any Act, law, or custom, the bishops, clergy, and laity of the Church in Wales may hold synods, or elect representatives thereto, and mav frame constitutions and regulations either by themselves or their representatives elected as they may think fit (l).

If a body is so appointed to represent the Church and laity, and to hold property for their uses, the Crown is empowered by charter to incorporate such persons (termed " the representative body") with power to hold land without licence in mortmain $(m)$. The constitutions and regulations made by the body may provide for the following matters: (i) The general management and good government of the Church in Wales, and the property and affairs of the same, as a whole or according to dioceses. (ii) The future representation of members of the Church in a general synod or diocesan synods or otherwise $(n)$. (iii) The establishment for the Church in Wales of ecclesiastical courts, and (if the Archbishop of Canterbury consents) for appeals from any such courts being heard and determined by the provincial court of the Archbishop, but such courts may not exercise any coercive jurisdiction, and no appeal is to lie therefrom to the Privy Council (o). (iv) Alterations and modifications in ecclesiastical law, including the law embodied in certain specified Acts, or any other Act $(p)$.

(k) Welsh Church Act, 1914 (4 \& 5 Geo. Y. c. 9]), s. 3 (1).

(l) $I b$. s. 13 (1).

(m) $I b$. s. $13(2)$.

(n) $I b$. s. $13(1)$.

(o) $I b$. s. 3 (3).

(p) $I b$. s. 3 (4). The Acts specified are the Church Discipline Act, 1840 ; Public Worship Regulation Act, 1874: Clergy Discipline Act, 1892; Ecclesiastical Dilapidations Acts. 1871 and 1872. 
Alterations in ecclesiastical law made under the above powers are not to be binding (except so far as they are necessary in consequence of the Welsh Church Act, 1914) on an ecclesiastical person having any existing interest saved by the Act so as to deprive him of that interest if he signifies his dissent to the representative body within a month after the making of the alteration $(q)$.

(3) Enforcement of Ecclesiastical Law as to Property.As from the date of disestablishment, the then existing ecclesiastical law, articles, doctrines, rites, rules, discipline, and ordinances of the Church of England (subject to any modification or alterutions made under the provisions just mentioned) are to be binding on members of the Church in Wales as though they had mutually agreed to be so bound, and are to be capable of being enforced in the tem: poral courts in relation to property held by virtue of the Act on behalf of the Church or any members of the same, as if such property had been expressly assured upon trust to be held on behalf of persons who should be so bound (r).

\section{Provisions as to Church Property.-Gencral Effect.-A} body termed the "Welsh Commissioners" are constituted by the Act, in whom, as from the date of disestablishment, Church property in Wales (whether vested in the Ecclesiastical Commissioners or otherwise) is in general to be vested. The property so rested is to be divided as to certain specified parts between the Church representative body previously mentioned $(s)$, and certain local bodies, the latter being either county, or borough, or urban district councils, or in some cases the parish meeting, or burial authority. The transfer of the various classes of property as specified is to be made by the Welsh Commissioners to the appropriate bodies, and provision is made for the preservation, compensation, or commutation of existing interests. The Welsh Commissioners are invested with certain plenary powers of deciding questions of law or fact necessary to be decided for the purposes of the Act; but in

(q) 4 \& 5 Geo. V. c. 91 , s. 3 (2).

(r) $I b$, s. 3 (2).

(s) See p. 339, ante. 
certain specified cases appeal from their decision lies to the Privy Council.

The Welsh Commissioners.-The Welsh Commissioners, being three in number appointed by the Crown by warrant under the sign manual $(t)$, are to be a body corporate styled the "Commissioners of Church Temporalities in Wales," with a common seal, and power to hold land for the purposes of the Act without licence in mortmain (u). They may act by one of their number, notwithstanding any racancy $(x)$. Two of the Commissioners are to be salaried (y), and these, with any officers or other persons employed by the Commissioners under the powers of the Act $(z)$ may not during office be elected to or sit as members of the House of Commons $(a)$.

The powers of the Commissioners are to last to the end of the year 1914, and three years after, and they are then to be dissolved; power, however, being given by a later Act to the Crown in Council, on the application of the Commissioners, to suspend their dissolution, subject to revision of salaries and number of officers, for such time as the Crown should think fit (b). The Commissioners enjoy the following powers: (i) They may make rules regulating their procedure, which must be confirmed by the Crown in Council and laid before both Houses of Parliament, when they are to have effect as if part of the Act (c). (ii) They may decide all questions of law or fact for the purposes of the Act; they cannot be restrained in the due execution of

( $t) 4 \& 5$ Geo. Y. c. 91, s. 10 (1). Vacancies are to he filled in the same manner.

(u) $I b$. s. $10(2)$.

(x) $I \bar{b}$. s. 10 (3). On requisition by any person aggrieved an order made by one commissioner must be reconsiciered by the three commissioners. $I b$.

(y) $I b$. s. 10 (4). Viz. salaries not exceeding $\$ 1.500$ and $\$ 1.000$ are to be paid as the Treasury direct.

(z) $I b$. s. $10(5)$. The consent of a Secretary of State and the Treasury is required for the appointment of a secretary and any other officers required, and as to renoval, remuneration, etc. Their remuneration is to be paid out of funds in the hands of the comnissioners, but not so as to reduce any property to be transferred to the representative body or county councils.

(a) Ib. s. $10(8)$.

(b) 9 \& 10 Geo. V. c. 65.

(c) 4 \& 5 Geo. V.c. 91, s. 11 (4). 
their powers by any order of the court; and certiorari does not lie to remove proceedings before them into any court. They are to have all the powers of the High Court as to certain matters $(d)$, and their proceedings are to be deemed judicial proceedings before a court of record $(e)$.

The Commissioners must make a report each year to the Secretary of State of their proceedings under the Act, and this report is to be laid before Parliament $(f)$.

Appeals from the Welsh Commissioners.-Appeal lies to the Judicial Committee of the Privy Council (in the same mamner as ordinary appeals) against a decision of the Commissioners as to: (i) what constitutes a "private benefaction ", (ii) what sum by way of annuity or otherwise should be paid to any person as commutation; (iii) what sum should be paid to any person in substitution for and in satisfaction of his interest in any tithe rent-charge $(g)$.

Yesting of Property.-(1) In the Welsh Commissioners.As from the date of disestablishment the following classes of property are to rest in the Welsh Commissioners:-

(i) All property rested in the Ecclesiastical Commissioners or Queen Anne's Bounty ascertained to be "Welsh Ecclesiastical property under the provisions of the Act" ( $h$ ).

(ii) All property not so vested and not consisting of charges on the common fund of the Ecclesiastical Commissioner's which, at the passing of the Act, belongs to, or is appropriated to the use of, any ecclesiastical office or cathedral corporation in the Church in Wales, or the holder of any such office as such.

(d) Viz. as to attendance and examination of witnesses, production of documents, commissions for examining witnesses, punishment for refusal to comply in such matters or for contempt, and as to enforcing any order made for carrying out the Act. $I b$. s. 11 (2). Orders made by the commissioners are final (except where a right of appeal is given), but they may be reviewed or rescindel by the commissioners. 4 \& 5 Geo. Y. c. 91 , s. 11 (3).

(e) $I b$. s. $11(2)$.

(f) 16 . s. 11 (5).

(g) $I b$. s. 12 .

(h) $I b$. s. 4 (1). The provisions for enabling the Ecclesiastical Commissioners and Queen Ame's Bounty respectively to determine what is Welsh ecclesiastical property vested in them (which they are to do before the date of disestablishnient) are contained in s. 5 and Scheds. I. and II. 
The resting, as to both these classes of property, is to be subject to all tenancies, charges, and incumbrances, and to all rights and interests saved by the Act, affecting the property (i).

(2) In the Representative Body.-From the date of disestablishment all plate, furniture, and other moveable chattels belonging to any church affected by the Act, or used in connection with the celebration of Divine worship therein (not being the property of a private individual), is to rest in the representative body before referred to if and when incorporated; and if the last-named body is not incorporated at the date of disestablishment, then, until the incorporation of such a body, ther are to remain vested in the same persons for the same purposes as before the date of disestablishment ( $i)$.

(3) In the Ecclesiastical Commissioners and Qucen Anne's Bounty.-As from the passing of the Act certain property belonging or appropriated to the use of any ecclesiastical office or cathedral corporation in the Church in Wales, or the holder of any such office as such (being property other than ecclesiastical residences), is to become rested in the above two bodies respectively, but not so as to affect any beneficial interest in the property $\left(F_{i}\right)$.

Abolition in Wales of Powers of Ecclesiastical Commissioners and Queen Anne's Bounty.-As from the date of disestablishment any liability or power of these two bodies to make payments for any ecclesiastical purpose in or connected with the Church in Wales is to cease subject to the four following exceptions:-

(i) They are to continue to make payments required for preserving any existing interest (1).

(ii) They may carry out contracts made before the passing of the Act for the sale or purchase of any property affected by the Act, or otherwise in relation to such pro-

(i) 1 \& 5 Geo. V. c. 91, s. 4 (1).

(i) $I b$. s. 4 (2)

(k) $I b$. s. 5 (3). This provision applies to all property above deseribed towards the purchase of which grants hy the two bodies respectively have been applied.

(l) Ib. s. $6(a)$. 
perty; and they may make any payments required or anthorised under the Aet $(m)$.

(iii) Either body may if it thinks fit transfer to the representative body within one year from disestablishment, certain elasses of property $(n)$.

(iv) Either body in any year after the date of disestablishment may pay to the representative body such sum (if any) as it thinks fit, but the sum paid by the Ecclesiastical Commissioners in any year is limited by the Act (o).

\section{Distribution of Property by the Welsh Commissioners. -} Generally.-The Welsh Commissioners are to transfer the property rested in them to various bodies, being (1) the representative bodr; (2) county councils, or in the case of burial grounds to certain loeal bodies; (3) the University of Wales $(p)$. The classes of property to be transferred to each of these bodies respectively are specified by the Act and are as follows:-

(1) To the Representative Body.-(i) All churches; (ii) ecclesiastical residences with any moveable chattels enjoyed by the incumbent for the time being as incident to the oceupation of the residence; (iii) funds or endowments specially allocated to the repair, restoration, or improvement of the fabric of any such church or residence; (iv) property consisting of, or the produce of, or derived from grants made by Queen Imne's Bounty out of money provided by Parliament, or out of the royal bounty fund; $(\mathrm{r})$ all private benefactions $(q)$; (ri) if requested by the representative

(m) 4 \& 5 Geo. T. c. 91, s. 6 (b).

(n) $I b$. s. $6(c)$. The Ecclesinstical Commissioners may also in certain cases eharge their common fund with the parment of a perpetual annuity to the representative body. Ib.; Sched. III., Pt. iii. The classes of property mentioned above are set out in sehed. III. Pts. i. and ii.

(o) $I b$. s. 6 (d). Sched. III. Pt. iv. The Ecelesiastical Commissioners are limited to a sum equal to the average amount granted hy them out of the annual appropriations from the surplus income of their common fund during the seven years ended the 31st October, 1911, by way of alumentation or endowment of benefiees or towarls the stipends of assiotant clergy in Wales or Monmouthshire. Ib. Sehed. III. Pt. ir.

(p) $I b$. s. 8 . As to the preservation of existing interests and tenancies except in the case of tithe rent-charge, see p. 346, post.

(q) Private benefactions are defined by s. $i$, and are property which eonsists of, or is the produce of, or derived from property given by any person out of his private resources since the year 1662 , or money raised 
body, glebe or other land (not comprised in the abcre, and not being a burial ground), subject to parment by the representative body to the Welsh Commissioners of a sun equal to the value of the same $(r)$; (vii) if requested by the representative body, burial grounds which have been closed before the date of disestablishment under any Act or Order in Council under any Act.

The property not falling in the above category is to be transferred as follows:-

(2) To Burial Authorities, etc.-Burial grounds of ecclesiastical parishes are to be transferred to the existing incumbents; and, on the determination of the incumbencies, to either the burial authority $(s)$, or the parish council $(t)$, or the borough or urban district council (u), according to certain specified conditions attaching to the burial ground $(x)$.

(3) To the County Councils.-To this body is to be transferred, (i) any tithe rent-charge formerly appropriated to. the use of any parochial benefice, (ii) any other property

by voluntary subscriptions since that year out of funds not liable by statutory provisions to be applied to ecclesiastical purposes, or which is the produce of or derived from the sale of arlvorsons under the Lord Chancellor's Augmentation Act, and applied for the augmentation of livings in Wales or Monmouthshire. Property given or money raised since 1662 , the source from which it is derived being unknown, is to be deemed a private benefaction. The Ecelesiastical Commissioners, Qucen Anne's Bounty, and the Welsh Commissioners are directed to make certain orders declaring what property transfered by the first two bodies, or vested in the last-named body, constitutes private benefactions. Ib. s. 7 (2) (3).

(r) 4 \& 5 Geo. V.c. 91 , s. 8 (1) (vii). If not determined by agreement the value is to be arrived at by arbitration, regard heing had to the tenancies, charges, incumbrances, interests, and rights subject to which the land is transferred.

(s) This is the case where the burial grcund is in an area in which the Burial Acts, 1852 to 1906 , are in force, or in which (not being a rural district) a burial grom has been provided under the Public Health (Intements) Act, 1879, or a local Act. Where the burial authority is a joint committe the ground is to vest in such one or more of the authorities represented on the committee, or in truste's on their behalf, as the Welsh Commissioners think fit. Ib. s. 8 (1) (b).

( $t$ ) This is the case where the ground is situate in a rural parish or part of such parish in which the Burial Acts, 1852 to 1906, are not in force. If there is no parish council, the ground is to vest in the chairman of the parish meeting and overseers of the parish. Ib.

(u) This is so in all cases not covered by the last two notes.

(r) See the three previous notes. 
appropriated to a similar use (including money paid under the above provisions by the representative body in respect of glebes) (y).

(4) To the University of Wales.-All other property rested in the Welsh Commissioners, not falling under the above provisions, is to be transferred to the University of Wales $(z)$.

Preservation of Existing Interests after Transfer.-All property transferred under the above provisions is to be held subject to all existing public and private rights, and to all tenancies, charges, and incumbrances subsisting at the date of transfer; and in the case of all property except tithe rent-charge transferred to a county council, subject to the existing interests of all persons holding ecclesiastical offices in the Church in Wales at the time of the passing of the Act. In the case of tithe rent-charge the transfer is to be subject to the obligation to compensate existing interests in the manner provided by the Act $(a)$.

Provisions as to Border Parishes.-The following provisions are made by the Act as to border parishes: (1) As to parishes situated only partly in Wales or Monmouthshire the Welsh Commissioners are to determine by order (subject to appeal by any parishioner to the Privy Council) whether the parish is to be treated as wholly within or without Wales or Monmouthshire, reference being had to the general wishes of the parishioners with respect thereto (b). (2) Ecclesiastical parishes which at the passing of the Act are situate in a Welsh diocese but not in Wales

(y) In case (i) where the land is not situate in Wales or Monmouthshire the tithe rent-charge is to be transferred to the council of such county in Wales or Monmouthshire as the Welsh Commissioners think fit. In ease (ii) the council is to be that of the county in which the ecelesiastical parish to the use of which the property is appropriated is situate; but if the ecclesiastical parish is in more than one county the property is to be transferred to such one or more of those councils, or be divided between them, as the Welsh Commissioners think fit. 4 \& 5 Geo. V. c. 91 , s. $8(1)(d)$.

(z) $I b . s .8$ (1) $(e)$.

(a) $I b$. s. 8 (2). Provision is made by sub-s. (3) for the trausfer in its appropriate class of property sold or converted before the date of disestablishment. As to tithe rent-charge, provision is made by s. 15 .

(b) Ib. s. 9 (1). 
or Monmouthshire (including parishes excluded from Wales and Monmouthshire under provision (1) above) are to be attached to an English diocese by order of the Ecclesiastical Commissioners (c). (3) Ecclesiastical parishes which are situate at the passing of the Act wholly in Wales or Monmouthshire (or which are to be treated as so situate under (1) above), and which form part of an English diocese, are from the date of disestablishment to be attached to such Welsh diocese as may be determined under the constitution and regulations of the Church in Wales $(d)$.

\section{Application of Property yested in Welsh Commissioners.} -The property vested in the Welsh Commissioners under the Act, other than that which is transferred to the representative body and burial grounds, is divided into two classes and is to be applied as follows: (1) Property formerly appropriated to the use of parochial benefices and transferred to a county council is to be applied to any charitable or eleemosynary purpose of local or general utility (including the aiding of poor scholars), under a scheme or schemes made by such council (either alone or jointly with any other such council) with the approval of a Secretary of State. Schemes so made must be laid before both Houses of Parliament as soon as inay be ifter bring confirmed (semble by the Secretary of State), and operate as if enacted in the Act $(e)$.

(2) All other property not falling within the above is to be applied, firstly towards the expenses of carrying the Act into execution (exclusive of the expenses incurred in the administration of the above schemes), and subject thereto $i$ s to be applied by the University of Wales for the benefit of itself and various named institutions by way of appro-

(c) 4 \& 5 Geo. V. c. 91, s. 9 (2). Any necessary or incidental provisions may be made by the order, including the transfer to the Bishop in certain cases of the right of patronage. $I b$.

(d) $I b$. s. 9 (3). Except as to these provisions for border parishes nothing in the Act is to affect any Enghish diocese. $I b$. (4).

(e) $\mathrm{Ib}$. s. 19 (1) (4). In framing schemes dne regard is to be had to the wants and circumstances of the parish in which the property is situate, or from which it is or was derived, and of the parish comprising the ecclesiastical parish to which it was attached, and generally to the circumstances of cach case. Schemes may be revoked or amended by schemes made in like manner. Ib. s. 19 (2) (3). . 
priation or payment of capital or annual sums, or partly of one or the other $(f)$.

\section{Preservation of Existing Interests, Compensation, etc.-} Provision is made by the Aet for the preservation of existing interests in the emoluments of ecclesiastical offices held at the passing of the Act by freehold tenure, or by tenure equivalent in practice to freehold tenure $(g)$. Also for compensation in case of resignation of such offices on account of permanent mental or bodily infirmity $(h)$; and for compensation for existing interests in any tithe rent-charge transferred to a county council (i); and for the continued payment of pensions to which persons may have become entitled before the date of disestablishment under certain Acts $(j)$. Compensation (not exceeding one rear's emoluments of the benefice on a three years' average computation) may also be obtained in certain eases by persons entitled to any right of patronage of any benefice affected by the Act, on the extinction of such right $(k)$; and by holders of lay offices in the Church in Wales by freehold tenure (or tenure equiralent to freehold) who are deprived of their emoluments by the operation of the Aet (l).

Commutation of Existing Interests.-A seheme for the commutation of the existing interests of the holders o all ecelesiastical offices in the Chureh in Wales in all property (cther than burial grounds) rested in the Welsh Commissioners, and to be transferred by the latter to county councils or the University of Wales, is provided by the Act. This selieme may be adopted by the representative body before or within one month after the date of disestablish-

(f) 4 \& 5 Geo. T. c. 91, s. $19(1)(b)$. The institutions named are the university colleges (1) of Wales, Aberystwyth. (2) of North Wales, (3) of South Wales, and the National Jibrary of Wales; but so that the ultimate share of each miversity college is one-fourth. and of the National Library one-eighth of the total amount distributable, and that, in applying its share, each miversity college shall have regard to the needs if poo: scholars. $l b$.

(a) Ib. s. 11 .

(h) $I b . s .14(2)$.

(i) $I b$. s. 15 .

(i) $I b$. s. $1 t$ (7). The Acts mentioned are the Bishops' Resignation Act. 1869; the Dean and Canons' Resignation Act, 1872; and the Incumbents' Resignation Act, 1871.
(k) $\mathrm{Ib}, \mathrm{s}, 16$.
(l) $I b . \mathrm{s}, 17$. 
ment, by giving notice in writing to the Welsh Commissioners. On such notice being given such existing interests are to determine, and the provisions of the Act in respect to the same are to cease, and the Welsh Commissioners are to pay to the representative body the amount payable under the schene of commutation ( $m$ ).

\section{Transfer of Powers of Yestries and Churchwardens.-} The powers, duties, and liabilities of the vestry and of the churchwardens of every parish within all boroughs and urban districts in Wales and Monmouthshire, except so far as they relate to the affairs of the church or to ecclesiastical charities (or to charities generally in the case of churchwardens, and subject also in their case to certain other exceptions $(n)$ ) are to be transferred to the councils of the respective boroughs and urban districts (o). The latter councils are also to have the powers and duties as to the appointment of overseers and the appointment and revocation of appointment of assistant overseers conferred upon parish councils by the Local Government Act, $1894(p)$.

Supplemental Provisions.-Provision is made by the Act as to the following various supplemental matters: (1) As to firstfruits and tenths in respect of appointments to ecclesiastical offices in the Church in Wales after the date of disestablishment, which are to cease to be payable in respect of such offices $(q)$. (2) As to the filling of vacancies in ecclesiastical offices during the suspensory period between the passing of the Act and the date of disestablishment $(r)$. (3) As to property held in trust for charitable purposes by

(m) 4 \& 5 Geo. V. c. 91, s. 18.

(n) $I b$. s. $25(1)(b)$.

(o) $I b$. s. 25 (1).

(p) $I b$. s. 25 (2). Section 5 of the Local Government Act, 1894, is to apply accordingly except sub-s. (2) $(c)$, as to which other provision is made unless the Local Government Board otherwise direct. Orders which may have been made under the Local Government Act, 1894, s. 33 , are not to be affected by this provision.

(q) $I b$. s. 20. This is subject to a proviso preserving the liability to pay tenths in respect of persons having existing interests in the emoluments of ecclesiastical offices in Wales, such tenths being made payable to the Welsh Commissioners, or as they direct. Ib.

(r) $I b$, s. 21. 
cathedrals or ecclesiastical corporations dissolved by the Act, or by any ecclesiastical persons in right of their offices (s). (4) As to marriages in churches of the Church of England in Wales and Monmouthshire after disestablishment, to which the Marriage Acts, 1811 to 1898, are made applicable so far as they relate to marriages in registered buildings, subject to certain provisos $(t)$. (5) As to the preservation of certain existing rights and interests in burial grounds; and as to certain rights of way and rules to be observed after the determination of existing incumbencies $(u)$. (6) As to the exercise of any powers of sale, leasing, mortgaging, exchanging, or otherwise dealing with property exerciseable by holders of ecclesiastical offices in the Church in Wales during the continuance of their existing interests $(x)$. (7) As to the powers of managing, selling, leasing, etc., to be exercised by the various bodies in whom Church property becomes vested under the Act $(y)$. (8) As to the powers of borrowing to be exercised by the IVelsh Commissioners $(z)$; and as to the annual auditing of their accounts $(a)$. (9) As to the resting of property in the Welsh Commissioner's under the Act, where such property consists of stock within the meaning of the Trustee Act, 1893; and as to the vesting of copyholds in the Ecclesiastical Commissioners, the Welsh Commissioners, or Queen Anne's Bounty under the Act (b). (10) As to charges on the emoluments of ecclesiastical offices in the Church in Wales created in favour of Queen Anne's Bounty under certain Acts (c). (11) As to the decision of questions arising under the Act betreen local authorities by the Welsh Commissioners $(d)$. (12) As to agreements between the various

(s) $4 \& 5$ Geo. T. c. 91, s. 22.

(t) $I b$. s. 23 .

(u) $I b$. s. 24 .

(x) $I b$, s. 26.

(y) $\mathrm{Ib}, \mathrm{s}, 27$.

(z) Ib. s. 30 .

(a.) $I b$. s. 31 .

(b) Ib. s. 32 .

(c) $I b$. s. 33. The Acts mentioned are, the Clergy Residences Repair Act, 1779; Pluralities Act, 1838; Ecclesiastical Dilapidations Act, 1871; Ecclesiastical Commissioners Acts, 1836 and 1840 ; as subsequently amended or extended.

(d) $I b$. s. 34 . 
public authorities interested for adjusting or apportioning any property, income, debts, etc., so far as affected by the Act $(e)$. (13) As to arbitrations under the Act, which are to be in accordance with the Arbitration Act, $1889(f)$. (14) As to the appointment of notaries public within Wales and Mommouthshire by the Lord Chancellor in place of the Archbishop of Canterbury $(g)$. (15) As to the liability of any person to pay tithe rent-charge, or of any lay impropriator of tithe rent-charge to repair any ecclesiastical buildings, which liabilities are preserved by the Act subject to an exemption in favour of County Councils becoming entitled to tithe rent-charge under the Act $(h)$. (16) As to delivery up to the Welsh Commissioners of bools and documents relating to property rested in them under the Act (i).

\section{The Church in the Colonies.}

Present Position.-The various branches of the English Church in foreign parts have been placed upon episcopalian footing and are divided into seven provinces, viz. Canada, Rupertsland, the West Indies, New South Wales, New Zealand, South Africa, and India and Ceylon, with their corresponding metropolitans. Corresponding to these provinces are sixty-eight dioceses and twenty-five independent dioceses. In some colonies the Church has been formally established with a constitution for provincial or diocesan synods and rules of internal government by Act of the Imperial Legislature: $e . g$. the East Indies ( $j$ ). In other colonies the constitutions of provincial or diocesan synods and the rules of internal government have been fixed by Acts of the local legislature, $c . y$. the diocese of Melbourne $(l i)$; the diocese of Toronto $(l)$; the province of New South Wales. In other colonies, again, the Church has

(e) $4 \& 5$ Geo. V. c. 91 , s. 35 .

(f) $I b$. s. 36 .

(g) Ib. s. 37 .

(h) $I b$. s. 28 .

(i) Ib. s. 29 .

(j) As to the East Indies, see 53 Geo. III. c. $155 ; 3 \& 4$ Will. IV. c. 85 .

(k) 18 Vict. No. 45 (Victorian Act).

(l) $19 \& 20$ Tict. c. 141 (Canadian Act). 
never been so established, but has formed its own rules of intemal government, and enjoys the same freedom from State intervention as the Church in Scotland or Ireland; e.g. the diocese of Adelaide; the provinces of New Zealand and South Africa.

Decisions as to Status of Colonial Church.-Several decisions of the Privy Council in recent years throw some light on the status of the Church in the colonies; and from these it may be gathered that this status differs largely in colonies which have a Parliamentary representation, and in those which have not (usually called Crown colonies).

In a Crown colony, or in cases where the letters patent are made by the authority of an Act of Parliament, the Crown can by its sole authority constitute a bishopric and confer ecclesiastical jurisdiction. But it cannot, at any rate, confer ecclesiastical jurisdiction in colonies with a local legislature. (Re the Bishop of Natal ( $m$ )).

In colonies where there is no Church established by law, the Church is in no better or no worse position than any other religious body; it may constitute its own tribunals and form its own rules of internal government, but to enforce sentences of those tribunals it must apply to the civil courts. (Long r. Bishop of C'apetown, $1863(n)$ ). Since these decisions the Crown has ceased to appoint bishops by letters patent in colonies possessing a Parliament (o). But when a colonial bishop is consecrated in England, it is customary for the Crown to issue a licence to the archbishop for that purpose. In Scotland, Ireland, or in any colony, umless prevented by the provisions of some Act of Parliament, bishops may be consecrated by other bishops without licence from the Crown.

Apparently, however, the Crown can legally create bishops by letters patent in colonies with a Parliament, but cannot confer any coercive jurisdiction, and the bishop so created must enforce obedience from his clergy by having recourse to the eivil courts. (The Bishop of Natal v. Gladstcne $(p)$ ).

(m) (1864) 3 Moo. P. C. (N. S.) 115.

(n) (1863) 1 Moo. P. C. (N. S.) 411. (o) Phill.. Eccl. Law, p. 1786.

(p) 1866 ) L. R. 3 Eq. 1; and see In re the Bishop of Natal cited, supra. 
In colonies where the Church enjoys no legal status, it comes under the law of roluntary societies, and the civil courts will only take cognizance of the rules made by such a voluntary association in order to determine who is entitled to property or funds under those rules, or to protect some right or interest infringed by their operation. (Forbes v. Eden $(q)$ ).

(q) (1867) L. R. 1 Sc. \& D. 568. 
CHAPTER II.

THE NAVY.

The Naval Forces.

The naval forces consist of his Majesty's Royal Navy and the Naval Reserve.

Maintenance of the Nayy.-Parliament does not seem at any period of our history to have regarded the maintenance of the naval force by the Crown with the same jealousy with which it regarded the maintenance of the army. The reason of this is not hard to discern, for a navy could hardly be used as a means of oppression, or as a support to the exercise of arbitrary authority in derogation of the liberties of the subject, whilst at the same time its existence was manifestly necessary for the adequate defence of an insular power. Hence no special Parliamentary sanction was or is required for the navy beyond the granting of the necessary supplies, and its numbers are not limited by statute.

Entry and Term of Seryice.-Impressment was the regular means of recruiting for the navy down to the nineteenth century, and it was recognized by statute $(a)$. It is still apparently legal at common law in time of war, but only sea-faring men are liable to impressment, and only then under warrant issued by the Admiralty in pursuance of a proclamation by the Crown or of an Order in Council $(b)$.

Wrongful impressment is a civil injury for which damages may be recovered, and wrongful and malicious impressment is a gross mistemeanour for which a person is liable to fine and imprisonment.

(a) See 2 Ric. II. c. 4; 2 Phil. \& Mary, c. 16; 5 Eliz. c. 5.

(b) See R. v. Broadfoot (1743), Foster, 154. 
At the present time officers in the navy hold their commissions from the Admiralty, and an officer may not resign his commission so as to cease to be a person belonging to his Majesty's navy without the consent of the Admiralty (c).

Recruits are obtained by enlistment under the Naval Enlistment Acts, 1853 to 1884 (d), by which it is provided that no person may be detained in the nary for a term of more than five years against his consent, mless he has entered or re-entered for a longer term, which he may do in accordance with the regulations made from time to time by the Admiralty $(e)$.

Officers and men serving in coastguard and revenue cruisers, and naval pensioners, may be required to serve in the navy for not more than five years $(f)$.

The Naval Reserve.-The Naval Reserve consists of forces raised under various Acts. These are-

(1) The Naval Coast Volunteers raised by the Admiralty under the Naval Coast Volunteers Act, 1853 ( $g$ ). Their number is limited to 10,000 ; they are engaged for a term of five years subject to an annual training of twenty-eight days. They may be called out for actual service, on shore or at sea, by proclamation for a term of one year, which may be extended for an additional year by proclamation.

(2) The Royal Naval (Volunteer) Reserve, commonly known as the Royal Naval Reserve $(h)$, raised under the Royal Naval Reserve (Volunteer) Act, 1859 (i). They are engaged for a term of five years subject to an annual training of twenty-eight days. They may be called out by proclamation for actual service on

(c) Hearson v. Churchill, C. A., [1892] 2 Q. B. 144; Peg. v. Cuming (1887), 19 Q. B. D. 13.

(d) 5 \& 6 Will. IV. c. $24 ; 16 \& 17$ Vict. c. $69 ; 47$ \& 48 Vict. c. 46 ; short title given by 55 \& 56 Vict. c. 10 .

(e) $47 \& 48$ Vict. c. 46 , s. 2 .

(f) Service of Seafaring Men Act, 1853 (16 \& 17 Vict. c. 73 ) ; $19 \&$ 20 Vict. c. 83 , s. 3.

(g) $16 \& 17$ Vict. c. 73.

(h) See 631 \& 64 Vict. c. 52 , s. 1.

(i) $22 \& 23$ Vict. c. 40. 
shore or at sea for a term of three years, extendible to five rears by proclamation.

(3) A new division of the Royal Naval (Volunteer) Reserve raised under the Naval Reserve Act, $1900(k)$. The term of service is limited in the case of pensioners by the conditions attached to the pension, or in other cases by the terms of the enlistment or employment (l). In other respects they are subject to the provisions of the Royal Naval Reserve (Volunteer) Act, 1859. The numbers of the last two mentioned forces are not subject to any limit $(m)$.

(4) The Royal Naval (Volunteer) Reserve raised under the Naval Forces Act, 1903 ( $n$ ). This force is subject to the provisions of the Royal Naval Reserve (Volunteer) Act, 1859, subject to certain modifications. In addition to these there are certain other forces generally spoken of as forming part of the Naval Reserve.

These are-

(1) The Royal Naval Artillery Volunteers, who may be called out by proclamation in case of actual or apprehended invasion, the occasion having been first communicated to Parliament, if sitting, if not by the proclamation $(o)$.

(2) The Royal Marine Volunteers raised under the Naval Forces Act, $1903(p)$, and subject to the enactments in force relating to volunteers, with the proviso that they are to be available for service beyond the seas.

(3) Officers and men of the coastguard or revenue services, and all sea-faring men belonging to other Government departments, who are liable to be required to serve for not more than five vears $(q)$.

(4) Petty officers and seamen of the Royal Navy who are in the receipt of pensions, who may be required to serve for not more than five years $(r)$.

(k) 6.3 \& 64 Vict. c. 52 .

(m) $3 \mathrm{Edw}$. VII. c. 6, s. 5 .

(l) $I b, \mathrm{~s}, 3$.

(n) $I b$.

(o) Naval Artillery Volunteers Act, 1873 (36 \& 37 Yict. c. 77).

(p) 3 Edw. VII. c. 6.

(q) 16 \& 17 Vict. $c, 73 ; 47 \& 48$ Vict. c, 46.

(r) $I b$. 


\section{Naval Discipline.}

The naval forces were in early times regarded merely as an adjunct to the land forces, and such sailors as were required for the transport of troops no doubt came under the regulations drawn from time to time for the military forces gencrally by the king, with the advice of the constable and ear' marshal. After the battle of Sluys in 1340, which gave England the command of the seas, the navy acquired new importance, and towards the close of the fourteenth century admirals were appointed who exercised certain disciplinary jurisdiction over the naval forces $(s)$. From the beginning of the fifteenth century onwards a single lord high admiral was appointed, and in 1661 an Act was passed for the regulation of the naval forces, giving the lord high admiral power to issue regulations for the trial of offences by court-martial $(t)$.

The regulations for the trial and punishment of offences committed by seamen are now contained in the Naval Dis. cipline Acts of 1866 and 1884 (u), and these Acts, unlike the Army Act, which must be re-enacted annually, are permanent.

Persons Subject to the Naval Discipline Acts.-The principal persons subject to the Acts are: (1) Every person in or belonging to his Majesty's navy and borne on the books of one of his Majesty's ships in commission $(x)$; (2) land forces when embarked on any of his Majesty's ships to such an extent as provided hy Order in Council $(y)$; (3) all other persons or passenger's on board his Majesty's ships subject to regulations made by the Admiralty $(z)$; (4) persons borne upon the books of hired ressels in his Majesty's service, if the Admiralty so direct (a); (5) marines when serving on board his Majesty's ships to such an extent as may be pro-

(s) See ante, p. 248.

(t) 13 Car. II. c. 9.

(u) $29 \& 30$ Vict. c. $109 ; 47$ \& 48 Vict. c. 39.

(.r) 29 \& 30 Vict. c. 109, s. 87.

(y) $I b$. s. 88 .

(z) S. 89.

(a) S. 90 . 
vided by Order in Council (b), and subject to the other provisions contained in the Army Act, 1881; (6) officers and men of the naval reserve forces, officers and men in the coastguard and revenue services, and petty officers and seamen in receipt of pensions at such times and subject to such provisions as are contained in the various Acts relating to such persons.

Such persons are subject to the Acts for all offences committed in any harbour, havell, or creek, or on any lake or river, in or out of the United Kingdom, or anywhere within the jurisdiction of the Admiralty, or at any place on shore out of the United Kingdom, or in any of his Majesty's dockyards, yards, wharres, arsenals, barracks, or hospitals, in or out of the United Kingdom $(c)$.

In addition, certain offences are made punishable under the Act if committed anywhere on shore, whether in or out of the United Kingdom (d).

Features of Nayal Discipline.-Offences under the Acts are triable by court-martial, or, if committed by seamen, except in the cases expressly prorided for or made capital by the Acts, they may be tried summarily by the officer in command of the ship to which the offender belongs $(e)$. The constitution and procedure of naral courts-martial are regulated by the Act, and in default of the judge advocate of the fleet, or his deputy, or any person appointed by the Admiralty or commander-in-chief of the fleet or squadron, the president of the court-martial must appoint a deputy judge advocate $(f)$, whose duty it is to send a report of the proceedings to the commander-in-chief or senior officer, who rnust transmit it to the secretary of the Admiralty; copies of this report can be obtained by any person tried by courtmartial at any time within three years of the final decision $(y)$.

Sailors, like soldiers, are not exempt from jurisdiction of

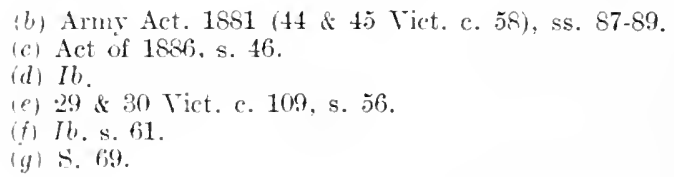


the ordinary eivil and criminal eourts, and the Naval Discipline Act specially declares that nothing in the Act shall prevent any person triable under the Act from being trier in a civil court in respect of any offence punishable or cognizable by the common or statute law $(h)$.

Sailor's (excepting commissioned officers) are protected from arrest for debt, unless the debt was contracted at a time when the debtor did not belong to his Majesty's service, and unless the plaintiff has made an affidavit to that effect $(i)$. Though the scale of crimes and penalties is regulated by the Acts, any erime not punishable by death or penal servitude may be punished according to the laws and customs used at sea $(k)$.

\section{Superior Officers and their Subordinates (l).}

\section{Liability of Subordinate for Illegal Acts done under} Orders.-The law on this point seems to be that if acting honestly in discharge of his duty, a soldier or sailor will not be liable for wrongful acts committed in obedience to the orders of a superior, unless it can be shown that such orders were clearly and manifestly illegal $(m)$.

The ordinary rule of law is that a man must justify any direct violation of the personal rights of another $(n)$, and in such a case he must justify, not only by showing that he had orders, but that the orders were such as he was bound to obey (o). A state of actual war might be held sufficient justification for obedience to any order, whether clearly and manifestly illegal or not $(p)$.

In $R$. v. Thomas $(q)$, where a sentry on board H.M.S. Achitle, who had been ordered to keep all boats off, and had

(h) S. 101.

(i) S. 97 .

(i) S. 44 .

(l) These points may be taken to anply both to the navy and the army. 805.

(in) Per Willes, J., in Keighly v. Bell (1866), 4 F. \& F., at pp. 790,

(n) See Hayling v. Oliey (1853), 8 Ex. 531.

(o) Keighly v. Bell, supra, at p. 805.

(p) $I b$. p. 790 .

(q) Russell on Crimes, 6th Eil., iii. 94. 
been supplied with three blank cartridges and three ball, under a mistaken sense of his duty fired and killed a man, the jury found that he had acted under the mistaken impression that it was his duty. But, the case being reserved for the judges, it was unanimously held to be murder, with the proviso that it was a proper case for a pardon.

\section{Liability of Superior to Subordinate for Acts done in the} Exercise of his Authority. - Whether an action by a person subject to naval or military law lies against a superior officer for acts done within his authority, but maliciously and without probable cause, appears doubtful.

In Sutton. v. Johnstone (1787) (r), Johnstone having caused his inferior officer Sutton to be arrested and tried by court-martial for neglect of duty, cowardice, and disobedience to orders, and Sutton having been honourably acquitted by the court-martial, the latter brought an action against his superior before a special jury at the Guildhall for false imprisonment and malicious prosecution, and recovered $£ 6,000$ damages.

The defendant brought a motion in the Court of Exchequer in arrest of judgment, which was discharged; but on writ of error in the Exchequer Chamber the judgment was reversed on the ground that the absence of reasonable and probable cause had not been shown.

In Durkins v. Paulet (s), which was an action for libel in consequence of defamatory matter contained in a report. made by a superior officer to the comnuanding officer, it was held by two judges out of three (Lord Chief Justice Cockbum dissenting) that an officer cannot maintain an action against his superior officer for acts done in the discharge of his duty, even though done maliciously and without reasonable, probable, and justifiable cause, but that he must pursue the redress prescribed by the articles of war.

Superior officers are, however, liable, it would seem, to an action for false imprisonment by a subordinate, in the absence of reasonable and probable cause $(t)$. But officers

(r) 11787) 1 Bro. P. C. 76 .

(s) (1869) I. R. 5 Q. B. 94.

(t) See Warlen v. Bailey (1811), 4 Taunt. 67 . 
generally are not liable for acts done bont ficle through mistake or misapprehension in the exercise of their duty, and in the absence of cruelty, malice, and oppression (u).

In Keighly v. Bell $(x)$ it was held that a soldier cannot maintain an action against an officer for acts done under the orders of a superior officer, which the superior officer would have a right to give, and the officer be bound to obey, unless the latter has caused or procured such orders by means of false reports or representations made maliciously or for some sinister and improper motive, and also without any reasonable or probable grounds. In order to support such an action the report through which the order was procured must be wilfully untrue and without probable ground.

Wrongful Dismissal.-Officers in the army (and semble this would apply to all non-commissioned officel's and men of both services also) hold their commissions durante bene placito, and are therefore liable to instant dismissal without notice or cause assigned. The court will not, therefore, entertain an action for wrongful dismissal against the superior authorities, or inquire into the grounds of the dismissal, either on Petition of Right or in any other proceeding $(y)$.

(u) See per Lord Mansfield in Wall v. Macnamara eited in Sutton v. Jolinstone (1 Term. Rep. at p. 536).

(x) $(1866) 4$ F. \& F. 763

(y) In re Tufnell (1876), 3 Ch. D. 164; and see Grant. v. Secretary of State for India (1877), 2 C. P. D. 445 ; Dickson v. Combermere (Viscount) (1863), 3 F. \& F. 527. Denning v. Secretary of State for India, 37 T. L. R. 138. 


\section{Chapter III.}

\section{THE REGULAR AND AUXILIARY FORCES.}

\section{The Regular Forces.}

Definition.-The regular forces, as defined by the Army Act, 1881, consist of such officers and soldiers who by their commission, terms of enlistment, or otherwise are liable to render continuous service to his Majesty in any part of the world, including the Royal Marines, his Majesty's Indian forces, the Royal Malta Artillery, and the reserve forces (comprising the army reserve and the militia reserve) (a) when subject to military law. In addition to these, certain troops are raised by order of his Majesty beyond the limits of the United Kingdom or of India (b), and are maintained under the authority of the Colonial Office or of the Foreign Office. These would come under the above definition in cases when, by the terms of their enlistment or otherwise, they are liable to serve in any part of the world, and in any case they are subject to the regulations contained in the Amy Act, $1881(c)$.

Prior to the declaration of war with Germany in August, 1914 , the regular army at home numbered 121,000 men of all ranks and arms, the regular army abroad 117,000 men (viz. white troops in India, Egypt, S. Africa, and elsewhere), whilst the army reserve numbered 146,000 men $(d)$.

(a) 44 \& 45 Vict. c. 58, s. 190 (8) (9): 58 \& 59 Vict. c. 7. s. 9.

(b) As to such troops being subject to military law see $44 \& 45$ Tict. c. 58, ss. 175 (4). 176 (3).

(c) $I b . s .177$.

(d) See the speech of the Secretary of State for War (The Times, 11th Mar. 1914). The Army estimates of the effective and non-effective surves for 1921-192. show the number of nen on the establishment of the Arny, exclusive of India, at 341.000. but this number is expected to fall in the course of the year. In February, 1922, the Territorial Army was numbered at 132.412. 
Maintenance of a Standing Army.-Prior to the Revolution of 1688 and the subsequent recognition by Parliament of a regular standing army upon a legal footing, there had been two legal kinds of military forces at the disposal of the Crown, and these were (1) the old feudal array, resulting out of the tenures by military service; (2) the old train bands, which became known as the militia during the reign of Charles I.

The feudal array declined with the commutation of military service inco money payments, and the prerogative of pressing was frequently resorted to for the purpose of obtaining men for military service. Sometimes also contracts were entered into by the nobles with the Crown for the supply of voluntary recruits, as in the French wars of Henry III. and Edward II. Pressing was finally declared illegal by the 16 Car. I. c. 28 , and the old feudal system of obtaining troops fell entirely into disuse when the feudal tenures were abolished in $1661(e)$.

The train bands, or militia, could legally be used for domestic or defensive purposes only, and could not be sent abroad $(f)$. Originally these troops were under the supervision of the sheriffs, who were replaced by the lords lieutenants in the reign of Mary. It was the control of this body which formed one of the chief causes of dissension between Charles I. and the Long Parliament, but after the Restoration it was enacted that "the militia and all other forces by sea and land were to be under the sole government and command of the ling" (g).

A force of guards to the sovereign was maintained by Charles II. with Parliamentary sanction, and James II. increased their number to 30,000 on his own authority $(h)$. Subsequently these guards and garrisons were voted annually by Parliament till the beginning of the last century, since when the guards have been continued as portion of the regular army (i).

Parliament had always denied the right of the Crown to

(e) 12 Car. II. c. 24.

(f) See 16 Car. I. c. 28.

(g) 13 Car. II. st. 1, e. 6.

(h) Steph. Comm., ii 598.

(i) See Clode, Mil. and Mart. Law, p. 5. 
maintain on its own authority a standing army in time of peace as being a menace to the country and an aid to despotism, and whether the question was the unfettered control of the militia, as in the reign of Charles I., or the unauthorized additions of James to the guards and garrisons legally allowed him, the principle at stake was the same throughout. This question was finally disposed of by the Bill of Rights, $1688(j)$, which declared " that the raising or keeping a standing army within the kingdom in times of peace, unless it be with consent of Parliament, is against law.,

From 1689 to the present day the regular standing army has been maintained on a legal footing by means of annual Acts linown down to 1881 as Mutiny dets, and since then as Army Annual Acts.

The Annual Army Act performs two functions; (1) The preamble authorizes the maintenance and limits the number of the forces to be raised in each year " for the safety of the United Kingdom and the defence of the possessions of his Majesty's crown, including those to be employed at the depôts in the United Kingdom for the training of recruits for service at lone and abroad, but exclusive of the numbers actually serving within his Majesty's Indian possessions " $(k)$. The preamble also recites the necessity for the employment of a force of marines, without, however, limiting their number ( $(l)$. Thus it provides the statutory authority required by the Bill of Rights for the maintenance of a standing army. (2) It re-enacts annually, and sometimes adds new clauses or makes amendments to, the Army Act, 1881, which with the regulations made thereunder forms the code of military law for the discipline of the forces authorized to be raised, and all other forces to which the Army Let, 1881, applics. Thus it provides the statutory authority for the exercise of a special code of military

(j) 1 Will. \& Mary, sess. 2, c. 2.

(b) The minber so authorized by the Army and Air Force Annual Act, 1921, is 341,000 , to which must be added 30,880 for the Air Force. See also p. 362 , ante.

(1) The marines are not apparently inchuded in the number actually authorized by the Act. See s. 2 (3) of the Army Annual Act, 1914. 
law in time of peace, rendered necessary by the terms of Magna Carta, the Petition of Right, and the Bill of Rights.

It may be noted that the Crown has no power to compel enlistment in time of peace. At common law, however, the Crown is entitled to the services of every man capable of bearing arms, in case of sudden invasion or dangerous rebellion $(m)$.

Entry on Service.-Ofticers' commissions were formerly issued by the Crown under sign manual, but by the $25 \& 26$. Vict. c. 4, her Majesty was empowered to direct by Order in Council that they should in future be issued under the signature of the commander-in-chief (whose duties have now devolved upon the Army Council $(n)$ ) and a principal Secretary of State, and in the case of the marines under the signature of the Lords Commissioners of the Admiralty, power being reserved to his Majesty to issue any commissions under the sign manual in such cases as his Majesty may think fit.

Officers in the army hold their commissions durante bene. placito, and are liable to be dismissed at any moment without cause assigned. The court has therefore no jurisciction to inquire into the circumstances of the dismissal on Petition of Right or any other proceeding for wrongful dismissal (o). The same principle would, it seems, apply to all non-commissioned officers and men in the army or navy.

The principal points with regard to the enlistment and terms of service for soldiers under the Army Act are as follows:-

The enlistment of a soldier in the regular forces is effected by the recruiting officer delivering to the intending recruit a notice in the form authorized by the Secretary of State, stating the general requirements of attestation, and the general conditions of the contract to be cutered into, and requiring him to attend before a justice of the peace, either forthwith or at the time and place named in the notice $(p)$.

(m) Broadfont's Case (1743), Fost. 154 .

(n) The office of commander-in-chief has now been abolished, and the statutory powers formerly exercised by him are transferred to the Army Council by statute.

(o) In re 'Tufnell (1876), 3 (h. D. 164.

(p) 44 \& 45 Vict. c. 58, s. 80 (1). 
On appearance before the justice of the peace, if the intending recruit assents to be enlisted, the questions in the attestation paper are read over to him and his answers taken down. Enlistment is completed by the intending recruit signing the declaration attached to the attestation paper, and taking the oath of allegiance contained in the paper $(q)$. After enlistment a recruit may at any time within three months of the signing of the attestation paper purchase his discharge on payment of the sum of $£ 10$ for the use of his Majesty, provided no proclamation has been issued requiring soldiers entitled to be transferred to the reserve to remain in any service, in which case his discharge may be postponed during that period $(r)$.

The term of original enlistment is for twelve years, or for such less period as his Majesty may fix, but not for any longer period; and the enlistment may be either for the whole period in army service, or for such portion in army service and the rest in the reserve as the Secretary of State may from time to time fix $(s)$. The Secretary of State has power to make regulations enabling a soldier to vary the conditions of service under his original enlistment as to the period in army service and with the reserve $(t)$.

Until the changes introduced by the then Secretary of State for War (Mr. Arnold-Forster) in 1904, it was the practice to enlist the whole army primarily for three years' service with the colours (in army service) $(u)$. The term is now seven years with the colours, and five vears in the reserve $(v)$.

After the expiration of nine years from the date of his original enlistment the soldier may, with the assent of the competent military authority, extend his term of service for such term as will make up twenty-one vears $(x)$.

(q) 44 \& 45 Vict. c. 58 , s. 80 (2) (3) (4).)

(r) $I b$. s. 81 .

(s) $I b$. ss. 76,77 .

(t) $I b$. s. $78: 63$ Vict. c. 5, s. 4 .

(u) See memorandum of the Secretary of State for War published in The Times, the 16 th of July, 1904.

(v) See speech of the Secretary of State for War (The Times, 11th Mar., 1914).

(x) $14 \& 45$ Tict. c. 58. s. 84 ; and see as to continuance in service after twenty-one years, ib. s. 85 . 
Provisions are contained in the Act enabling his Majesty to prolong the term of service for the period of twelve months of any soldier who becomes entitled to his discharge whilst on service beyond the seas, or while a state of war exists, or while soldiers in the reserve are required by proclamation to continue in or re-enter upon army service; and while a state of war exists a soldier who becomes entitled to be transferred into the reserve mal be detained in army service during the same period $(y)$.

In time of imminent national danger or great emergency his Majesty in Council may, by proclanation, the occasion being first communicated to Parliament, if then sitting, or declared by the proclamation if not sitting, continue soldiers in army service who would otherwise be entitled to be transferred to the reserve $(z)$.

The Army Reserve.-The constitution and regulation of the army reserve, which was first created in 1859 by the Reserve Forces Act of that vear, now depends, with that of the militia reserve, upon the Reserve Forces Act, $1882(a)$, and the various amending Acts. In addition to the two classes of reservists created by that Act, there must now be added a new branch of the Army Reserve termed the "Special Reserve," created by the Territorial and Reserve For'ces Act, 1907.

Under the Act of 1882 there are two classes of the army reserve: Class $I$. of the army reserve consists of such number of men as may from time to time be provided by Parliament (b), and is composed of such men as have served in any of the regular forces and are (1) transferred into the reserve under the Army Act, 1881; or (2) enlisted or re-engaged in pursuance of the Reserve Forces Act, $1882(c)$.

(y) 44 \& 45 Vict. c. 58 , s. $87 ; 45 \& 46$ Vict. c. 7 , s. 4 (2).

(z) 44 \& 45 Vict. c. 58 , s. $88 ; 48$ Vict. c. 8 , s. 5 .

(a) $45 \& 46$ Vict. c. 48 .

(b) Apparently the reserves are not included in the number authorized by the Army Annual Act. This number for 1914 was 186,400 (4 Geo. V. c. 2), whilst the number of men actually employed was-British Army, 121,000 ; Reserves, 146,000. Speech of Secretary of State for War (The Times, the 11th day of March, 1911).

(c) $45 \& 46$ Vict. c. 48 , s. 3 . 
The first class of the amy reserve is divided into two divisions, the men of the second division forming a supplemental reserve, which, under the Act of 1882 , was not liable to be called ont on permanent service until the whole of the first division had been called out $(d)$. Now, however, it is liable to be called out without any such restriction $(e)$.

Class II., which is not usually raised, is composed of certain out-pensioners of Greenwich and Chelsea Hospitals, and men who, having served the full term of their original enlistment, are enlisted or re-engaged in pursuance of the Reserve Forces Act, 1882 (f). The second class of the army reserve is not liable to serve out of the United Kingdom $(g)$.

The term of service for men transferred under the Army Act, 1881, is for the residue of the term for which they originally enlisted, or for the residue of such term as extended under the Army Act, 1881. The term of service for men entering otherwise than by transfer under the Army Act, 1881, is such as may be prescribed by the terms of enlistment or re-engagement in the reserve $(h)$.

The mode and form of enlistment for both the army and the militia reserve is the same as that provided by the Army Act, 1881, on entrance into the regular forces (i).

The army reserve may be called ont to aid the civil power in the preservation of peace, (1) by a Secretary of State or the lord lieutenant in Ireland, at any time when occasion requires; (2) by the officer commanding his Majesty's forces in any town or district on the requisition in writing of any justice of the peace.

His Majesty in Council may, by proclamation, call out hoth the army reserve and the militia reserve on permanent service in case of imminent national danger or great emergency, the occasion being first communicated to Parliament if then sitting, or declared in Council and notified by the proclamation if Parliament be not then sitting $(k)$. If Par-

(d) $45 \& 46$ Vict. c. 48, s. 3 .

(e) 63 \& 64 Vict. c. 42, s. 1 .

(f) $45 \& 46$ Vict. c. 48, s. 3.

(g) Ib. s. 14 (3).

(h) $I b, \mathrm{~s} .4$

(i) $I b . \mathrm{s} .18$.

(k) $I b . \mathrm{s} .12$. As to the engagement of men, not exceeding 5,000 , in the reserve, who may be called out on permanent service outside the Tnited Kingdom, see 61 \& 62 Vict. c. 9, s. 1. 
liament stands adjourned or prorogued for more than ten days from the date of the calling out of the reserves, it must be summoned by proclamation to meet within ten days $(l)$.

When called out on permanent service men of both reserve forces are liable to serve for the unexpired residue of their term of service, and for any further period, not exceeding twelve months, during which, as soldiers of the regular forces, they can be detained under the Army Act, $1881(\mathrm{~m})$.

Whilst called out on permanent service, or when subject to military law, the reserves form part of the regular forces, and are subject to the Army Act, $1881(n)$.

When called out on permanent service men of the first class of the army reserve are liable to service in any part of the world, but men of the second class are not liable to serve outside the United Kingdom (o).

Men of the army reserve are subject to be called out for annual training for a period not exceeding twelve days or twenty drills, when they may be attached to, and trained with, a body of the regular or auxiliary forces $(p)$.

The Militia or Special Reserve.-Classes I. and II. of the army reserve formed under the Army and Reserve Forces Act, 1882, are composed entirely of men who have served in the regular forces; but by the Territorial and Reserve Forces Act, 1907, men who have not served in any of the regular forces may be enlisted into the army reserve, and when so enlisted are termed " Special Reservists," and may be re-engaged as such after serving their term $(q)$.

Power is afforded by the Act of 1907 to transfer militia battalions to the army reserve by Order in Council, which must be laid before both Houses of Parliament, and when so transferred they are to be deemed lawfully formed as battalions of special reservists. But unless an officer or man so transferred indicates his assent to the transfer, certified

(l) 45 \& 46 Vict. c. 48 , s. 13.

(m) $I b$. s. $14 ; 44 \& 45$ Vict. c. 58, s. 87.

(n) $45 \& 46$ Vict. c. 48 , s. 14 (2); $44 \& 45$ Vict. c. 58, s. 190 (8) (9).

(o) $45 \& 46$ Vict. c. 48 , s. 14 (3).

(p) $I$ b. s. 11 .

(q) 7 Ed. VII. c. 9 , s. 34 .

C.L.E. 
by his commanding officer, his existing conditions of service are not to be affected by the order effecting the transfer $(r)$.

Under this power a large number of militia units have been transferred to the special reserve, and in cases where assent to the transfer has not been withheld, have become subject to such provisions relating to the army reserve as are applicable to them, and to the special provisions contained in the Act of 1907 , relating to the special reserve, which are briefly as follows:-

Special reservists may be called out for annual training for such period or periods as may be prescribed by order or regulation under the Army and Reserve Forces Act, 1882. In addition to the annual training they may be called out for a special course or courses of training not exceeding six months in the whole, when they may be attached to, or trained with, any body of his Majesty's forces. But in neither case is a man to be liable to be called out for any longer period than is specified in his attestation paper $(s)$.

The conditions as to embodiment and disembodiment applicable to the army reserve apply also, it would seem, to special reservists; and when a proclamation is issued calling out the army reserve, power is afforded under the Act of 1907 to order the special reserve to cease to be called out by proclamation $(t)$.

Members of the special reserve not exceeding 4,000, and members of the 1st Class of the army reserve whose characters on transfer into the reserve are good, may agree in writing (in the case of the army reserve as to the first two years of their service only) to be liable to be called out on permanent service without any such proclamation or communication to Parliament as is required by the Reserve Forces Act, 1882; and in this case their calling out does not involve the meeting of Parliament within ten days required by the Act of 1882 . This power may only be exercised for service outside the United Kingdom, and must be reported to Parliament as soon as may be $(u)$.

(r) 7 Ed. VII. c. 9, s. 34 .

(s) $I b$. s. 30.

(t) $\mathrm{Ib}$. s. 30 .

(u) Reserve Forces and Militia Act. 1898 (61 \& 62 Vict. c. 9), s. 1; Act of 1907 , s. 32. 
Acceptance of a commission as officer in the reserve of officers does not vacate the seat of a member of Parliament $(x)$.

By the Territorial Army and Militia Act, 1921, it is provided that "the special reserve" shall be called "the militia," and all references in any Act or document to the special reserve shall have effect as though references to the militia were substituted for references to the special reserve.

The Marines.-The necessity for maintaining a force of marines is recited in the preamble to the Army Annual Act, but the number to be raised is not limited by the Act. They consist of infantry and artillery, and are liable to serve either on shore or on board ship. They form part of the regular forces $(y)$, and when on shore or on board transport, merchant, and other ships and vessels, they are subject to the regulations contained in the Army Act, 1881, subject to any articles of war which may be made by the Admiralty ( $z$ ). A general court-martial, however, can only be convened for the trial of a soldier of the marines by an officer under the authority of a warrant from the Admiralty, though a district court-martial may be convened by any officer having authority to convene a district court-martial for any soldier of any other portion of the regular forces $(a)$.

During the time that they are borne on the books of any ship commissioned by his Majesty (otherwise than for service on shore), officers and men of the marines are subject to the Naval Discipline Acts (b). When on board a ship in commission, but borne on the books of such ship for service on shore, officers and men of the marines are subject. to the Naval Discipline Acts to such an extent as his Majesty by Order in Council directs, or, in default of such direction, as is for the time being directed with regard to the other regular forces $(c)$.

With regard to the term of enlistment, conditions of ser-

(x) Act of 1907, s. 36 .

(y) 44 \& 45 Vict. c. 58, s. 190 (8).

(z) See the preamble to the Army Annual Act; Army Act, 1881, s. 179.

(a) Ib. s. 179 (1) (2).

(b) $I b$. s. 179 (15).

(c) Ib. s. 179 (18). 
vice, transfer to the reserve, or re-engagement or prolongation of service, the marines are not subject to the provisions of the Army Act, $1881(d)$, but to the special Acts relating to those matters $(e)$.

The Indian Forces.-The Indian forces comprise officers and men of the regular British Army serving in India, and the Indian Army proper composed of native troops under British officers.

Officers and men of the British Army in India are subject to the Army Act, 1881, with certain modifications (f), but they are not included in the number of troops authorized to be raised by the preamble to the Army Annual Act.

With regard to the Indian Army proper the Government of India Act, $1858(g)$, provided that the naval and military forces of the old East India Company were to continue, subject to all such Acts of Parliament, laws of the GovernorGeneral in Council, and Articles of War as had then been passed. The Army Act, 1881, has further provided that nothing in that Act contained is to affect the Indian military law respecting officers and soldiers or followers in his Majesty's Indian forces being natives of India; and the expression "Indian military law" means the Articles of War, or other matters, made, enacted, or in force or hereafter to be made under the authority of the Government of India, and such articles are to extend to native officers, soldiers, and followers wherever they may be serving $(h)$.

It is provided by the Government of India Act, 1915, that, except in case of invasion, the expenses of any expedition carried on outside the Indian frontiers cannot be defrayed out of the Indian revenues without the consent of both Houses of Parliament (i). In connection with this

(d) Army Act, 1881, s. 179 (12).

(e) As to term of enlistment see $10 \& 11$ Vict. c. 63 , s. $1 ; 20$ Vict. c. 1. As to re-engagement and prolongation of service, 10 \& 11 Vict. c. 63, ss. $3-5 ; 20$ Vict. c. $1 ; 44 \& 45$ Vict. c. 58 , s. 179 (12) (13).

(f) Army Act, 1881, s. 180 (1).

(g) $21 \& 22$ Vict. c. 106.

(h) Army Aet, 1881 , s. 180 (2). And see 53 Geo. III. c. 155, s. 96 ; $3 \& 4$ Will. IV. c. 85 , s. 73 , as to the powers to make articles of war for native troops.

(i) 5 \& 6 Geo. T., c. 61, s. 22 . 
provision, it may be noted that by the preamble to the Amy Annual Act the number of forces authorized to be maintained by the Crom is limited to a certain number, "exclusive of the numbers actually serving within his Majesty's Indian possessions" ; seeing that this is so, it has been doubted whether any portion of the Indian Army conld be employed outside India without special Pariamentary sanction. The objection taken by Parliament to the maintenance of troops by the Crown without Parliamentary sanction was, no doubt, in its origin applicable to the United Kingdom only, and by the Army Annual Act it is expressly provided that persons subject to military law shall not be exempted from the provisions of the Army Act in the event of the number of forces for the time being in the service of his Majesty, exclusive of the marine forces, being either greater or less than the number authorized $(k)$. So that Parliament would probably view with equanimity the employment of troops by the Crown ahove the number authorized, at least outside the United Kingdom (l).

Colonial Forces. - These are either forces raised by colonial Governments, or forces raised by order of his Majesty beyond the limits of the United Fingdom and India $(m)$.

(1) Forces raised by colonial Governments are ordimarily subject to the laws of their own colony, but when serving with the regulars they become subject to the Army Act, in so far as the law of their own colony may have failed to provide for their government and discipline $(n)$.

(2) Forces raised by order of his Majesty beyond the limits of the United Kingtom and India, such as the West Indian and African regiments, are subject to the Army Act when under the command of an officer of the regular forces, but this provision is not to affect the application to such forces of any Act passed by the legislature of a colony (o). These

(k) See 11 Geo. V., c. 9, 2 (3).

(l) A discussion on this point arose in 1878, when Indian troops were ordered to Malta.

(m) See Army Act, 1881 , s. 176 (3).

(n) $I b$. s. $177^{\circ}$ (o) $I b$. s. $176(3)$. 
troops are generally under the authority of the Colonial or Foreign Othices.

\section{The Auxiliary Forces.}

Prior to the passing of the Territorial and Reserve Forces Act, $1907(p)$, the auxiliary forces, as defined by the Army Act, 1881, consisted of the militia, the yeomanry, and the volunteers $(q)$.

On the creation of the territorial force by the Act of 1907 , provision was made by the Act for the transfer of units of the yeomanry and the volunteer forces to the territorial fcree by Order in Council; and under the exercise of this power the former yeomanry and rolunteer forces may be said to have become merged in the territorial force. The Act also created a new branch of the army reserve called the special reserve, and provided for the transfer of units of the old militia force into this body by Order in Council. A large number of militia units have so been transferred by Order in Council. In both cases, however, the Act provided that the transfer, if made without consent, was not to affect the conditions of service of persons enlisted before the passing of the Act, and for this reason, as also from the fact that the old militia, yeomanry and volunteer Acts still remain in force, and may have some bearing on the units transferred, the subject would best be understood by a short reference to these before proceeding to consider the territorial force.

The Militia.-The term Militia seems first to have been applied to the old train bands in the reign of Charles $I$., in connection with the disputes between the Crown and the Long Parliament as to the control of that body.

After the Restoration the 13 Car. II. st. 1, c. 6 recited that the king was the supreme hear of the militia and all forees by sea and land, and by an tet of the following year the lords lientenant of counties were emporered to call the 
militia together and employ them within the realm in eases of insurreetion, invasion, or rebellion.

By the Regulation of the Forees Act, 1871, the jurisdiction, powers, duties, eommand, and privileges formerly exercised by the lord lieutenant in relation to the militia, yeomanry and rolunteers were revested in the Crown, to be exercised through a Secretary of State, or such offieers as the Crown might appoint with the advice of a Secretary of State $(r)$. The lord lientenant was, however, to retain the power of raising the militia by ballot when-as is never now the case-that method is adopted, and of reeommending persons for appointment as junior offieers of the militia $(s)$. These provisions, with regard to the militia, were re-enacted by the Militia Act, 1882, and appointments to the lowest rank of militia offieer were made upon the recommendation of the lord lieutenant $(t)$. There were (prior to the creation of the Territorial Foree in 1907) two kinds of militia, the general and the local militia (u), the former of which alone was of importance. The general militia might be raised under either the compulsory or the voluntary system, though the former had fallen into disuse.

By the Territorial Army and Militia Aet, 1921, the power to raise and maintain a militia force ceased.

The Yeomanry.-The mounted volunteer troops known as the yeomanry were placed upon a statutory footing in 1804 by the 44 Geo. III. c. 54, whieh empowered the Crown to aeeept the services of any corps of yeomanry, subject to such rules and regulations as should be made thereafter. Those rules and regulations are contained in the King's Regulations.

The yeomanry were to a great extent rendered obsolete by transfer of yeomanry units into the territorial foree.

By the Territorial Army and Militia Act, 1921 (11 \& 12 Geo. V. c. 37), the power to raise and maintain a yeomanry foree shall eease.

(r) $34 \& 35$ Tict. e. 86, s. 6.

(s) $I b$.

(t) 15 \& 46 Vict. c. 49 , ss. 5,6 .

(u) Army Act, 1881, s. 199 (13). 
The Volunteers. - The volunteers were first placed upon a statutory basis by the Volunteer Act of 1863, which empowered the Crown to aceept the serviees of volunteer corps through the lords lieutenant of counties $(x)$.

The volunteer's have now become merged in the territorial force by transfer of the various former units into the latter body under the Territorial and Reserve Forees Act, 1907, and presumably no further corps will be raised under the Acts relating to the volunteers, which, however, remain unrepealed, and (except such as relate to raising, service, pay, discipline, or government) may be applied to the territorial force by Order in Council $(y)$.

The Territorial Army.-The Acts relating to the militia, yeomanry, and volumteers, have now largely become obsolete owing to the transfer of the former various units of the yeomanry and volunteers into the territorial army $(z)$, and of the militia into the special reserve, under the Territorial and Reserve Forces Act, 1907 (a), the object of which was to unify and amalgamate the various voluntary branches of the service into a more homogeneous whole. The former provisions relating, therefore, to the seomanry and rolumteers have heen, for the most part, superseded by the provisions of the Act of 1907 relating to the territorial force; whilst the status of the militia, and the importance of the Acts relating to that branch of the service, have been largely modified or superseded by the provisions of the Act relating to the special reserve, and the transfer under the Act of units of the former militia into that body.

Acts relating to the militia, yeomanry, or rolunteers (except as to the raising, serrice, pay, discipline, and gorermment, of those forces) may be applied to the territorial forces by Order in Council (which must he laid before both Houses of Parliament) under the Act $(b)$; and the transfer without his consent, of a member of one of the former voluntary units into the new territorial reserve forces

(x) 26 \& 27 Vict. c. 65.

(y) See infra.

(z) The title was changed to "Territorial Army" by the Territorial Arny and Militia Act, 1921.

(a) 7 El. VII. c. 9 .

(b) $I b$. s. 28 (3). 
created by the Act, is not to affect his previous conditions of service $(c)$.

County Associations.-The initial step in the composition of the territorial force under the Act of 1907 is the formation of an association for each comty, in accordance with schemes made for each county by the Army Council, which must be laid before both Houses of Parliament. The scheme provides for the appointment of the lord lieutenant or some other fitting person as president of the association, together with officers (not less than half the whole number of the association) representative of all branches of the territorial force; also, where deemed desirable, for the appointment of representatives of the county and borough councils, and universities, within the county, and of co-opted members including (if thought desirable) representatives of the interests of employers and workmen. The scheme also provides for the appointment of a chairman and vice-chairman, a secretary, and other officers, and makes provision for offices.

The scheme further formulates rules for procedure, and the formation of committees, and for enabling general officers of H.MI.'s forces to attend. Also for the division of the county into parts where considered advisable, and for constituting sub-associations. The scheme may also contain any consequential, supplemental, or transitory provisions respecting any matter for which regulations may he made under the Act $(d)$.

The duties of the comnty associations (which have no powers of command or training orer any of his Majesty's forces) are to conform to the plan of the Army Council for the organization of the forces within the comnty, to ascertain the military resources and capabilities of the connty and advise and assist the Army Council and other officers. They are to perform the duties of orginization and administration transferred or assigned to them hy order of a Secretary of State or by regulations under the Act. and in particular they are to attend to the following matters $(c)$ :

(c) T Erl. VII. c. 9, ss. 29, 34.

(d) $I 6$, s. 1 .

(e) $I b$. s. 2 . 
(1) The organization, administration, and maintenance of the various units except when called out for training, or military service, or embodied; (2) recruiting in peace and war; (3) provision and maintenance of rifle ranges, buildings, magazines, and sites for camps; (4) facilitating the provision of areas for mancuvres; (5) arranging with employers as to holidays for training, and ascertaining the times best suited; (6) establishing or assisting cadet battalions and corps, and rifle clubs; (7) provision of horses in time of peace; (8) provision of accommodation for safe custody of arms and equipment; (9) supply of requirements on mobilization if directed by the Army Council; (10) the payment of separation and other allowances to the families of members of the force when embodied or called out on military service; (11) the registration of horses for his Majesty's forces; (12) the care of reservists and discharged soldiers. The associations must annually at the prescribed times, and may at any time for special purposes, submit a statement of requirements to meet expenditure, and the Army Council must pay to the associations out of money roted by Parliament such sums as they may consider requisite on the basis of the statements.

The accounts of an association are to be made up and andited annually, and copies sent to the Army Council $(f)$.

Members of the association are not under any pecuniary liability for acts done by them in their capacity as members of the association in carrying out the provisions of the Act $(g)$.

The Army Council may make regulations for carrying out the provisions of the Act as to the association, and may also make regulations on certain specified matters. These regulations must be laid before both Houses of Parliament as soon as may be $(h)$.

County associations may appoint joint committees for any purpose in which they are jointly interested (i).

Composition, Enlistment, and Discharge.-The territorial

(f) 7 Ed. VII. c. 9 , s. 3 .

(g) $I b$. But they would be liable (semble) for acts done beyond the scope of their authority.

(h) $I b . \mathrm{s}, 4$.

(i) Ib. s. o. 
force is composed either of (1) officers and men appointed or enlisted directly under the Act of 1907, or of (2) units of the former yeomanry and volunteer forces which have been transferred into, and become units of, the force by Order in Council under the authority of the Act. In the case of the latter the transfer does not, without their consent, affect the conditions or area of service of persons commissioned, enlisted, or enrolled before the passing of the Act of 1907 .

First appointments to the lowest rank of officers in the force are given to the persons recommended by the president of the county association, provided the latter makes such recommendation within thirty days after notice of a vacancy has been given to him. The mode of enlistment and attestation for recruits to the territorial force is the same as that which applies to the regular forces under the Army Act, $1881(k)$. The enlistment is for a county for which an association has been formed, and the recruit may select the corps or unit of a corps, and the area, comprising the whole or part of the county, in which he is to serve. The term of cnlistment is for such period as is prescribed by the proper authority, not exceeding four years.

A man of the territorial force holds his position practically at pleasure, since he may be discharged at any time for disobedience, neglect of duty, misconduct, or other cause which his commanding officer may judge sufficient. $\mathrm{He}$ may, however, appeal to the Army Council, who may make such direction as they think fit $(l)$.

Men of the force are also entitled to their discharge (except when the army reserve is called out) on giving three months' notice, and paying to the county association the prescribed sum, not exceeding $£ 5$, and delivering up any public property issued to them, or paying for the same $(m)$.

If the time for his discharge occurs while a proclamation ordering the army reserve out on permanent service is in force, a man may be required to prolong his service for a term not exceeding twelve months $(n)$.

(k) Act of 1907. s. 10, which applies s. 80 of the Army Act, 1881, to the territorial force.

(l) $I b$. s. 9 (4).

(m) $I b$. s. 9 (3).

(n) $I b$. s. $9(5)$. 
Training and Embodiment.-Members of the force may be called out once or oftener during the first year to serve a preliminary training if so required by Order in Council, which specifies the number of days; and whether preliminary training is directed by Order in Couneil or not, members must attend the number of drills, and fulfil the other conditions prescribed for recruits of that arm or branch of the service to which they belong. Unless dispensed with by the proper officer, they are also required to serve an annual training (and may be ealled out once or oftener for that purpose) of not less than eight or more than fifteen days, or, in the case of the mounted portion, not more than eighteen days $(o)$.

The term of annual training may be extended by Order in Council for all or any part of the force, so that the whole period does not exceed thirty days. But any Order in Council for preliminary training or for extending the annual training must be laid before each House of Parliament for forty days; and if either House presents an address to the Crown opposing it, no further proceedings are to be taken $(p)$.

Embodiment of all or part of the force may be directed (or revolied or varied) by the Army Council when a proclamation calling out the army reserve on permanent service has been issued. And where under a proclamation directions have been issued for calling out all the men of the first class of the army reserve, the Army Council must within one month issue directions for embodying all the men of the territorial force, unless an address is presented to the Sorereign by both Houses of Parliament, praying that they shall not be so embodied. In the latter case, where such directions are required Parliament, if separated by adjoumment or prorogation for a period not expiring within ten days, must be summoned by proclamation to meet within that period. And directions for embodiment are not to issue until Parliament has had an opportunity of presenting an address to the Cromn $(q)$.

(o) Act of 1907 , ss. 14,15 .

(p) $I b$. s. 16 .

(q) $I b$. s. 17 (1) (2). 
Disembodiment of the force is effected by proclamation, the Army Council giving the necessary directions. Until such proclamation the Army Council may direct the embodiment of any part of the force, or the disembodiment of any embodied part, as it thinks fit $(r)$.

Failure to attend the preliminary or annual training, or the requisite drills, without leave or reasonable excuse, entails liability to a penalty not exceeding $£ 5$ recoverable by the proper officer on complaint to a court of summary jurisdiction. Failure to attend on embodiment without leave or reasonable excuse constitutes desertion, and the offender may be tried by court martial $(s)$.

General Status of Territorials.-The following points may be noted with regard to the status of members of the territorial force: (1) The acceptance of a commission in the force does not vacate the seat of a member of Parliament; (2) an officer or man of the force is not liable to any penalty owing to absence during the time he is voting at a parliamentary election, or going to or returning from such roting; (3) if a sheriff is a member of the force, his duties during embodiment devolve upon the under-sheriff; (4) no officer or man of the force is compelled to serve as a peace or parish officer, or to serve on a jury; a field officer cannot be required to serve as sheriff $(t)$; $(5)$ the Army Act applies to officers and men of the territorial force as it applies to officers and men of the militia, and in addition territorials are subject to military law when called out on actual service for purposes of defence, and are to be liable to dismissal as a pumishment $(x)$; $(6)$ any enactment relating to the militia, yeomanry, or volunteers (other than as to certain specified matters) may be applied to the territorials with the necessary adaptation by Order in Council, which must be laid before both Houses of Parliament $(y)$.

(r) Act of 1907, s. 18 (1) (2).

(s) $I b$. ss. $20,21$.

(t) $I b$. s. 23.

(x) Act of 1907, s. 28 (1).

(y) $I b$. s. 28 (3). The excepted Acts are such as relate to the raising, service, pay, discipline, or government of the respective forces. 


\section{General Nature of Military Law.}

Origin of Military Law.-In early times the troops employed by the Crown, both at home and abroad, were subject to the regulations made by the Crown, with the advice of the constable and earl marshal, and administered in the court of the constable and earl marshal. According to one derivation, this special code came to be known as marshal, and subsequently martial law.

The office of constable, like that of earl marshal, was hereditary, and became extinguished by the attainder of the Duke of Buckingham in the reign of Henry VIII. The office of constable being extinguished, the court of the constable and earl marshal ceased to exist, and the jurisdiction which it exercised reverted to the Crown $(z)$. The undue extension of this jurisdiction under the Tudors and Stuarts was one of the causes which led to the rupture between the Crown and Parliament in the reign of Charles I. Accordingly, one of the grievances recited in the Petition of Right was the issue of commissions to try persons " according to the law martial . . as is used by armies in time of war," instead of by the process of the ordinary courts. On the Revolution of 1688 , the issue of commissions of martial law in time of peace was again declared illegal by the Bill of Rights, and the first Annual Mutiny Act was passed in 1689 (a), establishing the army on a legal footing, and providing for its discipline. This Act, after reciting the provisions of Magna Carta, that no man should be punished or judged otherwise than by the established laws of the realm, but that it was requisite to retain such forces as should be raised in exact discipline, enacted that all officers and soldiers found guilty by court martial of mutiny, sedition, or desertion, should be punished as such court martial should direct.

Thus originated that code which is now called military law, consisting of all those rules relating to the regulation and discipline of the army, and which are either enacted

(z) See Adye on Courts Martial, p. 3. The office of earl marshal continued to exist, and is hereditary in the Duke of Norfolk's family. (Ib.)

(a) 1 Will. \& Mary, c 5 . 
directly by Parliament, or issued directly by the Crown under statutory authority; and this military law must be distinguished from what we now call martial law. The Mutiny Act of 1715 and subsequent Acts empowered the Crown to make "Articles of War" for the army at home and abroad, and in 1879 the provisions of the Mutiny Act and the Articles of War were consolidated in the Army Discipline and Regulation Act of that year $(b)$. This Act was repealed and its provisions re-enacted in an amended form by the Army Act, 1881 (c), which, like the Act of 1879, must be re-enacted by the Annual Act, known as the Army Annual Act, which also regulates the number of the troops to be maintained. The Army Aet, 1881, and various amending Acts, with the King's Regulations and Army Orders made by statutory authority, form the present code of military law.

General Features of Military Law.-The following points may be noted with regard to the constitution and jurisdiction of the military courts:-

(1) Certain purely military offences are created by the Act of 1881 which are cognizable only by courts martial, and these offences come under such general headings as-Offences in relation to the enemy; Mutiny and insubordination; Desertion and fraudulent enlistment; Offences in relation to prisoners; with some others, all of which are to be found in the Army Act, 1881.

(2) All offences against the ordinary law are triable by court martial, except that (i.) treason, murder, manslaughter, treason felony, and rape, if committed in the United Kingdom, are not triable by court martial, but by the competent civil court (d). (ii.) The same offences, if committed in any place within his Majesty's dominions other than the United Kingdom or Gibraltar, are not triable by court martial unless conmitted whilst on active ser-

(c) $44 \& 45$ Vict. c. 58.

(b) 42 \& 43 Vict. c. 33.

(d) Army Act, 1881, s. 41 (a). 
vice, or unless the place where the offence was committed is more than one hundred miles in a straight line from any city or town in which the offender night be tried by a competent civil court $(e)$.

(3) Any person subject to military law when in the king's dominions may be tried by any competent civil court for offences for which he would be liable if he were not subject to military law $(f)$. Except that all soldiers of the regular forces are exempt from civil process except on account of (i.) a charge of or conviction for felony or misdemeanour punishable with fine or imprisonment; (ii.) on account of any debt, damages, or sum of money exceeding $£ 30$. But where the debt or damage is less than $£ 30$, after due notice in writing given to the soldier or left at his last quarters, the creditor may proceed to judgment in his suit or action, and have execution other than against the person, pay, arms, ammunition, equipments, regimental necessaries, or clothing of such scldier $(g)$.

(4) The courts martial, the constitution and proceedings of which are regulated by the Act, are either fieldgeneral, district, regimental, or summary courts martial. The sentences passed by such courts martial must be confirmed by the officer appointed by the Act, but in cases of acquittal no confirmation is needed. The confirming officer may send back the finding and sentence once for revision $(h)$, or refer it to any superior authority competent to confirm, or he may mitigate, remit, commute, or suspend the sentence. But in no case may he reconmend the increase of a sentence (i).

(5) In addition to the jurisdiction of the courts martial, the commanding officer has jurisdiction to try offences under the Act in a summary way $(k)$.

(e) Army Act, 1881, s. 41 (a).

(f) $I b$. s. $41(b)$.

(g) Ib. s. 144.

(h) S. 54. In case of revision no new evidence may be taken ( $I b$.$) .$

(i) Ss. 54, 57 .

(k) S. 46. 
(6) The rules of evidence in trials by courts martial are the same as those in use in civil courts (l), and with regard to the conduct of proceedings and the reception and rejection of evidence, courts martial are subject only to such laws as may be made by the Parliament of the United Kingdom ( $m$ ).

(7) At a trial by court martial counsel may appear both for the prosecution and defence, and are subject to the same rules for contempt as in the High Court $(n)$.

(8) A person, though sentenced or acquitted by court martial, may afterwards (in cases triable by a civil court) be tried by a civil court, but any military punishment he may have already received must be taken into consideration in awarding punishment $(o)$.

(9) A person acquitted by a civil court of competent jurisdiction is not liable to be tried by court martial on the same charge $(p)$.

(10) The Crown is empowered to make Articles of War for the better govermment of officers and soldiers, and these are to be taken notice of judicially in all the Courts $(q)$.

(11) Assignments of, or charges on, their pay or pension made by officers or soldiers are void unless made in pursuance of a royal warrant or by statutory authority $(r)$.

(12) Officer's and soldiers when on duty or on the march are exempt from tolls $(s)$.

(13) All soldiers are exempt from serving on juries $(t)$.

(14) Officers and soldiers have the right of voting for and sitting as members of Parliament; soldiers are, howerer, subject to certain statutory regulations

(l) S. 128 .

(m) S. 127. See the Rules of Procedure, 1899, made under the authority of s. 70 (St. R. \& O, 1899, p. 141).

(n) S. 129. The regulations for the conduct of a case by counsel are ta be found in the Rules of Procedure, 1899, rr. 87-9.4. (See St. R. \& O. 1899).

(o) S. 162 (1) (2).

(p) S. 162 (6).

(q) S. 69.

(r) S. 141.

(s) S. 143 .

(t) S. 147.

C.L.E. 
with regard to remaining in barracks during parliamentary elections except for the purpose of their military duties, or for giving their votes $(u)$.

(15) An officer on the active list may not be appointed sheriff, and may not be mayor or alderman or hold any post in any municipal corporation $(x)$. Officers are not, however, disqualified from being county councillors $(y)$.

The Judge Advocate General. - The judge advocate general acted as secretary and legal adviser to the Board of General Officers through which the Crown carried on the administration of military matters down to the year 1793. In that year the commander-in-chief of the army took the place of the Board, the judge advocate general remaining his chief legal adviser, but ceasing to perform secretarial duties.

Down to the year 1892 the office was political, and the holder of it a member of the ministry and a privy councillor (z). In 1892 the office was conferred upon the president of the Probate, Divorce, and Admiralty Division. In 1905 it was decided to appoint to the post by letters patent a legal officer, who is a salaried civil servant at $£ 2,000$ a year and gives his whole time to the work. He is assisted by two legal deputies and six military deputy judge advocates. The duties of the department are to review the proceedings of all courts martial held in the United Kingdom and advise the Secretary of State as to the confirmation of the finding and sentence.

In cases where a commissioned officer is sentenced to death or penal servitude, or to be cashiered, dismissed, or discharged by a court martial held outside the United Kingdom, except in India, the proceedings are sent to be reviewed by the judge adrocate general's department (a); and any confirming officer outside the United Kingdom may

(u) See $10 \& 11$ Vict. c. $21 ; 26 \& 27$ Vict. c. 12 .

(x) Army Act, 1881. s. $146 ; 52$ Vict. e. 3, s. 6 .

(y) 54 Vict. c. 5, s. 8.

(z) See Simmons on Courts Martial, 462n.

(a) $I b$. 
send the proceedings to be so reviewed if he elects to do so $(b)$.

The proceedings of general and district courts martial must be sent to the department and there kept for not less than seven years in the case of a general, and three years in the case of a district, court martial (c). Within these times persons who have been tried by such courts martial may have a copy of the proceedings (including revision and confirmation) on payment of the prescribed fees $(d)$.

Judge Adyocates.-At all general courts martial the convening officer must, and at district courts martial he may, if he chooses, summon a judge advocate to attend the proceedings, and these judge advocates are such persons as are appointed either by commission under the sign manual, or as deputies (permanent or special) by the judge advocate general acting under his letters patent, or by the convening officer himself, where he is empowered to do so by the terms of his warrant.

Formerly the officiating judge advocate acted as prosecutor, but this practice was discontinued in 1860. Generally speaking, his duties are to act as adviser to the court on all questions of law, procedure, evidence, etc., and to make a record of the proceedings and forward the same to the judge adrocate general's department.

(b) Simmons on Courts Martial, 462n.

(c) Rules of Procedure, 1899, rr. 97, 98. The record of the proceedings of regimental courts martial are sent to the convening officer and kept with the regimental records for three years. Ib. r. $98^{\prime}$ (B).

(d) Ib. r. 99 . 


\section{$(388)$}

\section{Chapter IV.}

\section{THE ROYAL AIR FORCE.}

This force is recruited by voluntary enlistment and is administered by the Air Ministry. The Air Ministry was established in 1918 to take over the control of the Royal Air Force, which was formed by the amalgamation of the Royal Naral Air Service and the Royal Flying Corps. The Air Force Constitution Act, 1917 ( 7 \& 8 Geo. V. c. 51) provides for the establishment, administration, and discipline of an Air Force and the establishment of an Air Council. The Air Council consists of the Secretary of State for Air and other persons as already described (unte, p. 207).

The Air liorce estimates for 1921-1922 show a net expenditure of $\mathfrak{f} 18,411,000$, representing a reduction on the revised figures for 1920-1921 of $£ 4,581,230$. The strength of this. force is 30,880 of all ranks, as against 29,730 in 1920-1921. The details of the expenditure are as follows:-

\begin{tabular}{|c|c|}
\hline & $\mathfrak{E}$ \\
\hline Pay, \&c., of the Air Force & $4,794,000$ \\
\hline dartering stores, supplies and transport ... & $3,105,000$ \\
\hline hnical and warlike stores .................. & $3,758,000$ \\
\hline orks, buildings and lands ......... & $3,018,000$ \\
\hline ir Ministry $\quad \ldots \ldots \ldots \ldots \ldots \ldots$ & 915,000 \\
\hline iscellaneous effective services ........ & 129,000 \\
\hline 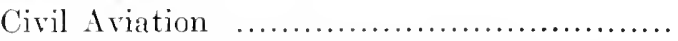 & 880,000 \\
\hline spermental and research services. & $1,706,000$ \\
\hline lf-pay, pensions and non-effective sc & 106,000 \\
\hline
\end{tabular}

$£ 18,411,000$

The Air Force programme for 1921-1922 is as follows:United Kingdom. 
Co-operation with Fleet .............. 5 squadrons.

Co-operation with Army .............. 3 ,,

\section{Overseas.}

Army of Occupation (Rhine) ..... 1 squadron.

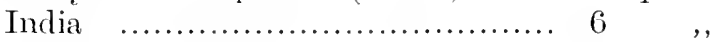

Irak ….............................. 6 ,

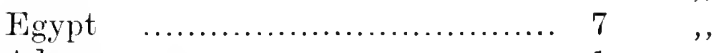

Aden …............................ $\frac{1}{3} \quad$,,

Mediterranean …................... 1 ,, 


\title{
Part VI.--Countries subject to the Laws of England.
}

\author{
Chapter I.
}

THE UNITED KINGDOM, THE CHANNEL ISLANDS, AND THE ISLE OF MAN.

\section{General Scheme of Local Govermment in England and Wales.}

PrIor to the creation of the county councils by the Local Government Act of 1888, much of the administration of the county was in the hands of the justices of the peace, either in or out of sessions. At the present day the administration of matters relating to police, licensing, reformatories, asylums, industrial schools, education, highways and open spaces, allotments, cemeteries, and in particular the administration of the Public Health Acts and of the poor laws, has been handed over to the county councils and various other bodies under the general supervision of the Ministry of Health.

Beneath the county councils come the rural and urban district councils, and the borough councils in towns having a municipal corporation, and beneath these again the parish councils and parish meetings in rural districts, and the vestries in urban districts and boroughs.

This scheme of local government was perfected by the Local Govermment Act of 1894, which created the present parish meetings and parish councils to take the place of vestries in rural districts, and the rural and urban district councils.

In urban districts parish meetings and parish councils were not created by the Act of 1894, and the old vestries 
still exercise such of their former powers as have not been transferred to the urban district councils or borough councils, either by the Act of 1894 or by order of the Ministry of Health. In the metropolis the London County Council, created under the Local Government Act of 1888, took the place of the former Metropolitan Board of Works, whilst beneath this body were the various vestries and district boards (a), whose constitution, powers, and duties were regulated by the various icts passed for the management of the metropolis, the principal of which was the Metropolis Management Act, 1855, and by the Local Government Act, 1894.

Under the London Government Act, 1899, the administrative county of London has now been divided into twentyeight boroughs, and the town councils constituted for these boroughs by Order in Council under the Act $(b)$ have taken over the powers and duties of the old vestries and district boards, together with some of the duties of the county council. Local government in Scotland and Ireland does not come under the scheme provided for England and Wales, but is regulated by special Acts relating to those two countries respectively.

The Ministry of Health has now taken the place of the Local Government Board (c).

The Parish Meeting.-A parish means a place " for which a separate poor law is, or can be, made, or for which a separate overseer is, or can be, appointed" (d). The constitution and powers of the parish meeting are regulated by the Local Gorernment Act of $1894(e)$. Briefly they are as follows:-

All parochial electors, that is, all persons who are on the parliamentary or local government registers $(f)$, are entitled

(a) Certain metropolitan vestries were united into groups to form district boards, whose constitution was regulated by the Metropolis Management Act, 1855.

(b) Orders in Council, 15th of May, 1900, Nos. 380-407 (St. R. \& O. 1900, p. 987).

(c) See ante, p. 213.

(d) Interpretation Act, 1889 (52 \& 53 Vict. c. 63, s. 5).

(e) $56 \& 57$ Vict. c. 73.

(f) As to what women are entitled to be registered as local government electors, see $7 \& 8$ Geo. T., c. 64, s. 4 . 
to attend the parish meeting, which must be held in every rural parish once a year $(g)$, and, if there is no parish council, twice a year $(h)$.

If there is a parish council, the principal duty of the parish meeting is to elect the parish councillors (i), but in any case the parish meeting has the exclusive power of putting in force the Adoptive Acts, viz. the Lighting and Watching Act, the Baths and Washhouses Acts, the Burial Acts, the Public Improvements Act, and the Public Libraries Acts $(k)$.

Where there is no parish council the county council may confer any of the powers of that body upon the parish meeting, upon the application of the latter $(l)$. The parish meeting also exercises the former powers of the vestry, except with regard to Church matters $(m)$, appoints overseers, and attends to public paths and rights of way. The parish property vests in the chairman of the parish meeting and overseers, and the parish meeting may levy a rate not exceeding $6 d$. in the $\&(n)$.

The Parish Council.-This body is the creation of the Local Govemment Act of $1894(\mathrm{o})$. Every rural parish with a population of three hundred and upwards must have a parish council, and if the population amounts to one hundred or upwards, it is entitled to one if the parish meeting so resolves. Parishes in which the population is less than one hundred may have a parish council, with the consent of the parish meeting, on application to the county council $(p)$.

The number of parish councillors is fixed by the county council, but must not be less than five, or more than fifteen. They are elected at the annual parish meeting, and

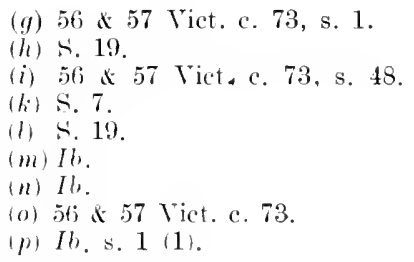


may be of either sex $(q)$; they are elected for three years $(r)$ and retire simultaneously; their qualification is regulated by the Local Government Acts of 1894 and 1897. The parish council must hold an anmual meeting $(s)$, and is presided over by a chairman. Its chief powers and duties are: (1) To exercise the powers and duties of the vestry and churchwardens, except in affairs relating to the Church and charities $(t)$. (2) To appoint annually a chairman and overseers of the poor $(u)$. (3) To hire land for allotments $(x)$. (4) To appoint trustees of non-ecclesiastical parochial charities $(y)$. (5) To deal with certain sanitary matters with regard to recreation grounds, public walks, ponds, ditches, drains, etc. (z). (6) To exercise any powers delegated to it by the district council $(a)$. In the exercise of these powers the parish council may not incur expenses involving a rate of more than $6 d$. in the $f(b)$.

By the Parochial Church Councils (Powers) Measure, 1921, there shall be transferred to the church council of every parish all powers, duties, and liabilities of the vestry of such parish relating to the affairs of the church except as regards the election of churchwardens and the administration of ecclesiastical charities, also the powers, duties, and liabilities of churchwardens with regard to church affairs except as therein mentioned $(c)$.

Yestries.-In rural distriets the parish meetings and parish councils created by the Local Government Act of 1894 took over the duties of the vestry with regard to parish property, parochial charities, adopting the permissive Acts (e.g. the Public Libraries Act), etc., but in urban districts the vestry still retains its old powers, or such of them as have not been handed over to the town council or urban

(q) 56 \& 57 Vict. c. 73 , ss. $3,48$.

(r) 60 \& 63 Vict. c. 10, s. 1.

(s) 56 \& 57 Tiet. c. 73 , s. $3(7)$.

(t) S. 6 .

(u) Ss. 3. 5 .

(x) $\mathrm{S} .10$.

(y) S. 14 .

(z) S. 8 .

(a) S. 15 .

(b) S. 11 .

(c) See ante, p. 334 . 
district council by order of the Local Government Board, or by the Local Government Act, 1894.

Vestries are either Common Vestries or Select Vestries. The common vestry is merely a meeting of all the ratepayers, male and female, in vestry assembled $(d)$.

The various matters connected with the meeting of vestries, the manner of voting, and the persons who may attend, are regulated by statute $(e)$. Every person may vote according to the value at which he is rated, one vote for $£ 50$ or less, and if above $£ 50$, then one vote for every $£ 25$ of the sum at which he is assessed, but no person may have more than six votes $(f)$.

In some parishes the right of all the ratepayers to attend the vestry may be restrained by immemorial custom to a select number, who are then termed a select vestry $(g)$.

Select vestries were also created by Hobhouse's Act, 1831 ( $h$ ), which is permissive, and can be adopted by parishes with more than 800 ratepayers.

In the metropolis the operation of Hobhouse's Act was superseded by the Metropolis Management Act, 1855 (i), and the election of vestries subsequently regulated by order of the Local Government Board $(k)$. The Metropolis Management Acts, 1855 to 1890 , regulated the administration of such matters as sewers, paving, lighting, highways, streetwatering, cleansing, etc., by the various metropolitan vestries and district boards, who were also the authorities for administering the Public Health Act, $1891(l)$. But the powers and duties of these bodies have now been handed over to the twenty-eight metropolitan borough councils created by Order in Council under the London Government Act, $1899(\mathrm{~m})$.

(d) See per Lord Fenyon in Berry v. Banner (1793), Peake, p. 217.

(e) See 58 Geo. III. c. 69 ; 59 Geo. III. c. 85 ; 7 Will. IV. \& 1 Vict. c. $45 ; 13 \& 14$ Vict. c. 87 .

(f) 58 Geo. III. c. 69 , s. 3.

(g) Per Lord Kenyon in Berry v. Banner (1793), Peake, p. 217.

(h) $1 \& 2$ Will. IV. c. 60.

(i) 18 \& 19 Vict. c. 120 , s. 1.

(i) St. R. \& O. 1898. No. 244.

(l) $54 \& 55$ Tict. c. 76, s. 99.

(m) $62 \& 63$ Vict. c. 14 . 
Some of the powers of vestries have now been handed over to the parochial church councils as above.

Rural and Urban District Councils.-England and Wales were first divided into rural and urban districts by the Public Health Act, $1872(n)$. By that Act urban districts were defined as either (1) boroughs, (2) existing Improvement Act districts, (3) local government districts; rural districts were poor law unions, or such parts of them as were not included in urban districts. The sanitary authorities placed over these divisions to administer the Act were :-

(1) Urban $\left\{\begin{array}{l}\text { Borough councils. } \\ \text { Improvement commissioners. } \\ \text { Local boards of health. }\end{array}\right.$

(2) The boards of guardians for the rural districts.

The Public Health Act, 1875, gave the Local Government Board certain powers over these rural and urban sanitary authorities, and consolidated the law. The Local Government Act, $1894(\mathrm{o})$, created the present rural and urban district councils in place of the old sanitary authorities of the Acts of 1872 and 1875, and the constitution and functions of these bodies is now briefly as follows. The Act of 1894 provided that the old urban sanitary authorities were henceforward to be known as urban district councils (borough councils excepted, which were to retain their name). At the same time the Act altered the constitutions of the old bodies in the following manner:-

(1) There are no nominated or ex-officio members $(p)$. (2) The voting power of the electors does not depend upon the amount of their property as previously, but each elector has one vote $(q)$. Under the Act of 1894 the rural district council consists of a chairman and councillors, who, like the board of guardians, are elected for three years, one-third of their number retiring by rotation in every year. The number of councillors is the same as the number of guardians for the parish or area $(r)$. The rural district councillors

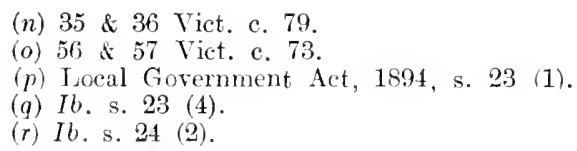


act as guardians of the poor, and no separate guardians as such are to be elected for the parish or area $(s)$. The persons eligible to be rural district councillors are subject to the qualifications provided by the Act with regard to guardians, and may be of either sex $(t)$. Generally speaking, the powers conferred by the Act of 1894 and various other Acts, and now exercised by the rural and urban district councils, and the corresponding borough councils in towns which have a municipal corporation, relate to the following matters: the administration of the Public Health Acts, the maintenance and repair of highways and streets, the protection of rights of way and roadside wastes, the preservation and management of commons, together with some of the duties formerly exercised by the justices out of session, such as the licensing of gang-master's and dealers in game, passage brokers and emigrant runners, the abolition of fairs, and the execution of the Acts relating to petroleum and infant life protection $(u)$.

Borough Councils.-In towns which have a corporation the borough council takes the place of the district council, and there are no parish councils. As early as the reign of Henry III. royal charters were granted to various towns giving them power to elect their own officers and to hear their own pleas to the exclusion of the Sheriff"s Court. The constitutions of all corporate boroughs were remodelled by the Municipal Corporations Act, 1835, and the various Acts relating to municipal corporations were consolidated in the Municipal Corporations Act, 1882 (x), by whicl their constitution and functions are now governed.

Under this Act a municipal corporation is created by roval charter, and may be granted by the king on the advice of the Privy Council on petition from the resident householders.

(s) Lucal Government Act, 1894, s. 24 (3). In urban distriets the poor laws are still administered by the boards of guardians, who are a body entirely distinct from the urban district council or borough council, and consisting. since the Act of 1894, entirely of elected members. (Ib. s. 20$)$.

(t) Sis. 20, 24.

(u) Local Government Act, 1894, s. 27 . (x) $45 \& 46$ Vict. c. 50. 
The corporation consists of burgesses (or citizens in the case of a city), who are the ratepayers of the borough, a mayor, and aldermen (y), and acts through a council composed of the mayor, aldermen, and comcillors. The councillors are appointed by the burgesses, and hold office for three years, one-third of their number retiring by rotation in every year $(z)$. The aldermen are chosen by the councillors from amongst their own number, and hold office for six years; their number is one-thind of the number of councillors (a). The mayor is elected annually by the council; he need not be a councillor, but must be duly qualified to be a councillor (b); he is a magistrate virtute officii. The council may make bye-laws for the borough subject to disallowance by the King in Coumcil; it manages the property of the borough, and may lery a rate; in adilition, it exercises the powers conferred upon it and the district councils by the Local Government Act of 1894.

By the County and Borough Councils (Qualification) Act, 1914 (4\&5 Geo. V. c. 21), any person of either" sex may be nominated and clected councillor or alderman of a county council or borough council if he or she has resided within the county or borough for the whole twelve months preceding the election. But this provision does not extend to Scotland or Ireland or affect any other qualification or disqualification.

Some boroughs have a separate quarter sessions, with a recorder as judge, who must be a barrister of five years' standing, and is appointed by the King on the advice of the Home Secretary. Separate quarter sessions are now granted by Order in Council under the Municipal Corporations Act, $1882(c)$.

The County Councils.-By the Local Government Act, 1888 (d), a county council consisting of a chairman, aldermen, and councillors was established in every administrative

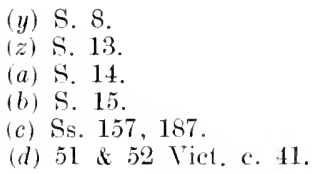


county. The regulations for the appointment and terms of office of the chairmen and councillors are the same as those relating to the mayor and aldermen under the Municipal Corporations Act, $1882(\mathrm{e})$. One-third of the councillors, therefore, retire by rotation in every year. The number of councillors for each county is determined by the. Ministry of Health $(f)$, each county being divided into electoral divisions, which return one councillor each.

The persons entitled to vote at the election of county councillors are all persons, male or female, who are either (1) burgesses enrolled in pursuance of the Municipal Corporations Act, 1882, or (2) persons registered as county electors under the County Electors Act, $1888(g)$. In London parochial electors under the Local Government Act of 1894 are also qualified to vote at county council elections (h). The provisions of the County and Borough Councils (Qualification) Act, 1914, previously noted, by which the disqualification of women is removed, applies to the eligibility of councillors (i). The Act of 1882 transfers to the county council most of the powers formerly exercised by the justices in quarter sessions, and some, such as the licensing of playhouses and the administration of the Explosives Act, 1874, formerly exercised by the justices out of session.

Generally speaking, the business of the county* council comes under the following heads: the repair of main roads and bridges, pauper lunatic asylums, reformatories, and industrial schools; the pollution of rivers; the protection of birds and fish; the appointment of coroners; licences for music, dancing, and racecourses; the administration of the Acts relating to weights and measures; it pays the salary of the clerk to the justices, and the expenses of the assizes and quarter sessions, and levies the county and other rates; it

(e) $51 \& 52$ Vict. c. 41 , s. 2 .

(f) $I b$. s. 2 (3) (a).

(g) 51 \& 52 Vict. c. 10.

(h) The London County Council Electors' Qualification Act, 1900 (63 $\& 64$ Vict. c. 29$)$.

(i) See p. 397, ante. As to the previous ineligibility of women, see Beresford Hope v. Lady Sandhurst (1889), 23 Q. B. D. 79 ; and see D'Souza v. Cobden [1891] 1 Q. B. 687. 
also exercises certain supervision over parish and district councils under the Local Government Act of 1894.

In most of these matters the council acts through committees, and its accounts are audited by a district auditor appointed by the Ministry of Health.

\section{County Officials.}

The consideration of the general scheme of local government in England and Wales would not be complete without some mention of the functions of certain county officials. These are the sheriff, the lord lieutenant, the custos rotulorum, the clerk of the peace, and the chief constable. The functions of justices of the peace have already been dealt with $(k)$.

Sheriffs.-The mode of appointment and duties of the sheriffs are now principally regulated by the Sheriffs Act, $1887(l)$. Every county must have a sheriff, and they are appointed under the Act in accordance with the ancient usage in the following manner.

On the 12 th of November in each year the lord chancellor, the Chancellor of the Exchequer, the lord chief justice, the lord president of the Council, and certain other privy councillors, or any two of these dignitaries, attend with the judges, or any two or more of them, at the Royal Courts of Justice $(m)$. A list of the names of persons fitted to be sheriff of each county, who are always persons of considerable standing and importance, and, in the words of the Act, " having sufficient land within his county or bailiwick to answer the king and his people," is submitted for each county by the senior judge who visited the county on circuit at the previous summer assizes.

Excuses are considered on behalf of the persons named, and finally three names are selected for each county. The roll, so made up, is submitted to the King, who selects the sheriffs by pricking off their names upon the list. The list is then gazetted, and a royal warrant of appointment sent

(k) See ante, p. 264.

(l) $50 \& 51$ Vict. c. 55.

(m) S. 6 . 
to the sheriff-elect, and a copy of the warrant to the clerk of the peace for the county.

The sheriff is appointed for one year, and holds office durante bene placito. On appointment he must make the declaration prescribed by the Act $(n)$. His office is not affected by the demise of the Crown $(o)$. The same person may not be chosen twice in three years if there is any other person in the county qualified $(p)$.

The sheriff is the returning officer for county elections $(q)$, and performs certain duties with regard to election petitions $(r)$. He may no longer hold criminal pleas, and may not act as a justice of the peace $(s)$. Acting through the under-sheriff, to whom the writs are actually delivered, and bailiffs, he executes criminal process, and all writs and processes issuing out of the superior courts $(t)$. In executing a criminal process he may breali open an onter door (u), but not in civil cases $(x)$, except the door of an outhouse. The sheriff also summons jurors for the superior courts $(y)$.

The principal duties of the sheriff are performed by subordinates, viz. the under and deputy sheriffs and bailiffs. Every sheriff must appoint a sufficient deputy, resident or having an office within one mile of the Inner Temple Hall, for the receipt of writs, granting warrants thereon, making returns thereto, and generally for the acceptance of all rules and orders to be made on or touching the execution of any writ or process directed to the sheriff $(z)$. The actual execution of the writ or process is effected by the undersheriff through sheriffs' officers or hailiffs, who, upon

(n) Ss. 7 (1), 23 (3); Sched. II.

(o) Ss. 3, 6, 7 .

(p) S. 5. In Lancaster the sheriff is appointed by the King as Duke of Lancaster; in Cornwall by the Duke of Cornwall. See the Prince's rase (1606), 8 Rep. 1. The Sheriff of Durham was formerly appointed by the bishop, but since 1836 by the Crown $(6 \& 7$ Will. IV. c. 19).

(q) $7 \& 8$ Will. III. c. 25 , s. 2.

(r) See 31 \& 32 Vict. c. 125 , ss. $7,30$.

(s) 50 \& 51 Vict. c. 55 , s. 17.

(t) $I b . \mathrm{ss} .10,11$.

(u) $42 \& 43$ Vict. c. 59 , s. 3.

(x) See Burdett v. Abbot (1811), 14 East, p. 154.

(y) 50 \& 51 Vict. c. 55 , s. 12.

(z) Ib. s. 24 . 
appointment, must make the declaration provided by the Act (a).

Every sheriff must also appoint an under-sheriff, who generally performs the actual duties of the sheriff and takes his place on the death or suspension of the sheriff himself $(b)$.

The duties of the bailiff of a franchise are either exercised personally, or by a deputy bailiff (who must reside in or near the franchise), and bailiffs corresponding to the undersheriff and sheriffs' officers $(c)$. In the case of a liberty or franchise the writs are directed to the sheriff in the ordinary way, and he issues his precept to the bailiff of the franchise. The principal personal duties of the sheriff are, in case of resistance to the execution of a writ, to go in proper person with the power of the county (it being the duty of all persons in the county to assist him), and arrest the resisters and commit them $(d)$. He also goes to meet the judges, attends them at assize, and provides for their lodging and retinue, and in certain cases for the attendance of menservants in liveries $(e)$.

The sheriff of a county of a city, or a county of a town (other than London, where the sheriffs are elected by the liverymen, subject to the Crown's approval), is appointed by the town council under the Municipal Corporations Act, $1882(f)$.

The Lord Lieutenant.-Formerly the lords lieutenant of counties commanded the militia, yeomanry, and volunteers, was responsible for their efficiency, and appointed and removed officers. By the Regulation of the Forces Act, 1871 (g), the jurisdiction, powers, duties, command, and privileges formerly exercised by the lord lieutenant in relation to the militia, yeomanry, and volunteers, was revested in the Crown, with the exception of the power to raise the militia by ballot, when-as is never now the case-that

(a) S. 26 , Sched. II.

(b) Ss. 23, 25 .

(c) See s. 34 .

(d) Ss. 8, 9 .

(e) 2 Ed. II. c. $3 ; 50$ \& 51 Vict. c. 55, s. 9.

(f) $I b$. s. 36 ; Municipal Corporations Act, 1882 , s, 170.

(g) 34 \& 35 Vict. c. 86 , s. 6.

C. L.E. 
method is resorted to. The power of recommending persons for first appointments to the lowest rank of militia officers was also reserved to the lord lieutenant by the Act of 1871 , and these provisions were re-enacted by the Militia Act, $1882(h)$. The Militia Act, 1882, provides that his Majesty shall from time to time appoint lieutenants for the several counties in the United Fingdom (i). They are accordingly appointed by letters patent under the great seal, and are usually, though not necessarily, the same person as the custos rotulorum. Since the changes in the auxiliary forces introduced by the Territorial and Reserve Forces Act, 1907, which have been previously noticed $(k)$, appointments to lowest rank of officer in the territorial force are now made on the recommendation of the presidents of the various county associations (l).

The lords lieutenant must appoint deputy lieutenants to the number of twenty at least for each county if such number of duly qualified persons can be found within the county. The qualifications of these deputy lieutenants are contained in the Militia Act, 1882, and they are persons of considerable importance in the county, being either peers or the heirs apparent of peers, or possessing certain property qualifications $(m)$.

Lords lieutenant and deputy lieutenants exercise such jurisdiction, duties, powers, and privileges as are rested in them by any Act of Parliament (n), and these porvers and duties are principally connected with the raising of the compulsory militia, and, prior to the creation of the territorial force in 1907 , with the ordinary general militia, the yeomanry, and volunteers.

The lord lieutenant also recommends persons to the lord chancellor for appointment as justices of the peace by the Crown.

The Custos Rotulorum.-This functionary, who is always a person of high standing in the county, and is usually the

(h) 45 \& 46 Vict. c. 49 , s. 5.

(i) $I b$. s. 29 .

(k) See p. 376, ante.

(l) Territorial and Reserve Forces Act, 1907, s. 10, and see p. 379, ante.

(m) 45 \& 46 Vict. c. 49 , ss. $30,33-35,52,53$.

(n) Ib. s. 36 . 
same person as the lord lieutenant, was appointed originally by the lord chancellor. Since the reign of Henry VIII. he has been appointed by the Crown under the royal sign manual $(o)$. He is nominally the keeper of the records for the county, both of sessions of the peace and commissions of the peace, but in reality that duty is performed by the clerk of the peace $(p)$. Formerly he appointed the clerk of the peace, but that duty is now performed by the standing joint committee of the county council and the county justices, under the Local Government Act, $1888(q)$.

The Clerk of the Peace.-This functionary is now appointed by the standing joint committee of the county council and the county justices $(r)$; in boroughs which have a separate quarter sessions he is appointed by the borough council, and holds office during good behaviour $(s)$.

The principal duties of the clerk of the peace are as follows :-

(1) $\mathrm{He}$ represents the custos rotulorum with regard to the custody and charge of the administrative and judicial records of the county, subject, however, to the direction of the custos rotulorum, the quarter sessions, and the county council $(t)$. In boroughs some of these duties are performed by the town clerk.

(2) $\mathrm{He}$ acts as clerk of the county council (u), and as such supplies the Secretary of State or Ministry of Health with returns or information required by either House of Parliament, receives lists of the parliamentary and local government electors as prepared at the annual revision court, and prints and distributes them, attends to the deposit of plans and documents under various Acts, and receives the jury lists. In all these matters

(o) 37 Hen. VIII. c. 1, s. 1; 1 Will. \& M. c. 21 , s. 3.

(p) See the Local Government Act, 1888 (51 \& 52 Vict. c. 41 , s. 83 (3)).

(q) Local Government Act, 1888 (51 \& 52 Vict. c. 41, s. 83 (2)).

(r) $\mathrm{Ib}$.

(s) Municipal Corporations Act, 1882 (45 \& 46 Vict. c. 50, s. 164 (2)).

(t) Local Government Act, 1888 (51 \& 52 Vict. c. 41, s. 83 (3)).

(u) Ib. s. $83(1)$. 
he is subject to the direction of the county council $(x)$.

(3) At quarter sessions he prepares indictments, calls over and swears the grand and petty jurors, receives bills found by the grand jury, arraigns prisoners, charges the jury, and receives the verdict $(y)$. $\mathrm{He}$ receives and is entitled to an account of all fines imposed (z).

The Chief Constable.-In boroughs the chief constable is appointed by the watch committee of the town council $(a)$; in counties by the joint committee of the county council and of the county justices subject to the approval of the Secretary of State $(b)$. The chief constable is the head officer of the borough and county police, and makes reports to the county justices on such matters as they may require $(c)$. He also appoints and dismisses superintendent and petty constables $(d)$.

\section{Srotland.}

By the Act for the umion of England and Scotland, $1706(c)$, the two kingdoms became united as from the 1st of May, 1707, into one kingdom, under the name of Great Britain, with a common Parliament. Pursuant to the Act, Scotland is represented in the House of Lords by sixteen representative peers, elected in the manner prescribed by the Act $(f)$, and in the House of Commons by seventy-four nember's $(y)$; the parliamentary franchise is now, however, the same for the two kingdons except with regard to certain modifications which are not very important $(h)$.

(.x) $51 \& 52$ Vict. c. 41 , s. 83 (6).

(y) Sce Archbold, Quarter Sessions, 82.

(z) 11 \& 12 Vict. c. 43, s. $31 ; 50$ \& 51 Vict. c. 71, s. 19 (4).

(a) $10 \& 11$ Tict. c. 89, s. $6 ; 45$ \& 46 Vict. c. 50 , s. 190 (1) (2).

(b) 2 \& 3 Vict. c. 93 , ss. 4, 24; 51 \& 52 Vict. c. 41, s. 9.

(c) 2 \& 3 Vict. c. 93, s. $17 ; 3 \& 4$ Vict. c. 88, s. 31 .

(d) $2 \& 3$ Vict. c. 93, s. $6 ; 3$ \& 4 Vict. c. 88, s. 26.

(e) 5 Anne, c. 8 .

(f) S. 25 (12). As to the morle of election. see ante, p. 76.

(g) Originally 45 (5 Anne, c. 8, s. 22), increased to 72 by various statutes.

(h) As to these modifications, see $7 \& 8$ Geo. V. c. 64, s. 43. 
The Act placed the two kingdoms on the same footing with regard to trade and navigation, and also with regard to customs and excise, with a few minor differences, which have since been removed, and fixed the proportion which Scotland was to contribute to the land tax (i). The Scotch Court of Session and the other Scotch courts and system of laws then existing were preserved by the Act, subject to any future alterations to be made by Parliament, and no Scotch causes are cognizable by the English courts. Appeal lies, however, to the House of Lords from the Scotch Court of Session.

The preservation of the Presbyterian Church in Scotland with the form of government established by a Scotch Act was made an essential term of the union, but it is only in this sense that the Church in Scotland can be said to be an established Church $(k)$.

The executive government of Scotland is rested in the Crown, and Scotch affairs are now conducted by the Scotch Office, at the head of which is the Secretary for Scotland, who is a member of the Cabinet, and goes out of office with the Ministry.

Scotland does not come under the Acts regulating local government in England and Wales. County and parish councils were, however, established in Scotland by the Local Government (Scotland) Acts of 1889 and 1894 respectively $(l)$, and these bodies are under the supervision of a Scotch Local Govermment Board, consisting of three ex-officio members, viz. the Secretary for Scotland as president of the board, the unter-secretary, and the solicitorgeneral for Scotland, and three appointed members $(m)$.

\section{Ireland.}

The Act of Union, $1800(n)$.- Under this Act the lingdoms of Great Britain and Ireland were uniter as from the 1st of January, 1801, into one kingdom, under the nime of

(i) S. 9. As to the land tax, see ante, p. 106 .

(k) As to the Church in Scotland, sec ante, p. 336.

(l) 52 \& 53 Vict. c. $50 ; 57$ \& 58 Vict. c. 58.

(m) $57 \& 58$ Vict. c. 58, s. 4 .

(n) 39 \& 40 Geo. III. c. $67 ; 40$ Geo. III. c. 38 (Irish Act). 
" the United Kingdom of Great Britain and Ireland," with one Parliament for the two kingdoms. By the terms of the Act Ireland was to be represented in the House of Lords by four spiritual and twenty-eight temporal peers (o), but on the disestablishment of the Irish Church in 1869 the Irish bishops lost their right to sit, and Ireland was then represented in the House of Lords by the twenty-eight temporal peers. In the Commons Ireland was to be represented by 100 members; this number was subsequently increased to 105, and, except during the disenfranchisement of the boroughs of Cashel and Sligo for corruption in $1870(p)$, it remained at 105 until 1920 .

By the Act of Union the Churches of England and Ireland were united in one Protestant Episcopalian Church, and the continuance of the established Church of England and Ireland was declared to be an essential and fundamental part of the union. The Irish Church was, however, disestablished in $1869(q)$, in spite of this provision. England and Ireland were placed on the same footing by the Act with regard to trade, navigation, and customs $(r)$, but the two countries were to contribute separately to the general expenditure of the United Kingdom in the proportion of fifteen to two $(s)$. This continued until the year 1818, when the revenues of the two countries were consolidated into one fund and applied indiscriminately to the service of the United Kingdom $(t)$. Ireland retained its own judicial institutions and system of laws, and has a Supreme Court of Judicature, divided into a Court of Appeal and a High Court of Justice, the latter comprising the Chancery and King's Bench Divisions and a Court of Appeal $(u)$. Appeal from the Court of Appeal in Ireland lay to the House of Lords. The head of the executive in Ireland was the lord lieutenant, whose office was not created by the Act of Union, but has been in existence under various names since

(o) $39 \& 40$ Geo. III. c. 67 , Art. 4.

(p) $33 \& 34$ Vict. c. 38.

(q) $32 \& 33$ Vict. c. 42 . As to the present position of the Church in Ireland, see ante, p. 335.

(r) $39 \& 40$ Geo. III. c. 67 , Art. 6.

(s) $I b$. Art. 7.

(t) 56 Geo. III. c. 98 .

(u) The result of the Judicature (Ireland) Acts of 1877, 1887, and 1897 . 
the reign of Henry II. The lord lieutenant was assisted by a Privy Council, consisting of some sixty-four members appointed by the Crown, but his duties were, for the most part, confined to merely formal executive acts, the real person of importance being the Secretary for Ireland, who was a member of the Cabinet, the head of the Irish Office, and controlled the policy of the Irish executive. All executive acts, however, were done in the name of the lieutenant governor, who carried on the administration of the country through the various Irish Government departments.

\section{The Government of Ireland Acts, 1914 (x) and $1920(y)$.} -The former of these Acts, which was passed under the provisions of the Parliament Act, 1911, for the purpose of granting representative and responsible government to Ireland under a separate Irish Parliament, received the royal assent on the 18th September, 1914, and was to come into operation on the first Tuesday in the month of May, 1915; or such other day not more than seven months earlier or later as might be fixed by Order in Council either generally or with reference to particular provisions of the Act. But the first Irish Parliament was to be summoned to meet not later than four months after the first Tuesday in May, 1915.

As a consequence, however, of the state of war existing with Germany at the date of the passing of the Act, the operation of the Act was further suspended by the Suspensory Act, 1914 (z), under which no steps were to be taken to put the Act into effect until the expiration of twelve months from the 18th September, 1914, or if the war with Germany had not then ended, until such later date (not being later than the end of the war) as might be fixed by Order in Council.

The Irish Parliament was to consist of the King, the Irish Senate, and the Irish House of Commons, but the supreme power and authority of the Imperial Parliament was to remain unaffected and undiminished over all persons, 
matters, and things in Ireland and every part of the same $(a)$.

Under the Gorernment of Ireland Act, $1920(b)$, which repealed the Government of Ireland Act, 1914, provision was made for a legislature, executive and judicature for Northern Ireland, comprising six of the counties of the Province of Ulster, with the boroughs of Belfast and Derry, and for Southern Ireland, comprising the remainder of the kingdom. Until the establishment of a Parliament for the whole of Ireland there was constituted a Council of Ireland for the purpose of bringing about harmonious action between the Parliaments and Governments of Northern and Southern Ireland. These Parliaments might by identical Acts agreed to by an absolute majority of members establish a Parliament for the whole of Ireland which should take the place of the Council and the Northern and Southern Legislatures. The number of nembers to be returned by Irish constituencies to serve in the Parliament of the United Kingdom was fixed at forty-six, of whom thirty-three were to represent Southern Ireland and thirteen to represent Northern Ireland.

Irish Free State (Agreement) Act, 1922 (c).--By this Act, which received the royal assent on March 31, 1922, it is provided as follows:-

(1) The Articles of Agreement for a Treaty between Great Britain and Ireland set forth in the Schedule to the Act shall have the force of law as from the date of the passing of the Act.

(2) For the purpose of giving effect to Article 17 of the Agreement, Orders in Council may be made transferring to the Provisional Government established under that Article the powers and machinery therein referred to, and as soon as may be and not later than four months after the passing of the Act the l'irlimment of Southem Treland shall be dissolved and such steps shall be taken as may be neessary for holding, in acecrdance with the law now in force with

(a) 4 is 5 Geo. V. c. 88, s. 1 (2).

(b) $10 \ll 11$ Geo. 5, c. 67 .

(c) 12 Geo. V. c. 4. 
respect to the franchise number of members and method of election and holding of elections to that Parliament, an election of members for the constituencies which would have been entitled to elect members to that Parliament, and the members so elected shall constitute the House of the Parliament to which the Provisional Government shall be responsible, and that Parliament shall, as respects matters within the jurisdiction of the Provisional Government, have power to make laws in like manner as the Parliament of the Irish Free State when constituted. Any Order in Council under this section may contain such incidental, consequential, or supplemental provisions as may appear to be necessary or proper for the purpose of giving effect to. the foregoing provisions of this section.

(3) Any Order in Council made under this Act shall be laid before both Houses of Parliament as soon as may be after it is made, and if an Address is presented to His Majesty by either of those Houses within twenty-one days on which that House has sat next after any such Order is laid before it, praying that any such Order may be annulled, His Majesty may thereupon by Order in Council annul the same, and the Order so annulled shall forthwith become roid, but without prejudice to the validity of any proceedings which may in the meantime have been taken thereunder; and any Order in Council made under this Act shall, subject to the foregoing provisions of this subsection be of the same effect as if enacted in this Act, but may be reroked or amended by a subsequent Order in Council:

Provided that Orders in Council under this Act shall not be deemed to be Statutory Rules within the meaning of section one of the Rules Publication Act, 1893.

(t) No writ shall be issued after the passing of this Act for the election of a member to serve in the Commons House of Parliament for a constituency in Ireland other than a constituency in Northern Ireland.

(5) This Act shall not be deemed to be the Act of Parliament for the ratification of the said Articles of Agreement as from the passing whereof the month mentioned in Article 11 of the said Articles is to rum. 


\section{SCHEDULE.}

\section{ARTICLES OF AGREEMENT FOR A TREATY BETWEEN GREAT BRITAIN AND IRELAND, DATED DECEMBER 6, 1921}

1. Ireland shall have the same constitutional status in the Community of Nations known as the British Empire as the Dominion of Canada, the Commonwealth of Australia, the Dominion of New Zealand, and the Union of South Africa, with a Parliament having powers to make laws for the peace order and good government of Ireland and an Executive responsible to that Parliament, and shall be styled and known as the Irish Free State.

2. Subject to the provisions hereinafter set out the position of the Irish Free State in relation to the Imperial Parliament and Government and otherwise shall be that of the Dominion of Canada, and the law, practice and constitutional usage governing the relationship of the Crown or the representative of the Crown and of the Imperial Parliament to the Dominion of Canada shall govern their relationship to the Irish Free State.

3. The representative of the Crown in Ireland shall be appointed in like manner as the Governor-General of Canada, and in accordance with the practice observed in the making of such appointments.

4. The oath to be taken by Members of the Parliament of the Irish Free State shall be in the following form:-

I . . . . do solemnly swear true faith and allegiance to the Constitution of the Irish Free State as by law established and that I will be faithful to H.M. King George V., his heirs and successors by law in virtue of the common citizenship of Ireland with Great Britain and her adherence to and membership of the group of nations forming the British Commonwealth of Nations.

5. The Irish Free State shall assume liability for the service of the Public Debt of the United Kingdom as existing at the date hereof and towards the payment of war pensions as existing at that date in such proportion as may be fair and equitable, having regard to any just claims on 
the part of Ireland by way of set off or counterclaim, the amount of such sums being determined in default of agreement by the arbitration of one or more independent persons being citizens of the British Empire.

6. Until an arrangement has been made between the British and Irish Governments whereby the Irish Free State undertakes her own coastal defence, the defence by sea of Great Britain and Ireland shall be undertaken by His Majesty's Imperial Forees, but this shall not prevent the construction or maintenance by the Government of the Irish Free State of such vessels as are necessary for the protection of the Revenue or the Fisheries.

The foregoing provisions of this article shall be reviewed at a conference of Representatives of the British and Irish Governments to be held at the expiration of five years from the date hereof with a view to the undertaking by Ireland of a share in her own coastal defence.

7. The Government of the Irish Free State sliall afford to His Majesty's Imperial Forces:-

(a) In time of peace such harbour and other facilities as are indicated in the Annex hereto, or such other facilities as may from time to time be agreed between the British Govermment and the Government of the Irish Free State; and

(b) In time of war or of strained relations with a Foreign Power such harbour and other facilities as the British Govermment may require for the purposes of such defence as aforesaid.

8. With a view to securing the observance of the principle of international limitation of armaments, if the Government of the Irish Free State establishes and maintains a military defence force, the establishments thereof shall not exceed in size such proportion of the military establishments maintained in Great Britain as that which the population of Ireland bears to the population of Great Britain.

9. The ports of Great Britain and the Irish Free State shall be freely open to the ships of the other country on payment of the customary port and other dues.

10. The Government of the Irish Free State agrees to pay fair compensation on terms not less favourable than 
those accorded by the Act of 1920 to judges, officials, members of police forces, and other public servants who are discharged by it or who retire in consequence of the change of govermment effected in pursuance hereof.

l'rovided that this agreement shall not apply to members of the Auxiliary Police Force or to persons recruited in Great Britain for the Royal Irish Constabulary during the two years next preceding the date hereof. The British Govermment will assume responsibility for such compensation or pensions as may be payable to any of these excepted persons.

11. Until the expiration of one month from the passing of the Act of Parliament for the ratification of this instrument, the powers of the Parliament and the Government of the Irish Free State shall not be exercisable as respects Northern Ireland, and the provisions of the Government of Ireland Act, 1920, shall, so far as they relate to Northern Ireland, remain of full force and effect, and no election shall be held for the return of nembers to serve in the Parliament of the Irish Free State for constituencies in Northern Ireland, unless a resolution is passed by both Houses of the Parliament of Northern Ireland in favour of the holding of such elections before the end of the said month.

12. If before the expiration of the said month, an address is presented to His Majesty by both Houses of the Parliament of Northern Ireland to that effect, the powers of the Parliament and Gorernment of the Irish Free Strte shall no longer extend to Northern Ireland, and the provisions of the Govermment of Ireland Act, 1920 (including those relating to the Council of Ireland), shail so far as they relate to Northern Ireland, continue to be of full force and effect, and this instrument shall have effect subject to the necessary morlifications.

Provided that if such an address is so presented a Commission consisting of three persons, one to be appointed by the Government of the Irish Free State, one to be appointed by the Government of Northern Ireland and one who shall be Chairman to be appointed by the British Government shall determine in accordance with the wishes of the inhabitants, so far as may be compatible with economic and 
geographic conditions the boundaries between Northern Ireland and the rest of Ireland, and for the purposes of the Government of Ireland Act, 1920, and of this instrument, the boundary of Northern Ireland sliall be such as may be determined by such Commission.

13. For the purpose of the last foregoing Article, the powers of the Parliament of Southern Ireland under the Government of Ireland Aet, 1920, to elect members of the Couneil of Ireland shall after the Parliament of the Irish Free State is constituted be exercised by that Parliament.

14. After the expiration of the said month, if no such address as is mentioned in Article 12 lereof is presented, the Parliament and Government of Northern Ireland shall continue to exercise as respects Northern Ireland the powers conferred on them by the Government of Ireland Act, 1920, but the Parliament and Government of the Irish Free State shall in Northern Ireland lave in relation to matters in respect of which the Parliament of Northern Ireland has not power to make laws under that Act (ineluding matters which under the said Act are within the jurisdietion of the Couneil of Ireland) the same powers as in the rest of Ireland subject to such other provisions as may be agreed in manner hereinatter appearing.

15. At any time after the date hereof the Government of Northern Ireland and the provisional Government of Southern Ireland hereinafter constituted may meet for the purpose of diseussing the provisions subjeet to which the last foregoing Article is to operate in the event of no such address as is therein mentioned being presented, and those provisions may include:-

(a) Safeguards with regard to patronage in Northern Ireland.

(b) Safeguards with regard to the collection of revenue in Northern Ireland.

(c) Safeguards with regard to import and export duties affecting the trade or industry of Northern Ireland.

(d) Safeguards for minorities in Northern Ireland.

(e) The settlement of the financial relations between Northern Ireland and the Irish Free State.

(f) The establishment and powers of a local militia in 
Northem Ireland and the relation of the Defence Forces of the Irish Free State and of Northern Ireland respectively.

and if at any such meeting provisions are agreed to, the same shall have effect as if they were included amongst the provisions subject to which the powers of the Parliament and Government of the Irish Free State are to be exercisable in Northern Ireland under Article 14 hereof.

16. Neither the Parliament of the Irish Free State nor the Parliament of Northern Ireland shall make any law so as either directly or indirectly to endow any religion or prohibit or restrict the free exercise thereof or give any preference or impose any disability on account of religious belief or religious status or affect prejudicially the right of any child to attend a school receiving public money without attending the religious instruction at the school or make any discrimination as respects State aid between schools under the management of different religious denominations or divert from any religious denomination or any educational institution any of its property except for public utility purposes and on payment of compensation.

17. By way of provisional arrangement for the administration of Southern Ireland during the interval which must elapse between the date hereof and the constitution of a Parliament and Government of the Irish Free State in accordance therewith, steps shall be taken forthwith for summoning a meeting of members of Parliament elected for constituencies in Southern Ireland since the passing of the Government of Ireland Act, 1920, and for constituting a provisional Government, and the British Government shall take the steps necessary to transfer to such provisional Government the powers and machinery requisite for the discharge of its duties, provided that every member of such provisional Government shall have signified in writing his or her acceptance of this instrument. But this arrangement shall not continue in force beyond the expiration of twelve months from the date hereof.

18. This instrument shall be submitted forthwith by His Majesty's Government for the approval of Parliament and by the Irish signatories to a meeting summoned for the 
purpose of the members elected to sit in the House of Commons of Southern Ireland, and if approved shall be ratified by the necessary legislation.

(Signed)

On behalf of the British Delegation,

D. Lloyd GeORgE.

Austen Chamberlain.

Birkenhead.

Winston S. Churchill.

L. IVORThington-Evans.

Hamar Greenivood.

Gordon HEwART.

6th December, 1921.
On behalf of the Irish Delegation, Art Ó Griobhtha. (Arthur Griffith) Michál Ó Colleain. Riobárd Bartun. E. S. Ó Dugain. Seorsa Ghabhíin Úi Dhubhthaigi.

\section{ANNEX.}

1. The following are the specific facilities required.

\section{Dockyard Port at Berehaven.}

(a) Admiralty property and rights to be retained as at the date hereof. Harbour defences to remain in charge of British care and maintenance parties.

QueEnstown.

(b) Harbour defences to remain in charge of British care and maintenance parties. Certain mooring buoys to be retained for use of His Majesty's ships.

\section{Belfast Lough.}

(c) Harbour defences to remain in charge of British care and maintenance parties.

\section{Lough Sivilly.}

(d) Harbour defences to remain in charge of British care and maintenance parties.

\section{Aviation.}

(e) Facilities in the neighbourhood of the above ports for coastal defence by air. 


\section{Oil Fuel Storage.

(f) Haulbowline - $\left\{\begin{array}{l}\text { To be offered for sale to com- } \\ \text { mercial companies under } \\ \text { guarantee that purchasers } \\ \text { shall maintain a certain } \\ \text { minimum stock for Admiralty } \\ \text { purposes. }\end{array}\right.$

2. A convention shall be made between the British Government and the Government of the Irish Free State to give effect to the following conditions:-

(a) That submarine cables shall not be landed or wireless stations for communication with places outside Ireland be established except by agreement with the British Government; that the existing cable landing rights and wireless concessions shall not be withdrawn except by agreement with the British Government; and that the British Government shall be entitled to land additional submarine cables or establish additional wireless stations for communication with places outside Ireland:

(b) That lighthouses, buoys, beacons, and any navigational marks or navigational aids shall bemaintained by the Government of the Irish Free State as at the date hereof and shall not be removed or added to except by agreement with the British Government :

(c) The war signal stations shall be closed down and left in charge of care and maintenance parties, the Government of the Irish Free State being offered the option of taking them over and working them for commercial purposes subject to Admiralty inspection and guaranteeing the upkeep of existing telegraphic communication therewith.

3. A Convention shall be made between the same Governments for the regulation of Civil Communication by Air.
D. L. G.
M. Ó. C.
A. C.
B.
IV. S. C. 


\section{The Chamnel Islands.}

Constitutional Position.-The Channel Islands, consisting of Jersey, Guernsey, Alderney, and Sark, originally formed part of the Duchy of Normandy, and became incorporated in the dominions of the Crown of England at the time of the Conquest, William the Conqueror being Duke of Normandy. They are now the only portion of that territory remaining to England.

The islands have from the earliest times enjoyed peculiar liberties, being exempt from the general scheme of taxation, and possessing legislative, executive, and judicial institutions of their own. Their original charter of liberties and their present constitution is said to have been granted to them by King John, as a reward for their loyalty in not joining with the rest of Normandy when that territory became reunited to the French Crown. There seems to be some doubt as to this $(d)$, but in any event their liberties and institutions, as they then existed, were fully recognised and confirmed by the charters of succeeding monarchs $(e)$.

Jersey, the most important of the islands, and Guernsey have legislative and judicial institutions of their own, whilst Aldemey, though having its own institutions, is subject to Gucrnsey. Sark has its own court, but is otherwise governed by Guernsey. Though in great measure independent, like colonies, the Channel Islands are bound by Acts of the Imperial Parliament, and Acts relating to the islands are sent by the clerk of the Priry Council to the Royal Courts of the islands to be registered, published, and put into execution $(f)$. The registration, however, of an Act so transmitted is not essential to its operation in the islands $(g)$. An important question has arisen as to whether the Crown may, by prerogative, legislate for the islands

(d) See Le Quesne Const. Hist. of Jersey, p. 52 et seq.

(e) $1 b . \mathrm{p} .116$ et seq.

(f) Order in Council, the 1st of July, 1731.

(g) Order in Council, the 7th of May, 1806. The provisions of the 7 \& 8 Will. III. c. 22 may also be noted, by which " all bye-laws, usages, and customs in practice in any of the possessions of the Crown repugnant to any law already made or to be made relating to the said possessions shall be utterly void and of none effect." (See Duncan's Hist. Guerns., p. 427.) 
by Order in Council, and the question was raised before the Judicial Committee of the Priry Council in 1853, and again in 1894. That body, however, though they expressed serious doubts as to whether Orders in Council would be binding on the islands without the assent of their legislatures, did not definitely decide the point $(h)$.

In both Jersey and Guernsey a lieutenant-gorernor (i) is appointed by and represents the Crown. He commands the military forces and militia in the islands; his consent is necessary before the local legislatures or "States" can meet, and he may reto any Act passed by the States. In either case, however, he must state his reasons for refusal to the Home Secretary. The lieutenant-governor also exercises the right of expelling foreigners from the islands. The legislative and judicial institutions of the two islands are similar; those of Jersey are as follows:-

Local Officers.-Jersey is divided into twelve parishes, the head of which is the constable, or connetable, an officer elected by the people every three years. The duties of this officer correspond generally to those of an English mayor. He superintends the affairs of the parish, is the head of the police, and the president of the parish assembly; he also represents the parish at meetings of the legislative body or States.

The constable is assisted in his duties by centeniers $(k)$,

(h) Three Orders in Council of the 11th of February, 1852, were issued by the Crown to remedy some of the judicial abuses existing in the islands. This course was objected to by the legislatures of the islands, who, however, passed local Acts in accordance to some extent with the provisions of the orders. The case was remitted by the Crown to a committee of the Privy Council, which expressed serious doubt as to the validity of the orders, but did not definitely settle the point. An Order in Council of the 29th of December, 1853, accordingly revoked the previous orders and sanctioned the Acts of the local legislatures. (See In re the States of Jersey, 9 Moo. P. C. 185.) The same question came again before a conmittee of the Privy Council in 1894, the States of Jersey having refused to register an Order in Council with reference to the Prison Board. The committee took the same course as in the previous case, not definitely deciding the point, but recommending the Crown to give way to the wishes of the States.

(i) Besides the lieutenant-governor, a governor used also to be appointed, but his duties being merely nominal, the office has not latterly been filled.

(b) There are two centeniers for each parish, except St. Helens, which has eight. 
who are elected for three years, and have the power of arrest for misdemeanour or crime, and vingteniers (l), who act in subordination to the centeniers and collect the parish rates.

Beneath these officers come the offieicrs du connétable. They assist the constable, centeniers, and ringteniers in their duties, and in some cases act independently.

Courts and Laws.-In criminal cases the constable and twelve of his "officers" form the first jury, the bailiff presiding. Appeal lies to the grande enquête, or jury of twenty-four, stmnoned by the Proeureur du Roi (or Attorney-General).

The Royal Court, the chief court of the island, is presided over by the bailiff, an officer appointed by the Crown durante bene placito, and selected for his linowledge of the law. He acts as chief justice, and is assisted in civil suits by a certain number of the twelve jurats, according to the nature of the action, and in criminal suits by the grande enquête, a jury of twenty-four.

In civil matters appeal lies to the Judicial Committee of the Privy Council. The laws administered by the Court Royal is the common law of the island founded upon the old Coutume de Normandie, upon which have been grafted many local usages and customs; ordinances passed by the Court Royal and Acts of the States; Acts of the Imperial Parliament and Orders in Council relating to the island and registered in the Court Royal; and the regulations made from time to time by royal commissioners appointed under the Great Seal $(m)$.

The King's writ does not run in the islands (n) except the writs of habeas corpus, prohibition, ccrtiorari, and mandamus, which do so rum on a proper occasion $(o)$, as also does the King's commission under the Great Seal.

(l) Each parish is divided into vingtaines, varying in number with a vingtenier for each.

(m) In 1771 some of the more important laws then in force were embodied in a code.

(n) This privilege was affirmed by an Order in Council, 6 Eliz. (See Le Quesne, Const. Hist. of Jersey, p. 180 et seq.)

(o) See Le Cras, Laws of Jersey, p. 17 et seq. 
Ecclesiastical jurisdiction is exercised in the island by the dean, who is appointed by the Crown. Appeal lies to the Bishop of Winchester, the island being in his diocese $(p)$.

The Legislature.-The local legislature, or States, is composed of the bailiff (who acts as president), the twelve constables, the twelve jurats (who are ex-officio members), and the twelve rectors of the various parishes appointed by the Crown for life (one of whom is also the dean), together with fourteen deputies, three for St. Helens, and one for each of the other eleven parishes, elected for three years.

The attorney-general, the solicitor-general, and the vicomte or sheriff, may be present, but may not vote.

The bailiff has a casting vote, and may dissent from any measure, stating his reasons for so doing to the Home Secretary. His dissent so expressed acts as a suspension of the measure for the signification of his Majesty's pleasure thereon.

The consent of the lieutenant-governor is necessary before the States can meet, and he has the right of vetoing any measure, but his reasons must be stated to the Home Secretary, and in all cases permanent Acts of the States need the assent of the Crown, expressed by Order in Council. Provisional ordinances or bye-law's may, however, he made for three years without the assent of the Crown $(q)$.

Formerly the Court Royal had also the power to make ordinances and bye-laws, but this was tiken away in 1771, when the laws of the island were codified $(r)$.

Guernsey. - The institutions of Guernsey are almost precisely similar to those of Jersey, the island possessing its Court Royal, or Chef Plaids (composed of the bailiff and jurats), and its States (composed of the bailiff as president, the jurats, and the rectors, constables, and deputies of the various parishes).

The chief difference between the institutions of the two

(p) Order in Council, 11th of March, 1658.

(q) Order in Council, 28th of March, 1771. (Code of Laws, Jersey, 1771 , p. ii.)

(r) Code of Laws, Jersey, 1771, p. ii. 
islands is that the Court Royal, or Chef Plaids, of Guernsey has still the power of making ordinances $(s)$, and of suggesting legislative measures to the States $(t)$.

Alderney has its own institutions, similar to Jersey and Guernsey, but the States of Guernsey may legislate for Alderney, and appeal lies from the Court of Alderney to the Court of Guernsey, and thence to the Privy Council.

Sark.-Sark is also subordinate to Guernsey. It possesses its own Court, with limited jurisdiction. Appeal lies to Guernsey, and thence to the Privy Council.

\section{The Isle of Man.}

The sovereignty of the Isle of Man was for many centuries vested in grantees of the Crown by letters patent in return for homage and the granting of two falcons at the coronation of successive sovereigns, the island enjoying its own constitution and complete legislative independence $(u)$. The grantees of the royal dignity, though nominally lings of the island, did not assume that title, but styled themselves "Lords of Man and the Isles," and eventually the sovereignty was repurchased from the Duke of Atholl, the then holder, by George III., in the year 1765 , for $£ 70,000$, under statutory authority $(x)$, the Church patronage, most of the royal franchises, such as waifs, wrecks, mines, fairs, tolls, etc., together with the property in the soil, being reserved to the Duke of Atholl in return for the ancient honorary services.

The island still enjoys its ancient form of constitution, the supreme legislative authority being rested in the Crown, the governor and council, and the House of Keys, which constitute the Parliament of the island, linown as the Tynwald Court.

The members of the House of Keys are twenty-four in number, and formerly held office for life $(y)$. They are now

(s) These require the consent of the Crown in Council if any change in the existing law is made.

(t) See Le Quesne, Const. Hist of Jersey, p. 101 et seq.

(u) See the various letters patent recited in the 5 Geo. III. c. 26, commencing with that granted to Sir John de Stanley, $7 \mathrm{Hen}$. IV.

(x) 5 Geo. III. c. 26.

(y) Johnson's Jurisprudence of the Isle of Man, p. 20. 
elected for seren rears unless sooner dissolred by the Crown $(z)$.

The lieutenant-gorernor is appointed by the Crown, and his council for legislative purposes is composed of the principal dignitaries in the island virtute officii $(a)$.

The keys are summoned by the governor, and since 1765 Acts of the Trnwald must be confirmed by his Majesty, and before they receive the force of law they must be promulgated in the English and Manx languages on the Trnwald Hill and signed br the governor and such of the council and kers as are present.

(z) See the Laws of England. vol. x., p. 57\%.

(a) There seems to be some doubt as to the persons actually entitled to sit on the council, but the bishop. the treasurer or receicer-general, the two deemsters, the water-bailiff, and the clerk of the rolls, would appear to be included (Johnson's Jurisprudence of the Isle of Man, p. 22). 
Chapter II.

\section{THE COLONIES.}

Definition.-By the Interpretation Act, 1889, a colony is defined as being "any part of his Majesty"s dominions, exclusive of the British Islands and of British India" (a), and for the purposes of the definition, where parts of such dominions are under both a central and a local legislature, all parts under the central legislature are to be deemed one colony $(b)$.

According to the circumstances under which they are originally acquired, colonies may be classified as either settled, conquered, ceded, or mandatory.

Settled Colonies.-A colony is said to be settled when at the time of occupation it is uninhabited, or inhabited only by tribes whose laws and customs are inapplicable to a civilized race. Australia may be taken as a type of such a colony.

In settled colonies the settlers carry with them the English common law, and so much of English statute law as is applicable to them under their particular circumstances; but. English ecclesiastical law is not carried by English settlers into a new colony (c), and such portions of statute law as the Mortmain Acts, the Statutes of Limitations, the Marriage Acts, the Statutes of Charitable Uses, have been held inapplicable to certain colonies (d), and the New Wills Act (7 Will. IV. and 1 Vict. c. 26) has been held inapplicable to the Colonies and India $(e)$.

(a) 52 \& 53 Vict. c. 63 , s. 18 (3).

(b) The British Islands include the United Kingdom, the Channel Islands, and the Isle of Man. $I b$. s. 18 (1).

(c) In re the Lord Bishop of Natal (1864) 3 Moo. P. C. (N. S.) p. 152.

(d) See Tarring's Law relating to the Colonies, p. 9.

(e) In re the froods of Foy (1839) 2 Curt. 328. 
In addition to these laws, by the British Settlements Act, $1887(f)$, his Majesty in Council is empowered to establish such laws and institutions, constitute such courts and officers, and make such regulations for the administration of justice in any British settlement as to his Majesty may seem fit, but this is only applicable where representative government has not been granted. Where, in any colony, whether settled, conquered, or ceded, there exists already a native population with laws and customs of their own, though from their nature inapplicable to Englishmen, these laws and customs are not generally entirely suppressed, but retained and respected as personal or tribal in character so far as is compatible with the dictates of humanity. So the Hindu and Mohammedan laws and customs relating to marriage, inheritance, etc., are respected and enforced as personal or tribal in character in AngloIndian courts, and the laws and customs of the natives of the Gold Coast $(g)$, and of the aborigines of New Zealand $(h)$, have been statutorily preserved.

Conquered and Ceded Colonies.-In conquered colonies (and, semble, in ceded colonies also) where a system of civilized laws already exists, this continues in force until altered by the new owners (i), and in fact where such a system has been thoroughly established it is generally preserved; e.g. French law in Lower Canada, Roman-Dutch law in Ceylon and Cape Colony; and this is sometimes expressly stipulated in the treaty or articles of capitulation by which a colony is acquired. But laws contrary to the fundamental principles of the British Constitution cease at the moment of conquest or cession, and therefore torture, which was legal under the old law of Minorca, could not legally be inflicted by an English governor (k).

Where such a system of laws, however, has not been establisher, English law is introduced.

(f) $50 \& 51$ Vict. c. 54 .

(g) Ordinance No. 4 of 1876.

(h) $15 \& 16$ Vict. c. 72 , s. 71 .

(i) See Campbell v. Hall (1774) 20 St. Tri. p. 323.

(k) See judgment of De Grey, C.J., in Fabrigas v. Mostyn (1773) 20 St. Tri. p. 181. 
It seems that British subjects cannot take possession of a foreign country in their own right. If they acquire it by settlement the authority of the Crown extends to them $(l)$, and if by conquest, it becomes a dominion of the King in right of his Crown $(m)$. In 1842 the Sultan of Borneo granted to Sir James Brooke (commonly called "Rajah Brooke") the government of Sarawak subject to tribute. In 1853 the tribute was remitted, and he was given power to appoint a successor. In 1855 a British commission was appointed to inquire into the status of Rajah Brooke in Borneo. The eommissioners did not definitely define the position, but they inclined to the opinion that in face of the statutory assertion of the sovereignty of the Crown over the territory of the East India Company (53 Geo. III. c. 155 , s. 95) no British subject could attain to the position of an independent ruler of a foreign country $(n)$. In 1864, however, a British consul was appointed to Sarawak, which in 1888 beeame a British Protectorate by agreement with Rajah Brooke (o).

In conquered and ceded colonies, by virtue of the prerogative the Crown enjoys the right of legislation, of appointing executive officers, and establishing courts of justice, in so far as this right has not been restricted by the articles of eapitulation or by treaty $(p)$.

This right of legislation may be exercised by Order in Council, and also, it seems, by proclamation or letters patent $(q)$. In settled colonies, however, the power of legislation is by the British Settlements Act, 1887, only conferred upon the King in Council $\left(v^{*}\right)$, but this power may be delegated by any instrument under the Great Seal, or by instructions under the sign manual, to any three or more persons within the settlement $(s)$.

The Crown cannot, howerer, make laws contrary to the

(l) See per Lord Mansfield in Campbell v. Hall (20 St. Tri. p. 287).

(m) $I b$. pp. $322,323$.

(n) Report of Commissioners, 1855, p. 19.

(o) See Herts. Comm. Treat., xviii. p. 227.

(p) As to this right generally, see judgment of Lord Mansfield in Campbell v. Hall (1774) 20 St. Tri. p. 320 et seq.

(q) See Jephson v. Riera (1835) 3 Knapp, p. 152.

(r) $50 \& 51$ Vict. c. 54, s. 2.

(s) Ib. s. 3 . 
fundamental principles of the British Constitution, or exempting persons from the general laws of trade, or the authority of Parliament, or granting exclusive privileges to individuals $(t)$, and when a representative government has been granted to a colony the right of the Crown to legislate ceases $(u)$, unless it has been specially reserved, as in the case of British Guiana, Malta, and Mauritius.

Appeals from the Colonies.-From the highest civil or criminal court in any colony appeal lies to the King in Council, and since $1833(x)$ these appeals are heard by the Judicial Committee of the Privy Council. The right to appeal is, however, usually limited, by Order in Council or local legislation, to cases in which leave to appeal has been granted according to the rules in force in the colony $(y)$. In all cases, however, the Crown retains the prerogative right to grant special leave to appeal, unless that right has expressly been taken away by precise words. Accordingly an Act of the Canadian Dominion (z) which declared the judgment of the Canadian Court of Appeal in insolvency questions to be final, was held not to interfere with the prerogative of the Crown to grant special leave to appeal $(a)$. In criminal suits the Privy Council will not grant special leave to appeal unless " some substantial or grave injustice has been done through disregard of the forms of legal process, or some violation of the principles of natural justice" (b), or unless the question raised is of grave importance $(c)$. And in civil suits, where the issue in dispute is a question of fact only, the Judicial Committee of the Privy Council will not entertain an appeal (d), and special

(t) See 20 St. Tri. p. 323.

(u) $I b$, p. 329 .

(x) 3 \& 4 Will. IT. c. 41.

(y) As to the rules in force in the various colonies, sec Macpherson's Privy Council Practice, 2nd ed., pp. 69-118.

(z) 40 Vict. c. 41 , s. 28 (Canadian Act).

(a) Cushing v. Dupuy (1880) 5 App. Cas. 409, overruling Cuvillier v. Ayluin (1832) 2 Knapp, 72.

(b) Ex parte Deeming [1892] A. C. 422; Dal Singh v. King-Emperor, 44 Ind. App. 137.

(c) Reg. v. Bertrand (1867) L. R. 1 P. C. 520.

(d) Canada Central Railuay Co. v. Thomas Murray (1883) 8 App. Cas. 574. 
leave to appeal from the Supreme Court of Canada $(e)$ will be refused unless the case is of gravity, involving matter of public interest, or some important question of law, or affecting property of considerable amount, or where the case is otherwise of public importance $(f)$. It would seem that the same principle would apply in any other colony where the judgment of the colonial court is declared to be final. To meet the fact that the rules in force in some colonies prevented appeals to the Privy Council from courts other than a court of error or appeal in the colony, it is provided by statute $(g)$ that his Majesty may by Order in Council provide for appeals to his Majesty from any colonial court though not a court of error or appeal.

Where the leave of the colonial court is a necessary preliminary to an appeal, and the colonial court has no power to grant such leave, the proper course is to apply to the Privy Council for special leave to appeal, which may be granted by virtue of the prerogative.

The law of a colony upon any particular point must be proved as a fact in an English court, and this is usually done by an expert. Recourse may, however, be had to the provisions of the $22 \& 23$ Vict. e. 63 , which provides for the remission of cases by courts in one part of his Majesty's dominions for the opinion in law of the court in any other part of his Majesty's dominions $(h)$. The prerogative rights of the Crown, such as forfeiture, extend to the Colonies; therefore, prior to 1870 and the abolition of forfeiture on conviction for felony (i), the Crown was held entitled to a colonial felon's goods $(j)$.

The Judicial Committee has no power to enquire into the propriety or impropriety of a colonial statute $(k)$.

(e) The decision of which is by the British North America Act, 1867, declared to be final, saving the right of his Majesty to grant "special leave " to appeal.

(f) Prince v. Gagnon (1882) 8 App. Cas. 103.

(g) 7 \& 8 Vict. c. 69 , s. 1 .

(h) The 34 Tict. c. 11 enacts more generally that any superior court may remit a case to the court of any foreign state with whom a convention to that effect exists, to ascertain the law of such foreign state on any point.

(i) $33 \& 34$ Vict. c. 23.

(j) In re Bateman's Trust (1873) L. R. 15 Eq. 355.

(k) Tilonko v. Att.-Gen. for Natal [1907] A. C. 93. 
Legislation in Colonies.-Those colonies in which the Crown has the sole right of legislation, either through a governor or by Order in Council, are generally described as Crown colonies, to distinguish them from those which have representative, or representative and responsible, legislatures; and laws in such colonies are generally termed ordinances. But every colony, whether a Crown colony or not, is subject to the paramount authority of the Imperial Parliament (l). Examples of the exercise of this power are to be found in the suspension of the Canadian constitution on two occasions $(m)$, and the abolition of slavery $(n)$.

Representative legislatures are conferred generally by Act of the Imperial Parliament, or in cases where representative institutions have already been granted, the full system of responsible government may be established by a Colonial Act ratified by Imperial Act.

In Cape Colony a representative legislature was granted by letters patent in 1850, and in 1852 this legislature passed an Act establishing responsible government, which was ratified by the Crown by Order in Council. The present constitution of the Union of South Africa is effected by Imperial Act.

The validity or otherwise of colonial laws is regulated by the Act to Remove Doubts as to the Validity of Colonial Laws, $1865(o)$, which enacts that " any colonial law which is in any respect repugnant to any Act of Parliament extending to the colony, or to any order or regulation made under the authority of such Act, or having in the colony the force or effect of such Act, shall be read subject to such Act, order, or regulation, and shall, to the extent of such repugnancy, be void and inoperative" $(p)$. Br the same Act every colonial legislature is empowered to establish or abolish and reconstitute courts of justice within the colony;

(l) See, as to conquered colonies, per Lord Mansfield in Campbell v. Hall (1774) 20 St. Tri. p. 322 et seq.; and, semble, this applies to all colonies.

(m) See 1 \& 2 Vict. c. 9 ; and $2 \& 3$ Vict. c. 53.

(n) $3 \& 4$ Will. IV. c. 73.

(o) 28 \& 29 Vict. c. 63 .

(p) Ib. s. 2. 
and every representative legislature $(q)$ is empowered to make laws respecting the constitution, powers, and procedure of such legislature, provided they are enacted in the necessary form $(v)$.

\section{Classification of Colonies.}

At the present day, apart from the varions protectorates and the territories administered by chartered companies, there are thirty-four colonies with distinct governments. These may be divided into four groups, according to their constitutions :-

Crown Colonies.-Group I. consists of five colonies, in which the Crown has the sole power of legislation, which it exercises through a governor, commissioner, or resident, alone. These are-

Gibraltar.

Labuan.

St. Helena.

Basutoland $(s)$.

Ashanti $(t)$.

In all of these, except Basutoland, the Crown has reserved power to legislate by Order in Council.

Group 1I.- In fourteen colonies the Crown has the control of administration and legislation, which it exercises through a governor or administrator, assisted by executive and legislative councils, composed of ex-officio or official, or partly

(q) The term " representative legislature " includes all Colonial Legislatures, which shall comprise a legislative body, of which one-half are elected by inhabitants of the colony. (Ib. s. 1.)

(r) $I b$. s. $\ddot{0}$.

(s) Basutoland was annexed to Cape Colony in 1871 (Cape of Grood Hope Act, No. 12 of 1871), but was not made subject to the general laws of the colony, the Governor of Cape Colony legislating for Basutoland by proclamation. It was disannexed in 1883 , and the govermment is now administered by a resident commissioner, under the supervision of the High Commissioner for Sonth Africa, the latter liaving the pow $\leftarrow \mathrm{r}$ of legislation.

( $t$ ) Ashanti was annexed by Order in Council the 26th of September, 1901, consequent upon the successes of the British arms in that yar. It is now, therefore, a British colony, and by the same Order in Council the government is administered by a chief commissioner, appoiated by the governor of the Gold Coast; the latter has the power of legtslation by Ordinance. 
official and partly nominated, members, the Crown reserving the right of veto. These are-

Hong Kong.

Trinidad and Tobago.

Grenada

$\left.\begin{array}{l}\text { St. Lucia } \\ \text { St. Vincent }\end{array}\right\}$ known as the Windward Islands $(u)$.

The Seychelles.

The Straits Settlements (Singapore, Penang, and Malacca).

Sierra Leone.

Gambia.

"The Gold Coast.

The Falkland Islands.

British Honduras.

Nigeria (formerly linown as Lagos, and later Southern Nigeria) (x).

Turlis and Caicos Islands (y).

(u) The group known as the Windward Islands geographically includes Barbados, and Trinidad and Tobago, which are now separate colonies. Grenada, St. Lucia, and St. Vincent were united under a governor and commander-in-chief by letters patent of the 17th of March, 1885. Each island retains its own institutions, an administrator representing the governor-in-chief in St. Lueia and St. Vincent, and there is no common legislature or system of laws. A common Court of Appeal was, however, instituted in 1859.

(x) The colony of Lagos was constituted by letters patent of the 13 th of January, 1886, the name of the colony being subsequently changed to "Southern Nigeria " by letters patent in 1906, it being provided by Order in Council, 16th February, 1906, that the governor and legislative council for Southern Nigeria should exercise the power of legislating by Ordinance, and of appointing commissioners, judges, etc., for the territories formerly comprised within the protectorates of Lagos and Southern Nigeria respectively, which territories were by the same order amalgamated into the Protectorate of Southern Nigeria. (See Order in Council, 16th February, 1906, and see post, p. 467, as to the subsequent amalgamation of the Northern and Southern Nigeria Protectorates under the name of the Nigeria Protectorate. The boundaries of the Colony of Nigeria were defined by Order in Council of 22nd November, 1913. and a Council of Nigeria (for both the Colony and Protectorate) established. Letters patent of 29 th November, 1913, constituted the office of Governor and Commander-in-Chief for the Colony and provided for executive and legislative councils.

(y) The legislature consists of a commissioner and a legislative council, both appointed by the governor of Jamaica. 
In most of these colonies ( $z$ ) the Crown may legislate by Order in Council. The govermments of these colonies are constituted by means of three documents: (1) Letters patent under the Great Seal constitute the office of governor, create the executive and legislative councils, and frame the constitution (a). (2) By commission under the sign manual and signet the governor is appointed. (3) Instructions under the sign manual and signet or through the Secretary of State detail the procedure of the executive and legislative councils, reserve certain subjects on which legislation cannot take place without the sanction of the Crown in Council, and define the relations of the governor and the judiciary.

Colonies with Representative Governments. Group III.This comprises ten colonies to which representative legislatures have been granted, the Crown retaining only the right of veto except in cases where its right of legislation has been specially reserved. The public officers in these colonies are, however, under the control of, and responsible to, the Crown acting through the Colonial Secretary, and such colonies are therefore said to enjoy representative, but not responsible, governments.

In colonies with responsible govermments, on the other hand, the chief public officers or ministers are responsible, as in England, primarily to the local legislature, and ultimately to the Crown. In the colonies comprised in Group III. the executive is composed of a governor and an executive council appointed by the Crown or the governor, and generally containing some ex-officio, or official members.

In three colonies the legislature consists of the governor and two chambers, a legislative council nominated by the

(z) Until 1902, British New Guinea was included in this list. But that colony lias now been placed under the authority of the Commonwealth of Australia by letters patent of the 18th of March, 1902. (See St. R. \& O. 1902.) It is now a dependency of the colony under the name of Papua, by proclamation of the governor-general in 1906. Cevlon and Fiji were formerly in this list, but their legislative conncils now include elected members, and they fall therefore in Group III.

(a) In Honduras the legislative council is nominated under a local Act and not under letters patent. 
Crown, and an elected legislative assembly. These three colonies are-

The Bahamas,

Barbados (one of the Windward Islands, but separated from the latter and made a distinct government by letters patent in 1885),

Bermuda;

and in these the Crown cannot legislate by Order in Council.

In eight colonies there is one legislative chamber only, composed partly of members nominated by the Crown, or of ex-officio or official members, and partly of elected members. These are-

British Guiana.

Jamaica.

Cyprus (b).

The Leeward Islands (c).

Malta.

Mauritius.

Ceylon.

Fiji.

Colonies with Representative and Responsible Governments.-Group $I V$. comprises the most important of all our colonies, to which full representative and responsible polities have been granted, modelled on the lines of the English Constitution itself, the governor representing the Crown, the executive council corresponding to the English Privy Council, whilst the English Cabinet is represented by the Ninistry, or those members of the executive council selected by the governor, and who are always the principal public officers, and enjoy the confidence of the representative chamber. The governor, the executive council, and

(b) Sce post, p. 476.

(c) Comprising Antigua, Dominica, St. Christopher (St. Kitts) and Nevis, Montserrat, and the Virgin Islands, to which the island of Sombrero was added in 1904. The constitution depends upon the Leeward Islands Act. 1871 (34 \& 35 Vict. c. 107), as amended by Federal Act, No. 1, of 1899, and letters patent of the 2nd of October, 1902 (St. R. \& O., 1902. p. 596), by which the Crown's power of nominating members of the legislative council was delegated to the governorgeneral, and various provisions made with regard to the local governinents. 
the Ministry or Cabinet form the members of the executive, whilst the legislature consists of the governor and two legislative chambers corresponding to the Lords and Commons.

In three colonies the upper legislative chamber is composed of members nominated by the governor, whilst the lower chamber is elected. These are-

Canada $(d)$.

New Zealiand.

Newfoundland.

In one colony the upper chamber (or senate) is composed partly of members chosen by the govemor-general, and partly of elected members, the lower legislative chamber (or House of Assembly) being composed entirely of elected members: viz.-

The Union of South Africa.

In one colony the legislature consists of the governor and two elected legislative chambers: viz.-

The Commonwealth of Australia.

Three of these, viz. Canada, the Union of South Africa, and Australia, are federations of several colonies or provinces, each province enjoying a separate local responsible government, with lieutenant-governors (or administrators in the case of South Africa) and representative legislatures. These local governments are subordinate to the central federal government, and the local constitutions vary, except in South Africa, where they are all similar.

In the Dominion of Canada-

Quebec ( have a legislative council nominated by Nova Scotia the lieutenant-governor for life, and an elected legislative assembly.

Ontario

New Brunswick

Manitoba

British Columbia

Prince Edward Island

Alberta

Saskatchewan

have one chamber only.

(d) In Canada and South Africa the upper chamber is termed "the senate," those of the other colonies "legislative councils."

C.I.E. 
The Yukon $\left\{\begin{array}{c}\text { is under a commissioner with a legislative } \\ \text { council. }\end{array}\right.$ is under a commissioner, who is the comptroller of the Royal

The North- Mest Territories North-West Mounted Police, and exercises executive and legislative authority under the control of the Hudson's Bay Co.

In the Commonwealth of Australia-

New South Wales Queensland

Victoria

South Australia

Tasmania

Western Australia

have a legislative council nominated by the Crown, and an elected assembly.

In the Union of South Africa all the provinces, viz.-

have a legislative council elected

The Cape of Good Hope for three years, and an execuNatal

The Transvaal

The Orange Free State

have elected legislative councils and assemblies. tive committee composed of the Administrator and four members elected by the provincial councils.

Privileges of Colonial Parliaments. With regard to the privileges of colonial Parliaments, the lex et consuetudo Parliamenti have been held to apply exclusively to the Lords and Commons, and not to colonial Parliaments; and therefore the legislative council of Tasmania had no power to commit for contempt (e). But in the case of Victoria, whose constitution depends on a colonial Act of 1854, ratified by Imperial Act $(f)$, the colonial legislature was given porver to define its own powers and immunities, which were not to exceed those enjoyed by the House of Commons

(e) Fenton r. Hampton (1858) 11 Moo. P. C. 347, following Kielley v. Carson (1842) 4 Moo. P. C. 63.

(f) 18 \& 19 Vict. c. 55. 
in England. A Victorian Act (g) accordingly gave the legislative assembly the same powers and immunities as the House of Commons, and therefore the assembly was held to have power to conmit for contempt $(h)$. The same provisions have been made with regard to Canada (i) and Western Australia (j).

By the British Nationality and Status of Aliens Act, 1914 , s. 8, the Government of India and any self-governing dominion may grant certificates of naturalization. A similar grant by the government of any other British possession must be confirmed by the Secretary of State.

\section{Colonial Governors.}

Constitutional Position.-Colonial governor's are appointed by commission from the Crown, and their powers are limited and defined by the letters patent which constitute the office of governor, and by the instructions which are given to them on appointment. Where the commission extends to more than one colony, as in Australia or Canada, they are termed governors-general or governors-in-chief $(k)$.

In Crown colonies the powers of the governor are strictly defined, but within the limits of his authority he has absolute discretion. In self-governing colonies, on the other hand, though his powers are nominally wider, the governor takes the place of a constitutional monarch, and must act on the advice of his ministers. An example of this occurred in New Zealand in 1892, when the nominated upper chamber continually refused to support the measures of the Premier with a large parliamentary majority. The Ministry demanded an increase in the numbers of the upper house sufficient to give the Government a majority. This the governor refused, but on application to the Colonial Office he was instructed that where no Imperial interests were at stake, and where the constituencies were at one

(g) 20 Vict. No. 1.

(h) Dill v. Murphy (1864) 1 Moo. P. C. (N. S.) 487. Speaker of Victorian Legislative Assembly v. Glass, L. R. 3 P. C. 560.

(i) 38 \& 39 Vict. c. 38 , s. 1 .

(j) Western Australia Constitution Act, 53 \& 54 Vict. c. 26; s. 36.

(k) See the Interpretation Act, 1889. 
with the Ministry, he must accept the advice of his ministers.

In Canada lieutenant-governors are appointed not directly by the Crown, but by the governor-general in council, as representing the Crown (l).

The governor, with the advice of his council, exercises the executive powers conferred upon him by the terms of his commission. The members of the executive council, in colonies which have not responsible Governments are appointed from amongst the principal officers of the colony, sometimes with unofficial members, by the governor's instructions, or by warrant from the Crown on the advice of the Secretary of State. They can be dismissed only by the Crown, the governor having, however, a power of suspension.

In colonies with responsible Gorermments, the governor appoints or removes members of the executive council, whilst, in analogy to the formation of an English Cabinet, he also summons those members of the executive council who enjoy the confidence of the representative chambers to form the Ministry, corresponding to the English Cabinet; and it is upon the advice of the Ministry, who confer separately (in the same way that a Cabinet Council confer's in the absence of the Crom in England), that the governor acts, and not upon the advice of the executive council itself, which, like the Privy Council in England, meets only to transact formal business matters $(m)$.

It is through the instructions given to the governor that the system of ministerial responsibility has come to be a recognized constitutional doctrine in the colonies. The governor is responsible to the Crown only, and in certain matters, such as Imperial policy, he is the only person who can be made responsible. In all matters of local administration, however, the ministers are responsible, not immediately to the Crown, but to their own legislature.

In appointing and dismissing officials the governor is

(l) Such a mode of appointment is not unconstitutional, for the governor and council are merely exercising the delegated authority of the Crown. Per Lord Watson in Liquidators of the Maritime Bank of Canada v. Receiver-General of New Brunsuick [1902] A. C., at p. 443.

(im) See Todd's Parliamentary Government in the British Colonies, p. 37 et seq. 
generally bound to act on the advice of his council, but express power is conferred on colonial governors by statute $(n)$ to remove any person from office in case of aisence without reasonable cause, neglect, or misbehaviour, and the dismissal of a commissioner of Crown lands by it governor of new South Wales was held by the Judicial Committee of the Priry Council not to be a proper subject of appeal, because such offices are held, not by any patent right, but solely during the pleasure of the governor $(o)$.

Liability of Colonial Governors. - A colonial governor is liable to a civil action for acts done in his private and unofficial capacity both in the courts of the colony $(p)$ and in the court of King's Bench in England $(q)$; and he may be sued in England for acts done in his official capacity, but outside the limits of his authority $(r)$, or for acts which, though done officially and within the limits of his commission, are such as the Sovereign through his minister's cannot legally do, for the orders of the Crown are no excuse for such an act. But whether he can be sued for acts done in his official capacity within his own colony seems doubtful $(s)$. It is clear, however, that he cannot be sued either in the colony or in England for acts of state within the authority of his commission, provided they are acts which a Sovereign through his ministers can legally do $(t)$, and in cases of contract on behalf of the Sovereign the only remedy apparently would be by Petition of Right.

Governors are liable to criminal proceedings in the court of King's Bench in England umder the Governors Act $(u)$ "for acts of oppression within the area of their command, or for any other crime or offence contrary to the laws of

(n) 22 Geo. III. c. 75 .

(o) Ex parte Robertson (1858) 11 Moo. P. C. 288.

(p) Hill v. Bigge (1841) 3 Moo. P. C. 465.

(q) Fabrigas v. Mostyn (1774) 20 St. Tri. 81.

(r) Musgrave v. Pulido (1879) 5 App. Cas. 111; Phillips v. Eyre (1869) L. R. 4 Q. B. 225.

(s) Tandy v. The Earl of Westmoreland (1800) 27 St. Tri. 1246; Luby v. Lord Wodehouse (1865) 17 Ir. C. L. R. 618. But see Musgrave v. Pulido (1879) 5 App. Cas., p. 107.

( $t$ ) See the cases cited abore.

(u) $11 \& 12$ Will. III, c. 125. 
the realm or in force within their respective governments or commands" $(v)$. But whether a gorernor can be tried on a criminal charge in his own colony does not seem to have been judicially determined; seeing, however, that he is not a viceroy $(u)$, but is only in the position of an officer with limited authority $(x)$, it might be said that he could not claim exemption from a criminal prosecution any more than a Cabinet minister in England could do so. Against this must be set the public inconvenience which would arise if a governor were subject to arrest like any ordinary person, and under the old law of execution, though he could be sued for debt, his person, it seems, could not be taken in execution under a writ of capias $(y)$. Whether, then, a governor enjoys the privilege of absolute freedom from arrest in his own colony in criminal and civil suits does not seem to have been directly determined. The Governors Act (z) was extended by a subsequent Act (a) to "all persons in his Majesty's service, in any civil or military capacity out of Great Britain, guilty of any crime, misdemeanour, or offence, in the execution of, or under the colour or in the exercise of, any such employment." But this Act has been held not to extend to felonies (b). Breaches of official trust committed out of the United Kingdom are within the Act, and may be tried either in the place where they were committed, or in England $(c)$, and the

(v) There seems to be some doubt whether this Act extends to felonies. See Rex v. Shaue (1816) 5 M. \& S., p. 405 . In 1802 Governor Wall was tried at the Old Bailey for the murder of a soldier by flog. ging whilst governor of the Island of Goree, sentenced to death and executed. The 33 Hen. VIII. c. 23, under which the trial took place, was repealed by the 9 Geo. IV. c. 31 , s. $1 ; 9$ Geo. IV. c. 74 , s. 12.

(w) See Hill $v$. Bigge (1841) 3 Moo. P. C., p. 476 et seq., disapproving the dictum of Lord Mansfield to the contrary in Fabrigas v. Mostyn (1774) 20 St. Tri. 81.

(x) Camcron v. Kyle (1835) 3 Knapp P. C. 332.

(y) See Hill v. Bigge (1841) 3 Moo. P. C., p. 478.

(z) 11 \& 12 Will. III. e. 12 .

(a) 42 Geo. III. c. 85 .

(b) See Rex v. Shaue (1816) 5 M. \& S., p. 405. The judgment of Lord Ellenborongh, C.J., that the word "crime" in the Act does not extend to felonies chiefiy on the gromnd that the method of procedure provided by the Act (viz. criminal information exhibited by the attorney-geveral) does not apply to felonies, does not seem entirely satisfactory, seeing that the Act provides for prosecution by information or indictment.

(c) 52 \& 53 Vict. c. 52, s. 6 . 
corrupt communication of information acquired whilst acting in any official capacity under his Majesty is a breach of official trust $(d)$.

Capricious and indiscreet use of their powers by colonial othicers other than governors may also be restrained through the exercise of the power of suspension rested in the governor $(e)$.

With regard, however, to the liability of a governor or any other person to be sued or prosecuted in England for acts done in a colony, the following general proposition applies: "That no act is a wrong in England unless it is also a wrong in the country where it is committed, or if it has been indemnified in that country" $(f)$.

Powers and Duties.-The governor's powers and duties are mainly as follows:-

(1) He pardons or respites criminals, and remits fines or penalties due to the Crown.

(2) Money for the public service is issued under his warrant.

(3) He issues writs for the election of nembers, and convokes, prorogues, and dissolves legislative assemblies.

(4) He appoints absolutely, conditionally, or provisionally to offices in the colony. Where there is a responsible government these appointments are made with the adrice of the Ministry.

(5) In colonies with responsible governments he can suspend or dismiss public servants holding office during pleasure $(g)$. But it is recognized that he acts on the advice of the Ministry. In other colonies his powers of suspension or dismissal are subject to regulations made by the Colonial Secretary.

(6) In colonies with representative governments his consent is necessary to the enactment of colonial laws. The goremor may adopt one of four courses: (1)

(d) $52 \& 53$ Vict. c. 52 , s. 2 .

(e) See Cloete v. Reg. (1854) 8 Moo. P. C. 484.

(f) See Westlake's Privite International Law, 3rd Ed., p. 237.

(g) See Ex parte Robertson (1858) 11 Moo. P. C. 288. 
He may assent; (2) he may withhold his assent altogether; (3) he may assent suspending the operation of the bill until it has been confirmed by the Crown; (4) he may reserve the bill for the Crown's assent. In the case of bills concerning the army, the nary, differential duties, treaties, the royal prerogative, or the rights of subjects not within the colony, he must adopt course (3) or (4).

The Crown may disallow any law to which the governor has affixed his assent within a certain time of the receipt of the bill by the Colonial Secretary from the governor. In Canada $(h)$ and New South Wales (i) the power of disallowance must take place within two years of such receipt.

(7) He issues marriage licences, letters of administration, and grants probates, unless other regulations are made by local law or charter of justice.

Sometimes he presents to benefices of the Church of England in the colony.

(8) It is his duty to repel aggression, and suppress riot, rebellion, or piracy. He makes reports to the home authorities on the condition of the militia and volunteers in the colony.

(9) In colonies without representative governments he generally initiates legislation. In representative colonies he sometimes initiates all appropriation bills.

(10) He administers the Extradition Acts and the Fugitive Offenders Act, which extend to the colonies.

(11) He exercises in the colony the jurisdiction conferred by the Naturalization Act, $1870(k)$, upon a Secretary of State to readmit an alien to British nationality.

(12) He may not leave the colony without permission, or receive or give presents, or act as an agent in forwarding them to the Crown.

(13) He confirms the findings of courts martial when in

(h) $30 \& 31$ Vict. c. 3 , s. 56 .

(i) 5 \& 6 Vict. e. $76, \mathrm{~s}, 32$.

(k) See now British Nationality Act, ante, p. 145 . 
command of the military forces, or in the absence of any superior authority.

He may proclaim any military forces in the colony subject to the Army Act.

(14) He appoints to vacancies in the Vice-Admiralty Court of the colony, and in cases where no vice-admiral has been formally appointed, he is an ex-officio vice-admiral.

Colonial governments, as a rule, are not liable to be sued as a corporation, but the Govermment of New South Wales is liable to be sued in tort (l); so also the Government of the Straits Settlements $(m)$. In New Zealand claims against the Crown are to be made by Petition of Right $(n)$.

\section{The Dominion of Canada.}

The Dominion of Canada was discovered by Sebastian Cabot in 1497. Early in the sixteenth century (1525) the French took possession of the comntry and settled on the St. Lawrence. In 1759 General Wolfe defeated the French at the battle of Quebec, and the country was formally ceded to Great Britain by the Treaty of Paris, 1763. The constitution of the Dominion of Canada depends principally upon the British North America Act of 1867 (o), whieh empowered his Majesty to declare Canada (consisting of the provinces of Ontario or Upper Canada, and Quebec or Lower Canada), Nova Scotia, and New Brunswick one dominion under the name of Canada and provided for the constitution. This Act was brought into force by proclamation of the 22nd of May, 1867. By the British North America Acts of 1871 and $1886(p)$, the dominion parliament was empowered to erect and provide for the constitution of new provinces, and also to provide for the representation of such provinces, or of any territories form-

(l) 39 Vict. No. 38 (N. S. W. Act).

(m) Crown Suits Ordinance Act, 1876. (Laws of the Straits Settlements.)

(n) 35 Vict. No. 49 (New Zealand Act).

(o) $30 \& 31$ Vict. c. 3.

(p) 34 Vict. c. $28 ; 49 \& 50$ Vict. c. 35 ; these with the Act of 1867 may be cited as the British North America Acts, 1806 to 1886 (49 \& 50 Vict. c. 35 , s. 3 ). 
ing part of the dominion but not included in any province, in the Senate and House of Commons. Canada now consists of the following provinces and territories, which are represented in the House of Commons and Senate:-

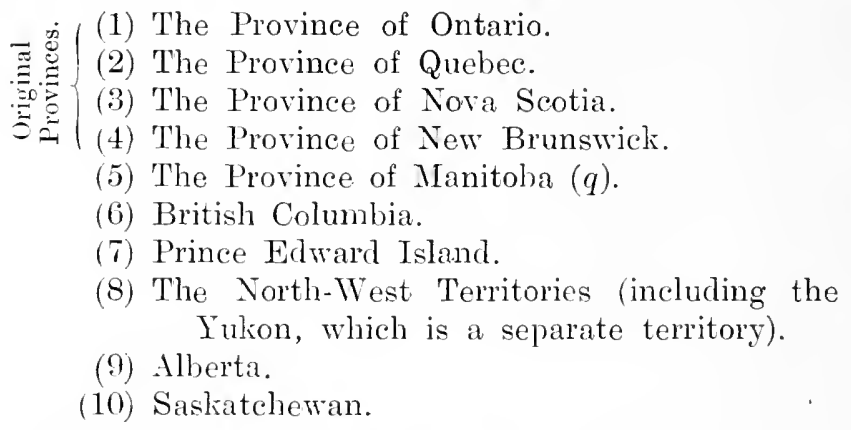

The executive power of the dominion government is vested in the Crown and exercised by a governor-general appointed by the Crown, and a privy council composed of nembers nominated by the governor-general. The governorgeneral acts on the advice of a Cabinet composed of such members of the privy council as are the heads of the principal government departments $(r)$ and enjor the confidence of the Canadian House of Commons. Legislative power is vested in the Crown, as represented by the governorgeneral, and a parliament consisting of an upper house or senate, whose members are nominated by the governorgeneral and sit for life, and a House of Commons composed of members elected by ballot in proportionate numbers for

(q) The various British possessions in North America (except Newfomdland) have been annexed to the Dominion by varions Orders in Council: Rupertsland (out of which tbe province of Manitoba ras erected by the Canadian Act, 33 Vict. c. 3) in 1870, British Columbia in 1871, Prince Edward Island in 1873, and all other British possessions not previously annexed, and which are $10 \mathrm{w}$ included in the North-West Territories and the Iukon in 1880. (See Orders in Council. the 23rd of June, 1870; the 16th of May, 1871: the 26th of June, 1873; the 31st of July, 1880; the 18th of December, 1897.) British Columbia and Prince Edward Island had already their own form of government on joining the Dominion; that for the North-West Territories was provided by the 38 Tict. c. 49 (Canadian); the Yukon was made a separate territory by a Canadian Act of 1898 (61 Tict. c. 6).

(r) Now twelve in number, the Cabinet including one member who is without a portfolio, and a Secretary of State. 
each province according to the population. The representation is readjusted on the taking of the census every ten years, and is arranged in proportion to the new population, but so that Quebec always remains represented by the fixed number of sixty-five members in the House of Commons $(s)$. The House of Commons sits for five years unless sooner dissolved, and the franchise is regulated by the legislatures of the various provinces.

Each province enjoys a responsible government, the executive being vested in a lieutenant-governor appointed by the governor-general and an executive council appointed by the lieutenant-governor, whilst the legislature is composed of the lieutenant-governor and an elected legislative assembly. Tro provinees, Quebec and Nova Scotia, have in addition an upper chamber or legislative council, composed of members elected by the lieutenant-governors in council for life.

The provincial legislatures have the power of altering their own constitutions except with regard to the lieutenantgovernors $(t)$, whilst the dominion constitution can only be altered by Act of the Imperial Parliament.

The dominion legislature has power to legislate on all matters not coming with in the classes of subjects exclusively assigned to the provincial legislatures (the converse is the case in the United States), whilst at the same time certain classes of subjects are exclusively assigned to the dominion legislature $(u)$.

With regard to such matters, therefore, as are not exclusively assigned to either, both the dominion and provincial legislatures have a concurrent power of legislation, subject. to this, that provincial Acts are void so far as they are repugnant to dominion Acts.

Cases of conflict between the dominion and provincial legislatures are settled by the Supreme Court of Camadi, which must interpret the constitution according to the terms of the British North America Act. The dominion judicature consists of the Supreme Court of Canada $(x)$,

(s) Act of 1867 , ss. 51,52 .

(t) 30 \& 31 Vict. c. 3 , s. 92 (1).

(u) $I b$. s. 91 .

(x) Established in 1875 by the 38 Vict. c. 11 (Canadian Act). 
and the Exchequer Court of Canada, which is also a colonial Court of Admiralty.

In the provinces there are superior district and county courts, and from the court of final resort in each, appeal in ciril and criminal cases lies to the Supreme Court of Canada, and there is also a concurrent right of appeal to the Privy Council without going through the Supreme Court $(y)$. But if the appeal is taken to the Supreme Court the decision is to be final, saving, however, any right of appeal which his Majesty may be pleased to exercise by virtue of his royal prerogative $(z)$.

The judges of the Supreme Court are appointed by letters patent under the great seal of Canada $(a)$.

\section{The Commonwealth of Australia.}

The Australian Commonwealth (proclaimed by letters patent of 17th September, 1900) is a federation of six states, namely, New South Wales, Queensland, Victoria, South Australia, Tasmania, and Western Australia. The federal constitution is regulated by the Commonwealth of Australia Constitution Act, 1900 (b).

Under this Act the executive is rested in a governorgeneral appointed by and representing the Crown, and a federal executive council, composed of members chosen by the governor-general $(c)$. The ministers of state, who form the advisory council of the governor-general corresponding to the English Cabinet, were to be seven in number until otherwise directed by the Federal Parliament. They are chosen by the governor-general, and act as the heads of such of the government departments as the Federal Parliament or, in default of that body, as the governor-general

(y) See Whecler's Confederation Lam of Canada, p. 396

(z) 38 Vict. c. 11, s. 47 (Canadian Act), and see ante, p. 426.

(a) $I b$. s. 4 .

(b) 63 \& 64 Vict. c. 12. Power is reserved to the Federal Government by the Act to admit new States.

(c) $I b$. c. 62. This council at present consists of the Prime Minister and Treasurer, the Attorney-General, the Ministers of State for external and home affairs, and for defence, and trade and customs, the Postmaster-General, the Vice-President of the Conncil, and two honorary ninisters. In addition living members of all past ministries may be summoned to attend. 
directs $(d)$. They must be members of the executive council, and of either the Senate or the House of Representatives. In accordance with the English constitutional usage this smaller group of ministers perfom the deliberative and advisory functions of the executive council, the latter body merely meeting to perform formal acts of the executive. Unless otherwise provided by the Federal Parliament all other officers of the executive are appointed by the governorgeneral in council $(e)$.

The legislature is composed of the King (represented by the governor-general) ( $f$ ), an elected Senate, and an elected House of Representatives, whose numbers are louble those of the Senate; the members of both Houses are returned by the various states in proportion to their population $(g)$. Senators are elected for six years, half their number retiring in rotation at the end of three years $(h)$. Nembers of the House of Representatives are elected for three years, unless the House is sooner dissolved by the governor-general (i).

The Parliament of the Commonwealth is given certain exclusive powers of legislation, and it may also legislate on a certain number of matters expressly specified by the Act $(k)$. The state parliaments may legislate on any subject not exclusively assigned to the Commonwealth Parliament, but in case of inconsistency the law of the Commonwealth is to prevail $(l)$. The constitutions and laws in force in each colony are preserved by the Act $(m)$, and the governors are appointed as before, by the Crown and not by the governor-general.

The judicial power of the Commonwealth is rested in a High Court of Australia ( $n$ ), which has jurisdiction to hear appeals from the High Court itself when exereising its original jurisdiction, from the Supreme Court of any State,

(d) $63 \& 64$ Vict. c. 12 , s. 65 .

(e) $I b$, s. 67 .

(f) S. 1 .

(g) Ss. 7, 24.

(h) Ss. 7,13 .

(i) S. 28 .

(k) S. 51,52 .

(l) S. 109 .

(m) Ss. 106, 108 .

(ii) S. 71 . 
and from the Inter-State Commission (o) constituted by the Act to execute and maintain the provisions of the Act relating to trade and commerce $(p)$; the decision of the High Court in such appeals is final, with a saving, however, of his Majesty's prerogative right to grant special leave to appeal to the Privy Council $(q)$, except in certain cases where a certificate from the High Court that the question is a proper one for appeal is required $(r)$.

The High Court has also certain original jurisdiction conferred upon it by the Act $(s)$.

It is noticeable that the right of appeal from the provincial courts to the Privy Council has not been taken away by the Act; it would seem, therefore, that a concurrent right of appeal exists both to the High Court and to the Privy Council.

The constitution can only be altered by an Act passed by an absolute majority in both Houses, or, in case one House refuses to pass it, by an Act passed by an absolute majority in either House for the second time after an interval of three months. In both cases the Act must be referred to the electors in each state, and if approved by a. majority of all the electors, and by the majority of the electors in a majority of the states, it may be presented for the Crown's assent $(t)$. No alteration diminishing the proportionate or minimum representation of, or affecting the provisions of the constitution with regard to any state, can become law unless approved by a majority of the electors in that state $(u)$.

Under the Australian States Constitution Act, $1907(x)$, bills passed by the state legislatures must be reserved for his Majesty's pleasure, which, (1) alter the constitution of the state legislature, or either House of the state legislature; (2) affect the salary of the governor; or (3) are required

(о) S. 73 .

(p) S. 101 .

(q) See ante, p. 426. as to the Crown's right to grant special leave to appeal in such cases.

(r) S. 74.

(s) Ss. 75,76 .

(t) S. 128 .

(u) $I b$.

(x) 7 Ed. VII. c. 7 . 
to be so reserved by Act of the state legislature, or by the bill itself.

Difference between the Australian and Canadian Constitutions.-The ehief features in which the Canadian and Australian constitutions differ are-

(1) In Canada the federal senators are chosen by the governor-general for life, in Australia they are elected by the various states and sit for six years.

(2) Canadian lieutenant-gorernors are appointed by the governor-general in council. In Australia the state governors are appointed by the Cromn.

(3) The Canadian Parliament can legislate on all matters not exelusively assigned to the provincial parliaments. In Australia the powers of the federal legislature are strictly defined, whilst the state parliaments ean legislate on any subjects not exclusively assigned to the Federal Parliament.

(4) The Canadian House of Commons is elected for five years unless sooner dissolved. The Australian House of Representatives for three years.

(5) There are no provisions in the British North America Act enabling the Federal Parliament to alter the constitution, whieh can only be done by Imperial statute. The Australian Parliament can alter the constitution in the manner previously noticed as laid down in the Commonwealth of Australia Act.

(6) The enactments of Canadian provincial legislatures are subject to the veto of the governor-general. Enactments of state legislatures in Australia are subject to the veto of the state governor or of the Crown, but not to that of the govemor-general.

The Former Transwal and Orange Piver Colonies.

The various steps relating to the annexation of conquered colonies and the subsequent settlement of the govermment may be illustrated by a short account of the former Transvaal and Orange River Colonies. A commission under the royal sign manual and signet empowered Field-Marshal Lord Roberts to annex the Transval, constitute himself 
administrator, and make laws. This was accordingly done by Lord Roberts' proclamation of the 1st of September, $1900(y)$.

Letters patent under the Great Seal of the 2 nd of August, 1501 , constituted the offices of governor and commander-inchief, and also of lieutenant-governor, and created executive and legislative councils, composed of members nominated by the Crown or the Secretary of State. These letters patent were subsequently revolied, and a similar form of government provided for the colony by letters patent of the 23rd of September, $1902(z)$. Under these, the government of the Transraal consisted of a governor and commander-in-chief, and a lieutenant-governor, who exercised the powers conferred upon them by the letters patent or their commissions, or by instructions under the royal sign manual and signet, or conveyed through the Secretary of State; an executive council, composed of members appointed by instrictions under the royal sign manual and signet, or conveyed through a principal Secretary of State; and a legislative council, consisting of the lieutenant-governor and members appointed by the Crown in the same manner as members of the executive council. The legislative council was empowered to legislate by ordinance, subject to disallowance by his Majesty, and to constitute courts and officers, and make regulations for the proceedings therein. The lieutenant-governor, with the consent of the governor, appointed judges and other officers.

Power was reserved to his Majesty by letters patent. to legislate for the colony by Order in Council.

Appeal lay from the Supreme Court of the Transvaal to the Priry Council. The successive steps in the formation ot the government of the Orange River Colony were similar to those taken in the case of the Transvaal, and until the union of South Africa under the South Africa Act, 1909, the former possessed a form of government similar to that of the latter.

Responsible govermments were subsequently granted to

(y) St. R. \& O. 1901, p. 540.

(z) St. R. \& O. 1902 , p. 614. These letters patent were proclaimed in the colony the 29 th of September, 1902. 
both colonies by letters patent in 1906 and 1907 respectively (a), the legislatures being composed of a legislative council nominated by the governor, and an elected legislative assembly in both colonies. They are now provinces of the Union of South Africa, with local legislatures formed under the South Africa Act, 1909, as stated in the next paragraph.

\section{The Union of South Africa.}

By proclamation issued by the Crown on the advice of the Privy Council under the authority of the South Africa Act, 1909 (b), the former colonies of the Cape of Good Hope, Natal, and the Transvaal and Orange River Colonies, were united in a legislative union under one government, bearing the name of the Union of South Africa, the four original provinces of the Union being the above four colonies under the names of the Cape of Good Hope, Natal, Transvaal, and Orange Free State respectively.

Power was reserved to the Crown by the Act to admit into the Union by Order in Council on an address by both Houses of the Union Parliament territories administered by the British South Africa Company, and to transfer to the Union on similar addresses the government of any territories inhabited wholly or in part by natives belonging to or under the protection of the Crown.

The executive government is rested under the Act in a governor-general appointed by the Crown, assisted by an executive council chosen and summoned by the governorgeneral and holding office during his pleasure. Not more than ten ministers of state, who must be members of either of the legislative Houses, are also appointed by the governorgeneral to administer the departments of state.

The legislative power is vested by the Act in a Senate and a House of Assembly. For ten years after the commencement of the Union the senate was to be composed of eight senators nominated by the governor-general, and eight senators for each original province, selected by the

(a) See the letters patent of 6th Decenber, 1906, and 5th June, 1907, respectively.

(b) 9 Ed. VII. c. 9

C.L.E. 
legislatures of the former colonies respectively, and holding office for ten years. The Union Parliament has power to provide for the constitution of the senate after the expiration of the first ten years; but if no provision is so made, eight senators are to continue to be nominated by the governor-general, and eight senators are to be elected for each province by the respective provincial councils and the nembers of the Union House of Assembly for the province sitting together. The senate chooses a president from amongst its own members.

The House of Assembly is composed of a fixed number of members for each province (subject to the provisions of the Act as to increase in their numbers) elected by the rotes of the Union in the various electoral divisions.

The Provincial Governments are composed of an administrator appointed by the governor-general, and holding office for five years, and a Council composed of the same number of members as represent the province in the Union House of Assembly, but not less than twenty-five in any province. The Provincial Councils are elected for three years, and can only be dissolved by effluxion of time. They are presided over by a chairman chosen by the council. An executive committee of four members elected by the provincial council forms, with the administrator as chairman, the executive committee for the province.

The Union Parliament possesses unlimited powers of legislation for the peace, order, and good government of the Union. The provincial councils have limited power to make ordinances: (1) with regard to certain subjects specified by the Act; (2) on all matters which in the opinion of the governor-general in council are of a purely local or private nature; (3) on all other subjects which the Union Parliament may delegate to them.

Provincial ordinances have effect only in so far as they are not repugnant to Acts of the Union Parliament.

The governor-general fixes the times for sessions of the Union Parliament, prorogues Parliament, and may dissolve both Houses simultaneously, or the House of Assembly alone. The dissolution of the senate does not affect the eight senators nominated by the governor-general. 
The governor-general may assent to bills of the Union Parliament, or withhold his assent, or reserve the bill for the eonsideration of the Crown. On eertain specified matters bills must be so reserved. On any bill so reserved the Crown may withhold assent; it may also disallow any law whieh has been enacted by the Union Parliament, within one year.

The appointment and removal of officers of the public service is vested in the governor-general; together with the command of the naval and military forees of the Union as representing the King.

The Union judiciary consists of the Supreme Court of South Africa, with an appellate division; the Supreme Courts in the former colonies beeoming divisions of the Supreme Court of South Africa. Appeal to the Privy Council in England does not lie from any division of the Supreme Court. But nothing in the Act is to impair the right of the Crown to grant special leave to appeal from the appellate division of the Supreme Court to the Privy Council.

The English and Duteh languages are both official languages of the Union, and on a footing of equality. Free trade is also to prevail throughout the Union. But until otherwise provided by the Union Parliament, the duties and customs of the former eolonies are to be levied in the various provinces. 
Chapter III.

\section{THE INDIAN EMPIRE.}

Legally, the expression India means " British India", (a), together with any territories of any native prince or chief under the suzerainty of his Majesty exercised through the Governor-General of India or any officer subordinate to him $"(b)$.

History of British Sovereignty.-The history of British sovereignty in India is briefly as follows:- In the year 1600 Elizabeth granted a charter to the merchants trading to the East Indies, by which they were incorporated as the "Governor and Company of Merchants Trading to the East Indies," and were to enjoy certain trading privileges to the exclusion of all other persons. In 1694 the House of Commons passed a resolution to the effect that " all subjects of England have equal rights to trade to the East Indies unless prohibited by Act of Parliament" $(c)$. The exclusive right of trading was, however, placed upon a statutory basis in $1698(d)$, and under the Act of that year and subsequent Acts successive charters continued to be granted to the Company $(c)$.

(a) British India means "all territories within his Majesty"s dominions governed by his Majesty through the Governor-General of India or any officer subordinate to lim." (Interpretation Act, 1889, s. 18 (4).)

(b) $I b$. s. 18 (5).

(c) 5 Parl. Hist. 828. The right of the Crown to grant exclusive trading privileges had previously come before the courts in 1689 , in the case of the East India Company v. Sandys, known as the great case of Monopolies, (1685) 10 St. Tri. 371, and held good by the judges.

(d) $9 \& 10$ Will. III. c, 44.

(e) From 1707 to 1833 the Company bore the name of "The United Company of Merchants trading to the East Indies." In the latter year the name was changed to "The East India Company" by the 3 \& 4 Will. IV. c. 85 , s. 111. 
In the year 1813 Indian trade, except that with China and the trade in tea, was thrown open to the public $(f)$, and in 1833 the Company was forbidden by statute to transact commercial business of any kind $(g)$. The government of India, however, lemained in the hands of the Company, the office of governor-general and the governorgeneral's council being constituted in 1773 , whilst the home ntanagement was carried on by a court of directors and a board of control.

In 1853 the Indian Civil Service was thrown open to competition, and in 1858 (the year after the Mutiny) the Crown assumed the government of the country by an Act for the better government of India passed in that year $(h)$. In 1861 an Act was passed enabling the Crown to erect new high courts for the various provinees, to take the place of the old supreme and sudder courts (i), and in 1876 the title of "Empress of India" was assumed by Queen Victoria under statutory authority $(k)$.

Present Constitution.--India is now governed by the Crown, acting on the advice of the Secretary of State for India in Council, the functions of the Secretary of State and the constitution and functions of his council (styled the Council of India) being regulated principally by the Government of India Act, 1915. In India the Crown is represented by a governor-general or viceroy, acting with an executive and legislative council, whose composition and functions are regulated chiefly by the Government of India Acts of 1915, 1916, and 1919 .

The Indian constitution comes nearer to that of a Crown colony than to that of any of our other dependeneies. It differs, however, from a Crown colony in this, that the Crown acts upon the advice of the Secretary of State for India in Council, and not upon the arlvice of the Secretary of State alone. The government of India may also be said to be a paternal as opposed to a representutive government.

(f) 53 Geo. III. c. 155, ss. 2, 3.

(g) 3 \& 4 Will. IV. c. 85 , ss. $3,4$.

(h) $21 \& 22$ Vict. c. 106.

(i) $24 \& 25$ Vict. c. 124.

(k) 39 Vict. c. 10 . 
Whether, as is the tendency with other Crown colonies, India will in time attain to full representative institutions is a problem which can only be solved by time. It is safe to say, however, that such a system, if it comes at all, can only be arrived at by very gradual steps and after the lapse of many years. It is significant that the Government of India Act, 1915 , s. 41, provides for the appointment in ten years' time of a commission to report on the desirability of establishing responsible government in India.

The Secretary of State for India.-The Secretary of State for India is a Cabinet minister, and comes into and goes out of office with the Ministry for the time being. $\mathrm{He}$ acts with the advice of the Council of India in all matters except those which require urgency or secrecy $(l)$, but at meetings of the council when the Secretary of State is present, in the event of a difference of opinion his decision is final $(m)$. No expenditure, however, of the revenues of India is legal without the consent of the Secretary of State and a majority of his council $(n)$. The Secretary of State in Council as representing the Crown may impose what commands he pleases upon the Governor-General in Council. He also makes rules and regulations for the admission of candidates for the Indian Civil Service, who when duly qualified are appointed and promoted by him (o).

All other appointments, naval and military, and all admissions to service not otherwise provided for, are vested in his Majesty (pi).

The Council of India.- The Council of India consists of not less than eight, or more than twelve members (as the Secretary of State directs) $(q)$, in addition to the Secretary of State, who acts as president $(r)$. They are nominated by the Secretary of State, and at least half of their number

(l) $5 \& 6$ Geo. V. c. 61 , ss. 12, 13.

(m) $I b$. s. 9 .

(n) $I b, \mathrm{~s} .21$.

(o) Ib. ss. 33, 97 .

(p) Ib. s. 33 .

(q) Ib. s. $3 ; 9$ \& 10 Geo. V. c. 101, s. 31.

(r) $5 \& 6$ Geo. V. c. 61 , s. 7. 
must have resided in India for at least ten years, and not left India for more than five years. Formerly they were appointed for life, and held office during good behaviour; now the term of office is five years, which may be extended for a further term of five years for special reasons of public advantage $(s)$.

The Governor-General in Council.-In India the governor-general, or viceroy, is appointed by the Crown under the sign manual ( $t$ ) on the advice of the Prime Minister, and usually holds office for five years. The superintendence, direction, and control of the civil and military government and $\mathrm{r} \in \mathrm{venues}$ is rested in the Governor-General in Council $(u)$, and the governor-general's council exercises both legislative and executive functions. The members of the executive council of the governor-general are appointed by his Majesty by warrant under the royal sign manual (y). The term of office for ordinary members of the council is by custom five years. The council meets and discusses matters of public policy as the Cabinet does in England, to perform formal executive acts, and to prepare measures for enactment by the legislative council. The viceroy acts as president, thus combining in great measure the functions of the constitutional monarch and prime minister in England. He can make rules and regulations for the conduct of business $(z)$, and his assent is necessary before any measure passed subsequently by the legislative council can become law $(a)$. In cases where the safety, tranquillity, or interest of the British possessions in India is concerned, the viceroy can act in opposition to his council $(b)$.

Indian Departments. - The administration is carried on in India by various departments, each of which is controlled by a permanent secretary under the supervision of one of

(s) 5 \& 6 Geo. V. c. 61 , s. $3 ; 9 \& 10$ Geo. V. c. 101, s. 31.

(t) 5 \& 6 Geo. V. c. 61, s. 34.

(u) $I b$. s. 33.

(y) $\mathrm{Ib}$. s. 36 .

(z) Ib. s. 40 .

(a) $I b$. s. 68

(b) Ib. s. 41 . 
the members of the viceroy's executive council, the viceroy himself supervising the conduct of foreign affairs. The principal of these departments are-

Foreign affairs,

Home affairs,

Army,

Legislative,

Finance,

Revenue and Agriculture,

Public Works,

Commerce and Industry.

The Indian Legislature.-This body consists of the governor-general and two chambers, namely, the Council of State and the Legislative Assembly (c). The Council of State consists of sixty members, of whom not more than twenty shall be official nembers, and the rest are elected; it continues for five rears $(d)$. The Legislative Asscmbly consists of 140 members, the number of non-elected nembers being forty, of whom twenty-six are official members; it continues three years (c). Either chamber may be dissclved or its sessions prorogued by the governor-general $(f)$. The power of the Indian Legislature to enact laws is subject to certain restrictions and it is not lawful without the pre. vious sanction of the governor-general to introduce into either chamber any measure relating to revenue, religion, discipline, foreign policy, and some other matters $(g)$.

When a law or regulation has been passed by the council three courses are open to the governor-general: (1) He may assent, when the enactment becomes law; (2) he may refuse his assent, when the measure is lost; (3) he may reserve his assent for the signification of his Majesty's pleasure thereon, in which case the meastire does not become law until his Majesty's assent has been signified $(h)$. The Indian Legislature can make laws and regulations

(c) \& 10 Geo. Y. c. 101, s. 17 .

(d) 16 . ss. $18,21$.

(e) $I b$. ss. 19,21 .

(f) Ib. s. 21 .

(g) $I b$. s. 27 .

(il) 5 \& 6 Geo. V. c. (i1, s. 68 . 
for the whole of British India, for all British subjects and servants of his Majesty resident in other parts of India, and for all Indian subjects of his Majesty without and beyond as well as within Indian territory (i). But the powers of the Indian Legislature "are limited by the Act which ereated it, and it can do nothing beyond the limits which circumscribe these power's. When acting, however, within these limits its powers are plenary and as large as those of Parliament itself " $(k)$. His Majesty in Council may in all cases signify his disallowance of any such Act $(l)$.

Local Governments in India.-British India is divided into fifteen local governments subordinate to the central government of the Governor-General in Council.

The presidencies of Fort William in Bengal, Fort St. George and Bombay and the provinces linown as the United Provinces, the Punjab, Bihar and Orissa, the Central Provinces and Assam are governed by a governor in comeil $(\mathrm{m})$. The governor and the members of the gorernor's executive council are appointed by the Crown (n). There is a legislative council in every governor's province, which consists of the members of the executive comcil and of members nominated or elected, not more than twenty per cent. being official members and at least seventy per cent being elected members (o). Every governor's legislative council continnes for three years hut may be dissolved sooner by the gorernor $(p)$. The local legislature of any province may make laws for the good government of the province, but it may not without the previous sanction of the governorgeneral make or take into consideration any law relating to the public debt and taxes, discipline, foreign policy, \&c. $(q)$.

Each of the provinces known as the Nortl-West Frontier Prorince, British Baluchistan, Delhi, Ajmere-Merwara,

(i) 5 \& 6 Geo. V. c. 61, s. 65 .

(b) See Req. v. Burah (1878) 3 App. Cas. 889.

(l) 5 \& 6 Geo. V. c. 61 , s. 69.

(m) $9 \& 10$ Geo. V. c. 101, s. 3.

(n) 5 \& 6 Geo. V. c. 61, ss. 46, 47.

(o) $9 \& 10$ Geo. V. c. 101, s. 7.

(p) $I b$. s. 8 .

(q) $I b$. s. 10 . 
Coorg, and the Andaman and Nicobar Islands is administered by a chief commissioner $(r)$.

The Judiciary and Indian Laws.-In Madras, Bombay, Bengal, Bihar and Orissa, the Punjab, and the united provinces of Agra and Oudh, high courts of justice, presided over by a chief justice and puisne judges, have been erected by letters patent under statutory authority $(s)$; these courts now take the place of the old Supreme and Sudder Courts. The Punjab and Lower Burma have chief courts presided over by a chief judge and judges. In the remaining provinces the highest court is that of the judicial commissioner, or, where no such person is appointed, of the chief commissioner.

Appeal in civil and criminal matters lies to these courts from the district courts, and the decision of the High Court is final, except where appeal lies to the Judicial Committee of the Privy Council, the conditions of appeal being regulated by the charters or letters patent by which the courts were erected $(t)$.

In every province there are also divisions with a sessions judge, and divisions are divided into districts with district and subordinate magistrates. These sessions judges (usually appointed from members of the Indian Civil Service) and the subordinate magistrates administer the criminal law, but sentences of death must be confirmed by the High Court. The civil inferior courts are presided over by district judges (usually the same as the sessions judge), subordinate judges, and munifs. The law administered by these courts consists of -

(1) Imperial Acts extending to India (u), and rules and orders made thereunder.

(2) Acts of the Governor-General in Council $(x)$, and rules, regulations, and orders made thereunder, and ordinances made by the governor-general $(y)$.

(r) 5 \& 6 Geo. V. e. 61 , s. 58.

(s) As to the constitution and jurisdiction of these Courts see 5 \& 6 Geo. V. c. 61, ss. 101-114.

( $t$ ) And, as to civil cases, also by the code of civil procedure, ss. 594,616 .

(u) Either expressly or by necessary implication.

(x) Under the $3 \& 4$ Will. IV. c. 85 and subsequent Acts.

(y) Under the 24 \& 25 Vict. c. 67, s. 23. 
(3) Acts passed by the local legislatures of the various presidencies, and provinces under licutenantgovernors $(z)$, and rules and regulations made thereunder.

(4) Certain regulations made by the governments of Bombay, Madras, and Bengal, before 1833 (a).

(5) Rules and regulations made by the governor-general under statutory authority. Orders in Council extending to India.

(6) The Hindu and Mohammedan law, and the customary law of particular castes or races, in causes between natives relating to family matters or inheritance, and so far as it has not been superseded by legislation $(b)$.

The Indian Civil Seryice.-The civil administration of India is carried on for the most part by members of the Indian Civil Service. This service was thrown open to competition amongst natural-born British subjects in 1853, and by the Act of 1915 all offices referred to in that Act are reserved for its members (c).

Certain judicial, ecclesiastical, and educational appointments are in the hands of the Secretary of State, and the various local governments nominate persons to fill the offices in their various government departments.

Members of the Indian Civil Service consist of the successful candidates (who must be subjects of his Majesty) at an open competitive examination held once in each year under regulations made by the Secretary of State in Council. Successful candidates have further to undergo a probationary period of one year and pass a final examinatiou, and if successful in this they are finally appointed by the Secretary of State.

In addition, natives of India of proved merit or ability may be appointed to any office or place in the Civil Service

(z) Under the authority of the Indian Conncils Act, 1861 (24 \& 25 Vict. c. 67).

(a) See the Madras, Bombay, and Bengal codes respectively.

(b) Indian native criminal law has been entirely superseded by legislative enactments.

(c) 5 \& 6 Geo. T. c. 61 , s. $98 ; 9$ \& 10 Geo. T. c. 101, 2nd Sch. 
without undergoing any preliminary qualification under the Act of $1915(d)$.

Throughout India the unit of civil administration is the district presided over by a collector magistrate or deputy commissioner, who performs both administrative and judicial functions. Districts are split up into sub-districts, and the districts themselves are grouped in divisions (e) under a commissioner.

Dependent Native States.-In addition to British India proper, there are also some 600 dependent native states $(f)$ under the suzerainty of Great Britain, and these occupy a somewhat anomalous position. The jurisdiction exercised by the Crown over these states depends primarily upon usage or treaties made with the various chiefs or native governments, and its exercise is regulated by an Act of the Governor-General in Council $(g)$. The territory of these native states is not British territory, nor are they, strictly speaking, British protectorates, though they are such for some purposes $(h)$. The extent of control exercised by the Crown varies in different states. In all cases, however, Great Britain controls the foreign relations of the native state, assumes responsibility for its internal peace and the welfare of British subjects within its borders, and requires its co-operation in repelling foreign aggression. In no case can the native state declare peace or war, or maintain diplomatic relations with other states or foreign countries.

Though primarily the jurisdiction of the Crown over the feudatory native states depends upon treaty or agreement, in practice the Crown claims and exercises a much larger

(d) 5 \& 6 Geo. V. c. 61 , s. 99 .

(e) Except in Madras.

(f) These vary greatly in size, only some 200 being of any great importance. The Nyzam of Hyderabad (the premier state in India) rules over a territory comprising some 82.000 square miles and containing a population of over 11 millions. The territories of some of the smaller chiefs comprise only a few acres.

(g) The Foreign Jurisdiction and Extradition Act, 1879, No. xxi. of 1879 .

(h) By the Foreign Jurisdiction Act, 1890, "where in future an Order in Council is made extending to persons enjoying his Majesty"s protection, all subjects of the several princes and states in India are to be included in that expression." 
measure of control where the interests of the Empire or of the subjects of the native princes are concerned (i). In cases of flagrant misgovernment the Crown even goes so far as to suspend temporarily, or actually to depose, the native rulers, and within the last half-century at least six native chiefs have been dethroned. In most native states, however, the management of internal affairs, including taxation and the administration of justice, is left in the hands of the native govermment with the help and advice of a British political resident agent.

British Indian law does not run into such states, but they are strictly limited as to the number of troops they are allowed to maintain, and no European is allowed to reside at their courts without a special permit from the British Government.

Outlying States.-Three outlying states come within the sphere of British influence, but cannot be said to be dependent states. These are-Nepal, Bhutan, and Afghanistan. They enjoy complete internal independence, but a resident British political agent represents Great Britain in Nepal and Afghanistan, and looks after her political interests in matters of foreign policy. Nepal and Bhutan have political relations with China; but with no other country except India, whilst the Amir of Afghanistan is bound by agreement not to maintain foreign relations with any power except India.

(i) See Hall, Foreign Jurisdiction, p. 206, n. 
Chapter IV.

PROTECTORATES AND MISCELLANEOUS POSSESSIONS.

\section{British Protectorates.}

Nature of British Protectorates.-Protectorates differ from colories in that they do not form an integral portion of the territory of the protecting state $(a)$. The amount of control exercised by various states over the internal administration of their protectorates has varied greatly, Germany (b), France, and other European nations claiming and exercising a much greater measure of control than Great Britain. Both foreign and British protectorates, however, have these points in common :-

(1) Internationally, they act as a barrier in farour of the protecting state, against conquest or occupation by or cession to any other state $(c)$.

(2) In all cases the protecting state assumes external sovereignty over the protected territory; that is to say, its foreign relations are controlled by the protecting state, and no other state can maintain diplomatic or political communication with it except through the medium of the protecting state.

(3) International law is not concerned with the relations between the protecting and the protected states. except in so far as other foreign states are concerned to see that the former carries out the obligations with regard to themselves which it has imposed upon itself by assuming the protectorate $(d)$. The

(a) Hall, International Law, p. 130.

(b) German protectorates would seem to have been protectorates in name only, and their administration based on the unrestricted sovereignty of the emperor as fully as in actual German colonies. (Ib. 134, n.)

(c) See Hall. International Law, p. 130.

(d) Hall, International Law, p. 131. 
minimum of obligations thus imposed are those which flow as a necessary consequence from the fact that other foreign states are debarred from all direct external diplomatic and political communication with the protected state. The protecting state would therefore in all cases be bound to interfere, at least so far in the internal administration of the protected territory as to ensure adequate protection to the rights of foreigners against the attacks of its own or protected subjects, as well as to the rights of its own and protected subjects against the attacks of foreigners.

(4) Protectorates assumed by European powers over barbarous tribes may generally be considered as a preliminary step to the exercise of complete internal and external sovereignty consequent on annexation $(e)$.

Such seem to be the principal characteristics common to all protectorates, British and foreign, but the powers of internal administration assumed by the protecting state differ amongst various European states, and in British protectorates themselves.

Generally speaking, other European nations claim and exercise within their protectorates an unlimited jurisdiction in civil and criminal matters over both protected subjects and foreigners. But the English standpoint seems to fall far short of tlisis, the ordinary course adopted being to make the consent of the foreigner and also the consent of his Government necessary before a suit can be brought against him in the Protectorate Court $(f)$.

Since the Brussels Conference of 1840, however, the view held by other European nations seems to have been adopted by England also, at least with regard to her African

(e) E.g. the annexation of Bechuanaland to Cape Colony, and Zuhuland to Natal. The influence of the Sultan is rapidly diminishing in the protectorate of Brunei, and that territory will no doubt be completely absorbed by England in course of time.

(f) This is so in the case of Brunei, Zanzibar, Sarawak, and North Borneo. This principle seems to have been based on the theory that the authority exercised by Great Britain is a delegated one only; and that the chief of barbarous tribes, having no jurisdiction over subjects of foreign nations, could not delegate such an authority to Great Britain. 
protectorates $(g)$. The jurisdiction exercised by the Crown in Protectorates depends primarily upon agreement or treaty with the native ruler or chief, or in cases where there is no responsible Government to grant jurisdiction, it has been assumed by the Crown either with or withont opposition on the part of the native population in order to afford protection to British commercial or political interests. Subject, however, to the respect which is shown to agreements or treaties with native rulers or chartered companies, the Crow may by prerogative impose legislation on, or establish its jurisdiction over, protectorates. This right, as well in foreign countries generally as in protectorates, has been placed on a statutory basis by various Foreign Jurisdiction Acts, now consolidated in the Foreign Jurisdiction Act, 1890 (h), which enacts that "whereas by treaty, capitulation, grant, usage, sufferance, and other lawful means, his Majesty has jurisdiction within divers foreign countries, ... it is and shall be lawful for his Majesty to hold and enjoy any jurisdiction which his Majesty now has, or may at any time hereafter have within a foreign country, in the same and as ample a manner as if his Majesty had acquired that jurisdiction by the cession or conquest of territory", (i).

In protectorates this jurisdiction is generally exercised by administrators, consuls, British agents, or resident connmissioners, and is regulated by Order in Council.

(g) At the Berlin Conference of 1884-5. England did not acquiesce in this view; but by assenting to the General Act of the Brussels Conference of 1890 , which had regard in particular to the measures to be adopted in African protectorates, she seems to have shifted her ground, at least so far as Africa is concerned. Accordingly jurisdiction over foreigners is claimed and exercised in various British protectorates in Africa. (See Hall, Foreign Jurisdiction, p. 210 et seq., and Hall, International Law, p. 131, n.)

(h) $53 \& 54$ Vict. c. 37.

(i) Ib. s, 1. By s. 2, where a foreign country is not subject to any government from whom his Majesty might obtain jurisdiction in the manner recited, his Majesty is to have jurisdiction over his Majesty's subjects for the time being resident in or resorting to that country. Objection has been taken to this limitation of the Crown's jurisdiction to his Majesty"s subjects on the ground that it might be open to a foreign subject to plead this section in support of a plea of want of jurisdiction (see Hall, Foreign Jurisdiction, p. 221 et seq.); but since other European nations claim and exereise jurisdiction over British subjects within their protectorates, they could not plead international law in support of such a contention. 
Status of Protected Subjects.-An important question arises as to the status of Britisl protected subjocts when in foreign countries. That they are not British subjects is clear, and in this they are in an inferior position to the protected subjects of other European nations, who are regarded for the most part by their respective Governments as subjects proper. Though not subjects in the full sense of the word, however, they are entitled to diplomatic protection when in foreign countries, and in foreign comtries with independent Governments in which his Majesty's jurisdiction has been established by Order in Council $(k)$ they are virtually in the same position as British subjects, being exempt from local laws (l). And with regard to the subjects of the various states in India which are in alliance with his Majesty, it is provided by the Foreign Jurisdiction Act, 1890 , that they shall be included amongst persons enjoying his Majesty's protection so as to come within the operation of any Order in Council extending to that class of persons $(m)$.

Classification of Protectorates.-The extent of interference by the Crown in matters of internal administration, or, in other words, the powers of internal sovereignty exercised by the Crown, forms a basis on which the various British protectorates may be classified, it being understood that in all cases the Crown controls foreign relations and exercises certain judicial jurisdiction over natives and British subjects, either by means of regularly established high courts of justice or by consular courts. The classification will then depend mainly on the amount of interference with internal legislation.

From this point of view British protectorates may be classed in three broad groups.

Group I. comprises those protectorates in which the amount of control exercised by the Crown is very nearly equivalent to that exercised in Crown colonies proper. Such

(k) E.g. Persia, Siam; the Persian coasts and islands.

(l) See Hall, Foreign Jurisdiction, p. 128.

(m) $53 \& 54$ Vict. c. 37 , s. 15 . For an example of such an order see the British Protectorates Neutrality Order in Council, 24th of October, 1904. (St. R. \& O. 1904, Nos. 1653, 1716.) 
protectorates differ from Crown colonies in little more than name, and apart from the fact that they have not been formally annexed and do not form a portion of British territory, and that the control exercised depends not upon conquest, cession, or settlement, but upon agreement with native rulers or chartered companies, or has been assumed without definite treaty or agreement, there is little to distinguish them from the latter.

The internal administration is regulated by Order in Council, and is entrusted either to the governor of some adjacent colony $(n)$, or to a governor and commander-in-chief, administrator, commissioner, consul-general, or resident appointed specially for the protectorate, who takes the place of a governor in a Crown colony, and whose powers are similar to those of the latter. Either alone, or with the assistance of his executive and legislative councils in cases where these have been constituted, he legislates by proclamation or ordinance, appoints and suspends public officers, judges, and magistrates, the approval of a Secretary of State being sometimes required, and is assisted in some cases (as in East Africa and Nyasaland (o)), by executive and legislative councils nominated by the Crown by instructions under the sign manual and signet, or through the Secretary of State. As in the case of Crown colonies, the Crown reserves the right of veto and in some cases of legislating by Order in Council. The judicial system also is regulated by Order in Council or local ordinance, high courts of justice being established and lower tribunals under local magistrates. Appeal lies in some cases to the supreme court of some adjacent colony, or protectorate, and thence to his Majesty in Council; in other cases to his Majesty in Council direct. In some of the African protectorates jurisdiction, both civil and criminal, is specifically assumed by

(n) E.g. the Southern Nigeria Protectorate (see Order in Council, 16th Feb., 1906) now amalgamated with the Northern Nigeria Protectorate under the name of the Nigeria Protectorate, of which the administration is entrusted to the governor and legislative council of the colony of Southern Nigeria. Similar powers are exercised by the governur and legislative council of the colony of Sierra Leone for the Sierra Leone Protectorate. (See Order in Council, 7th March, 1913.)

(o) See the East Africa Order in Council. 22nd October, 1906; and the Nyasaland Order in Council, 6th July, 1907. 
the Order in Council over all persons within the limits of the order, whether British subjects, natives, or foreigners $(p)$. In others, whilst jurisdiction is assumed over British subjects and natives, the extent of the jurisdiction over foreigners has been left undetermined by the order $(q)$.

Nine protectorates may be placed in this group, some of which (e.g. East Africa, Somaliland, Nyasaland) were formelly under the Foreign Office; they are now controlled by the Colonial Office.

These Protectorates are-

Nigeria (the former protectorates of Northern and South Nigeria having been amalgamated) ( $r$ ),

The Western Pacific (including the New Hebrides, and Banks and Torres Islands) ( $s$,

Swaziland.

Kenya,

Somaliland,

Uganda,

Nyasaland (formerly British Central Africa) ( $t$ ),

Territories adjacent to Nigeria,

," , , $\quad$ Gambia, $\quad(u)$

The Northern Territories of the Gold Coast $(x)$.

Group II. comprises two protectorates, which occupy an intermediate position between Group. I. (where full control

$(p)$ This is the case in the East Africa protectorate, Somaliland, and Uganda. (For the various Orders in Council see the Statutory Rules and Orders.)

(q) This is the ease in Nigeria and Nyasaland.

( $r$ ) By Order in Council of 22nd November, 1913.

(s) See Order in Council, 1907.

( $t$ ) See the Nyasaland Order in Couricsl, 6th July, 1907, by which the name of the British Central Africa Frotectorate was changed to Nyasaland, and a governor and commander-in-chief appointed with executive and legislative councils.

$(u)$ These territories are governed rather as though they formed part of the adjacent colonies than as protectorates proper, the Legislative Councils of the Nigeria, Gambia, and Sierra Leone colonies respectively having the power of legislating by ordinance subject to the veto of the governor or the Crown. See the Gambia Order in Council, 1893 (St. R. \& O. 1903, p. 311), and the Sierra Leene Order in Council, 1913.

$(x)$ The governor of the Gold Coast Colony exercises the jurishiction of his Majesty; appoints a resident conmissioner, judges, etc.; and legislates by proclamation subject to disal.ow:ance by his Majesty in Council or through a Secretary of State. 
of the legislative and judiciary is assumed by the Crown) and Group III. (where the internal administration is left almost entirely in the hands of the existing Government). These are-

Southern Rhodesia,

Northern Phodesia (Barotziland and North-Eastern Phodesia having been amalgamated).

In these the internal administration is left largely in the hands of the British South Africa Company (y), but in reality is controlled by the Crown, either through the Secretary of State or the High Commissioner for South Africa.

In both protectorates an administrator, appointed by the Company with the approval of the Secretary of State, administers the government, and there is also a resident commissioner appointed by the Secretary of State. The administrator acts with the advice of an executive council composed of the administrator as president (who has a casting rote) with the resident commissioner (who may be present and speak but may not vote), and not less than three members appointed by the Chartered Company with the approval of the Secretary of State. In Northern Phodesia the senior judge is also an $e x$ officio member.

In Southern Rhodesia there is a legislative council composed of the administrator with the resident commissioner and six members nominated by the Company, and twelve elected members. Ordinances made by the administrator and legislative council are subject to the veto of the High Commissioner for South Africa.

In Northern Rhodesia the High Commissioner for South Africa legislates by proclamation after consulting the administrator.

In both protectorates ordinances or proclamations affecting revenue matters, or certain rights of the Chartered Company, require the previous approval of the latter.

High Courts of Justice have been established by Order in Council in both protectorates, from which appeal lies to his Majesty in Council (z).

(y) Incorporated by charter, 29th of October, 1889. A supplemental charter mas issued on March 13, 1915.

(z) See the Southern Rhodesia Orders in Council, 1898, 1903, 1904, 
Group III. comprises five protectorates-
Zanzibar,
Sarawak (a),
Brunei,
North Borneo,

The Federated Malay States.

In these the internal administrations left almost entirely in the hands of the native government, or, in the case of North Borneo, in the hands of the British North Borneo Chartered Company, internal independence having been secured to them by the terms of the treaty or agreement by which the protectorate is constituted.

The Crown, however, exercises the right of constituting consular courts with jurisdiction over British subjects, and over natives to a limited extent. In Zanzibar and Brunei, as to suits in which foreigners are concerned, the consent of the foreigner, and of the authority representing his Government, to the jurisdiction must first be filed (b).

In the case of the Federated Malay States (comprising Perak, Selangor, Negri Sembilan and Pahang, a. British resident general, styled "chief secretary" (under the governor of the Straits Settlements, who is also high commissioner) together with residents in each state are appointed under an agreement made with the rarious states in 1895 , under which each state retains its own native government, the British resident. however, controlling the foreign relations of the state, and exercising jurisdiction over British subjects, for which purposes a supreme court and court of appeal, together with inferior magistrates' courts are constituted.

By a treaty, concluded in 1909, the Siamese Government transferred to Great Britain all its rights of suzerainty, pro-

10th August, 1909, and 4th May, 1911. As to Northern Rhodesia, the Northern Rhodesia Orders in Council, 4th May, 1911; 11 February, 1913.

(a) The history of Sarawak is interesting. The government was granted to Sir James Brooke (known as Rajah Brooke) by the Sultan of Brumei in 1842, and further concessions of territory were made in 1861. 1882, 1885, and 1890. An agreement was made with Rajah Brooke in 1888, by which Sarawak became a British protcctorate, his Majesty's Government having power to settle questions relating to succession, and the right to establish consular agencies and control foreign relations, but no power to interfere in the internal administration. The present "Rajah" is Sir Charles Vyner Brooke.

(b) See the Zanzibar Orders in Council, 1897 and 1903, and the Brunei Order in Council, 1901. 
tection, and control over the States of Kelantan, Trenganu, Kedah and Perlis, with the islands adjacent, lying to the north and north-east of the Federated Malay States, the latter assuming the indebtedness of the transferred states to Siam.

The control of foreign relations in Johore (one of the Malay States) was handed over to Great Britain in 1885, by the Sultan of Johore, the latter also agreeing to receive a. British agent.

\section{Splieres of Influence.}

European states frequently come to mutual understandings to respect certain territories as being within the "sphere of influence" of some particular state. When such an understanding has been arrived at the particular state is recognized to possess the moral right to exclude other states from interference in the territory in question, and this right is based upon the recognition by other states that the territory is important to the particular state for purposes of future expansion from adjacent colonies or protectorates, or as being strategically valuable.

When such an understanding has been arrived at, the particular state does not assume any definite responsibility with regard to the administration of the territory, which is left in the hands of the native rulers, but merely exercises a general restraining and directing force in the encouragement of commerce and security for traders.

The influence exerted by particular states in such territories prepares the way for the acceptance of that fuller control which is exercised in protectorates, and spheres of influence may be said to merge into protectorates.

\section{Mandatory Spheres.}

These are spheres where the responsibility for securing good government and a reasonable development of natural resources is confided to an already established Government by a mandate from the League of Nations. Such British spheres are parts of the former German colonies in West Africa and the former Turkish governments of Palestine and 
Mesopotamia. It will be the duty of all mandatories to furnish annual reports to the League in reference to the territory committed to their charge $(b b)$.

\section{Miscellaneous Territories.}

Several territories are administered by Great Britain which do not come under the head of colonies or protectorates proper.

Egypt.-Egypt does not form part of British territory, but owing to the important part which Great Britain has played in the affairs of that country during the last century, a short account of the relations which exist between our own Government and that of the Khedive may be found useful, and this will necessitate a brief reference to past history.

From 1798 to 1801 Egypt, which then formed a portion of the Sultan's dominions, was oecupied by the French Army under Napoleon and his gencrals. In the latter year, however, owing to the successful operations of General Abercrombic, the French were forced to evacuate Egypt, and Alexandria was occupied by the British until 1803, when they in turn evacuated the country.

After a period of internal dissension marked by a disastrous British expedition in 1807, Mahomet Ali, an Albanian, at length made himself master of the country in 1811, and was confirmed in the government by the Sultan, subject to the payment of an annual tribute, and under the suzerainty of Turkey $(c)$.

In 1866 Mahomet Ali's grandson Ismail was confirmed in the government by the Sultan, with the right of succession by primogeniture, and in 1867 the title of Khedive was conferred upon him $(d)$.

In consequence of misgovernment and the bankiupt state of the Egyptian treasury, the European powers were forced to intervene in the affairs of Egypt, and, as the result of

(bb) See post, p. 518 .

(c) See Firman of the Sultan, May, 1841 (Herts. Comm. Treat., xiv. 1024).

(d) Herts. Comm. Treat., xiv. pp. 1025, 1026, 1029. 
successive intemational commissions, the revenue, state railways and the landed property of the Khedive were brought under European control. This control, and the further interference of an English minister of finance and a French minister for public works, proved irksome to the Khedive, who, in 1878, endeavoured to throw off the yoke. This resulted in his deposition by firman of the Sultan in 1879 , and the appointment of his son Tewfik in his place (e), the govermment being carried on under the dual control of France and England.

In 1882 the Egyptian military party under Arabi Pasha broke out in revolt, and this resulted in the bombardment of Alexandria $(f)$ and the final overthrow of Arabi by Sir Garnet Wolseley at the battle of Tel-el-Kebir, on the 13th of September, 1882. France refused to take any part in the suppression of this revolt, and for that reason the dual control was abolished by khedivial decree of the 18th of January, 1883. Since that date the government of Egypt has been carried on subject to the control and advice of Great Britain alone.

Under the guidance of Great Britain the financial and intermal affairs of the country have now been placed upon a satisfactory footing, the successful flotation of a loan for $£ 9,000,000$ in 1885 being the basis of financial prosperity $(g)$, whilst the presence of an army of occupation of some 5,000 men has given to the British advisers of the Khedive that moral support which was necessary to enforce the acceptance of their adrice.

Prior to the 18th December, 1914, the actual position of Great Britain in Egypt depended upon a convention made between Great Britain and Turkey in $1885(h)$, by which it was arranged that British and Turkish high commissioners should act as adviser's to the Khedive, and co-operate to assure the security of the frontier and the good working and stability of the Egrptian Gorermment. As soon as this had

(e) Herts. Comm. Treat., xr. 581.

(f) 11 th of July, 1882 .

(g) See the Lendon Convention of 18th March, 1885 (Herts. Comm. 'Treat. xvii. p, :352).

(h) The convention of Constantinople, 24th of October, 1885, negotiated by Sir H. Drmmmond Wolff (Herts. Comm. Treat., xvii. p. 375). 
been effected a report was to be made by the commissioner's to their Governments, who were then to consult as to the terms of a convention regulating the withdrawal of the British troops.

The preliminary terms of the convention having been duly carried out, a convention providing for the withdrawal of the British troops within three years (Great Britain, however, reserving the right to renew the occupation in the event of internal or external danger) was signed at Constantinople by the English and Turkish representatives in 1887. This, however, the Sultan refused to ratify, so that England's position in Egypt depended nominally on the old Convention of 1885, and a Turkish high commissioner still resided at Cairo. The Khedive retained the power of legislation, which he exercised by decree, acting on the advice of a council of eight ministers presided over by a prine minister (i). The British financial arlviser attends all meetings of the council, and no financial measure cin be passed without his consent.

Representative institutions exist to a limited extent in Egypt, and prior to the year 1913, in addition to the provincial councils $(k)$ there was a legislative council composed of fourteen members elected by the provincial councils, and twelve members nominated (formerly) by the Khedive on the advice of his ministers. There was also a general assembly of eighty members, viz. eight ministers, twenty-

(i) The various ministers, who are the heads of corresponding departments, are (1) the Prime Minister and Minister of the Interior, with the following ministers, (2) of Public Works and War, (3) of Education, (4) of Finance, (5) of Waqfs, who administers the property of religions trusts), (6) of Foreign Affairs, (7) of Justice, (8) of Agricul. ture. See Lord Kitchener's Report on Egypt, 1914, Cd. 7358, p. 2.

(k) Egyptian affairs and institutions lave been the subject of various reports, e.g. by Lord Dufferin, 6th February, 1883, Lord Cromer, 1905, and Lord Kitchener, 28th March, 1914. P'rior to the change in ibs: electoral law noted in the text, the system was: (1) the villages elected representatives by manhood suffrage: (2) the representatives of the villages elected provincial councils; (3) the provincial councils elceted fourteen members of the legislative comncil, twelve being nominated by the Khedive; (4) the general assembly consisted of eighty members, viz. eight ministers, twenty-six members of the Legislative Conncil, and forty-six delegates elected by the representatives of the villages. (See Lord Kitchener's Report, 1914, p. 3). 
six members of the legislative council, and forty-six delegates elected by the representatives of the villages $(l)$.

These institutions were remodelled in the year 1913, and a new electoral law introduced. As a result of these changes the legislative council and general assembly were fused into one body under the name of the Legislative Assembly, which (in addition, semble, to the eight ministers, and twolve members nominated by the Khedive $(m)$ ) contains sixty-six members directly representing the population and elected, independently of the provincial councils, by delegates chosen by the people in the villages and tomns under the new electoral law, one delegate representing a group of sixty electors (n).

The legislative assembly enjoys the powers of both the old bodies with certain extensions. The most important of these are: (1) the power to delay legislation; (2) the recessity for the government to justify its persistence in passing measures, should they be disapproved by the assembly; (3) the power of the assembly to initiate decrecs and measures on its own responsibility; (4) the introduction of machinery enabling the government to consult the electors directly on propositions to which the assembly is opposed $(o)$.

In addition to the provincial councils there are also various "local commissions" or town councils, and bodies known as " mixed nunicipalities" (or local commissions with foreign representatives), which enjoy certain powers of local government $(p)$.

The Egyptian judiciary is supervised by a British judicial adviser, and the Sirdar or commander-in-chief of the Egyptian army was appointed by the Khedive with the

(l) Decrees involving administrative change were submitted to the legislative council before being approved, whilst measures involving fresh general taxation required the assent of the general assembly. Both these bodies enjoyed certain powers of eritieism, and of suggesting new legislation. (See ib. p. 3.)

(m) The report does not definitely state whether the ministers and twelve nominated members are included in the assembly, but apparently they are.

(n) See Lord Kitchener's Report, 1914, p. 7, where details are given.

(o) See Lord Kitchener's Report, 1914, p. 6.

(p) An outline of these will be found in Lord Kitchener's Report, 1914 , pp. 4,5 . 
consent of Great Britain. Great Britain also maintained a British agent, consul general, and minister plenipotentiary at Cairo with a legation staff, and consuls and viceconsuls. The judicial system, which is under British supervision, consists of mixed tribunals consisting of a court of first instance and a court of appeal presided over by Egyptian and European judges $(q)$; these deal with civil suits in which Europeans are concerned, and take the place of the old consular courts, which still, however, exercise jurisdiction over Europeans in criminal cases. In cases where natives only are concerned the native tribunals administer justice under British supervision. The law administered is contained in a code based upon Mahommedan law and the Code Napoléon $(r)$.

There are also certain religious courts which deal principally with questions concerning the status of Mahommedans. For purposes of local administration Egypt is divided into governorships and provinces, and by an agreement made in 1899 between the British and Egyptian Governments $(s)$, the civil and military government of the recently reconquered provinces of the Soudan is vested in a governorgeneral (assisted by a council since 1910) appsinted by the Khedive on the recommendation of the British Government, and not dismissible without the consent of the latter. In the Soudan the British and Egyptian flags were used together prior to the 18th Dec., 1914.

The Suez Canal was completed in 1869, and its management is in the hands of thirty-two administrators, ten of whom are British. In 1875 the British Government purchased from the Egyptian Government 176,602 shares in

(q) Established in 1876. See Herts. Comm. Treat., xiv. pp. 302, 315 , 316,320 . As the effect of recent changes ontlined in Lord Kitchener's Report, 1914 (see p. 52), in addition to the court of appeal there are now the following courts of first instance : viz. eight central tribunals (enjoying also certain appellate jurisdiction), ninety summary tribunals. twenty-eight markaz tribunals (for small criminal cases in Governorates), and two hundred and thirty-five cantonal tribunals.

( $r$ ) See Codes des Tribmaux Mixtes d'Egypte, 1896, and the Egyptian codes, 1892. And as to recent changes, Lord Kitchener's Report, 1914, pp. 55-57.

(s) See Herts. Comm. Treat., xxi. p. 356. 
the canal for the sum of $£ 3,976,582(t)$. By a convention signed by the powers at Constantinople in $1888(u)$, the canal is open to ships of commerce or war of all nations both in time of peace and war. The canal may not be blockaded, nor may any act of hostility be committed within three miles of either port of access.

The above outline represents the position of Egypt up to the 18th December, 1914, when, in consequence of the state of war existing with Turkey, and the adlerence of the late Khedive Abbas Hilmi Pasha to the Sultan's cause, it was deelared a British Protectorate, the administration being placed in the hands of a British High Commissioner. The late Khedive was at the same time deposed, and Prince Hussein Kamel Pasha, the eldest living prince of the family of Mahomet Ali, appointed Khedive in his place, with the title of " Sultan of Egypt."

Sultan Hussein Kamel died on October 9, 1917, and was succeeded by his brother, the present Sultan, Alımad Fuad. In December, 1919, a commission under the presideney of Lord Milner condueted an investigation into the affairs of Egypt with a view to report on the introduction of fuller measures of self-government and reforms in the judicial system. Ultimately, in February, 1922, Egypt was declared to be an independent sovereign state with certain reservations.

Cyprus.-A convention was arrived at in 1878 between the Sultan of Turkey and Great Britain, by which the latter undertook to assist under eertain circmmstances in defending the Sultan's Asiatic possessions against Russia, and in return the Turkish island of Cyprus was to be occupied and administered by England, Turkey retaining the right of controlling its foreign relations. The island was formally annexed in 1914, the inhabitants being granted a political franchise. The government consists of a high commissioner and a legislative council composed of eighteen

(t) See agreement with Egypt,. 25th of November, 1875 (Herts. Comm. Treat.. xiv. p. 1030. Confirmed by 39 \& 40 Vict. c. 67.)

(u) Convention of the 29th of October, 1888 (Herts. Comn. Treat., xviii. p, 369). 
members, six of whom are nominated and twelve dereted. There is a supreme court of justice, and assize and district courts; appeal lies to the Privy Council.

Ascension.-England took possession of this island in 1815, and a small naval station is now maintained there, and the administration is under the supervision of the Admiralty.

Tristan Da Cunha, a small island near St. Helena, is a British possession, having been settled by English soldiers when Napoleon was confined at the latter place. There is no formal constitution or government, the inhabitants sharing their property in common under the management of the head of the several families.

Aden is a British possession, and is administered by a resident, who is subjeet to the control of the Government of Bombay.

Perim, an island in the Red Sea, is a dependency of Aden and is under the same administration.

Socotra.-By an agreement with the Sultan, British protection was extended to this island in 1886 . Since 1876 it has been under the administration of Aden.

Wei-Hai-Wei.-By a convention with China signed at Peking on the 1st of July, 1898, England obtained a luase of the bay of Wei-Hai-Wei, together with a strip of land along the eoast ten miles wide, for so long a period as Russia remains in the oceupation of Port Arthur, and within those limits England was to have sole jurisclietion; the Chinese within the eity of Wei-Hai-Wei, however, remaining under the eontrol of the Chinese officials.

This territory is now under the control of the Colonial Office, and the administration is entrusted to a commissioner, who may make ordinances by proelanation and appoint or suspend public officers. A high eomt of justice is constituted by the order, from which appeal lies to the 
Supreme Court of Hong Kong, and thence to his Majesty in Council $(x)$.

Small Islands.-Many small islands or isolated rocks in various parts of the world belong to England or are under her protection, but do not form a separate colony or protectorate. For these there is no regular administration, but some are leased to trading firms by the Treasury for various purposes, whilst lighthouses are maintained on others by the Board of Trade $(y)$.

(x) Wei-Hai-Wei Order in Council of the 24th of July, 1901 (St. R. \& O. 1901, p. 140).

(y) For a list of some of these see the Colonial Office List. 


\section{APPENDIX A.}

\section{APPEAL IN CRIMINAL CASES.}

Under the Criminal Appeal Act, 1907, appeal may be brought, as previously stated $(a)$, to the Court of Criminal Appeal established by that Act, either against the conviction or against sentence, on all indictments, criminal informations, coroners' inquisitions, or cases dealt with by Quarter Sessions under the Vagrancy Act, 1824, except in cases involving privilege of peerage on indictments, or informations. The various modes of appeal in criminal cases as they existed prior to the passing of the Act of 1907 , however, still remain where not abolished (as in the case of writ of error, or motion for new trial) or changed (as in the case of transfer of jurisdiction to the Court of Criminal Appeal on cases stated under the Crown Cases Act, 1848) by the Act. The various modes of appeal were (and still are, except where so abolished or changed) as follows:-

Appeals from Petty Sessions.-Apart from the procedure under the Criminal Appeal Act, 1907, and on writs of certiorari, and habeas corpus, under the existing law appeals from petty sessions may be brought in two ways:-

(1) Appeal direct to general or quarter sessions;

(2) By special case stated for the opinion of a divisional court.

(1) Appeal to Quarter Sessions.-This is not as of general right, but only in such cases as are specially authorized by statute; the principal statutes being the Summary Jurisdiction Act, 1879, and, in the metropolis, the Metropolitan Police Courts Act, 1839.

By the Summary Jurisdiction Act, 1879, appeal lies to quarter sessions in all summary proceedings where a person is adjudged to imprisonment withont the option of a fine $(b)$.

(a) See ante, p. 306.

(b) 42 \& 43 Vict c. 49 , s. 19. 
This provision is, however, subject to the following exceptions:-

(1) Where imprisonment is adjudged for failure to comply with an order for the payment of money, for the finding of sureties, for the entering into any recognizances, or for the giving of any security (Summary Jurisdiction Act, 1879 , s. 19).

(2) Where a person elects to be dealt with summarily upon an indictable offence under ss. 10-13 of the Summary Jurisdiction Act, 1879 (R. v. JJ. London) (c); or where he pleads guilty or admits the truth of the information or complaint $(d)$.

By the Metropolitan Police Courts Aet, 1839, there is an appeal in all cases in the metropolis (except revenue cases) where a fine of more than $\$ 3$ is inflicted $(e)$. In revenue cases there is no appeal unless given by the Acts relating thereto.

The justices being made judges of fact as well as of law, their decision on such appeals is final, and cannot be reviewed by any court whatever without their consent $(f)$. They may, however, by virtue of the ordinary practice at common law, state a special case for the opinion of the King's Beneh (g), confirming or quashing the order of petty sessions subject to the special case stated. The Court of King's Bench (viz. a divisional court) affirms or quashes the order of quarter sessions and of petty sessions, but cannot make a new order $(7)$. Moreover, apart from the provisions of the Criminal Appeal Act, 1907, the exercise of the power of stating a case is perfectly optional on tho part of the justices, and if they refuse to do so the Court

(c) (1892) 40 W. R. 575; 56 J. P. 421 .

(d) Summ. Jur. Act, 1879, s. 19. As to appeals from an acquittal see post, p. 483. The procedure on appeal is regulated by the Summ. Jur. Act, 1879, ss. 31, 32, and the Summ. Jur. Act, 1884, sched. As to the costs of the appeal, see the Summ. Jur. Act, 1848, s. 27; and as to enforcing the order of quarter sessious by attachment from the K. B. D., see 12 \& 13 Vict. c. 45, s. 18.

(e) 2 \& 3 Vict. c. 71 . s. 50.

(f) R. v. Cottingham (Inhabitants of) (1834), 2 A. \& E. 250; and see Ex parte Martin (1876), 40 J. P. 133 ; and 12 \& 13 Vict. c. 45, s. 9.

(g) R. V. Allen (1812), 15 East, 333. It does not seem to be the practice on appeals to state a case for the Court of Crown Cases Reserved (now the Court of Criminal Appeal) under the provisions of the Cromn Cases Act, 1848 (11 \& 12 Vict. c. 78), s. 1 (sed quare whether it might not be possible to do this). For the law as stated in the text, see Arch. bold's Quarter Sessions, p. 552 .

(h) Sce R. v. Thomas (1857) 21 J. P. 661; 3 Jur. (N. S.) 713. 
of King's Bench will not grant a mandamus to compel them to state a case (i). But where sessions confirmed an order of petty sessions subject to a case, and for several sessions could not agree upon the terms of the case, the court granted a mandamus commanding them to enter continuances and hear the appeal, but not to state a case (j). Under the provisions of the Quarter Sessions Act, 1849 , before case heard, with the consent of the parties and by order of the King's Bench $(k)$, the facts may be stated in the form of a special case for the opinion of the High Court (l), and the judgment of the High Court thereon is to be entered on motion by eithel party at the sessions next, or next but one, and is to be the same in all respects as if the same had been given by the court of general or quarter sessions upon an appeal duly entered and determined $(m)$.

Formerly it was necessary to bring up a case stated by quarter sessions on writ of certiorari, but this was rendered unnecessary by a provision of the Summary Jurisdiction Act, $1879(n)$, and the proper course now is for the clerk of the peace to send the case up to the Crown Office (o).

In strict law the case is supposed to be stated by the justices, but in practice it is, as a rule, drawn up by the counsel of the party requiring it, and, after being signed by the opposing counsel, sent on to the clerk of the pence.

By the Judicature Act, $1873(p)$, the decision of the High Court in all criminal matters is to be final, except in case

(i) See R. v. JJ. Pembrokeshire (1831) 2 B. \& Ad. 391 ; Peat's C'ase (1704) 6 Mod. 229.

(j) R. v. JJ. Suffiolk (1832) 1 Dowl. P. C. 163. For the history of the practice, see $R$. v. Chantrell (1875) L. R. 10 Q. B. $587: 32 \mathrm{~L}$. 'T'. 305.

(k) Viz. a divisional court (see Stone's Justices' Manual, p. 81, n. g).

(l) Viz. a divisional court. See Holborn Union v. Chertsey Union (1885) 15 Q. B. D. 76 . A case stated under s. 11 of 12 \& 13 Vict. c. 45 is not an appeal within the provision of the Judicature Act, 1873, s. 45 , and therefore appeal lies from the Divisional Court to the Court of Appeal without leave in non-criminal matters. (See Holborn Union v. Chertsey Union, supra). But in criminal matters the decision of the divisional court is final under s. 47 of the Judicature Act, 1873, except in case of error of law apparent upon the record, as to which no question has been reserved for the consideration of the Court of Crown Cases Reserved (now the Court of Criminal Appeal).

(m) 12 \& 13 Vict. c. 45 , s. 11.

(n) $42 \& 43$ Vict. c. 49 , s. 40.

(o) See Clark v. Alderbury Union (1881) 29 W. R. $334 ; 50$ L. J. M. C. 35 .

(p) 36 \& 37 Vict. c. 66 , s. 47 . As to Error, see post, p. 512. C.L.E. 
of error of lau apparent upon the record, as to which no question has been reserved for the consideration of the Court of Crown Cases Reserved (now the Court of Criminal Appeal) under the Crown Cases Act, 1848. The decision of the divisional court on such cases stated is therefore final in criminal matters, except in case of error upon the record.

(2) Appeal by Case Stated.-Appeal may be brought by case stated under the provisions of two statutes; these are the Summary Jurisdiction Acts of 1857 and 1879. Also on an appeal to the Court of Criminal Appeal (in eases to which the Act applies) against conviction on a point of law, the Court of Criminal Appeal, may, if it so thinks fit, require a case to be stated under the Crown Cases Act, $1848(q)$.

Under the Summary Jurisdiction Act, 1857, either party to the proceedings, on information or complaint before a court of summary jurisdiction, may, after the hearing and determination, apply to the justice or justices to state a case for the opinion of the High Court, on the ground that the determination is erroneous in a point of law $(r)$.

Under the Summary Jurisdiction Act, 1879, any person aggrieved who desires to question a conviction, order, determination, or other proceeding of a court of summary jurisdiction, may apply to the court to state a case on either of two grounds:-

(1) That the conviction, order, etc., is in excess of jurisdiction;

(2) That it is erroneous in point of law (s).

Both under the Act of 1857 and under the Act of 1879, if the justice or justices refuse to state a case, the party interested may apply to the High Court for an order requiring the case to be so stated $(t)$.

A case so stated is heard by a divisional court $(u)$, whose decision in criminal cases is, by the Judicature Act, 1873,

(q) 7 Ed. VII. c. 23 , s. 20 (4).

(r) 21 \& 22 Vict c. 43, s. 2 .

(s) 42 \& 43 Vict. c. $49, \mathrm{~s} .33$.

(t) Summ. Jur. Act, 1857, s. 5 ; $I b .1879$, s. 38. The application must be made to a divisional court, or in the vacation, if the cause is urgent, to a judge at Chambers (Crown Office Rules, 1886, No. 80).

(u) Under the Jud. Act, 1894 , s. 1 (5), which enacts that " in all cases where there is a right of appeal to the High Court from any court or person, the appeal shall be heard and determined by a divisional court; and the determination thereof by the divisional court shall be final, unless leave to appeal is given by that court or the Court of Appeal." Appeals by case stated from quarter sessions under 11 \& 12 
declared to be final, except in case of error of law apparent upon the record $(x)$.

The metlod of bringing an appeal to a divisional court by case stated under the Quarter Sessions Act, 1849, s. 11, in cases where appeal lies to quarter sessions, has already been discussed $(y)$, so nothing further need be said on that head here.

When an appeal has been brought by way of case stated under the Summary Jurisdiction Act, 1857, the right of appeal to quarter sessions is lost (z), and this provision applies also to cases stated under the Summary Jurisdiction Act, 1879 (a).

An acquittal may be appealed against by case stated, and where a case stated under the Act of 1857 was sent back with the intimation that the magistrate ought to have convicted, the court granted a rule absolute for a mandamus to compel him to convict $(b)$.

On the other hand, no appeal lies to quarter sessions from an acquittal, since the prosecutor is not aggrieved thereby, unless such right of appeal is expressly given by the statute creating the offence $(c)$. And, therefore, where an acquittal was appealed against, a prohibition to quarter sessions was granted on the ground that there could be no appeal from an acquittal by the justices $(d)$.

Appeals from Quarter Sessions.-The manner in which the proceedings of quarter sessions exercisung its appellate jurisdiction in appeals from petty sessions nuay be brought up for review by a divisional court on case stated has already been treated of $(e)$; it romains to be considered by what means the proceedings or decisions of quarter sessions exercising its original criminal jurisdiction may be blought up for review by a superior court without having recourse

Vict. c. 78 , and $13 \& 14$ Vict. c. 45 , are not to be appeals under this section $(I b$. s. 2, (1)). The latter part of the section with regard to leave to appeal does not apply to criminal cases in which the decision of the divisional court is made final by s. 47 of the Jud. Act, 1875. except in cases of error apparent upon the record.

(x) Jud. Act, 1873, s. 47

(y) See ante, p. 481.

(z) Summ. Jur. Act, 1857 , s. 14.

(a) Summ. Jur. Act, 1879 , s. 33 (2).

(b) R. v. Haden Corser [1892] 8 T. I. R 563.

(c) R. v. JJ. London (1891) 55 J. P. 56 ; 31 Sol. J. 586.

(d) Payne v. JJ. Middlesex (1881) 45 J. P. 327; 16 Ib. 68.

(e) Ante, pp. 480, 481 . 
to the writs of certiorari, error (now abolished), or habeas corpus, which will be considered later $(f)$.

Until the passing of the Criminal Appeal Act, 1907, which provides a mode of direct appeal against conviction or sentence on indictments and informations, etc. $(g)$, there did not exist under the old law any right of direct appeal from a judgment of quarter sessions on the trial of an indictment, and provided the matter was one which fell within its jurisdiction, its judgment was as final and conclusive as that of the High Court itself. Further, before the passing of the Crown Cases Act, 1848 (11\& 12 Vict. c. 78), a case could not be reserved for the opinion of a higher court on the trial of an indictment at quarter sessions $(h)$. It is now, however, provided by that Act that "when any person shall have been convicted of any treason, felony, or misdemeanour before any court of over and terminer, or general gaol delivery, or court of quarter sessions (i), the judge or commissioner, or justices of the peace before whom the case shall have been tried, may, in his or their discretion, reserve any question of law which shall have arisen in the trial for the consideration of the justices of either bench and barons of the Exchequer; and thereupon shall have authority to respite execution of the judgment on such conviction, or postpone the judgment until such question shall have been considered and decided, as he or they may think fit; and in either case the court in its discretion shall commit the person convicted to prison, or shall talie a recognizance of bail, with ore or two sufficient sureties, and in such sum as the court shall think fit, conditioned to appear at such time or times as the court shall direct, and receive judgment, or to render himself in execution, as the case may be "' $(k)$.

By the Judicature Act, 1873, cases reserved under the Act of 1848 were no longer heard by the justices of either bench and the barons of the Exchequer, but by five or more judges of the High Court, of whom the Lord Chief Justice had to be one unless he certified under his hand,

(f) See post, pp. 487 et seq.

(g) See ante, p. 306.

(h) Per Ellenborongh, C.J., in R. v. Salop (Inhabitants of) (1810) 13 East, at p. 98.

(i) Including the recorder of a borough (see $R$. v. Masters (1848) 1 Den. C. C. 332). The Court of Quarter Sessions in boroughs consists of the recorder, who sits as sole judge $(I b$.$) .$

(k) 11 \& 12 Vict. c 78 , s. 1. 
or that of his medical attendant, that he was unable to be present, and the judges so sitting were known as the Court of Crown Cases Reserved $(l)$. If the judges differed, the minority were not bound by the decision of the majority, but any one of them might require the matter to be referred to all the judges of the King's Bench Division $(m)$. By the Criminal Appeal Act, 1907, the jurisdiction of the Court of Crown Cases Reserved as to cases stated under the Crown Cases Act, 1848, is transferred to the Court of Criminal Appeal, previously treated of, and cases so stated (or required by the Court of Criminal Appeal to be stated) will now accordingly be heard by the latter court $(n)$.

Upon the hearing of a case so reserved the Court is empowered to -

(1) Reverse, affirm, or amend the judgment.

(2) Avoid the judgment, and order an entry to be made on the record that, in the judgment of the High Court, the party convicted ought not to have been convicted.

(3) Arrest judgment, or order judgment to be given thereon at some future session of oycr and terminer or gaol delivery, or of the peace, if no judgment shall have been before that time given, as they shall be advised.

(4) Or to make such other order as justice may require $(o)$.

The judgment of the judges is to be delivered in open court, after hearing counsel for the parties, if either party so desires $(p)$, and the judgment is final and without appeal, save for error of law apparent upon the record, as to which no question shall have been reserved for the consideration of the High Court under the $11 \& 12$ Vict. c. 78 (Crown Cases Act, 1848). It will be noticed that under the latter Act the exercise of the power of stating a case was absolutely at the discretion of the judge or justices, as the case might be, and should he or they refuse to do so, no means

(l) Jud. Act, 1873, s. $47 ; I b .1881$, s. 15.

(m) See Steph. Hist. Crim. Law, i. 312.

(n) 7 Ed. VII. c. 23 , s. 20 (4). As to the Court of Criminal Appeal, see p. 306, ante, et seq.

(o) See $11 \& 12$ Vict. c. 78 , s. 2. The court has, however, no authority to award a venire de novo, or to order a new trial; $R$. v. Mellor (1858) Dears. \& B. 468 (sed quare).

(p) 11 \& 12 Vict. c. 78 , s. 3 . As to the practice on the hearing, see Chitty's Statutes, vol. ii. 253, n. $y$, and the authorities there cited. 
existed of compelling him or them to state a case. Now, however, under the Criminal Appeal Act, 1907, the Court of Criminal Appeal, upon an appeal against conviction on a point of law alone, may require a case to be stated under the Act of $1848(q)$.

\section{Appeals from the Assizes on the Nisi Prius side, and} from the High Court of Justice.-By section 19 of the Judicature Act, 1873, the Court of Appeal is empowered to " hear and determine appeals from any judgment or order of His Majesty's High Court of Justice, save as hereinafter mentioned.'

By section 47 of the same Act, " no appeal shall lie from any judgment of the High Cotirt in any criminal cause or matter, sare for some error of law apparent upon the record, as to which no question shall have been reserved for the consideration of the judges under the $11 \& 12$ Vict. c. 78 (Crown Cases Act, 1848)." As by the Judicature Act, 1873 , ss. 16,29 , courts of assize wele constituted part of the High Court of Justice, for the purposes of appeal in the strict sense they were embraced by section 47 of the Judicature Act, 1873, and until the passing of the Criminal Appeal Act, 1907, no appeal lay in criminal matters except in the case of error upon the record $(r)$. A direct mode of appeal to the Court of Criminal Appeal has now been provided by the last-mentioned Act, which at the same time abolished the writ of error $(s)$.

At the assizes or the Central Criminal Court a special case may be stated on a point of law by the judge for the consideration of the Court of Crown Cases Reserved (now the Court of Criminal Appeal), under the prorisions of the Crown Cases Act, 1848; he cannot, howerer, be compelled to do so, except under the power afforded to the Court of Criminal Appeal to require a case to be stated $(t)$. The jury may also return a special verdict $(u)$, and in certain cases, both at the assizes and in the High Court, the proceedings might formerly be heard by way, either of new

(q) Criminal Appeal Act, 1907 , s. 20 (4).

(r) As to the effect of s. 47 of the Jud. Act, 1873, see Ex parte IToodhall (1888) 29 Q. B. D. 832.

(s) See as to Court of Criminal Appeal, p. 306, ante, et seq. As to abolition of the writ of error, p. 310, ante.

(t) See ante, p. 310.

(u) As to special verdict, see post, p. 497. 
trial $(x)$, (which has now been abolished by the Criminal Appeal Act, 1907), or by venire de novo $(y)$. Beyond these methods, and except in case of error of law apparent upon the record, there was, in general, before the passing of the Criminal Appeal Act, 1907, no right of appeal in criminal matters from a judgment of the assize courts, or of the High Court of Justice exereising its original criminal jurisdiction, or in the hearing of cases removed into the King's Bench Division 'n writ of certiorari.

Proceedings in Error.-Prior to the year 1852 appeals in all actions in the superior courts went to the Court of Exchequer Chamber on wit of error (z). A memorandum in error was substituted for the writ of error by the Common Law Procedure Act, 1852, and by the effect of the Judicature Act, 1873 (a), and Order 58 of the Rules of the Supreme Court, 1875, the Court of Exchequer Chamber and the old procedure in error were entirely abolished, and a full appeal to the Court of Appeal in civil cases substituted therefor. In criminal cases, however, the old procedure in error still remained (b), and there were two methods of procedure, applicable to judgments in the inferior courts, and in the High Court respectively.

(1) Error from Inferior Courts.-From the courts of assize on the Nisi Prius side (c), the Central Criminal Court, and all inferior courts of record $(d)$ in which indictments may be tried (viz. quarter sessions, or the court of the Recorder, which corresponds to quarter sessions in

(x) As to new trial, see post, p. 49.5.

(y) As to venire de novo, see post, p. 496 .

(z) For the history of writs of error, see Steph. Hist. Crim. Law, i. p. 309 .

(a) S. 18

(b) Under the provisions of the Jud. Act, 1875, s. 19, and 0. 68, r. 1, the practice and procedure in criminal matters are to remain unaffected by the Judicature Acts and the rules made thereunder. And see short \& Mellor's Crown Office Practice, p. 313.

(c) That is to say in criminal cases.

(d) Superior courts in England are defined by the App. Jur. Act, 1876 , s. 25, as being his Majesty's High Court of .Tustice and his Miajesty's Court of Appeal and the superior courts of law and equity as they existed in England before the constitution of his Majesty's High Court of Justice. Courts of Assize and the Central Criminal Court were constituted part of the High Court of Justice by the effect of the Jud. Act, 1873, ss. 16, 29. Seeing that this is so, they can 110 longer be said to be inferior courts, but by s. 19 of the Jud. Act, 1875 , the proccdmre and practice in criminal natters remains maltered. 
boroughs), error lay to the King's Bench (e), and the writ was returnable before a divisional court $(f)$, whose decision was final, except in case of error apparent upon the record, as to which no question was reserved for the consideration of the Court of Crown Cases Reserved $(g)$.

The writ of error issued formerly from the common law side of the Court of Chancery, viz. the Office of the Petty Barr, but eventually from the Crown Office $(h)$, the fiat of the attorney-general being a necessary preliminary. If the attorney-general refused his fiat he could not be compelled to grant it (i). Error could only be brought by a defendant who was injured by a judgment on an indictment $(k)$; it did not lie from summary convictions. In form the writ of error was a direction to the judge or justices of one of the inferior courts mentioned above, directing him or them to send the record and the proceedings on which judgment had been pronounced, and in which error was alleged, to the King's Bench Division, the latter court being thereby authorized to affirm or reverse the same according to law $(l)$.

(2) Error from the Superior Courts.-By the provisions of the Judicature Act, 1873, the jurisdiction of the old Court of Exchequer Chamber became vested in the Court of Appeal $(\mathrm{m})$, and the latter was empowered to hear and determine appeals from any judgment or order, save as thereinafter provided $(n)$. It is provided by the same Act that in criminal matters the decision of the High Court is to be final, except in case of error of law apparent upon the record, as to which no question has been reserved for

(e) See Crown Office Rules, 1886, No. 183.

(f) See Jud. Act, 1873, ss. 41, 45, and s. 1 (5) of the Jud. Act, 1894. This latter section does not relate to an appeal from a judgment of the $\mathrm{H}_{\mathrm{ggh}}$ Court itself, see Wynne-Finch v. Chaytor, C. A. [1903] $2 \mathrm{Ch}$. 485. As to the procedure on such appeals, see post, p. 489.

(g) Jud. Act, 1873, s. 47.

(h) R. S. C. Jan. 1889; See Short and Mellor's Crown Office Practice, p. 313, and the Anmual Practice, 1905, p. $893 n$. The business of the Petty Bag Office was transferrer to the Crown Office in 1889 by rule of court. For the rule of court, see Short \& Mellor's Crown Office Practice, p. $10 \mathrm{n}$.

(i) See Short \& Mellor's Crown Office Practice, p. 317, and the authorities there cited.

(k) $I b$, p. 313 .

(l) For the form of the writ. see Crown Office Rules, Appendix D, No. 126

(m) Jud. Act, 1873, s. 18.

(n) $I b$. s. 19 . 
the consideration of the Court of Crown Cases Reserved (o). Therefore, in criminal matters appeal only lay from a judgment of the High Court when there was error of law apparent upon the record. But where error was apparent upon the record, appeal lay from a judgment of the High Court, upon an indictment or eriminal information, whether the judgment was that of a divisional court or of the Court of Crown Cases Reserved (semble), or that of the High Court exercising its ordinary original jurisdiction in criminal cases, which would generally be tried by either quarter sessions, an assize court, or the Central Criminal Court, but which might be removed into the King's Bench Division for some particular reason, either by writ of certiorari o! by an order of the court $(p)$. The appeal was by the old procedure on writ of error $(q)$, and the writ was returnable in the Court of Appeal (r). The fiat of the attorneygeneral to the issue of the writ had to be first obtained, and the form of the writ and the preliminaries to be observed on issue were, generally speaking; the same as in the case of error from the inferior courts treated of above $(s)$. If matters were not correctly stated upon the record, they might be amended on motion to the Court of Appeal (t); and if the record were imperfectly set out on the return to the writ, the plaintiff might apply for a writ of certiorari to certify the portion omitted.

If judgment was given by the Court of Appeal in favour of the plaintiff in error, then the court might either pronounce the proper judgment and order the discharge of the prisoner (if in custody), or it might remit the record to the King's Bench Division to be dealt with according to law $(u)$. From the decision of the Court of Appeal, appeal lay (semble) to the House of Lords $(x)$; and where the pro-

(o) Jud. Act, 1873, s. 47.

(p) As to removal of criminal cases into the King's Bench Division, see post, p. 496. Appeal also lay to the Court of Appeal for error upon a coroner's inquisition for murder or manslaughter.

(q) See R. v. Steel (1876) 2 Q. B. D. 37; Jud. Act, 1875. s. 19; Crown Office Rules, 1886, No. 2. For the cases in which error might ise brought, see Short \& Mellor, p. 322.

(r) Crown Office Rules, 1886, No. 207.

(s) Ante, p. 494. As to the practice and procedure, see Crown Office Rules, 1886 , Nos 183-215.

(t) See Gregory v. R. (1848) 15 Q. B. 957.

(u) Crown Office Rules, 1886, No. 215. Originally the only course open to the Court of Exchequer Chamber was to remit the record to the K. B. D., but this was altered by the $11 \& 12$ Vict. c. 78 , s. 5 .

(x) App. Jur. Act, 1876, s. 3 (1). 
ceedings were in error, the fiat of the attorney-general had to be first obtained $(y)$; the appeal was by the ordinary procedure on petition as in other cases of appeal, the old procedure in error to the House of Lords being abolished by the Appellate Jurisdiction Act, 1876 (z).

The writ of error has now been abolished by the Criminal Appeal Act, 1907, and a full means of appeal provided in criminal cases $(a)$.

Proceedings on writ of Certiorari. - The writ of certiorari was one of the means employed, at least as early as the reign of Edward I., to enable the Court of King's Bench to exercise supervision over the inferior courts, and on the reconstitution of the superior courts under the Iudicature Acts, this jurisdiction on writ of ccrtiorari passed to the present King's Bench Division of the High Court of Justice, as constituted by those Acts (b).

The writ is used for the purpose of removing the proceedings in an inferior court (c) into the King's Bench Division for the purpose of-

(1) Examining into their legality, and either affirming or quashing them $(d)$.

(2) Or giving fuller or more satisfactory effect to them than could be done in the court below.

It may be used in a variety of matters, both civil and criminal $(e)$, but it is proposed here to deal with the latter alone, and these fall naturally into two main groups:-

(1) The removal of presentments and indictments found in inferior courts into the King's Bench Division.

(2) The remoral of summary convictions and of orders of justices made either in or out of sessions.

(1) Certiorari for removal of Indictments into the King's Bench Division.-In form the writ is an order from the Crown, directed to the judge, magistrate, or justices of an inferior court, requiring them to certify and send the pro-

(y) App. Jur. Act, 1876, s. 10.

(z) $I b$. ss. 4, 11.

(a) 7 Ed. VII. c. 23 , s. 20 (1); and see p. 310, ante.

(b) See Jud. Act, 1873, s. 34 .

(c) As to the definition of superior courts, see ante, p. 487, n. (d).

(d) For a more complete account of the purposes for which certiorari may be brought, see Hale's Pleas of the Crown, ii. 210; Steph. Comm., 11th ed., iv. 369.

(e) For an enumeration of the matters that may be so dealt with, see Short \& Mellor's Crown Office Practice, p. 90. 
ceedings before them into the King's Bench Division, " that we may further cause to be done thereupon what of right we shall see fit to be done" $(f)$. The practice and procedure with regard to the issue and subsequent proceedings are regulated principally by the Crown Office Rules, 1886, and the following points may be noted:-

The writ of certiorari is a prerogative writ, and is granted as of course to the Crown, or to a private prosecutor of an indictment against a body corporate not authorized to appear by solicitor in the court in which the indictment is found; in the case of a private prosecutor or defendant it is only granted on application to a divisional court after good cause shown $(g)$. If the divisional court refuses to grant it, no appeal lies $(h)$, except in ease of error apparent upon the record as to which no question has been reserved for the consideration of the Court of Crown Cases Reserved (now the Court of Criminal Appeal). With the exception of certain statutory prohibitions (i) (which, however, do not extend to the Crown, or to a private person prosecuting in the name of the Crown, unless expressly so enacted) $(k)$, presentments and indictments found in any other court may be removed into the King's Bench Division for the purpose of being tried at Bar $(l)$, or by the judges of assize on the Nisi Prius side $(m)$.

The writ may also be used to remove indictments found at quarter sessions in certain districts within the jurisdiction of the Central Criminal Court to be tried in the latter $(n)$; and any case outside the jurisdiction of the Central Criminal Court may be sent to be tried therein $(o)$, or indictments removed into the King's Bench Division from any other court may be sent for trial to the Central Criminal

(f) For the form of the writ, see the Annual Practice, 1905, vol. ii. p. 106.

(g) Crown Office Rules, 1886, Nos. 28, 29; and see $5 \& 6$ Will. IV. c. $33 ; 16 \& 17$ Vict. c. 30, \&. 5 .

(h) Jud. Act, 1873. s. 47 ; and see R. v. Rudge (1886) 16 Q. B. D. 459.

(i) For examples of such enactments, see 1 Anne, st. 1, c. 18, s. 5; 7 \& 8 Geo. IV. c. 29, s. 53.

(k) The Crown is not affected by an Act of Parliament unless a $x$ pressiy mentioned, see dit.-Gen. V. Donaldson (1842) 10 M. \& II., l 124 As to the case of a private prosecutor, see $R$. v. Boultiee (1836) 4 A. \& E. 498.

(l) As to trial at Bar, see Short \& Mellor, p. 308.

(m) See Hale's Pleas of the Crom, ii. p. 210.

(n.) 4 \& 5 Will. IV. c. 36 , s. 16.

(o) Crown Office Rules, 1886, No. 42. 
Court $(p)$. On the other hand, in proper cases, proceedings at the Central Criminal Court or at assizes $(q)$ may be removed into the King's Bench Division and there tried; though it is only in very exceptional cases that indictments for felony will be tried in the King's Bench Division itself, the usual course being, in the case of indictments found at quarter sessions, to send the cause to the next assizes in the district, or, in the case of an indictment found at the assizes, to the Central Criminal Court, as the case may be. An indictment will not be removed into the King's Bench Division except upon one of the following grounds:-

(1) That a fair and impartial trial cannot be had in the court below.

(2) That some question of law of more than usual difficulty and importance is likely to arise.

(3) That a view of premises will be required $(r)$.

The writ may be applied for either before or after the indictment has been found $(s)$, and at any time before the jury has been sworn for trial $(t)$. Under very special circumstances it could (and semble still can) be granted (at any rate where error did not lie) after verdict given, and before final judgment $(u)$, but not to set aside a verdict and grant a new trial $(x)$. After judgment it will only be granted for carrying the judgment into execution; appeal under the Criminal Appeal Act, 1907, and error (now abolished) or case stated being the only remedy after judgment.

(2) Certiorari on Summary Convictions and Orders of Justices.- In the case of summary convictions, and orders of justices in or out of sessions, the writ of error (which has now been abolished) did not lie in the case of a defect in the proceedings $(y)$; therefore beyond the procedure by case stated under the Summary Jurisdiction Acts of 1857 and

(p) 19 Vict. c. $16, \mathrm{~s} 1$.

(q) Where a cause is removed into the K. B. D. from the assizes, a writ of certiorari is no longer required, a simple order being now sufficient, since, by the Jud. Act, 1873 , ss. 16, 29, courts of assize are constituted part of the High Court of Justice. See R. r. Dudley (1884) 14 Q. B. D. 273

(r) Crown Office Rules, 1886, No. 29.

(s) 60 Geo. III. c. 4, s. 4.

(t) 60 Geo. III. c. 4 , ss. 3,5 .

(u) R. v. Porter (1703) 1 Salk. 149.

(x) R. v. Oxford (1811) 13 East, 411.

(y) In the case of indictments, on the other hand, certiorari does not lie for a defect in the proceedings, and especially after judgment. 
$1879(z)$, and the Quarter Sessions Act of $1849(a)$, and the direct appeal to quarter sessions allowed by statute in certain cases from summary convictions at petty sessions (b), the writ of certiorari was, prior to the passing of the Criminal Appeal Act, 1907, the only other method by which summary convictions and orders of justices could be reviewed by a higher tribunal.

The writ lies in all such cases, whether before or after judgment, unless the right is expressly barred by statute, and provided the Court of King's Bench (viz. a divisional court, or a judge at chambers in vacation, and when the divisional court is not sitting) (c) deems it necessary. Generally speaking, the writ is granted in the following cases:-

(1) Where there is some defect or informality on the face of the proceedings $(d)$.

(2) For want of jurisdiction, and this may be on several grounds.

(i) The character and constitution of the tribunal itself; $e . g$. interest on the part of the justices.

(ii) The nature of the subject-matter of the inquiry; $e . g$. if it is such that the proceedings ought never to have been instituted at all.

(iii) The absence of essentials preliminary to the inquiry: e.g. notice, time, etc.

(iv) Where some fact arises after the proceedings have been legitimately instituted which ousts the jurisdiction; e.g. a defence raised which involves a question of the ownership of land.

(v) An omission of an essential element of jurisdiction.

(3) Excess of jurisdiction; e.g. a sentence ultra vires the court.

(4) On a conviction obtained by fraud.

The writ is granted in the above cases either before judgment, and for the purpose of removing the proceedings into another tribunal, or quashing them, or after judgment, for

(z) Ante, p. 482.

(a) Ante, p. 481.

(b) Ante, p. 479 .

(c) Crown Office Rules, 1886, Nos. 28, 29.

(d) Defects on account of omissions or mistakes in drawing up the order or conviction, and which would formerly have led to the quashing of the order through the inability of the court to amend them, mar now be amended under the $12 \& 13$ Vict. c. 45 , s. 7 . So that in suck cases the court is no longer obliged to quash the order or conviction. 
the purpose of quashing the judgment itself. But certiorari can only be brought, and will only be granted, by a divisional court after judgment, and for the purpose of quashing the order or conviction, in cases where there is some defect of jurisdiction or other informality, or for a defect apparent upon the face of the proceedings. And the order or conviction being final, if the justices have acted within their jurisdiction, upon the return to the certiorari, and where no case is stated by the justices, the court will not go into the merits of the case itself or the proceedings before the justices $(e)$, in order to show that the latter had come to a wrong conclusion, or inquire further than whether the proceedings were within the jurisdiction, and regular upon the face of them.

It the instance of a prosecutor, other than the attorneygeneral acting on behalf of the Crown, the writ is granted at the discretion of the court on good cause shown. Where good cause is shown it should be granted $e x$ debito justitice $(f)$; but if the divisional court refuses to grant it, there is no right of appeal to the Court of Appeal $(g)$, except (semble) in the case of error of law apparent upon the record. Statutory restrictions do not affect the Crown, $o r$ a private prosecutor on bethalf of the Cromn, unless expressly mentioned, and, generally speaking, the restrictions in the Crown Office Rules as to time, recognizances, etc., do not apply to a prosecutor $(h)$.

At the instance of a defendant the writ is granted at the discretion of the court on good grounds shown and ex debito justitix, subject, however, to the restrictions contained in the Crown Office Rules (i), and to statutory prohibitions (if any). The attorney-general obtains the writ as, of course, upon motion made by himself, or counsel with the fiat of the attorney-general.

Upon application to the divisional court for a certiorari, if prima facie grounds are shown, an order nisi is made, and when eause is shown against an order nisi to remove a judgment, order, or conviction, the court may, if it thinks

(e) R. v. Bolton (1841), 1 Q. B. $66 ; 10$ I. J. M. C. 49. Where. however, there is a collateral, and not an apparent, defect they may do so in so far as is necessary to prove defect of jurisdiction. $I b$.

(f) R. v. JJ. Surrey (1870), T. R. 5 Q. B. 466.

(a) Jud. Act, 1873, s. 47; and see R. v. Fletcher (1876), 2 Q. B. D. 43.

(h) See Short \& Mellor's Crown Office Practice, pp. 122, 123, 134, and the cases there eited.

(i) See Crown Office Rulcs, 1886, Nos. 32, 33, 35, 36. 40. 
fit, where no special case is stater, make it a part of the order absolute for a certiorari that the judgment, order, or conviction shall be quashed on retum without further order, and a menorandum to that effect is endorsed upon the writ at the time of issue by the proper officer $(k)$. After the order for the cortiorwi has been made absolute, the subsequent proceedings (when it is desired to quash an order or conviction) take place before the divisional court upon a motion to quash the order or conviction, and an order nisi, which is granted as of course.

After argument three courses only are open to the court.

(1) It may make the order misi to quash absolute.

(2) It may discharge it, in which case the order or conviction is affirmed.

(3) It may amend any mistake or omission in the drawing up of the order or conviction, and adjudicate upon it as if such mistake or omission had not been made (12\& 13 Vict. e. 45 , s. 7 ).

Under section 47 of the Judicature Act, 1873, the decision of the divisional court in criminal cases is final save for some error of law apparent upon the record, as to which no question has been reserved for the consideration of the Court of Crown Cases Reserved (now the Court of Criminal Appeal) (l).

Proceedings by Way of New Trial.-The powers and practice existing in the High Court at the time of the passing of the Criminal Appeal Act, 1907, with regard to motions for new trials have been abolished by that Act $(m)$, the former practice as to the granting of new trials is now, therefore, only of historical importance. The circumstances under which a new trial could be granted in criminal cases may be considered under two heads-

(1) Cases of misdemeanour.

(2) Cases of felony.

(1) In cases of misdcmeanour a new trial would only be granted when the case was tried by the King's Bench Division exercising its original jurisdiction, or where the caco was sent down by that division to be tried at the assizes on the Nisi Prius side $(n)$. In the case of a misdemeanour

(k) See Crown Office Rules, 1886, No. 37.

(l) Jud. Act, 1873 , s. 47.

(m) See ante, p. 310.

(n) Steph. Hist. Crim. Law, i. 310, where he cites Chitty, C.I. $653-660$, as his authority. 
tried at the assizes or at quarter sessions, certiorari would not be granted for the purpose of awarding a new trial. In such cases if either of the parties desired to have the possibility of a new trial, a certiorari had to be applied for on one of the grounds mentioned above (o), before the case came on to be tried, to remove the cause into the King's Bench Division. The case would then usually either be tried in the King's Bench Division or sent to the Central Criminal Court, and in either case a new trial might be applied for on any one of the following grounds $(p)$ :-

(1) Misdirection.

(2) That the verdict was against the weight of evidence.

(3) Any other ground upon which a new trial could be granted in eivil suits $(q)$.

(2) In felony there appears to be only one recorded case in which a new trial was granted, namely, the case of $R$. v. Scaife (1851) ( $r$ ), where the case having been removed into the King's Bench Division on writ of certiorari, a new trial was granted on the ground that the judge at the trial had admitted the deposition of a witness, who could not be produced at the trial, as evidence, and had left it generally to the jury witlout pointing out that it was evidence against Smith only, who had procured the absence of the witness, and not against the other tro defendants.

This course was not followed, however, in the case of $R$ v. Bertrand (1867) (s), and appears to have been an entirely isolated instance.

Procedure by "Yenire de Novo."-Before the passing of the Crown Cases Act, 1848, which provided for the stating of a special case on the trial of indictments at the assizes and quarter sessions for the consideration of the Court of Crown Cases Reserved (now the Court of Criminal Appeal) $(t)$, where a jury felt uncertain as to a point of law in an important case, the practice was to find the facts specially, referring the matter to the judges to say whether on those facts the prisoner was or was not guilty of the crime for which he had been indicted $(u)$. This form of

(o) See ante, p. 492, et seq.

(p) Steph. Hist. Crim. Law, i. 311.

(q) $I b$.

(r) R. v. Scaife, Smith \& Rooke (1851), 17 Q. B. 238.

(s) (1867) L. R. 1 P. C. 520.

(t) See as to the transfer of jurisdiction, ante, p. 310.

(u) Steph. Hist. Crim. Law, i. 311. 
proceeding was known as returuing a special verdict $(x)$. In such cases, when the jury returned an imperfect special verdict, a new jury might be summoned, and the cause reheard by venire de novo (y). Since the passing of the Crown Cases Act, 1848, however, special verdicts have gone out of use on the trial of indictments at quarter sessions and assizes, the present practice being to state a case for the consideration of the Court of Cromn Cases Reserved (now the Court of Criminal Appeal) under the provisions of that Act.

The Act does not apply to criminal cases tried in the King's Bench Division, and in such a case a special verdict might still be resorted to $(z)$.

The Writ of Prohibition.-This is a prerogative writ directed by one of the superior courts to an inferior court, when it is desired to prevent such inferior court usurping the jurisdiction of a higher tribunal.

Since the Judicature Acts any of the judges of the High Court may grant the writ, and it may also issue from the Crown Office (which has taken over in that respect the duties formerly exercised by the Petty Bag Office), upon affidavit. In criminal matters, however, with which we are now concerned, application must be made to a divisional court by motion for an order nisi $(a)$, and the order may be made absolute in the first instance ex parte; but this is in the discretion of the court, and it will only so be granted where special circumstances are shown $(b)$.

The writ is used for preventive purposes, and to prohibit actions, or the proceedings subsequent to judgment in actions wrongfully commenced in an inferior court, by reason of want or excess of jurisdiction (c). In criminal cases it lies to quarter sessions $(d)$, and also to petty

(x) For an instance of such a verdict. see the celebrated case of $R$. $\mathrm{r}$. Dudley of Stephens (1881), 14 Q. B. D. 273.

(y) Steph. Hist. Crim. Law, i. 311.

(z) For an instance of such a case, see $R$. v. Staines Local Boarl (1888), 52 J. P. 215.

(a) Crown Office Rules, 1886, No. 81.

(b) $I b$. No. 82. There is no provision with regard to an application in vacation.

(c) As to want of jurisdiction, see ante, p. 493. Where the court has no jurisaiction, this cannot be cured by agreement of the parties. See per Lord Campbell in De Haber v. Queen of Portugal (1851) 17 Q. B. at p. 213.

(d) See R. v. Middlesex Justices (1881) 45 J. P. 420.

C.L.E. 
sessions, but not to the assize courts, at least (semble) since the Judicature Act, 1873 , by which such courts have been made part of the High Court of Justice $(e)$.

A prohibition will in general only be granted after judgment in the inferior court, where some want or excess of jurisdiction is apparent on the face of the proceedings $(f)$, or where objection to the jurisdiction has been taken in the court below; and it will not be granted (scmble) where no defect of jurisdiction is apparent on the proceedings, and where the defendant has "lain by and accepted the jurisdiction " $(g)$.

In criminal matters, if an application for a prohibition be refused, appeal from the decision of the court is precluded by section 47 of the Judicature Act, 1873.

The Writ of Habeas Corpus.-There are various forms of the writ of habcas corpus which may be used in cases where it is desired to have a person legally or illegally detained or confined brought before the court, according to the various purposes for which it is desired to have the person so confined brought up. These forms are--

(1) Habeas corpus ad subjiciendum, used for examining into the legality of a commitment, or any other form of forcible detention of the person.

(2) Habeas corpus ad testificandum, used for bringing up prisoners to give evidence.

(3) Habeas corpus ad respondendum, used for bringing up nrisoners to be tried upon some fresh charge.

(4) Habeas corpus ad detiberandum and recipias, used for remoring prisoners from one custody to another for trial.

(5) Habeas corpus for the purpose of bringing a prisoner in the King's prison into court to be charged with a writ of attachment $(h)$.

Of these the writ of habeas corpus ad subiciendum is the great constitutional remedy for testing the legality of a commitment, or of any other form of forcible detention of the person, and this alone will be treated of here.

It is a ligh prerogative writ, and has existed at the common law from very early times, probably before the date

(e) Jud. Act, 18\%3, s. 16.

(f) See Serjeant v. Dale (1877) 2 Q. B. D. 558.

(g) See Roberts v. Humby (1837) 3 M. \& W., p. 126.

(h) See Short \& Mellor's Crown Office Practice, p. 411. 
of Magna Carta itself; but as delays and evasions were constantly occurring in connection with the issue of and return to the writ, the first Habeas Corpus Act (16 Car. I. c. 10) was passed with the object of remedying some of these abuses.

This Act applied only to commitments by the King or Privy Council, and as constant delays in complying with the writ, on the part of sheriffs, gaolers, and others, continued to occur, a subsequent Act (31 Car. II. c. 2) was passed, which, however, only applied to criminal cases of misdemeanour, all other cases being left to be remedied by the old common law writ. The penalty for refusing to make a return to the writ under this Act, or for refusing or neglecting to deliver within six hours after demand by a prisoner, or on his behalf, a copy of the warrant or commitment and detainer, is $£ 100$ and loss of office; and for a second offence $£ 200$ (i). The Act does not apply to persons convicted, or in execution upon legal process for any crime; and it does not apply where treason or felony is plainly expressed on the warrant $(k)$, or upon suspicion of any felony, or as accessory before the fact to any felony where such charge is expressed in the warrant $(l)$.

In civil cases the procedure of the common law writ in the case of a person confined or detained otherwise than for some criminal or supposed criminal matter was subsequently regulated by the statute 56 Geo. III. c. 100 . Disabedience to the writ under the Act is made a contempt of court $(\mathrm{m})$, and it is provided that although a return to a writ of habeas corpus is good and sufticient in law, the judge before whom the writ is returnable may examine into the truth of the facts set forth in the return by affidavit. or affirmation $(n)$.

Under the present procedure application for the writ may be made by counsel to a divisional court or to a judge at chambers $(o)$ during the sittings, and in extradition cases to a divisional court $(p)$. In vacation time it may be made to

(i) S. 5 .

(li) S. 3 .

(l) S. 21.

(m) S. 2 .

(n) S. 3.

(o) Crown Office Rules, 1886, No. 235. The application to a judge at chambers should, however, only be made in vacation time, except in the case of children. See Short is Mellor's Crown Office Practice, p. 352

(p) Crown Office Rules, 1886, No. 238. 
a judge $(q)$. The divisional court may either make an order absolute $e x$ parte for the writ to issue, or may grant an order nisi $\left(r^{\circ}\right)$. If the application is to a judge, he may either make an order for the writ to issue ex parte, or direct a summons (s), when the parties will be heard as to whether the writ shall issue or not. The usual practice in either case is to nuke an order nisi, or direct a summons, as the case may be, unless there is reason to fear that the ends of justice may be defeated by delay, when the writ will be issued $e x$ parte in the first instance.

The writ may be quashed upon motion if irregularly or improperty issued, or if obtained upon fraudulent misrepresentition; but it canmot be so quashed if the return is good on the face of it, although the judge, if he had inquired into the return, might have elicited facts which would have induced him not to grant it, or to have granted a rule nisi $(t)$.

The return to the writ must contain a copy of all the causes of the prisoner's detainer endorsed on the writ, or on a separate schedule annexed to it $(u)$, and the return may be amended, or another substituted for it, by leave of the court $(x)$.

The facts stated in the return are taken to be true unless impeached $(y)$, but an ambiguous return, unless supported by aftidavit, will be held evasive and bad (z).

If the commitment is alleged to be defective the court may examine the conviction itself, and in such cases (unless the right is taken away by statute) the conviction should be removed on writ of cortiorari (a).

In cases under the 56 Geo. III. c. 100 the judge or the court is empowered by affidarit or affirmation to examine into the truth of the facts set forth in the return, although the return is good and sufficient in law, and do what may seem just upon such examination $(b)$. And generally, when

(q) See Watson's Case (1839) 9 A. \& E. P. 780; Wilson's Case (1845) 7 Q. B. 984 .

(r) Crown Office Rules, No. 236.

(s) $I b$. No. 237.

(t) Wilson's Case (1845) 7 Q. B., p. 984, n.

(u) Crown Office Rules, 1886, No. 241.

(x) $I b$. No. 242.

(y) Leonard Watson's Case (1839), p. 782.

(z) R. v. Roberts (1860) 2 F. \& F. 272.

(a) As to a case where the right of certiorari is taken away, see $R$. V. Chaney (1838) 6 D. P. C. 281.

(b) Ss. 3. 4. 
the person detained is brought up under the old common law writ, the court or judge may, after examination into the cause of the detainer, set him at liberty with or without bail, or remand him back into custody, or otherwise deal with him according to law (c). And where the original warrant of commitment is bad, the judge or justices by whom the prisoner was committed may, in a proper case, substitute a good warrant for the bad one (d), and (semble) this might also be clone by the court or judge before whom the writ is returned.

In eases under the Extradition Acts, if the court refuses to grant a habeas corpus there is no right of appeal to the Court of Appeal (e). And generally, though on a refusal of the writ there is a right of appeal in all civil cases $(f)$, there is no such right of appeal where the proceedings arise out of a criminal cause or matter within section 47 of the Judicature Act, $1873(g)$.

In cases of disobedience to the writ, the person guilty of disobedience is subject to fine and loss of office if the writ is brought under the 31 Car. II. c. 2, or he may be committed for contempt if the writ is brought under the 56 Geo. III. c. $100(h)$, this provision having been extended by the latter Act (i) to cases under the 31 Car. II. c. 2. Upon disobedience to the common law writ, application may be made to the court upon affidavit, and an attachment for contempt will be granted $(k)$.

Petitions for Pardon.-The right of the subject to petition the Crown was expressly declared by the Bill of Rights, and may therefore be considered as one of the constitutional rights of the subject, and a fundamental provision of the contract between the Crown and people upon which the title to the Crown now depends.

Prior to the passing of the Criminal Appeal Act, 1907, beyond the remedy by petition to the Crown for a pardon, there did not exist any means of bringing the evidence

(c) Amongst other cases, see R. v. Clarkson (1720) 1 Stra. 444.

(d) See R. v. Richards (1814) 5 Q. B. 926.

(e) See Ex parte Woodhall (1888) 20 Q. B. D. 832.

(f) Tnder Jud. Act, 1873 , s. 19. See Ex parte Bell Cor (1887) 20 Q. B. D. 1: R. v. Barmardo (1889) 23 Q. B. D. 305.

(g) See Ex parte Woodhall (1888) 20 Q. B. D. 832, where the effect of s. 47 of the Jud. Act, 1873, is fully explained by Lord Esher, M.R.

(h) S. 2.

(i) S. 6 .

(k) Crown Office Rules, 1886, No. 240. 
upon which the jury had arrived at a finding of fact under the review of a highel tribunal $(l)$. A full means of appeal having been provided by the last-mentioned Act against conviction or against sentence, on indictments, informations, etc., the right of petitioning the Crown would now appear to have lost some of its former importance $(\mathrm{m})$. And though the right of petition is in no sense lost or superseded owing to the passing of the Criminal Appeal Act, 1907, it is now provided by that Act that on a petition for pardon having reference to conviction or sentence (other than sentence of death), on indictment, etc., after the 18th of April, 1908, the Home Secretary may at any time, if he thinks fit, either refer the whole case to the Court of Criminal Appeal, when it must be heard and determined by that Court as in the case of an appeal, or refer any point arising in the case to the Court of Criminal Appeal for their opinion $(n)$. This provision does not, however, extend to Scotland or Ireland, nor is the prerogative of mercy affected by it.

A pardon may be granted either before or after trial, but if granted before trial it must be expressly pleaded, otherwise it is held to be waived $(0)$. It may be granted in all cases except-

(1) By the Act of Settlement no pardon under the Great Seal is pleadable in bar of an impeachment by the Commons $(p)$.

(2) The penalty of a præmunire imposed by the Habeas Corpus Act, 1679, for the offence of committing to prison out of the realm, cannot be remitted by the Crown.

(3) The Crown could not by a pardon avoid the corruption of blood consequent upon attainder, for that could only be effected by an Act of Parliament $(q)$.

(l) See, however, pp. 490,495 , ante, as to the procedure by certiorari and new trial.

(m) It is stated in the report of the committec of enquiry into the case of Adolf Beck that the number of petitions received annually from criminals or friends on their behalf was then 4,000 and 1,000 respectively. See Report of the Committee, Appendix, p. 331, where the then existing procedure with regard to petitions in the Home Office is detailed. (See as to this case generally the first edition of this book, Appendix A.)

(n) 7 Ed. VII. c. 23, ss. 19, 23.

(o) See R. v. Boyes (1861) I B. \& S., at p. 319.

(p) See ante, p. 11, and see R. v. Boyes (1861) 1 B. \& S. 311.

(q) 3 Cu. Inst. 233. 
Corruption of blood on attainder has now, however, been abolished by the Forfeiture Act, 1870 .

(4) Under the maxim, " non potest rex gratiam facere cum damno et injuria alienorum," the Crown cannot by a pardon deprive an informer of his right to the penalty in the absence of express statutory authority; or prevent the abatement of a common nuisance by means of a pardon; or discharge a recognizance to keep the peace with regard to an individual.

The power of pardoning cannot be delegated by the Crown to any person within the realm $(r)$; it is, however, usually delegated to the governor's of colonies by their commission. Formerly, all pardons were required to pass under the Great Seal, and this (semble) is still necessary in treason, murder, and misdemeanour $(s)$. But in felonies which are not capital a sign-manual warrant, countersigned by a Secretary of State, is sufficient $(t)$.

The effect of a pardon is to clear the party from the infamy and all other consequences of the crime (except an impeachment by the Commons); the pardoned person may even bring an action of slander against a person calling him a felon or traitor after the pardon is granted, because the pardon makes him, as it rere, a new man, and gives him a capacity and credit $(u)$.

It may also be noted that serving a sentence for a felony not capital has now the like effects and consequences as a pardon under the Great Seal, except with regard to the effect of a previous conviction upon a subsequent conviction on any other felony $(x)$.

(r) 27 Hen. VIII. c. 24 , s. 1.

(s) See R. v. Boyes (1861) 1 B. \& S. 311, and the instances there cited.

(t) 7 \& 8 Geo. IV c. 28 , s. 13.

(u) Hawkins' Pleas of the Crown, ii. 547.

(x) 9 Geo. IV. c. 32 , s. 3. 


\section{APPENDIX B.}

THE CROWN IN FOREIGN RELATIONS (a).

In England, by virtue of the prerogative, the Crown enjoys the right of conducting relations with foreign coun. tries, of appointing diplomatic agents and consuls who form the medium of intercourse between one State and another, and of making treaties. It must, however, be understood that in the conduct of such matters the Crown acts upon the advice of its constitutional councillors, namely, the Cabinet or the Secretary of State for Foreign Affairs (b), and through its responsible minister, namely, the Secretary of State for Foreign Affairs as the parliamentary head of the Foreign Office.

In the appointment of high diplomatic functionaries, it is the rule for the Crown to adopt the advice of its ministers, though this rule was broken through upon at least one occasion, when William IV. refused to sign the appointment of Lord Durham as ambassador at St. Petersburg (c).

Diplomatic Agents. - It is the general practice amongst nations to conduct their intercourse with foreign States by means of diplomatic agents, duly accredited by the Government of the country which they represent, the establishment of permanent legations being generally dated from the peace of Westphalia in $1648(d)$.

Diplomatic agents were divided into three classes by the Vienna Congress. $1815(\mathrm{e})$, an intermediate class being

(a) This topic, being concerned rather with questions of international than of constitutional law, was omitted from the earlier pages of this book; it is hoped, however, that it may serve a useful purpose by insertion in the Appendix.

(b) As to whether a matter is sufficiently inprortant or not to be made a Cabinet question rests generally with the Prime Minister.

(c) The Sovereign may also exercise the right of refusing to receive accredited agents who are distasteful to him. For an instance, see Hall's International Law, p. 300.

(d) See Halleck's International Law, 3rd ed., i. p. 326, and the authorities there cited.

(e) Se: Herts. Comm. Treat., x. p. 194 
provided for ministers resident by the congress of Aix-laChapelle in $1818(f)$.

The various classes of diplomatic agents internationally recognized are now, therefore, as follows:-

(1) Ambassadors, legates, or nuncios.

(2) Envoys, ministers, or other persons accredited to sovereigns.

(3) Ministers resident, accredited to the various courts.

(4) Chargés d'affaires accredited to ministers for foreign affairs.

Ambassadors, legates, and nuncios are alone to have the “representative character," and precedence among diplomatic agents in their respective classes is to be according to the date of the official notification of their arrival $(g)$.

Diplomatic agents are appointed by letters of credence, which specify their name, rank, and authority to communicate in the nams of their respective governments; and when special envoys $(h)$ are employed to conduct negotiations on specific topics, or for discussing or signing treaties, these are usually appointed by letters-patent defining the limits of the power's conferred upon them (i)

Certain privileges and immumities are generally conceded to a diplonatic agent by the foreign State to which he is accredited, and, generally speaking, these are as follows:-

(1) Immunity for himself, his family, and suite from criminal jurisdiction and arrest (unless perhaps in a rery flagrant case, where he might be detained) $(k)$; the only remedy in such a case being an application to the State whom he represents for his recall, or, in more serious cases, an order to leave the country.

(2) Exemption for himself, his family, and suite within certain limits from civil jurisdiction, the limits of such exemption being subject to various opinions by different writers, it being generally concerled, however, that the exemption extends at least as far as to protect him from arrest for debt, and in the possession of such property and goods as are

(f) Herts Comm. Treat.. x. p. 195.

(g) Regulations of the Congress of Vienna, Arts. II., IV. (Herts. Comm. Treat.. x. p. 194).

(h) See Hall's International Law, 5th ed., p. 302.

(i) These may be either envoys, envoys extraordinary, or ministers plenipotentiary isee Halleck's International Law, i. 328).

(k) See Hall's International Law, p. 172. 
necessary for the proper maintenance of his dignity and the execution of his duties $(l)$.

(3) The diplomatic agent is regarded as being in an exterritorial position, and therefore his house is free from the territorial jurisdiction, at least in so far as to prevent any interference with the performance of his duties. But this privilege must not be used (in Fngland), it would seem, to support abuse of the legul rights of individuals, at least in the case of illegal detention of a foreign subject in the embassy of his country $(m)$.

(4) Diplomatic agents and their property are exempt from taxation; but not apparently from local rates, unless (as in England) expressly exempted by statute $(n)$. By courtesy, also, goods intended for their use are exempt from customs duty.

Consuls. - In addition to the diplomatic agents, who are appointed to act as a medium of intercourse between the governments of one State and another, it is customary for a State to appoint consuls to reside in foreign countries, for the purpose of looking after the interests of its subjects when within the foreign territory, of performing certain official acts, and exercising jurisdiction acquired by the State with regard to its own subjects when within the foreign territory, such jurisdiction having been acquired by "capitu-

(l) In England the privileges and inviolability of diplomatic agents are regulated (in part at least) by the statute 7 Anne, c. 12, passed in consequence of the arrest of the ambassador of the Czar, Peter the Great, for a debt of $\$ 50$ contracted in London. By this Act all suits, actions, and proceedings against any ambassador, and all bail, bail bonds, or judgments in connection therewith are to be absolutely null and void, and certain penalties are provided for persons offending against the Act, the benefit of which is extended to the domestic servants of the ambassador, except where they engage in trade. This Act has been held to be only declaratory of the common law and of the law of nations (see Novello v. Toogood (1823) 1 B. \& C.. p. 562). But where the ambassador voluntarily enter's an appearance, he is not entitled to have the proceedings set aside by reason of privilege, provided his person or property are not interfered with. Taylor v. Best (1854) 14 C. B. 487 .

(m) As to how far this exemption extends, see Hall's International Law, pp. 181, 182 As to the abuse of the privilege in the case of Sun-Yat-Sen, who was illegally detained in the embassy of his country and ordered to be released by the Foreign Secretary, see Halleck's International Law, 4th ed., i. 376.

(n) See Parkinson v. Potter (1886) 16 Q. B. D. 152. 
lation, grant, usage, sufferance, or other lavful means " $(o)$. Generally, the duties of consuls or consular agents relate to such matters as the administration of the estates of subjects of their own country dying abroad; arbitrations on matters lrought before them by fellow-subjects; the care of shipwrecked sailors and other fellow-subjects in distressed circumstances; the legalization of judicial or other acts for use in their own country by affixing the consular seal. Consuls also communicate with their Government in case of injustice done to a fellow-subject, and collect statistics upon commercial and other matters.

There are various degrees of consular rank, viz. consuls general, consuls, vice-consuls, and consular agents, and they are appointed by the Crown, by commission, or letters patent. The commission or letters-patent are communicated to the Government of the foreign country, and the consul's position and status is formally recognized by the latter by means of an exequatur, which may consist of a formal document signed by the sovereign of the foreign country, or merely of an endorsement upon the original commission.

Consuls are entitled to certain privileges, such as exemption from personal taxation, or from arrest for political reasons. They are subject, however, to the ordinary courts of the country in which they reside, in both civil and criminal matters, though not for acts done uniter the orders of their own Government; nor may the consular papers and documents be interfered with.

Treaties.-The power of making treaties or contracts between nation and nation belongs to every sorercign Statc, in so far as such State has not limited itself in the exercise of such right by compacts or treaties with other States. In non-sovereign or dependent States the power is either limited in extent, or non-existent; e.g. the various States of the American Union, or of the Dominion of Canada, which cannot conclude treaties with foreign nations, since that power is vested in their respective Federal Govermments. Treaties are known under various names-conventions, declarations, or in some instances General Acts, e.g. the General Act of the Berln Conference of 1885. Convention is usually, though not invariably, a term applied to com-

(o) See the Foreign Jurisdiction Act, 1870 (53 \& 54 Vict. c. 37). Preamble. 
mercial treaties and agreements, which are, however, also termed commercial treaties.

The authority in whom the treaty-making power in any State is rested depends upon the fundamental or constitutional law of the particular State. In England the treatymaking power is rested in the Crown, acting upon the advice of its responsible councillors, viz. the Cabinet, or, in matters of less importance, the Secretary of State for Foreign Affairs.

The terms of a treaty are usually agreed upon by agents appointed for the purpose by the treaty-making authority in either State, and who are vested with either full or limited powers. Where the terms of the treaty have been agreed upon by plenipotentiaries, or agents invested with full and unlimited powers, the treaty, which is invariably (though not necessarily) reduced into writing and signed by the agents, is in general binding without ratification $(p)$; but the usual course is for the sovereign power to ratify the agreement come to. Where the agents are acting under a limited authority, the agreements come to are termed sponsions, and must be either tacitly or explicitly ratified $(q)$.

Power of the Crown to bind the Subject by Treaty.-The treaty unay be said to be imperfect in its obligation, even after ratification, if some further eeremony is required by the fundamental law of the State, such as the consent of the legislature, in order to make it binding upon the nation. In England there is by the law of the Constitution no eodified Iist of subjects upon which the Crown has the porrer to make treaties without the consent of the legislature, but there is little doubt that upon a very wide class of topies the treaty-making power is imperfect and inoperative to bind the subject without express Parliamentary sanction or ratification.

This class of subjects was earefully considered by Sir $\mathrm{R}$. Phillimore in the case of the Parlement Belge. A consideration of the judgment in that case would seem to confirm the view that the Crown cannot make treaties so as to affect the private rights of the subject. The treaty in question in that case was, Sir R. Phillimore concluded, "a user of the treaty-making power of the Crown, without

(p) See the discussion in Wheaton's International Law, 4th ed., p. 366 et seq., upon this point.

(q) Wheaton, p 365. 
precedent, and in principle contrary to the laws of the Constitution" $(r)$.

It seems to be generally conceded, however, that the Crown may make a treaty ceding territory without the consent of Parliament $(t)$; and that treaties concluding peace or declaring war are also valid without Parliamentary sanction. In either of the latter cases, however, the necessity for the consent of Parliament would be indirectly supplied where the terms of peace or the declaration of war necessitated a Parliamentary grant of money, and in the case of a disgraceful peace being concluded withont Parliamentary sanction, the royal prerogative would probably not shield the responsible minister from an impeachment by the Commons. Conventions relating to commerce require Parliamentary sanction (semble) when they impose taxation upon, or interfere with, the private rights of the subjects (u).

Foreign Enlistment.-By the rules of international law, as generally received, no breach of neutrality is committed by the Govermment of a State in permitting its subjects to build, fit out, and bona fide sell a ship of war to a friendly State engaged in a war with another friendly State, or in selling arms and ammunition to such State. Ships of war and arms are articles of commerce, and neutrals are entitled to continue their ordinary commerce with belligerents,

(r) The Parlement Belge (1879) 4 P. D. 129. The question in this case, as decided by Sir R. Phillimore, was whether the Crown by a convention concluded with Belginm arranging for the carrying of the English mails by certain Belgian packet boats "belonging to the Belgian Government, or freighted by order of the Govermment," could confer upon such Belgian packet boats the status of Belgian ships of war when in British ports. Sir R. Phillimore decided that the Crown had no anthority "to clothe with immmity foregn vessels which are really not vessals of war," (ib., p. 155), and judgment was therefore given against the Parlement Belge, which had collided with an English boat in Dover harbour. Whereas if the status of a ship of war could have been conferred by the convention, the Parlement Belge would have been outside the jurisdiction, the mle of international law being that a ship of war, being govermment property, is outside the jurisdiction of a foreign court. The judgment of Sir $R$. Phillimore was subsequently reversed in the Court of Appeal. on the ground, however, that the Parlement Belge was outside the jurisdiction, as being in the employ of the Belgian Govermment, independently of the convention (sce the Parlement Belge (1879) 5 P. D., p. 220, C. A.).

$(t)$ Parliamentary sanction was, however, given to the cession of Heligoland to Germany in $18 \% 0$.

(u) See the Parlement Belge, cited supra. 
subject to the risk of capture and confiscation of their goods if they are contraband $(x)$.

It is true that after the American Civil War the Geneva arbitration tribunal awarded damages of $\$ 15,000,000$ in gold against England for permitting ships to be fitted out and equipped in British ports for the use of the Confederate States $(y)$. But in that ease England had, by the Treaty of Washington (1871), by which the matter was referred to the Geneva arbitration tribunal, consented to be bound in the arbitration by $c x$ post facto rules, which did not in fact represent the existing state of international law upon the subject, the particular rule in point being to the effect that a neutral Government is bound "to use diligence to prevent the fitting out, arming, or equipping, within its jurisdiction, of any vessel which it has reasonable ground to believe is intended to cruise or carry on war against a Power with which it is at peace." It was, however, expressly stipulated in the treaty that her Majesty's Government did not assent to the rules as a statement of the principles of international law which were in force at the time when the claims arose.

The case of the Alabama, Florida, and Shenandoah (the vessels complained of) cannot be taken, therefore, as a precedent that such a rule of international law exists.

Though this is so from an international standpoint, England has, since the year 1819 (z), adopted the policy of making it a statutory offence to fit out or equip warlike vessels for the use of a belligerent.

The Foreign Enlistment Act, 1819, was passed "to prevent the enlisting or engagement of his Majesty's subjects to serve in foreign service, and the fitting out or equipping in his Majesty's dominions vessels for warlike purposes without his Majesty's licence."

In 1868 a commission (a) was appointed to enquire into the working of the Act of 1819 , and the results of the recommendations made by this commission were embodied in the Foreign Enlistment Act of 1870, which is now in force.

(x) See Wheaton's International Law, 4th ed., p. 599.

(y) For an account of the cases against the Alabama, Florida, and Shenandoah, see Wheaton's International Law, p. 606 et seq.

(z) Two previous Acts, viz. the 9 Geo. II. c. 30 , and the 29 Geo. II. c. 17 , made it a felony punishable with death to enter the service of a foreign State. But these Acts were passed with the object of preventing the formation of Jacobite armies in France.

(a) The Neutrality Laws Commission. 1868. 
By the terms of this statute (b) it is an offence punishable by fine and imprisonment-

(1) For a British subject without his Majesty's licence to accept any commission or engagement in the military or naval service of any foreign State at war with any other friendly foreign State.

(2) For any person, whether a British subject or nos, within his Majesty's dominions, to induce any other person to accept or agree to accept any such commission or engagement.

(3) For a British subject to quit, or go on board any ship with a view of quitting his Majesty's dominions with intent to accept any such eommission or engagement.

(4) For any person within his Majesty's dominions to induce any person to quit, or go on board any ship, etc., with a like intent.

(5) For any person to induce any person to quit his Majesty's dominions, or to embark on any ship within his Majesty's dominions under a misrepresentation, or false representation, in order that such person may accept any such commission, etc.

It is an offence punishable with fine or imprisonment, and entailing forfeiture of the ship to his Majesty, for any person within his Majesty's dominions and without his Majesty's licence-

(1) To build, or agree to build, or cause to be built, any ship with intent or knowledge, or having reasonable cause to believe, that the same shall or will be employed in the military or naval service of any foreign State at war with any friendly State.

(2) To issue or deliver any commission for any ship with the like intent or knowledge.

(3) To equip any ship with the like intent or knowledge.

(4) To despatch, or cause or allow to be despatched, any ship with a like intent or knowledge.

The Act also contains provisions against taking on board any ship within his Majesty's dominions, and without his Majesty's licence, persons referred to in the Act as illegally enlisted per'sons; and against aiding the equipment of foreign ships, or fitting out naval or military expeditions without his Majesty's licence.

These are the principal offences created by the let,

(b) 33 \& 34 Vict. c. 90. 
which, it may be noted, extends to England, and to all the dominions of his Majesty, including the adjacent territorial waters.

In addition to these statutory restrictions upon the freedom of intercourse allowed to British subjects with a belligerent State, England has further restricted her freedom of action in such matters, at least with regard to America, by the terms of the Treaty of Washington, concluded May 8, 1871 (c).

By the terms of this treaty England " has agreed for the future to use due diligence to prevent the fitting out, arming, or equipping within the jurisdiction of any ressel which it has reasonable grounds to believe is intended to cruise or carry on war against a Power with which it is at peace: and also to use the like diligence to prevent the departure from its jurisdiction of any ressel intended to cruise or carry on war as abore, such ressel having been specially adapted in whole or in part within such jurisdiction to warlike use."

However desirable it may be that such a rule with regard to the duties of a neutral power should become the standard recognized by international law, there is much to be said against the wisdom of adopting a policy which may tend to tie the hands of the Government with regard to future action in such matters. Moreorer, if the provisions of the Foreign Enlistment Act or of the Washington Treaty are to be strictly enforced, it might well be said that neutrality was infringed unless they were enforced with equal strictness in the case of the one belligerent as in the case of the other. In fact, in adopting such a policy the Government of the country would appear to lay itself open to endless difficulties and embarrassments in her diplomatic relations with one or other of the belligerent Powers.

Letters of Denization.-The Crown may br prerogatire grant letter's patent of denization under the Great Seal to any alien, and no residence in England by such alien is a necessary preliminary to the grant, nor are there any conditions as to future residence attached to the grant.

Under the Naturalization Act, 1870 , a previous residence of five years in England was required before an alien could acquire the full status of a British subject by becoming naturalized under the Act. Letters of denization may thus

(c) See Herts. Comm. Treat., xiii. p. 970. 
be made use of by the Crown where it is desired to confer upon an alien some of the privileges of a British subject, without resorting to the more lengthy and expensive process of obtaining an Act of Parliament. The status of denizens is somewhat anomalous. The Naturalization Act, 1870, provides that nothing in that Aet is to affect the grant of letters of denization $(d)$; the position of a denizen therefore remains as it was previously to the passing of the Act.

The Act of Settlement provided that "no person born out of the United Kingdom or the dominions thereunto belonging (although he be naturalized or made a denizen, except such as are born of British parents) shall be capable to be of the Privy Council, or to be a member of either House of Parliament, or to enjoy any office or place of trust, either civil or military, or to have any grants of lands, tenements, or hereditaments from the Crown to himself or to any other or others in trust for him "' $(e)$.

With regard to aliens naturalized under the Act of 1870 , or the Act of 1914, this provision is no longer of any effect, since by those Acts naturalization confers upon them all the political rights of a British subject $(f)$. But the provision still applies to denizens, though there seems to be some doubt as to whether they may not be employed in an "office or place of trust," or, at any rate, as British consular agents in foreign countries $(g)$.

There is also authority for saying that a denizen may vote at Parliamentary elections $(h)$.

(d) 33 \& 34 Vict. c. 2, s. 3.

(e) 12 \& 13 Will. III. c. 2, s. 3 . The words " naturalized or" were repealed by the British Nationality and Status of Aliens Act, 1914, s. 3.

(f) Rex v. Speyer [1916] 2 K. B. 858.

(g) See Hall's Foreign Jurisdiction, p. 34.

(h) Solomon's Case (1804) 2 Peck. 117. 


\section{APPENDIX C.}

\section{STATUTORY PROVISIONS FOR THE PREVENTION OF SEDITION, ETC.}

A $\mathrm{T}$ the present time, when the use of force in opposing the wishes of legally constituted authority would seem to be regarded by many as a legitimate, constitutional and political weapon, a short summary of some of the more important provisions of the Acts in force for the prevention and suppression of sedition, may be found useful.

(1) The Treason Felony Act, 1848.-Under this Act there are two main offences, which have been briefly referred to earlier in this book $(a)$, punishable equally in the case of principals in the first and second degree, and accessories before the fact with penal servitude for life, or for any period not less than three years, or with imprisonment not exceeding two years with or without hard labour $(b)$. Accessories after the fact are punishable with imprisonment not exceeding two years with or without hard labour. These offences are:-

(a) Within the United Kingdom or without, to compass, imagine, invent, devise, or intend, to deprive or depose the sovereign from the style, honour, or royal name, of the Imperial Crown of the United Kingdom, or of any other of his Majesty's dominions and countries $(c)$. In connection with this offence, it may be noted that a conspiracy to levy war for a public purpose, or the storing and sending of arms to be used in aid of a treasonable confederacy to overthrow the Government in any part of his Majesty's dominions, is sufficient to support an indictment $(d)$.

(a) See ante, p. 150.

(b) Treason Felony Act, 1848, s. 3; Penal Servitude Act, 1891, s. 1.

(c) Treason Felony Act, 1848, s. 3.

(d) See R. v. Davitt and Another (1870), 11 Cox, C. C. 334 ; R. v. Gallagher and Others (1883) $15 \mathrm{Cox}$, C. C. $291 ;$ Mulcahy v. R. (1868) L. R. 3 H. L. 306. 
(b) It is felony for any person within the United Kingdom or without, to compass, invent, devise, or intend to levy war against the sovereign in any part of the United Kingdom in order by force or constraint to compel him to change his measures or counsels, or in order to put any force or constraint upon, or in order to intimidate or overawe both Houses or either House of Parliament, or to move or stir any foreigner or stranger with force to invade the United Kingdom, or any other of the sovereign's dominions or countries under the obeisance of the sovereign $(e)$.

It may be noted that when such acts of force liave been committed, it is to show an intention for some public purpose to bring the offence within the Act $(f)$; and that the offence of "levying war" is evidenced by an intention to use violent measures either against public or private property, or against the lives of the sovereign's subjects for some public purpose, as distinguished from private spite or enmity against particular persons $(g)$.

(2) The Unlawful Oaths Act, 1797 and $1812(h)$.-Cunder the Act of 1797 it is a felony punishable with penal servitude not exceeding seven years, for any per'son to administer or cause to be administered, or assisting, or being present at and consenting to the administration or taking of any oath or engagement purporting to bind the person taking it to engage in any mutinous or seditious purpose, or to disturb the public peace, or to be of any society, association, or confederation formed for any such purpose, or to obey the orders or commands of any committee or body of men not lawfully constituted, or of any leader or commander or other person not having authority by law for that purpose, or not to disclose the existence, confederation, or association, or not to inform or give evidence.

The penalty is the same for persons taking the oath or engagement not being under compulsion; and persons aiding or assisting at the administration, or causing the outh to be administered, are to be deemed principal offenders though not actually present at the administration.

(e) Treason Felony Act, 1848, s. 3, partially repealed by the Statute Law Revision Acts, 1891 and 1892.

$(f)$ See the cases cited in note $(d)$, and R. v. Meaney (1867) I. R. 1 C. L. 500 .

(g) R. v. Gallagher and Others, supra, at p. 514.

(h) 37 Geo. III. c. 70 ; 52 Geo. III. c. 104. 
By the Unlawful Oaths Act, 1812 (i), where the with or engagement purports or intends to bind the person taking it to commit any treason or murder, or any felony punishable with death, the punishment in the case of the person administering the oath, and the person taking it not being under compulsion, is increased to penal servitude for life, or such other term as the Court may adjudge.

(3) The Incitement to Mutiny Act, $1797(k)$.-Under this Act any person who maliciously and advisedly endeavours to seduce any person serving in his Majesty's forces by sea or land from his duty to his Majesty, or to incite or stir up any such person to commit any act of mutiny, or to make or endeavour to make any mutinous assembly, or to commit any traitorous or mutinous practice, is guilty of felony punishable with penal servitude for life $(l)$.

(4) The Unlawful Drilling Act, 1820 (m).-Under this Act meetings and assemblies of persons in the United Kingdom for the purpose of training or drilling themselves, or practising military evolutions, without lawful authority from his Majesty, or a Secretary of State or officer deputed by him, are prohibited, and persons present at such meetings for the purpose of training and drilling others, or aiding or assisting therein, are liable to seven years' penal servitude, or imprisonment not exceeding two years. Persons attending such meetings or being present to be trained are liable to fine and imprisonment not exceeding two years.

(5) Aliens Restriction. (Amendment) Act, 1919 (n).Under this tet if any alien attempts or does any act likely to cause sedition or disaffection amongst his Majesty's forces or the forces of his allies or amongst the civilian population he is liable to penal servitude for ten years or imprisonment for three months; and if an alien promotes industrial strife in any industry in which he has not been engaged for two years he is liable to imprisonment for three months.

(i) 52 Geo. III. c. 104 ; and as to the penalty see the Punishment of Offences Act, 1837. An association the members of which are bound not to reveal its secrets is an unlamful association within the statutes, for whatever purpose it is formed. See $R$. v. Lovelass (1834) 6 C. \& P. 596.

(k) 37 Geo. III. c. 70; Punishment of Offences Act, 1837.

(l) For cases under this Act, see R. v. Tierney (1804) Russ. \& R. 74; R. v. Bowman, 22 Cox, C. C. 729.

(m) 60 Geo. III. and 1 Geo. IV. c. 1, as amended by the Firearms Act, 1920 , s. 16 ; and see as to the punishment, the Penal Servitude Act, 1891, s. 1 (1).

(n) $9 \& 10$ Geo. T. c. 92 , s. 3. 


\section{APPENDIX D.}

\section{THE LEAGUE OF NATIONS.}

Although the Lengue of Nations does not, strictly speaking, form part of the Constitutional Law of Engliand, yet it does seem sufficiently germane to call for some notice in the present work. It may not at present have any serious effect or bearing on the English constitution, but if and when it reaches its full strength and stature and is supported by the great moral forces of the world it may well be that its influence will be felt not only in questions of an international character, but also in those of a more domestic nature. The Covenant of the League is a solemn agreement between sovereign states which consent to limit their complete freedom of action on certain points for the greater good of themselves, and the world at large. And that being so it seems likely that the influence of the League when once fuily established will extend and be felt beyond the mere settlement of international disputes. The future of the League, however, is a matter beyond the scope of this treatise, but the following three provisions may be briefly noticed.

The Sovereignty of Parliament.-It has been said that the League of Nations is a super-State and that it will or may affect the sovereignty of Parliament. "There has been," says Sir Frederick Pollock (a), " much alarm about the sovereignty of independent States which it is alleged that the Leagne of Nations will entail. Few, if any, of the objectors have noticed that the parties to the League have already limited their freedom of action in many directions by existing international conventions. They can, indeed, release themselves by withdrawal, but only by notice and in due form, and in the more important cases the consequences of withdrawing from the joint business would be so inconvenient that reversion to the former state of isolation

(a) Pollock's League of Nations, 2nd ed., p. 80. 
cannot be regarded as a practical contingency." It should also be noticed that it is officially declared that the Covenant is not the constitution of a super-State, but an agreement between sorereign states to the effect above stated. It should also be noticed that the members of the League undertake to respect and preserve the existing political independence of all members. The League does not prescribe any particular form of government and every member is declared to be sovereign in its own affairs. Nevertheless, it must be admitted that some of the prorisions of the Corenant, such as those relating to the reduction of armaments and the output of munitions, must almost inevitably tend to impair the ornnipotence or sovereignty of Parliament which forms so important a feature of the English constitution (b).

Permanent Court of International Justice.-The formal opening of this Court took place at The Hague on the 15th February, 1922. Dr. Loder, of the Netherlands, was elected President, Professor Weiss, of France, Vice-President, and Lord Finlay represented Great Britain. The Court is competent to hear and determine any dispute of an intemational character which the parties submit to it, and may also give an advisory opinion upon any dispute or question referred to it by the Council or the Assembly of the League of Nations. Its jurisdiction is not compulsory save as it may be made so by special submission, and it has no executive of its own (c). Neither is it a court of appeal, its jurisdiction being original only. Under these circumstances there is little to add. The Court may well be found useful and we can only hope that it will be so.

Mandates.-In territories which have ceased to be under the States which formerly governed them and which are inhabited by peoples not yet able to stand by themselves, the tutelage of such peoples is to he entrusted to the adranced nations who can best undertake the responsibility. The character of the mandate differs according to the circumstances. Great Britain is entrusted as mandatory on behalf of the League with three linds of territory: (1) Certain countries formerly under Turkish rule which require only administrative advice and assistance until they can

(b) $\dot{A}$ s to the sovereignty of Parliament, see ante, p. 12.

(c) Pollock's League of Nations, 2nd ed., p. 150. 
stand alone; (2) certain peoples of Central Africa, where the mandatory must be responsible for administration with freedom of religion and subject only to maintenance of public order, prohibition of slavery, arms and liquor traffic and formation of armies and navies except for police or defensive purposes; (3) certain territories in South-West Africa which can be best administered under the laws of the mandatory subject to the safeguards above-mentioned. In every case the mandatory must render to the Council an annual report in reference to the territory. The authority and administration of the mandatory, if not previously agreed upon, is to be defined by the Council and a permanent commission is to examine the reports and advise the Council as to the observance of the mandate.

In December, 1920, mandates for the following territories were settled by the Council:-

Island of Nauru: Great Britain.

German Samoa: New Zealand.

German possessions in South Pacific: Australia.

German South-West Africa: Union of South Africa. 

ABJURATION

\section{N D EX.}

oath of, 54

ACKNOWLEDGMENT BY MARRIED WOMEN, 286;

ACT OF SETTLEMENT, THE, 2

a constitutional landmark, 2, 6

provisions of , 10,11

reasons for, 10,139

ACTS OF GRACE, 88

ADEN, 177

ADJOURNMENT OF PARLIAMENT, 58

ADMIRAL, THE LORD HIGH, 248

ADMIRALTY, THE, 208

ADMIRALTY, THE COLRT OF, 247

appeals from. 250

colonial courts, 250

jurisdiction of, 248

origin of, 247

ADMISSION OF CLERT TO BENEFICE, 327

ADOPTIVE ACTS, THE, 392

ADVOCATE-GENERAL, THE JUDGE, 386

ADVOCATES, JUDGE, 387

AFGHANISTAN, BRITISH RELATIONS WITH, 461

AFRICA, THE UNION OF SOUTH, 449

AGRICULTURE AND FISHERIES, THE MINISTRY OF, 214

AIDS, 100

AIR FORCE, 388

Ministry, 207

ALDERMEN, 397

ALDERNEY, INSTITUTIONS OF, 417

ALFRED, LAWS OF, 219, 225

ALFRED'S CODE, 219, 225

AIIENS

who are, 146

may not be nembers of Parliament, 11

may not be privy councillors, 11

may not exercise Parliamentary franchise, 61

naturalization of, 146

sedition by, 516

ALLEGIANCE, 144

local or natural, 145

oath of, by members of Parliament, 51 
AMBASSADORS AND DIPLOMATIC AGENTS, Appendix, p. 504

AMERICAN CONSTITUTION, THE, 15

differences between the Swiss and, 20

ANGLO-SAXON LAWS, 218-220

APPEAL

Colonies, from the, 426

courts of, before the Judicature Acts, 303

courts of, since the Judicature Acts, 304

criminal accusation, by, 236

Criminal Appeal, to Court of, 306, 479

from inferior courts, 267, 304

in Court of Appeal heard generally by three judges, 313

in criminal cases, 306,479

lords of, in ordinary. 313

to the Honse of Lords, 240, 313

APPEAL, THE COURT OF

composition of, 310

judges of, 311

jurisdiction of, 312

restrictions on appeal to, 312

APPEAL, THE COURT OF CRIMINAL, 306

APPROPRTATION ACTS, THE, 94, 212

APPROPRIATIONS, ECCLESIASTICAL, 325

ARBITRARY IMPRISONMENT

forbidden by Magna Carta, 7

Petition of Right, 8

ARCHBISHOPS

appointment of, 77, 321

duties of, 321

ARCHDEACONS

appointment and duties of, 323

ARCHDEACON'S COURT', THE, 254

ARCHES, 'THE COURT OF', 254

ARMY, THE, 362

enlistment in, 365

maintenance of a standing army, 363

military law, 383

reserve forces, 367

special reserve, 371

Territorial Army, 376

ARMY ACT, THE ANNUAL, 364

ARMY COUNCIL, THE, 206

functions of, 206

ARRIËRE BAN, 221

ARTICLES, THE THIRTY-NINE, 320

ASCENSION, 477

ASHANTI, 429

ASSEMBI,, CHURCH, 333 
ASSEMBLY, PUBLIC

lawful, right of persons to resist police dispersing a, 49 common law right to take part in, 47

unlawful, what constitutes an, 47

ASSIZE

commissions of, 260

grand, the, 227

of Darrein Presentment, the, 228

of Mort d'Ancestre, the, 228

of Novel Disseisin, the, 228

petty, the, 227

procedure, by, 227

Utrum, the, 228

ASSIZES, THE, 259

appeals from the, in criminal cases, Appendix, p. 486; and see Criminal Appeal, Coort of.

ASSUMPSIT, ACTION OF, 281

ATTAINDER, 238

ATTORNEY-GENERAL

appointment and duties of the, 193

AUDIENCE, COURTS OF, 253

AUDITOR-GENERAL, FUNCTIONS OF THE, 212

AUSTRALIA, THE COMMONWEALTH OF, 444

alteration of the Constitution, 446

Australian and Canadian Constitutions compared, 447

federal constitution, the, 444

courts, the, 445

appeals from, 446

executive, the, 444

legislature, the, 445

AUXILIARY FORCES, THE, 374

Militia, the, 369. 371, 374

Territorial Army, 376

Volunteers, the, 376

Yeomanry, 375

BAHAMAS, THE, 432

BAIL, 231

BALLOT, THE MILITIA, 375

BALLOT ACT, REGISTRATION UNDER THE, 62

BANKRUPTCY, THE COURT OF, $298,302 n$.

BARBADOS, 432

BARON, THE COURT, 223, 234

BARONS

created by tenure originally, 73,74

creation of, by letters patent, 74

by writ, and taking seat in House of Lords, 74 
BARRISTERS, HISTORY OF', 292

BASUTOLAND, 429

BATTLE, TRIAL BY, 228

BENEFICE, ENTRY UPON, 327

BENEFIT OF CLERGY, 239, 256

BENEVOLENCES, 100

forbidden by Petition of Right, 8, 101

BERMUDA, 432

BHUTAN, BRITISH RELATIONS WITH, 461

BILL OF RIGHTS, THE, 2, 8 provisions of 8,9

BIllis in Parliament. See Bills, Public, Private, Moner.

BILLS, CONSOLIDATED FUND, 91

BILLS, MONEY, 88

Committee of Supply, 90

of Ways and Means, 90

constiutional position with regard to, 90

procedure with regard to, 90

under the Parliament Act, 1911...92

BILLS, PRIVATE, 86

procedure on enactment of, 86

BIJLS, PUBLIC, $81-86$

committee stage, 82

creation of peers to ensure passage of, in Lords, 84

first reading, 82

leave to introduce, 82

money and appropriation Bills originate in Commons, 81,88

notice of motion, 81

origin of, 81

procedure on enactment of, 81

reading in the other House, 83

refusal of royal assent, 86

rejection of, by the other House, 84

report stage, 83

royal assent, 86

second reading, 82

sending on the Bill, 83

third reading, 83

under the Parliament Act, 1911...86

BISHOPS

appointment of 77,322

coadjutor, 322

duties of 322

objections, on confirmation of, 78

suffragan, 322

trial of, 239,322

BLASPHEMY, 44

BOARD OF TRADE, THE, 208

BORNEO, NORTH, 469 
BOROUGH COUNCILS, 396

in the metropolis, 394

BOROUGH SESSIONS, 263

BOT, 217

BREACH OF TRUST

claims for, how far barred by Statute of Limitations, 302

BRITISH COLUMBIA, 433

BRUNEI, 469

BURGHMOTE, 223

BUSHELL'S CASE, 3

BUTLERAGE, 95

CABINET, THE, 171

composition of, 174

constitutional position of, 178

duties of, 180 et seq.

history of, 171

how formed, 178

relations with the Crown and Parliament, 180-184

responsibility of, 184

CANADA, THE DOMINION OF, 433, 441

ceded by the French, 441

Constitution under the British North America Acts, 441

courts of, the, 443

executive in, the, 442

legislature in, the, 442

provincial legislatures in, 443

provinces of , 433,442

CANONS, APPOINTMENT OF, 323

enactment of, by Convocation, 319

CASE STATED, 310, 482

CATHEDRAL

deans and chapters of, 323

CENTRAL AFRICA, BRITISH, 467

CENTRAL CRIMINAL COURT, THE, 263

CERTIORARI, WRIT OF, 232

in criminal cases, Appendix, p. 490

CEYLON, 432

CHANCELloR. See under Lord Chaxcellor; Laxcaster, ChaxCELLOR OF.

CHANCERY

Inns of, 293

CHANCERY, THE COURT OF

appeals from, 240,247

composition of, under the Judicature Acts, 301

early stages of, 244 
CHANCERY, THE COURT OF-continued. jurisdiction of, 245,301

procedure, 245

rise of, 244

CHANNEL ISLANDS, THE, 417

Alderney, 421

constitutional position of, 417

Guernsey, 420

Jersey, institutions of, 417

King's writ does not run in, 419

Sark, 421

CHAPELS OF EASE, 329

CHAPLAINS, 324, 329

CHAPTER, CATHEDRAL, 323

CHARTERS

permitted in evidence under the Anglo-Saxons, 220

CHESTER, COUNTY PALATINE OF, 276

CHURCH, THE

in the Colonies, 351

in Ireland, 334

in Scotland, 336

in Wales, 337

abolition of powers of Ecclesiastical Commissioners and Queen Anne's Bounty, 343

border parishes, provisions as to, 346

Commissioners, the Welsh, 341 appeals from, 342

disestablishment of the Welsh Church, 337 effect of, 337

ecclesiastical law, effect of Welsh Church Act on, 338 enforcement of, as to property, 340

existing interests, preservation of, 348 commutation of, 348 compensation for, 348

property of the, 340

application of, by Welsh Commissioners, 347

distribution of, by Welsh Commissioners, 344

vesting of, under the Welsh Church Act, 1914...342

representative body, power of Church in Wales to form, 339

vestries and churchwardens, transfer of powers of, 349

CHURCH ASSEMBLT, THE, 333

CHURCH OF ENGLAND, THE ESTABLISHED, 316-353

archbishops of, 77,321

Articles of Religion, the Thirty-Nine, 320

Assembly, the, 333

bishops of $, 77,322$

canons, enactment of, 319

Church Council, the Parochial, 334

Common Prayer, the Book of, 321

Convocations, 318

deans and chapters of cathedrals, 323 
CHURCH OF ENGLAND, THE ESTABLISHED-continued.

ecclesiastical dignitaries, 321

divisions, 321

establishment, meaning of, 316

Laymen, the Houses of, 320,333

Reformation, changes brought about by the, 317 position of the Church before the, 316

Rome, appeals to, 317

CIRCUITS, COUNTY COURT, 271

CIRCUIT SYSTEM, THE, 259

CIVIL LIST, THE, 111, 150

application of, 151

origin of, 111

CIVIL SERVICE, THE, 197

CIVIL SERVICE, THE INDIAN, 459

CLERGY

beneficed, the, 324

benefit of, 239,256

disabilities of the, 332

entry upon benefice, 327

franchise of the, 318

offences of the, how tried, 253

ordination of the, 331

privileges of the, 332

right of the, to vote at Parliamentary elections, 318

taxation of the, 317,318

unbeneficed, the, 328

CLERK OF THE PEACE, 403

CLOSURE, THE, 67

COIF, ORDER OF THE, 294

COLLATION, 328

COLLUSIVE ACTIONS, 284

COLONIAL FORCES, THE, 373

COLONIAL OFFICE, THE, 202

COLONIAL SECRETARY, THE, 176, 202

COLONIES, THE, 423

appeals from colonial courts to the Privy Council, 426

bishops, appointment of, in, 352

Church in, the, 351

classification of colonies, 429

colonial governors, 435

colonies with representative governments, 431,432

with representative institutions, legislation in, 428

conquered and ceded colonies, 424

crown colonies, 429

legislation in, 128

definition of colony, 423

ecclesiastical jurisdiction in, 352

English comnion law in, 423

legislation by the Cromn in, 425, 428 
COLONIES, THE-continued.

native laws in, 424

privileges of colonial parliaments, 434

recognized in royal title, 143

settled colonies, 423

special leave to appeal from colonial courts, 426

Vice-Admiralty courts in, 250

COMMISSIONERS FOR ECCLESIASTICAL CAUSES, THE COURT OF, 8,255

declared illegal, 8,255

COMMITTEE OF SUPPLY, 90

COMMITTEE OF WAYS AND MEANS, 90

COMMON PLEAS, THE, 230

not to follow the King, $7,222,226$

when fixed at Westminster, 222, 230

COMMUNE CONCILIUM, THE, 222, 230

COMPTROLLER AND AUDITOR-GENERAL

appointment and duties of the, 212

COMPURGATION, 219, 229

CONSCIENCE OR REQUEST, COURTS OF, 270

CONSIMILI CASU, 234

CONSISTORY COURTS, THE, 253

CONSOLIDATED FUND, THE, 93

CONSOLIDATED FUND ACTS, 93, 94

CONSORT, THE KING AND QUEEN, 152, 153

CONSTABLE, OFFICE OF THE, 280

CONSTABLE AND EARL MARSHAL, COURT OF THE, 280

CONSTABLE, THE CHIEF, 404

CONSTITUTIONAL LAW

characteristics of English, 12

sources of English, 1-11

CONSULS, Appendix B, p. 506

CONTRACT, ACTIONS FOUNDED ON, 281

CONVENTIONS, $3-6$

examples of, 3

nature of, 4

observance of, necessity for the, 6

sanction of, 5

the adoption and observance of, a characteristic of the English constitution, $3,4,50$

CONTOCATION

clergy tazed themselves in, 52, 318

enactment of canons by, 319

meetings of, 320

summons of, 318

CORONATION

ceremonies observed on, 141 
CORONATION OATH

obligatory on person inheriting the crown, 10, 141, 144

CORONER, THE, 268

court of, 268

duties of, 269

CORPORATION PROFITS TAX, 104

CORPUS CUM CAUSA, WRIT OF, 245

COUNCIL OF INDIA, THE, 454

COUNCIL, THE KING'S, 230, 233, 241

appellate jurisdiction of $240,241,247,250,255,314$

transferred to the Judicial Committee of the Privy Council, 247

original jurisdiction of , 230, 233,241, 247

procedure of, 241

splits off from Parliament, 241

COUNTY COUNCIL, THE, 397

COUNTY COURT, 270

Admiralty jurisdiction of the, 274

appeals from the, 272

circuits, 271

judges, appointment of , 193, 271

juries, 273

jurisdiction of the, 272

extended to $£ 100$ in contract and tort, 272, 273 stannaries trausferred to, 275

in Norman times, 223

procedure in the, 271

COURT BARON, THE, 223

COURT-MARTIAL, TRIAL BY, 383-385

\section{COURTS}

Anglo-Saxon, the, 218

Mayor's, the, 274

Norman, the, 221

Palatine, the, 276

Superior, the, before and after the Judicature Acts, 298

Welsh, the, 277

COVENANT, ACTIONS OF, 281

CRIMINAL APPEAL, THE COURT OF, 306, 479

various modes of, 479 et seq.

CROWN, THE

abdication of James II., 139

accession and coronation, 141

allegiance to, from whom due, 144

appointment of judges by, 159

ceremonies on coronation, 141

Civil List, the, 150

coronation oath, the, $10,141,144$

declaration against transubstantiation, 9,141

demise of, 140, 143

$\checkmark$ dismissal of servant by, 357

duty of, to the subject, 144

grant of monopolies by, 157

C.L.E. 
CROWN, THE-continued.

growth of doctrine of hereditary right, 139

in Colonies, 425

in relation to the royal family, 151

legislation by, illegal, 13, 161

in colonies, $161,425,431$

$\checkmark$ liability of, in actions of tort, 37

in contract, 37

$\checkmark$ limitation of actions by, 165

limitations of succession to, by Bill of Rights, 9, 139

maintenance of a standing army by, 156

no papist may inherit, 9, 139

prohibition against marrying papist, 9, 139

$\checkmark$ right of subjects to petition, 9

royal title, the, 138,143

succession to, 9,139

suspending and dispensing powers of, 8, 39, 158

taxation by, 155

title to 138

the Act of Settlement, 10, 139

the royal prerogative, 154

conduct of foreign relations by, Appendix, p. 504

CROWN CASES RESERVED, THE COURT OF

composition of, former, 306

questions of law reserved for, 305

transfer of jurisdiction of, to Court of Criminal Appeal, 305, 306

CROWN LANDS, 110

control of, 112

the revenue from, relinquished to the nation, 111

CURATES, PERPETUAL, 325

CURATES, STIPENDIARY, 328

CURIA REGIS, 222

CUSTOMARY COUR'T IN MANORS, THE, 224

CUSTOMS, THE

condition of, in $1815 \ldots 96$

collection of, 97

history of, 95

origin of, 95

present state of, 97

punishment of offences against, 98

tariff revisions, 97

CUSTOS ROTULORUM, THE, 402

CYPRUS, 476

DARREIN PRESENTMENT, ASSIZE OF, 228

DEAT AND CHAPTER, THE, 323

DEAN, 'THE RURAL

appointment and duties of, 323 
DEATH DUTIES, THE, 113

estate duty under the Finance Act, 1894...119

generally, 113

legacy duty, 114

settlement estate duty, 125

succession duty, 117

DEBATES, PARLIAMENTARY

freedom of, 68

publication of, 68

DEBT, ACTIONS OF, 281

DEFAMATORY WORDS

definition of, 43

DEFENCE COMMITTEE, THE IMPERIAL, 207

DE HERETICO COMBURENDO, WRIT OF, 257

DELEGATES, THE COURT OF, 250, 255

DENIZATION, LETTERS PATENT OF, Appendix, p. 512

\section{DENIZEN}

status of, 11, Appendix, p. 512

DEPARTMENTS, THE GOVERNMENT, 196 advantages of parliamentary heads to, 198 generally, 196

non-political departments, 216

political departments, 200

DETINUE, 281

\section{DIPLOMATIC AGENTS}

appointment, duties, and status of, Appendix, p. 504

DISSOLUTION OF PARLIAMENT, 56

DIVISIONAL COURT, THE

appeals from, 305

appeals from quarter sessions to 305,483

appeals to, generally, 305

appeals to, from county courts, 268

composition of, 305

DOM-BOC, 219

DOMESDAY BOOK, COMPILATION OF, 221

DONEES, 326

DRILLING, UNLAWFUL, 516

DROIT ADMINISTRATIF, 40

not admitted by English constitution, 40

DUKE

origin of title, 72

DUKE OF CORNWALL

the Black Prince created, 73

DURHAM, COUNTY PALATINE OF, 276 


\section{EARL}

origin of the title, 73

EARL MARSHAL

court of the constable and, 280

office of the, 280

ECCLESIASTICAL COURTS, THE, 250

abolition of, in $1640 \ldots 257$

appeals from, 247

ecclesiastical divisions, 251 $1 \mathrm{aw}, 250$

jurisdiction of, 255

restoration of, 257

separation of civil and, 225, 251

EDITCATION, THE BOARD OF, 215

EGYPT

British relations with, history of, 471

judiciary in, 474

legislative institutions, 474

present relations with Great Britain, 476

Soudan, the, 475

Suez Canal, the, 475

EJECTMENT, ACTION OF, 282

ELECTION OF Members of PaRLiament. See Parliament, Hodse of Commons, Franchise.

ELECTORATE, THE

the political sovereign, 5

ultimate power of, 4

EMERGENCY POWERS, 161

ENGLISH CONSTITUTION

flexibility of the, 15

EQUALITY OF ALL PERSONS BEFORE THE LAW, 37 exceptions to the rule, $37-39$

EQUITABLE SYSTEM evolution of an, 246

EQUITY, RULES OF, 302

to be observed in all the courts, 303

ERROR, WRIT OF, 227, 233

abolition of, 232,310

in criminal cases. Appendix, p. 487

ESTATE DUTY, 119

allowances, 122

by whom payable, 124

property subject to, 120

rates of duty, 121, 123

relief from, on quick snccessious, 123

valuation of estate for purposes of, 121

when payable, 124

EXAMINATION OF INTENDING CLERK IN HOLY ORDERS, 331

EXCHEQUER CHAMBER, THE COURT OF, 240

EXCHEQUER, THE, 210 
EXCHEQUER, THE COURT OF, 223, 230, 233

EXCISE, THE

duties, collection of, 99

history of, 98

licences, 99

EXECUTIVE, THE

nlembers of , 137, 175, 192-216

Privy and Cabinet Councils, and the Ministry, 168-191

the Crown the head of 137,165

FACULTIES, MASTER OF THE, 253

FALKLAND ISLANDS, THE, 430

FEDERAL CONSTITUTIONS

America, 15

Australia, 444

Canada, 433

characteristics of, 14, 15

Switzerland, 19

Union of South Africa, 449

FEDERATION, IMPERIAL, 21

general conclusions as to, 26

proposed federal constitutions, 24

requirements for successful, 21

topics for, 23

FEUDAI, SYSTEM, THE, 220

FIJI, 432

FINES, 284

FISHERIES, THE MINISTRY OF AGRICULTURE AND, 214

FORCED LOANS AND BENEVOLENCES, 100

forbidden by Petition of Right, 8, 101

FOREIGN ENLISTMENT ACT, THE, Appendix, p. 509

FOREIGN OFFICE, THE, 201

FOREIGN SECRETARY, THE, 197, ¿U2

FOREST COURT, THE, 224

FRANCHISE, THE PARLIAMENTARY, 60

occupation, legal requirements for, 60

persons discualified from exercising, 61

registration of votes, 62

Scotch property qualifications, 404

the occupation, 60

the service, 60

the university, 60

the women, 60,63

FRANCHISE, THE LOCAL GOVERNMEN'T, 391, 395, 398

FRANKPLEDGE, 219, 223, 229 
FREEDOM FROM ARREST, 64

FREEDOM OF DISCUSSION, THE RIGHT TO, 42

limits of , 42

meaning of, 42

FREEDOM OF SPEECH

declared a privilege of Parliament, 9

in Parliament, 64

GAMBIA, 430

GAMBIA, TERRITORIES ADJACENT TO, 467

GENERAL GAOL DELIVERY, COMMISSIONS OF, 260

GENERAL PRINCIPLES OF CONSTITUTIONAL LAW FROM

DECISIONS IN PARTICULAR CASES, INDUCTION OF, 41 a characteristic of the English constitution, 12, 41

freedom of discussion, 42

the immunity of judges, 41

the independence of juries, 41

the right of public meeting, 46

GENTLEMAN U'SHER OF THE BLACK ROD, THE, 59

GIBRALTAR, 429

GLOUCESTER, STATUTE OF, 226

GOLD COAST COLONY, THE, 430

GOVERNOR-GENERAL, THE

of Australia, 444

of Canada, 442

of India, 455

of the Union of Sonth Africa, 449

GOVERNORS. COLONIAL

constitutional position of , 435

liability of 437

powers and duties of, 439

GRENADA, 430

GUARDIANS, POOR LAW, 392, 396

in urban districts, $396 \mathrm{n}$.

GUERNSEY, INSTITUTIONS OF, 417, 420

GUIANA, 432

GLILLOTINE, 67

\section{HABE.AS CORPUS}

Act. suspension of the, 28

ad subjiciendum. Appendix, p. 498

different forms of writ, Appendix, p. 498

the writ of: 28,498

HERESY, 257

HIGH COMMISSION, THE COURT UF, 254 
HIGH COURT OF JUSTICE, THE, 299

appeals to, 305

composition of, 299

jurisdiction of, 301

HOLY ORDERS, 331

HOME OFFICE, THE, 200

HOME SECRETARY, THE, 176, 200

HONDURAS, BRITISH, 430

HONG KONG, 430

HOUSE OF COMMONS, THE, 60

disputed elections, 62,66

disqualification of members, 71

Velection petitions, 62,66

evidence of title to sit in, 54

expulsion of members, 66

$\checkmark$ franchise, the, 60

oath, the Parliamentary, 54

origination of Bills by, 81,90

privileges of the, 63

resolution of, cannot make new law, 13

speaker of, election of the, 59

HOUSE OF LAITY, 333

HOUSE OF LORDS, appeals to, 313

appellate jurisdiction of, $\mathbf{2 4 0}$

composition of the, 72

composition of the, on hearing appeals, 313

creation of peers. 74

eviderice of title to sit, 54

Irish representative peers, 75

lords of appeal in ordinary, the, 79

privileges of the, 79

Scotch representative peers, 76

spiritual peers, 77

the Lord Chancellor the Speaker of, 58

the gentleman usher of the black rod, 59

trial of peers by, 238

HOWELL'S CASE. 3

HUNDRED COURT: THE, 219, 223

\section{IMPEACHMENT}

history of, 237

pardon by Crown no bar to an, 11, 501

procedure on, 238

IMPROPRIATORS, LAY, 326

INCOME TAX, THE, 101

abatements, 103

classification of incomes for purposes of, 102

collection of, 105

exemptions, 102

history of taxes on personalty, 101 
INCOME TAX, THE-contimued.

imposition of, 101

incidence of 101

relief from, 104

super tax, 104

INCREMENT VALUE DLTY, 126

INDEMNTTY, ACT OF, 28

INDIA, THE EMPIRE OF, 452

British sovereignty in, 452

Civil Service, the Indian, 459

constitution of, 453

Council of India. the, 454

dependent native states, 460

forces, the Indian, 362, 372

Governor-General in Council, the, 455

India Office, the, 202

judiciary, the Indian, 458

legislative council, the, 456

local governments in, 457

Secretary of State for India, the, 176, 202, 454

INDIA, THE SECRETARY OF STATE FOR, 176, 202, 454

INDIA OFFICE, THE, 202

INDIAN FORCES, THE, 362, 372

INHABITED HOUSE DUTY, THE, 109

assessment of, 109

history of, 109

incidence of, 109

rates at which payable, 109

INJUNCTION, 245

INNS OF CHANCERY, 293

of Court, 293

INQUEST

coroner's, the, 268

procedure by, 227

INSPECTOR-GENERAL OF THE FORCES, THE, 207

INSTITUTION TO BENEFICE, 327

INTERROGATORIES, 245

INTIMIDATION OF PARLIAMENT, 515

IRELAND

church in, the, 334

Free State Act, 408

Government of Ireland Acts, 1914 and 1920...407

Irish Office, the 213

lord-lientenant, the. 213

Parliament, oath by numbers, 410

status of, 410

I'nion, the Act of, 405 
IRISH FREE STATE (AGRFEMENT) ACT, 408

IRISH OFFICE, THE, 213

ISLANDS, MISCELLANEOUS, 477, 478

ISLE OF MAN, THE. 421

JAMAICA, 432

JERSEY, INSTITUTIONS OF, 417

JUDGE-ADYOCATE GENERAL, THE, $386^{\circ}$

JUDGE-ADVOCATES, 387

JUDGES

appointment of, $11,159,294$

immunity of, for acts outside jurisdiction, 38 for official acts, $3,38,41$

JUDICATURE ACTS, THE. 299-315

changes effected by, 299

rules of law introduced by, 302

JUDICIAL COMMITTEE OF THE PRIVY COUNCIL, 241, 247, 314 archbishops and bishops as assessors of, 315

composition of, 314

jurisdiction of, $241,247,304,314$

quorum of, 315

JUDICIAL INSTITUTIONS

Anglo-Saxon period, 218

changes under the Judicature Acts, 298

Edward I. to the Judicature Acts, 236

in the reign of Edward I., 229

Norman period, 221

JUDICIARY, THE, 217

JUDICIUM PARIUM, 224

JURIES

independence of, 3,290

JUR

alien on, 287

civil, the, 286

criminal, the, 288

dismissal of, by the iudge, 291

independence of the, established, 3, 290

trial by, 286

women on, 287

JUSTICES OF THE PEACE, 264

liability of, for official acts, 39

petty sessions, 265

qualification of, 264

quarter sessions, 261

summary jurisdiction of, 266

JUSTICES, WRIT OF, 226 
KENT, CUSTOMS OF, 225

KENYA, 467

KING, THE. See under Crown.

KING'S BENCH, THE, 230, 298, 301

KING'S COUNCIL, THE. See under Council, the King's,

KING'S COURT, THE, 222, 230. See under Common Pleas, King's Council, King's Bench.

LABUAN, 429

LAGOS, THE FORMER COLONY OF, 430

LAITY, HOUSE OF, 333

LANCASTER, COUNTY PALATINE OF, 276

LANCASTER, THE CHANCELLOR OF THE DUCHY OF, 138, 195

LAND TAX, THE, 106

assessment of, 106

history of, 106

incideñce of, 108

quotas of, for Scotland and England fixed, 107

redemption of, 108

LAND VALUE DUTIES, THE, 126

abolished, 126

appeals, 128

exemptions, general, 127

increment value duty, 129

mineral rights duty, 134

reversion duty, 131

undeveloped land duty, 132

LATERAN COUNCIL, THE, 220, 229

LATITAT, WRIT OF, 226

LAYMEN, HOUSE OF, 320, 333

LEAGUE OF NATIONS, 517

LECTURERS, 330

LEET, COURT, 226

LEEWARD ISLANDS, THE, 432

LEGACY DUTY, 114

exemptions, 115

foreign personalty, when subject to, 116

payable in addition to estate duty, 114

property subject to, 114

rates of duty, 115

reduction of duty, 116

LEGISLATION BI MEASURES, 334

by Order in Council, 13, 161

by Proclamation, 160

Emergency, 161

LEGISLATURE, THE, 51-80

composition of, 51 
LIBEL, 43

a criminal offence in certain cases, 43

LOCAL GOVERNMENT, 390

borough councils, 396

district council, the, 395

county councils, the, 397

general scheme of, in England and Wales, 390

parish council, the, 392

meeting, the, 391

vestries, 393

LOCAL GOVERNMENT BOARD, THE, 213

LORD CHANCELLOR, THE, 192

appointment of, 192

ex-lord chancellors, 311

position and duties of, 192, 311

LORD CHIEF JUSTICE, THE

appointment of, 193

member of Court of Appeal, 311

was obliged to sit in the former Court of Crown Cases Reserved, 306

LORD HIGH STEWARD, THE, 239

Court of, 239

LORD LIEUTENANT, THE, 401

appointment and duties of, 401

LORD LIEUTENANT OF IRELAND, THE, 213

LORDS MARCHERS, THE, 277

LORDS OF APPEAL IN ORDINARY, THE, 79, 314

LORDS, THE HOUSE OF. See under HodsE OF LoRDs.

\section{MAGISTRATE}

duty of, to suppress riot or insurrection, 30,47

Magistrates. See under Justices of the Peace, Quarter Sessions, Petty Sessions. stipendiary, 270

MAGNA CARTA

a constitutional landmark, 2,6

provisions of, 6,7

MALTA, 432

MAN, THE ISLE OF, 421

institutions of, 421

sovereignty of, 421

MANDAMUS, THE WRIT OF, 231

does not lie to judge of the High Court on assize, 261

MANDATORY SPHERES, 470, 518

MANITOBA, 442

MANORIAL COURTS, THE, 223, 234

replaced by the county courts, 270

MARCHERS, THE LORDS, 277

jurisdiction of, abolished, 277 


\section{MARQUESS}

origin of title, 73

present numbers of, 72

MARSHALSEA, THE COURT OF THE, 279

MARTIAL LAW, 29-36

extent of Crown's right to proclaim, 32

how far admitted by English constitution, 30, 36

indemnity for Acts done under, 31, 35

issue of commissions of forbidden, 8, 156, 382

meaning of term, 29

proclamation of, in South Africa, 33

instances, 32

in time of peace illegal, $8,35,156,382$

by virtue of the prerogative, 32

rights at common law, 30

sentences of imprisonment, how far valid under, 32, 35

MAYOR, 397

MAYOR'S COURT, THE, 274

MEASURES, LEGISLATION BY, 334

MERCHANT

guilds, 278

law, the, 277

MERGER

provision of Judicature Act, 1873, with regard to, 302

MIDDLESEX, BILL OF, 231

MIIITARY LA II, 383

features of, 383

what constitutes, 383

MILITARY SERVICE IN FEUDAL TIMES, 221

MILITIA, THE, 369, 371, 374

compulsory system, the, 375

special reserve now called, 371

transfer of, to Territorial Forces, 376

MILITIA RESERVE, THE, 371

MINERAL RIGHTS DUTY, 134

MINISTERS OF CHAPELS OF EASE, 329

MINISTRY, THE

dismissal of, by the Crown, 5, 187

dissolution of, 187

distinguished from the Cabinet, 172, 175

members of, 175,177

nomination of, 175

responsibility of, 187

resignation of, 5, 188

status of , 177 
MONASTERIES, DISSOLUTION OF THE, 325

MONEY BILLS, 88 introduction of, by Minister of the Crown, 88 originate in Commons, 89 procedure on enactment of, 90

MORT D'ANCESTRE, ASSIZE OF, 228

MORTON'S FORK, 100

MUTE, STANDING, 289

MUTINY, INCITEMENT TO, 516

NATAL, 449

NATURALIZATION

effect of, 145

how effected, 146

revocation of, 148

NAVY, THE

discipline in, 357

enlistment in, 354

maintenance of, 354

naval courts-martial, 358

reserve, the, 355

persons subject to the Naval Discipline Acts, 357

NE EXEAT REGNO, WRIT OF, 242

NEPAL, BRITISH RELATIONS WITH, 461

NEW BRUNSWICK, 433, 442

NEWFOUNDLAND, 433

NEW SOUTH WALES, 434, 444

NEW TRIAL

in criminal cases, Appendix, p. 495

NEW ZEALAND, 433

NIGERIA, COLONY OF, 430

NIGERIA, PROTECTORATE OF, 467

NISI PRIUS, COMMISSIONS OF, 234, 260

NON-SOVEREIGN LAW-MAKING BODIES, 14

companies, 14

federal States, 15-21

NORMAN COURTS OF JUSTICE, THE, 221

NORTHERN TERRITORIES OF THE GOLD COAS'T, 467

NORTH-WEST TERRITORIES, THE, 434, 442

NOYA SCOTIA, 433, 442

NOVEL DISSEISIN, ASSIZE OF, 227 


\section{OATH}

affirmation in lieu of, 55

the Parliamentary, 54, 56

OATHS, ADMINISTERING UNLAWFUL, 515

OBSCENE WORDS. 44

OFFICIAL SECRETS, 41

ONTARIO, 433, 442

ORANGE FREE STATE, 449

ORDEAL, 220

ORDERS, HOLY, 331

ORDERS IN COUNCIL, 13, 161

OYER AND TERMINER, COMMISSIONS OF, 242, 260

PALACE COURT, THE, 279

\section{PALATINE. THE COUNTIES}

courts of the, 276

jurisdiction of the courts of, 276

\section{PARDON}

petitions for, Appendix, p. 501

reference of petition for, to Court of Criminal Appeal, 502

\section{PARISH}

council, the, 392

definition of, 391

meeting, the, 391

\section{PARISH CHURCH, ORIGIN OF THE, 324}

PARLIAMENT. See also House of Commons, House of Lords. adjournment of, 58

as a court of first instance, 239

composition of , $6,51,53$

consent of, necessary to taxation, 6,8

dissolution of, 56

duration of, 56

not affected by demise of the Crown, 57

effluxion of time, 57

- first shire representation $3 n, 51$

High Court of, 236

impeachments in, 237

intimidation of, 515

meeting of, 52

necessity for frequent summons of, 52, 53

$\checkmark$ opening of, 54

petitions to, 233

power of, extermal and internal limits to the, 13

privileges of , 63,79

prorogation of, 58

provisions of Magna Carta with regard to, 51

representation of clergy in, 52 
PARLIAMENT-continued.

Simon de Montfort's, 51

sovereignty of, 12

speech from the throne, 56

statutory authorities for regular summons of, 52, 53

summons by proclamation, 52,53

termination of , 56

the appellate jurisdiction of , 240,313

the franchise, 60

to whom writs of summons issued, 53

PARLIAMENT ACT. 1911, PROTISIONS OF THE, 57, 84, 92 as to money bills, 92

as to public bills. 84

PARLIAMENTARY PRIVILEGES, 63, 79

courts may determine extent of, 70

PAROCHIAL CHURCH COUNCILS, 334

PARSON, 324

PECUIIAR COURTS, THE, 254

PEERESS

cannot sit in House of Lords, 74

PEERS

creation of, 74

Irish representative, 75,410

restrictions on creation of, 74

Scotch representative, 76,404

spiritual peers in House of Lords, 77

trial of , in treason and felony, 238

PEINE FORTE ET DURE, 218, 288

PENSIONS, MINISTRY OF, 214

PERIM, 477

PERPE'TUAL CURATES, 325

PERSONAI ACTIONS, DIVISION OF, 281

PERSONAL FREEDOM

safeguards for, 27

the right to, 27

PERSONALTY, TAXS ON, 99

PETITION OF RIGHT

procedure by, 37, 165

PETITION OF RIGHT, THE, 2, 7, 8

a constitutional landmark, 2, 7

provisions of, 7,8

PETTY BAG OFFICE, THE

duties of, transferred to the Crown Office, Appendix, p. 488, note $(h)$

PETTY SESSIONS, 264

appeals from, 267

courts of, how constituted, 265

jurisdiction of, 265

procedure at, 267

PIED POUDRE, COURTS OF, 279 
POLICE COURTS, METROPOLITAN, 270

POLICIES OF ASSURANCE, THE COURT OF, 279

PONE, WRIT OF, 227

POSTMASTER-GENERAL, THE, 176, 212

POST-OFFICE, THE, 212

PRACIPE QUOD REDDAT, WRIT OF, 226

PREMUNIRE, 78, 242, 245

PRAMUNIENTES CIAAUSE

in writs to the bishops, 52

PRAYER BOOK, THE, 321

PREBENDARIES, 323

PREROGATIVE COURTS, THE, 252

PREROGATIVE, THE ROYAL, 15t-167

definition of, 154

delegated, 162

limitations of, 154

martial law by virtue of, 32

merger of, 164

origin of, 154

present state of, 163

with relation to the colonies, 425

PRESENTATION, 327

\section{PRESS}

freedom of the, 45,46

restrictions, 45

PRINCE EDWARD ISLAND, 433, 442

PRINCE OF WALES, THE, 151, 152

\section{PRIVATE BILLS}

procedure on enactment of, 86

PRIVIIEGES OF THE HOUSE OF COMMONS, 63 access to the Crown, 65

closure, 67

commitment for contempt, 69

courts may determine validity of, 70

demanded by Speaker, 63

exclusion of strangers, 67

enforcement of privileges, 69

exemption from attending as witnesses, 70

freedom from arrest, 64

freedom of speech, 64

publication of debates, 68

regulation of proceedings, 66

sheriff, exemption from service as, 70

the right to have the most farourable construction placed upon proceediugs, 65

the right to provide for its due composition, 65 
PRIVILEGES OF THE HOUSE OF LORDS, 79

PRIVY COUNCIL, THE

appellate jurisdiction of , 247, 256,314, 426

colonial appeals, 426

composition of , 170

duties of , 168, 169

ecclesiastical appeals to, 256

judicial committee of, 247,314

original jurisdiction of, 241

PRIVY COUNCILLORS

appointment of, 170

persons born outside the United Kingtom may not be, 11, 170

unless naturalized, 11,170

status of, 171

PRIVY SEAL, THE

documents no longer passed under, 193

PRIVY SEAL, THE LORD

duties of, abolished, 193

office of, 193

PROBATE, FORMERLY GRANTED BY ECCLESIASTICAL COURTS, 255

PROBATE, DIVORCE; AND ADMIRALTY DIVISION, THE, 300

PROBATE DUTY, 113

not payable since August 1st, 1894...114

\section{PROCEDURE}

abolition of forms of actions, 282

abolition of real and mixed actions, 28.2

Anglo-Saxon, 221

by criminal appeal and battle, 229, 230

by inquest or assize, 227

civil actions, in, 281

criminal, before and after 1688...289

divisions of actions, 281

ejectment, the action of, 282,283

forms of actions, 281

mixed actions, 282

Norman, 228

on appeals in criminal cases, 306, 479

peine forte et dure, the, 218, 288

personal actions, 281

real actions, 282

trial by jury, 286

PROCLAMATION, LEGISLATION BY, 160

PROHIBITION, WRIT OF, 231

in criminal cases, Appendix, p. 497

PROPERTY AND INCOME TAX See INCONE TAX.

PROTECTORATES, BRITISH, 462

characteristics of, 462

classification of, 465

C.L.E. 
PROTECTORATES, BRITISH-continued.

government of, 466

Indian dependent native States, 460

jurisdiction in, 463, 464, 466

protected subjects, status of, 465

PROVINCIAL COURTS, THE, 252

PUBLIC MEETING, THE RIGHT OF, 46

meaning of, 46

restrictions as to, 46

unlawful assembly, 47, 516

PUBLIC OFFICERS

liability of, for official acts, 38

PUBLIC REVENUE, 93

advances on Treasury Bills, 94

authority for expenditure of, by Treasury, 93, 94

Consolidated Fund services, 93

Crown Lands, revenue from, 110

Customs, the, 95

death duties, the, 113

Excise, the, 98

generally, 93

growth of the, 94

income tax, the, 99, 101

inhabited house duty, the, 109

land $\mathrm{tax}$, the, 106

land value duties, 126

paid into Consolidated Fund, 93

payment out of Consolidated Fund, 93, 91

supply services, 93

super tax, 104

QUARE IMPEDIT, WRIT OF, 282

QUARTER SESSIONS, THE, 261

appeals from, 263,307

appeals to, from petty sessions, 267, 479

QUASI STATUTES, 2

QUEBEC, 433, 442

QUEENSLAND, 434, 444

QUOMINUS, WRIT OF, 233

QUO IYARRANTO, WRIT OF, 221, 224, 234

READERS, 331

REAL ACTIONS, 282

REBELLION, COMMISSIONS OF, 242

RECORDARI FACIAS, WRIT OF, 227

RECOYERIES, 285

RECTOR, 324 
REGISTRATION (PARLIAMENTARY), 62

effect of, 62

of parliamentary voters, 62

REGULAR FORCES, THE, 362

army reserve, the, 367

colonial forces, the. 362,373

composition of, 362

Indian forces, the, 362,372

maintenance of, 363

marines, the, 371

martial law, $29,360,382$

military law, 382

militia, the, 369,374

special reserve, the, 369

term of service, 366

REQUEST OR CONSCIENCE, COURTS OF, 270

REQUESTS, THE COURT OF, 244

RESERVE FORCES, THE

army reserve, the, 367

militia reserve, the, 369

naval reserve, the, 355

special reserve, the, 369

RESPONSIBILITY, MINISTERIAL, 184

in the colonies, 437

RETURNING OFFICERS

writs directed to, 53

Revenue. See Public Revenue.

REVERSION DUTY, 131

RHODESIA, NORTHERN, 468

RHODESIA, SOUTHERN, 468

RIGHT, WRIT OF, 226

RIOT

duty of magistrate to suppress, 30,47

RIOT ACT, EFFECT OF READING THE, 47

ROYAL FAMILY, 'THE, 151

marriage by nembers of, 152

precedence of royal children, 152

the Duke of Comwall, 152

the King and Queen Consort, 152, 153

the Prince of Wales, 152

what persons comprised in, 151

ROYAL JUSTICE, RISE OF, 225

ROYAL TITLE, 143

ROYAL WRIT, THE, 226

RURAL DEAN, THE, 323

court of, 254 
$S A C$ AND $S O C, 221$

SAILORS

and soldiers, liability of, for acts done under orders, 359 engagement of, 354

liability of superior officers to subordinate, 360

protected from arrest for debt, 359

subject to the jurisdiction of the ordinary courts, 358,359

wrongful dismissal of, 361

ST. HELENA, 429

ST. LUCIA, 430

ST. VINCENT, 430

SANITARI AUTHORITIES, 395

SARAWAK

constitutional position of, 425

protectorate of, $469, n$. (a)

SARK, INSTITUTIONS OF, 421

SARUM, S'TATUTE OF, 221

SCIRE FACIAS, WRIT OF, 242

SCOTCH OFFICE, THE, 212

SCO'TLAND, 404

Church in, the, 336, 405

Franchise, Parliamentary, in, 404

local govermment in, 405

quota of land tax paid by, 107, 405

representative peers, 76,404

union with England, 404

SECRETARIAT, THE

duties of, 195

history of, 195

SECRETARIES, PARLIAMENTARY, 177

SECRE'TARY

for Ireland, the, 176,213

for Scotland, the, $176,212,405$

SECRETARY OF STATE

for air, 207

for colonies, 197, 202

for foreign affairs, 197, 201

for home affairs, 196,200

for India, 197, 202, 454

for war, 197,202

SEDITION, STATUTORY PROVISIONS FOR THE PREVENTION

OF, 514

drilling, unlawful, 516

mutiny, incitement to, 516

oaths, administering unlawful, 515

Parliament, intimidating, 515

treason felony, 514

SEDITIOUS WORDS, 44

SEQUESTRATION, COMMISSION OF , 245 
SERJEANT-AT-ARMS, THE, 59

SERJEAN'TS-AT-LAW, 294

SERVICE FRANCHISE, THE, 60

SETTLEMENT ESTATE DUTY, 125

abolition of, after 11th May, 1914...125

SEYCHELLES, THE, 430

\section{SHERIFF}

appointment of, 70, 399

execution of process by, 400,401

judges of assize, attendance on, 401

members of Parliament exempt from appointment as, 70

Territorial Force, exempt, 381

power of, to hold pleas of the Crown taken away, 7,400

the coroner a substitute for the, 269

SHERIFF'S TOURN, THE, 218, 226

SHIREMOTE, 223

replaced by county court, 270

SIERRA LEONE, 430

territories adjacent to, 467

SLANDER, 43

SOCOTRA, 477

SOLDIERS

and sailors, liability of, for acts done under orders, 359

enlistment of, 365

exempt from civil process, except in certain cases, 384

liability of superior officer to subordinate, 360

may vote for members of Parliament, 385

offences by, triable by civil courts, 381

wrongful dismissal of, 361

SOLICITOR-GENERAL

appointment and duties of the, 193, 194

SOLICITORS, HISTORY OF, 295

SOMALILAND, 467

SOUDAN, THE, 475

SOURCES OF ENGLISH CONSTITUTIONAL, LAW, THE, 1 et seq.

SOUTH AFRICA, THE UNION OF, 449

SOUTH AUSTRALIA, 434, 444

SOVEREIGNTY OF PARLIAMENT, THE, 12, 517

SPEAKER, THE

of the House of Commons, 54, 59

of the House of Lords, 58

SPECIAL CASE

from petty sessions, Appendix, p. 482

from quarter sessions, Appendix, p. 485

for the former court of Crown Cases Reserved, Appendix, p. 485

SPECIAL VERDICT, Appendix, p. 497

SPEECH FROM THE THRONE, 56 
SHERES OF INFLUENCE, 470

STANDING ARMY

maintenance of the, $9,156,363$

STANNARIES, THE COURTS OF THE, 275

appeals from, 276

STAPLE

courts of the, 278

statute, 278

STAR CHAMBER, THE COURT OF, 242

STATUTE MERCHANT, 278

STATUTE STAPLE, 278

STATUTES, 2

S'TEWARD, THE COURT OF THE LORD HIGH, 239

STRAITS SETTLEMENTS, THE, 430

SUBPENA, 242

SUBSIDIES, 100

SUCCESSION DUTY, 117

property subject to, 117

reduction of duty, 119

valuation of property for purposes of, 118

when payable, 118

SUEZ CANAL, THE, 475

SUMMARY JURISDICTION OF MAGISTRATES, 267

SUPERIOR OFFICER

liability of subordinate for obeying orders of, 40,359

actions by subordinates against, 360

SUPPLY, COMMITTEE OF, 90, 91

SUPPLY SERVICES, 93

SUPREMACY

oath of, 54

the Act of, 317

SUPREME COURT OF JUDICATURE, THE, 299

SWAZILAND, 467

SWITZERLAND

constitution of, 19

American and Swiss constitutions compared, 20

TALTARUM'S CASE, 285

TASMANIA, 434, 444

TAXATION, ARBITRARY, 8. 155

TAXes. See Public Revenue.

TENTHS AND FIFTEENTHS, 100

TERRITORIAL ARMY, THE, 376

TOLT, WRIT OF, 227 
TORT

actions founded on, 281

actions of, against the Crown, 37, 165

TRANSUBSTANTIATION

declaration against, abolished, 54, 55

on accession to the Crown, 10, 141

TRANSVAAL, THE, 447

TREASON

offences which constitute, 148

TREASON FELONY

offences which constitute, 150

TREASURY BILLS, 94

TREASURY BOARD, THE, 210

TREATIES

how negotiated, Appendix, pp. 507, 508

the royal prerogative with regard to, Appendix, pp. 507, 508

TRESPASS, ACTION OF, 281

TRESPASS ON THE CASE, 282

TRIBUNAL DES CONFLITS, 40

TRINIDAD AND TOBAGO, 430

TRISTAN DA CUNHA, 477

TROVER, 282

TUNNAGE AND POUNDAGE, 95

TURKS AND CAICOS ISIAANDS, 130

TYNWALD COERT, THE, 421

UGANDA, 467

UNDEVEI,OPED LAND DUTY, 132

UNION OF SOUTH AFRICA, THE, 449

UNITED STATES, THE

constitution of, 15

the President of, 18

UNLAWFUL ASSEMBLY, 47

definition of, 47

duty of magistrate to disperse an, 47

effect of reading the Riot Act, 47

proclamation by secretary of state cannot constitute an, 49

UTRUM, THE ASSIZE, 228

\section{VENIRE DE NOVO}

when granted in criminal cases, Appendix, p. 496

VESTRIES, 393

metropolitan, 394

VICARS, 325

VICE-ADMIRALTY COURTS IN THE COLONIES, THE, 250 
VICEROY OF INDIA, THE, 455

VICTORIA, COLONY OF, 434, 444

VIENNA CONGRESS, THE, Appendix, p. 504

VISCOUNT, ORIGIN OF THE TITLE, 73

VOLUNTEERS, THE FORMER, 376

Territorial Force, now merged into, 376

VOUCHEE, THE COMMON, 285

WAGER OF LAW, 219

WALES, THE CHURCH IN, 337

WALES, THE COURTS $\Pi N, 277$

WAR, THE SECRETARY OF STATE FOR, 176, 202, 206

WAR OFFICE, THE

history of, 202

reorganization of, 204

WASHINGTON, TREATY OF, Appendix, p. 510

WAYS AND MEANS, COMMITTEE OF, 90, 91

WEI-HAI-WEI, 477

WEREGILD, 217

WESTERN AUSTRALLA, 434, 444

WESTERN PACIFIC, THE, 467

WITENAGEMOTE, THE, 221, 222

WITNESSES

become distinct from jurors, 289

in Anglo-Saxon times, 220

the parties admitted as, 289,290 in criminal cases, 290

WOMEN

barristers, 295

electors, 60,63

on juries, 287

peeress, 74

solicitors, 297

WOODS, FORESTS. AND LAND REVENUES, COMMISSIONERS $\mathrm{OF}, 112$

WORKS AND PUBLIC BUILDINGS, THE BOARD OF, 215

WRIT OF RIGHT, 226

WRONG, KING CAN DO NO, 165

YEOMANRY, THE, 375

ZANZIBAR, 469

THE END.

Printed at Reading, England, by the Eastern Press, Ltd. 


\section{A}

\section{SELECTION}

OF

RECENT LAW WORKS

PUBLISHED BY

\section{STEVENS \& SONS, LIMITED,}

$119 \&$ 120, CHANCERY LANE, LONDON, W.C.2.

* A Discount of 20 per cent. off all new Books (except where marked net) for Cash with Order. (Carriage or Postage extra.)

Complete Catalogue of New and Secondhand Law Works post free.

A B C GUIDE TO THE PRACTICE OF THE SUPREME COURT, $1922 . \quad$ Net, $8 s .6 d$.

ACCOUNTS.-Hodsoll's Practical Accounts for Executors and Trustees. $1914 . \quad$ Net, 10s. $6 d$. "Invaluable to law and accountancy students, solicitors and others."-Law Times.

ADMIRALTY.-Roscoe's Admiralty Practice. Fourth Edition. (Incorporating Williams and Bruce's Admiralty Practice.) 1920. Net, 2l. $2 s$.

ADVOCACY.-Harris' Hints on Advocacy.-Fifteenth Edition. By J. H. Watrs, Barrister-at-Law. 1920.

$10 s$.

AGRICULTURAL LAW.-Spencer's Agricultural Holding Acts, 1908 to 1921. Sixth Edition. Net, 12s. 6d. Spencer's Small Holdings and Allotments Acts.With Notes. Second Edition. $1920 . \quad 10$ s.

ANNUAL COUNTY COURTS PRACTICE, 1922.

Net, $2 l$.

"It admirably fulfils the essential requisites of a practice book."-Law Times.

ANNUAL DIGEST, 1921.

Net, 15 s.

ANNUAL PRACTICE, 1922.

Net, $2 l$.

"A book which every practising English lawyer must have.",

ANNUAL STATUTES, 1921 . Net, $1 \mathrm{l}$. $1 \mathrm{~s}$.

- Law Quarterly Review. 
ARBITRATION.-Russell on the Power and Duty of an Arbitrator.-Tenth Edition. By A. A. Hudson, K.C. 1919.

Net, $2 l .2 s$.

BANKING.-Hart's Law of Banking.-Third Edition. 1914.

1l. $12 \mathrm{~s}$.

BANKRUPTCY.-Aggs' Handbook on Bankruptcy. 1915. Net, $4 s$.

Lawrance's Deeds of Arrangement, with Precedents. Ninth Edition. 1922.

"Concise, practical, and reliable."-Law Times.

Net, $10 \mathrm{~s}$.

Williams' Law and Practice in Bankruptcy.Twelfth Edition. By W. N. Stable. 1921. Net, 2l. 10s.

BILLS OF EXCHANGE.-Chalmers' Bills of Exchange. Eighth Edition. 1919.

1l. 10 s.

BUILDING SOCIETIES.-Wurtzburg's Law relating to Building Societies.-Fifth Edition. $1920.20 \mathrm{~s}$.

CARRIERS.-Carver's Treatise on the Law relating to the Carriage of Goods by Sea.-Sixth Edition. By JAMES S. HENDERSON. 1918.

Net, 2l. $2 s$.

"The standard modern book on carriage by sea."-Law Quarterly.

Disney's Law of Carriage by Railway.-Fifth Edition. 1921.

Net, $12 s .6 d$.

"Can be cordially recommended to the lawyer."-Law Times.

CHANCERY.-Daniell's Chancery Practice.-Eighth Edition. By Sydney E. Williams and F. Guthrie-Smith. 2 vols. 1914.

$5 l .5 s$

Daniell's Chancery Forms and Precedents.-Sixth Edition. By R. White, F. E. W. Nichols and H. G. GarRetT. $1914.2 l .10 s$.

"The two volumes on Practice and the one volume of Forms constitute torrether a most valuable work on the practice of the Chancery Division."-Law Quarterly Reviepl.

CIVIL ACTIONS.-Roscoe's Digest of the Law of Evidence on the Trial of Civil Actions.-Nineteenth Edition. By James S. Hexperson. 2 rols. 1922.

N'et, 3l. 3s.

A thin yuper edition in one volume may be had at the same price.

"A vast and closely packed storehouse of information."-Law Jounal.

COLLISIONS AT SEA.-Marsden's Collisions at Sea.Seventh Edition. By Marcus W. Slade. 1919. 1l.15s.

"Indispensable for Admiralty practitioners."-Law Journal.

Roscoe's Measure of Damages in Action of Maritime Collisions.-Second Edition. $1920 . \quad$ Net, 12s.6d. 
COMPANY LAW.-Palmer's Company Law. A Practical Handbook for Lawyers and Business Men. Eleventh Edition. By Alfred F. Topham. 1921. Net, $25 \mathrm{~s}$.

Palmer's Company Precedents.

Part I. General Forms. Twelfth Edition.

(In the press.)

Part II. Winding up. Twelfth Edition. 1921. Net, $3 l$. Part III. Debentures. Twelfth Edition. 1920.

Net, $1 l .15 s$.

Palmer's Private Companies.-Thirty-fourth Edition. 1922.

Net, 1 s. $6 d$.

Palmer's Shareholders', Directors', and Voluntary Liquidators' Legal Companion.-Thirty-first Edition. 1921.

Net, $4 s$.

Sutcliffe's Company Law. 1920.

Net, $12 s .6 d$.

COMPENSATION.-Cripps' Treatise on the Principles of the Law of Compensation.-Sixth Edition. By Aubrey T. Lawhence and R. Stafford Cripps. 1922.

Net, $35 \mathrm{~s}$

CONFLICT OF LAWS.-Dicey's Digest of the Law of England with reference to the Conflict of Laws.Third Edition. By A. V. Direy, K.C., and A. BerrieDALE KeITH. 1922.

Net, $2 l .5 s$.

CONTRACTS.-Addison's Law of Contracts.- Eleventh Edition. By W. E. Gordon and J. Ritchie. 1911. $2 l .2 s$.

Leake's Principles of the Law of Contracts.-Seventh Edition. By A. E. Randall. 1921. Net, 2l. 10 s. "A full and reliable guide to the principles of the English Law of Contract."-Law Journal.

Pollock's Principles of Contract.-Ninth Edition. $1921 . \quad \quad N e t, 2 l .2 s$.

"There is no book on the English Law of Contract which deals so lucidly and yet so comprehensively as this."-Law Journal.

CONVEYANCING. - Armitage's Short Conveyancing Forms. 1918.

Net, $12 s .6 d$.

Prideaux's Forms and Precedents in Conveyancing.

-Twenty-first Edition. 2 vols. 191:. Net, 5l. " "Prideaux" is the best work on Conveyancing."-Law Journal.

CORPORATION PROFITS TAX.-The Tax explained and Annotated. By Cyril L. KING. 1921. Net, 2s. 6d.

CRIMINAL LAW.-Denman's Digest of Criminal Law."ARCHBOLD abridged and alphabetically arranged." Second Edition. 1918.

Net, $17.5 s$.

Roscoe's Digest of the Law of Evidence and the Practice in Criminal Cases,-Fifteenth Edition. Br H. Cohen. 1921. 
CRIMINAL LAW-continued.

Russell's Treatise on Crimes and Misdemeanors.-

Serenth Edition. 3. vols. 1909.

$4 l .10 s$.

"Indispensable in every Court of criminal justice here and in our colonies."-The Times.

Warburton's Leading Cases in Criminal Law.-Fifth Edition. By the late H. Warburton and Claude $\mathrm{H}$. Grundy. 1921.

DEATH DUTIES.-Harman's Finance Act, 1894, and subsequent legislation as to the Death Duties.Fourth Edition. 1921.

$10 s .6 d$.

Webster-Brown's Finance Acts.-(Estate and other Death Duties.) Fourth Edition. 1921. Net, 1l. 5s.

"Contains much practical advice which will be of substantial assistance to practitioners."-The Times.

DIARY.-The Lawyer's Companion and Diary, 1922. Net, $5 s$. to $13 s$.

DICTIONARY.-Wharton's Law Lexicon.-Twelfth Edition. By E. A. WURTZBURG. $1916 . \quad 2 l .10 \mathrm{~s}$.

"The most useful of legal works."-Law Journal.

The Pocket Law Lexicon.-Fifth Edition. 1921.

Net, $10 s$.

"A wonderful little legal Dictionary."-Law Students' Journal.

DIGEST.-Mews' Digest to End of $1920 . \quad$ Net, 15l.5s. Full Particulars on application.

DIVORCE.-Browne and Watts' Law and Practice in Divorce, \&c.; incorporating Oakley's Divorce Practice.-Ninth Edition. 1921. Net, 2l.2s.

EASEMENTS.-Goddard's Treatise on the Law of Easements.-Eighth Edition. $1921 . \quad N^{\prime} e t, 1 l .10 \mathrm{~s}$.

"Nowhere has the subject been treated so exhaustively."-Law Times.

EDUCATION.-Aggs and Knowles' Handbook on Education.-1922.

Net, $6 s .6 d$.

ELECTIONS.-Rogers' Parliamentary Elections and Petitions.-Nineteenth Edition. With Addenda, March, 1922.

Net, 1 l. $5 s$.

ELECTRICITY.-Knowles' Law relating to Electricity. - In two Parts. Part I., Electric Lighting and Power; Part II., Electric Traction. 1911. 2l. 10s. The Parts may be had separately, each 1l. 5s. net.

EQUITY.-Seton's Forms of Judgments and Orders. With Practical Notes. Seventh Edition. 3 vols. 1912. 6 .

"A wost valuable and indixper:sable work."-Lau Journal.

Smith's Practical Exposition of the Principles of Equity.-Fifth Edition. $1914 . \quad 21 s$.

"Useful to both practitioner and student alike."-Law students' Journal. 
EXCESS PROFITS.-Sutcliffe's Excess Profits Duty. With Supplement bringing the Work down to 1920. $10 \mathrm{~s}$. ** The Supplement may be had separately, Net, $2 s .6 d$.

EXECUTORS.-Walker's Law relating to Executors and Administrators. - Fifth Edition. 1920. Net, 1l.5s.

Williams' Law of Executors and Administrators.Eleventh Edition. 2 vols. $1921 . \quad$ Net, $5 l$.

"This book-the standard work on its subject-is a storehonse of learning on every point of administration law."-Lau Journal.

FARM.-Hopkins' Farm Law.-1920.

Net, $3 s .6 d$.

FORMS.-Bowstead's Collection of Forms and Precedents other than Conveyancing, Company, Local Govern ment and Practice Forms.-2 vols. 1914. Net, 2l. $10 \mathrm{~s}$

Chitty's Forms of Civil Proceedings in the King's Bench Division.-Fourteenth Edition. 1912. 2l. $10 \mathrm{~s}$. "An indispensable adjunct to every working lawyer's library." -Law Journal.

Daniell's Chancery Forms and Precedents.-Sixth Edition. 1914.

2l. 10 s.

"The standard work on Chancery Procedure."-Law Quarterly Reviero.

HIRE-PURCHASE SYSTEM.-Russell's Practical Manual of Hire-Trade Law.-Fifth Edition. With Supplement to June, 1920.

Net, 10s. 6d. ** The Supplement may be had separately, Net, 3s. 6 d.

INCOME TAX.-Aggs' Income Tax, 1918. Net, 12s.6d. Konstam on the Law of Income Tax. With Supplement (Oct., 1921). 1921.

Net, $1 l$. 15 s.

INDUSTRIAL COURTS.-Stoker's Industrial Courts Act, and the kindred Acts, and Rules. -1920 .

Net, $3 s .6 d$.

INSURANCE.-Arnould's Law of Marine Insurance and Average.-Tenth Edition. 2 vols. $1921 . \quad$ Net, $5 l$.

INTERNATIONAL LAW.-Anthonis' Sanctions of International Law. 1917.

Net, 1 s.

Wheaton's Elements of International Law.-Fifth English Edition. 1916.

"Wheaton stands too high for criticism."-Law Trmes.

INVESTIGATION OF TITLE.-Jackson and Gosset's Investigation of Title.-Fourth Edition. Br THOROLD GosSET. 1922. 
LANDLORD AND TENANT.-Woodfall's Law of Landlord and Tenant.-Twentieth Edition. 1921.

Net, $2 l .15 s$.

"Woodfall is really indispensable to the practising lawyer, of whatever degree he mav be."-Law Journal.

LAW LIST, 1922.

Net, $12 s .6 \pi$.

LEADING CASES.-Caporn's Selected Cases on the Law of Contracts.-Third Edition. 1920.

Randall's Selection of Leading Cases in Equity.1912.

10s. $6 d$.

"One of the foremost, if not the best, of Equity case books." Law Students' Journal. .

Shirley's Selection of Leading Cases in the Common Law.-Ninth Edition. By R. Watson. $1913.18 s$.

Warburton's Leading Cases in Criminal Law.-Fifth Edition. 1921.

LEAGUE OF NATIONS.-Pollock on the League of Nations.-By Rt. Hon. Sir Frenfrick Poldock, Bt., K.C. Second Edition. 1922.

Net, $16 s$.

LEGAL HISTORY.-Deans' Student's Legal History.Fourth Edition. 1921.

$15 s$.

"There is no better short introduction to the study of the law." - Law Notes.

LIBEL AND SLANDER.-Ball's Law of Libel as affecting Newspapers and Journalists. - 1912.

$6 s$.

"A well-arranged and well-executed work."--Law Journal.

Odgers' Digest of the Law of Libel and Slander.Fifth Edition. 1911.

1l. $18 s$.

"Should be found on the shelves of every practitioner." - Law Students' Journal.

LUNACY.-Heywood and Massey's Lunacy Practice.Fifth Edition. 1920.

1l. $10 \mathrm{~s}$.

MENTAL DEFICIENCY.-Davey's Law relating to the Mentally Defective.-Second Edition. 1914. $10 \mathrm{~s}$.

"This admirably arranged and handy book."-Law Journal.

MILITARY LAW.-O'Sullivan on Military Law and the Supremacy of the Civil Courts.-1921. Net, 7 s. $6 d$. 
MORTGAGE.-Coote's Treatise on the Law of Mortgages.-Eighth Edition. 22 rols. 1912. Net,3l.33x.

NOTARY.-Brooke's Office and Practice of a Notary. - Seventh Edition. By J. Cranstoun. 1913. 1l. $10 \mathrm{~s}$.

OBLIGATIONS.-Waiton on the Egyptian Law of Obligations. A Comparative Study, with special reference to the French and the English Law. 2 Vols. 1920. Net, $2 l .10 s$.

PARTNERSHIP.-Pollock's Digest of the Law of Partnership.-Eleventh Edition. $1920 . \quad 15 s$.

PATENTS.-Thompson's Hand-book of Patent Law of all Countries.-Eighteenth Edition. 1920. Net, $6 s$. ** British Portion only.

PEACE TREATY.-Picciotto and Wort's Treaty of Peace with Germany: Clauses affecting Mercantile Law. 1919.

Net, $6 s$.

PLEADING.-Bullen and Leake's Precedents oi Pleadings.-Seventh Edition. 1915.

$2 l .10 s$.

"The standard work on modern pleading."-Law Journal.

Odgers' Principles of Pleading and Practice.-Eighth Edition (Revised Reprint). 1922.

$15 s$.

POOR LAW SETTLEMENT.-Davey's Poor Law Settlement and Removal.--Second Edition. $1913.15 \mathrm{~s}$.

POWERS.-Farwell's Concise Treatise on Powers.Third Edition. 1916.

1l. $15 s$.

PRIVATE BILLS.-Landers' Procedure and Practice relating to Private Bills in Parliament. 1919.

1l. $12 \mathrm{~s}$.

PRIZE CASES.-Cases Decided in the Prize Court and on Appeal to the Privy Council.

Each Part Net, $7 s .6 d$.

PROPERTY.-Strahan's General View of the Law of Property.-Sixth Edition. 1919.

RAILWAYS.-Aggs and Knowles' Handbook on Railways. 1922 .

Net, 5 s.

Disney's Law of Carriage by Railway.-Fifth Edition. By H. W. Disney. 1921.

Nel, 12s. 6il.

RATING.-Davey's Law of Rating.-With Supplement bringing the Work down to June, 1919. Net, 1l. 10 s. ** The Supplement may be Tad separately, Net, 5 s.

RECEIVERS AND MANAGERS.-Riviere's Law relating to Receivers and Managers.--1912. 
ROMAN PRAETORS, THE. 1922.

Net, כss.

SHIPPING.-Temperley's Merchant Shipping Acts.Third Edition. 1922.

Net, $2 l .10 s$.

SMALL HOLDINGS.-Spencer's Small Holdings and Allotments Acts.-Second Edition. 1920.

SPECIFIC PERFORMANCE.-Fry's Treatise on the Specific Performance of Contracts.-Sixth Edition. 1921.

2l. 10 s.

"The leading authority on its subject."-Law Joumal.

STAMP LAWS.-Highmore's Stamp Laws.-With Notes of Decided Cases. Fourth Edition. 1921. Net, 15s.

STATUTES.-Chitty's Statutes to End of 1920. Net, $21 l$. Full Particulars on application.

TORTS.-Addison's Law of Torts.-Eighth Edition. By W. E. Gordon and W. H. Grifrith. 1906. Net, 1l. 18s.

Pollock's Law of Torts.-Eleventh Edition. By the Rt. Hon. Sir Fredk. Pollocr, Bart., K.C. 1920. 1l. 12s. ** An Analysis of the above for Students.-Third Edition. By J. K. ManNooch. 1920.

$7 s .6 d$.

TRADE MARKS.-Sebastian's Law of Trade Mark Registration.-Second Edition. By L: B. Sebastian, F. E. Bray and J. Q. Henriques. 1922. Net, 15s.

TRADE UNIONS.-Greenwood's Law relating to Trade Unions.-1911.

$10 s$.

A Supplement to above, including the Trade Union Act, 1913. 1913. Net, $3 s .6 d$.

The two works together, net, $10 s$.

TRANSPORT.-Robertson's Ministry of Transport Act, 1919. - With an Introduction and Notes.

$6 s$.

TRUSTS AND TRUSTEES.-Godefrni on the Law of Trusts and Trustees.-Fourth Edition. 1915. 1l. 16s.

WATER.-O'Hagan's Law of Water in Greater London. 1920. Net, $1 l$.

WILLS.-Theobald's Concise Treatise on the Law.of Wills. Seventh Edition. 1908.

$2 l$.

WORKMEN'S COMPENSATION.-Knowles' Law relating to Compensation for Injuries to Workmen.Third Edition. 1912. .

11.

Workmen's Compensation Reports.

Annual Subscription, 25s. net (post free).

STEVENS \& SONS, Ltd., 119 \& 120, Chancery Lane, London, 




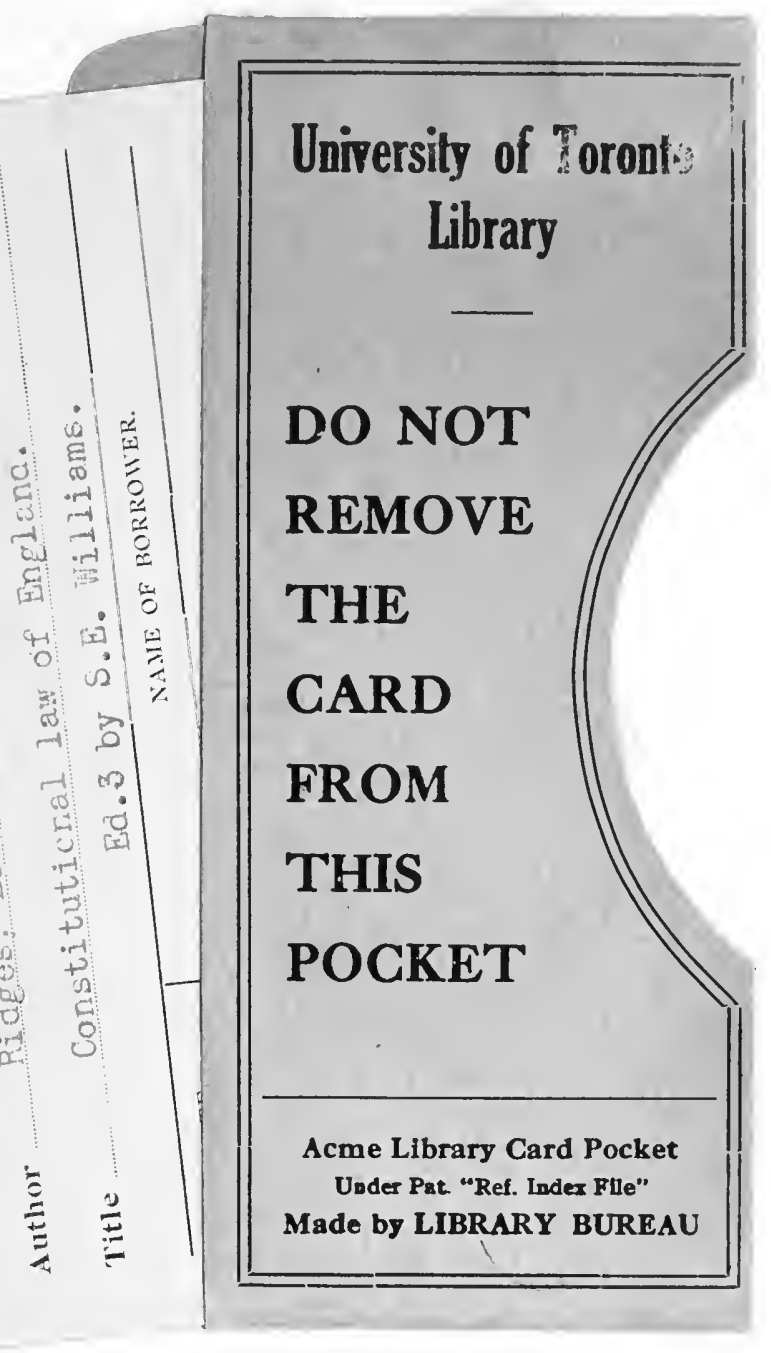


.

$$
\text { - }
$$

